МИНИСТЕРСТВО ЗДРАВООХРАНЕНИЯ И СОЦИАЛЬНОГО РАЗВИТИЯ РОССИЙСКОЙ ФЕДЕРАЦИИ ГОУ ВПО «САМАРСКИЙ ГОСУДАРСТВЕННЫЙ МЕДИЦИНСКИЙ УНИВЕРСИТЕТ» СТОМАТОЛОГИЧЕСКИЙ ИНСТИТУТ СаМГМУ

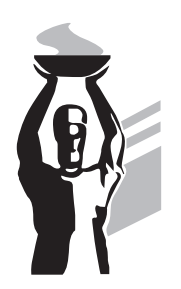

\author{
П.Ю. Столяренко
}

\title{
ИСТОРИЯ ОБЕЗБОЛИВАНИЯ В СТОМАТОЛОГИИ (от древности до современности)
}

\author{
Монография \\ 2-е издание, переработанное и дополненное
}


УДК 616.31-089.5(091)

ББК 56.6

$\mathrm{C} 81$

\author{
Рекомендовано \\ Учебно-методическим объединением \\ по медицинскому и фармацевтическому образованию вузов России \\ в качестве учебного пособия для студентов медицинских вузов, \\ обучающихся по спеииальности - 060105 - «Стоматология»
}

\title{
Рецензенты:
}

C.A. Рабинович - заведующий кафедрой стоматологии общей практики и анестезиологии ГОУ ВПО «МГМСУ», заслуженный врач РФ, доктор медицинских наук, профессор;

A.Г. Сапрыкина - зав. кафедрой общественного здоровья и здравоохранения ГОУ ВПО «СамГМУ», доктор медицинских наук, профессор;

В.П. Бережной - профессор кафедры терапевтической стоматологии ГОУ ВПО «СамГМУ», доктор медицинских наук, профессор

\section{Столяренко П.Ю.}

С81 История обезболивания в стоматологии (от древности до современности) : монография / П.Ю. Столяренко. - 2-е изд., перераб. и доп. - Самара : ООО «Офорт» ; ГОУ ВПО «СамГМУ», 2010. 342 с.; ил. 315.

ISBN 978-5-473-00602-5

Все права защищены.

Ни одна часть этого издания не может быть занесена в память компьютера либо воспроизведена любым способом

без предварительного письменного разрешения владельцев авторских прав.

ISBN 978-5-473-00602-5

(С) Столяренко П.Ю., 2001

(c) Столяренко П.Ю., 2010, с изменениями

(с) ГОУ ВПО «Самарский государственный медицинский университет», 2010

(с) Оформление. ООО «Офорт», 2010 


\section{П.Ю. Столяренко \\ ИСТОРИЯ ОБЕЗБОЛИВАНИЯ В СТОМАТОЛОГИИ}

Первая отечественная монография, посвящённая истории возникновения и развития обезболивания в стоматологии - от древних цивилизаций до начала третьего тысячелетия.

Охвачены периоды от использования примитивных средств для обезболивания, открытия шприца и инъекционной иглы, первых анестетиков до современных техник и технологий общей, местной и других способов анестезии: ларингеальная маска и другие воздуховоды, специальные инъекторы, автоматизированный компьютерный шприц, анестетики последнего поколения и др.

В работе уточнены многие исторические факты, сообщаются интересные подробности, публикуются редкие документы и иллюстрации. Использованы как раритетные издания, так и информация, полученная через Интернет.

Со времени выхода из печати первого издания прошло 10 лет. Интерес читателей и новые сведения побудили автора к выпуску 2-го издания монографии, дополненного и исправленного.

В книге 315 иллюстраций, библиография: 394 названия.

Для широкого круга читателей - стоматологов, анестезиологов, хирургов, историков медицины, научных работников, студентов медицинских вузов.

\section{P.Yu. Stolyarenko}

\section{The History of Anesthesia in Stomatology}

The first domestic monograph on the history and development of anesthesia in stomatology - from ancient civilizations to the third millennium. It covers the period from the use of primitive ways of anesthesia, the syringe and the injection needle discovery, the first anesthetics, modern techniques and technology of general, local and other methods of anesthesia: a laryngeal mask and other airducts, special injectors, computer-automated syringe, the latest generation of anesthetics and other. The monograph clarifies many historical facts, interesting details are reported, contains rare documents and illustrations. Rare editions and information obtained through the Internet are used in the book. 10 years have passed since the first edition appeared and the readers' interest and new information inspired the author to release the second edition of the monograph, added and corrected. The book contains 315 illustrations; the bibliography list includes 394 titles. This book is for a wide range of readers - stomatologists, anesthesiologists, surgeons, historians, medical researchers and medical students. 


\section{ПРЕДИСЛОВИЕ}

Предлагаемая читателю работа посвящена истории обезболивания в стоматологии. Специфика стоматологии предопределяет доминирующее применение местной анестезии по отношению к наркозу (кратковременность, частая повторяемость и локальность вмешательства). Вместе с тем развитие черепно-челюстно-лицевой хирургии немыслимо без наркоза. В монографии с учётом исторического развития специальности слово «стоматология» условно подразумевается в более широком смысле, включая и зубоврачевание, и черепно-челюстно-лицевую, и косметическую хирургию.

Во многих изданиях по стоматологии, особенно вышедших в последние десятилетия, вопросы истории обезболивания совсем не рассматриваются или освещены кратко, однобоко (особенно в советский период), поверхностно и противоречиво.

На стыке тысячелетий повышается актуальность вопросов истории. Без знания истории нельзя созидать новое, немыслим прогресс в медицине и стоматологии. Уходят люди с энциклопедическими знаниями, которые создавали научные школы и растили себе достойную смену, фанатично занимаясь обучением и передачей знаний более молодым коллегам. На смену им приходят новые поколения и специалисты. Классические труды не переиздаются по экономическим причинам. Информация, размещаемая на лазерных дисках, к сожалению, не имеет ещё достаточной глубины поиска и пока малодоступна широкому кругу отечественных специалистов и студентов.

Цель работы - хотя бы частично восполнить пробел наших знаний по вопросам истории обезболивания в стоматологии. Как удалось это сделать - судить читателю. Книга не претендует на право истины в последней инстанции. Любые замечания по форме и содержанию работы будут восприняты с вниманием и глубокой благодарностью.

Хочу выразить свою самую искреннюю признательность сотрудникам, родственникам и знакомым, благодаря моральной поддержке и пониманию которых, а также финансовой помощи руководства Самарского государственного медицинского университета (ректор СамГМУ - Г.П. Котельников, академик РАМН, лауреат Государственной премии РФ и премии Правительства РФ, доктор медицинских наук, профессор) и Стоматологического института (президент - И.М. Федяев, доктор медицинских наук, профессор, заслуженный врач РФ, почётный профессор СамГМУ), был выполнен этот труд. 
Настоящее бывает следствием промедиего.

Чтобы судить о первом, подлежит вспомнить последнее...

H.М. Карамзин

\section{ПРИМЕНЕНИЕ ОБЕЗБОЛИВАНИЯ ОТ ГЛУБОКОЙ ДРЕВНОСТИ ДО ХVIII ВЕКА}

С древнейших времен человечество стремилось найти способы обезболивания при операциях, но до XIX века обезболивания в современном понимании не было. Применявшиеся методы понижения болевой чувствительности были примитивны, малодейственны и даже опасны для жизни оперируемого.

Считается, что греческий философ Диоскорид первым применил термин «анестезия» в I веке н.э. для описания наркотикоподобного действия мандрагоры (действующее начало - М-холинолитик скополамин).

B 1721 г. в универсальном этимологическом английском словаре Bailey's было дано определение термина «анестезия»- это «дефицит чувствительности». В Британской энциклопедии 1771 года под анестезией понималось «лишение чувств». Как сноподобное состояние, позволяющее проводить хирургические вмешательства, анестезию определил, предположительно, Оливер Уэнделл Холмс (Oliver Wendell Holmes) в 1846 г.

История развития обезболивания показывает, что параллельно с изысканием средств для общего обезболивания всё время делались попытки оперировать под местной анестезией, и мысль достигнуть обезболивания тканей человеческого тела на месте предстоящей хирургической операции едва ли даже не более древняя, чем идея наркоза. По крайней мере, поскольку можно судить по дошедшим до нас средневековым источникам, ещё египтяне пытались вызвать потерю чувствительности на коже прикладыванием жира священного нильского крокодила. Они также славились своим умением изготовлять различные опьяняющие и анестезирующие средства, главными составными частями которых являлись индийская конопля и опий. Вместо калёного железа были в ходу моксы из конопли, так как они полагали, что болезненность операции значительно уменьшится при помощи усыпительных свойств дыма индийской конопли. 
По свидетельству Каспара Гофмана, ассирияне, производя у мальчиков обрезание, сдавливали им шейные сосуды и тем уничтожали боль, испытываемую при этой операции (Каппелер О., 1881).

Плиний Младший (Plinius secundus, 32-79 гг. н.э.) и Dioscorides pedanius в 50-м году н.э. рассказывали, что мемфисский камень, истолчённый в порошок и политый уксусом, будучи приложен к обожжённым или поражённым частям тела, уничтожал все болезненные ощущения. Литтре полагает, что этот мемфисский камень был не что иное, как особый вид мрамора, который при обливании уксусом образовывал уксусную кислоту, производящую местную анестезию.

Покрынный альраунный корень (Atropa mandragora L.) также часто упоминается в числе старинных анестезирующих препаратов. Он хорошо был известен грекам и, по мнению Бодена, до конца 16-го столетия этот корень весьма часто употреблялся как снотворное и анестезирующее средство. В странах, расположенных ближе к северу, основным средством общей анальгезии был этиловый спирт, с которым человечество в виде пива и вина знакомо более 6000 лет.

Отсутствие совершенного метода обезболивания компенсировалось скоростью проведения операции. Ещё в V веке до н.э. Гиппократ писал, что, «так как приходится оперируемым страдать, причиняющее боль должно быть в них наиболее короткое время, а это будет, когда сечения выполняются скоро».

В более близкие к нам времена - средние века, в эпоху Возрождения зародилось немало идей, которые не потеряли своего значения до сих пор. Да и не могли медики всех времён не думать об обезболивании. Операция, даже самая незначительная, часто заканчивалась смертью пациента от болевого шока. В операционной одной из лондонских больниц до наших дней сохранился колокол, звуками которого пытались заглушить крики несчастных, подвергавшихся хирургическому вмешательству.

С.С. Юдин (рис. 1), выдающийся отечественный хирург и историк хирургии, приводит дошедшее до нас описание Даниэля Бекера (Daniel Becker, 1636) тяжёлой операции удаления ножа из желудка в XVII веке. Оно интересно с двух точек зрения. Во-первых, мы можем убедиться, насколько сложными могли быть хирургические вмешательства уже в те далёкие времена, а во-вторых, насколько несовершенно было «обезболивание». Сейчас этот термин в отношении к тому времени едва ли возможно употреблять без кавычек. Итак...

«... 25 июня 1625 года, убедившись, что сообщаемый больным анамнез «не есть плод фантазии» и что силы больного допускают операцию, пореши- 
ли сделать её, дав «болеутоляющего испанского бальзама». 9 июля при большом стечении врачей, учащихся и членов медицинской коллегии приступили к гастротомии. Помолившись богу, больного привязали к доске; декан наметил углём место разреза длиной в четыре поперечных пальца, на два пальца ниже рёбер и отступя влево от пупка на ширину ладони. Хирург Daniel Schabe вскрыл литотомом брюшную стенку. Прошло полчаса, наступили обмороки, и больного повторно отвязывали и вновь привязывали к доске. Попытки вытянуть желудок щипцами не удавались; наконец его зацепили острым крючком, провели сквозь стенку лигатуру и вскрыли по указанию декана. Нож был извлечён «при аплодисментах присутствующих». На стенку живота наложили пять швов и повязку с бальзамом. В течение 14 суток дава-

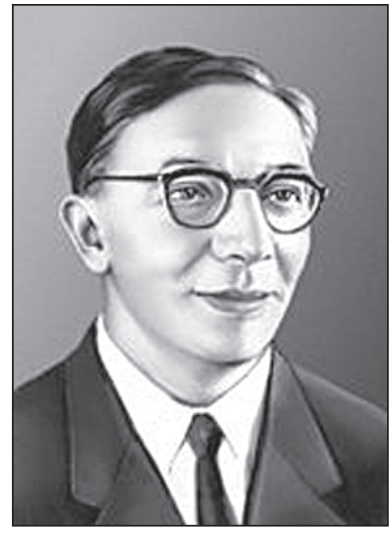

Рис. 1. Сергей Сергеевич Юдин (1891-1954). Внёс большой вклад в совершенствование методов хирургического обезболивания лось лишь тепловатое питьё. Выздоровление.

В работе Бекера помещён портрет больного и изображение ножа размером 5,5 дюймов».

Таковы были хирургия и обезболивание (рис. 2). Неудивительно, что большинство оперируемых умирали не столько от самой хирургической травмы, сколько от боли и мук.

\section{Многочисленные войны} этого периода, внедрение в военную практику огнестрельного оружия и как следствие - многочисленные тяжёлые ранения - всё это способствовало развитию хирургии.

В 1537 г. великий Амбруаз Паре (рис. 3), которого впоследствии стали называть отцом хирургии, был участником похода Франциска I против германского императора Карла V.

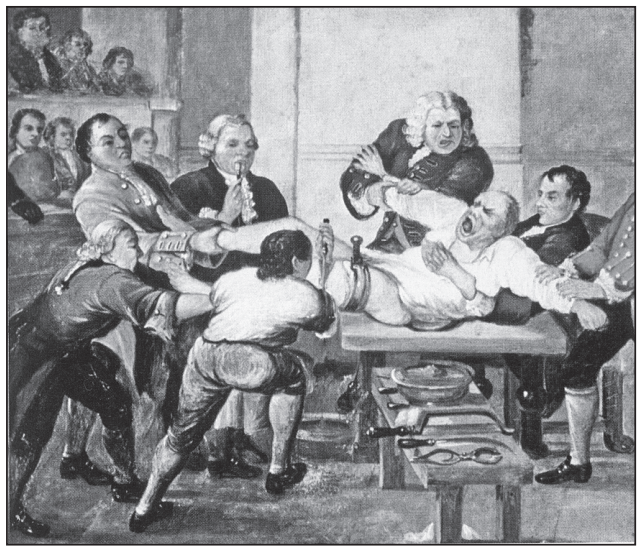

Рис. 2. Хирургическая операция в «донаркозный» период 


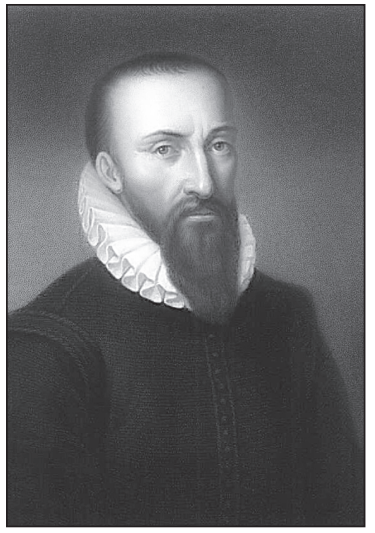

Рис. 3. Амбруаз Паре (1510-1590).

Портрет кисти

Вильяма Холла (фантазия)
В то время огнестрельные раны надлежало заливать кипящим бузинным маслом. Пользы от этого было мало: муки же раненые испытывали жесточайшие. Они корчились от боли, а лекарь - от сознания, что их причиняет. Только люди железного здоровья могли выдержать эту варварскую процедуру. Этот метод лечения был в то время «обоснован» учеными-медиками. Они говорили, что пуля вносит в рану особый яд, и только огненный бальзам - бузинное масло - способен спасти раненого. Случай помог избавиться от этого принятого как должного метода лечения. Случай, сделавший переворот в хирургии благодаря тому, что произошёл он с великим человеком, способным из обычного наблюдения извлечь урок. У Амбруаза Паре после одного жестокого боя, когда раненые поступали сплошным потоком, кончился кипящий бальзам.

Вместо «целительного масла» Амбруаз Паре приготовил свою болеутоляющую смесь. Наутро осмотр показал, что раны, обработанные «новоиспечённым» бальзамом, не имели покраснения, припухлости, ожогов; в то же время раны, обработанные кипящим маслом, были, как всегда, резко отёчны, кожа вокруг была покрасневшей и обожжённой. И, кроме того, все раненые, при лечении которых применялось новое средство, спокойно провели ночь, спали и проснулись свежими, исполненными новых сил, что, безусловно, способствовало выздоровлению. Те, кому обработали повреждения кипящим маслом, были совершенно обессилены болью.

Позволим себе привести описание этого случая.

«... Сия тонкая и деликатная работа исполняется руками и инструментами...

Через минуту зонд наткнулся на твёрдое препятствие. Паре облегчённо вздохнул:

- Пуля найдена! Тонкими щипцами с зазубренными губками удалось её ухватить; Паре потянул сильнее, и пуля, наконец, вышла. Солдат вскрикнул, лицо его залила бледность.

- Терпи! - приказал Паре. Оставалось влить в рану масло и перевязать пострадавшего. Паре повернулся и замер: на дне котелка чадило лишь несколько капель почерневшей от огня жидкости.

- Жан! - позвал Паре. - Масло, скорее! Жан откинул полог и с недоумением посмотрел на хозяина. 
- Я же говорил, что масло кончилось, произнёс он.

- Совсем? - молодой хирург был ошарашен.

- В бутыли ни капли.

Что делать? Только что он совершил невозможное: извлёк пулю, засевшую так неудобно, что здесь спасовал бы сам Шолиак, и всё напрасно! Пациент умрёт потому лишь, что неопытный хирург слишком щедро расходовал масло. Как назло, он перевязал полсотни врагов, а масла не хватило именно своему, пусть даже и мародёру. Теперь жди неприятностей, ведь полковник только сегодня предупреждал его: «Будь предусмотрительнее!» Что делать?.. Выжечь рану раскалённым пекеленом? (рис. 4).

Но сухое железо не сможет уничтожить сухой пороховой яд, и страдания больного только усугубятся. Здесь мог бы помочь териак (древнее, мнимое противоядие и всеисцеляющее снадобье, состав из множества ядовитых трав), но его нет под рукой. Дубле лечит отравления индийским безоаром. Скотина! Паре сам видел, как эмпирик собирал «индийский» камень на берегу реки.

Молодой человек представил торжествующий взгляд соперника, и растерянность сменилась злостью.

Какого чёрта! Шарлатаны отправляют на тот свет сотни людей, получая за это деньги! Кто определит среди бойни, отчего умер этот прохвост? Да если сейчас рассечь бритвой яремную вену и выпустить из парня всю кровь, то никто, даже Жан, не заподозрит дурного. Ещё один труп среди сотни других...

Паре бросил взгляд на раненого, и мерзкие мысли споткнулись. Легионер сидел, запрокинув голову, на лбу выступили капли пота. Было видно, что ему очень нехорошо. Закон природы: любить и, любя, помогать. Помогать всем, без различия веры и подданства. С мародёра спросится и в этой, и в последующей жизни, но пока это не преступник, а страждущий. Значит, надо лечить, и то, что у тебя нет больше масла, не оправдывает тебя ни перед Богом, ни перед собственной совестью. Старуха-знахарка из Пьемонта учила прикладывать к воспалённым ранам печёный лук. Лука под рукой нет, но ведь существуют и другие средства. Можно использовать кровь голубки, а иной раз помогают душистые масла.

Паре взял флакончик с дорогим розовым маслом, смочил им клок белой, хорошо прочёсанной шерсти и вставил тампон в устье пулевого отверстия. Может быть, 
летучее масло оттянет на себя часть яда. Сверху Паре наложил обычную повязку с терпентином (сосновая смола) и яичным желтком.

Когда Жан увёл легионера, Паре ощутил слабость. Но надо работать, и он, превозмогая себя, продолжал операции. Ещё пять человек он перевязал, не выжигая в ране порохового яда. И то, что среди них оказалось два испанца, ничуть не утешало. Неважная ночь выпала на долю Паре. Он ворочался, часто вставал, но, опасаясь потревожить больных, к навесу не подходил, вздыхал и снова ложился в смятую постель. До его слуха доносились стоны, неразборчивый бред, порой - болезненные вскрики. Многие ли из лежащих под навесом доживут до утра? Более всего беспокоился Паре о тех, кому по недостатку масла не сделал прижигания. Жан де Виго один из немногих авторов, писавших на родном языке и потому доступных Паре, - в восьмой главе первой книги «О ранах» утверждал, что заражение пороховым ядом убивает человека за сутки. Паре ждал утра.

Какой же ты медик, если не можешь спасти доверившегося тебе человека? Хирург-брадобрей! Брадобрей - ещё куда ни шло. Презренное звание, недаром палач относится к тому же цеху, что и ты... За прошедший день Паре пролил больше крови, чем иной палач в дни больших казней, не меньше десятка человек скончались у него на руках. Почему же так больно и тревожно именно за шестерых, обречённых на смерть авторитетом Виго? Должно быть, потому, что они гибнут по его, Амбруаза Паре, недосмотру.

Солнце ещё не появилось, ночной мрак едва начинал седеть, под утро удушливая жара спала, от Роны потянуло прохладой. Паре растолкал Жана, велел ему достать тонкие шерстяные одеяла и как следует укрыть раненых, чтобы уберечь от столбняка, происходящего, как известно, от холода и сырости. Потом пошёл по рядам, вглядываясь в бледные или пылающие лица, собственноручно напоил лихорадящих ячменной водой - простонародным средством, снимающим жажду и в силу своей слизистости гасящим всякий жар. Когда достаточно рассвело, Паре начал осмотр. Ночью умерли несколько больных, но среди них - ни одного из тех, за кого он больше всего волновался. Более того, приступив к перевязкам, Паре обнаружил, что раненые, не получившие должного лечения, чувствуют себя лучше остальных. Лихорадка тронула их слабее, раны почти не воспалились. Правда, края сохраняли синюшный оттенок, но так ведёт себя любая размозжённая рана. Но куда в таком случае делся яд? Ведь не может быть, чтобы десятки учёнейших медиков со времён Иеронима Бруншвига находились в плену чудовищного заблуждения!

... В этот день Паре не опасался неприятностей из-за нехватки медикаментов. Хирурги других отрядов были в том же положении. Лекарств не хватило всем, и материала для наблюдений оказалось более чем достаточно: на этот раз Паре огнестрельные раны не прижигал уже вполне сознательно...»

Рутина и косность всегда отличались жизнестойкостью. Амбруазу Паре не сразу удалось убедить коллег в том, что от предложенной им смеси гораздо больше пользы, чем от традиционного «бальзама». Однако у Паре был великий союзник - Гиппократ. «Прежде всего - не повреди!» - гласит одна из его бес- 
смертных заповедей. Паре действовал в полном соответствии с ней. «Лечение, - втолковывал он, - не должно быть причиной новых страданий. Лечебный фактор должен не только устранять основное заболевание, но и облегчить страдание, вызванное им, а не увеличивать его». (Цит. по В.Ю. Островскому, 1983.) Так зарождалась идея противошоковой терапии, лежащей в основе современной анестезиологии.

Средние века породили идею - как общего, так и местного обезболивания. Правда, некоторые приёмы и методы тех времён с сегодняшних позиций всерьёз рассматривать нельзя. Например, имел распространение «метод общего обезболивания» путём удара тяжёлым предметом по голове. В результате сотрясения мозга больной впадал в бессознательное состояние и оставался безучастным

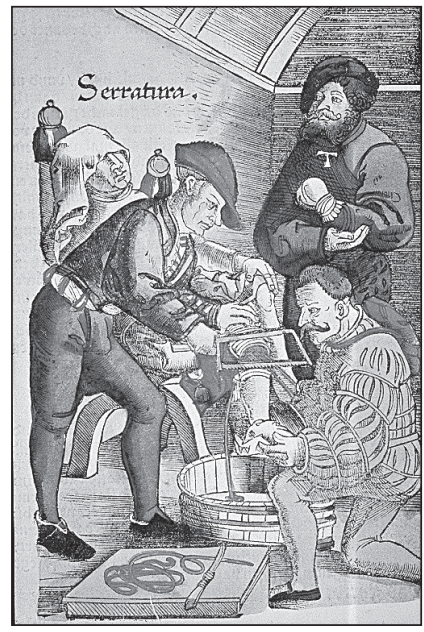

Рис. 5. Хирургическая операция в XVI веке (ампутация) к манипуляциям хирурга. К счастью, этот метод не получил дальнейшего распространения.

Для притупления сознания применялись и другие жесточайшие приёмы, в большинстве - физические, например, кровопускание, пережатие сонных артерий. До сих пор среди немедиков бытует термин «заморозка», хотя сейчас под этим отнюдь не имеется в виду охлаждение тканей как таковое (рис. 5). Об обезболивающем действии охлаждения впервые упоминает великий учёный и врач Востока X-XI вв. Абу Али Ибн Сина (Авиценна).

Следующая цитата, заимствованная нами из сочинений Томаса Бартолина (Thomas Bartholinus), несомненным образом свидетельствует, что уже в средние века делались попытки получить местную анестезию: «An tiquam cauterio ulcera in membris excitentur, nix affricata induit stuporem. Id me docuit Marcus Aurelius Sewerinus in Gymnasio Neopolitano olim praeceptor meus et hospes, Chirurgorum hoc saeculo princeps. Rectissime autem nivem in vasculum materiae convenientis capax, sed olonga ad extremum et myrtiformi spezie, conjectam, sine rei ullius interventu applicavit. A gangraenae metu securos nos jussit, medicamento sub angustis parallelis lineis applicato, sensu vero post horae quadrantem sopito, secare locum indolentem licebit».

Приводим перевод этого фрагмента с латинского: «С древности язвы на конечностях прижигали каутером, натирали снегом, чтобы вызвать онемение. Этому меня давно учил мой наставник, авторитет целого поколения 
хирургов, Марк Аврелий Северный и чужеземцы в Неаполитанской гимназии. Правильнее же всего, если вы прикладываете к ткани конечности снег вблизи сосуда, но не надолго и в виде миртовой ветки, без опасения за последствия. Он приказывал нам делать, это не боясь гангрены. Истинная чувствительность восстанавливается через четверть часа, и до этого можно рассекать (ампутировать) нечувствительное место».

На территории современной Латинской Америки до вторжения на американский континент в конце XV - начале XVI веков испанских и других европейских завоевателей, хлынувших на новые земли вслед за Христофором Колумбом, существовали высокоразвитые культуры. Главными районами их распространения были Мексика, Центральная Америка и зона Северных и Центральных Анд. Наибольшего развития достигли культуры ацтеков, майя, инков. Медицинские познания индейцев доколониальной Америки были достаточно высокими, а в ряде случаев стояли выше европейских соответствующего периода (Прыгова Н.М., 1978). По мнению современных мексиканских специалистов в области истории медицины - Amezquita и соавт., - медицина мексиканских индейцев хотя и была связана с магией, но имела много рационального и внесла большой вклад в европейскую медицину. Болезнями органов полости рта занимались специалисты, именовавшиеся на языке науатл «нетлантатакони», а зубов - «тланпаланалицтли» или «тланатонауалицтли». Эти врачи широко пользовались в своей практи-

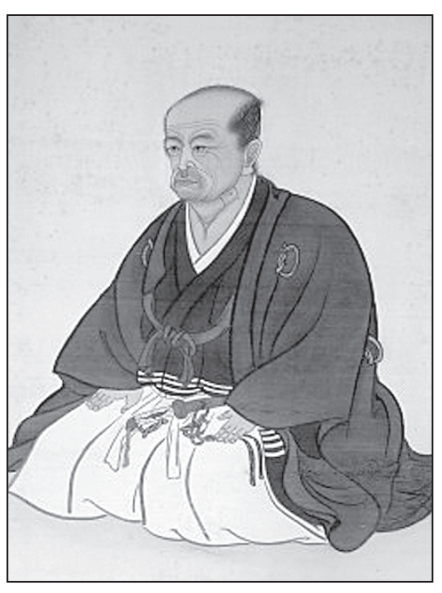

Рис. 6. Сейшу Ханаока (1760-1835)

Ил. любезно предоставлена профессором Yuzuru Kaneko, Япония ке местной анестезией, употребляя экстракт корня мандрагоры, марихуаны, коку, тлапатл (Datura stramonium), пациентам давали вдыхать пары экстрактов из наркотических трав (de la Cruz).

Первое использование общей анестезии, вероятно, было в начале XIX столетия в Японии (Takebayashi H., 1964; Ogata T., 1973). 13 октября 1805 г. доктор Сейшу Ханаока (Seishu Hanaoka - рис. 6) хирургическим путём удалил опухоль молочной железы под общей анестезией. Его пациенткой была 60-летняя женщина по имени Kan Aiya. Bce её сёстры умерли от рака молочной железы. Кан искала помощи у Ханаоки. Для обезболивания он использовал «Tsusensan»применяемую внутрь через рот смесь трав, которую Ханаока подобрал после многочис- 
ленных экспериментов в течение 20 лет. Главный активный компонент растение Chosen-asagao.

В рукописных книгах по медицине значительное место уделялось лечению «зубной боли». Были распространены «заговоры» и заклинания зубной боли, кроме того, на основании опыта народа при заболеваниях зубов принимались различные средства растительного происхождения: камфора, всевозможные полоскания из настоев трав, припарки семенами и др.

С мучительной зубной болью человечество имело дело всегда. Ещё из глубины веков пришла поговорка: «Человек часто забывает, что у него только одна жизнь, но то, что у него тридцать два зуба, - помнит всегда». B XVII веке шотландский поэт Роберт Бёрнс так описал свои страдания в «Оде к зубной боли» (на рукописи есть пометка: «Написано в то время, когда автора терзала зубная боль»):

«Ты, завладев моей скулой,

Пронзаешь десна мне иглой,

Сверлишь сверлом, пилишь пилой

Без остановки,

Мечусь, истерзанный и злой,

Как в мышеловке.

Так много видим мы забот,

Когда нас лихорадка бьёт,

Когда подагра нас грызёт

Иль резь в желудке.

А эта боль - предмет острот

И праздной шутки!

Бешусь я, исходя слюной,

Ломаю стулья, как шальной,

Когда соседи надо мной

В углу хохочут.

Пускай их бесы бороной

В аду щекочут!

(Перевод С. Маршака.)

Даже скульптурное изображение жреца Лаокоона с сыновьями, задушенного в Трое змеями, насланными Афиной, не передает, может быть, настолько весь спектр физических мучений, сколь ярко это изобразил в стихотворной форме Р. Бёрнс. 


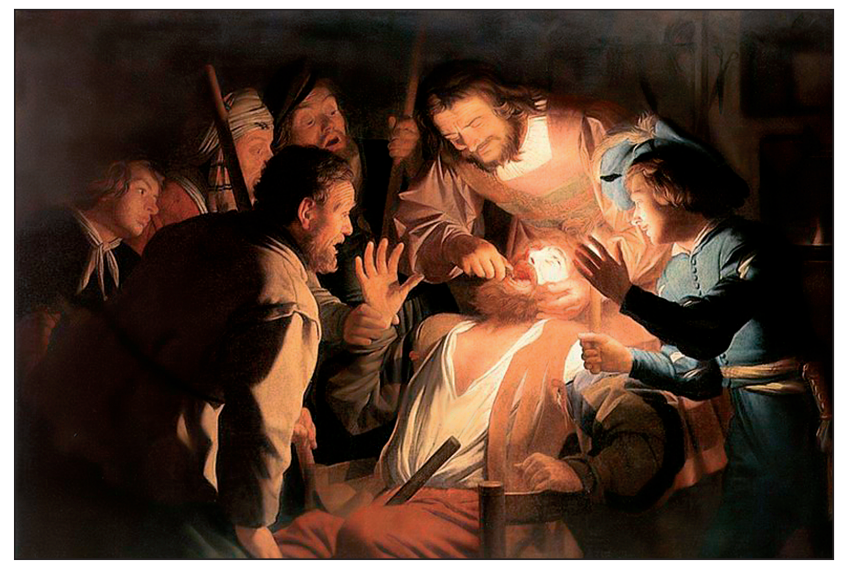

Рис. 7. Дантист (1622 г.), Геррит ван Хонтхорст (1590-1656)

В течение многих веков удаление зубов выполнялось без обезболивания. Удаление зубов - излюбленная тема голландских и итальянских художников XVII века (рис. 7-9). Обращает на себя внимание отсутствие обезболивания при этой операции и наличие глубоко заинтересованных зрителей.

Развитие зубоврачевания в России происходило при Петре I, который сам интересовался и практиковал в этой области. Пётр I овладел техникой удаления зубов и нередко применял её на практике. Он постоянно носил при себе два набора инструментов: математический и хирургический (в последнем находились пеликан и щипцы для удаления зубов).

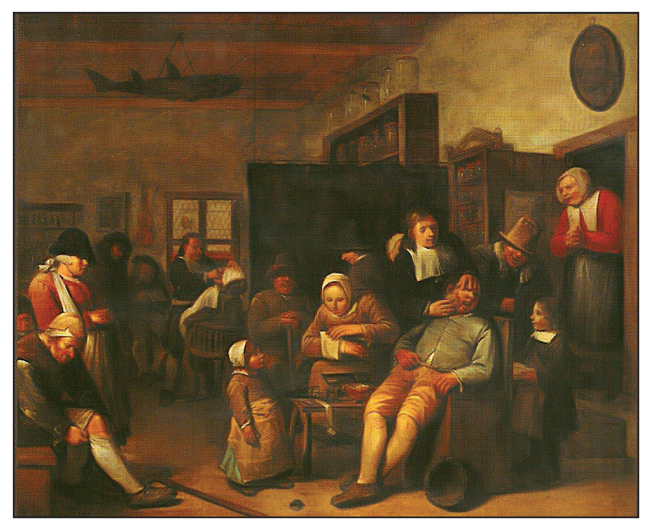

Рис. 8. Заезжие лекари. М. Хемскерк, ок. 1650 г. 


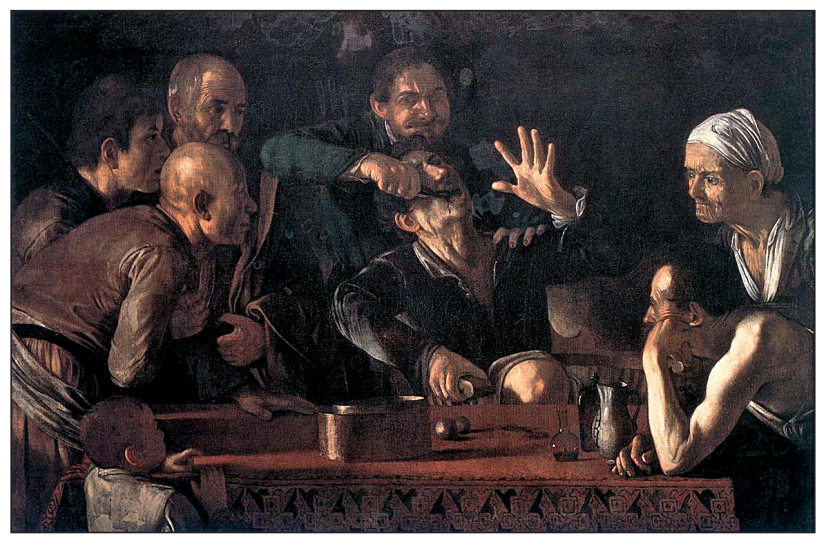

Рис. 9. Микеланджело Меризи да Караваджо «Зубодёр», 1607-09. Галерея degli Uffizi, Флоренция

В Санкт-Петербургском музее антропологии и этнографии хранится «Реестр зубам, дёрганым императором Петром I». В коллекции содержится 73 зуба, удалённых лично Петром I, причём большинство зубов относится к молярам, то есть к группе трудноудаляемых. Несмотря на искривлённость корней, у большинства зубов верхушки сохранены, что свидетельствует о хорошем для того времени владении техникой удаления.

В книге «Седая старина Москвы» написано: «...Царь превосходно рвал зубы. Однажды, гуляя по рынку Амстердама, остановился у лавки одного цирюльника, который дошёл до такого совершенства, что рвал зубы ручкой чайной ложки и концом шпаги. Государь призвал его к себе, велел ему повторить опыты своего искусства и после нескольких уроков не уступал своему учителю. К русскому царю в гостиницу под вывеской слона, где царь жил, стали во множестве приходить голландцы, страдавшие зубной болью. Царь Пётр рвал им зубы очень искусно и платил за то по шиллингу». Это уникальный пример того, что не лекарю платят деньги за лечение, а наоборот. (Цит. по Н. Смирнову, 1998.)

В 1710 г. им было введено звание «зубной врач». С открытием постоянных госпиталей (1707) и госпитальных школ при них стала осуществляться подготовка врачей широкого профиля, в программу обучения которых входило изучение патологии челюстно-лицевой системы (являющейся в то время разделом хирургии). Эта помощь включала ряд терапевтических, хирургических и зубоврачебных мероприятий. Лица, желавшие заняться зубоврачебной практикой в России, должны были сдавать испытания перед медицинской коллегией (что часто не соблюдалось). Из-за нехватки зубных 
врачей население практически было лишено возможности получить зубоврачебную помощь. В народе врачевали люди, которые получали свои навыки путём ученичества (Левицкий А.П., 1899).

Однако вернёмся к хирургии. Большое значение в древние времена приобрело сдавление нервных стволов (так называемая ligatura fortis) как мера, уменьшающая боль при операциях. Этот способ применяли в глубокой древности греки, арабы, в средние века и в начале эпохи Возрождения им пользовались Амбруаз Паре, Шухман (Ambroise Pare, Schuhman) и др. В 1781 г. английский хирург Джеймс Мур предложил в качестве болеутоляющего средства прижатие нервов различными способами: тугим бинтованием конечности, перетягиванием её, пальцевым прижатием, прижатием пелотами (Moore J., 1784). Эта методика встретила энергичную защиту в лице Хантера, Бэлля и других английских хирургов, но, несмотря на это, не нашлось охотников воспользоваться ею на практике, и только гораздо позже Жюве и Лигард применили этот способ в несколько уже изменённом виде. Однако эта методика в истории хирургии неоднократно осуждалась ввиду отрицательных особенностей: болезненности самого сдавления, возможных стойких параличей сдавливаемых нервов и даже гангрены конечности. В 1879 г. Эсмарх (рис. 10) ввёл в целях предварительной остановки кровотечения при операциях эластический жгут, который, помимо своего прямого назначения, сыграл большую роль в дальнейшем развитии анестезии конечностей.
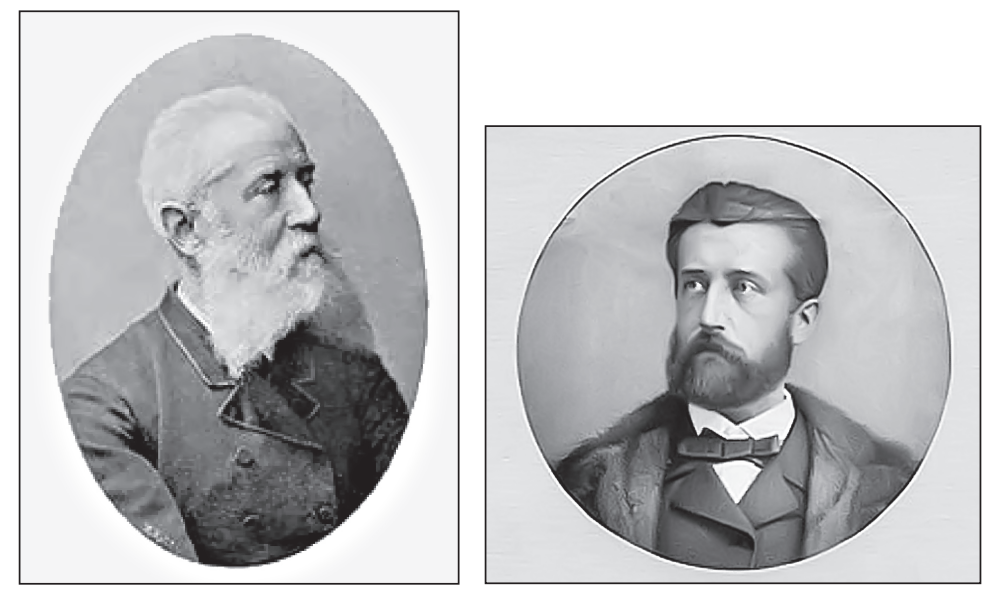

Рис. 10. Фридрих Август фон Эсмарх (1823-1908).

Немецкий хирург, пионер медицины критических состояний и медицины катастроф. Фотография Эсмарха (справа), по всей видимости, сделана в начале 60-х годов XIX века (www.critical.onego.ru) 

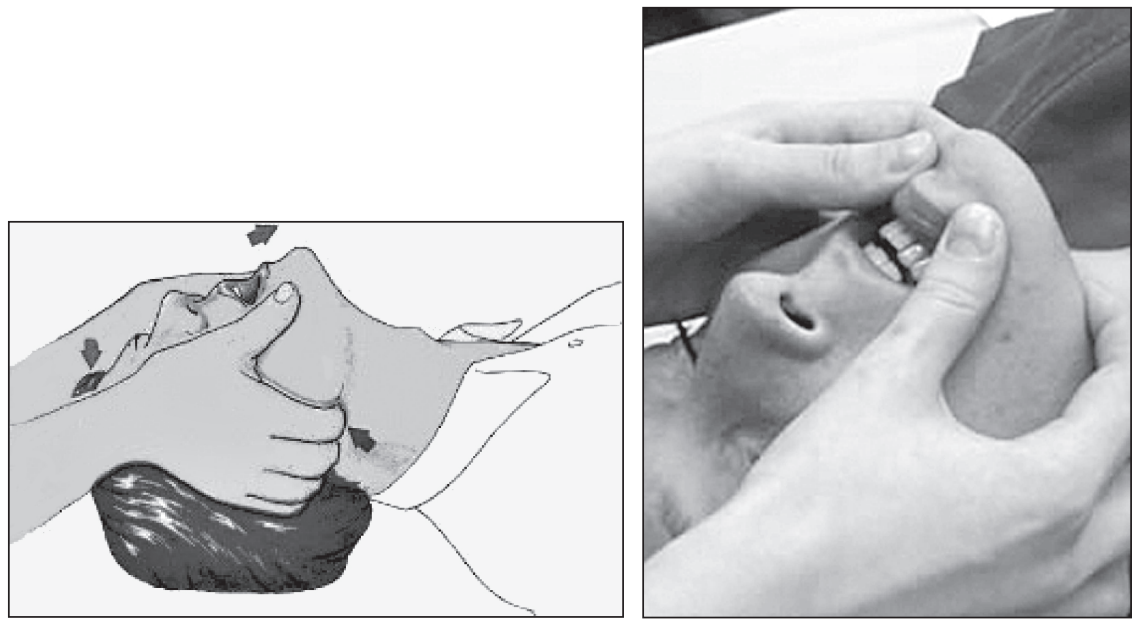

Рис. 11. Приём Эсмарха

Фридрих Эсмарх установил, что причиной асфиксии во время наркоза является обструкция верхних дыхательных путей из-за западения нижней челюсти и атонии языка. Он разработал простой, но, как оказалось, эффективный метод профилактики этого осложнения, заключающийся в выдвижении нижней челюсти вперёд. Для этого наркотизатору (а в настоящее время анестезиологу-реаниматологу) необходимо пальцами обеих рук захватить углы нижней челюсти и переместить её вперёд, большими пальцами надавить на подбородок и тем самым открыть рот. Вот что писал сам Эсмарх по поводу данной процедуры: «При асфиксии необходимо немедленно открыть больному рот, выдвинуть нижнюю челюсть вперёд двумя руками, расположив указательные пальцы на восходящую ветвь и угол челюсти таким образом, что нижние зубы должны выступать кпереди от верхних... Если это не может быть выполнено из-за судорожного сокращения мышц, раздвиньте зубы расширителем, захватите конец языка пальцами или языкодержателем и вытяните язык изо рта насколько это возможно». В настоящее время эта простая процедура называется приёмом Эсмарха и входит в алгоритм элементарных действий при выполнении реанимации (рис. 11).

Другим вкладом Эсмарха в анестезиологию является разработанная им простая проволочная наркозная маска для проведения эфирной анестезии по открытому контуру (1877). Корзинообразный проволочный каркас маски позволял наркотизатору удобнее приспособить маску к лицу пациента вокруг рта и носа. Один конец маски был изогнутым в виде ручки. Над каркасом растягивалась трикотажная или марлевая ткань (6-10 слоев), на 


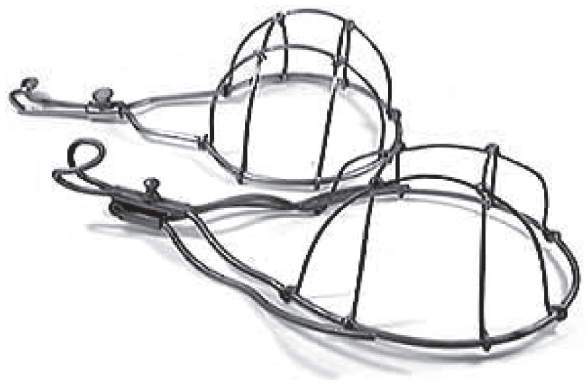

Рис. 12. Маска Эсмарха (www.critical.onego.ru)

которую капали эфир или хлороформ. Поскольку маска не прилегала плотно к лицу больного, он вдыхал пары анестетика вместе с воздухом (рис. 12).

В дальнейшем он разработал специально для военно-полевой хирургии комплект усовершенствованных им же принадлежностей для проведения анестезии хлороформом по открытому контуру. Этот комплект находился в

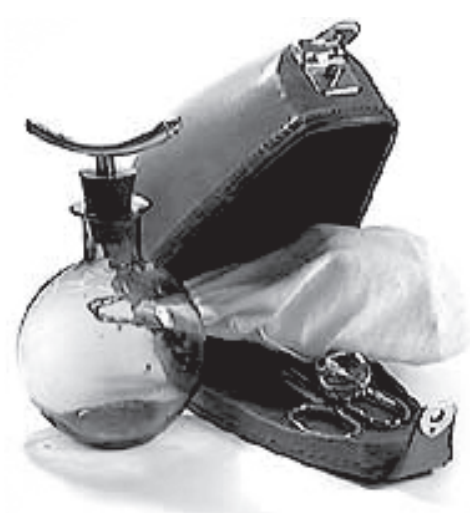

Рис. 13. Наркозный набор Эсмарха для военно-полевой хирургии кожаном чехле и включал в себя языкодержатель, роторасширитель, усовершенствованную маску Эсмарха и градуированную бутыль для хлороформа (рис. 13).

Давно известно действие холода как обезболивающего средства (рис. 14). С середины XVI столетия им пользовались по совету Томаса Бартолина (Thomas Bartholinus, 1661). Затем это средство было забыто, и только спустя два столетия Арнот и Герард (Arnott, Gerard) стали вновь применять его для анестезии. В 1848 г. Арнотт провёл первые опыты по местному анестезирующему действию холода. В 1866 г. был основательно разработан способ местной анестезии при помощи предложенного Ричардсоном (Benjamin Richardson) распыления эфира (рис. 15). В 1867 г. он же предложил ещё два новых анестезирующих средства: метиловый эфир и двухлористый метилен. Распыление эфира при помощи пульверизатора (рис. 16) было наиболее совершенным методом местной анестезии и сохраняет определённое значение и в настоящее время. Л.Л. Левшин так описывал этот метод: «Защитив соседние части кожи ватой, пульверизуют серным эфиром приблизительно на расстоянии 1-3 см от места, где хотят сделать разрез». Через 2-3 мин после начала распыления эфира поверхность кожи белела и замораживалась. Поверхностные слои кожи при разрезе были нечувствительны и бескровны. При более глубоких разрезах появлялись чувствительность и кровотечение. Поэтому и распыление эфира было применимо только при небольших поверхностных операциях - 


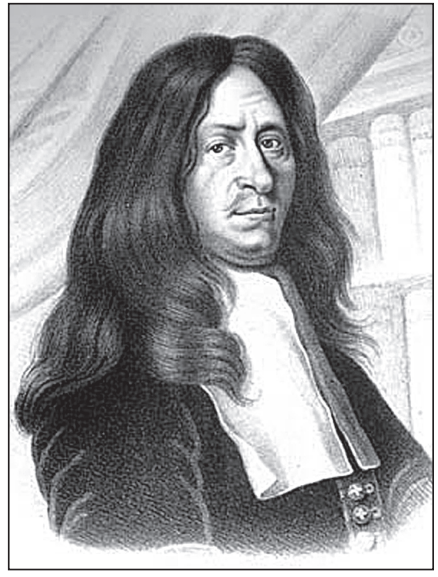

Рис. 14. Томас Бартолин (1616-1680).

Врач, профессор анатомии и математики Копенгагенского университета, лейб-медик датского короля и член Государственного совета. Описал метод местной анестезии с помощью охлаждения снегом

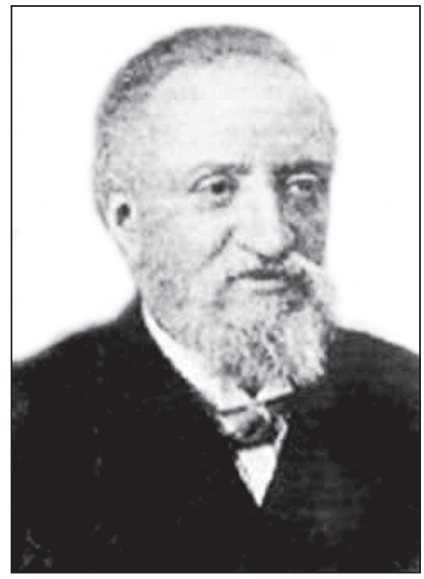

Рис. 15. Бенджамен В. Ричардсон (1828-1896). Английский врач. Использовал эфир для быстрого охлаждения тканей. Возглавлял Лондонское медицинское общество, издавал два медицинских журнала и был известным поэтом, писателем и драматургом, автор научнофантастических романов

вскрытие абсцессов, поверхностных флегмон и т.п.

Для более быстрого действия предполагалось вместо серного эфира применять для разбрызгивания на коже хлорметил, замораживающее действие которого в принципе ничем не отличалось от действия эфира.

Жидкий углекислый газ и сернистый углерод тоже применялись для местного обезболивания, но замораживающее действие, основанное на быстром испарении, мало, чем отличалось от прочих подобных им средств. Кроме того, их применение было громоздко и технически затруднительно.

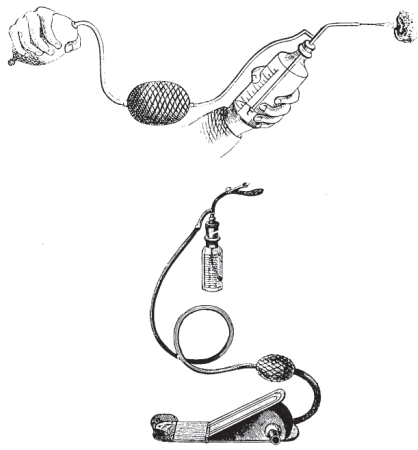

Рис. 16. Распылитель эфира Ричардсона и улучшенное исполнение Welsh, 1866 г. (Ил. W. Hoffmann-Asthelm, 1985 г.) 


\section{ОБЕЗБОЛИВАНИЕ В ЗУБОВРАЧЕВАНИИ ХІХ ВЕКА}

В первой половине XIX века до открытия наркоза и местной инъекционной анестезии основными источниками обезболивания в зубоврачевании были народная медицина и опыт предыдущих поколений. Из далекого прошлого к нам дошли любопытные рекомендации (цит. по Г. Мироненко, 1997): «Зубную боль можно успокоить, если ... обернуть больной зуб маленьким кусочком пергамента, исписанным молитвами; поместить в дупло живую вошь или поцеловать осла, или откусить голову живой мыши, или полоскать зубы утренней мочой ребёнка (предпочтительно мужского пола).

Кай Плиний Старший описал распространённые способы лечения зубной боли в античном Риме:

- лягушку сварить в вине и этим отваром полоскать рот; у кого крепкий желудок - можно съесть лягушку;

- сорок шесть лягушачьих сердец сварить в старом масле и класть масло в ухо соответствующей стороны;

- класть в ухо соответствующей стороны вороний или воробьиный помёт, смешанный с маслом;

- нюхательный порошок вкладывать в ноздрю: у мужчин - левую, у женщин - в правую или противоположной стороны.

Серапиний Старший при затруднённом прорезывании зубов рекомендовал массаж дёсен и смазывание их заячьим мозгом, мёдом и куриным жиром».

После разработки способа Ричардсона с целью анестезии при удалении зубов и для распыления эфира одновременно с обеих сторон альвеолярного отростка применялось предложенное Кюне (Kühne) приспособление - вилкообразный стержень (рис. 17). Получаемое в результате распыления эфира обезболивание было поверхностно и непродолжительно. Следует при этом отметить, что оттаивание замороженных тканей сопровождалось болями.

В России проводились также работы по изучению обезболивающего действия холода (Ефремовский И., 1879; Березовский С.Е., 1890; Маслов Г.А., 1904; клиники, руководимые А. Китером, П.П. Заболоцким-Десятовским и др.).

И. Ефремовский установил, что распыление эфира на слизистую оболочку сопровождается более значительной болезненностью, чем распыление на кожу, и напоминает боль при ожоге второй степени. Он также отметил, что метод обезболивания холодом ото льда вызывает воспалительные явления и иногда даже гангрену, а анестезируются только поверхностные ткани. 


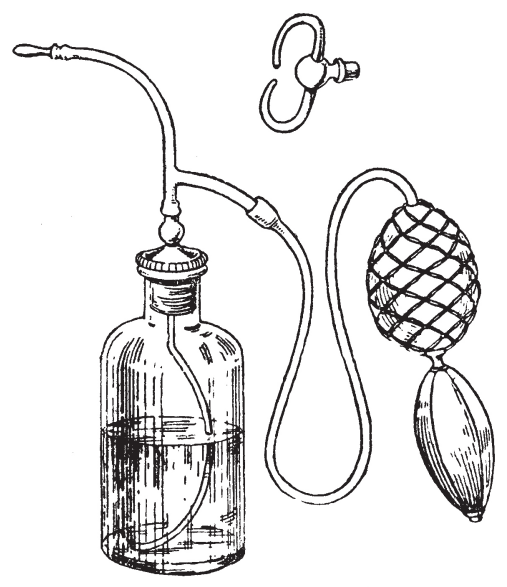

Рис. 17. Распылитель Ричардсона, применявшийся для местного обезболивания при удалении зубов.

(Ил. по С.Н. Вайсблату, 1962.)

С.Е. Березовский испытал как местно-обезболивающее средство хлористый метил (хлорметил). По указаниям автора, хлорметил, несмотря на хорошее обезболивающее действие, из-за многих местных осложнений не получил распространения.

Г.А. Маслов, применивший бромистый этил и хлорметил в зубоврачебной хирургии, указывает, что распыление бромистого этила применяется редко, так как достигаемое им охлаждение быстро проходит, обезболивание недостаточно, применение хлопотливо (требуется аппарат Ричардсона) и нередко вызывает омертвение тканей. Единственным достоинством хлорметила является невоспламеняемость его паров.

В 1867 г. впервые был рекомендован хлорэтил как обезболивающее средство путём замораживания. Из всех замораживающих жидкостей только он сохранил своё значение как местно-обезболивающее средство в общей и стоматологической хирургии (Вайсблат С.Н., 1962). Хлорэтил сравнительно с эфиром давал более быстрое и интенсивное охлаждение, но также на небольшую глубину. Замораживанием с помощью хлорэтила пользовались для вскрытия поверхностных абсцессов и флегмон, а также для удаления зуба.

Обычно он не вызывал некроз тканей, если прекращали замораживание при появлении «снежной полосы». 
Получаемое хлорэтилом обезболивание также поверхностно и кратковременно. Даже удаление не очень подвижного зуба часто сопровождалось значительной болью.

Многие авторы занимались измерением температуры внутри лунки зуба после анестезии десны хлорэтилом и выявили, что температура понижается только до $+19^{\circ}$, а для существенной потери чувствительности необходимо $+4^{\circ}$.

По наблюдениям М. Каменской (1900), Г.А. Маслова (1904), С.Н. Вайсблата (1948), безболезненное удаление зубов под хлорэтиловым замораживанием десны связано с общим действием хлорэтила, когда больные при местном применении препарата вследствие вдыхания его паров впадают в состояние кратковременного полузабытья (анальгетическая стадия наркоза).

В 1894 г. зубной врач Карлсон (Carlson) в результате применения хлорэтила для обезболивания вмешательства во рту обнаружил, что пары хлорэтила вызывают состояние, сходное с наркозом. Это открытие дало основание предложить хлорэтил в качестве средства для наркоза.

Л.Л. Левшин описывает способ химического воздействия на кожу для получения обезболивания. После смазывания кожи расплавленной карболовой кислотой в $85^{\circ}$ спиртовом растворе появляется чувство жжения, сменяющееся анестезией кожи, после чего производят разрез кожи через все слои, не причиняя боли. Предварительное смазывание кожи уксусом усиливало действие фенола.

А.В. Вишневский (1956) отмечает, что настоящая история современных способов местного обезболивания начинается с открытия Вуда (Wood), предложившего вводить лекарственные вещества под кожу при посредстве полых игл (1853). Его метод дал возможность не только вводить вещества в общий круг кровообращения в силу всасывания их из подкожной клетчатки, но и подводить эти вещества к нервам. Из этой мысли он исходил, когда лечил невралгии впрыскиванием морфина по соседству с нервными стволами.

Хирурги сразу воспользовались этим открытием и пытались проделывать различные мелкие операции, впрыскивая больным под кожу в месте предполагаемой операции различные другие вещества: хлороформ [Хантер (Hunter)], глюкозид сапонин [Пеликан, Кёлер (Pelikan, Koeler)] и т.п. Конечно, это было быстро оставлено, так как инъекции в ткани большинства из этих веществ вызывали болезненность и раздражение на месте их введения, и только морфин в силу своего общего действия позволял получать иногда некоторое понижение чувствительности при операциях. Все виды местного обезболивания, сопровождающиеся раздражением и болью до наступления 
анестезии, Либрейх (Libreich) называл «anaesthesia dolorosa» и тогда же показал, что даже дистиллированная вода, введённая в ткань, обладает свойствами вызывать анестезию. Представление, что вещества, действующие как наркотики, должны влиять обезболивающим образом и местно, странным образом сохранялось у хирургов очень долго. Аран (Aran) говорил: «Все летучие вещества, известные как обезболивающие, обладают в равной мере местно-обезболивающим действием при применении их внутрь или на кожу». Однако на самом деле этим качеством обладали лишь некоторые вещества - этилен хлористый, этил и отчасти эфир. Эта «болевая анестезия», вполне естественно, в дальнейшем не нашла практического применения. Подкожное введение растворов морфина и атропина из-за общего действия морфина могло вызывать некоторое понижение болевой чувствительности в месте введения, но не в такой степени, чтобы производить безболезненно даже простейшие хирургические и зубоврачебные вмешательства. Естественно, что сколько-нибудь широкого практического применения подкожное обезболивание не имело. В руководстве под редакцией Питы и Бильрота по этому поводу написано следующее: «Многие врачи теперь ещё верят в местное действие подкожных впрыскиваний. А между тем опыт показывает, что действие впрыскиваний бывает только общее».

Из сказанного надо сделать вывод, что уже в 70-е годы XIX века была подготовлена почва для подкожного введения лекарств - с целью местного обезболивания. Хирургическая мысль работала в этом направлении. Неизвестными оставались вещества, избирательно действовавшие на чувствительные нервные окончания кожи, слизистой оболочки, надкостницы и глубжележащих тканей.

При изучении клинических отчётов больниц и госпиталей 70-х годов XIX столетия A.А. Зыкову (1954) не удалось найти указаний на применение местного обезболивания. Автор пишет: «Если оно и применялось, то, очевидно, в самых незначительных масштабах для простейших хирургических вмешательств».

Очень наглядно соотношение внимания к наркозу и местной анестезии в 70-80 гг. XIX века. В руководстве к общей и частной хирургии под редакцией Бильрота и Люкке в разделе, посвящённом анестезирующим средствам, общей анестезии отведена 251 страница, а местному обезболиванию только 7 (Каппелер О., 1881).

Как же в конце XIX века решалась проблема местной анестезии в зубоврачебной практике? Начнём с рассмотрения вопроса обезболивания при удалении зуба. В «Руководстве по зубоврачебной науке» Д.С. Леви (1882) пишет: «Для того чтобы подавить неизбежную при выдергивании 
боль или, по крайней мере, уменьшить её, при зубоврачебных операциях, соединённых с сильными болями, прибегают к анестезии. Здесь следует строго отличать местную от общей (наркоза); тогда как при первой только оперируемая часть делается нечувствительной и никогда не бывает серьёзных последствий, вторая действует на мозг и, лишая сознания, ведёт к общей нечувствительности (анестезии). Местная анестезия только в некоторых случаях приносит пользу и, по причине неверности действия, мало употребляется. Сюда относятся: 1) действие холода посредством Ричардсоновского эфирного пульверизатора и 2) разогревания окружающих мягких частей посредством calorific fluid Снэпа. Оба эти способа при хороших условиях, то есть если зуб вообще можно выдернуть без особенных болей, дают благоприятные результаты. Если же подлежащий извлечению зуб стоит крепко в челюсти, и если при экстракции его неизбежна сильная боль, то ни одно из обоих средств не принесёт существенной пользы. Электричество было применено в различных случаях как средство, вызывающее местную анестезию; о нём можно сказать то же, что уже было высказано по поводу других средств. Кроме того, иногда благоприятный успех заключается в воображении больного».

Говоря о наркозе и целесообразности обезболивания, автор сообщает следующее: «Здесь, прежде всего, нужно обратить внимание, следует ли вообще прибегать при зубных операциях к общей анестезии, имевшей иногда гибельные последствия. Отдельные болезненные зубные операции, как-то: извлечение зуба, экстирпация пульпы и т.д. - так непродолжительны, что непростительно, ради такой пустой операции, подвергать жизнь человека опасности. Бывают, однако, положения, где мы принуждены прибегнуть к общему наркозу: выдергивание зуба мудрости при полном анкилозе, необходимость одномоментного удаления большого числа крепко сидящих зубов, также выраженное желание больным только при общем наркозе подвергнуться операции."

В «Руководстве зубных болезней» Ю. Шефф (1882), касаясь местной анестезии при «извлечении зубов», указывает: «Сюда относится холод, смачивание десны над и под удаляемым зубом эфиром и местное применение электричества. Richardson устроил особый аппарат, эфирный spray, которым эфир направляется в виде мельчайшего дождя на оперируемое место десны. В новейшее время в торговле появилось новое средство «calorific fluid», которое расхваливается как местно-анестезирующее. Об успехах его до сих пор ничего не известно».

B 1890 г. в руководстве по зубным болезням J. Parreidt, касаясь вопроса обезболивания «при извлечении зубов», пишет: «Так как извлечение зубов 
нередко представляет весьма болезненную операцию, то больные обыкновенно испытывают перед ним большой страх и сплошь и рядом, елико возможно, откладывают его в долгий ящик. В силу этого приходится подчас даже и при такой кратковременной операции прибегать к наркозу...»

Так как согласно имеющимся пока наблюдениям ни одно narcoticum не представляется абсолютно безопасным, то снова начали обращаться к местной анестезии. Эфирное орошение известно было уже раньше; но несколько лет тому назад его опять попробовали применять при извлечении зубов в форме, предложенной v. Lesser'oм. К сожалению, холод даже в лучшем случае действует крайне ненадёжно.

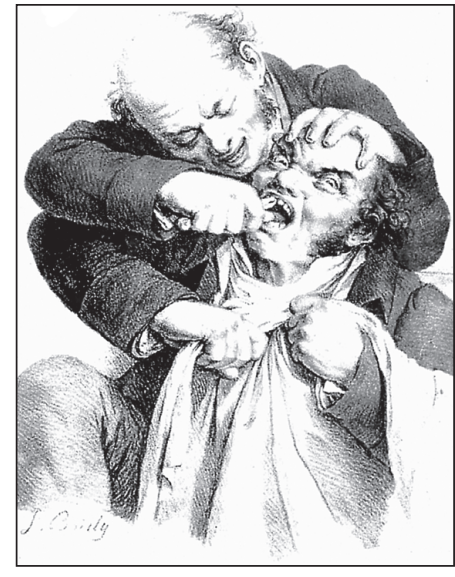

Рис. 18. Удаление зуба без анестезии. (Ил. по А.Ж. Петрикасу, 1997.) Начнём, прежде всего с того, что при пульпите он совсем не переносится, а при альвеолярном периостите давление, производимое платиновыми ящичками, в которых испаряется эфир при Lesser'овском аппарате, точно так же причиняет жестокую боль. Таким образом, только для periostitis dentalis и некоторых других случаев остаётся возможным применять Lesser'овский аппарат.

Прочие средства столь же ненадёжны или даже ещё менее действенны, нежели холод. Это относится также и к кокаину, если употреблять только смазывания, а не инъекции. Впрыскивание 0,03 (gr. 1/2) кокаина в десну близ зуба, подлежащего извлечению, по-видимому, значительно уменьшает болезненность этой операции».

Partsch (Парч) в 6 главе многотомного руководства по хирургии под редакцией Е. Бергмана и П. Брунса (1901), описывая «извлечение зубов», ни слова не говорит об анестезии (рис. 18).

Как же обстояло дело с обезболиванием при пульпите? В 1885 г. предложена внутрипульпарная инъекция - Book, Германия. В этом же году E.H. Raynold (США) впервые провёл аппликационную анестезию кокаином обнажённой пульпы клыка (Петрикас А.Ж., 1997). Намного ранее, в «Руководстве к преподаванию в хирургии» И.Ф. Буш (1807) при лечении пульпита рекомендует перед пломбированием производить выжигание пульпы раскалённой иглой.

Ю. Шефф в «Руководстве зубных болезней» для устранения зубной боли предлагает мышьяковистую пасту и карболовую кислоту. Приводит 
несколько рецептов, содержащих наркотики, для местной анестезии при непосредственном соприкосновении с обнажённой пульпой: настойка опия, настойка, состоящая из морфия, спирта и хлороформа; пилюли, содержащие креозот. После приготовления рекомендовалось «вкладывать на вате на болящую полость». При остром периодонтите в первом периоде рекомендует применение холода в виде часто переменяемых холодных примочек снаружи и в виде ледяных пилюль, часто принимаемых внутрь. Холод продолжают применять до исчезновения воспалительных симптомов. При начале воспаления, т.е. в первый период, «йодная настойка даёт блестящие результаты ... смазыванием десны, соответствующей верхушке корня и на смежные места ... На следующий день смазанная часть слизистой оболочки десны снимается в виде белых лоскутков ...» Если болезненность сохраняется, переходят к согревающим компрессам, припаркам и полосканиям (отваром мальвы с молоком и настойкой опия).

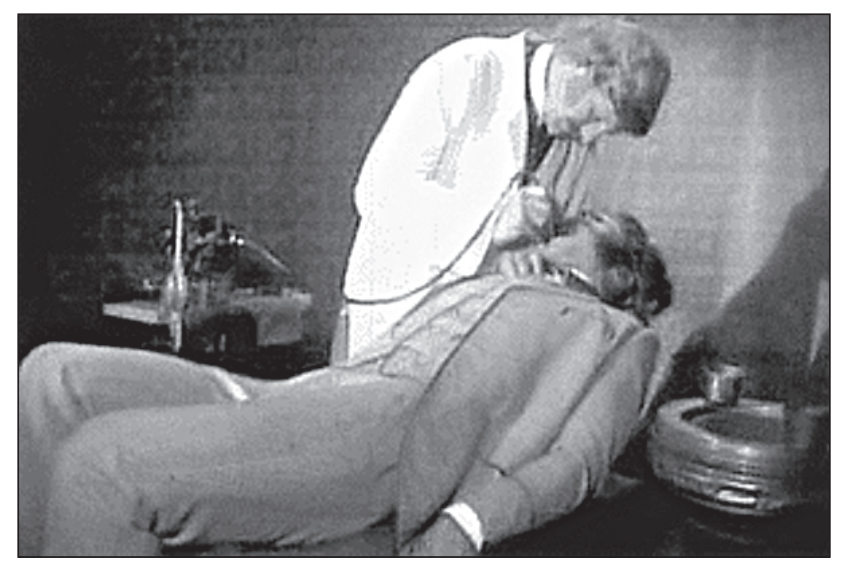

Рис. 19. Былые времена... Лечение зуба. (Ил. по М. Lipp, 1992.)

А вот как описывает обезболивание при воспалении пульпы J. Parreidt (1890): «Удаляют пломбу, прижигают и выскабливают зубную мякоть». Для прижигания автор рекомендует мышьяк, к которому прибавляют небольшое количество карболовой кислоты. Вместо морфия - употребление йодоформа. Паррейдт пользовался прижигающим средством следующего состава:

Rp. Acid arsenicosi

Pulv. Jodoform. pur. alcoholisat.

Acid. carbolic. pur. ana. 
В.Д. Миллер (1898) в «Руководстве консервативного зубоврачевания» при пульпите с целью обезболивания предлагает «применение местноанестеризующих средств, смазывание поверхности ляписом, двууглекислым натром, прижигание гальванокаутером».

Таким образом, практически большинство удалений зубов в то время проводилось без всякой анестезии, а обезболивание пульпы в редких случаях осуществлялось по типу «болевой анестезии» (рис. 19). Причиной тому был ограниченный и часто неверный арсенал средств местного обезболивания, отношение хирургов и дантистов к зубоврачебным вмешательствам, как к малозначимым, и, по-видимому, более высокая выносливость боли, чем у современного человека. 


\section{ОТ ОТКРЫТИЯ ЭФИРНОГО НАРКОЗА ДО МЕСТНОГО ОБЕЗБОЛИВАНИЯ (Лавина открытий - кто же первый?)}

Реальные предпосылки для разработки эффективных методов обезболивания начали складываться в конце XVIII века. Определяющее значение имело интенсивное развитие естественных наук, особенно химии и физики. Среди многочисленных открытий того периода было получение в чистом виде кислорода (Шееле, 1972 и Пристли, 1974) и закиси азота (Пристли Д., 1772). Официально признанные претенденты на приоритет в открытии кислорода: Карл Вильгельм Шееле, Джозеф Пристли, Антуан Лавуазье.

В классической дискуссии по поводу открытия кислорода рассматриваются кандидатуры сразу трёх учёных, имеющих законное право претендовать на это великое открытие. Это шведский химик Карл Вильгельм Шееле, английский священник Джозеф Пристли (Joseph Priestley, 1733-1804), и французский химик Антуан Лавуазье (Lavoisier, Antoine Laurent, 1743-1794). Возможно, наличие такого обилия претендентов связано с тем, что пред-

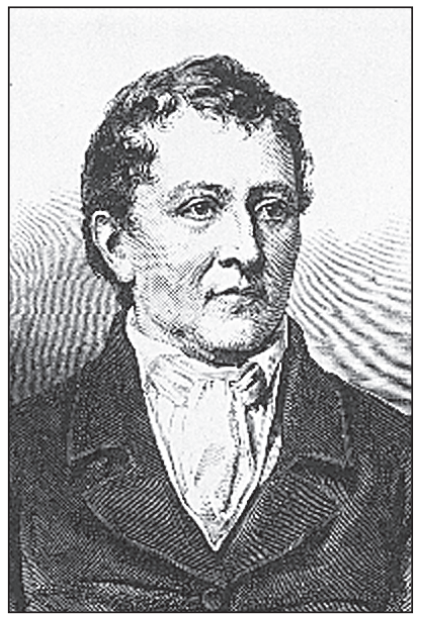

Рис. 20. Carl Wilgelm Scheele, 1742-1786 - шведский химик шествующий открытию кислорода прогресс нормальной науки, в данном случае химии газов, весьма основательно подготовил почву для этого события. Самым первым претендентом, получившим относительно чистую пробу кислорода, был шведский аптекарь Карл Вильгельм Шееле (рис. 20).

Наиболее значительный труд Карла Вильгельма Шееле - Химический трактат о воздухе и огне (Chemische Abhandlung von der Luft und dem Feuer, 1777 г.). Эта книга содержит результаты его многочисленных экспериментов 1768-1773 гг. по исследованию газов и процессов горения. Из Трактата видно, что Шееле - независимо от Пристли и Лавуазье и за два года до них - открыл кислород и подробно описал его свойства. При этом кислород был получен им многими способами: прокаливанием оксида ртути (как это сделали 
Пристли и Лавуазье), нагреванием карбоната ртути и карбоната серебра и т.д. Несомненно, Шееле первым (1772) «держал в руках» чистый кислород.

По некоторым данным уже в 1771 г. Карл Шееле при нагреве пиролюзита с концентрированной серной кислотой наблюдал выделение «виртольно20 воздуха», поддерживающего горение, т.е. кислорода.

Карл Шееле хотел раскрыть загадку огня и при этом неожиданно обнаружил, что воздух - не элемент, а смесь двух газов, которые он называл воздухом «огненным» и воздухом «негодным». Это было величайшим из всех открытий Шееле.

Но в действительности тайна огня и полученного им «огненного» воздуха так и осталась для него тайной. Во всём была виновата господствовавшая в те времена теория флогистона, по которой считалось, что всякое вещество может гореть только в том случае, если в нём много особой горючей материи - флогистона, а горение представляет собой распад сложного горючего вещества на особый огненный элемент - флогистон - и другие составные части. Карл Шееле тоже был сторонником этой теории, поэтому он объяснял, что «огненный воздух» имеет большое сродство (влечение) к флогистону, поэтому и сгорает в нём так быстро, а «негодныци» воздух не имеет влечения к флогистону, поэтому в нём и гаснет всякий огонь. Это было довольно правдоподобно, но оставалась одна большая загадка, которая казалась совершенно необъяснимой. Куда уходил во время горения «огненный» воздух из закрытого сосуда? Наконец, он придумал такое объяснение. Когда сгорает какое-нибудь тело, говорил он, то выделяющийся из него флогистон соединяется с «огненным» воздухом и это невидимое соединение настолько летуче, что оно незаметно просачивается сквозь стекло, как вода сквозь сито.

С флогистоном покончил другой великий химик XVIII века - француз Антуан Лавуазье. И когда это было сделано, то странное исчезновение «огненного воздуха» и многие другие непонятные явления сразу потеряли всю свою загадочность. Шееле действительно был первым исследователем, получившим относительно чистую пробу кислорода (1772). Однако он опубликовал свои результаты в 1777 г., позже, чем это сделал Джозеф Пристли, поэтому формально он не может считаться первооткрывателем кислорода. Но во многих академических изданиях и справочниках по химии приоритет отдаётся именно Карлу Вильгельму Шееле. Кроме того, ему принадлежит неоспоримый приоритет открытия химических элементов хлора $\mathrm{Cl}$, фтора F, бария Ва, молибдена Мо, вольфрама W...

Несмотря на то, что Шееле не имел высшего образования и был рядовым аптекарем, в возрасте 32 лет он был избран членом Стокгольмской 
академии наук. Ему предлагали кафедру в Упсальском университете, работу в центре шведской горнометаллургической промышленности в Фалуне, кафедру в Берлинском университете, однако учёный отклонял все предложения, предпочитая заниматься своими опытами.

Годы упорного самоотверженного труда, к сожалению, подорвали здоровье этого поразительно целеустремлённого человека, и он прожил всего до 44 лет. В истории химии с открытием Шееле цианистого водорода связан ещё один миф: якобы его первооткрыватель погиб в момент открытия. Это, так сказать, полуправда. На самом деле Шееле впервые получил синильную кислоту из жёлтой кровяной соли в 1782 г., а умер в 1786 г., в возрасте 44 лет. Однако не подлежит сомнению, что Шееле погубили органолептические методы исследования. В XVIII веке было принято пробовать на вкус продукты реакции, а Шееле, помимо цианидов, работал с соединениями ртути и мышьяка... Умер К.В. Шееле в Чёпинге 21 мая 1786 г.

Вторым официально признанным претендентом на лавры первооткрывателя кислорода является английский священник и химик Джозеф Пристли (рис 21). 1 августа 1774 г. Пристли наблюдал выделение «нового воздуха»

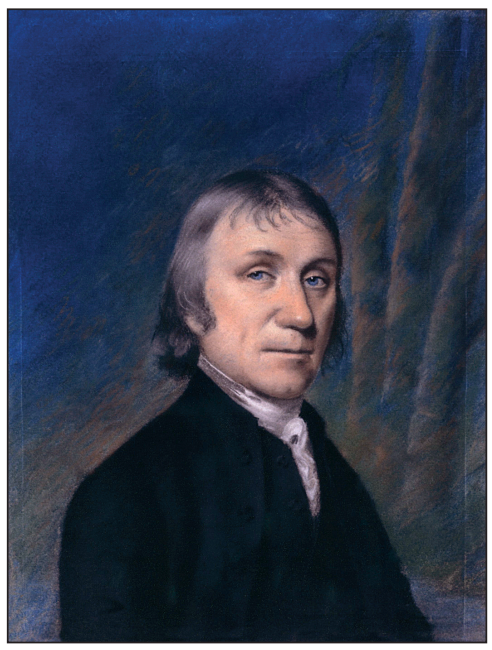

Рис. 21. Джозеф Пристли (Joseph Priestley, 1733-1804) - английский священник, химик, философ, общественный деятель. Анестезиологам всего мира имя Джозефа Пристли в первую очередь памятно и дорого в связи с открытием им в 1772 г. закиси азота, впоследствии ставшей широко применяемым и популярным анестетиком. Он также открыл чистый газ, сейчас известный как кислород (Ellen Sharples, 1794) 
при нагревании с помощью двояковыпуклой линзы без доступа воздуха ртутной окалины, находящейся под стеклянным колпаком. Это твёрдое вещество было известно ещё алхимикам под названием «меркуриус кальцинатус пер се», или жжёная ртуть. На современном химическом языке это вещество называется оксидом ртути, а уравнение его разложения при нагревании выглядит следующим образом:

\begin{tabular}{|c|c|c|c|c|}
\hline $2 \mathrm{HgO}$ & $=$ & $2 \mathrm{Hg}$ & + & $\mathrm{O}_{2}$ \\
\hline оксид ртути & нагревание & ртуть & & кислород \\
\hline
\end{tabular}

Получаемый при нагревании оксида ртути неизвестный ему газ он выводил через трубку в сосуд, заполненный не водой, а ртутью, так как Пристли уже ранее убедился в том, что вода слишком хорошо растворяет газы. В собранный газ Пристли из любопытства внёс тлеющую свечу, и она вспыхнула необыкновенно ярко.

Вы можете теперь представить, как трудно было изучать химию во времена, когда химические формулы ещё не были изобретены. То, что мы только что записали коротким химическим уравнением, Пристли описал в 1774 г. следующим образом: «Я поместил под перевёрнутой банкой, погружённой в ртуть, немного порошка «меркуриус кальцинатус пер се». Затем я взял небольшое зажигательное стекло и направил лучи Солниа прямо внутрь банки на порошок. Из порошка стал выделяться воздух, который вытеснил ртуть из банки. Я принялся изучать этот воздух. И меня удивило, даже взволновало до глубины моей души, что в этом воздухе свеча горит лучше и светлее, чем в обычной атмосфере».

Разумеется, такое описание реакции выглядит весьма поэтично по сравнению с обычным химическим уравнением, но, к сожалению, суть произошедшей химической реакции не отражает.

Сам Пристли, будучи, как и Шееле, сторонником теории флогистона, тоже так и не смог объяснить суть процесса горения; он защищал свои представления даже после того, как Антуан Лавуазье обнародовал новую теорию горения.

Претензии сторонников Джозефа Пристли по поводу открытия именно этим учёным кислорода основывались на его приоритете в получении газа, который позднее был признан особым, не известным до тех пор видом газа. Но проба газа, полученного Пристли, не была чистой, и если получение кислорода с примесями считать его открытием, тогда то же в принципе можно сказать обо всех тех, кто когда-либо заключал в сосуд атмосферный воздух. 


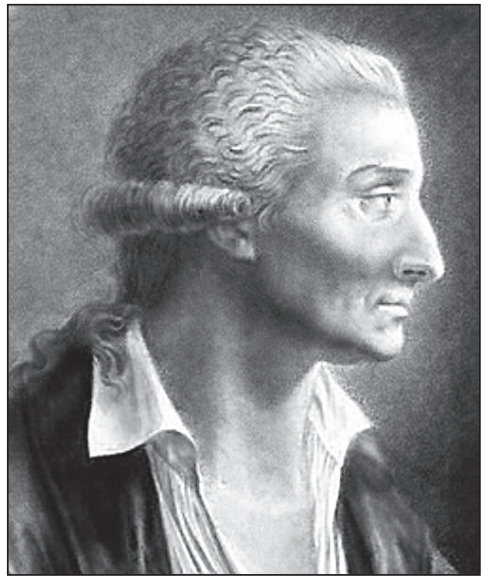

Рис. 22. Антуан Лоран Лавуазье

(Lavoisier, Antoine Laurent, 1743-1794)
Кроме того, если Пристли был первооткрывателем, то когда в таком случае было сделано открытие? В 1774 г. он считал, что получил закись азота, то есть разновидность газа, которую он уже знал. В 1775 г. он полагал, что полученный газ является дефлогистированным воздухом, но ещё не кислородом. То есть, в 1775 г. Джозеф Пристли отождествил газ, полученный им при нагревании красной окиси ртути, с воздухом вообще, но имеющим меньшую, чем обычно, дозу флогистона. Для химика, придерживающегося теории флогистона, это, конечно же, был совершенно неведомый ранее вид газа.

Третий официальный претендент в первооткрыватели кислорода, французский химик Антуан Лавуазье (рис. 22) начал свою работу, которая привела его к открытию, после эксперимента Джозефа Пристли в 1774 г., и, возможно, благодаря намёку со стороны Пристли. Из своих собственных опытов и предшествовавших опытов Пристли и Шееле Лавуазье уже знал, что с горючими веществами связывается лишь одна пятая часть воздуха, но природа этой части была ему неясна. Когда же Пристли сообщил ему в 1774 г. об обнаружении «деблогистированного воздуха», он сразу понял, что это и есть та самая часть воздуха, которая при горении соединяется с горючими веществами. Повторив опыты Пристли, Лавуазье заключил, что атмосферный воздух состоит из смеси «жизненного» (кислород) и «удушливого» (азот) воздуха и объяснил процесс горения соединением веществ с кислородом.

В начале 1775 г. Лавуазье сообщил, что газ, получаемый после нагревания красной окиси ртути, представляет собой «воздух как таковой без изменений (за исключением того, что)... он оказывается более чистым, более пригодным для дыхания». К 1777 г., вероятно, не без второго намёка Пристли, Лавуазье пришёл к выводу, что это был газ особой разновидности, один из основных компонентов, составляющих атмосферу. Правда, сам Пристли как сторонник теории флогистона с таким выводом никогда не смог бы согласиться.

Таким образом, более главной фигурой в истории открытия кислорода является Лавуазье, а не Шееле и Пристли. Они просто выделили новый газ - 
и только. Позже Фридрих Энгельс напишет об этом: «Оба они так и не узнали, что оказалось у них в руках. Элемент, которому суждено было революиионизировать химию, пропадал в их руках бесследно... Собственно открывщим кислород, поэтому остаётся Лавуазье, а не те двое, которые только описали кислород, даже не догадываясь, что они описывают».

Исследования Антуана Лавуазье сыграли выдающуюся роль в развитии химии XVIII века. Речь идёт, прежде всего, о создании им научной теории горения, ознаменовавшей отказ от теории флогистона, что кардинально отличает его работы от экспериментов Шееле и Пристли.

В борьбе со сторонниками теории флогистона у Лавуазье был замечательный союзник, который хорошо помогал ему в работе. Шееле и Пристли тоже имели такого союзника, но они не всегда пользовались его услугами и не придава-

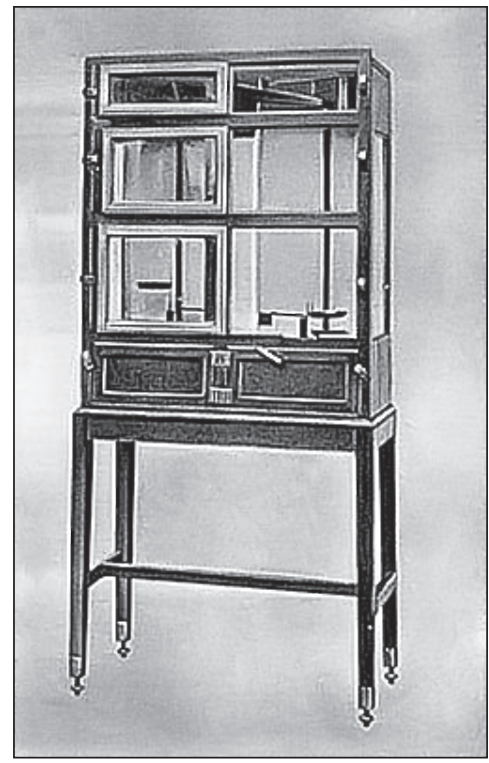

Рис. 23. Весы, которыми пользовался Лавуазье для своих опытов в конце XVIII века ли большого значения его советам. Главным помощником Лавуазье были... весы (рис. 23).

Приступая к какому-нибудь опыту, Лавуазье почти всегда тщательно взвешивал все вещества, которые должны были подвергнуться химическому превращению, а по окончании опыта снова взвешивал. Как и Шееле, Лавуазье тоже пробовал сжигать фосфор в закрытой колбе. Но Лавуазье не терялся в догадках, куда исчезала пятая часть воздуха при горении. Весы дали ему на этот счёт совершенно точный ответ. Перед тем как положить кусок фосфора в колбу и поджечь, Лавуазье его взвесил. А когда фосфор сгорел, Лавуазье взвесил всю сухую фосфорную кислоту, которая осталась в колбе. По теории флогистона фосфорной кислоты должно было получиться меньше, чем было фосфора до горения, так как, сгорая, фосфор разрушался и терял флогистон. Если даже допустить, что флогистон вовсе не имеет веса, то фосфорная кислота должна весить ровно столько, сколько весил фосфор, из которого она получилась. Однако выяснилось, что белый иней, осевший на стенках колбы после горения, весит больше сгоревшего фосфора. Следовательно, та самая часть воздуха, которая якобы исчезла из колбы, 
в действительности вовсе не уходила из неё, а просто присоединилась во время горения к фосфору. От этого соединения и получилась фосфорная кислота. Теперь мы называем это вещество фосфорным ангидридом. Лавуазье понимал, что горение фосфора не исключение. Его опыты показали, что всякий раз, когда сгорает любое вещество или ржавеет металл, происходит то же самое.

Интересно, что наш гениальный соотечественник Михаил Васильевич Ломоносов ещё за пятнадцать лет до Лавуазье сравнивал вес запаянной реторты с металлом до и после прокаливания. "Деланы опыты в заплавленных накрепко сосудах, чтобы исследовать: прибывает ли вес металла от чисто20 жара», - записал Ломоносов в 1756 г., и в двух строчках прибавил результат: «Оными опытами нашлось, что... без пропущения внешнего воздуха вес сожжённого металла остаётся в одной мере». Так Ломоносов нанёс сильный удар по разделявшейся химиками того времени теории флогистона. Но мало этого: Ломоносов сделал из своих опытов и другой замечательный вывод, что «все перемены, в натуре случающиеся, такого суть состояния, что, сколько чего у одного тела отнимется, столько присовокупиться к другому, так, ежели где убудет несколько материи, то умножится в другом месте». Этими словами великий учёный выразил один из важнейших законов химии - закон сохранения вещества.

Свои опыты по изучению горения веществ Лавуазье начал в 1772 г. и к концу года представил в Академию некоторые показавшиеся ему важными результаты. В прилагаемой им записке сообщалось, что при сгорании серы и фосфора вес продуктов горения становится больше, чем вес исходных веществ, за счёт связывания воздуха, а вес свинцового глета (оксида свинца) при восстановлении до свинца уменьшается, при этом выделяется значительное количество воздуха.

В 1877 г. учёный выступил со своей теорией горения на заседании Академии наук. Сделанные им выводы существенно ослабляли основы теории флогистона, а окончательное поражение ей было нанесено исследованиями состава воды. В 1783 г. Лавуазье, повторив опыты Кавендиша по сжиганию «горючего» воздуха (водорода), сделал вывод, что «вода не есть вовсе простое тело», а является соединением водорода и кислорода. Её можно разложить пропусканием водяного пара через раскалённый докрасна ружейный ствол. Последнее он доказал совместно с лейтенантом инженерных войск Ж. Мёнье.

Так кто же, в конце концов, является первооткрывателем кислорода? И когда он был открыт? Претензии Антуана Лавуазье на этот счёт являются более убедительными и основательными, но даже и они оставляют под собой почву для очень больших сомнений. 
Всё дело в том, что подробное изучение свойств кислорода и его роли в процессах горения и образования окислов привело Лавуазье к неправильному выводу о том, что этот газ представляет собой кислотообразующее начало. В 1779 г. Лавуазье даже ввёл для кислорода название «оxygenium» (от греч. «окис» - кислый, и «геннао» - рождаю) - «рождающий кислоты».

И в 1777 г., и до конца своей жизни Лавуазье настаивал на том, что кислород представляет собой атомарный «элемент кислотности» и что кислород как газ образуется только тогда, когда этот «элемент» соединяется с «теплородом», с «материей теплоты». Можем ли мы на этом основании говорить, что кислород в 1777 г. ещё не был открыт? Подобный соблазн может возникнуть, и возникает. Элемент кислотности был изгнан из химии только после 1810 г., а понятие теплорода умирало ещё до 60-х годов XIX века. Кислород стал рассматриваться в качестве обычного химического вещества ещё до этих событий, но открытие кислорода, по всей видимости, является плодом коллективного разума и взаимоиндуцирующего творчества всех перечисленных выше учёных, а, возможно, и Мао Хоа, и Дребелля (www. ctitical.ru).

То, о чём писал Лавуазье в своих статьях, начиная с 1777 г., было не столько открытием кислорода, сколько кислородной теорией горения (рис. 24). Эта теория была ключом для перестройки химии, причём такой основательной, что её обычно называют революцией в химии. Задолго до того, как Лавуазье сыграл свою роль в открытии нового газа, он был убеждён, что в теории флогистона было что-то неверным, и что горящие тела поглощают какую-то часть атмосферы. Многие соображения по этому вопросу он сообщил в заметках, отданных на хранение во Французскую Академию в 1772 г. Работа Лавуазье над вопросом о существовании кислорода дополнительно способствовала укреплению его прежнего мнения, что где-то был допущен просчёт. Она подсказала ему то, что он уже готов был открыть, природу вещества, которое при окислении поглощается из атмосферы.

XIX век был веком промышленной революции и социальных преобразований феодальной формации в капиталистическую. Это был век научных открытий - электричества и законов наследственности, радиоактивности и микробов как причины инфекционных болезней. В ряду этих открытий стоит и открытие наркоза, чему предшествовали в значительной мере эмпирические, но и частично научные попытки устранить боль при хирургических вмешательствах. Эта идея принадлежит не одному человеку. Историю анестезиологии - как, впрочем, и всю историю человечества - делали высокие профессионалы и вместе с тем разносторонние личности. Многие из них прославились не только в медицине, но и в других сферах деятельности. Они называются врачами-труэнтами, которых история анестезиологии 


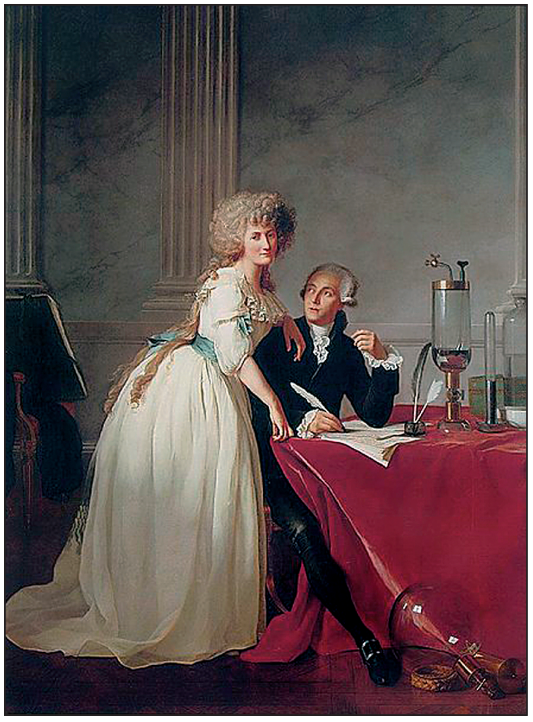

Рис. 24. Антуан Лавуазье с женой в лаборатории. Художник Жак Луи Давид (Jacques-Louis David, 1748-1825). Холст, масло, 259,6х196 см. Мемориальный музей искусства, Нью-Йорк

насчитывает свыше ста (Зильбер А.П., 1996). Продолжающиеся споры о том, кто открыл наркоз - Уэллс или Мортон, Хикмен или Лонг, беспредметны. Они чаще свидетельствуют о желании поднять престиж своей страны, нежели выяснить действительную роль того или другого исследователя. Первыми общими анестетиками были ингаляционные препараты: эфир, закись азота и хлороформ. Важно отметить, что зубная боль была главным стимулом к необходимости обезболивания.

Термин «эфир» происходит от греческого слова aityr или персидского attar, что означает небесный огонь, самый чистый элемент. Эфир впервые был открыт в 1200 г. Раймондом Люллиусом (Raymond Lullius). Он был известен под названием сладкого купороса. В 1540 г. Парацельс установил его обезболивающие свойства. В том же году эфир синтезирован из алкоголя и серной кислоты Валериусом Кордусом (Valerius Cordus), доцентом медицинского факультета в Виттенберге, автором первой Европейской Фармакопеи. Кордус назвал полученное им летучее вещество сладким купоросным маслом (oleum vitriole dulcererum).

Роберт Бойль (Boyle) в 1680 г. вторично синтезировал эфир, Исаак Ньютон в 1704 г. в поисках синтеза искусственного золота открыл эфир в третий раз и, наконец, Фробениус в 1730 г. синтезировал это вещество в четвёртый раз и назвал его эфиром. В 1744 г. Меттью Турнер опубликовал работу под названием «Необычная жидкость, называемая эфиром», где он указывал целебное свойство эфира при приёме внутрь и вдыхании его вместе со спиртом.

В 1794 г. эфир был испытан для вдыханий с целью уменьшения болей, а в 1795 г. Беддо (Beddoes) создал так называемый Медицинский пневматический институт для лечения различных лёгочных заболеваний газами, или, как тогда их называли, искусственным воздухом. Вдыхание паров эфира продолжало оставаться драгоценным средством в руках врачей, хотя они 
и пользовались им далеко не с целью вызвать анестезию при производстве хирургических операций. Уоррен (Warren) и Вулкомб (Woolcombe) в начале XIX столетия пробовали лечить чахотку вдыханиями паров эфира. Англада (Anglada) из Монпелье при помощи того же средства исцелял невралгические боли.

В 1818 г. великий английский естествоиспытатель Майкл Фарадей (рис. 25) сообщил аналогичные свойствам закиси азота, данные в отношении диэтилового эфира, при этом он «передал случай, бывший с одним молодым человеком, который вследствие ингаляции паров эфира оставался в бесчувственном состоянии в течение 30 часов и был близок к смерти». В химических лабораториях студенты, в виде забавы, вдыхали веселящий газ и пары эфира до полной потери сознания и усыпления. Орфилла, Бродий, Джиакомини, Христизон констатировали анестезирующее действие эфира. Однако все эти наблюдения и опыты ничем не обогатили хирургию, и никто ещё не воспользовался анестезирующим действием эфира и закиси азота при хирургических и зубоврачебных вмешательствах.
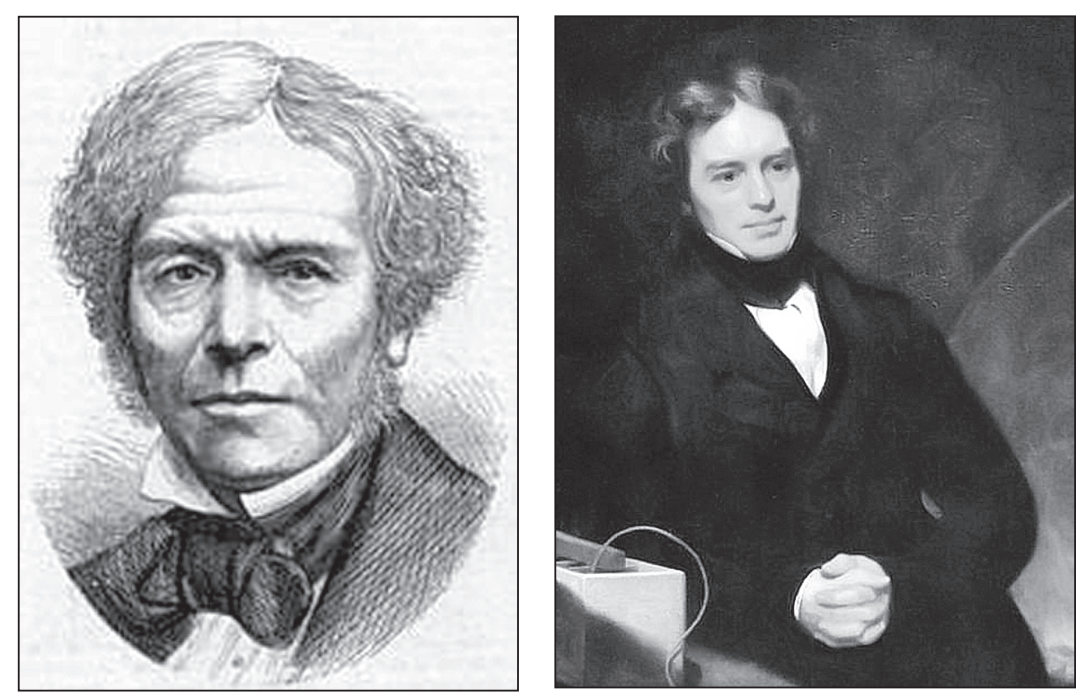

Рис. 25. Майкл Фарадей (1791-1867) - английский физик и химик. (Ил. John Watkins.)

Учение об анестезии сошло с научной дороги и затерялось в мистическом тумане, окружающем явления магнетизма и гипнотизма (рис. 26). 


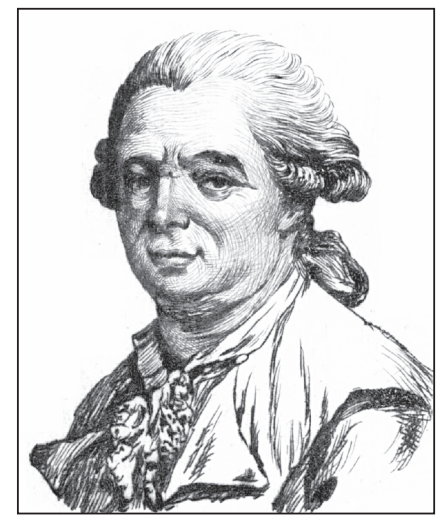

Рис. 26. Франц Антон Месмер (1734-1815) - австрийский врач, создатель учения о животном магнетизме («месмеризме»), которое получило довольно широкое распространение в начале XIX века как метод хирургического обезболивания

12 апреля 1829 г. Клоке произвёл безболезненное вылущивание грудной железы у 64-летней дамы, находящейся в состоянии магнетического сна, а Уорд в 1842 г. ампутировал бедро. Неудивительно, что попытки хирургов в клинике Вельпо и дальнейшие опыты подобного рода не убедили в безболезненности выполнения различных операций.

В XIX веке, наверное, не было более активного сторонника применения гипноза для хирургического обезболивания, чем шотландский хирург Джеймс Эсдейл (James Esdaile, 1808-1859), и, скореe всего, именно он и выполнил больше всех операций под гипнозом.

После окончания медицинского факультета в Эдинбурге в 1830 г. Эсдел уехал для продолжения своей врачебной практики в Восточную Индию. Во время учёбы он увлёкся идеями популярного в Европе в начале XIX века «месмеризма», и его не покидала мысль попробовать провести обезболивание операции с помощью гипноза.

В 1845 г. он возглавил госпиталь для индийцев в Хугли, где 4 апреля сделал первую операцию на «месмеризированном» больном. Успех был полный, и Эсдейл продолжал активно использовать гипноз в своей хирургической практике. Это позволило ему 22 января 1846 г. опубликовать в журнале «Zoist» (1845, № 3, p. 380-389), основанном доктором Джоном Эллиотсоном (John Elliotson, 1791-1868), материалы о 73 больших и малых операциях, выполненных под гипнозом. В числе этих безболезненных операций, выполненных Эсделом за 8 месяцев, значатся различные операции, включая 3 экстракции зубов. 
Когда Джеймс Эсдейл сделал доклад о первой сотне своих операций под гипнозом, генерал-губернатор Бенгалии учредил специальную комиссию для проверки деятельности Эсдейла. На основе заключения комиссии было решено предоставить Джеймсу Эсдейлу небольшую больницу в Калькутте для продолжения этих исследований и дальнейшей проверки метода. Эта больница в Калькутте просуществовала с ноября 1846 г. по декабрь 1847 г., когда она была закрыта вопреки вполне благоприятному отзыву, который был сделан медицинской комиссией, присланной губернатором, чтобы обследовать «месмерическую» больницу. Эсдейл был назначен в больницу Sukeas Lane, где и проработал, занимаясь месмеризмом вплоть до своего отъезда из Индии в Шотландию в 1851 г. Он выполнил здесь больше тысячи операций под гипнозом, в том числе около трёхсот больших вмешательств, считая ампутации, камнесечения, гидроцеле, катаракт и удаления гигантских слоновых опухолей мошонки (рис. 27).

Эсдейл четырежды опубликовал свои наблюдения и достижения отдельными изданиями, вышедшими в Индии; они регулярно печатались в журнале «Zoist». Но в № 4 журнала (1846-1847 гг.) главный редактор Джон Эллиотсон опубликовал письмо, пересланное ему от доктора Эшбернера. Оно было адресовано мисс Эджеворс в Америку и содержало в себе довольно подробное описание совершенно безболезненного извлечения двух зубов у некой Лиззи в Бостоне под «эфирным газом».

Итак, эфирный наркоз не только стал реальностью, но и Эсдейл начал его испытывать, как только узнал о нём. Большой интерес представляет следующая цитата из публикации Эсдейла в № 5 журнала «Zoist»: «Ocторожными дозами и, зная лучшие антидоты, мы, я думаю, скоро достигнем безопасного способа обеспечивать нечувствительность даже при самых ужасных хирургических операциях... Ведь применение месмеризма в хирургии началось только за последние годы и значительно выдвинулось вперёд главным образом с целью продемонстрировать воочию значение этого жизненного агента. Главное же поприще, на котором разыграется вся его польза, есть лечение внутренних болезней, где часто он приходит к нам на помощь тогда, когда остальные ресурсы изменили». Такое признание со стороны Эсдейла довольно неожиданно. Мог ли кто думать, что тот самый хирург, который сделал больше всех хирургов в мире операций под гипнозом, и который заполнял страницы журнала «Zoist» всё новыми и новыми отчётами о безболезненных операциях, сам заявит, что применение месмеризма в хирургии делалось главным образом в целях пропаганды и что затрата многих часов на достижение гипноза самим им будет расцениваться как «чёрная работа»? 


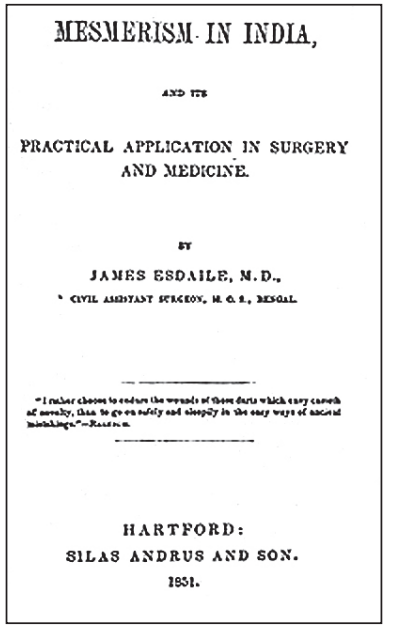

Рис. 27. Книга Джеймса Эсдейла «Месмеризм в Индии» с описанием проведённых им операций под гипнозом. Ил. с сайта Календарь Critical http://critical.ru/calendar/0602Esdaile.htm

Разумеется, не эти мотивы были главными, чтобы месмеризм в скором времени полностью уступил место наркозу эфиром и хлороформом. Основная причина заключалась в том, что эфирный и хлороформный наркоз обеспечивали полное и быстрое обезболивание всем оперируемым подряд, а не одним лишь лицам, поддающимся гипнозу.

Джеймс Эсдейл, в отличие от другого лидера «месмеризма», Джона Эллиотсона, не был одержим одной идеей и не стал её рабом. Главная ошибка Эллиотсона, как в своё время и Месмера, заключалась в том, что сложные и самые разнообразные вопросы патогенеза различных болезней он рассматривал односторонне, стремясь схематизировать, унифицировать причины заболеваний и лечить их универсальным средством. Это классическое заблуждение, к сожалению, дожившее вплоть до наших дней, и пример распространённого в медицине явления, когда, увлекшись интересной, но односторонней собственной концепцией, авторы теряют самокритику, перестают принимать чужие доводы и превращаются в фанатиков своей идеи (рис. 28).

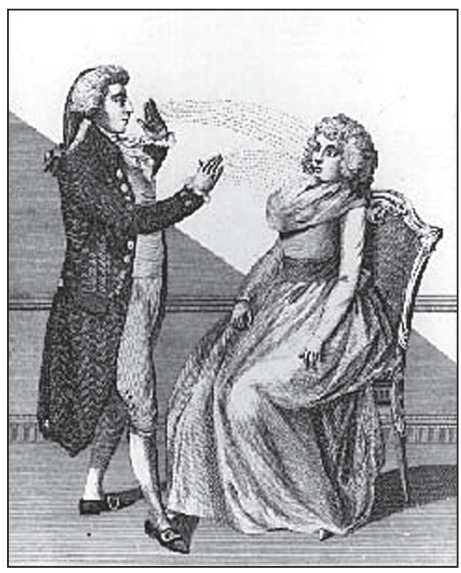

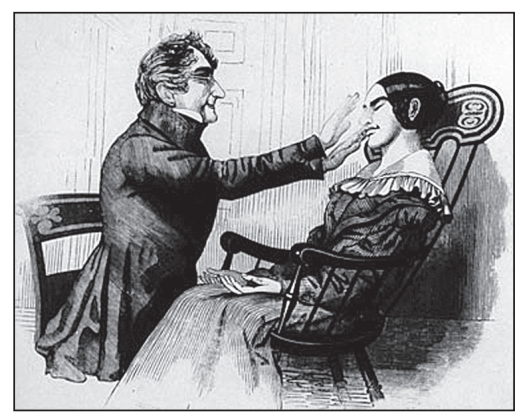

Рис. 28. «Месмерические сеансы». Как это было в 19 веке. Ил. с сайта Календарь Critical 
В 1772 г. Джозеф Пристли (Joseph Pristley, 1733-1804) открыл закись азота. Способ получения азота из воздуха описал Резерфорд (Reserford). В 1799 г. английский химик Хемфри Дэви (Humphry Davy), ученик Дж. Пристли заметил, что, когда он находился в камере с закисью азота, у него проходила зубная боль (рис. 29). Он установил, что закись азота вызывает опьянение, эйфорию, склонность к смеху, и назвал её «веселящим газом». Дэви много экспериментировал на животных. Он многократно подвергал и самого себя воздействию закиси азота. При этом он заметил, что закись азота способна устранять физическую боль, и высказал мысль о возможности её применения для обезболивания при проведении операций. К 1800 г. относится такое описание X. Дэви впечатлений о действии закиси азота: «При прорезывании зуба му-

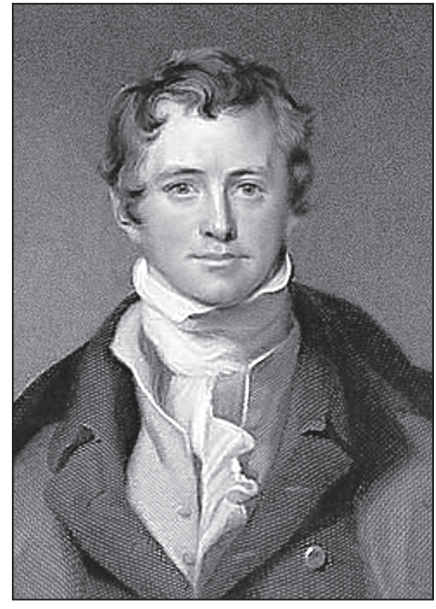

Рис. 29. Хемфри Дэви (1778-1829). Открыл обезболивающие свойства закиси азота, дал ей название «веселящий газ» дрости (dentes sapientiae) я испытывал острое воспаление десны, сопровождающееся большой болью, которая одинаково мешала как отдыху, так и сознательной работе. Однажды, когда воспаление было чрезвычайно мучительно, я вдохнул три большие дозы закиси азота. Боль совершенно исчезла после первых четырёх или пяти вдыханий, и неприятные ощущения сменились чувством удовлетворения». (Цит. по А.Д. Беляевскому, Г.Д. Монченко, 1999.) При публикации результатов обстоятельного изучения физико-химических и других свойств он писал: «Так как закись азота способна устранять боль, то она, вероятно, может быть использована с успехом при хирургических операциях, при которых нет больших кровопотерь». (Цит. по H. Killian, 1934.) Для большей точности приводим эти достопримечательные в истории анестезиологии слова: «As nitrous oxide in its expensive operation seems capable of destroying physical pain, it may probably be used with advantage during surgical operations, in which no great effusion of blood takes place». (Цит. по О. Каппелеру, 1881.)

Опыты Дэви много раз были повторены с неодинаковым успехом в Англии и на континенте и вскоре надолго были забыты, не получив никакого дальнейшего приложения в практической медицине. В 1821 г. химик Штокман (Stockmann) во время демонстрации действия закиси азота заме- 


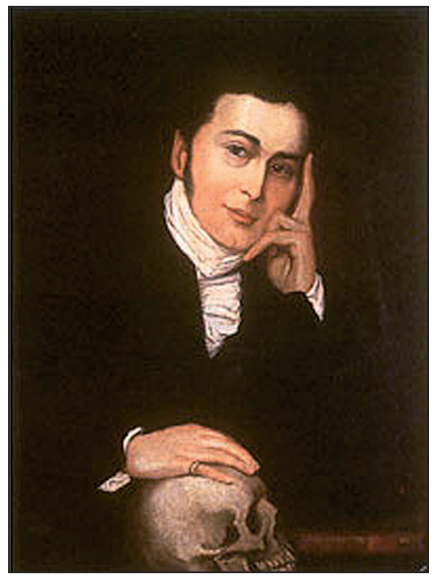

Рис. 30. Генри Хилл Хикмен (1800-1830). Настойчиво, но безуспешно, пропагандировал идею анестезии в Англии и Франции. (Ил. по А.П. Зильберу, 1996.) тил, что помогавший ему мальчик впал в бессознательное состояние. Оказалось, что баллон пропускал газ. Но и этот факт был оставлен без внимания. Вероятно, это произошло потому, что врачи ещё не были готовы к этому открытию, что особенно ярко видно на примере судьбы Хикмена.

Генри Хикмен (Henry Hill Hickmann) английский учёный, по образованию врач (рис. 30). Он знал об опытах Дэви. С 1820 до 1828 г. экспериментировал с углекислотой, закисью азота и диэтиловым эфиром над животными с целью получения обезболивания. Вначале он давал угольную кислоту, чтобы возбудить, усилить дыхание, затем прибавлял веселящий газ и выжидал наступления полной потери сознания. Многочис-

ленные опыты с животными привели к столь однообразным результатам, что Хикмен решил испытать применение закиси азота при операциях на людях. В течение 3 лет он многократно, но безуспешно делал попытки доказать необходимость и важность внедрения закиси азота в хирургическую практику. Не получив поддержки среди английских хирургов, Хикмен решил обратиться в Париж, который в то время был общепризнанным центром научной медицинской мысли. В письме королю Франции Карлу Х он стремился доказать, что речь идёт о важнейшем открытии для человечества. Он писал, что у животных ему удавалось на известный срок «выключить жизнь», что он убеждён в возможности и у человека «приостановить жизнь» (Suspended animation) на время проведения операции. Хикмен просил разрешить ему испытать свой наркоз на человеке. Это письмо Карл Х в августе 1828 г. послал в Парижскую медицинскую академию, которая выделила для обсуждения его комитет из 5 человек. На пленуме академии 21 октября 1828 г. о предложении Хикмена сделал сообщение Э. Жерарден (Gerarden). Пленум отверг это предложение как иллюзорное. Лишь один человек из этого учёного синдиката восторженно поддержал Хикмена, больше того, он даже предложил себя для эксперимента. Это был известный хирург Ларрей. Хикмен, совершенно разочарованный и психически подавленный, вернулся в Англию, и скоро после этого в возрасте 29 лет он умер, как говорили в те времена, «от огорчения сердца». 
Генри Хикмен первым понял, что задача анестезии состоит не только в обезболивании, но и в предупреждении других вредных воздействий операции. В своих экспериментах он изучал как обезболивающие свойства различных веществ, так и их влияние на дыхание, кровообращение, заживление ран. Он применял для восстановления дыхания ИВЛ специальными мехами, а для нормализации работы сердца - электрический ток.

К сожалению, современники оказались неспособными понять значение открытия Хикмена. Консерватизм большинства учёных того периода в Англии и Франции не позволил реализовать предложение Хикмена и сделать его достоянием медицины. Результаты его многолетних исследований по наркозу были преданы забвению почти на два десятка лет.

Безучастность крупных хирургов того времени к открывающейся возможности использования очевидных достижений науки с целью разработки эффективных методов обезболивания можно объяснить лишь устоявшимся в течение столетий представлением о невозможном устранении болевых ощущений при операциях. Например, выдающийся хирург XIX века Вельпо (1795 -1867 г.) утверждал, что устранение боли при операции есть химера, что хирургический нож и боль - два неразделимых понятия. Во время операции советовали больному «думать о чём-нибудь другом», при нестерпимых болях «покусать компресс» и т.д. Больные неохотно соглашались на операцию, так как каждая операция, не говоря уже о сомнительном исходе её, была мучительной пыткой, и больные иногда погибали от нестерпимых болей и шока.

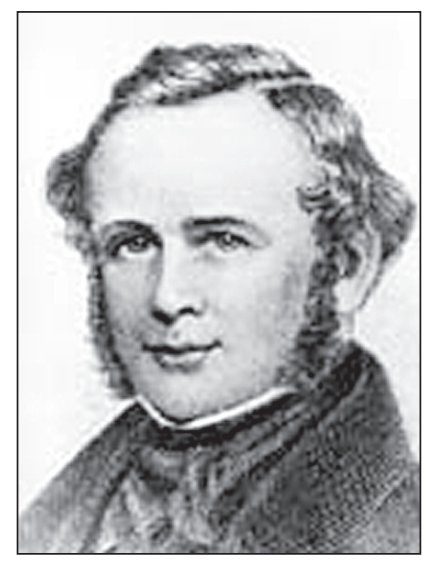

Рис. 31. Хорас Уэллс (1815-1848). Американский дантист из Хартфорда.

Был первым, кто оценил потенциальное значение анальгетического свойства закиси азота при удалении зубов. Предложил в целях обезболивания применять закись азота, испытав её, прежде всего на себе, а затем на 15 больных при удалении зубов 


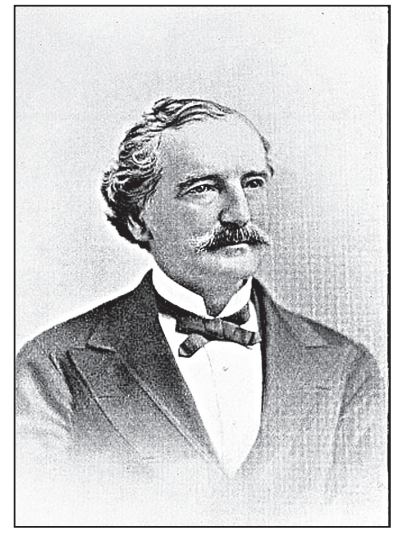

Pис. 32. Gardner Quincy Colton

(1814-1898) - анестезиолог в зубоврачебной практике и изобретатель

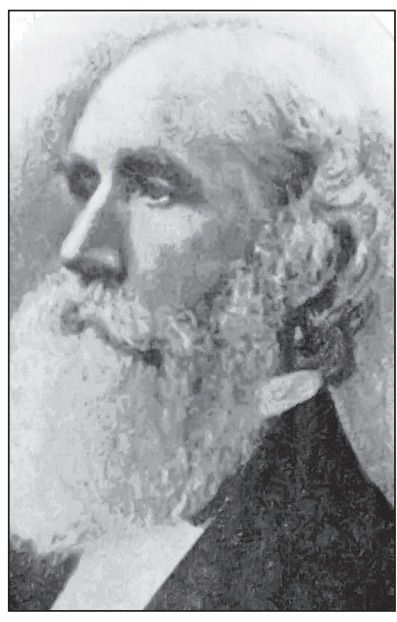

Рис. 33. Джон Риггс (1811-1885) американский дантист, впервые в мире провёл операцию удаления зуба под наркозом закисью азота
В 40-е годы XIX столетия вновь ожили попытки применить закись азота для обезболивания. В 1844 году начали осуществляться взгляды, высказанные Дэви, Фарадеем и Хикменом. Гарднеру Колтону (Gardner Colton) и Хорасу Уэллcy (Horace Wells - рис. 31) принадлежит первенство в использовании закиси азота в качестве общего анестетика у человека (1844 г.). Х. Уэллс, зубной врач и студент-медик из Гартфорда, познакомившись на лекциях химика Колтона с обезболивающим действием закиси азота, раздобыл у последнего этот газ, чтобы испытать на себе при удалении зуба (рис. 32). 11 декабря 1844 г. зубной врач Джон М. Риггс (John Mankey Riggs - рис. 33) под наркозом закисью азота без боли удалил зуб мудрости Уэллсу. Наркоз проводил химик Колтон (рис. 34).

С этих пор Уэллс начал пользоваться закисью азота в своей зубоврачебной практике и после 15 случаев удаления зубов под наркозом решил предать гласности свои опыты. Для этой цели он поехал в Бостон (в то время официальный медицинский центр Америки), где в январе 1845 г. публично демонстрировал метод перед хирургами бостонского общества и студентами.

При этой демонстрации присутствовали известный профессор хирург Уоррен, химик Джексон и зубной врач Мортон. Уэллс был и хирургом, и проводил наркоз. Предварительно сделав короткое сообщение о действии закиси азота, он поднёс подушку-мешок с газом больному. Последний хорошо вдыхал закись азота и вскоре потерял сознание. Тогда Уэллс взял щипцы и совершенно безболезненно «всадил их низко в десну». Однако при расшатывании и извлечении зуба больной кричал, двигался, затем продолжал стонать. В аудитории раздались смех, свист, выкрики: «Выскочка, обман!» И, несмотря на то, что после операции больной говорил об отсутствии болевых ощущений, хирурги не поверили в эффективность метода. 


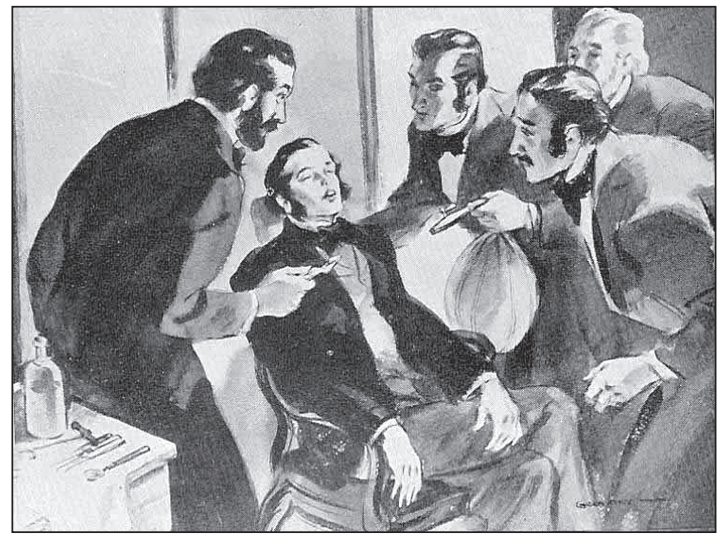

Рис. 34. Первый наркоз закисью азота (11 декабря 1844 г.).

Химик Колтон проводит наркоз Уэллсу, которому дантист Риггс удаляет зуб

В провале демонстрации была повинна не закись азота, а техника наркоза, отсутствие знаний о механизме действия этого анестетика, о возможных осложнениях в клинике этого наркоза. Уэллс не смог создать достаточной концентрации закиси азота во вдыхаемом воздухе, так как он пользовался мешком Колтона, который давал возможность получить только кратковременное оглушение, но не наркоз. Кроме того, нельзя было давать наркоз и делать операцию одновременно. Ведь закись азота очень быстро после прекращения её подачи выдыхается и больной пробуждается.

Несмотря на неудачу демонстрации, Уэллс остался верен идее наркоза закисью азота. Стремясь достигнуть не оглушения, а длительного наркоза, он применил чистую закись азота без кислорода (так называемый «чёрный газ») и без соответствующей аппаратуры; при этом он в одном случае получил смертельный исход. Ряд неудач и в особенности непризнание приоритета в открытии ингаляционного наркоза вызвали у Уэллса очень тяжёлые личные переживания, и в 1848 г. он покончил жизнь самоубийством, вскрыв себе вены и надышавшись хлороформом в ванне тюремной камеры.

Применение закиси азота без кислорода не могло быть использовано в большой хирургии, так как она не отщепляет кислорода. Закись азота могла применяться только в зубоврачебной практике: для извлечения зуба часто было достаточно нескольких вдохов чистой закиси азота. Попытки применить веселящий газ в чистом виде для длительного наркоза, естественно, приводили к значительным осложнениям и смертельным асфиксиям. 
В 1863 г. внимание хирургов снова было привлечено к закиси азота. Колтон, опыты которого в своё время подали Уэллсу мысль о применении закиси азота для обезболивания, организовал в Лондоне ассоциацию дантистов, которые применяли этот газ в зубоврачебной практике. Однако даже в этой области закись азота использовали сравнительно редко. В рассказе А.П. Чехова «Общее образование. Последние выводы зубоврачебной науки» в подтверждение сказанному описывается ситуация, связанная с обезболиванием, так: «...В зубе чепуха, вырвать надо и больше ничего, но ты копайся долго, с расстановкой... раз десять зеркало всунь в рот, потому что барыни любят, если их болезнями долго занимаются. Барыня визжит, а ты ей: «Сударыня! Мой долг облегчить ваши ужасные страдания, а потому прошу относиться ко мне с доверием», - и этак, знаешь, величественно, трагично... А на столе перед барыней челюсти, черепа, кости разные, всевозможные инструменты, банки с адамовыми головами - всё страшное, таинственное. Сам я в чёрном балахоне, словно инквизитор какой. Тут же около кресла стоит машина для веселящего газа. Машину-то я никогда не употребляю, но все-таки страшно! Зуб рву я огромнейшим ключом. Вообще, чем крупнее и страшнее инструмент, тем лучше. Рву я быстро, без запинки».

Закись азота была наименее популярным препаратом среди трёх первых ингаляционных анестетиков вследствие относительно низкой мощности и тенденции вызывать асфиксию при моноанестезии. Интерес к закиси азота не возрождался до тех пор, пока Эдмунд Андрюс (Edmund Andrews) в 1868 г. не применил её в смеси с кислородом (содержание кислорода составляло 20\%). Однако популярность смеси закиси азота и кислорода не превзошла популярности эфира и хлороформа. По иронии судьбы, закись азота - это единственный препарат из трёх вышеперечисленных анестетиков, широко применяющийся и по сей день.

Физиологические свойства закиси азота изучались многими исследователями, начиная с Дэви. Герман (Hermann) в 1864 г. установил, что закись азота только физически растворяется в крови, не изменяя химической структуры последней. Применение закиси азота с кислородом значительно улучшило течение наркоза, устранило часто наблюдавшиеся цианоз и асфиксию и дало возможность длительно применять наркоз закисью азота. Решающее значение для возрождения газовых наркозов имели исследования французского физиолога Поля Бера (рис. 35) в 1877 г. Своими работами он внёс много ценного в понимание сущности наркоза закисью азота с кислородом. Раньше полагали, что именно асфиксия является непосредственной причиной наркоза, так как при даче чистой закиси азота через маску, герметически закрывающую рот и нос, асфиксия имела место постоянно. 
Бер установил, что болеутоляющее и обезболивающее действие закиси азота объясняется не асфиксией, а специфическим воздействием её на нервную ткань. Если смешать закись азота с таким количеством кислорода, какое имеется в атмосферном воздухе, то асфиксия полностью устраняется. Правда, при этом часто получается недостаточный обезболивающий эффект. Бер объяснял это явление тем, что количество атомов закиси азота в единице объёма газовой смеси недостаточно и что концентрация её в крови меньше нужной для достижения обезболивания. Между тем неразбавленная закись азота при атмосферном давлении давала хороший обезболивающий результат. На этом основании Бер и решил повысить давление газовой смеси в такой степени, в какой уменьшено на-

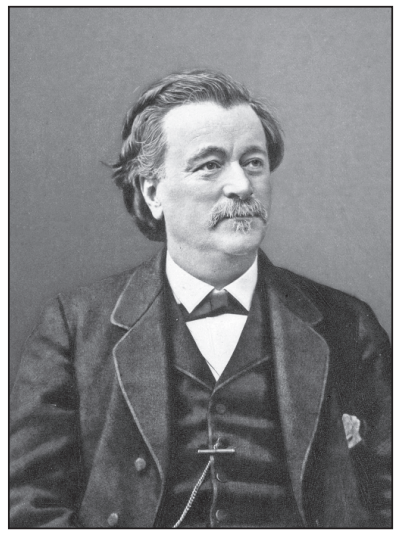

Pис. 35. Paul Bert (1833-1886). Фото приблизительно 1880 г., автор Destréguil пряжение закиси азота из-за разбавления её кислородом. Так как для устранения асфиксии к закиси азота добавлялось $20 \%$ кислорода, то напряжение закиси уменьшалось на $1 / 5$. Для устранения этого он предложил увеличить давление смеси закиси азота и кислорода на $1 / 5$ атмосферы, сконструировав колокол (операционный зал), куда помещались животные, и где смесь закиси азота с кислородом вдыхалась под повышенным давлением (рис. 36). Таким образом, удалось достигнуть полного обезболивающего эффекта без явлений асфиксии.

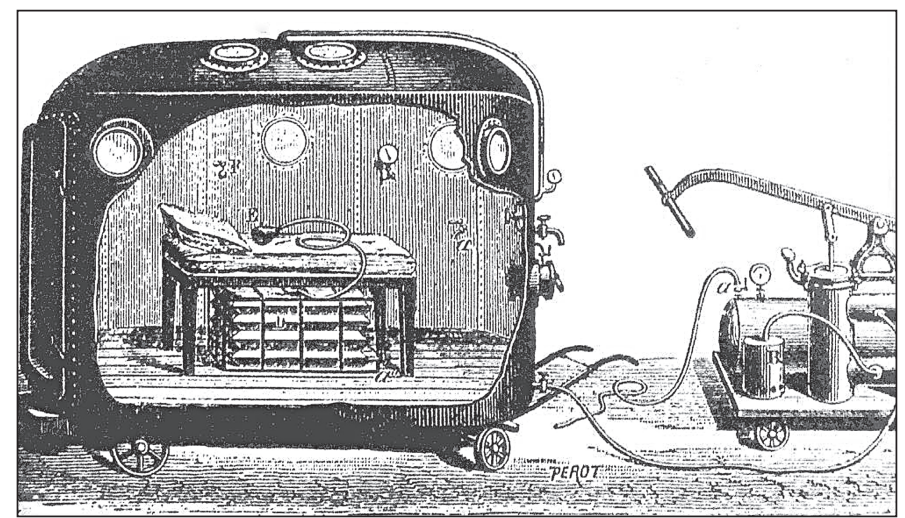

Рис. 36. Операционный зал Бера (Ил. представлена Petr Sykora, Прага) 
На основании своих исследований Бер пришёл к выводу, что при вдыхании под повышенным давлением закись азота становится идеальным наркотиком. Преимуществом наркоза закисью азота с кислородом он считал следующее: 1) закись азота не вступает в химическую связь с кровью, а только растворяется; 2) наркоз начинается и прекращается в зависимости от начала и конца вдыхания газа; 3) отсутствуют сильно выраженное возбуждение, рвота, головная боль; 4) закись азота безвредна, не влияет на сердце, лёгкие и другие органы.

Закись азота весьма интересовала русских хирургов и зубных врачей. В 1879 г. проф. А.С. Таубер в клинике французского хирурга ЖюляЭмиля Пеана (Pean, Jules Emile, 1830-1898) сам подвергся наркозу закисью азота с кислородом в колоколе Бера. Он был усыплён, вдыхая эту газовую смесь под повышенным давлением. А.Я. Красовский писал, что в 1888 г. в Петербурге дантистами применялся наркоз закисью азота. В 1902 г. в Петербургском обществе зубных врачей был заслушан доклад Ф.А. Звержховского об успешном применении закиси азота с кислородом при удалении зубов. Тем не менее, этот вид обезболивания в России в тот период не смог получить широкого распространения, так как закись азота для наркоза не вырабатывалась. Она была весьма дорога и, кроме того, в России не было аппаратуры для газовых наркозов (Жоров И.С., 1959).

Впервые эфирный наркоз применил Кроуфорд У. Лонг (Crawford Williamson Long - рис. 37) 30 марта 1842 г. при хирургической операции. Об удивительных свойствах эфира К. Лонг узнал ещё во время своей учёбы в медицинской школе университета Пенсильвании. В то время среди молодых людей были довольно распространены «эфирные шалости» (ether frolics), когда они «нанюхивались» эфиром с целью достижения эйфории и веселья. Впоследствии наблюдательный врач К. Лонг решил использовать анальгетический и наркотический эффекты эфира в своей практике.

Есть сведения о том, что Лонг использовал эфир для амбулаторных операций ещё раньше, в 1841 году. Может быть именно эти факты, а также не доказанные документально (или надуманные поклонниками К. Лонга для успеха в борьбе за приоритет открытия эфирного наркоза), оставляют в тени Уильяма Э. Кларка (William E. Clarke, 1818-1878) - ещё одного претендента на честь называться первооткрывателем эфирного наркоза? Известно, что в том же 1842 г., но несколько раньше К. Лонга (в январе) Уильям Кларк, химик из Рочестера, Нью-Йорк, и студент Беркширского медицинского колледжа штата Массачусетс, применил эфир на полотен- 
це мисс Хобби (Hobby), после чего дантист Элиджа Поуп (Eljah Pope) удалил ей больной зуб. Кларк был вдохновлён своим ранним опытом «эфирных шалостей» (ether frolics) в Рочестере. Всё это было одноразово. Так или иначе, Кларк и Поуп были не в состоянии распознать важные потенциальные возможности того, что они сделали. Кроме того, этот случай не был опубликован своевременно. Сообщение Генри М. Лимана (Henry M. Lyman) появилось почти через 40 лет в «Artificial anesthesia and anesthetics», New York, William Wood and Co., 1881 (Vandam L.D., 1996; Pancholi A., Desai S.P., 2007).

Доктор Лонг был молодым бакалавром 26 лет, когда он заметил, что участники при региональном использовании эфира не чувствовали никакой боли от повреждений, полученных в течение их «шалостей». Он пришёл к выводу, что эфир мог сделать хирургию безболезненной. Возможность проверить его теорию возникла, когда Джеймс Венэйбл просил, чтобы доктор Лонг удалил кисту (опухоль) у него на шее (затылке). Три свидетеля сообщили, что, 30 марта 1842 года, операция была успешна, и Венэйбл не чувствовал боли. Однако об этом стало известно в печати только в 1849 г. Публичная демонстрация эфирного наркоза впервые произведена 16 октября 1846 г. Мортоном. Эта дата справедливо считается днём открытия эфирного наркоза.
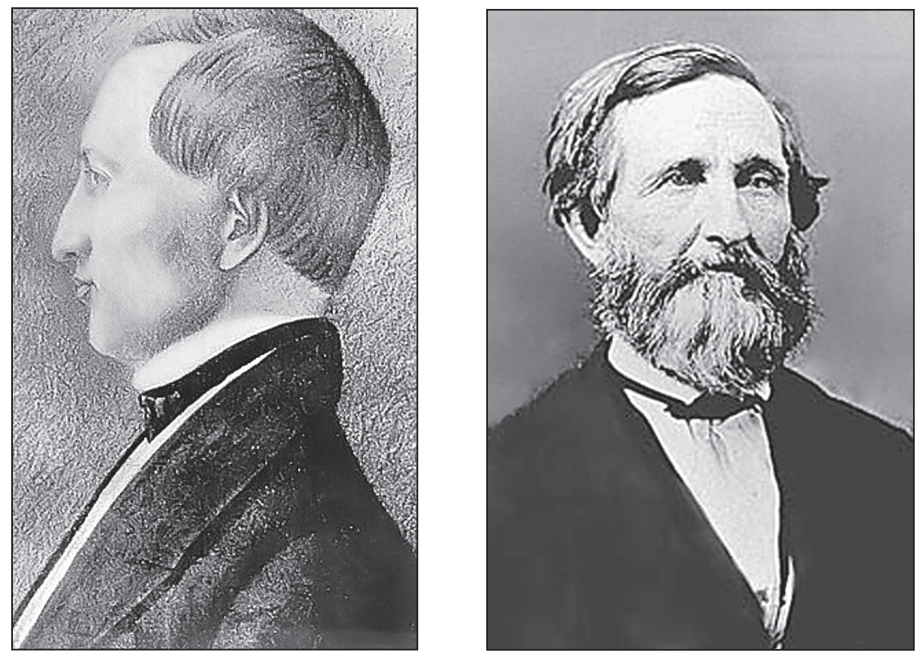

Рис. 37. Кроуфорд Уильям Лонг (1815-1878).

Американский хирург (в молодости и зрелом возрасте) 

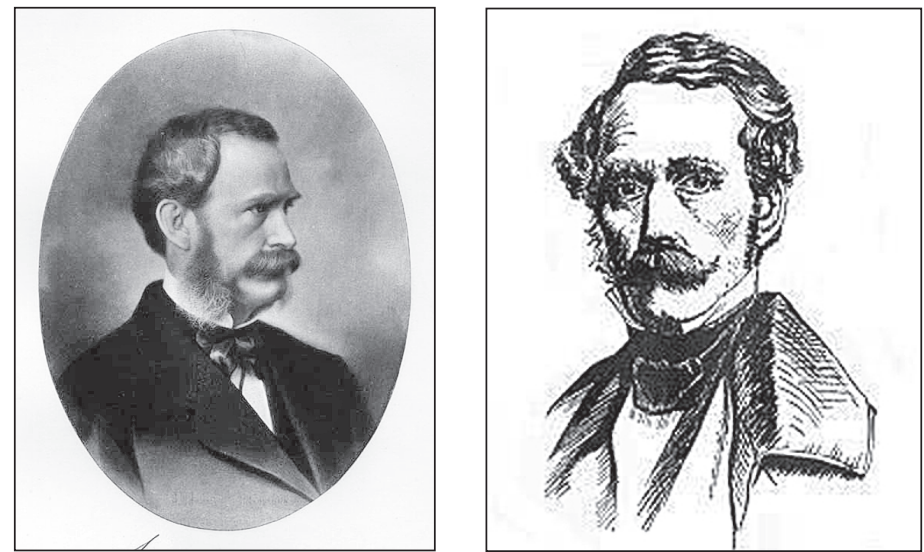

Рис. 38. Уильям Томас Грин Мортон (1819-1868), американский дантист.

Окончил зубоврачебную школу в Балтиморе, работал в Бостоне. Один из основоположников метода общего обезболивания. Первым успешно продемонстрировал (1846) эфирный наркоз при хирургической операции. (Ил. Wood Library-Museum of Anesthesiology, Park Ridge, Illinois)

Уильям Томас Грин Мортон (William T.G. Morton), ученик Уэллса, был зубным врачом в Бостоне (США). Он специализировался главным образом на протезировании зубов, и до протезирования ему приходилось удалять все корни зубов. Эта болезненная процедура пугала больных, что и побудило Мортона найти способ, устраняющий боль при удалении зубов и других операциях в полости рта. В 1844 г. Мортон получил диплом врача. В том же году он по совету химика Джексона (Jekson) начал применять жидкий эфир местно при лечении и удалении зубов (рис. 38,39 ). При этом он заметил, что пары эфира, смешанные с атмосферным воздухом, оказывают одурманивающее действие. Тогда Мортон решил испытать эфир для общего обезболивания в своей зубоврачебной практике, пользуясь способом вдыхания эфира через платок. Он начал свои исследования с эксперимента на самом себе, а затем на домашних животных. Собака, надышавшись эфиром, заснула и оказалась нечувствительной к болевым раздражениям. После прекращения вдыхания эфира она через 2-3 мин проснулась. Мортон понял, что дальнейшие исследования в этом направлении могут привести к большому открытию. От экспериментов он перешёл к испытанию эфира на людях. 1 августа и 30 сентября 1846 г. под эфирным усыплением Мортон произвёл удаление зубов у зубного врача Спира и больного Фроста. Но не всегда удавалось вызвать у больных сон при вдыхании эфира с платка. Тогда Мортон приступил к созданию аппарата. Этот аппарат был очень прост - стеклянный шар 
имел два отверстия: одно служило для наливания эфира, другое соединялось с трубкой, которая вставлялась в рот больного для вдыхания.

Джексон, узнав об успешном обезболивании при удалении зубов, убедил Мортона испытать анестезирующее действие эфира при какой-нибудь более травматичной операции. После накопления некоторого опыта Мортон обратился к главному хирургу Массачусетской больницы общей практики Д. Уоррену (John Collins Warren, 1778-1856) с просьбой разрешить ему продемонстрировать эфирный наркоз для безболезненного проведения операции. Операция была назначена на 10 часов утра 16 октября 1846 г. Уорреном была удалена сосуди-

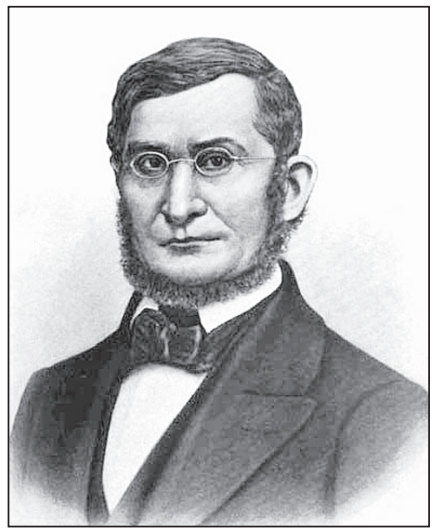

Рис. 39. Чарльз Томас Джексон (1805-1880).

Американский химик и врач из Бостона.

Один из основоположников наркоза эфиром.

Художник George Perkins Merrill (1906) стая опухоль подчелюстной области у больного Джильбера Эббота, 20 лет.

И вот настал тот исторический день, когда человечеству суждено было навсегда избавиться от невыносимых страданий и болей, совершенно не предотвратимых до того при каждой хирургической операции. Эти нестерпимые боли от скальпеля хирурга представлялись столь неизбежными и естественными, что казалось невероятным и даже смешным пытаться ликвидировать устроенное самой природой. Каждая новая попытка устранения боли при операциях в широкой публике заранее представлялась «вздором» или «надувательством». Когда же ареной испытания подобного сомнительного изобретения оказалась солидная государственная больница и операционная одного из наиболее известных и заслуженных хирургов города и штата, то посмотреть на заведомую неудачу и «очередной скандальчик» нашлось достаточно охотников (Юдин С.С., 1960). Утром 16 октября в операционном амфитеатре Массачусетской больницы общей практики собралось много зрителей. Тут были врачи больницы и студенты-однокашники Мортона. Все с нескрываемым любопытством ждали «спектакля», который, по общему мнению, был обречён на неудачу. К тому же и главное действующее лицо само как бы подавало повод для недоверия и даже насмешек, ибо, занятый доделкой своего нового ингалятора, Мортон непростительно опаздывал к назначенному ему времени. Впоследствии выяснилось, что на случай какой-либо неудачи Мортон сбегал на квартиру Фроста и привёл его в больницу как живого свидетеля 
применения своего первого наркоза, чтобы убедить в безопасности и эффективности «летеона» беспокоящегося пациента и аудиторию. Суров и полон достоинства был Уоррен 16 октября 1846 г. в своей переполненной операционной, ожидая опаздывавшего Мортона. Уоррену было тогда 68 лет, он верил в себя и мог позволить себе допустить столь неслыханный эксперимент. И если бы никакого обезболивания не получилось, то кто же, как не он, Уоррен, сумел бы выполнить эту сложную операцию без всякого наркоза, как он это делал уже сотни раз за сорок с лишним лет своей хирургической деятельности. Предоставим описание этого исторического события одному из очевидцев - доктору Вашингтону Айри из Сан-Франциско, как это было изложено им в «Докладе о 50-летии обезболивания в Гарвардской медицинской школе» (1896) [Account of the Semi-Centennial of Anesthesia]: «И этот день наступил. В назначенное по расписанию время больной был подан в операционную комнату, и доктор Уоррен с группой наиболее выдающихся хирургов штата собрались вокруг страдальиа. Было объявлено: «Должно быть проведено испытание некоего состава, о котором сделано удивительное заявление: этот состав делает оперируемого больного не чувствительным к болям», - таковы были слова, которыми доктор Уоррен прервал молчание. Все присутствующие оставались недоверчивыми, а так как доктор Мортон не прибыл вовремя, и прошло уже лишних пятнадиать минут, то доктор Уоррен произнёс многозначительно: «Я полагаю, что он занят где-нибудь в другой больнице». Это заявление вызвало общий насмешливьй возглас, и доктор Уоррен, взяв свой нож, готов был приступить к операции. В этот момент доктор Мортон вошёл через боковую дверь, а доктор Уоррен, повернувшись кнему, сказал строгим голосом: «Ну что же, сэр, Ваш больной готов». Через несколько минут он был подготовлен для ножа хирурга, и доктор Мортон тихо произнёс: «Ваш больной готов, сэр». Теперь наступила наиболее величественная сиена, когда-либо происходившая в операционной, с больным, который сам добровольно лёг на тот стол, который отныне становился алтарём вечной будущей славы. Конечно, он делал это не для надобностей прогресса медицинской науки и не для блага людей-собратьев; поступок его был чисто тичным, эгоистическим. Но ему суждено было участвовать в решении новой и важной лечебной проблемы, благодеяние которой должно было распространиться на всё человечество. А сейчас в полном бессознательном состоянии он не мог испьтыввать ни всей торжественности происходившего события, ни роли, которую он в нём играл. Это был кульминационный пункт в самом изумительном открытии, и умри больной во время операции, науке пришлось бы долго ждать открытия наркотического действия какого-нибудь другого текарственного средства равной мощности и безопасности; и справедливо спросить себя, смог ли бы тогда хло- 
роформ войти в употребление так, как это ныне имеет место. А героическая храбрость человека, который добровольно сам лёг на стол как объект хирургического ножа, должна быть отмечена, а его имя вписано в пергамент, который должен быть вывешен на стенах того хирургического амфитеатра, в котором эта операщия была выполнена. Его имя было Джильберт Эббот (Gilbert Abbott). Операция производилась по поводу врождённой опухоли на левой стороне шеи, распространявщейся вдоль челюсти к подчелюстной железе и в рот, захватывая край языка. Операция прошла успешно. И когда больной проснулся, он заявил, ито не испытал никакой боли, а доктор Уоррен обернулся ко всем присутствующим и со слезами в глазах произнёс: «Господа, это не обман». Итак, свериилось... чудесное, невероятное... Нечто настолько неправдоподобное, от чего все присутствовавшие сидели в немом изумлении, почти не веря собственным глазам. Это всеобщее недоумение и должны были рассеять слова самого Уоррена, которыми он нарушил торжественную тишину: «Господа, в этом нет никакого обмана. Началась эра безболезненной хирургии». Все ужасы операционных страданий отныне навсегда исчезнут. Операционные перестанут внешне походить на средневековые застенки. А хирурги под благодетельным покровительством наркоза смогут спокойно оперировать многое из того, чего немыслимо было делать, истязая больных, корчившихся и вырывавщихся от непереносимых болей с громкими криками и нечеловеческими стонами и воплями, или на утихших страдальиах, почти без пульса, в холодном поту, с застывщими, широкими зрачками... Восторженное изумление очевидиа вылилось также и в реплике Бигелоу, произнесённой тотчас вслед за фразой Уоррена: «Сегодня я видел кое-что такое, что обойдёт весь свет» (Юдин С.С., 1960; Vandam L.D., 1995, 1996). Операция продолжалась приблизительно 10 минут. Но обратимся к подлинной истории болезни Джильберта Эббота: «Джильберт Эббот, возраст 20 лет; живописеи; холост; врождённая опухоль под челюстью слева. Она занимает все пространства спереди шеи, доходя кнутри до средней линии, снаружи - до края челюсти, книзу - до уровня адамова яблока и фронтально, постепенно суживаясь до уровня челюсти; с кожными покровами не спаяна; кожа мягкая и естественной окраски; опухоль однородно мягкая, кроме иентра, где можно прощупать небольшой плотный узел, соответствующий по величине и по положению подчелюстной железе; при сдавлении опухоль исчезает, но, очевидно, скорее за счёт смещения, чем опорожнения. Край нижней челюсти может быть прощупан сквозь опухоль и кажется неровным. При исследовании внутри рта находят мягкую ровную опухоль, полуокружность которой диаметром около пяти линий, багрового ивета на левой доле языка, не доходя около дюйма до кончика. Эта часть органа спереди и под опухолью имеет тёмно- 
пурпурную окраску. Опухоль опорожняется при слабом давлении, но наполняется снова за 1-2 секунды, если одновременно не производится давление на наружную опухоль. На расстоянии пяти линий от угла рта справа нижняя губа имеет багровую окраску. Это представляется продолжением той же каймы, которая распространяется от угла челюсти на правую сторону примерно до уровня нижних зубов; она около четырёх линий шириной и слегка приподнята; её ивет, по-видимому, определяется маленькими крапинками вроде грануляций багрового извета, расположенных на нормальной слизистой оболочке». Такова запись в официальной «истории болезни». Случай этот замечателен в анналах хирургии. Это была первая хирургическая операция, произведённая под воздействием эфира. К доктору Уоррену обратился дантист Мортон с просьбой использовать ингаляцию жидкости, которая, как он говорил, эффективно предотвращала боли во время операций на зубах. Уоррен, убедившись сам в том, что вдыхание жидкости безвредно, согласился применить её, когда представится случай. Так как такового не представилось в течение одного или двух дней в частной практике, он решил применить это на данном больном. До того как началась операция, было потеряно некоторое количество времени на ожидание Мортона и, в конце концов, решили, что он вообще не появится. Наконец Мортон прибыл и объяснил своё опоздание приготовлением наркозного аппарата, который состоял из трубки, соединённой со стеклянным шаром (рис. 40).

Через четыре или пять минут после начала вдыханий больной, как казалось, заснул, и операция была выполнена. К удивлению доктора Уоррена и других присутствующих, больной не вырывался, не кричал, но во время выделения вен двигал ногами и произносил необычайные звуки, и эти движения, казалось, указывали на наличие болей; но, когда восстановилось со-

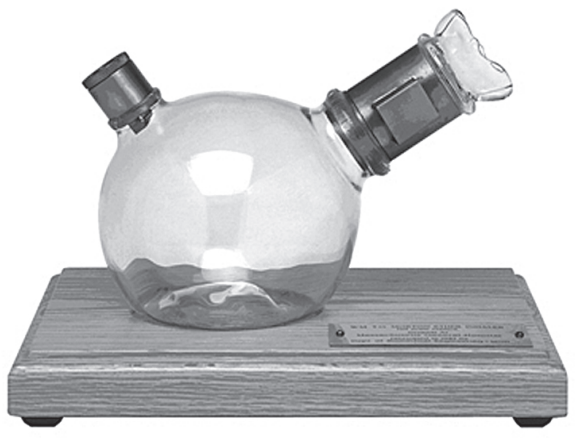

Рис. 40. Ингалятор Мортона. (Ил. из музея Гведела) знание, больной сказал, что он не испытал никаких болей, а лишь ощущение, подобное поскабливанию тупым инструментом. Результаты этой операции побудили к повторению применения эфира в других случаях, и успех был подтверждён несколько дней спустя. Его стали применять при каждой значительной операции в городе Бостоне и в его окрестности. Можно процитировать и запись самого Уоррена об этой 
замечательной операции. «17 октября (ошибка: 16), когда больной был приготовлен для операции, кего рту приблизительно на три минуты был приставлен доктором Мортоном аппарат, после чего больной впал в состояние нечувствительности. Я немедленно сделал разрез длиной около трёх дюймов через кожу шеи и начал рассечение вдоль важных нервов и кровеносных сосудов; больной на боль не реагировал. Вскоре после этого он начал бессвязно говорить и, казалось, находился в возбуждённом состоянии в течение операиии. Будучи спрочен тотчас после этого, сильно ли он страдал, тот сказал, что чувствовал, будто ему иарапают шею, но впоследствии, когда я его расспрашивал, он утверждал, что в то время не испытывал боли, хотя и сознавал, что операция совершается» (Юдин С.С., 1960). Необходимо осознать важную роль самого Джона Коллинза Уоррена в том, что с 16 октября 1846 г. началась эра анестезии. Ответственность за проведение общественной демонстрации эфирного наркоза на серьёзной операции взял на себя именно он. Уоррен рисковал, приглашая никому неизвестного дантиста (а Мортон и был всего лишь дантистом, не имевшим права заниматься чем-либо другим, кроме лечения зубов), чтобы провести наркоз секретным средством (в эфир добавили померанцевое масло, чтобы замаскировать известный многим запах эфира), тем более, что в 1845 г. здесь же потерпел неудачу Хорас Уэллс, пытаясь выполнить безболезненно удаление зуба с помощью ингаляции больному закиси азота. Уоррен был известной и уважаемой фигурой в медицине. Без его готовности пробовать новую процедуру публично, революция в обезболивании, возможно, была бы отсрочена на много лет.

Итак, что же было после успешной публичной демонстрации эфирного наркоза?

Через 52 дня после операции, 7 декабря, Джильберт Эббот в хорошем самочувствии был выписан из больницы. 17 октября 1846 г., на следующий день после проведения первой в мировой истории операции под эфирным наркозом, в той же Массачусетской больнице общей практики в Бостоне доктор Джордж Хейуорд (George Hayward) произвёл ещё одну операцию: удаление липомы больших размеров на плече. Наркоз проводил опять сам Мортон. Успех был полный: больная не проявила никаких признаков боли, за исключением самых последних минут, когда она изредка стонала, но, проснувшись, сказала, что это было вследствие тяжёлого сновидения.

7 ноября 1846 г. хирург Джордж Хейуорд произвёл ампутацию нижней конечности и резекцию нижней челюсти под эфирным наркозом (Каппелер О., 1881). 12 ноября 1846 г. Джон Мэсон Уоррен (John Mason Warren), сын Джона Коллинза Уоррена, сделал в Бостоне первую хирургическую операцию в частной практике под эфирным наркозом (Wright A.J., 2006). 
21 ноября 1846 г. Джон Коллинз Уоррен ампутировал ногу женщине под эфирным наркозом, проводимым Мортоном. Из доступных лекарств эфир оказался лучше, чем закись азота. Флаконы с жидким эфиром было легче транспортировать, а летучесть препарата обеспечивала эффективную ингаляцию. Концентрации, необходимые для достижения хирургической стадии анестезии, были такими низкими, что у пациентов обычно не развивалось опасной гипоксии при дыхании комнатным воздухом. Эффект стимуляции дыхания и низкая скорость индукции гарантировали широкий диапазон безопасности пациента в то время, когда врачи овладевали мастерством нового искусства ингаляционного применения анестезии (Бараш П.Д., 2004). Несмотря на успех, Мортон продолжал держать в тайне своё открытие, что было вполне в его натуре. Он хотел застраховать себя от конкурентов, и поэтому коллеги очень сердились на него. Это была справедливая реакция, ибо нельзя патентовать большие достижения медицины, которые должны идти на пользу всем людям. Мортон, однако, запатентовал свой эфир как «летеон», предварительно договорившись с Джексоном, заявившим о своих претензиях, что тот получит 10 процентов выручки.

Всё это было, однако, не столь важно. Главное в том, что Мортон помог «открыть» эфир, совершив удачный опыт на себе. Здесь нет необходимости говорить, что Мортон боролся за практическое претворение своих притязаний, как повсюду рассылал своих агентов для сбора денег за пользование летеоном - патентованным средством для анестезии. Совершенно очевидно, что вскоре вновь всплыло имя Джексона, давшего решающий совет, и поэтому историки медицины, оценивая роль обоих открывателей, склонны отдавать предпочтение Джексону.

Что же навело Джексона на мысль заняться эфиром, а затем сообщить всё, что знал об этом, Мортону? Случайность и удачный опыт на себе.

Джексон, как известно, много занимался химическими опытами. Однажды, надышавшись хлором больше, чем следует, он стал искать в своих учебниках средство, которое можно было бы применить как противоядие. Учебники рекомендовали в таких случаях попеременное вдыхание аммиака и эфира.

Он так и сделал. Однако на следующее утро горло все ещё продолжало болеть. Поэтому он устроился поудобнее в откидном кресле, сильно смочил носовой платок в эфире и стал вдыхать его пары. Он сразу же заметил, что перестал ощущать боль. «Постепенно, - говорил он позже, - я пришёл к убеждению, что открыл способ, как на некоторое время делать чувствительные нервы невосприимчивыми к боли». Джексон верил в себя и в открытие. Но у него не было пациентов, и поэтому при первом удобном случае поде- 
лился им с Мортоном. Так началось их сотрудничество, их вражда, а заодно и открытие эфирного наркоза, а это было главное для человечества.

Как только эфирный наркоз был признан великим открытием, за рубежом началась тяжба за приоритет. Спор этот длился более 20 лет. Даже американские историки пишут, что в борьбе за приоритет столь много «искажённых данных, путаницы, противоречий, что неизвестно, чему верить» (Raper H., 1945). Достаточно указать, что южные штаты считают изобретателем наркоза Лонга. Ему в Джефферсоне поставлен памятник с надписью: «Первый изобретатель обезболивания». Северные штаты считают изобретателем эфирного наркоза Мортона, на памятнике которому в Бостоне написано: «Открывшему наркоз Мортону». Установлению приоритета в открытии эфирного наркоза в Америке и Англии посвящено много книг.

По поводу приоритета остроумно написал физиолог Оливер Холмс, современник Уэллса и Мортона: «Приоритет в открытии наркоза принадлежит to e(i) ther», что можно понимать двояко, а именно: to ether - эфиру и to either - каждому, то есть эфиру и всем. Мортон после апробации эфирного наркоза больше не занимался вопросами обезболивания.

Трагично кончилась судьба людей, открывших наркоз. Мортон в 48 лет нищим умер внезапно 15 июля 1868 г. на улице Нью-Йорка. Уэллс, открывший наркоз закисью азота, в возрасте 33 лет покончил жизнь самоубийством. Химик Джексон закончил свою жизнь в доме для психических больных.

Похоронен Мортон в Бостоне, на кладбище «Mount Auburn Cemetery», на том же самом кладбище, где через 12 лет был предан земле и Чарльз Джексон (рис. 41). На его похоронах присутствовало много известных бостонских врачей. На могиле Генри Бигелоу поместил следующую надпись: «Уильям Т.Г. Мортон, изобретатель и создатель анестезирующих ингаляиий, кем боль в хирургии была предупреждена и уничтожена, до которого во все времена хирургия была ужасом, после которого наука получила управление над болью".

Возможно, ничто не отражает достижения Мортона лучше, чем эта надпись на памятнике. Публичная демонстрация практического применения эфирного наркоза, которую Мортон устроил октябрьским утром 1846 года - одна из великих точек отсчёта в истории человечества. 48-летний Мортон умер нищим 15 июля 1868 г. в Нью-Йорке. В городском парке Бостона установлен памятник эфиру. Надпись на памятнике: «В ознаменование открытия нечувствительности к боли, вызываемой ингаляцией эфира, впервые показанной в Массачусетской общей больнице в Бостоне 16 октября 1846 г.». Здание Массачусетской общей больницы, бережно сохра- 


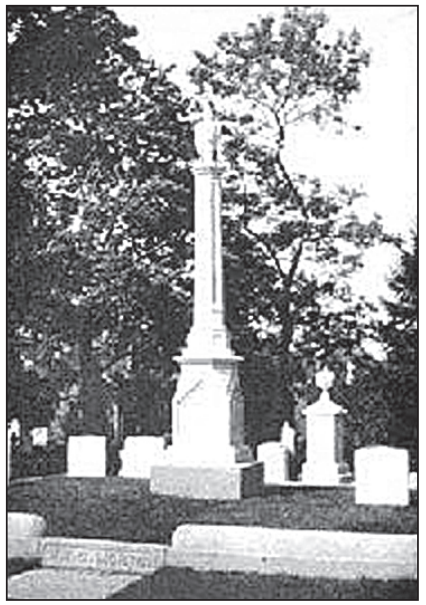

Рис. 41. Памятник Мортону на бостонском кладбище «Mount Auburn Cemetery»

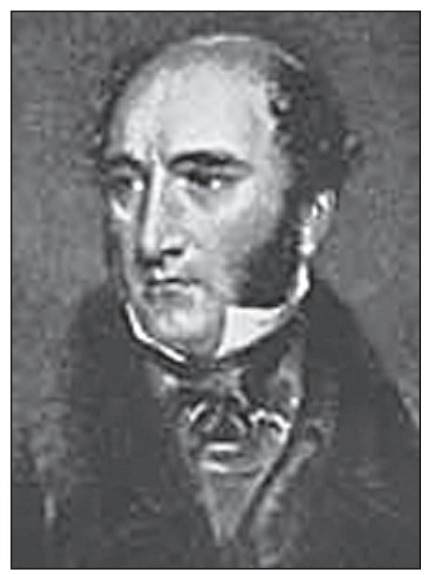

Рис. 42. Роберт Листон

(1794-1847) нённое до настоящего времени, называется местными жителями «Эфирным домом».

Открытие наркоза, который оказался эффективным методом хирургического обезболивания, вызвало широкий интерес хирургов во всём мире. Первый в Европе наркоз эфиром провёл в Париже 15 декабря 1846 г. молодой врач Френсис Уиллис Фишер (Francis Willis Fisher) 59-летнему мужчине при удалении обширной раковой опухоли нижней губы. Отчёт о первом применении эфирной анестезии в Париже был опубликован в «Бостонском медицинском и хирургическом журнале» (№ 36, с. 109-111) в 1847 г. (Столяренко П.Ю., Федяев И.М., 2006; Wright A.J., 2005). 19 декабря 1846 г., в Англии дантист Джеймс Робинсон (James Robinson, 1813-1862) применил эфирный наркоз при удалении зуба молодой пациентке, мисс Лонгсдейл (Longsdale). 21 декабря 1846 г. впервые в Англии знаменитый шотландский хирург Роберт Листон (Robert Liston, рис. 42) провёл несколько оперативных вмешательств под эфирным наркозом.

22 января 1847 г. Мальген сделал сообщение в Королевской медицинской академии о многих случаях наркоза эфиром. О новом открытии заговорили также и в Академии наук, где весть нашла энергичную поддержку в лице таких учёных, как Вельпо, Ру, Жерди, Бланден, Жоберт, Амюсса, Логье и др. Хирурги Лиона, Страсбурга, Нанси и Монпелье также сочувственно приняли новое открытие.

В Германии Шу 27 января 1847 г. сделал впервые вылущивание телеангиоэктазии, пользуясь эфирным наркозом. Его примеру последовали Гейфельдер, Ротмунд, фон Брунс, Диффенбах, Юнкен и многие другие. Италия, Испания, Россия, Бельгия и Швейцария не замедлили также выразить своё уважение к новому средству. 


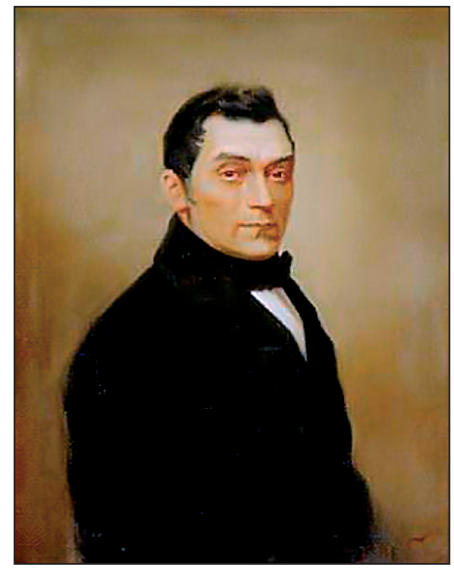

Рис. 43. Фёдор Иванович Иноземцев (1802-1869).

Выдающийся русский врач, педагог и общественный деятель. Первым в Российской Империи применил эфирный наркоз. Усыпил эфиром больную и удалил раковую опухоль молочной железы

с метастазами в подмышечную область. Портрет Ф. И. Иноземцева написан художником специально для факультетской хирургической клиники, вероятно, по заказу Н. В. Склифосовского, возглавлявшего её в то время. Развивая лучшие университетские традиции,

он радел об увековечивании памяти выдающихся врачей,

в том числе и своего знаменитого учителя

В нашей стране первую операцию под эфирным наркозом произвёл 7 февраля 1847 г. профессор московского университета Ф.И. Иноземцев (рис. $43,44)$. Через неделю после этого столь же успешно метод был использован Н.И. Пироговым в Петербурге (рис. 45). Затем наркоз стали применять другие крупные отечественные хирурги.

Результатом обобщения первого опыта применения эфирного наркоза в клинике и в эксперименте явились две монографии, опубликованные в 1847 г. Автором одной из них («Практические и физиологические наблюдения над действием паров эфира») был Н.И. Пирогов. Книга вышла на французском языке в расчёте не только на отечественных, но и западноевропейских читателей (рис. 46). Вторая монография («Об употреблении в оперативной медицине паров серного эфира») была написана Н.В. Маклаковым.

Самый большой вклад в изучение эфирного наркоза на этапе его освоения и в дальнейшем при введении в практику хлороформного наркоза внёс Н.И. Пирогов. В связи с этим V. Robinson, автор одной из наиболее содержательных книг по истории хирургического обезболивания, в 1946 г. писал: «Многие пионеры обезболивания были посредственными. В результате случайных обстоятельств 
они приложили руку к этому открытию. Их ссоры и мелкая зависть оставили неприятный след в науке. Но имеются фигуры и более крупного масштаба, которые участвовали в этом открытии, и среди них наиболее крупным человеком и исследователем следует считать, прежде всего, Н.И. Пирогова».

После первого применения у больных Н.И. Пирогов дал эфирному наркозу следующую оценку: «Эфирный пар есть действительно великое средство, которое в известном отношении может дать совершенно новое направление развитию всей хирургии». Давая такую характеристику методу, он одним из первых привлёк внимание хирургов к отрицательным свойствам наркоза, возможности тяжёлых осложнений, на необходимость знаний клиники наркоза. В его трудах заключены идеи многих современных методов - эндотрахеального, внутривенного, ректального наркоза, спинальной анестезии.

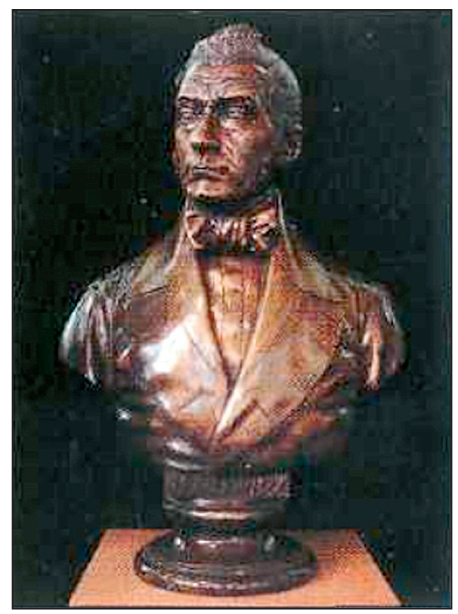

Рис. 44. Ф. И. Иноземцев (1802-1869). В.С. Бронский, 1877 г., бронза.

Музей истории ММА имени И. М. Сеченова

Профессор практической хирургии Московского университета, доктор медицины, директор факультетской хирургической клиники, издатель «Московской медицинской газеты» (с 1858 г.), основатель «0бщества русских врачей» в Москве (1861 г.). Бронзовый бюст Ф.И. Иноземцева был установлен в большой лекционной аудитории анатомического корпуса факультетской хирургической клиники Московского университета в 1877 году. После открытия клиник на Девичьем поле в 1890 году бюст был перевезён и установлен в здании Института оперативной хирургии. До недавнего времени скульптурный портрет хранился на кафедре истории медицины. В 1990 году он передан в Музей истории ММА имени И. М. Сеченова. Созданная Иноземцевым система организации факультетских и госпитальных клиник была применена Н.В. Склифосовским при строительстве Клинического городка на Девичьем поле. Всегда будут актуальны сказанные Ф.И. Иноземцевым слова: «Честность в науке неразлучна с честностью в жизни, и врач в своей практической деятельности, прежде всего, должен быть другом человечества». 
Но слава эфира продолжалась недолго. Уже через несколько месяцев после обнародования эфирный наркоз перестал быть привилегией избранных хирургических учреждений. Он стал массовым повседневным видом обезболивания во всём мире. Всеобщее увлечение сменилось объективной оценкой достоинств и недостатков эфира. Осложнения во время и после наркоза стали публиковаться чаще. Всё это привело к поискам новых агентов для обезболивания. Было испытано большое число новых средств: алкоголь, дихлорэтан, трихлорэтилен, сернистый углерод, углекислота, газообразные вещества ненасыщенного ряда углеводородов: этилен, ацетилен, пропилен,

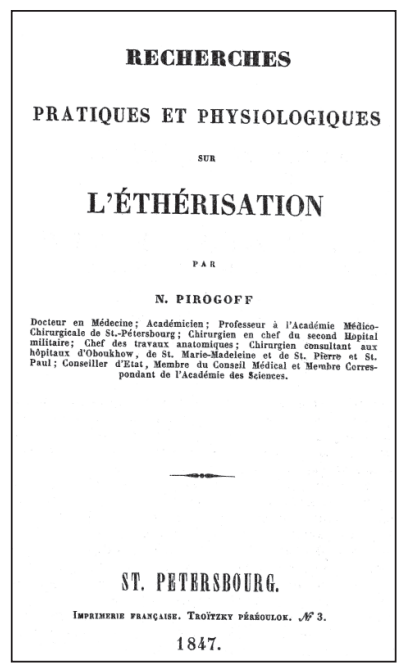

Рис. 46. Титульный лист монографии Н.И. Пирогова «Практические и физиологические наблюдения над действием паров эфира». Это была первая в мире монография, посвящённая эфирному наркозу

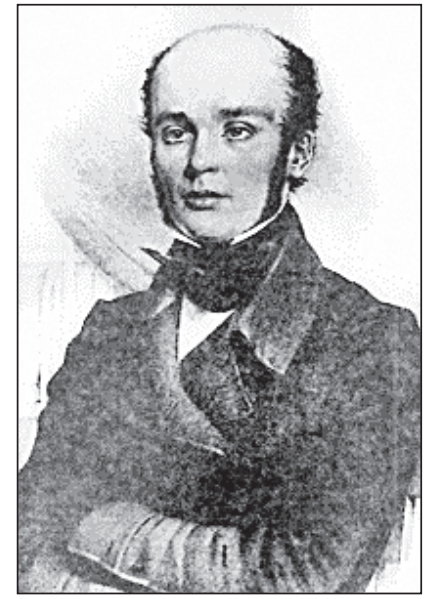

Рис. 45. Николай Иванович Пирогов

(1810-1881). Основоположник обезболивания в России. Портрет работы Г.Митрейтора ды, пары бензина (Каппелер О., 1881; Жоров И.С., 1959). Многие из исследованных препаратов были отброшены как неудовлетворительные, кое-какие не выдержали конкуренции с эфиром и только некоторые стали применяться наряду с эфиром.

Значительное распространение получил хлороформ. Он был открыт в 1831 г. в качестве растворителя каучука Самуэлем Гатре (Samuel Guthrie) в Гарборе. Гатре полагал, что приготовил хлористый эфир. Почти одновременно и независимо друг от друга Эжен Соберан (Souberain) в Париже и Юстус Либих (von Liebig) в Гиссене также открыли хлороформ, который был ими назван двухлористым эфиром. Формулу и наименование хлороформу дал француз Дюма (Dumas) в 1834 г. Впервые анестезирующее действие хлороформа на животных установил в 1847 г. французский физиолог Флуранс (Flourens). Первый наркоз хлоро- 


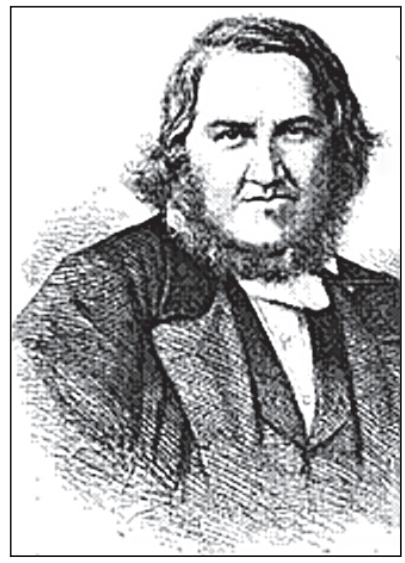

Рис. 47. Сэр Джеймс Янг Симпсон (1811-1870). Шотландский акушер и хирург. Автор наркоза хлороформом. Известный антиквар и археолог

формом был выполнен в Страсбурге в 1847 г. Седилло (Sedillo), но этот случай не был опубликован. Хлороформ был применён для наркоза лондонским хирургом Беллом (Bell), но, считая его по действию аналогичным эфиру, Белл также не опубликовал своего опыта. Есть мнение, что в клинике в качестве общего анестетика хлороформ впервые применил Холмс Кут (Holmes Coote). (Цит. по Моргану-мл. Дж., Мэгиду С., 1998.)

Автором хлороформного наркоза считается английский акушер и хирург Джеймс Янг Симпсон (James Young Simpson) - рис. 47. Он по совету химика Дэвида Уолди (Waldi) впервые применил хлороформ для уменьшения боли при родах. 10 ноября 1847 г. Симпсон представил Эдинбургскому медико-хирургическому обществу свою замечательную работу, оставившую след в истории медицины, о новом анестезирующем средстве - хлороформе. Опираясь на 80 наблюдений, сделанных им у кровати хирургических больных и рожениц, доказывал преимущества «хлороформирования перед этеризацией», особенно он настаивал на том, что хлороформ действует гораздо быстрее, совершеннее и продолжительнее эфира, что вдыхание хлороформа гораздо приятнее для больных, чем эфира, что вдыхание хлороформа не требует никаких особых инструментов и аппаратов, не столь резко выражена посленаркозная депрессия и др.

Вот какие подробности открытия Симпсона сообщает Гуго Глязер: «Известен день, когда он обнаружил наркотизирующее действие паров хлороформа: 4 ноября 1847 г. В этот день, проверяя усыпляющее действие различных средств, он и его ассистенты слегка надышались хлороформа. Некоторые сидели, другие стояли вокруг, непринуждённо беседуя. Вдруг изумлённый Симпсон обнаружил, что он и один из его помощников оказались на полу, а вся семья Симпсона и персонал дома либо застыли от неожиданности, либо бросились выяснять, в чём дело. Они не знали, что произошло, и поэтому все были ужасно перепуганы. Один Симпсон сразу понял, что он, наконец, открыл средство, которое может помочь при родах» (рис. 48). Вызывает некоторое сомнение хронология дат. Если она верна, то 80 наблюдений и их описание были сделаны за 6 дней. 


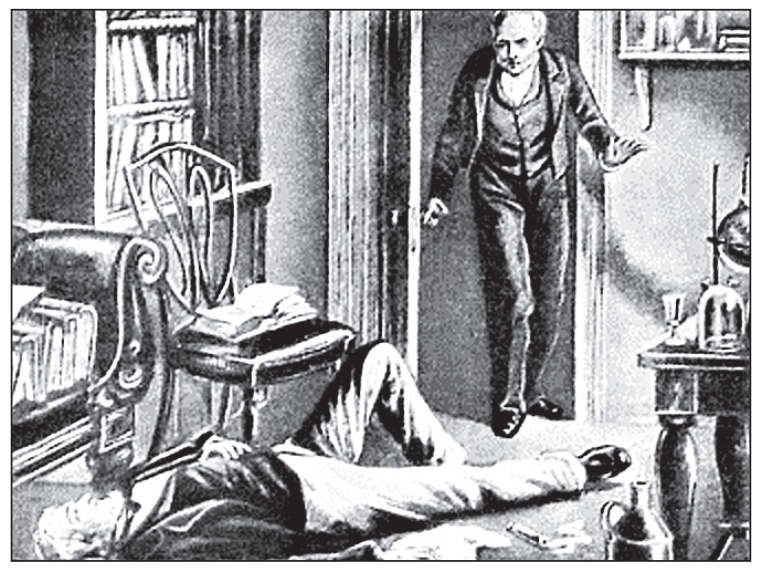

Рис. 48. Симпсон во время своего опыта с хлороформом. Иллюстрация того времени (Глязер Г., 1965)

Особая заслуга Симпсона заключается в том, что он лишь после тщательного исследования нового средства, после обширного ряда наблюдений решился обнародовать своё открытие. Этим обстоятельством и объясняется тот успех, который имела его первая публикация, и признание его заслуг, a не Х. Кута и студента Фурнелля (последний гораздо раньше произвёл в госпитале Святого Варфоломея один опыт с хлороформом).

С необычайной быстротой хлороформ стал вытеснять повсюду эфир, но уже в 1849 г. Diday и Петрякин «объявили войну» хлороформу и на основании многочисленных смертных случаев, наблюдаемых в Лионе, признали хлороформ опасным ядом. Но главный довод, приводимый Петрякиным в защиту эфира, рухнул, когда в 1867 г. сначала Laroyenne, а затем Gayet coобщили, соответственно, о 1 и 6 случаях смерти во время наркоза эфиром. В России хлороформ был впервые применён Н.И. Пироговым 30 ноября 1847 г. в 1-м Военно-сухопутном госпитале в Петербурге, 8 декабря того же года - Д.Я. Лосневским в Варшавском военном госпитале, 9 декабря А.И. Полем в госпитальной хирургической клинике медицинского факультета Московского университета (Екатерининская больница).

В декабре 1847 г. Н.И. Пироговым были произведены в Москве эксперименты на собаке по испытанию хлороформа.

Появление хлороформа произвело ещё большую сенсацию, чем открытие эфира. Мощный наркотический эффект, быстрое наступление сна, простота применения (открытая маска, платок, кусок марли), невоспла- 


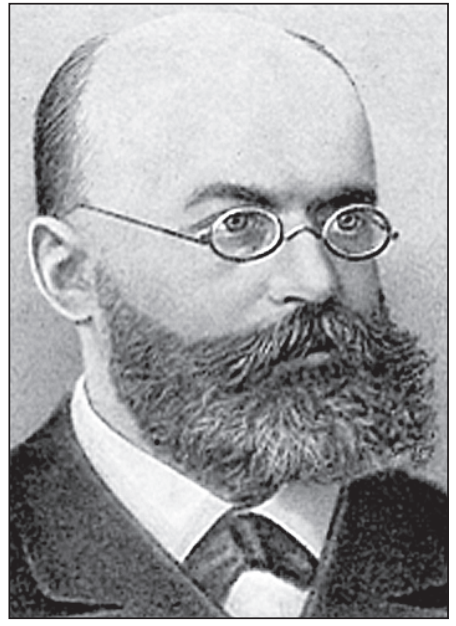

Рис. 49. Пётр Иванович Дьяконов (1855-1908). Профессор госпитальной хирургической клиники Московского и монографий по вопросам общего обезболивания. Совместно с А.А. Бобровым разработал метод дезинтоксикационной терапии университета. Автор ряда статей

меняемость - всё это вначале выгодно отличало хлороформ от эфира. Хлороформ начал вытеснять эфир, так как создалось впечатление, что применение его более безопасно. Хлороформный наркоз стал преимущественным видом обезболивания в России, и ему в течение многих лет посвящается основная масса публикаций по обезболиванию. Об этом свидетельствует работа П.И. Дьяконова (1896), подводящая итоги по применению наркоза к 50-летию его существования. Согласно его данным, хлороформ в чистом виде и в комбинации с другими наркотиками был применён в 83,7\% всех наркозов. П.И. Дьяконов уделял много внимания разработке и пропаганде наркоза в России (рис. 49).

Широкое распространение хлороформа довольно быстро начало выявлять не только положительные его качества, но и отрицательные. Последних было достаточно много, начиная от неприятных ощущений при засыпании до поражения печени, остановки дыхания, сердечной деятельности и летальных исходов. В 1881 г. в монографии «Анестезирующие средства» (рис. 50) О. Каппелер приводит из литературы подробный анализ 101 смерти при проведении наркоза хлороформом за период 1865-1876 гг. Он описывает 10 наблюдений смерти при операциях в челюстно-лицевой области (6 - при экстракции зубов и корней, 3 - удалении опухоли языка и нижней челюсти, 1 - вскрытии абсцесса в области подбородка). Приводим выписки из этих наблюдений без изменения стиля описания.

Наблюдение № 4. Stake из Филадельфии, 1 июня 1866 г. Женщина без сопутствующей патологии. Операция: выдёргивание зуба. После нескольких вдыханий хлороформа больная умерла от паралича сердца.

Наблюдение № 6. Gillespie, Эдинбург, январь 1866 г. Молодая дама без сопутствующей патологии. Операция: выдёргивание зуба. После нескольких вдыханий пациентка громко вскрикнула, как будто ей на самом деле выдернули зуб, перевернулась и сдернула платок. Ввиду глубокого наркоза снова было приступлено к извлечению зуба. Вследствие столбняка жевательных мышц 
между челюстей была положена распорка. G. отошёл от стола, чтобы добыть воды для полоскания рта, и не успел он вернуться, как пациентка лишилась чувств и скончалась, сделав несколько быстрых дыхательных движений. Зрачки были сильно расширены. На вскрытии: сильное сокращение левого желудочка и предсердия, полости их пусты. Правое сердце и лёгкие не представляют явлений гиперемии. Все остальные органы здоровы. Примечание: несколько раньше была хлороформирована без всяких дурных последствий.

Наблюдение № 22. Monckton (Brit. med. J.), 11 декабря 1869 г. Женщина 39 лет, анемичного сложения, без сопутствующей патологии. Операция: экстирпация фунгозной злокачественной опухоли нижней челюсти с помощью гальванокаутера. Больная находилась под влиянием умеренного наркоза, произведённого с

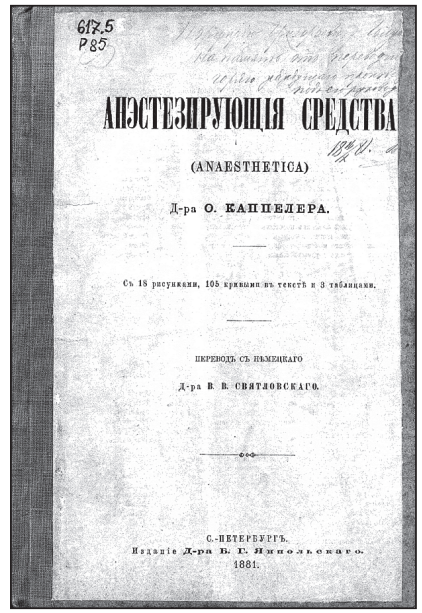

Рис. 50. Титульный лист монографии Отто Каппелера, известного немецкого анестезиолога помощью фланелевой маски Скиннера. По истечении 18 минут, когда третий раз была введена раскаленная проволока, она внезапно скончалась. Все попытки возвратить её к жизни (электричество на грудь, вдыхание ртом воздуха в лёгкие, искусственное дыхание по способу Сильвестра) не повели ни к чему.

Наблюдение № 23. Cotton, Boston med. and surg. J., 23 января 1869 г. Дама без сопутствующей патологии. Операция: выдёргивание зуба. Сперва у захлороформированной больной были выдернуты 3 зуба. Больная совершенно оправилась от действия хлороформа. Ввиду того, что у ней оставались ещё три корешка, решено было снова дать ей хлороформу. Когда корешки были удалены, Cotton заметил, что дыхание почти совсем прекратилось. Голова больной была наклонена вперёд, чтобы дать выход скопившейся во рту крови, и затем было произведено искусственное дыхание. Но все усилия были тщетны, больная скончалась.

Наблюдение № 40. Скибб, Нью-Йоркский мед. журнал, 23 сентября 1870 г. Жена одного врача, мать 8 человек детей. Без сопутствующей патологии. Операция: экстирпация эпителиального рака языка. Израсходовано от 1 до 2 унций хлороформа при помощи носового платка. Анестезия была легко достигнута, и больная весьма недолго находилась в возбуждении. Хотя операция длилась довольно долго и была порядком трудна, хлороформирование было прекращено. По удалении опухоли, вслед за наложением 
шва, больная внезапно лишилась чувств и, несмотря на все усилия, не могла быть возвращена к жизни. Примечание: Скибб объясняет смерть отравлением ЦНС хлороформом.

Наблюдение № 70. Д-р Галль, Lousville, Brit. меd. J., 28 июня 1873 г. Девочка 12 лет. Подозревалось лёгкое страдание сердца. Операция: выдёргивание зуба. Хлороформирована с помощью платка. Непосредственно после того, как зуб был выдернут, пульс сделался слабым, лицо побледнело и черты его исказились. Вслед за первыми попытками к оживлению получилась глубокая инспирация. Сделав 10 глубоких вдыханий, больная снова перестала дышать. Сердечная деятельность не могла быть восстановлена. Описание способов оживления: опускание головы, вытягивание языка вперёд, аммиак, холодный душ, искусственное дыхание. О вскрытии ничего не упомянуто.

Наблюдение № 74. Blaker, Lancet, 6 сентября 1873 г. Женщина 42 лет без сопутствующей патологии. Операция: выдёргивание зуба. Метод хлороформирования: с помощью губки. Непосредственно перед операцией пациентка выпила стакан хереса и уселась в кресло. Возбуждение было невелико, но развился сильный trismus, так что челюсти были разжаты с большим трудом. Вслед за извлечением зуба пульс исчез и все попытки в оживлении были безуспешны (искусственное дыхание, душ из холодной воды, фарадизация). При вскрытии - жировое перерождение сердца. Примечание: раньше несколько раз была хлороформирована. В день смерти ничего не ела.

Наблюдение № 78.University College Hospital. Lancet, 11 апреля 1871 г. Мужчина 30 лет. Сильный пьяница. Диагноз: глубокий абсцесс в области подбородка. Израсходовано хлороформа 3 драхмы. Сначала пациент был сильно возбуждён, хотя анестезия и не была полная. В этот период наркоза была введена игла аспиратора, но ввиду того, что операция длилась слишком долго, было прибавлено ещё хлороформа, при этом больной внезапно побледнел и пульс его исчез. Способы оживления - аммиак, искусственное дыхание. При вскрытии: сердце здорово, левая половина его пуста, в правой большое количество жидкой крови и рыхлых зернистых свёртков. Лёгкие эмфизематозны.

Наблюдение № 81. Кловер, Brit. medical Journal, 20 июня 1874 г. Мужчина без сопутствующих болезней. Операция: вылущивание носоглоточной опухоли. Хлороформирование производилось попеременно с помощью аппарата Кловера и губки. Между зубами больного был помещён кусок каучука. Он вдыхал хорошо и только делал частые глотательные движения. По прошествии 5 мин его вырвало, причём вышло около 3-4 унц. жёлтой жидкости. Когда рвота окончилась, он разговаривал, затем спокойно откинул голову назад и снова вдыхал хлороформ в течение 3 или 4 мин. Предварительное исследование снова сопровождалось рвотой, а потому наркотиза- 
ция была продолжена до тех пор, пока зрачки сузились и роговица потеряла свою чувствительность. Пульс был правильный, но слегка слабый к этому времени, то есть приблизительно спустя 15 мин от начала вдыханий, опухоль была снова исследована и была сделана попытка провести лигатуру через нос в рот. Вследствие этой манипуляции и благодаря моментальному удалению аппарата, пациент наполовину пришёл в себя, так что ему снова пришлось дать хлороформа. Через 1/2 мин вновь появилась рвота и пульс сделался ещё слабее. Хлороформ был удалён и как только что заметили, что он страшно побледнел и зрачки его расширились, как его немедленно уложили в горизонтальное положение. Больной дышал слабо, но был напряжён, и когда было замечено, что дыхание его постепенно ослабевает, то было произведено искусственное дыхание по способу Сильвестра и Брена. Каучуковый тампон, помещённый между зубами, облегчал доступ атмосферного воздуха, который свободно, без шума, проходил через гортань. Больной 3 или 4 раза постонал и раза 2 думали, что пульс снова появился, но зрачки по-прежнему оставались расширенными и нечувствительными. По истечении 1/4 часа появилось немного слизи из воздухоносных путей. Больному давали нюхать аммиак, лицо было опрыскано холодной водой, на грудь были положены горячие полотенца, и искусственное дыхание производилось в течение целого часа. Вскрытие не было дозволено. Примечание: пациент был хлороформирован сидя. Кловер полагает, что больной вдыхал слишком концентрированные пары хлороформа.

Наблюдение № 95. Evan Abraham Morgan, Brit. medical Journal, 1 aпреля 1876 г. Дама без сопутствующих заболеваний. Операция: выдёргивание многих зубных корешков. Израсходовано 11/2 драхмы. Morgan исследовал пульс и сердце и не нашёл ничего ненормального, хлороформ давался постепенно, а не вдруг. Когда были выдернуты 3 зубных корешка, цвет лица больной внезапно изменился, почему тотчас же были открыты окна и больную опрыскали холодной водой. Дыхание постепенно слабело всё более и более, больная была положена на пол, вслед за тем дыхание совершенно прекратилось. Производили искусственное дыхание по способу Сильвестра, удалось вызвать дыхание в течение 2-х минут, но затем оно снова прекратилось навсегда, несмотря на применение электричества. Вскрытие обнаружило страдание сердца. Примечание: больная была хлороформирована в сидячем положении. Причина смерти - остановка сердца.

Из зарубежных врачей для изучения, совершенствования и пропаганды методов наркотизации во второй половине XIX века много сделал Джон Cноу (John Snow). Его считают отцом анестезиологии (рис. 51). Он был первым врачом, посвятившим полностью себя исследованию и примене- 


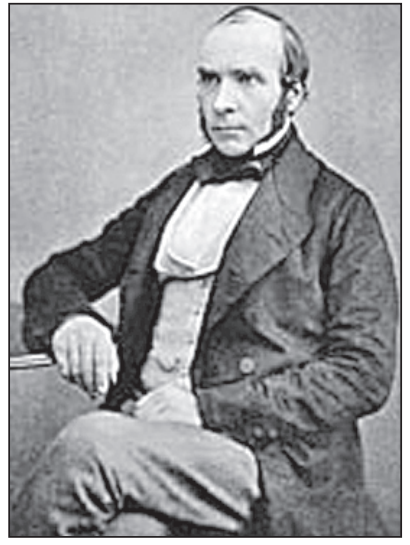

Рис. 51. Джон Сноу (1813-1858).

Первый профессиональный специалист-анестезиолог.

Описал стадии наркоза эфиром, предложил лицевую маску, изобрёл специальный ингалятор нию эфира, изобрёл специальный ингалятор. Джон Сноу первым в Англии провёл научные исследования эфира и физиологии общей анестезии. Сноу был также пионером эпидемиологии: он помог остановить эпидемию холеры в Лондоне, предположив, что вызывающий холеру возбудитель передаётся через желудочнокишечный тракт, а не воздушно-капельным путём. В 1847 г. Сноу опубликовал первую книгу по общей анестезии - «Об ингаляции эфира» («On the Inhalation of Ether»). Когда стало известно о применении хлороформа для анестезии, Сноу быстро изучил его свойства и создал ингалятор также и для этого препарата. Учёный верил, что употребление ингаляторов для введения препаратов позволит регулировать дозу анестетика. Его вторая книга - «О хлороформе и других анестетиках» («On Chloroform and Other Anaesthetics») - была издана посмертно в 1858 г.

После смерти Сноу место ведущего английского врача-анестезиолога по праву стало принадлежать Джозефу Томасу Кловеру (рис. 52).

Джозеф Томас Кловер родился в Эйлесхэме под Норфолком в 1825 г. Он получил образование в монастырской школе в Норвиче. Когда Джозефу исполнилось 16 лет, его отдали в обучение в качестве помощника к местному хирургу Чарльзу Гибсону. В 1844 г. Кловер поступил в медицинский колледж при Лондонском университете и окончил его с отличием в 1846 г.

В течение двенадцати лет Джозеф Кловер занимался хирургической и общей медицинской практикой, отдавая предпочтение урологии. Он разработал специальные инструменты для разрушения камней в мочеточниках, специальные шприцы для извлечения камней и их фрагментов, приспособление для фиксации ног во время литотомии. За весь этот период времени, начиная с 1846 г., он довольно часто проводил эфирные и хлороформные наркозы, и в вопросах анестезии ориентировался достаточно профессионально. Считая занятие общей практикой слишком скучным и утомительным делом, Кловер охотно принял приглашение занять должность штатного анестезиолога в университетской клинике, Вестминстерском госпитале и лондонской зубоврачебной клинике. Объём работы в этих клиниках был настолько велик, что Джозеф Кловер к концу своей анестезиологической карьеры выполнил более 20000 нар- 
козов. Если учесть, что все эти колоссальные нагрузки проходили на фоне постоянных длительных переездов на кэбе между госпиталями и домами частных пациентов, то это огромное количество анестезий производит ошеломляющее впечатление даже на анестезиологов с солидным стажем.

Как хороший и грамотный анестезиолог Кловер был весьма популярен в Лондоне, поэтому в числе его пациентов было очень много известных личностей, таких, например, как Принцесса Уэльсская, будущая Королева Александра; сэр Роберт Пиль, основатель Скотланд-Ярда и лондонской полиции, служащих которой теперь называют по его имени «бобби»; сэр Эразмус Уилсон; Флоренс Найтингейл, знаменитая сестра милосердия и общественный деятель Великобритании; Чарльз Луи Наполеон, проживавший одно время в Англии, и позднее провозгласивший себя императором Франции Наполеоном III; и многие-многие другие известные люди Англии. Историкам и биографам этих знаменитостей остаётся теперь только сожалеть, что в отличие от другого выдающегося британского анестезиолога Викторианской эпохи, Джона Сноу, Джозеф Кловер в своих записях представлял такие «VIP-случаи» анестезии скудно и недостаточно подробно.

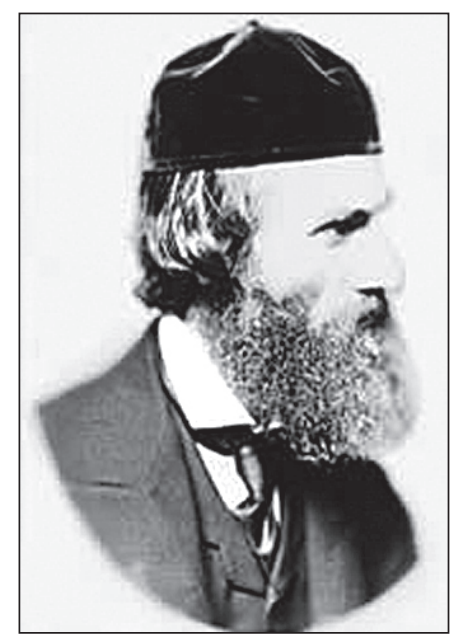

Рис. 52. Джозеф Томас Кловер (Joseph Thomas Clover, 1825-1882) - выдающийся английский анестезиолог. Первым из анестезиологов применил выдвижение челюсти больного во время наркоза для предотвращения обструкции дыхательных путей, первым настоял на том, чтобы оборудование для реанимационных мероприятий во время анестезии всегда находилось в операционной и первым применил пункционную коникотомию (для спасения пациента с опухолью полости рта и угрозой полной обструкции дыхательных путей) 


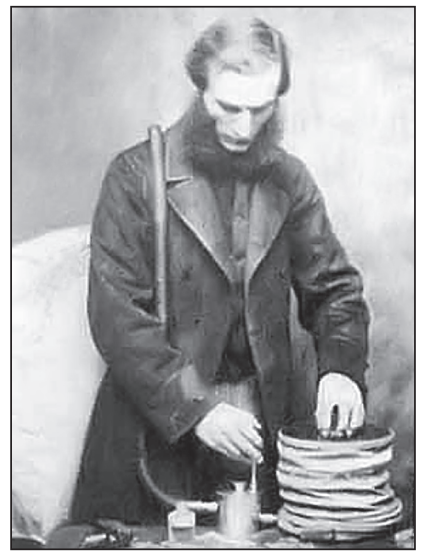

Рис. 53. Джозеф Кловер заканчивает подготовку к хлороформному наркозу.

Мешок с воздухом, содержащим 4,5\% паров хлороформа, находится за плечами Кловера.

(Ил. В.M. Duncum: The History of Inhalation Anaesthesia. Oxford University Press, London, 1947.)

Понимая, что хлороформный наркоз станет более безопасным, если анестезиологу в каждый конкретный момент анестезии хотя бы приблизительно будут известны используемые им концентрации анестетика, Джозеф Кловер усовершенствовал наркозный мешок Джона Сноу (рис. 53). Мешок Кловера был сделан из водонепроницаемой шёлковой ткани, и по своей форме, как мы видим на фотографии, напоминал обычную наволочку. Воздуходувные мехи, сделанные Кловером из шестигранной гармоники, соединялись с помощью наконечника с корпусом испарителя. В испарителе устанавливалась металлическая бутылка с горячей водой. Эта бутылка оборачивалась промокательной бумагой для увеличения площади поверхности испарения хлороформа. В камеру испарителя через специальное отверстие с помощью градуированного стеклянного шприца вводился хлороформ. Ёмкость воздуходувных мехов составляла 1000 кубических дюймов (16 литров). Кловер вводил в испаритель 2,4 мл хлороформа, после чего прокачивал через него мехами определённый, рассчитанный заранее, объём воздуха, чтобы мешок заполнялся именно 4,5\% паром хлороформа. Это была достаточно сильная концентрация, чтобы обезболить любого пациента в течение 4 минут.

Перед началом наркоза Кловер отсоединял трубку мешка от испарителя и прикреплял её к лицевой маске с тонкими клапанами вдоха и выдоха из слоновой кости с пружинами. В маске имелось отверстие для подачи чистого воздуха и снижения тем самым концентрации паров хлороформа 
во вдыхаемой пациентом смеси. Во время своих наркозов Кловер не размещал газовый мешок на полу под ногами у хирурга, как это делалось обычно другими анестезиологами, а вешал его себе за спину. С техникой анестезии, предложенной Кловером, можно ознакомиться, благодаря представленной ниже чудом сохранившейся фотографии (рис. 54).

В 1868 г. Кловер доложил о 1802 наркозах, проведённых им по данной методике. При этом не было ни одного случая наркозной смерти. Для того времени это были более чем хорошие показатели безопасности анестезии.

Правда, спустя некоторое время, при последующих анестезиях один из его пациентов умер от передозировки хлороформа [см. Отто Каппелер (1881): Наблюдение № 81. Кловер, Brit. medical Journal, 20 июня 1874 г.]. По объяснению Кловера, причиной наркозной смерти послужила его собственная ошибка в расчётах концентрации хлороформа при заполнении газового мешка. И всё-таки, несмотря на проявленную Кловером научную изобретательность и тщательность в разработке мешка, это устройство не пользовалось большой популярностью среди анестезиологов.

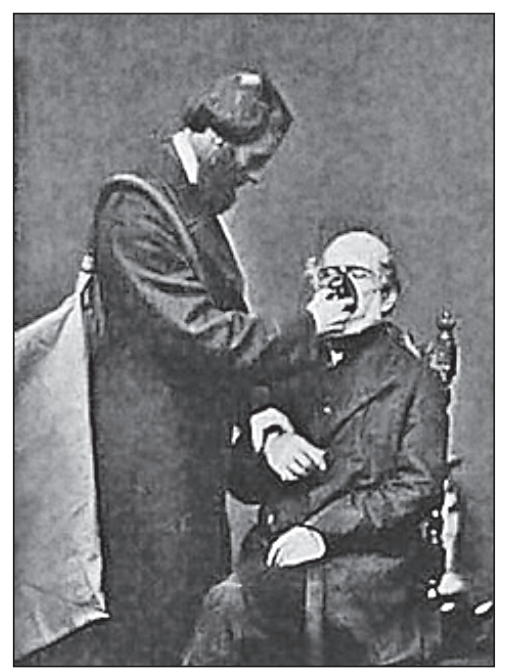

Рис. 54. Джозеф Кловер демонстрирует хлороформный наркоз с помощью аппарата собственной конструкции. Обратите внимание на использование элемента «простейшей формы клинического мониторинга» - указательный палец анестезиолога контролирует пульс пациента на лучевой артерии. Следует отметить, что Кловер придавал особое значение постоянному наблюдению за пульсом больного во время анестезии, что не было широко распространено в те годы. (Ил. В.M. Duncum: The History of Inhalation Anaesthesia. Oxford University Press, London, 1947.) 

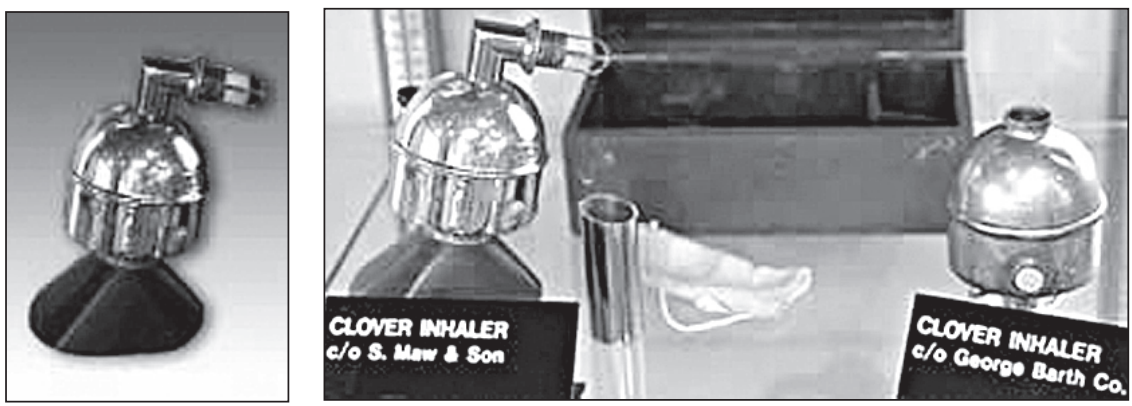

Рис. 55. Эфирные ингаляторы Джозефа Кловера

В 1864 г. Королевское Медицинское и Хирургическое Общество (ныне Королевское Общество Медицины) основало специальный комитет для анализа смертности при хирургических операциях, выполненных под наркозом хлороформом. Джозеф Кловер был приглашён в качестве эксперта. Он же провёл многочисленные демонстрационные наркозы на животных. И хотя комитет посчитал его методику хлороформного наркоза наиболее приемлемой и вынес заключение о безопасности хлороформного наркоза, сам Кловер дополнительно рекомендовал анестезиологам непрерывно контролировать пульс пациента во время анестезии и временно прекращать её, если пульс становится нерегулярным или ослабевает: «Если палеи на пульсе обнаружил какие-то изменения в его работе, я бы дал больному немного воздуха».

В 1868 г. доктор Т.У. Эванс (T.W. Evans), американский хирург-дантист, успешно практиковавший в Париже, провёл в Лондоне демонстрации

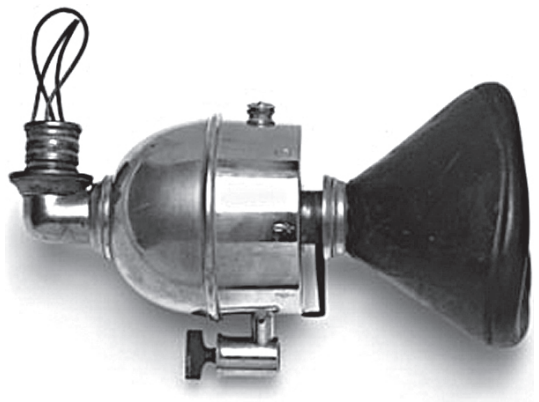

Рис. 56. Регулируемый эфирный ингалятор Джозефа Кловера обезболивания зубоврачебных операций при помощи закиси азота. Эффективность анестезии закисью азота и её безопасность произвели огромное впечатление на Кловера, хотя "внешний вид пациентов, их циинотичность и конвульсивные движения» вызвали у него некоторую настороженность.

Приступив к наркозам с применением закиси азота, Кловер использовал свой собственный мешок с хлороформом и добавил в контур ещё 
один дополнительный мешок ёмкостью 200 кубических унций (3,3 литра), расположив его рядом с лицевой маской. Он открывал этот мешок с помощью специального клапана после первых 6-7 вдохов из мешка с парами хлороформа. Кловер попытался применять носовую маску для обеспечения непрерывной анестезии при помощи закиси азота во время зубоврачебных операций, но обнаружил, что у него слишком часто появлялась необходимость прибегать к добавлению хлороформа.

В 1874 г. Кловер применил разработанный им ингалятор для комбинированных наркозов эфиром и закисью азота, и, благодаря его успехам, эфир снова нашёл широкое применение в анестезиологической практике того времени (рис. 55).

Кловер отчётливо продемонстрировал своим коллегам, что основными преимуществами применения данной комбинации анестетиков являются быстрая индукция, лучшая

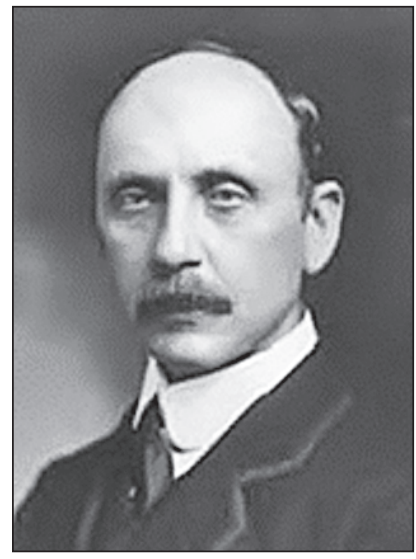

Рис. 57. Сэр Фредерик Хьюитт (1857-1916) - первый «Рыцарь анестезии» Великобритании.

(Ил. American Society of Anesthesiologists Newsletter, Sept. 2008, vol. 72, № 9, p. 10.) управляемость анестезией, снижение частоты осложнений и низкая себестоимость наркоза.

В 1877 г. Кловер внедрил потребовавший от него много сил и энергии компактный «портативный регулируемый эфирный ингалятор», который позднее был модифицирован изобретателями, включая Луи Омбреданна (Louis Ombredanne, 1871-1956) и использовался вплоть до второй мировой войны (рис. 56).

В 1882 г. Джозеф Кловер умер от уремии в возрасте 57 лет. Он был похоронен рядом с Джоном Сноу на Бромптонском кладбище в Лондоне. С 1949 г. по инициативе Королевской коллегии хирургов в Лондоне стали проводиться ежегодные чтения лекций в память Джозефа Кловера в знак уважения его вклада как клинициста, изобретателя, автора научных работ и ведущего анестезиолога Викторианской эпохи. Эти лекции проводились ежегодно до 1958 г., а затем один раз в два года, чередуясь с лекциями в честь другого известного британского

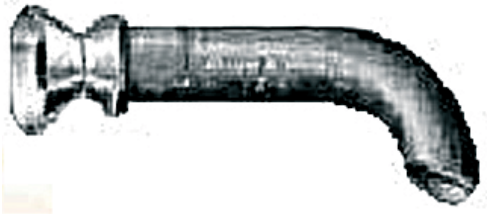

Рис. 58. Воздуховод Хьюитта (1908). (Ил. American Society of Anesthesiologists Newsletter, Sept. 2008, vol. 72, № 9, p. 12.) 


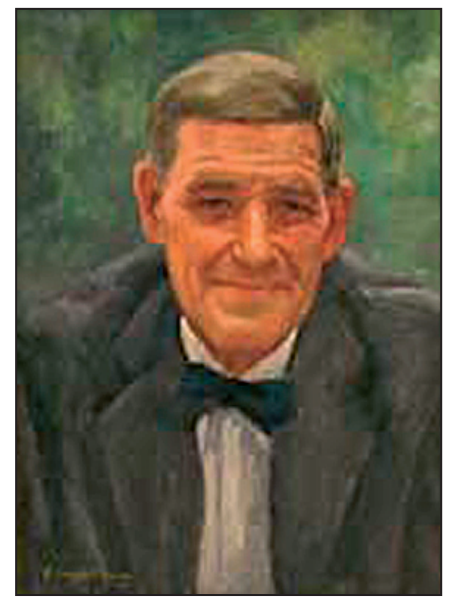

Рис. 59. Артур Гведел

(Arthur Guedel, 1883-1956)

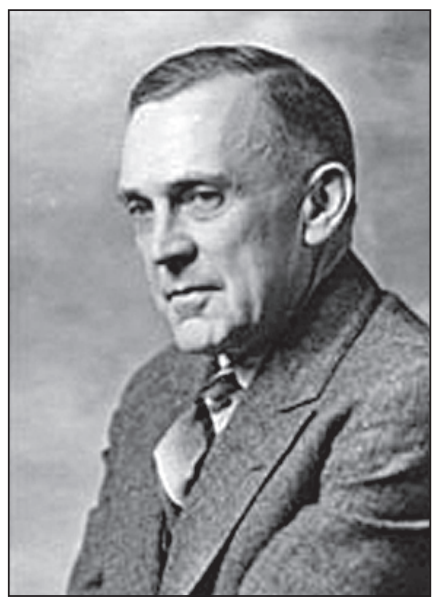

Рис. 60. Ральф Уотерс (Ralph Milton Waters, 1883-1928) Американский анестезиолог, выполнивший исследования, которые привели к внедрению в практику интубационной трубки с раздувной манжетой анестезиолога, сэра Фредерика Уильяма Хьюитта.

Сэр Фредерик Хьюитт (Frederick Hewitt) - ведущий английский анестезиолог конца XIX века (рис. 57). Работал в Национальном Зубоврачебном госпитале в 1885 г. и в Лондонской больнице в 1886 г. Он создал различные наркозные аппараты. Вначале из-за его интереса к анестезии в зубоврачебной практике, основанной на наркозе закисью азота как единственного препарата, он сделал специальные зубные распорки и один из первых ротовых воздуховодов (Hewitt F.W., 1908), модифицировал ингалятор Юнкера (Junker). Хьютт разработал специальные устройства, которые позволяли поддердивать постоянные концентрации кислорода при вдохе; написал два больших учебника по анестезии, каждый из которых выдержал 5 выпусков. В 1893 г. Хьюитт стал членом Лондонского общества анестезиологов и энергично проводил кампанию за законодательное включение анестезии обязательным предметом в медицинский учебный план, за надлежащую административную организацию в пределах отделов анестезии, собирал сведения по анестезиологической летальности. Хьюитт изучал обструкцию дыхательных путей при анестезии в 1890 г., но только в 1908 г., он представил предшественника многих современных орофарингеальных воздуховодов (рис. 58). Эта первая модель, должно быть, имела только ограниченный успех при устранении дислокации языка, и скоро изогнутая модель была увеличена в длине. Из-под пера Хьюитта вышли также труды, которые явились первым настоящим руководством по анестезиологии. 
В 1901 г. Хьюитт был назначен анестезиологом Короля Эдуарда VII. Он стал первым «Рыцарем в анестезии» в 1911 г. (Wilkinson D.J., 2007).

Сноу, Кловер и Хьюитт заложили традиции врачебной анестезиологии, которые сохраняются в Англии до сих пор.

Три врача стояли у истоков развития анестезиологии в США в конце XIX века: Артур Е. Гведел (Arthur Е. Guedel), Ральф M. Уотерс (Ralph M. Waters) и Джон С. Ланди (John Silas Lundy) - рис. 59, 60, 61.

Гведел был первым, кто, после первоначального описания Сноу, выделил и подробно охарактеризовал стадии эфирного наркоза. Он выступал за использование эндотрахеальных

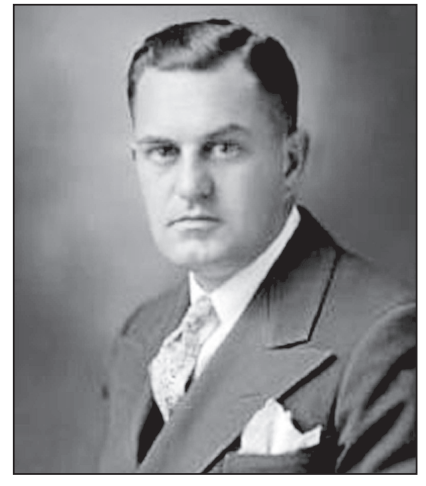

Рис. 61. Джон Ланди (John Lundy, 1894-1973) американский анестезиолог трубок с манжетками и проведение искусственной вентиляции во время эфирной анестезии. Первая плановая интубация трахеи во время наркоза была выполнена в конце XIX века хирургами: сэром Уильямом Мак-Эвеном (William Macewen) в Шотландии в 1878 г., Джозефом О'Двайером (Joseph O'Dwyer) в США и Францем Куном (Franz Kuhn) в Германии. 


\section{Вклад врачей России}

Имеются определённые основания считать, что применение эфирного наркоза в России началось никак не позднее, чем в Америке, а, возможно, даже на два года раньше. В.Ю. Островский (1983) сообщает, что исследователи в двух источниках обнаружили указание на то, что в газете «Русский инвалид» в 1844 г. была опубликована статья Я.А. Чистовича «Об ампутации бедра при посредстве серного эфира».

Я.А. Чистович (1820-1885) был выдаю-

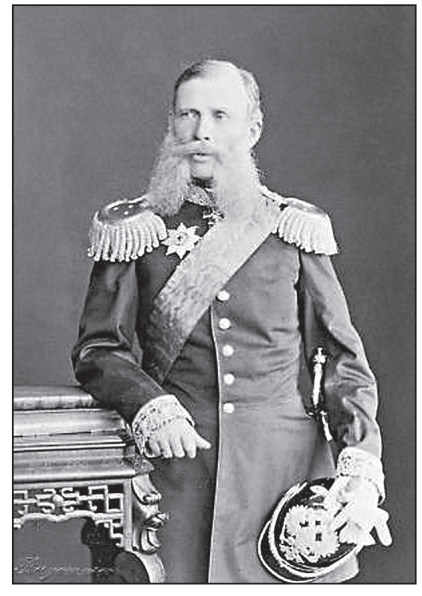

Рис. 62. Яков Алексеевич Чистович

(1820-1885). Пионер эфирного наркоза в России щимся врачом, администратором, гигиенистом, судебным медиком и историком медицины (рис. 62). О статье есть свидетельства Л.Ф. Змеева в библиографическом словаре «Русские врачи-писатели». Второе свидетельство принадлежит сыну Я.А. Чистовича - видному терапевту, начальнику терапевтической клиники ВМА, академику Н.Я. Чистовичу (1860-1926), который в биографическом очерке, посвящённом отцу, писал: «В 1844 г. он напечатал свою первую работу «Об отнятии бедра под наркозом эфира». Работа прошла незамеченной, а обнародована она была за три года до того, как Н.И. Пирогов стал широко применять эфирный наркоз».

Оставляя приоритет открытия эфирного наркоза упорному и честолюбивому Мортону, мы отдаём дань уважения русским медикам. Прежде всего, это Ф.И. Иноземцев, проведший первую в России анестезию эфиром 7 февраля 1847 г., то есть меньше чем через четыре месяца после успешной демонстрации Мортона. Ровно через четыре месяца после Мортона, 16 и 18 февраля, великий русский хирург Н.И. Пирогов провёл в Петербурге в Обуховской больнице и в Первом Военносухопутном госпитале две операции под эфирным наркозом. И, наконец, уже широко известно, что 3 марта 1847 г. Я.А. Чистович наркотизировал в бригадном лазарете - фактически в полевых условиях - больного, которому хирург Радзевич произвёл ампутацию бедра. 


\section{Отображение открытия анестезии в изобразительном искусстве и литературе}

Следует отметить роль художников, запечатлевших это величайшее событие в истории медицины. Несмотря на разногласия историков медицины в отдании пальмы первенства тому или иному претенденту на приоритет в первооткрытии, их участие в событиях 1840-х годов стало вкладом в победу человечества над болью с помощью анестезии (Vandam L.D., 1980; Wolfe R.J., 1993; Desai S.P., Desai R.M., Battit G.E., 2007). В 1882 году начинающий художник Роберт Кутлер Хинкли (Robert Cutler Hinckley, 1853-1941), следуя совету французского портретиста Каролюса-Дюрана (Carolus-Duran, 1838-1917) и выполняя требования программы обучения для парижских студентов-живописцев, решил написать картину о первой успешной публичной демонстрации эфирной анестезии. В последствии эта зачётная и учебная картина Хинкли «The First Operation with Ether (Первая операция под эфиром)» (рис. 63, 64) стала одной из наиболее популярных картин в истории медицины.

Несколько лет после празднования 150-й годовщины первого эфирного наркоза совет попечителей Массачусетской больницы общей практики (Бостон, Массачусетс), вдохновлённый доктором Джоном Херманом (John B. Herman), поручил Уоррену и Люции Проспери (Warren, Lucia Prosperi) воссоздать более точную и достоверную по возможности картину о первой демонстрации эфирного наркоза. Картина «День эфира, 1846 год» (рис. 65, 66), была представлена 16 октября 2001 года, ровно через 155 лет после исторической демонстрации анестезии эфиром. Картина была преподнесена в качестве подарка Массачусетской больнице общей практики.

Теперь информация о самих художниках. Роберт Кутлер Хинкли (Robert Cutler Hinckley, 1853-1941) родился в штате Массачусетс 3 апреля 1853 года. Место рождения художника по разным источникам отмечено как Бостон (Wolfe R. J., 1993) и Нортгемптон (Vandam L. D., 1980). Роберт был ещё подростком, когда родители отправили его в Париж для обучения искусству. Хинкли провёл там почти 20 лет и проходил обучение живописи под руководством замечательного портретиста Каролюса-Дюрана (Charles Auguste Emile Durand, 1838-1917). В 1882 году по совету учителя Хинкли начал работать над картиной «Первая операция под эфиром». Интересен тот факт, что первая публичная демонстрация анестезии эфиром была проведена задолго до того, как родился сам Хинкли, и маловероятно, что он когда-либо был лично знаком с кем-нибудь из участников этого события. Поэтому он потратил много времени, выясняя, кто присутствовал на этом наркозе, консультируясь с разными людьми в Бостоне и просматривая записи и газетные статьи. Эта работа продолжалась 11 лет до 1893 года, когда картина была почти завершена (Vandam L.D., 1980; Wolfe R.J., 1993). 


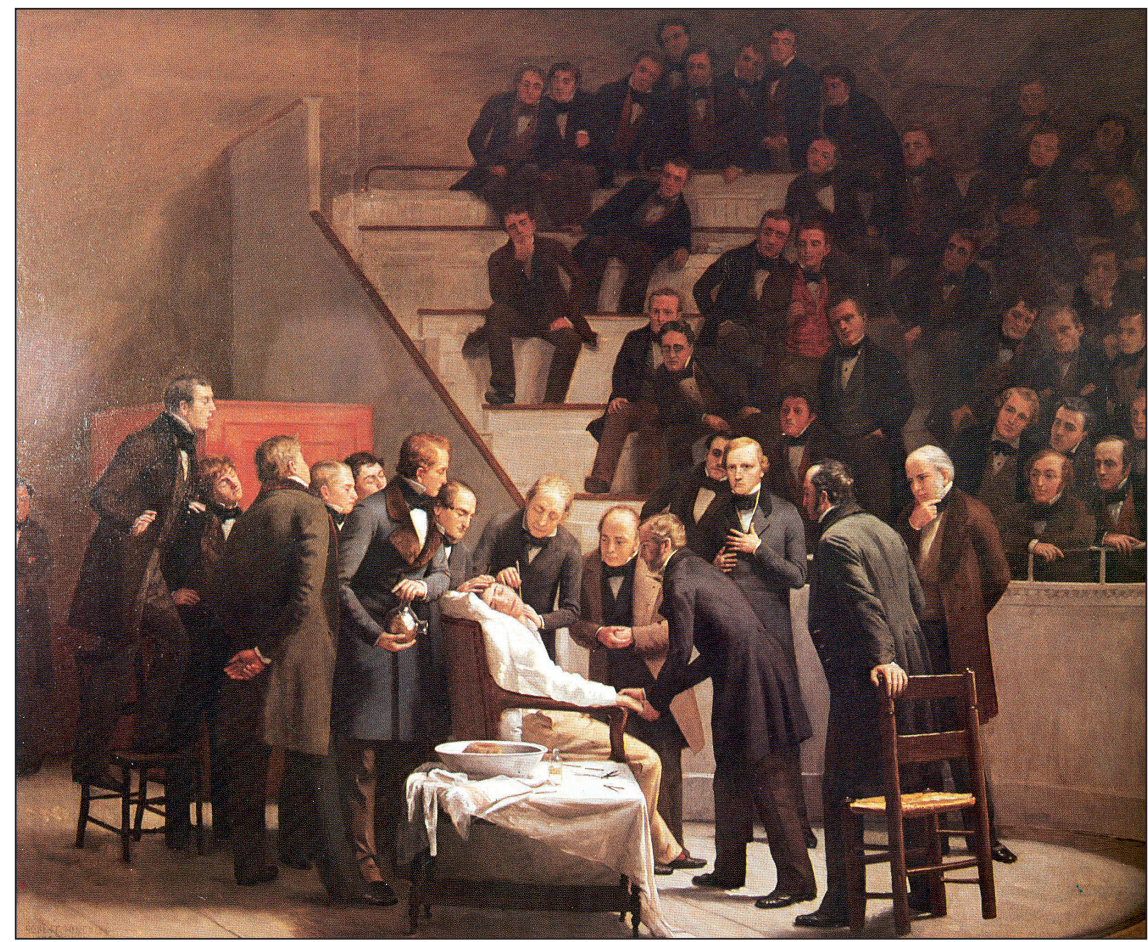

Рис. 63. Картина Robert Cutler Hinckley «Первая операция подэфиром», 1882 г. Холст, масло, 8' x 10'. Бостонская Медицинская Библиотека при БиблиотекеМедицины Francis A. Countway, Бостон, Массачусетс. На переднем плане изображены слева направо:Уильям Томас Грин Мортон с ингалятором эфира в руках, Джон Коллинз Уоррен, оперирующий художника Эдварда Джильберта Эббота, Эбен Фрост, которому 30 сентября 1846 г. Мортон под эфирным наркозом безболезненно удалил зуб, Чарльз Ф. Хейвуд (хирург-интерн), Генри Джекоб Бигелоу (хирург, автор первой статьи об ингаляционном наркозе), Огастес э. Гулд (врач Массачусетской больницы общей практики, ставший медицинским консультантом Мортона; предложил в эфирном аппарате дыхательные клапаны, дал название препарату «летеон» (от греч. Лета - река забвения), был пропагандистом нового метода и свидетелем Мортона при регистрации открытия в бюро патентов 


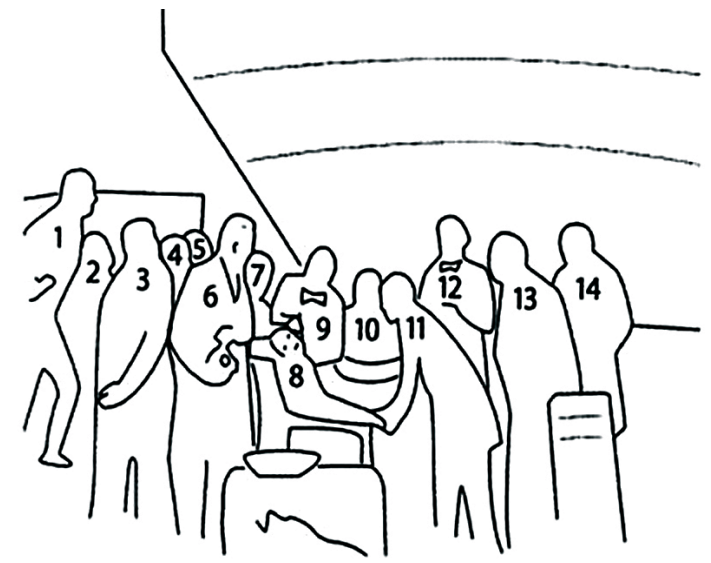

Рис. 64. Персонажи на картине Роберта Кутлера Хинкли (Ил. по S.P. Desai., R.M. Desai., G.E. Battit, 2007.):

1. Неизвестный репортёр газеты;

2. Джон Кэлл Дэлтон (John Call Dalton, 1825-1889), студент Гарвардской школы медицины;

3. Уильям Уильямсон Веллингтон (William Williamson Wellington, 1814-1896), двоюродный брат больного Эдварда Джильберта Эббота;

4. Абель Лоуренс Пирсон (Abel Lawrence Peirson, 1794-1853), хирург-консультант, Массачусетская больница общей практики;

5. Чарльз Осеа Хелдрет (Charles Hosea Hildreth, 1825-1884), студент Гарвардской школы медицины;

6. Уильям Томас Грин Мортон (William Thomas Green Morton, 1819-1868), анестезиолог;

7. Джонатан Мэйсон Уоррен (Jonathan Mason Warren, 1811-1867), хирург Массачусетской больницы общей практики;

8. Эдвард Джильберт Эббот (Edward Gilbert Abbott, 1825-1855), пациент;

9. Джон Коллинз Уоррен (John Collins Warren, 1778-1856), профессор анатомии и хирургии Гарвардской медицинской школы, руководитель хирургии и основатель Массачусетской больницы общей практики, оперирующий хирург;

10. Эбен Фрост (Ebenezer Hopkins Frost, 1824-1866), учитель музыки, получавший общую анестезию при экстракции зуба несколько ранее, 30 сентября 1846 года;

11. Чарльз Фредерик Хейвуд (Charles Frederick Heywood, 1823-1893), штатный хирург Массачусетской больницы общей практики;

12. Генри Джекоб Бигелоу (Henry Jacob Bigelow, 1818-1890), профессор хирургии Гарвардской медицинской школы;

13. Огастес Эддисон Гулд (Augustus Addison Gould, 1805--1866), врач и конхиолог, секретарь, Массачусетского 0бщества Медицины;

14. Соломон Дэвис Таунсенд (Solomon Davis Townsend, Массачусетской больницы общей практики. 


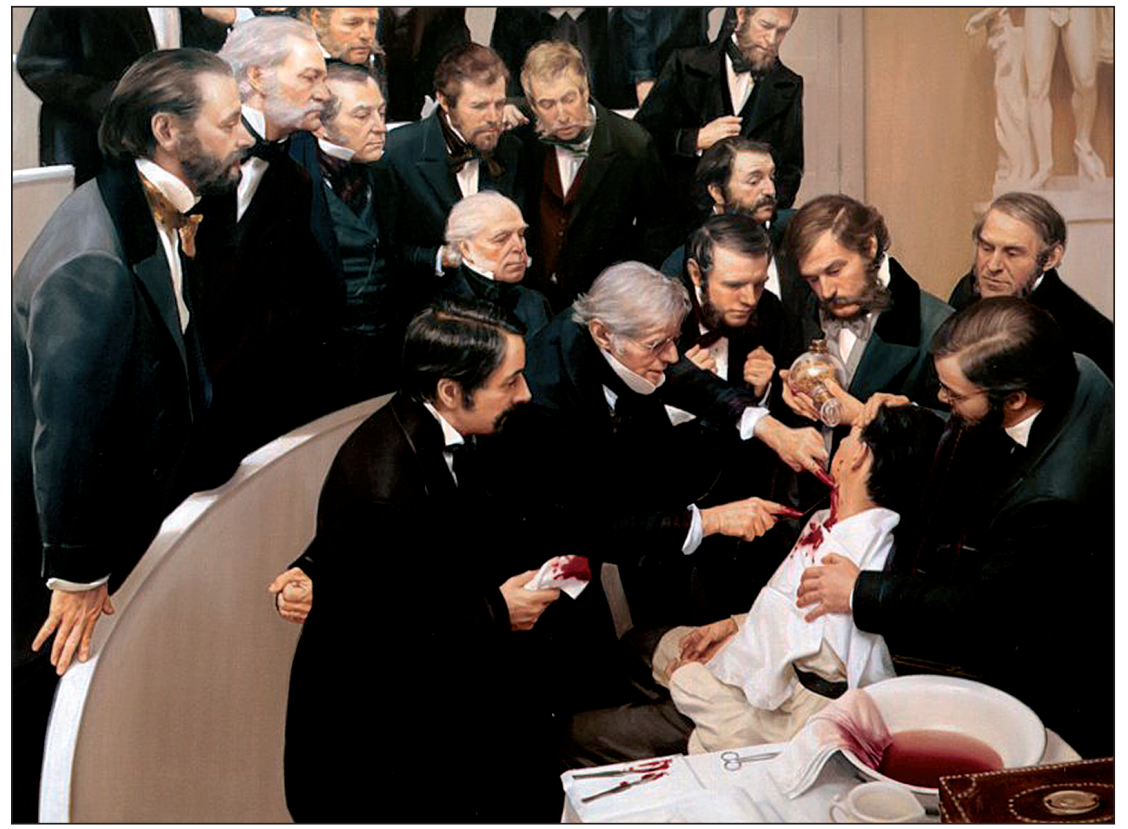

Рис. 65. Картина Warren и Lucia Prosperi «День Эфира, 1846 год», 2001 г. Холст, масло, 6' х 8'. Массачусетская больница общей практики, архивы и специальные коллекции, Бостон, Массачусетс.

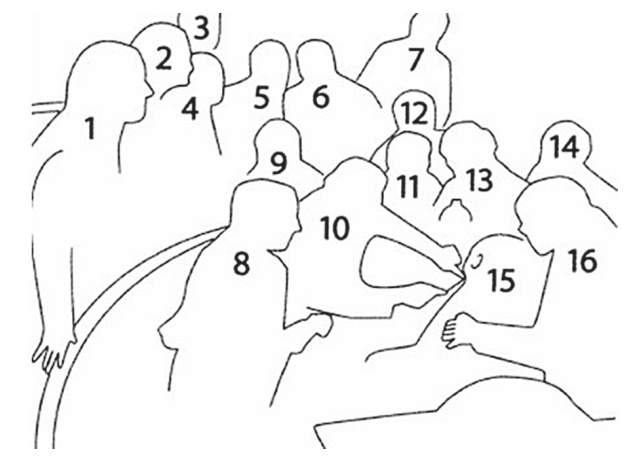

Рис. 66. Персонажи на картине Уоррена и Люции Проспери

[имена людей, позировавших для картины] (Ил. по S.P. Desai., R.M. Desai., G.E. Battit, 2007.):

Все академические названия относятся к Гарвардской медицинской школе, отделенческие - к Массачусетской больнице общей практики, Бостон, Массачусетс. 
1. Студент-медик [позировал Edward A. Stern, адъюнкт-профессор неврологии, отделение неврологии];

2. Уильям Уильямсон Веллингтон (William Williamson Wellington, 1814-1896) [позировал Michael Long, доцент анестезии, отделение анестезии и интенсивной терапии];

3. Студент-медик [позировал John Donohoe, приглашённый гость];

4. Генри Джекоб Бигелоу (Henry Jacob Bigelow, 1818-1890), [позировал W. Gerald Austen, професcop хирургии];

5. Студент-медик [позировал James W. Мау, профессор хирургии, руководитель отделения пластической и реконструктивной хирургии];

6. Студент- медик [позировал Andrew L. Warshaw, профессор хирургии, отделение хирургического лечения];

7. Студент-медик [позировали W. Scott McDougal, Walter S. Kerr, профессор урологии, отделение урологии];

8. Чарльз Фредерик Хейвуд (Charles Frederick Heywood) [позировал Glen M. La Muraglia, адъюнктпрофессор хирургии, отделение хирургии];

9. Соломон Дэвис Таунсенд (Solomon Davis Townsend) [позировал John D. Stoeckle, профессор медицины, заслуженный деятель, отделение медицины];

10. Джон Коллинз Уоррен (John Collins Warren, 1778-1856) [позировал J. Philip Kistler, профессор неврологии, отделение неврологии];

11. Генри Джекоб Бигелоу (Henry Jacob Bigelow, 1818-1890) [позировал Robert L. Martuza, Higgins профессор нейрохирургии, руководитель, отделение нейрохирургии];

12. Эбен Фрост (Ebenezer Hopkins Frost, 1824-1866) [позировал John B. Herman, адъюнкт-профессор психиатрии, отделение психиатрии];

13. Уильям Томас Грин Мортон (William Thomas Green Morton, 1819-1868) [позировали Warren M. Zapol, Reginald Jenney, профессор анестезии, руководитель, отделение анестезии и интенсивной терапии];

14. Огастес Эддисон Гулд (Augustus Addison Gould, 1805-1866) [позировал William E. Minichiello, адъюнкт-профессор психологии в отделении психиатрии, отделение психиатрии];

15. Эдвард Джильберт Эббот (Edward Gilbert Abbott, 1825-1855) [позировал David Silverman, студент, друг художников];

16. Джон Кэлл Дэлтон (John Call Dalton, 1825-1889) [позировал William G. Austen, доцент хирургии, отделение пластической и реконструктивной хирургии].

Несмотря на то, что творчество Роберта Хинкли насчитывает более чем 300 картин, главным образом, портретов, широкой известности эти работы не получили. Исключение составляют лишь две его работы: портрет капитана Джона Бэрри (John Barry, 1745-1803), являющийся частью коллекции морского ведомства США, и портрет члена Конгресса от штата Джорджия Чарльза Фредерика Криспа (Charles Frederick Crisp, 1845-1896) из коллекции Палаты представителей США. 
Современные художники Уоррен и Люция Проспери выросли во Флориде и Новой Англии, соответственно, и в настоящее время проживают в Саутбороу, штат Массачусетс. Их работы - это портреты, пейзажи и мемориальные картины. Некоторые их картины представлены на выставках в больницах, в клиниках и торговых зданиях в Новой Англии; предпочитаемая техника - холст, масло (Desai S.P., Desai R.M., Battit G.E., 2007).

Хотя эти две картины показывают одну и ту же сцену, традиционный подход Хинкли резко контрастирует с «фотожурналистским» толкованием Проспери. Зрителям трудно сравнивать достоинства двух картин, написанных в различные периоды с помощью различных стилей и имеющих различные цели. S.P. Desai, R.M. Desai, G.E. Battit (2007) в статье «История двух картин, изображающих первую публичную демонстрацию эфирной анестезии», очень верно отметили дополнительный вклад, внесённый работой четы Проспери и изучили эмоциональную реакцию, вызываемую этими работами, когда и где они были созданы, цель их создания и различие в стилях. «Современная картина Проспери отражает больше видимых деталей, она более точна в историческом плане и передаёт больше ощущения действия, чем картина Хинкли. Эти эффекты достигаются отчасти с помощью использования четой Проспери света с различной насыщенностью, путём изображения пространства, а не полного обзора участников, и путём использования более общей композиции. Картина Хинкли была создана в Париже, во Франции, а картина Проспери в современном Вашингтоне. Хинкли в своей работе в течение периода свыше 10 лет придерживается традиций, превалирующих во второй половине 19-го столетия. Он поставил участников действие перед пациентом, а не вокруг пациента. Кроме того, он рассредоточил участников, расположив их на расстоянии друг от друга, создал тем самым драматическую сцену.

Подобно работам Эйкинса и Рембрандта ... семья Проспери старается соблюдать медицинскую точность, обеспечивая наблюдателям наиболее выгодное положение ближе к месту действия и расставляет участников вокруг места этого действия. Картина Проспери показывает пациента, спокойного во время операции. Уильям Мортон изображён как наблюдатель, стоящий перед пациентом. Эта картина более точная, однако, следует принять во внимание трудности, с которыми столкнулся Хинкли при выяснении списка присутствующих, их роли и используемого оборудования. Зато Хинкли более преуспел в изображении сцены, которая предвещала открытие анестезии. Сцена кажется театральной, а более скромного размера на самом деле «Купол Эфира» кажется вполне большим, с множеством участников на переднем и на заднем плане. Хинкли обращает наше внимание на пациента, 
используя более светлые краски, изображая передний план с более чёткими контурами, и показывая предполагаемые эмоции на лицах наблюдателей. Зритель не может видеть разрез и кровь, так что у каждого зрителя картины возникают сомнения - действительно ли хирург сделал разрез.

Внешний вид обоих хирургов, Генри Джекоба Бигелоу и Джона Коллинза Уоррена заметно отличается от облика хирургов на фотографиях и портретах того времени. Кроме того, Хинкли изобразил на картине людей, которые вероятнее всего отсутствовали во время этого события (студентмедик Charles Hosea Hildreth (1825-1884), хирург Abel Lawrence Peirson (17941853), хирург Jonathan Mason Warren (1811-1867) и врач William Williamson Wellington (1814-1896) [Vandam L.D., 1980; Wofle R.J., 1993]. Также он не изобразил двух врачей, которые вероятно присутствовали на демонстрации - хирурги Samuel Parkman (1816-1854) и George Hayward (1791-1863) [Vandam L.D., 1980; Wofle R.J., 1993].

Несмотря на эти недостатки, картина Хинкли является выдающимся достижением для художника, только завершающего своё обучение. Картина Хинкли «Первая операция под эфиром» донесла до нас волнение этого замечательного события и позволила нам участвовать в его праздновании.

В отличие от Хинкли чета Проспери передвинула пациента на передний план картины от центра вправо. Центральной фигурой действия является хирург Джон Коллинз Уоррен, показанный за работой. Кровь явно видна не только на руках у хирурга, но также на шее пациента и в тазу. Сцена действия и его участники по существу одни и те же, как на картине Хинкли, но наблюдатели переносятся ближе и смотрят сверху вниз на происходящее. Первая реакция, которая возникает у зрителя, особенно если смотреть на картину «День Эфира, 1846 год» издали, - может это действительно фотография? Но всё становится понятным, когда узнаёшь, что для достижения точности художники взяли более чем 200 фотографий сцены, созданной натурщиками, одетыми в костюмы того периода.

Работа выглядит крайне реалистичной, тщательный её осмотр и вид крови усиливают ощущение этого важного события. Реалистичное, фотожурналистское качество, которое доминирует в работе Проспери, является следствием не соединения мельчайших деталей, а следствием чёткого акцента на определённые моменты. Картина не оказалась настолько тёплой как работа Хинкли вследствие её единообразного света, отсутствия теней, небольшой глубины обзора и возможно её реалистических качеств. «Купол Эфира» оказывается близким к его действительному размеру, а участники более однородно распределены как на переднем, так и на заднем плане. 
Если Хинкли празднует первую демонстрацию анестезии эфиром на расстоянии, то Проспери приглашают нас стать свидетелями очень близко к месту действия. Более тёмные тона, которые доминируют, более раннее изображение замещается ярко освещённой операционной комнатой. Хинкли использует расходящееся освещение и постепенно растворяет чёткие линии субъектов путём смешивания одного тона с другим. Его большее драматическое изображение отодвигает наблюдателя назад в атмосферу зрителей за происходящим.

Проспери умело использовали этапность события, при котором участники были сфотографированы в костюмах того периода, и замечательно следовали своей цели - создать точный, реалистичный, близкий обзор действительной операции. Так как они перенесли наблюдателей в ряды вокруг демонстрации, сцена является настолько правдоподобной, что легко представить себе, как двигался бы пациент, если бы имел неадекватную анестезию. Хотя Мортон и наблюдает, и работает на картине Хинкли, Проспери показывают его тревогу и готовность к немедленным действиям. В сравнении с подавленной атмосферой, которая наполняет сцену Хинкли, степень предчувствия здесь более значительная.

Художникам во время работы необходимо организовать сцену, а также одеть участников в костюмы соответствующим образом. Проспери использовали фотографию, чтобы совместить этот двухступенчатый процесс в один. Точность к реальности и достоверность являются признаками их картины. Они выбрали Д.Ф. Кистлера для позирования в качестве хирурга из-за его замечательного сходства с Уорреном. Проспери более точны с исторической точки зрения, так как они исключили большинство врачей, которые, как известно, отсутствовали во время демонстрации. Они правильно исключили Чарльз Хилдрета, Абеля Пирсона и Джонатана Мэйсона Уоррена; однако при этом они включили Уильяма Веллингтона, который, вероятнее всего, не присутствовал на этой демонстрации.

Данные о погоде на утро 16 октября 1846 года и расположение окон в «Куполе Эфира» свидетельствуют о том, что участники были хорошо освещены естественным светом. Проспери даже использовали освещение, чтобы сохранить всех участников в чётком фокусе и создать условия более скромного размера «Купола Эфира». Эти детали, наряду с выражениями лиц участников, предполагают, что это было истинно грандиозное событие.

Обе картины, которые мы сравниваем, изображают одно и то же незабываемое, историческое событие, но художники преследовали при этом различные цели. Для Хинкли написание картины - необходимое условие для завершения обучения искусству в Париже, тогда как чета Проспери полу- 
чила поручение от Массачусетской больницы общей практики на создание более точного изображения данного события. Как Хинкли, так и Проспери использовали дагерротипы и фотографические источники для своей работы. С помощью живописных мазков кистью и используя все преимущества освещения, Хинкли обратил наше внимание на пациента, который является центральной фигурой. Пациент, расположенный лицом к наблюдателю, весь в белом - для усиления эффекта освещения. Общая сцена является достаточно широкой, и её стадийность оказывает драматический эффект. Наблюдатель отчасти исключен из сцены, ему отведено место в аудитории. Насыщенный естественный свет, который падает вниз из окон купола, может даже предполагать, что более высокая сила руководит руками хирурга и Мортоном.

Проспери широко использовали краски, а яркий свет равномерно освещает всю сцену. Центральная фигура здесь - хирург, а не пациент, лицо которого наблюдатель не видит.

Хинкли использует тёплый традиционный стиль, характерный для конца XIX столетия. Он также имел успех, изобразив на хирургической сцене большинство выдающихся людей Бостона; однако, работа Проспери технически более точна по некоторым аспектам, нераспознанным Хинкли. Внешний вид участников, наличие крови добавляют реалистичности. Их изображение было бы даже более убедительным, если бы один из участников прощупывал пульс у больного - деталь, точная или нет, но включённая у Хинкли. Деталь, которую следовало бы изменить - это испаритель эфира, наклонённый не вниз и горизонтально, а вертикально с наконечником, расположенным у рта.

Немногие картины, если таковые и имеются, изображающие важные сцены из истории медицины, имеют оригинальные продолжения. Возможно, нет ни одной картины, где сцена была восстановлена современниками, позирующими как исторические фигуры. Эти шедевры могут рассматриваться как дополняющие друг друга, а не конкурирующие друг с другом. Различия в картинах возникают не только благодаря стилю написания картины, освещению, точкам обзора и деталям, но что более важно, благодаря периоду времени, в котором эти картины написаны.

Работа Хинкли написана в традициях XIX столетия, в то время как работа Проспери является современной. Интересующиеся люди приезжают в Бостон со всего мира посмотреть на картину Хинкли. Люди, которым посчастливилось посетить «Дом Эфира» в Массачусетской больнице общей практики в Бостоне, где происходило описанное событие, также будут иметь возможность изучить и современную картину Проспери.»

На рисунках 67, 68 мы видим прототипы героев этого историического события и работу Уоррена Проспери над фрагментом картины. 


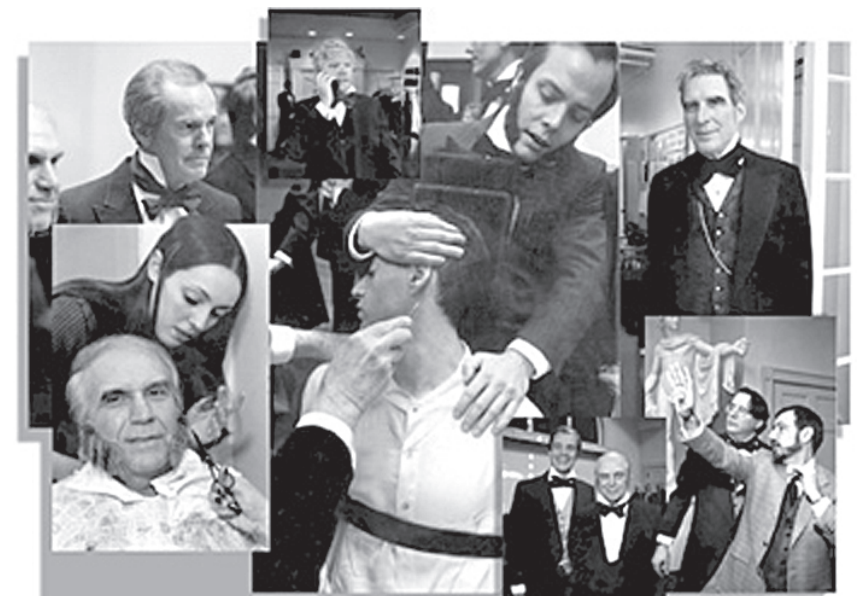

Рис. 67. Прототипы героев события для картины «День Эфира, 1846 год». Ил. Массачусетской больницы общей практики

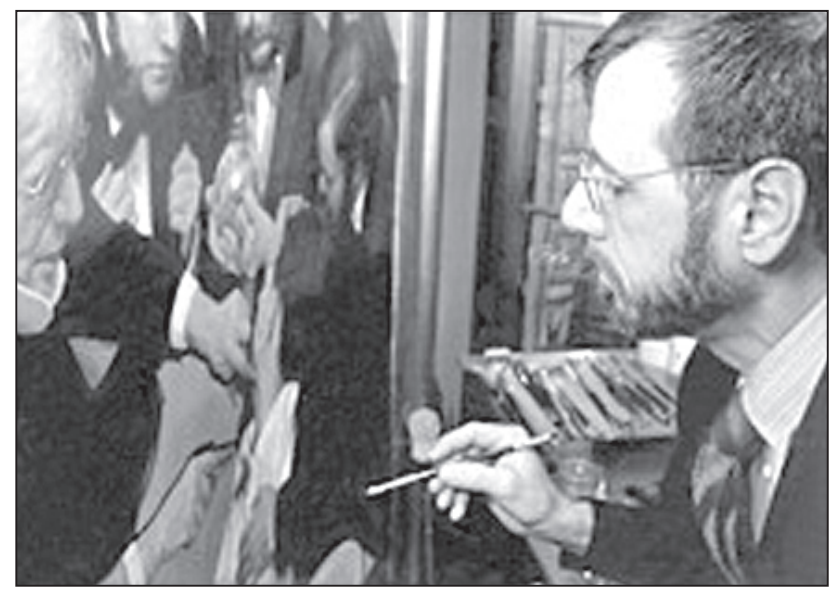

Рис. 68. Уоррен Проспери, художник из штата Массачусетс. После почти года работы... Ил. Массачусетской больницы общей практики

До публичной демонстрации анестезии Мортон в своём офисе удалил зуб молодому музыканту Эбену Фросту (Iben H. Frost) 30 сентября 1846 г., давая вдыхать эфир через носовой платок (рис. 69). Это событие стало причиной дальнейшего успеха Мортона. 


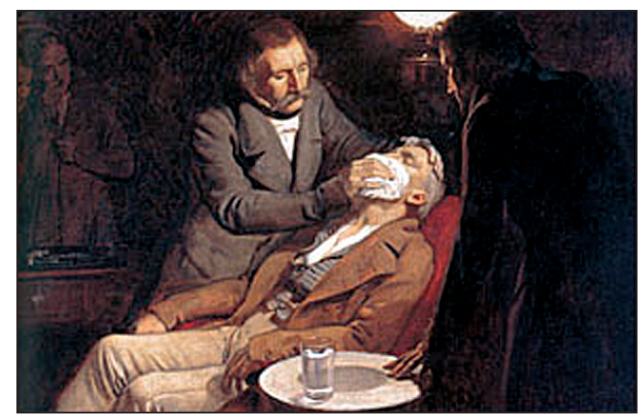

Рис. 69. Первое использование эфира в зубной хирургии, 1846 год.

Картина английского художника Эрнеста Боарда (Ernest Board, 1877-1934), написана маслом. Библиотека Wellcome, Лондон

Вот что писал об этом сам Мортон: «К вечеру мужчина, живущий в Бостоне, пришёл, испьтьвая сильные боли и желая удалить зуб. Он боялся операции и просил его месмеризировать. Я сказал ему, что имею кое-что более подходящее и, смочив мой носовой платок эфиром, дал ему для ингаляиии. Он сделался бессознательным почти немедленно. Бьло темно, а доктор Хайден держал лампу, пока я удалял крепко сидевший в челюсти малый коренной зуб. Больших изменений пульса и релаксации мускулов не было. Он очнулся через минуту и не знал ничего, что было ему сделано. Он остался на некоторое время, разговаривая по поводу эксперимента. Это было 30 сентября 1846 г.».

А вот и текст расписки самого Фроста, заверенной подписью Хайдена: «Настоящим удостоверяю, что я обратился к доктору Мортону в шесть часов нынче вечером (30 сентября 1846 г.), страдая невыносимой зубной болью. Доктор Мортон вынул из кармана носовой платок,намочил его свочм составом, которым я дышиал около полуминуты, а затем я заснул. Через мгновенье я очнулся и увидел мой зуб лежащим на полу. Я не испьтал ни малейшей боли и, оставшись на двадияать минут в его приёмной после того, не почувствовал никакого неприятного эбфекта от операции».

В тот же вечер, 30 сентября, Мортон уже был в редакции большой бостонской газеты, а наутро, чуть свет, явился к дверям Бюро патентов. В качестве свидетелей в редакцию газеты Мортон привёл с собой Хайдена и самого Фроста, и на следующий день, 1 октября, в утреннем выпуске бостонской Daily Journal была напечатана следующая заметка: «Вчера вечером, как о том мы были информированы джентльменом, который присутствовал при операции, у некоего субъекта был удалён коренной зуб без малейшей боли. Он был погружён в сон путём ингаляции особого состава, эфбект ко- 


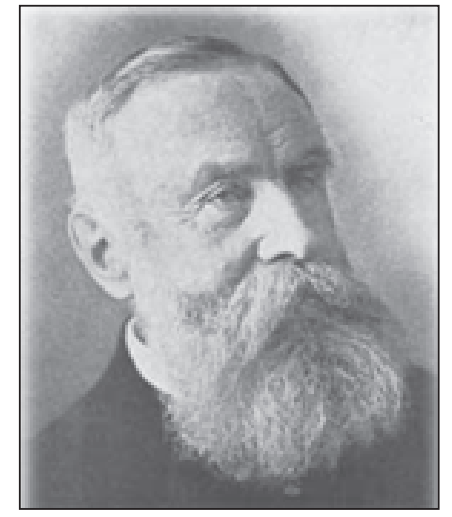

Puc. 70. Henry Jacob Bigelow (1818-1871)

торого продолжался около трёх четвертей минуты - ровно столько, чтобы произвести экстракцию зуба».

Таково было первое в мире печатное извещение об удачном наркозе в хирургии. Хотя в нём не было фамилии Мортона и адреса, весть об авторе и месте происшествия, конечно, быстро распространилась по Бостону, и это стало привлекать много любопытных и больных. Благодаря этому Мортон провёл ещё несколько наркозов при удалении зуба у своих пациентов.

К сожалению, не всё сразу пошло гладко, и уже следующий пациент, мальчик, не заснул, а почувствовал себя весьма плохо: у него появилась неукротимая рвота. Родители увезли ребёнка к врачу, который заявил, что мальчик отравлен. Через час разъярённый отец вернулся к Мортону и угрожал судом за попытку убийства ребёнка.

Вскоре ещё одна дама легко сделалась сонливой, но совсем не засыпала. При дальнейшей ингаляции она впала в возбуждение и с упрямой настойчивостью монотонно выкрикивала слова. Мортон не мог наложить щипцы, он много раз почтительно просил её успокоиться, но та кричала ещё громче. Как это ни курьёзно, но она успокоилась только после того, как Мортон предложил ей в награду несколько долларов. Зуб был удалён без боли.

Ещё одна больная, 25-летняя особа, мгновенно переменила свой облик и характер под действием эфира, «она взлетела в воздух, взвизгивая, как краснокожий индеец», и оторопевший дантист с трудом боролся с ней, пытаясь водрузить её обратно в зубоврачебное кресло. Очнувшись, она снова стала исключительно корректной и спокойной, не помня ничего о своём возбуждении. Мортон предложил ей ещё несколько глубоких вдохов эфира, от которых она сразу заснула, и два моляра были удалены без всяких затруднений и помех. Но подобные случаи были всё же исключениями. Как правило, наркозы протекали отлично.

В связи с тем, что не всегда удавалось вызвать у больных сон при вдыхании эфира с платка, Мортон приступил к созданию аппарата. Этот аппарат был очень прост: в первоначальном виде стеклянный шар имел одно отверстие, соединённое с трубкой, которая вставлялась в рот для вдыхания, позже было добавлено второе отверстие для наливания эфира. 
И вот, наконец, на квартиру Мортона для ознакомления с безболезненными экстракциями зубов явился Генри Бигелоу (рис. 70), один из известных хирургов знаменитой Массачусетской больницы общей практики в Бостоне. Создавалось довольно щекотливое положение. Ведь для того, чтобы рассчитывать на апробацию и поддержку Бигелоу, Мортон должен был сообщить ему состав своего наркотического средства, без чего нельзя было рассчитывать на то, чтобы больничные врачи стали применять такой наркоз своим больным. Но Мортон, не являясь врачом и следуя общепринятым для дантистов правилам, стремился засекретить и запатентовать своё открытие. Поэтому трудно понять, как мог согласиться на применение такого «секретного средства» на своём больном главный хирург Массачусетской больницы общей практики Джон Коллинз Уоррен.

По-видимому, Бигелоу либо сам понял, что «состав» Мортона представляет собой серный эфир, либо по полученным впечатлениям он смог уверить Уоррена в достаточной безопасности этого средства. Нельзя не удивиться той смелости, с которой Уоррен и Бигелоу позволили неизвестному молодому дантисту применить своё секретное средство для усыпления больного при большой, тяжёлой операции. И хотя победителей не судят, тем не менее, в поднявшейся шумихе, неизбежной вокруг всякого важного события, конкуренты и всевозможные присяжные критики и моралисты не раз и в довольно резкой форме осуждали хирургов Массачусетской больницы общей практики за проявленную излишнюю доверчивость и либерализм.

Через 10 дней после визита Генри Бигелоу Мортон получил от Чарльза Ф. Хейвуда (Charles F. Hеywood), дежурного интерна больницы, письмо, которому было суждено стать историческим документом в мировой медицине. Вот текст этого письма:

«14 октября 1846 г. доктору Мортону.

\section{Дорогой сэр!}

Я пиму по поручению доктора Уоррена, приглашая Вас прибыть в пятнииу в десять часов в больнииу, чтобы применить на пациенте, который будет оперирован, состав, изобретённый Вами для ослабления боли.

С почтением к Вам Ч.Ф. Хейвуд, хирург общей больницьљ».

Диорама - лентообразная, изогнутая полукругом живописная картина с передним предметным планом (сооружения, реальные и бутафорские предметы). Диораму относят к массовому зрелищному искусству, в котором 
иллюзия присутствия зрителя в природном пространстве достигается синтезом художественных и технических средств (рис. 71).

Дагерротипия изобретена французским художником Даге́ром в 1839 году и считается первым практическим способом фотографирования. Это была единственная возможность получения фотографических изображений до изобретения в 1851 году мокрого коллоидного процесса, полностью вытеснившего более сложную и опасную дагерротипию.

В качестве фотоматериала использовали посеребрённую медную пластинку. Пластинку тщательно полировали, затем непосредственно перед съёмкой обрабатывали парами йода, в результате чего образовывался тончайший слой светочувствительного йодистого серебра. Под действием света в этом слое возникало скрытое изображение, проявляемое парами ртути. Полученное изображение закрепляли раствором тиосульфата натрия.

Ниже приводим ряд иллюстраций, посвящённых открытию наркоза эфиром (рис. 72-85).

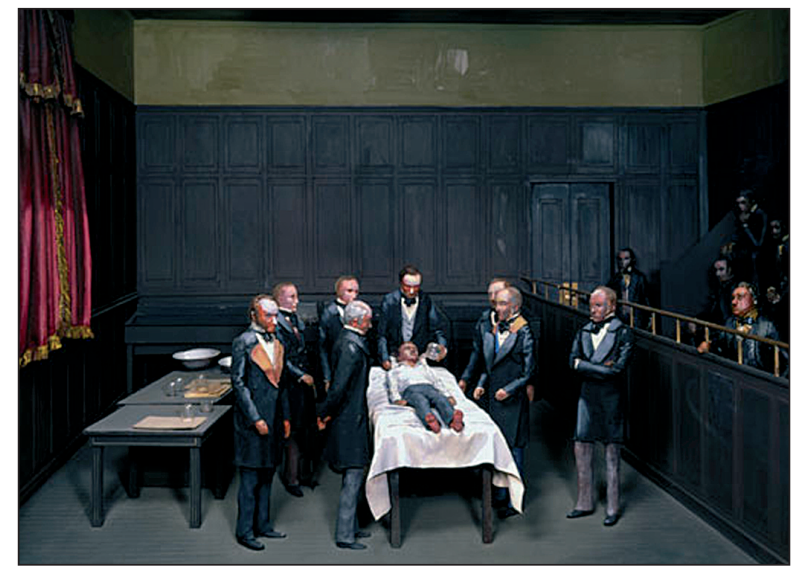

Рис. 71. Диорама, основанная на оригинальном дагерротипе сцены,

показывающая выполнение первой хирургической операции Джоном Коллинсом Уорреном

(1778-1856) под общим обезболиванием в Массачусетской больнице общей практики 16 октября 1846 года. Доктор Томас Мортон (1819-1868), пионер в области анестезиологии в дальнем конце стола, держит ингалятор около лица пациента. Уоррен успешно удалил опухоль на шее пациенту Джильберту Эбботу. Ил. Музея Науки, Лондон

В 1946 году, в год 100-летия открытия анестезии, американский писатель Рэйчел Бэйкер написала биографический роман «Д-р Мортон - пионер в использовании эфира». 


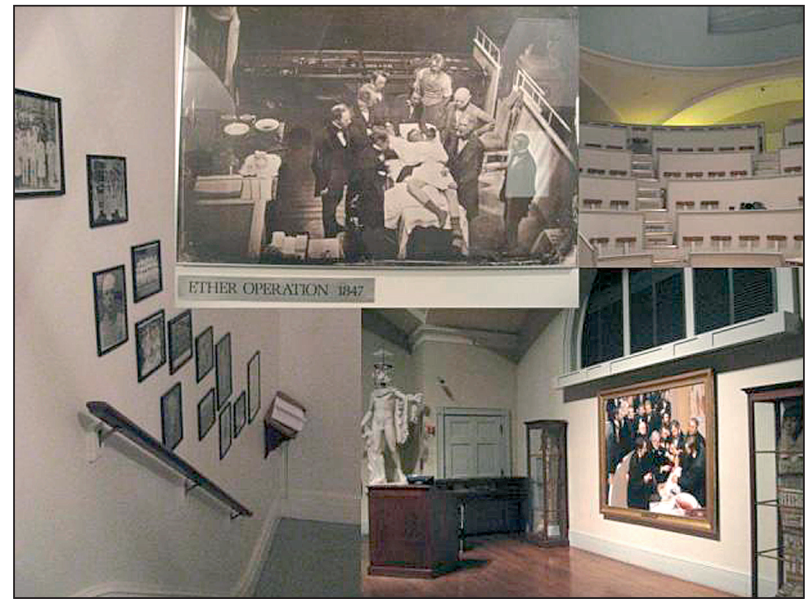

Рис. 72. Дом эфира и сегодня открыт для публики.

Это один из самых старых существующих операционных театров

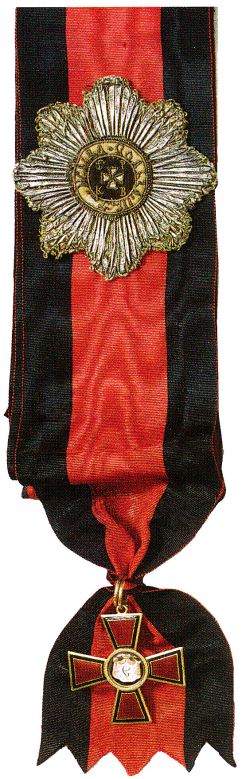

Рис. 73. Орден Св. Владимира - знак признания великого открытия У.Т.Г. Мортона русским царём Николаем I 

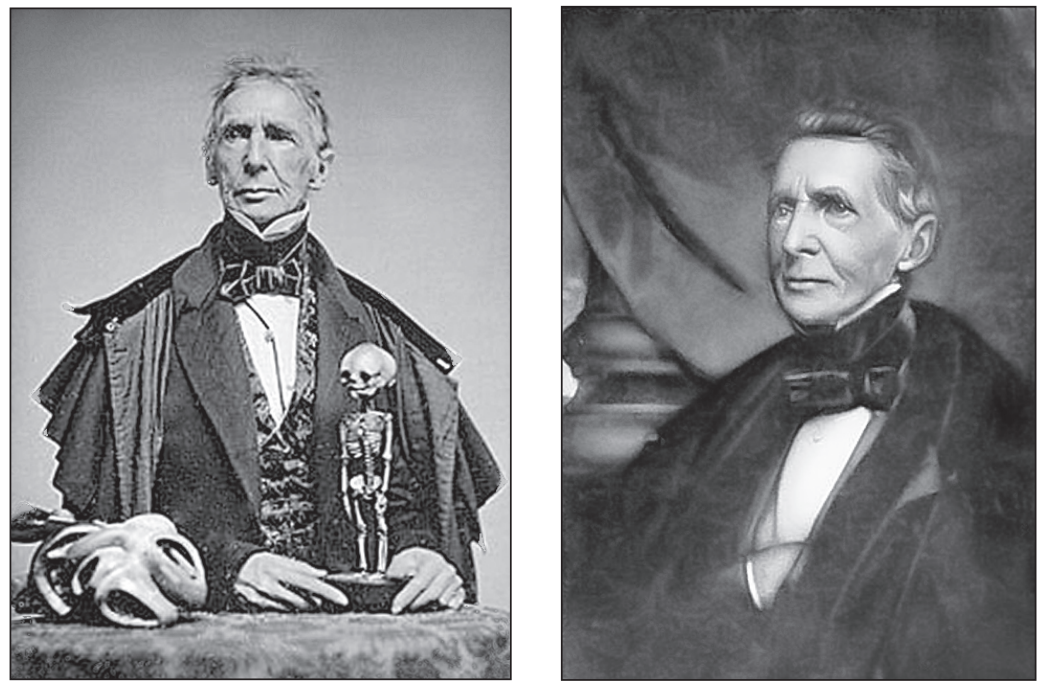

Рис. 74. Уоррен, Джон Коллинз (Warren, John Collins, 1778-1856). Из коллекции фотографий Ralph Herman Major (1884-1970)

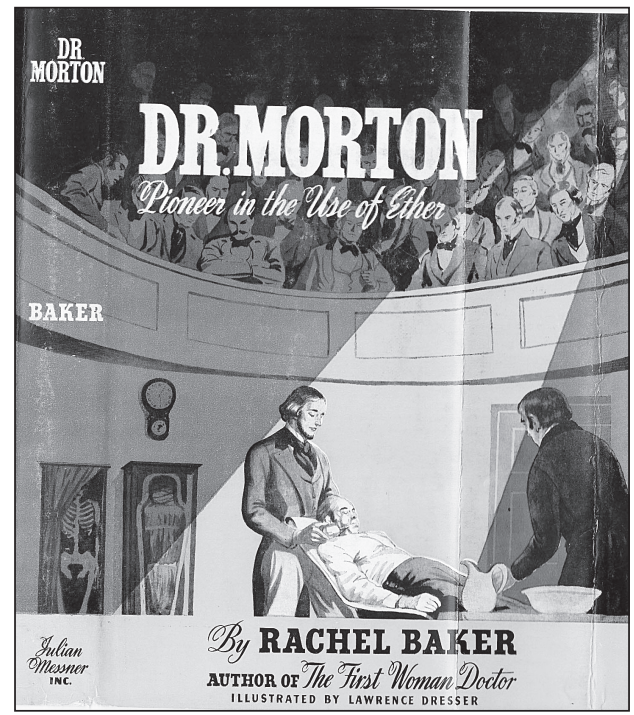

Рис. 75. Обложка книги Рэйчел Бэйкер

«Д-р Мортон - пионер в использовании эфира» 


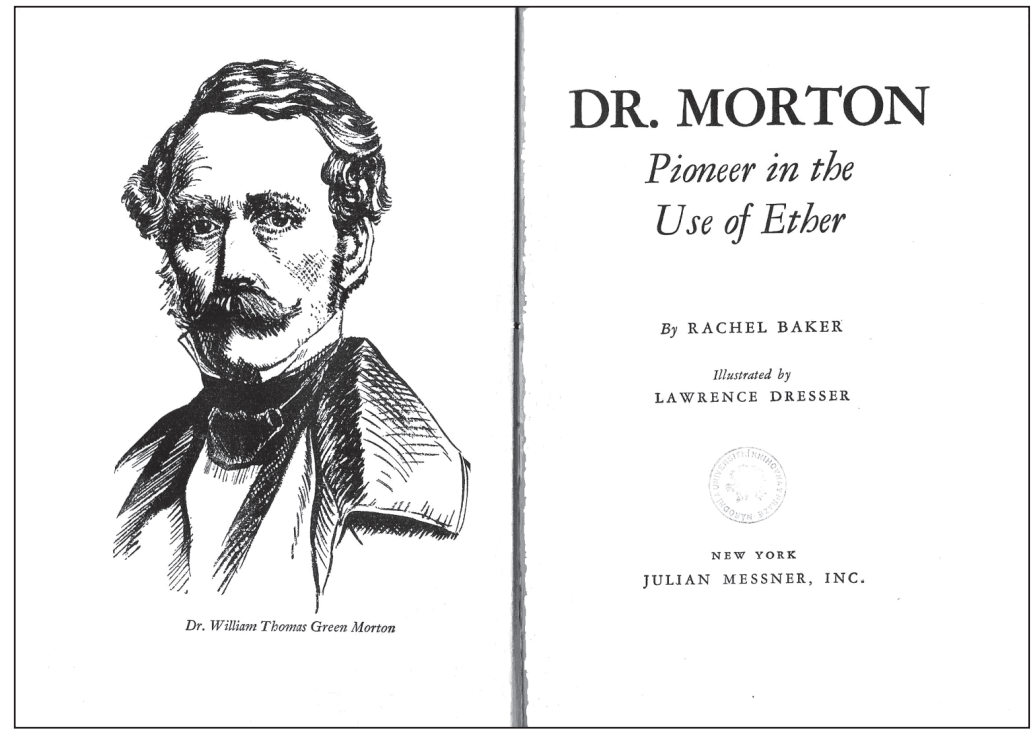

Рис. 76. Титул книги «Д-р Мортон - пионер в использовании эфира»

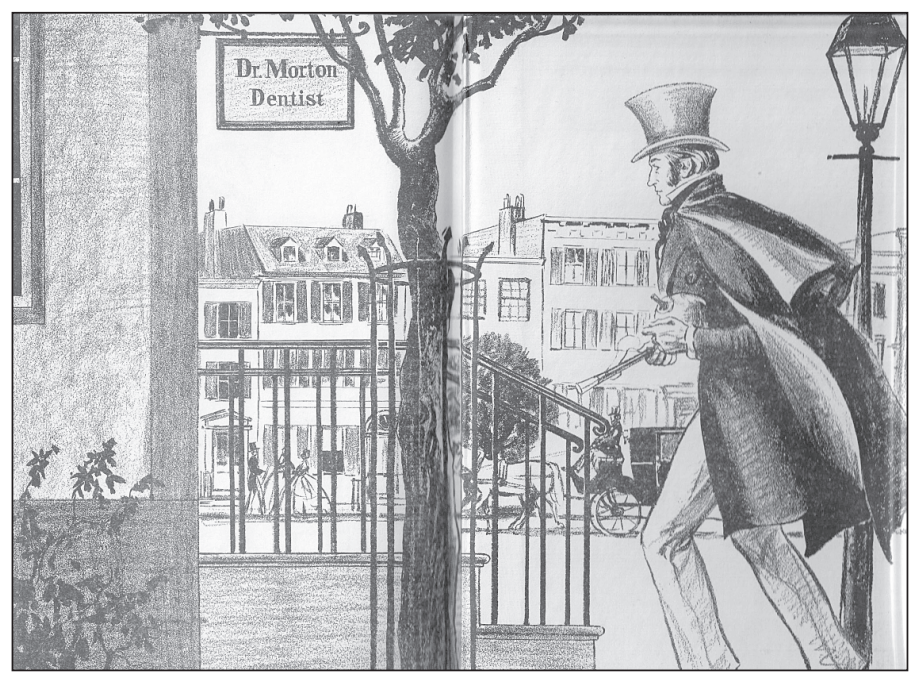

Рис. 77. Иллюстрация Lawrence Dresser книги «Д-р Мортон - пионер в использовании эфира» 


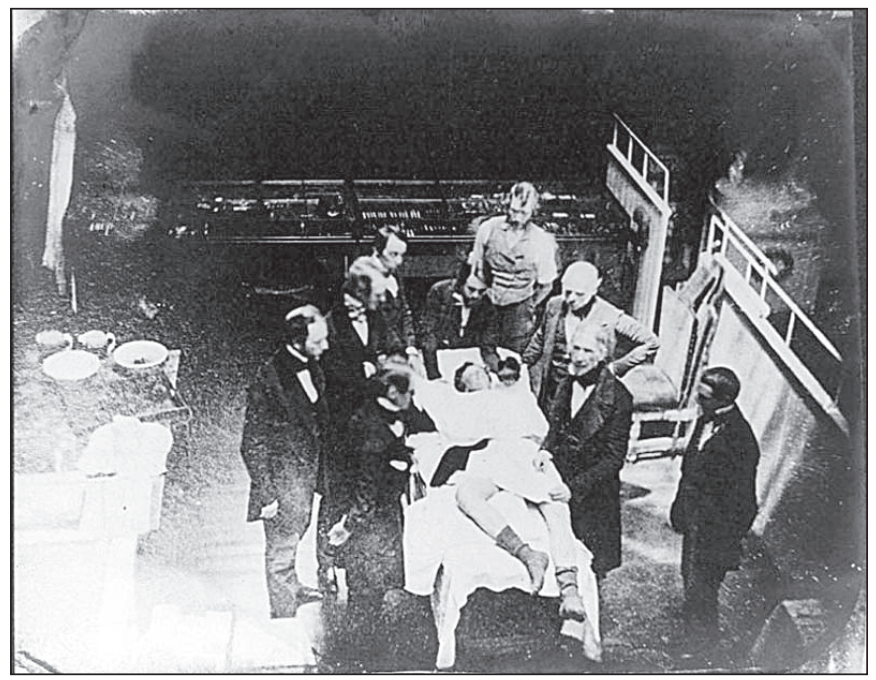

Рис. 78. Первое фотографическое изображение демонстрации Мортоном наркоза эфиром (1846).

Зарегистрировано в дагерротипе приблизительно через шесть месяцев после события в 1847 году Альбертом Сандсом Сутуортом (Albert Sands Southworth) и Джозей Джонсоном Хоесом (Josiah Johnson Hawes)

Памятник эфиру установлен в 1868 году в парке Public Garden, находящемся в самом центре Бостона. Выполнен из гранита и мрамора, этот памятник называется «Монумент эфиру» и является старейшим скульптурным произведением, установленном в этом парке, и единственным в мире памятником ... лекарству. Монумент находится слева от входа в сад с улицы Arlington St. (напротив Marlborough St.). На памятнике не указано имя первооткрывателя анестезирующих свойств эфира, так как на это звание претендовало несколько человек, и спор так и не был разрешён. Вот почему скульптура, завершающая монумент, изображает не одного из тех, кто оспаривал звание первооткрывателя наркоза, а абстрактного «Доброго Самаритянина», держащего на руках больного юношу. Этим произведением скульптор - Джон Квинси Адамс Ворд (John Quincy Adams Ward) - положил начало своей успешной карьере художника.

Три надписи на памятнике гласят:

«В благодарность за избавление от людских страданий жители Бостона воздвигли этот монумент»;

«Отмечается открытие того, что вдыхание эфира вызывает нечувствительность к боли. Впервые в мире испытано в Mass General Hospital»; «Боли больше не будет». 
На четырёх барельефах, помещённых под готическими арками, переплетены научные и религиозные символы. На южном барельефе показана операция под наркозом, на восточном - ангел милосердия. Западный барельеф изображает женщину, олицетворяющую триумф науки. Она сидит на троне, составленном из медицинского оборудования (колбы, дистилляторы и т.п.), а сбоку - Мадонна с младенцем с одобрением смотрит на неё. Лучший барельеф находится на северной стороне и посвящён Гражданской войне в США. Полевой врач собирается ампутировать ногу раненому солдату. Благодаря наркозу, тот спокойно спит, а доктор готовится к непростой работе.

Скульптурные памятники, стоящие на открытом воздухе, требуют постоянного ухода. Монумент неоднократно ремонтировался, но, как правило, это были косметические ремонты. В 2006 году его капитально отремонтировали,

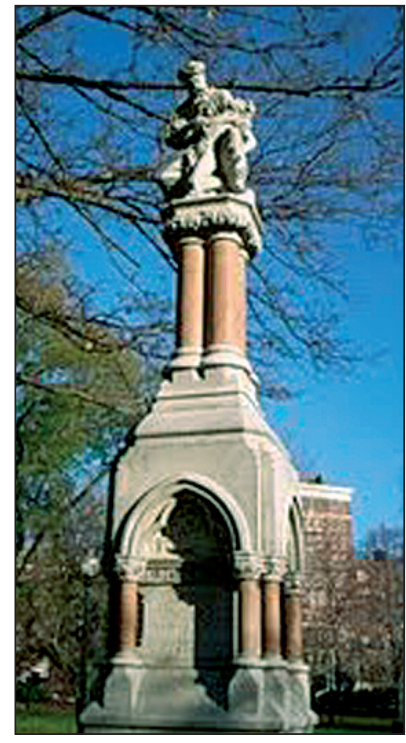

Рис. 79. Памятник эфиру а также добавили ночное освещение. Работы производились по инициативе Массачусетского общества анестезиологов (Ушомирская А., 2008).

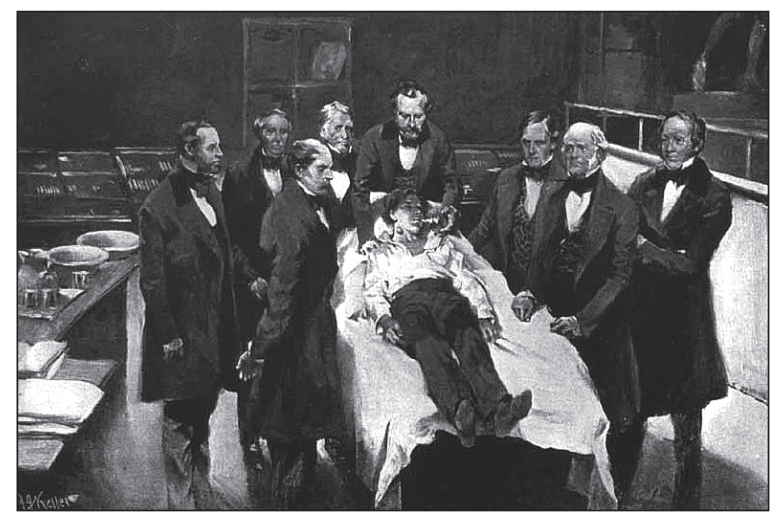

Рис. 80. Первая публичная демонстрация наркоза в хирургии.Бостон, 16 октября 1846 г. Ил. Francis A. Countway Library of Medicine. Подпись под фотографией: Dr H.J. Bigelow, Dr A.A. Gould, Dr J.C. Warren, W.T.G. Morton, Dr Samuel Parkman, Dr Charles Hayward, Dr Mason Warren. The First Public Demonstration of Surgery Anaesthesia. Boston. October 16. 1846 


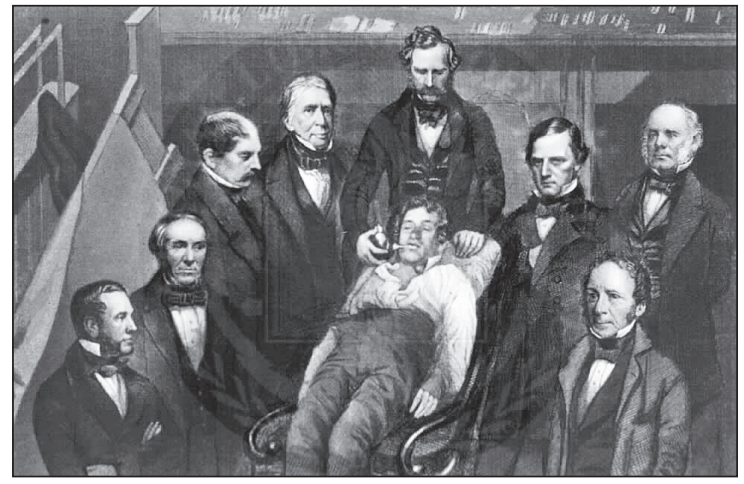

Рис. 81. Гравюра. Уильям Т. Г. Мортон, Бостонский дантист, проводит первую публичную демонстрацию наркоза эфиром

в Массачусетской больнице общей практики 16 октября 1846 года

(Ил. J.P. Bunker в статье Winter 2000 issue of the Harvard Medical Alumni Bulletin)

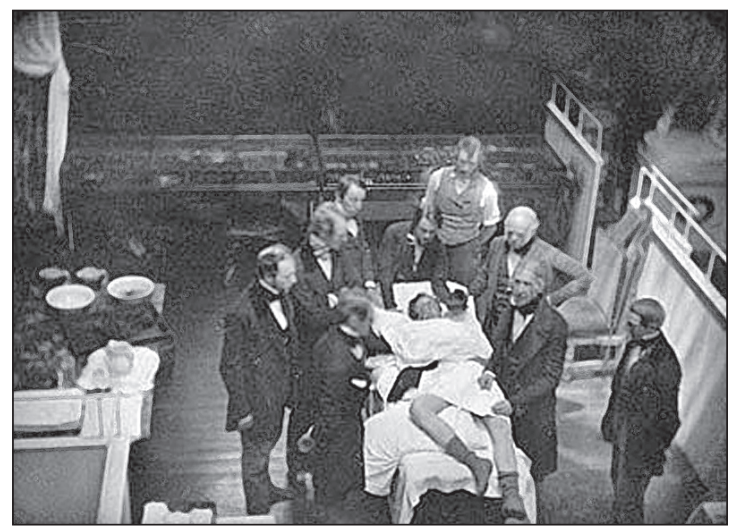

Рис. 82. Эта интересная фотография была сделана, по всей видимости, в Массачусетской больнице общей практики, спустя некоторое время после успешной публичной демонстрации У.Т.Мортоном эфирного наркоза. Мортон (в жилете), на заднем плане снимка, уже, находясь в лучах славы первооткрывателя эфирного наркоза, инструктирует одного из коллег, как надо давать наркоз. Дж. К.Уоррен в правом нижнем углу снимка (руки расположены на бедре пациента). Возможно, этот снимок относится к событиям 7 ноября 1846 г., когда хирург Массачусетской больницы общей практики George Hayward произвёл ампутацию нижней конечности и резекцию нижней челюсти под эфирным наркозом. Это были третья и четвертая, официально документированные операции,

на которых дантист Уильям Томас Грин Мортон присутствовал в качестве анестезиолога (Ил. и пояснения из календаря истории <www. critical.onego.ru>) 


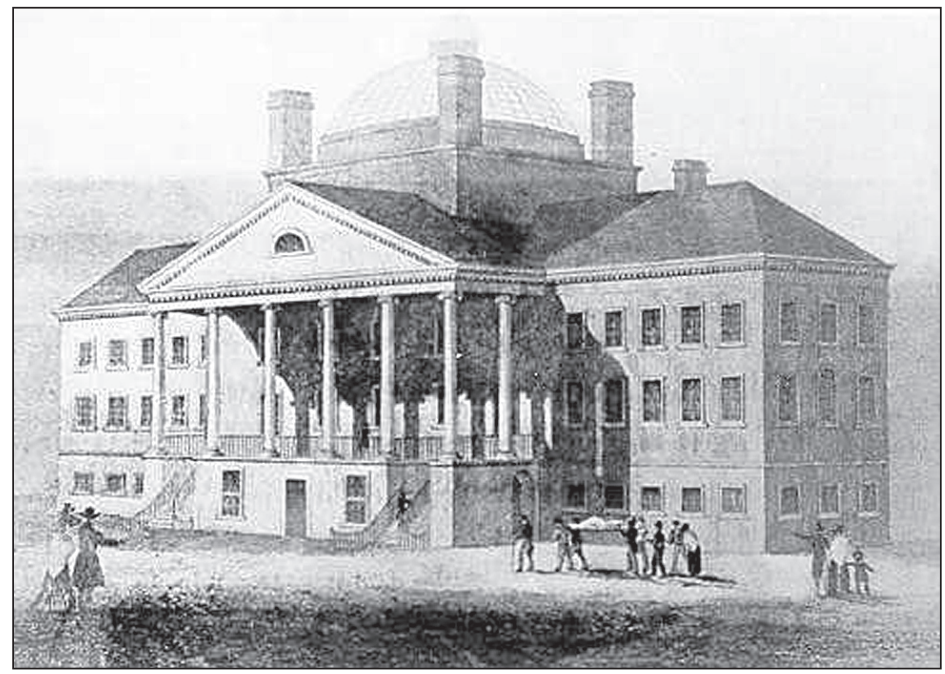

Рис. 83. Массачусетская больница общей практики

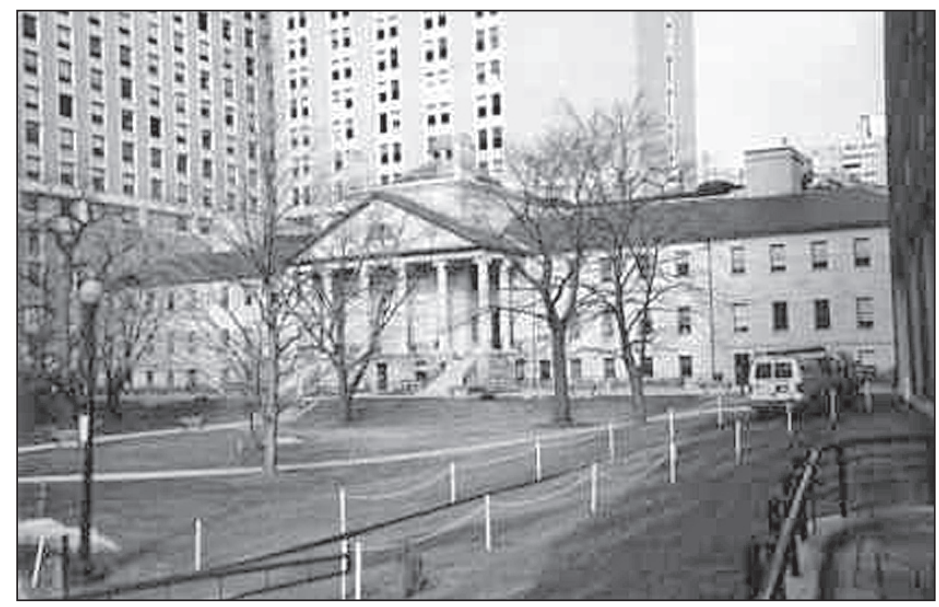

Рис. 84. Здание Массачусетской больницы общей практики, бережно сохранённое до настоящего времени и называемое теперь «Эфирным домом»

Другие претенденты на открытие анестезии - Кроуфорд Лонг и Хорас Уэллс также не оставлены без внимания живописцев (рис. 86-90). 

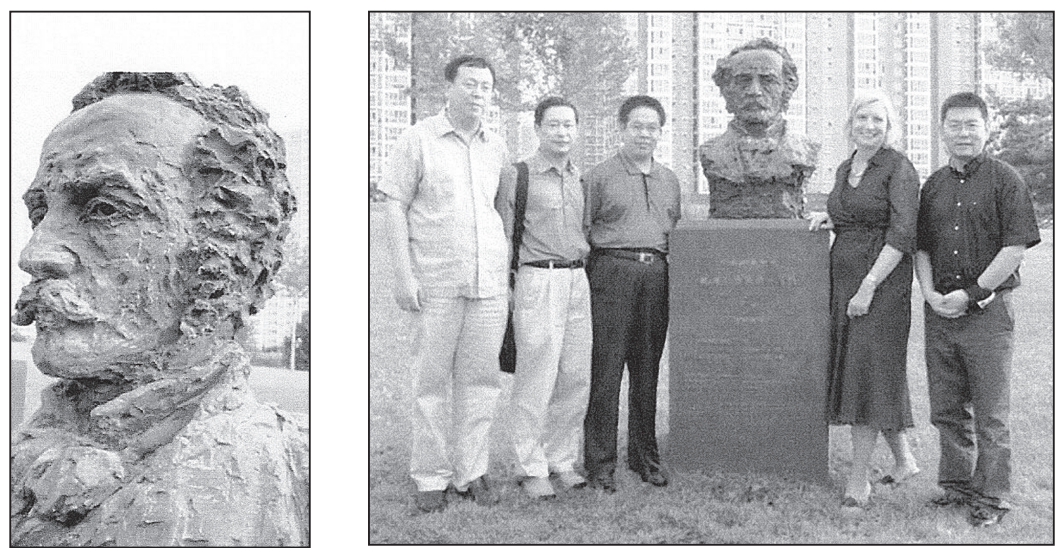

Рис. 85. Скульптура У.Т. Мортона в Пекинском Международном Парке Скульптуры, одном из важных новых парков Пекина, открытом при подготовке к Летним Олимпийским Играм в Китае 2008 года.

Справа: китайские анестезиологи на фоне скульптуры

(Ил. Bulletin of Anesthesia History, 2007 0ct., p. 21.)

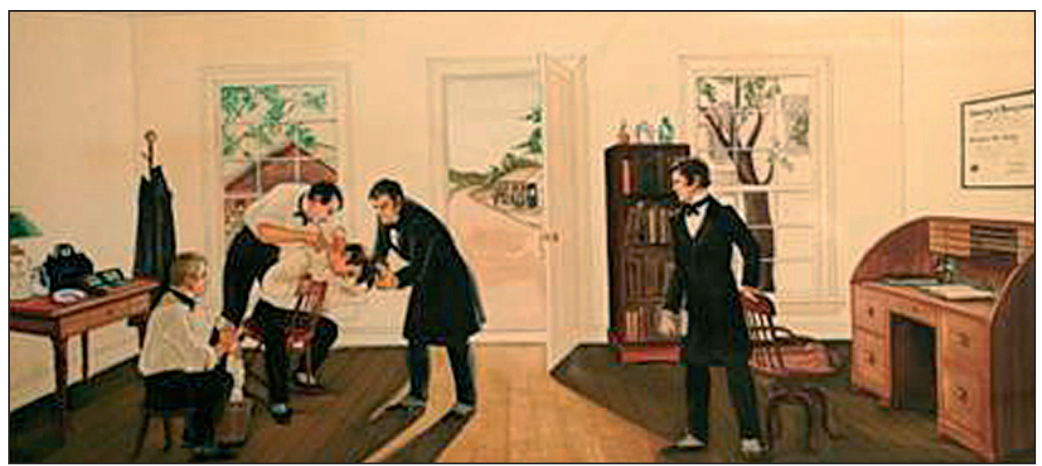

Рис. 86. Иллюстрация первой операции молодого пионера анестезии Лонга в его офисе с использованием эфира в присутствии трёх свидетелей 30 марта 1842 года. (Из мемориального музея Крауфорда Лонга. Джефферсон, Джорджия, (ША) 


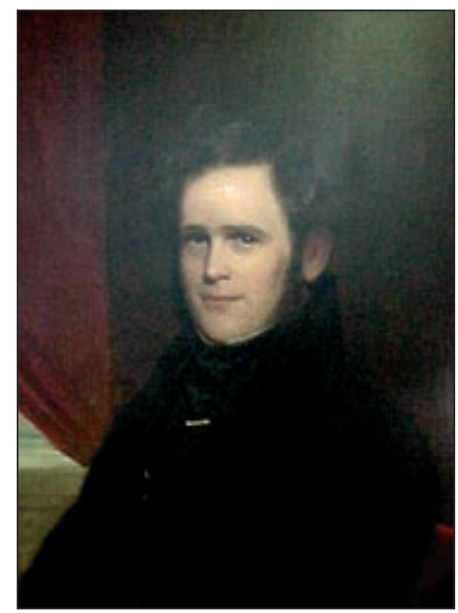

Рис. 87. Хорас Уэллс

(Horace Wells, 1815-1848)

Портрет работы неизвестного

художника, 1838 г., масло.Музей

Медицинского и Стоматологического

обществ г. Хартфорда (США)

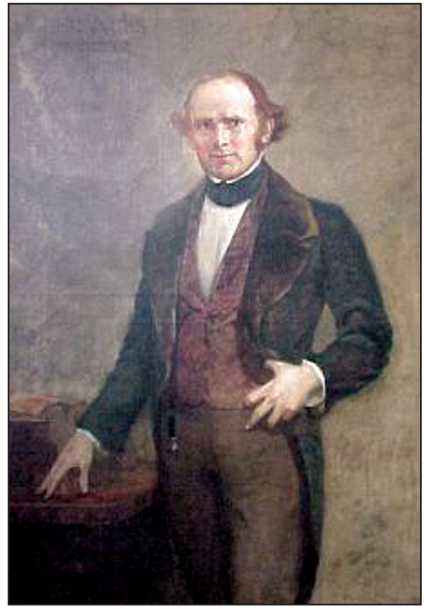

Рис. 88. Хорас Уэллс.

Ил. из книги «Вклад дантистов

в развитие хирургического

обезболивания»

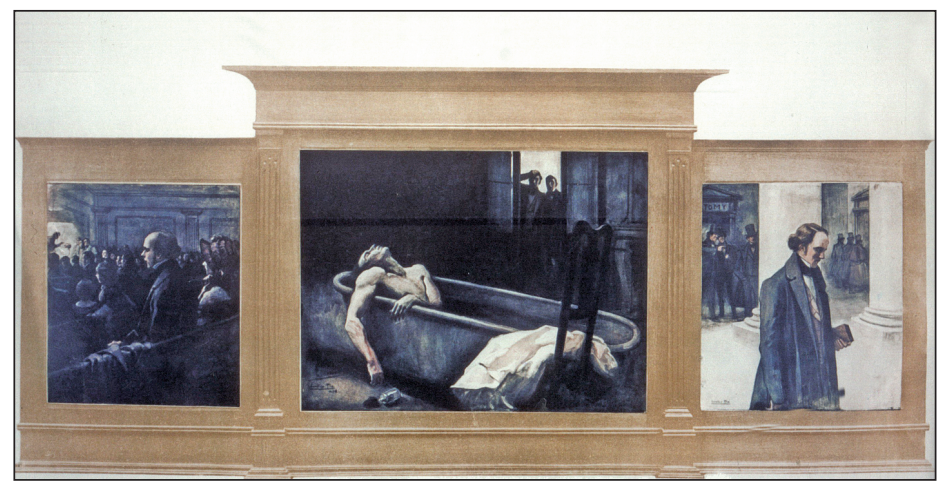

Рис. 89. Триптих испанского художника Cecilio Plá (1860-1934) «0ткрытие анестезии» (1906), написанный по инициативе дантиста Luis Subirana Matas (1871-1938). Слева - демонстрация Колтона; справа - выход расстроенного Уэллса из лекционного зала Гарвардского университета, сопровождаемый насмешками студентов; в центре испуганные тюремщики, обнаружившие тело Уэллса в ванне с перерезанными венами правой руки, на полу опрокинутая бутылка с хлороформом и губка (любезно предоставлено господином Dr. Avelino Franko (Сантьяго, Испания) 


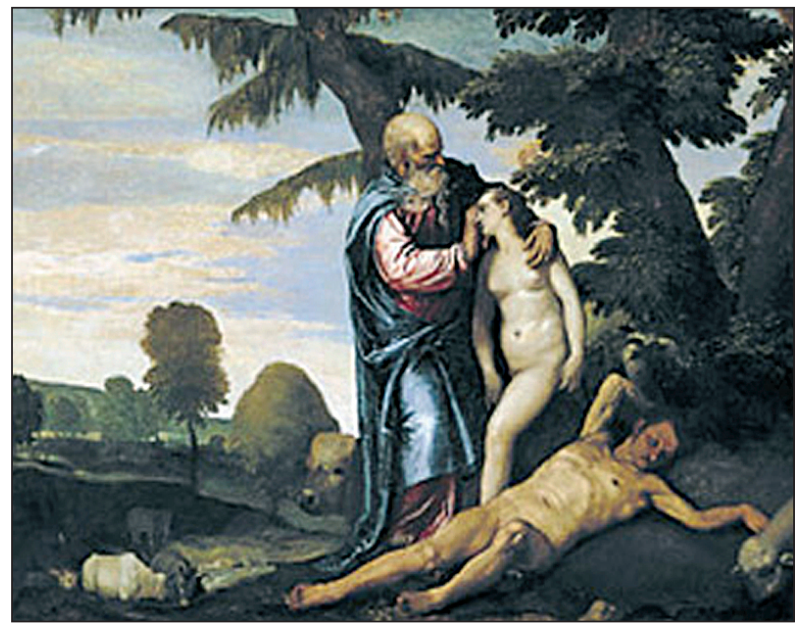

Рис. 90. Первый анестезист?

«Создание Евы» Паоло Кальари (Paolo Caliari, 1528-1588)

«И господь Бог заставил впасть в глубокий сон Адама, и он спал». Genesis 2:21 


\section{МЕСТНОЕ ОБЕЗБОЛИВАНИЕ В ПЕРИОД ПРИМЕНЕНИЯ РАСТВОРОВ КОКАИНА (1884 - до 20-х годов XX века)}

Создание эффективных методов местной анестезии было подготовлено введением в медицинскую практику шприца [Вуд (A. Wood), Правац (Ch.-G. Pravaz - рис. 91), 1853], полой иглы [Фрэнсис Ринд (Francis Rynd, 1801-1861), 1844] и, в первую очередь, открытием местно-анестезирующего действия кокаина.

Идея, давшая начало разработкам современной местной анестезии в хирургии и стоматологии, была почерпнута в Южной Америке. Родоначальником местных анестетиков является кокаин, алкалоид из листьев кустарника Erythroxylon Coca (рис. 92), произраставшего в Южной Америке. В некоторых источниках о культуре инков в высокогорных Андах имеются доказательства о проведении операций под «местной анестезией» с помощью сока от разжёванных листьев коки: оперирующий капал для этого кокасодержащей слюной из своего рта на рану пациента (Lipp M., 1992). Индейцы Перу и Боливии ещё и сегодня жуют листья коки, которые избавляют их от печали, усталости и голода (рис. 93).

В 1855 г. из листьев коки Фридрих Гедке (Friedrich Gaedke) выделил действующее начало, которое он назвал Erythroxylon.

Первый серьёзный опыт поставлен в 1859 г. врачом и писателем Паоло Мантегацца (Paolo Mantegazza), книги которого по разным разделам физиологии и особенно физиологии наркотиков длительное время пользовались большой популярностью. Одну из своих книг, отмеченную премией и называвшуюся «Гигиенические и медицинские достоинства коки», Мантегацца посвятил описанию этого растения. Мантегацца сам провёл несколько лет в Южной Америке. В описаниях употребления коки и её действия на человеческий организм Мантегацца исходил из своего собственного опыта.

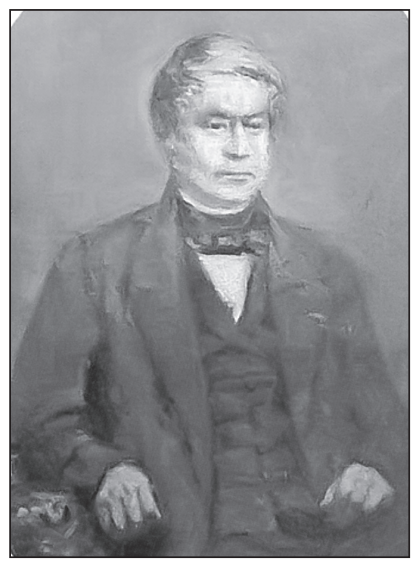

Puc. 91. Charles-Gabriel Pravaz (1791-1853) 


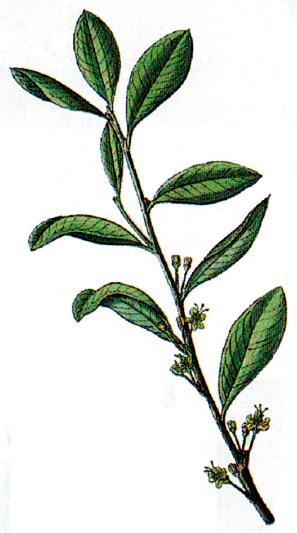

Рис. 92. Листья кустарника Erythroxylon Coca

Американский врач Самуэль Перси (Samuel Persi), работавший в Нью-Йорке в качестве фармаколога, также описывал свои опыты с употреблением настоя из листьев коки.

В европейской медицине опиоид появился с помощью австрийского доктора Шерцера (Scherzer), который в 1859 г. привёз листья коки в Вену. Важнее всего было, однако, открытие в 1859-1860 годах возбуждающего вещества, содержащегося в листьях коки, которое отныне поступило в распоряжение химиков и врачей в чистом виде. Это произошло в лаборатории великого химика Вёлера (Wöhler) в Гёттингене (рис. 94).

Над разгадкой секрета листьев коки работал ученик Вёлера Альберт Ниманн (Albert Niemann, 1834-1861), которому и удалось открыть основное действующее начало, получившее название «Кокаин». Этим работам он посвятил и свою диссертацию на тему «О новом органическом основании, содержащемся в листьях коки». Ниманн вскоре умер, так и не завершив начатых работ. Это удалось сделать Вильгельму Лоссену (Wilhelm Lossen), сумевшему получить кокаин в чистом виде. В печати появилось несколько сообщений об анестезирующем действии раствора этого препарата (Cocainum hydrochloricum) на слизистую оболочку ротоглотки. В 1862 г. Шрофф (Schroff) писал, что кокаин вызывает анестезию слизистой оболочки полости рта. В 1870 г. Газо (Gaso) наблюдал понижение чувствительности языка и слизистой оболочки рта при жевании листьев коки и предлагал употреблять их при цинге и стоматитах. В 1877 г. Фовель (Fovel) применял раствор кокаина для анестезии слизистой оболочки зева.

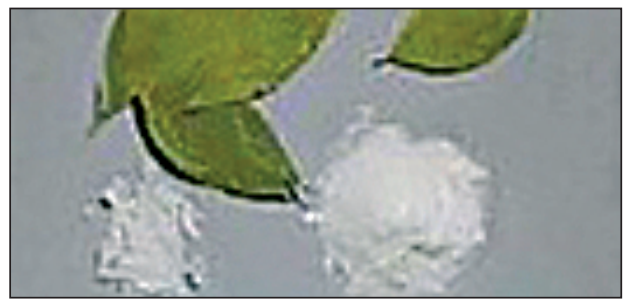

Рис. 93. Порошок кокаина, полученный из листьев коки
Работы этих авторов, опубликованные в разное время и в разных странах, не носили характера детального исследования действия кокаина на организм человека. В них сообщалось лишь о попытках использовать известное свойство кокаина с терапевтической целью. Ни Шрофф, ни Газо, ни 
Фовель не дали теоретического обоснования применения кокаина в хирургии и зубоврачебной практике. Как уже упоминалось ранее, свойство листьев коки понижать чувствительность слизистой оболочки рта было известно в Европе значительно раньше, чем об этом написали Шрофф и другие авторы.

Подтверждают сказанное и исторические данные из первой работы В.К. Анрепа, опубликованной в журнале «Архив Пфлюгера» (Pflüger's Archiv, т. 21, 1879). Он писал, что самые ранние путешественники по Южной Америке обращали внимание на большое распространение листьев коки среди туземного населения. Индейцам часто было легче оставаться без пищи, чем без листьев коки,

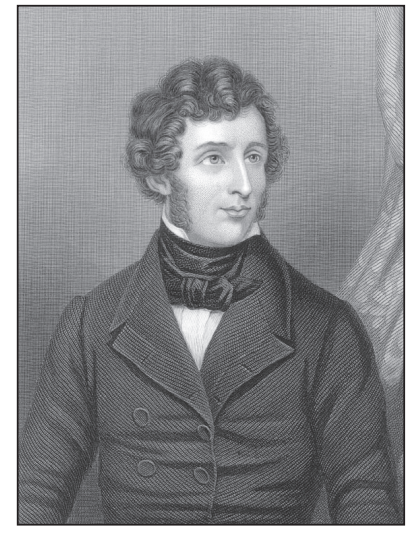

Рис. 94. Фридрих Вёлер

(1800-1882) которые с раннего детства до глубокой старости употреблялись у них для жевания. По мнению туземцев, листья коки придавали бодрость и сохраняли физические силы. Испытать на себе это свойство мог каждый, стоило только пожевать эти листья, как быстро наступало понижение чувствительности слизистой оболочки полости рта. Шрофф и другие авторы, узнав о свойствах кокаина, применили его с терапевтической целью. О применении кокаина при хирургических и стоматологических операциях в то время не было и речи.

Профессор Петербургского клинического института Василий Константинович Анреп (рис. 95) первый обстоятельно изучил физиологические свойства кокаина. Будучи молодым врачом, с 1876 г. на стажировке в Германии он изучал фармакологию и физиологию. Его заинтересовали свойства кокаина. В 1879 г. В.К.Анреп, введя себе под кожу кокаин, установил её нечувствительность к уколам иглой. Через 20-25 мин чувствительность восстанавливалась.

В 1879 г. В.К. Анреп опубликовал в немецком журнале «Архив Пфлюгера» экспериментальную работу «О физиологическом действии кокаина» (рис. 96). В своей большой статье он привёл данные о местном и общем действии кокаина. В выводах автор писал: «У лягушек кокаин парализует нервные окончания и нервные центры, причём окончания чувствительных нервов в первую очередь... Малые дозы повышают рефлексы, большие - понижают (у теплокровных), но парализующее действие совершенно такое же, как это наблюдалось у лягушек». 


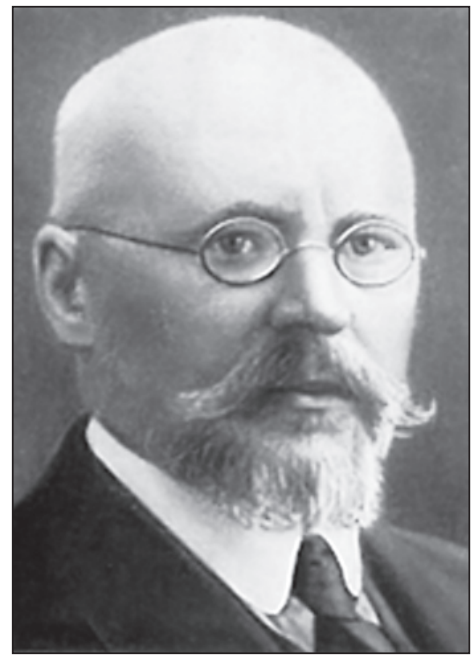

Рис. 95. Василий Константинович Анреп (1852-1927),

русский учёный, профессор медицины и фармакологии, государственный

и общественный деятель. Окончил курс Петербургской медико-хирургической академии, затем изучал физиологию и фармакологию в Лейпциге. Основоположник местной анестезии кокаином. Описал анестезирующее действие кокаина и рекомендовал его для применения в медицинской практике

В заключение этой статьи В.К. Анреп говорит: «Автор хотел поставить опыты и на людях, но другие занятия помешали ему, а перенести имеющиеся данные на человека без дальнейшего эксперимента не может, но рекомендует испытать кокаин в качестве местно-анестезирующего средства на людях и терапевтического на меланхоликах» (курсив наш).

Историческое значение его работы вполне очевидно. На основании приведённых данных есть убедительная возможность полагать, что идея местной анестезии кокаином и её физиологическое обоснование были впервые опубликованы В.К. Анрепом. Именно его и следует считать родоначальником местной анестезии кокаином.

Вопрос о приоритете в открытии местной анестезии кокаином поднимался уже неоднократно. Целый ряд учёных считает автором местноанестезирующего действия кокаина русского физиолога и фармаколога В.К. Анрепа. Об этом писали Р.Р. Вреден, С.Н. Делицин, А.А. Зыков, специально занимавшиеся вопросами истории развития местного обезболивания в хирургии. Подобного взгляда придерживался и А.В. Вишневский. 
P.P. Вреден (1898) подчеркивает: «Алкалоид кокаин добыт Ниманном (A. Niemann) в 1859 г. Анреп, изучая физиологическое действие кокаина, обратил внимание на свойства последнего вызывать при соприкосновении со слизистой оболочкой полости рта местную потерю чувствительности».

М.П. Николаев (1948) пишет: «Первую основательную работу о кокаине на животных и себе самом провёл (1878-1879) русский фармаколог проф. В.К. Анреп, который предложил его испытать как местное обезболивающее средство».

В иностранной литературе честь открытия местно-анестезирующего действия кокаина приписывается венскому офтальмологу Карлу Коллеру (Karl Koller, рис. 97) [Braun H., Fischer G., Lipp M., Travers B. и др.]. Вот как описывает M. Lipp (1992): «У австрийского невропатолога Зигмунда Фрейда (Sigmund Freud) возник психофармакологический интерес к этому препарату (попытка

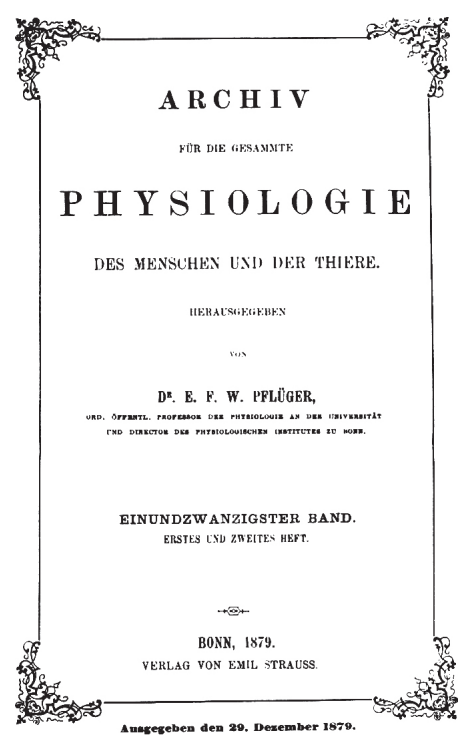

Рис. 96. Титульный лист журнала «Архив физиологии человека и животных», издаваемого Эдуардом Фридрихом Вильгельмом Пфлюгером. (Из личного архива В.И. Дедюлина.

Публикуется ( разрешения.) уменьшить лекарственную зависимость к морфину и алкоголю), и он вместе с офтальмологом Карлом Коллером испытывал его в различных опытах на себе. К. Коллер заметил свойства кокаина лишать чувствительности язык после приёма и решил использовать местно-анестезирующее действие для обезболивания глаза... Кокаин как местный анестетик был успешно введён только после конгресса офтальмологов в Хайдельберге (Heidelberg), состоявшегося 15 сентября 1884 г. Там выступил Джозеф Бреттауер (Joseph Brettauer), замещающий Карла Коллера, который не мог финансировать свою поездку (Koller К., 1884)». На конгрессе была зачитана телеграмма К. Коллера. Текст этой исторической телеграммы гласил: «Лично я не могу приехать. Мои опыты показали, что мы можем безболезненно оперировать на глазах, если впустим несколько капель $2 \%$ водного раствора солянокислого кокаина в конъюнктивальный мешок». 


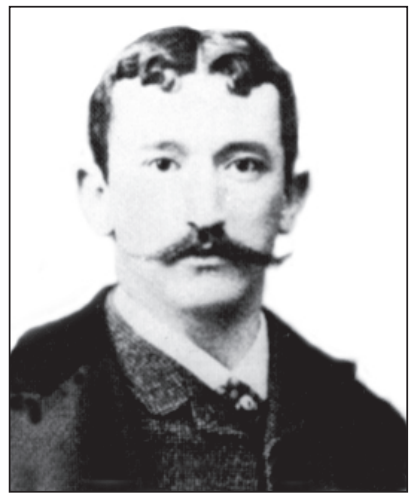

Рис. 97. Карл Коллер 1857-1944). Австрийский офтальмолог, один из основоположников местной анестезии. После доклада его ассистента на Хайдельбергском конгрессе местная анестезия кокаином привлекла внимание врачей во всём мире
Это сообщение очень быстро распространилось за границей и создало славу К. Коллеру. Уже через несколько дней после опубликования телеграммы Коллера венский отиатр Иеллинек (Jellinek) сообщил о своих наблюдениях по анестезии глотки, которую он смазывал растворами кокаина (Зыков А.А., 1954).

Зигмунд Фрейд (рис. 98), почти что, вошёл в историю медицины как первооткрыватель местной анестезии, он тоже связывал отсутствие чувствительности языка с местной анестезией и вместе с Леопольдом Кёнигштайном (Leopold Königstein) энуклеировал глаз собаки безболезненно под кокаиновой анестезией! Но отчёт об этом появился только 17 октября 1884 года, то есть через месяц после доклада Джозефа Бреттауера ... (Lipp M., 1992).

В русской литературе первое сообщение об открытии К. Коллера было напечатано в медицинской газете «Врач», 1884 г., № 39, то есть спустя 12 дней с момента опубликования телеграммы на конгрессе офтальмологов. В кратком реферате сообщалось о местном действии раствора кокаина на глаз и о применении кокаина Иелинеком.
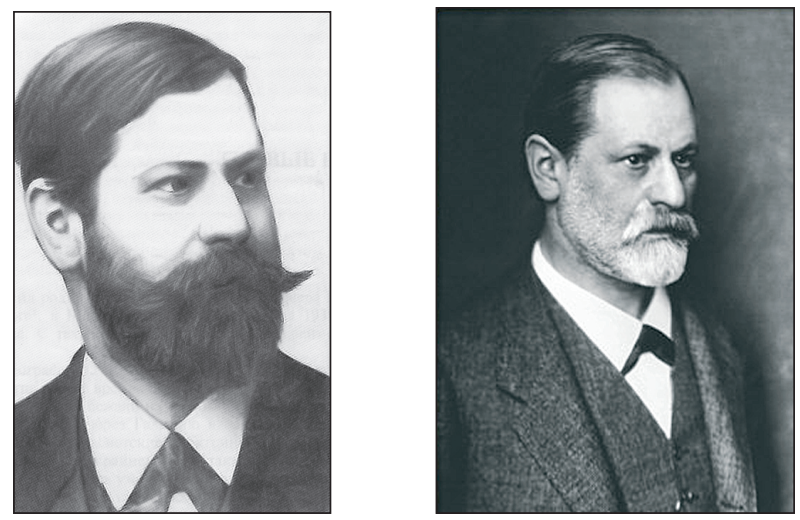

Pис. 98. Sigmund Freud, 1856-1939.

Зигмунд Фрейд в возрасте 35 лет (Ил. Э. Джонс, 1996.) и в среднем возрасте 
На основе применения кокаина были разработаны методы терминальной и инфильтрационной местной анестезии. С 1884 г. местное обезболивание стало применяться почти во всех отраслях медицины, в том числе и в зубоврачебной практике.

Возникает вопрос, почему сообщение В.К. Анрепа в известном немецком журнале не послужило началом развития местной анестезии ни в Европе, ни в России? Почему краткая телеграмма К. Коллера возымела больший эффект, чем подробное сообщение В.К. Анрепа, детально изучившего физиологические свойства кокаина?

Это не случайно. Существовал целый ряд условий, мешавших распространению замечательного открытия В.К. Анрепа. Его статья, напечатанная в немецком физиологическом журнале «Архив Пфлюгера», не была переведена на русский язык, эффекту местной анестезии он посвятил небольшой абзац, кроме того, В.К. Анреп не сделал устного сообщения о своём открытии для широкого круга врачей. По-видимому, поэтому работа В.К. Анрепа могла остаться незамеченной практическими врачами.

И.С. Жоров (1951) отмечает, что стремление Коллера скрыть достижения русского учёного нашло свое выражение на Хайдельбергском конгрессе (Гейдельбергском съезде) офтальмологов (1884), где было доложено, что Коллер первый открыл обезболивающие свойства кокаина и применил его в клинике.

В России местная анестезия в самое непродолжительное время встретила горячих последователей. Ярославский офтальмолог И.Н. Кацауров опубликовал большую статью о применении кокаина в глазной хирургии («Врач», 1884, № 43). Не зная ещё методики Коллера [в первом русском реферате не указывался метод применения кокаина, предложенный Коллером, а также дозировка («Врач», 1884, № 39)], Кацауров использовал только идею применения кокаина для обезболивания. Он применил для обезболивания глаза им самим приготовленную 5\% мазь солянокислого кокаина и получил блестящий результат. Так, основываясь на исследованиях В.К. Анрепа, русские врачи-офтальмологи И.Н. Кацауров и за ним А. Захарьевский ещё до Коллера стали производить глазные операции, пользуясь кокаиновой анестезией по методу, разработанному И.Н. Кацауровым (Зыков А.А., 1949, 1954).

Спустя 20 дней после опубликования работы И.Н. Кацаурова в статье «Кокаин, как средство местно-анестезирующее» В.К. Анреп знакомит русских врачей со своим пятилетним опытом применения кокаина (рис. 99). «Сколько мне известно, я первый указал на местно-анестезирующее свойство кокаина. В моей работе о физиологических свойствах кокаина, напе- 


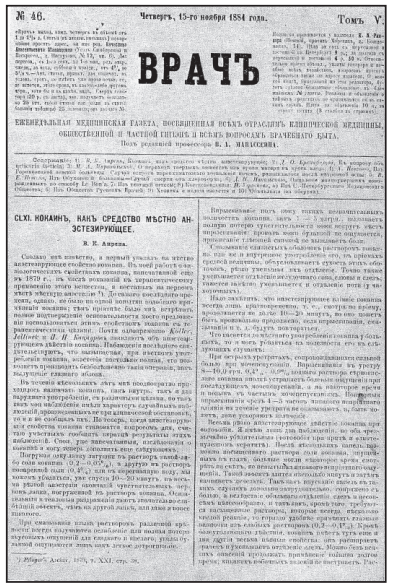

Рис. 99. Статья В.К. Анрепа, «Врач», 1884, № 46 чатанной ещё в 1879 г., в числе показаний к терапевтическому применению этого вещества, я поставил на первом месте местную анестезию (Phluger's Archiv, 1879, т. XXI, с. 38). До самого последнего времени, однако, не было ни одной попытки подобного применения кокаина; тем приятнее было мне встретить полное подтверждение основательности моего предложения воспользоваться этим свойством кокаина с терапевтическими целями. Почти одновременно Koller, Jellinek и И.Н. Кацауров заявляют об анестезирующем действии кокаина. Наблюдения последнего свидетельствуют, что вызываемая, при местном употреблении кокаина, анестезия настолько полная, что позволяет производить безболезненно такие операции, как вылущивание глазного яблока.

В течение нескольких лет мне неоднократно приходилось назначать кокаин как внутрь, так и для наружного употребления, с различными целями, но так как мои наблюдения имели характер случайных наблюдений, произведённых не при клинической обстановке, то я и не сообщал их. Но теперь, когда анестезирующие свойства кокаина становятся вопросом дня, считаю уместным сообщить вкратце результаты этих наблюдений. Свои, уже напечатанные, исследования о кокаине я могу теперь дополнить ещё следующим.

Погружая одну лапку лягушки в раствор какой-либо соли кокаина $(0,2-0,005 \%)$ и другую в раствор поваренной соли $(0,4 \%)$ или в перегнанную воду, мы можем убедиться, уже спустя 10-20 минут, в весьма резкой анестезии окончаний чувствительных нервов лапки, погружённой в раствор кокаина. Осязательные и тепловые раздражения дают значительно слабейший эффект, чем на другой лапке, или даже вовсе никакого.

При смазывании языка раствором различной крепости всегда получаются ослабление или полная потеря вкусовых ощущений для сладкого и кислого; уколы булавкой ощущаются лишь как лёгкое дотрагивание.

Впрыскивание под кожу таких незначительных количеств кокаина, как 1-3 млгрм., вызывает полную потерю чувствительности кожи вокруг места впрыскивания: прокол кожи булавкой не ощущается, прижигание тлеющей спичкой не вызывает боли.

Смазывание слизистых оболочек раствором кокаина или же и внутреннее употребление его, в приёмах средней величины, обусловливает сухость 
этих оболочек, резко уменьшая их отделение. Точно так же уменьшается отделение желудочного сока, слюны и слез; кажется, заметно уменьшается и отделение пота (у чахоточных).

Надо заметить, что анестезирующее влияние кокаина всегда лишь кратковременно, т.е. смотря по приёму, продолжается не долее 10-20 минут, но оно может быть произвольно продолжено, если впрыскивания, смазывания и т.д. будут повторяться.

Что касается до местного употребления кокаина у больных, то я мог убедиться в полезности его в следующих случаях:

При острых уретритах, сопровождающихся сильной болью при мочеиспускании. Впрыскивания в уретру 8-10,0 грм. 0,4-0,9\% водного раствора сернокислого кокаина вполне устраняет болевые ощущения при последующем мочеиспускании, а на некоторое время и позыв к частым мочеиспусканиям. Повторные впрыскивания через 4-5 часов никакого неприятного влияния на течение уретрита не оказывают, а, быть может, даже ускоряют излечение."

Автор отмечает благоприятное влияние кокаина при фотофобии (светобоязни): кроме болеутоляющего действия и прекращения светобоязни наступало расширение зрачка и уменьшение слезотечения.

В.К. Анреп, прежде всего, на себе убедился в анестезирующих свойствах кокаина и затем в нескольких случаях применил его на больных людях. Больному с острым плевритом он впрыснул раствор кокаина $(0,025)$ в одно из межреберий больной стороны. Через 10 минут боли стали утихать, и больной мог вдохнуть полной грудью. Эффект продолжался около 2 часов. Больному с межреберной невралгией В.К. Анреп произвёл за 5 дней 8 впрыскиваний раствора кокаина для достижения кратковременного эффекта, причём без всякого влияния на саму болезнь. Эффект облегчения был очень хорошим. В трёх случаях В.К.Анреп применил кокаин в виде порошка в смеси с безразличными веществами для присыпания болезненных язв. Результаты были удовлетворительные. Кроме того, В.К.Анреп использовал кокаин при насморке с целью уменьшить отделение слизи и опять получил временный успех (за счёт сосудосуживающего действия кокаина) без заметного действия на течение болезни.

Статья В.К. Анрепа, напечатанная через два месяца (а написанная за несколько дней до подачи в редакцию) после оглашения телеграммы К. Коллера и доклада его помощника Дж. Бреттауера на конгрессе офтальмологов (15 сентября 1884 г.), выгодно отличалась научной широтой взгляда, содержала конкретные случаи применения кокаина при различных заболеваниях периферической нервной системы и совершенно чётко формулировала 


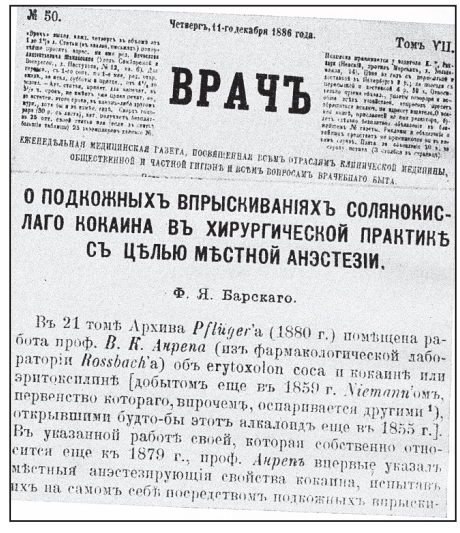

Рис. 100. Статья Ф.Я. Барского, «Врач», 1886, № 50 местно-анестезирующее действие кокаина при впрыскивании растворов его под кожу.

В.К. Анреп установил, что кокаин действует на все чувствительные нервные окончания, а не только на слизистые оболочки. Он первый применил кокаин для обезболивания (но не при операциях, а для устранения болей при различных заболеваниях) и первый стал вводить кокаин под кожу с целью анестезии.

Небезынтересно, что применение кокаина для длительного воздействия на болезнь ни разу не увенчалось успехом, на что автор каждый раз обращал внимание. Тем самым он особо подчёркивал значение кокаина как местно-анестезирующего средства.

Однако в отечественной и зарубежной литературе приоритет первой публикации В.К. Анрепа по кокаину относят к разным годам. Одни отечественные авторы и В.К. Анреп в их числе (Барский Ф.Я., Вреден Р.Р., Вишневский А.В., Вишневский А.А., Жоров И.С., Николаев М.П.) считают, что она была в 1879 г. Другие отечественные (Зыков А.А., Петрикас А.Ж.) и зарубежные (H. Braun, G. Fischer, M. Lipp) - в 1880 г. Кто же прав? На сегодняшний день, как считают А.И. Трещинский и соавт. (1973), к сожалению, трудно ответить на этот вопрос, так как первая работа В.К. Анрепа, опубликованная в 1879 г., до сих пор остается неизвестной.

Проясняет истину статья Ф.Я. Барского (1886) - рис. 100. Он пишет: «В 21 томе «Архива Пфлюгера» (1880 г.) помещена работа проф. В.К. Анрепа (из фармакологической лаборатории Rossbach'a) ... В указанной работе своей, которая собственно относится ещё к 1879 г., проф. Анреп впервые указал местные анестезирующие свойства кокаина ..."

Таким образом, формально годом открытия кокаина считают 1880, а фактически, как указывают сам Анреп и Барский, это произошло в 1879 г., то есть речь идёт об одной и той же публикации.

Вслед за офтальмологами стали применять кокаин ларингологи и ринологи (на слизистых оболочках), а затем хирурги: у нас Лукашевич, Смирнов, Барский, Монастырский, Орлов, за рубежом Шлезингер, Корнинг, Ландерер (Schlesinger, Corning, Landerer). При этом в хирургии с самого начала был использован путь, указанный Анрепом, - впрыскивания в ткани. Этот 
путь особенно разрабатывался Робертсом (Roberts), который ещё в 1885 г. говорил о планомерном введении раствора в ткани, то есть выдвигал принцип, на котором в дальнейшем строился метод местной инфильтрационной анестезии.

Первым русским хирургом, занимавшимся вопросами местного обезболивания кокаином, является В.Ф. Спримон. Он, прежде всего, на себе проделал ряд экспериментов по изучению общего и местного действия кокаина и получил анестезию слизистых оболочек, при этом обратил внимание на наступавшую ишемию. При подкожном введении он наблюдал тот же местно-анестезирующий эффект, но слабее, чем при смазывании слизистых. Через 20 минут после введения под кожу конечности 0,5 грана (1 гран = 0,06 грамма) на фоне анестезии наступало резкое побледнение кожи и понижение температуры конечности на $0,6^{\circ}$.

Зарубежные хирурги шли главным образом по линии накопления большого личного опыта и сводного материала, так что, например, Поль Реклю (Paul Reclus) к 1894 г. смог представить уже 2200 операций под кокаиновой анестезией.

В то же время русские учёные и врачи шли по пути глубокого изучения физиологического действия кокаина - общего и местного (Анреп, Спримон, Лукашевич) - с целью сделать метод наиболее безопасным и вместе с тем эффективным. Изучались дозировки кокаина (Барский, Орлов), было открыто противоядие амил-нитрит (Барский), установлены преимущества слабых растворов кокаина (Орлов), выявлено значение обескровливания для усиления действия кокаина (Барский) и др.

В 1886 г. в России было опубликовано несколько значительных работ по применению растворов кокаина в хирургии. Первая из этих работ - «О подкожных впрыскиваниях кокаина» - принадлежит врачу военного госпиталя А.И. Лукашевичу (рис. 101). Он подробно сообщает о 150 случаях введения растворов кокаина под кожу себе и здоровым людям для эксперимента, а также о 36 операциях под кокаиновым обезболиванием. Тщательно изучая эффект действия введённого под кожу раствора кокаина (с лета 1885 г.), автор пришёл к выводу, что с места введения анестезия распространяется больше книзу, чем кверху. Это указывает на нарушение проводимости нервов. При всех операциях А.И. Лукашевич не превысил дозы кокаина 0,03. Замечательное описание своего метода А.И. Лукашевич дал при операциях по поводу панарициев. Значение работы А.И. Лукашевича огромно. Он первый на большом количестве опытов изучил физиологическое действие кокаина на человеке, и первый указал на допустимые дозы кокаина. Он первый в России на опыте доказал возможность проводниковой анесте- 


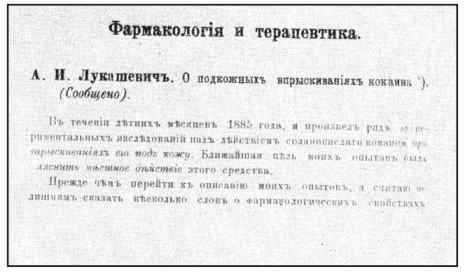

Рис. 101. Страница

из работы А.И. Лукашевича, «Медицинское обозрение», 1886, № 10 зии и применил свой метод обезболивания пальца раньше Оберста. Таким образом, родоначальником проводниковой анестезии в хирургии является А.И. Лукашевич.

В том же 1886 г. Ф.Я. Барский из клиники проф. Грубе (Харьков) в статье «О подкожных впрыскиваниях солянокислого кокаина в хирургической практике с целью местной анестезии» приводит большой хирургический материал. В своей статье автор делает несколько важных практических выводов. Местное обескровливание усиливает действие кокаина. Доза кокаина 0,1-0,2 безопасна. В случаях токсического действия лучшим противоядием является амил-нитрит, 1-3 капли которого при вдыхании быстро купируют токсическое действие кокаина.

Статья Ф.Я. Барского является логическим продолжением работы А.И. Лукашевича и во многом с ней сходна. В работе Ф.Я. Барского ещё раз подчеркивается, с какой осторожностью относились русские хирурги к допустимым дозам кокаина. Он первый в России указал на значение обескровливания при местном обезболивании и ясно представлял себе перспективу дальнейшего развития местного обезболивания в хирургии.

Эти исследования позволили русским хирургам, имевшим количественно меньший опыт, опередить зарубежных коллег в отношении расширения сферы применения кокаиновой анестезии. Если Реклю к моменту опубликования своего огромного по тому времени материала не решался всё ещё на применение кокаина в брюшной полости, Н.Д. Монастырский уже за 7 лет до публикации Реклю, в 1887 г., сообщил об успешном применении им кокаиновой анестезии в ряде случаев при брюшных и других крупных операциях.

Судя по сообщениям из-за границы, 1885 г. был годом увлечения кокаином. Не было почти ни одной отрасли медицины, где бы не применяли кокаин (Зыков А.А., 1954). Это было безмерное и опасное увлечение. Для иллюстрации происходившего за границей увлечения можно привести далеко не полные данные по рефератам, опубликованным только в газете «Врач» за 1885 г. Кокаин применялся с терапевтической целью в детской практике, при болезнях глаз, горла, носа, зубов, кожи, мочевого пузыря, уретры, коклюше, морфинизме, ожогах, рвоте беременных, роже, при родах, сенной лихорадке.

В этом же году был получен синтетический кокаин [Мерк (Merck E., 1885)], что послужило стимулом к его ещё большему распространению, а Ко- 
нуэй (Conwey, 1885) предложил пользоваться местной анестезией при переломах костей, впрыскивая кокаин прямо в место расположения отломков.

Примером увлечения кокаином за рубежом может служить сообщение Вихеркевича («Врач», 1885, № 42, с. 704), который рекомендовал давать детям по 0,03-0,05 кокаина на приём в начале морского путешествия во избежание морской болезни, причём советовал повторять эти приёмы через каждые 2-3 часа.

Подобные сведения беспрепятственно публиковались во всех журналах, и нужно только удивляться, как ещё сравнительно мало было сообщений об отравлении кокаином. Приведённые данные об очень большом распространении кокаина за рубежом не указывают на изучение врачами его физиологического действия. Отсутствовало и теоретическое обоснование его применения. Существовало легкомысленное отношение к кокаину без учёта его токсичности, не было представления о допустимых терапевтических дозах.

Изредка появлявшиеся в прессе сообщения о случаях отравления кокаином совершенно тонули в десятках восторженных статей из различных отраслей медицины («Врач», 1885, № 44, с. 737).

Но вслед за увлечением быстро наступило разочарование, и уже с 1886 г. за рубежом применение кокаина во многих отраслях медицины резко сократилось. Причиной этому послужило то, что, во-первых, кокаин оказался бесполезным во многих случаях его применения с терапевтической целью; во-вторых, появилось всё больше и больше сообщений о тяжёлых и даже смертельных отравлениях кокаином (так, за первые 7 лет после введения кокаина в медицинскую практику опубликовано не менее 13 сообщений о смертельных исходах при его применении), а также о привыкании и о хроническом отравлении кокаином - кокаинизме.

G. Fischer (Гвидо Фишер) ярко описал эротические, галлюциногенные, истерические проявления применения кокаина. Многие из его исследователей стали наркоманами.

Эти факты произвели отрезвляющее действие на многих поклонников кокаина за границей.

Русские врачи выгодно отличались от иностранных своим пониманием физиологических свойств кокаина и учётом опасности при его применении, но иногда слепое доверие к иностранным авторитетам приводило к плачевному результату. Приведём лишь один пример трагического случая, вызвавший потрясение у русских хирургов.

Талантливый хирург, профессор Военно-медицинской академии С.П. Коломнин (рис. 102), основываясь на сообщениях французских авто- 


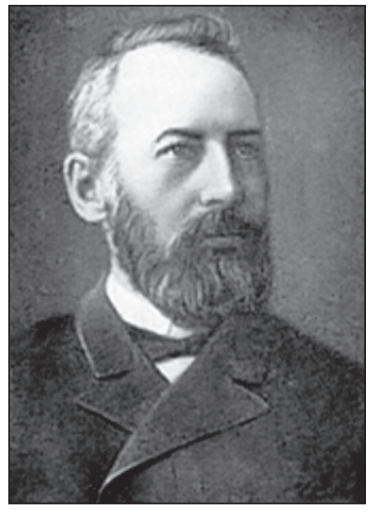

Рис. 102. Сергей Петрович Коломнин (1842-1886). Профессор хирургии Медикохирургической академии в Петербурге. Предложил тампонировать полость рта при ингаляционном наркозе через трахеостому ров о применении больших доз кокаина, 6 ноября 1886 г. произвёл прижигание язвы прямой кишки молодой женщине, специально приехавшей для этого в Петербург. Ввиду опасности, по его мнению, хлороформного наркоза для больной хирург решил произвести операцию под местной анестезией. Кокаина было употреблено 24 грана (1,44 г) - доза, вдвое меньшая, чем рекомендовалось во французской хирургической литературе. Операция прошла успешно, но вскоре у больной появились признаки отравления кокаином - головная боль, тошнота, рвота, судороги. Несмотря на все принятые меры, больная умерла приблизительно через 2-3 часа после операции. С.П. Коломнин был крайне удручён и глубоко переживал смерть оперированной молодой женщины. После нескольких дней тяжёлых нравственных мучений, которые усугубились репортёрскими кривотолками в бульварной прессе с недвусмысленными намёками и прямыми обвинениями, что «женщину убили», С.П. Коломнин застрелился. В записке, наспех составленной утром 11 ноября, за несколько минут до смерти, он написал: «На прошлой неделе, вероятно, случилось временное помрачение ума от неприятности, и оттого - та операция. Я не виноват, желал добра. Доктора Морозова и других прошу не винить».

Спустя несколько лет патологоанатом К.Н. Виноградов выступил с подробным разбором этого случая отравления кокаином. Для местного обезболивания перед операцией больной через клизму было введено в прямую кишку $30 \mathrm{~cm}^{3} 5 \%$ раствора солянокислого кокаина. Учитывая, что при операции во время введения зеркал в прямую кишку часть жидкости вылилась наружу, в организм поступило значительно меньшее её количество. При исследовании содержания кокаина в тканях трупа установлено, что общее содержание кокаина в трупе было около 0,5. Усугубляющим фактором, очевидно, служило то, что у больной было старое заболевание почек. К.Н. Виноградов ссылается на Занчевского, у которого в эксперименте с собаками наблюдались аналогичные изменения тканей при отравлении кокаином, что Виноградов наблюдал у погибшей в клинике Коломнина. В оправдание действий Коломнина он ссылается на иностранных авторов 
(Делляфос, Бёкл), которые вводили в прямую кишку и в мочевой пузырь ещё большие дозы кокаина безнаказанно. В заключение К.Н. Виноградов считает, что С.П. Коломнина «... постигло несчастье, которое может случиться со всяким врачом, вынужденным обращаться к ядовитым средствам».

Смерть Коломнина посеяла большое недоверие к кокаину и, очевидно, послужила причиной задержки развития местного обезболивания кокаином. Во всяком случае, в течение ряда лет того периода почти не встречалось работ провинциальных и, тем более, земских хи-

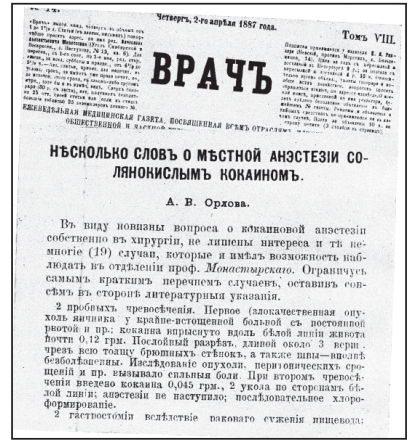

Рис. 103. Статья А.В. Орлова, «Врач», 1887, № 14 рургов, которые бы указывали на применение растворов кокаина в их практической деятельности (Зыков А.А., 1949).

Зато в клиниках русской столицы врачи продолжали разрабатывать методы местного обезболивания, и в начале 1887 г. из клиники проф. Н.Д. Монастырского (Клинический институт) вышла замечательная статья, которая по праву может считаться наиболее выдающейся работой того времени не только в России, но и за рубежом. А.В. Орлов опубликовал её под скромным названием «Несколько слов о местной анестезии солянокислым кокаином» (рис. 103). Эта статья является первой работой - как в России, так и на Западе, в которой подчёркивается преимущество растворов кокаина слабой концентрации и даётся глубокое научное обоснование практического применения местного обезболивания при больших хирургических операциях.

Разработка метода и применение местного обезболивания в клинике проф. Н.Д. Монастырского (рис. 104) бесспорно имели большое пропагандирующее значение и являлись примером для провинциальных хирургов. И всё же, о сравнительно малом распространении кокаина в хирургии говорит и весьма краткая характеристика А.А. Боброва, которую он приводит в своём учебнике «Курс оперативной хирургии и хирургической анатомии», вышедшем в 1887 г. Среди различных методов местного обезболивания средств охлаждения, прижатия нервных стволов и т. п. о действии кокаина написано следующее: «В последнее время очень часто в качестве местноанестезирующего средства применяют кокаин. Обыкновенно употребляются 4-10-20\% растворы кокаина в воде». В этом же учебнике А.А. Бобров высказывает недоверие к новому методу местного обезболивания. Он пишет: «С целью анестезии кожи и глубжележащих тканей предлагают делать подкожные впрыскивания кокаина, но, как показал опыт, это малонадёж- 


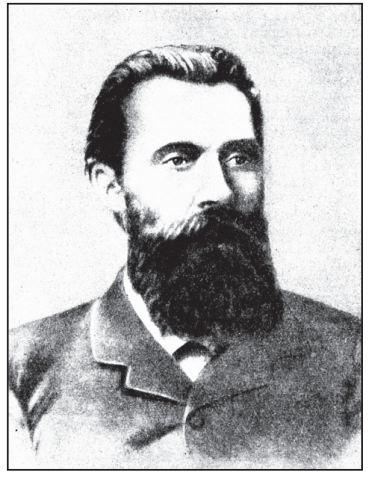

Рис. 104. Нестор Дмитриевич

Монастырский (1847-1888) но». Известный хирург того времени ни слова не говорит о методике, допустимых дозах кокаина, о его токсичности и возможных осложнениях.

Неприязненное отношение к наркозу, а часто и страх перед ним создали благоприятные условия для развития метода местного обезболивания в земской хирургии. Но, как отмечает А.А. Зыков (1954), в условиях разрозненной и замкнутой деятельности большинства земских врачебных участков трудно было рассчитывать на быстрое распространение метода обезболивания кокаином не только в силу ограниченности материальных средств земских больниц, но и, главным образом, слишком большой оторванностью земских врачей от передового опыта клиник. Большие достижения клинических учреждений сравнительно долгое время не становились достоянием врачей, работающих в провинции. После статьи А.В. Орлова до начала 90-х годов в России не было опубликовано ни одной значительной работы по местному обезболиванию.

За рубежом в этот период (1887-1890) распространение местного обезболивания кокаином было несколько большее, чем в России, особенно это касается Австрии, Германии и Франции. Из наиболее заслуживающих внимания следует упомянуть об интересном сообщении известного швейцарского хирурга Ру (Roux) («Врач», 1889, № 8, с. 214), выступившего против введения концентрированных растворов кокаина. Ру считал, что $1 \%$ раствор кокаина вполне достаточен для проведения операций.

В 1891 г. на хирургическом обществе Пирогова впервые обсуждался вопрос о местном обезболивании кокаином (Змигродский, Троянов А.А., Шлезингер А., Субботин М.С., Эберман А.Л.). Заседание общества имело большое значение для развития и пропаганды местного обезболивания кокаином. У врачей того времени ещё жило воспоминание о трагической смерти С.П. Коломнина, вызывавшее недоверие к кокаину.

Период с 1891 по 1897 г. характерен большой популяризацией местного обезболивания в России. Широкое распространение получили работы французского хирурга Поля Реклю (Paul Reclus). Его статьи и лекции систематически переводились на русский язык и печатались в русских журналах («Военно-медицинский журнал», 1891, октябрь, с. 192; 1894, январь, июль и октябрь, с. $59,108,137)$. Реклю применял $0,5-1 \%$ раствор кокаина для всех операций, считая более концентрированные растворы ненужными и 
небезопасными. Одна из заслуг Реклю заключается в том, что он дал анализ всех опубликованных в то время смертельных случаев, последовавших после применения кокаина. Реклю указал, что доза свыше 0,15 опасна для жизни. Он считал, что из 14 смертельных исходов, известных ему из литературы, 11 случаев смерти были следствием применения доз кокаина 0,22 и выше, в остальных 3 - зависимость смерти от анестезии кокаином он считал не доказанной.

Заслуги Реклю в распространении метода местного обезболивания кокаином бесспорны, но возникает вопрос, почему метод Реклю получил такое быстрое и широкое внедрение в России? Почему работы отечественных авторов, указавших задолго до Реклю и на преимущества слабых растворов, и на допустимые дозы кокаина, не сыграли

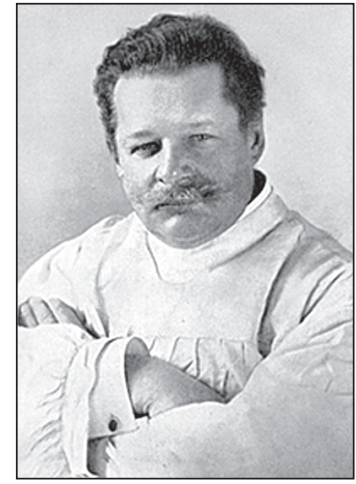

Рис. 105. Карл Людвиг Шлейх (1859-1922), немецкий хирург, один из основоположников местной инфильтрационной анестезии в хирургии такого решающего значения в деле распространения метода обезболивания кокаином в России? По всей вероятности, это было связано с преклонением перед иностранными авторитетами.

Ещё до Реклю А.В. Орлов и другие хирурги указывали на преимущества слабых растворов кокаина (1:60) и на допустимые дозы его. Но, как пишет А.А. Зыков (1954): «... из-за преклонения перед заграницей только освящённый иностранным авторитетом метод мог найти широкое признание в русской хирургии».

Вслед за работами Реклю в России получили распространение статьи К. Шлейха (Schleich C.L.) из Германии (рис. 105). Подробные сообщения о трудах Шлейха впервые были напечатаны в «Военно-медицинском журнале» (1895, май, c. 18). Он применил принцип обезболивания, основанный на анестезирующем действии индифферентных жидкостей, пропитывающих всю область операции. Для этой цели он брал растворы различных солей, а для уменьшения болей, возникающих после введения растворов, применял кокаин, морфин и кодеин.

Шлейх предложил три концентрации растворов: крепкий - для областей с повышенной чувствительностью, средний - для участков кожи нормальной чувствительности и слабый - для областей с пониженной чувствительностью. Растворы отличались соответствующим понижением концентрации кокаина, морфина и кодеина. Основное преимущество метода Шлейха заключалось в том, что он был более безопасен, так как предложенные им самые крепкие растворы содержали $0,2 \%$ кокаина. 
В самое ближайшее время после публикации работ Шлейха появились статьи русских хирургов с положительными отзывами о его методе (Готтлиб М., 1897; Загорский, 1897). М. Готтлиб в своей статье предсказывает будущность методу Шлейха в русской хирургии. В историческом обзоре он сообщает, что метод Шлейха не сразу получил общее признание. Вначале Шлейха постигла неудача. В 1892 г. он демонстрировал больного на XXI съезде немецких хирургов. Случай оказался настолько непоказательным, что скорее посеял недоверие, чем убедил хирургов. Но в дальнейшем способ Шлейха за рубежом и у нас нашёл широкое распространение.

Переход к применению слабых растворов кокаина способствовал снижению числа осложнений при анестезии кокаином и расширил его использование. И всё же опасности, связанные с применением кокаина, дали основание к изысканию для местной анестезии новых препаратов, менее токсичных, чем кокаин. Этому способствовала быстро развивающаяся химическая промышленность, особенно в Германии. Появляются новые местно-анестезирующие средства: тропакокаин (Tropacocain, 1893), голокаин (Holocain, 1897), эйкаин (Eicain, 1898), а позже них - стоваин (Stuvain, 1904), алипин (Alipin, 1905). Наибольшее распространение из них нашёл эйкаин. Эти вещества, менее токсичные, чем кокаин, имели своих приверженцев, но большого распространения в хирургии и зубоврачебной практике не нашли вследствие меньшей длительности обезболивающего действия и эффективности. Кокаин по-прежнему оставался наиболее распространённым средством местного обезболивания.

К последним годам XIX века местное обезболивание в хирургии было уже признанным методом, но практическое использование местной анестезии ещё не было настолько велико, чтобы оно могло конкурировать с наркозом.

Важнейшим событием в разработке средств местной анестезии явилось комбинирование местного анестетика с адреналином. В 1892 г. английский врач G. Olivier (Дж. Оливиер) сообщил о том, что выдержка из ткани надпочечников оказывает мощное действие на сердце и кровеносные сосуды, а спустя несколько лет американский фармаколог J. Abel (Дж. Абель, 1897) выделил активное начало, названное им эпинефрином (адреналин). В 1901 г. японский химик J. Takamine (Дж. Такамине) разработал технологию получения адреналина в чистой форме. Достаточно было впрыснуть в вену собаки незначительное количество этой вытяжки, как немедленно замечалось повышение артериального давления. При действии препаратом на периферические кровеносные сосуды вытяжка не вызывала их сужения. Немецкий профессор Н. Braun и Е. Mayer в 1901 г. предложили сочетание этого 
препарата с местным анестетиком, сравнивая адреналин «с химическим турникетом» (жгутом), уменьшающим скорость всасывания кокаина и пролонгирующим анестезию.

Сегодня некоторые решения того времени выглядят нелепо. Так, на рис. 106 из монографии Г. Фишера изображена специальная давящая повязка для обеспечения депо местного анестетика в месте инъекции и уменьшения резорбции его оттуда.

Дальнейшее развитие местного обезболивания в России связано главным образом

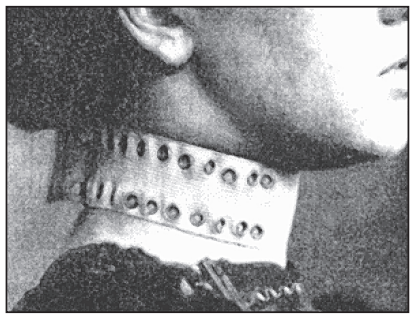

Рис. 106. Бандаж, надеваемый на шею пациентке, для уменьшения опасности интоксикации местным анестетиком (Fischer, 1914) со школой проф. В.А. Ратимова (Военномедицинская академия). Его ученикам и, прежде всего, Р.Р. Вредену (рис. 107) принадлежит ведущая роль в разработке новых, более совершенных методов местной анестезии.

В своей лекции, прочитанной на соискание звания приват-доцента (1898) и опубликованной в «Летописи русской хирургии», Р.Р. Вреден указывал, что применение кокаина не является новым методом, но распространение использования до сих пор является недостаточным «... благодаря крайне разноречивым, подчас даже противоречивым отзывам, несомненно, требующим разъяснения».

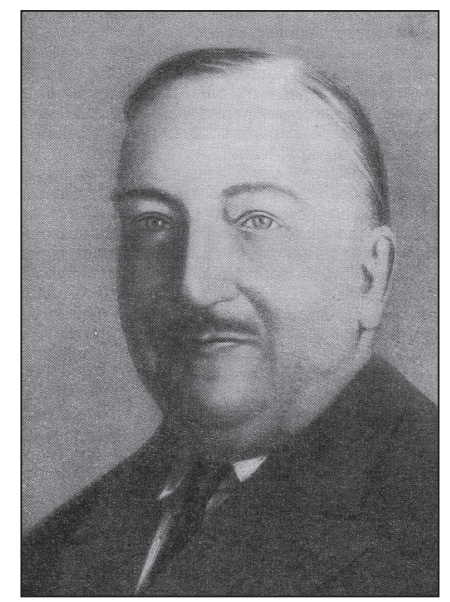

Рис. 107. Роман Романович Вреден (1867-1934).

Его теоретические разработки и клиническое применение растворов кокаина значительно упрочили позиции местного обезболивания в отечественной хирургии 
Он указывал, что развитию обезболивания кокаином мешало большое количество более токсичных, чем сам кокаин, суррогатов, наводнивших рынок, слабое знание многими хирургами физиологических и токсических свойств кокаина. Р.Р. Вреден предложил свой метод, который заключается в следующем: после внутрикожной инъекции $1 \%$ раствора кокаина по линии разреза операционное поле окружается поясом кокаинизированных тканей посредством ряда глубоких инъекций. Метод выгоден тем, что парализуются все проходящие чувствительные нервы, не наводняются ткани, непосредственно подверженные оперативному воздействию, не требуется применения жгута и анестезия длится 0,5-1 час. Автор считал полезным добавление морфина при операциях на брюшной полости для устранения раздражения брюшины. По его мнению, доза кокаина не должна превышать 0,2, а 1\% раствор кокаина вполне достаточен для проведения любой операции. Р.P. Вреден предостерегал хирургов от применения концентрированных растворов и обращал внимание на опасность попадания кокаина в кровеносное русло. Противопоказанием к местному обезболиванию он считал детский возраст, нервность больных и неизвестный объём операции.

Своей работой Р.Р. Вреден значительно упрочил позиции местного обезболивания в отечественной хирургии, дал исчерпывающие объяснения физиологического действия кокаина и окончательно разбил тот страх перед этим анестетиком, который всё ещё существовал среди русских хирургов.

В 1899 г. на хирургическом обществе Пирогова второй раз был поставлен вопрос о местном обезболивании растворами кокаина. В.Н. Гейнац (из клиники проф. В.А. Ратимова) сделал доклад «О местном обезболивании пропитыванием тканей по способу Шлейха». Его сообщение вызвало оживлённые и разноречивые прения, принявшие характер широкой, принципиальной дискуссии об отношении к обезболиванию кокаином вообще. Положительную оценку применению этого метода дали Н.В. Склифосовский, P.Р. Вреден, Г.Х. Ауэ. Отрицали возможность применения кокаина при больших операциях А.А. Троянов, А.А. Кадьян. Из этих выступлений видно, что не все хирурги одинаково оценивали возможность операций под обезболиванием кокаином, но характерным является то, что вопрос уже стоял не о том, стоило или не стоило применять кокаин в хирургии, а лишь в том, можно ли применять его при больших операциях.

Из клиники проф. А.А. Боброва было опубликовано сообщение А. Залоги (1898) о применении эйкаина в зубоврачебной практике. Автор считал эйкаин весьма ценным средством при удалении зубов, но этот анестетик, по его мнению, является избирательным сердечным ядом. 
В конце 90-х годов и начале XX столетия продолжаются поиски более безопасных заменителей кокаина. За границей кроме ранее перечисленных был предложен ряд анестетиков ортоформ, нирванин, анезон, алипин и др. Из наиболее заслуживающих внимания работ следует указать на публикацию Г. Брауна «Областная анестезия кокаином», вышедшую в 1897 г.

16 августа 1898 г. (а не 1896 г., как сообщают А.В. Троянский с соавт.) Августом Биром (Bier A.) был предложен метод спинномозговой анестезии. Пользуясь поясничным проколом, он ввёл в подпаутинное пространство 1 мл 0,5\% раствора кокаина и произвёл совершенно безболезненно резекцию поражённого туберкулёзом голеностопного сустава. Первоначальное описание метода А. Биром (рис. 108) было опубликовано в 1899 г. (Morgan G., Mikhail M., 1997).

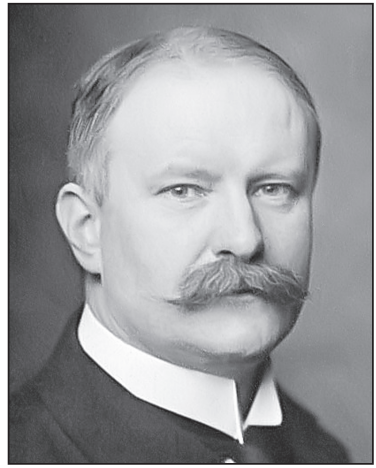

Рис. 108. Август Бир (August Bier, 1861-1949). Основоположник спинномозговой анестезии (1898). Развил учение о венозной регионарной анестезии (1908)

И.Я. Меерович в своём выступлении на I съезде российских хирургов сообщил о том, что впервые метод спинномозговой анестезии применил невропатолог из Нью-Йорка Корнинг (Corning J.I.) в 1885 г., однако наблюдения последнего остались неизвестными. Он был первым, кто ввёл раствор кокаина между остистыми отростками позвоночника человека. В результате больной отмечал «одеревенение» в ногах со значительным снижением чувствительности во всей нижней половине тела и в лёгкой степени даже в руках. В.А. Корячкин и В.И. Страшнов (1998) сообщают, что до 1894 г. J.I. Corning опубликовал ещё шесть подобных клинических описаний, однако результаты его наблюдений не получили дальнейшего распространения и остались неизвестными как в Америке, так и в Европе. В России впервые этот метод применил И.Я. Меерович в апреле 1899 г. в Екатеринодарской городской больнице.

Продолжая разрабатывать методы обезболивания в брюшной хирургии, Р.Р. Вреден в 1900 г. выступил на хирургическом обществе Пирогова, а в 1901 г. опубликовал выдающуюся работу «О местной анестезии в брюшной хирургии». В этой работе он дал физиологическое обоснование противошокового действия морфина при операциях в брюшной полости, привёл 15 примеров комбинации кокаина с морфином и предостерёг от полного вытеснения наркоза местной анестезией. 
В России к сочетанию адреналина с кокаином хирурги относились осторожно. Р.Р. Вреден (1903) считал уместным применять адренал-кокаиновое обезболивание только при удалении зубов из воспаленной надкостницы (при периодонтите). Во всех остальных случаях - достаточно одного кокаина. Р.Р. Вреден, Г.Ф. Цейдлер уже в самом начале применения адреналина предвидели возможные после него осложнения и опасности. Фактически уже в 1903 г. они пришли к тому, к чему многие хирурги пришли значительно позже, почти полностью отказавшись от применения адреналина при операциях под местным обезболиванием. В дальнейшем метод адреналкокаинового обезболивания нашёл своих сторонников.

На IV съезде российских хирургов В.Н. Гейнац (1904) выступил с сообщением о 212 случаях операций из амбулаторной практики под адреналинококаиновой анестезией. Он главным образом отмечал большую длительность обезболивания. Его пропорция лекарств была следующей: 1 часть адреналина, 50 - кокаина, 10000 - воды. По поводу сообщения В.Н. Гейнаца выступил только московский хирург В.М. Минц, указавший на уместность такого обезболивания при операциях на твёрдом и мягком нёбе 1 .

А.П. Крымов (1903) в газете «Русский врач» сообщает об успешном обезболивании $1 \%$ раствором кокаина при операции по поводу «заячьей губы», рака нижней губы с поражением подчелюстных лимфатических желёз (этого больного оперировал Ф.А. Голубев) и 12 вылущиваниях атером.

Г.А. Маслов (1904) на основе своего многолетнего опыта применения слабых растворов кокаина указывает, что для уменьшения опасности интоксикации требуется соблюдение некоторых «весьма существенных условий» при введении кокаина для удаления зубов. При этом автор пишет: «Применять следует лишь растворы слабой концентрации, так как доказано, что одно и то же вещество в той же дозе действует тем ядовитее, чем большей концентрации его раствор вводится в организм».

В 1904 г. вышел в свет капитальный труд С.Н. Делицина (рис. 109) монография «Местное и общее обезболивание», где автор подводит итоги почти шестидесятилетнего (считая с открытия наркоза в 1846 г.) опыта применения обезболивания при хирургических операциях, опыта, который был накоплен не только хирургами, но и физиологами, морфологами, фармакологами и другими специалистами. Это была первая отечественная монография по обезболиванию. Признавая неизбежность вредного влияния анестезирующих веществ на организм больного, автор замечает, что

${ }^{1}$ Впервые в мире применил местное обезболивание раствором кокаина при операции по поводу расщелины твёрдого нёба Н.В. Склифосовский в 1899 г. 
эти вещества действуют не сами по себе, а их применяет врач. С.Н. Делицин первым в России поднимает вопрос о квалификации наркотизаторов, верно подметив, что в большинстве своём печальные исходы зависят не от действия эфира или хлороформа, а от того, кто пользуется этими веществами. К применению эфира он относился настороженно. Отмечая наименьшую токсичность закиси азота в ряду известных наркотических веществ, С.Н. Делицин указывает на кратковременность и ненадёжность эффекта при использовании последней. Из-за большого числа осложнений при применении общего обезболивания и недостатка в кадрах квалифицированных наркотизаторов наркоз должен быть по возможности ограничен и там, где это осуществимо, заменён местной анестезией.

Значение монографии С.Н. Делицина для развития местного обезболивания в России очень велико. Она была первой русской работой, суммировавшей опыт обезболивания

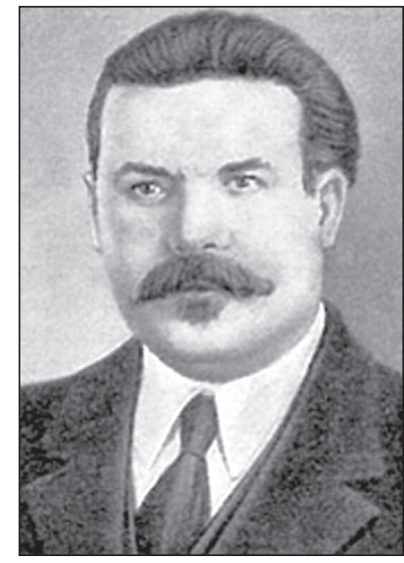

Рис. 109. Сергей Николаевич

Делицин (1858-1918). Профессор кафедры оперативной хирургии и топографической анатомии ВМА в Петербурге. Автор первого отечественного руководства по общему и местному обезболиванию кокаином за истекшие 20 лет, и являлась прекрасным практическим руководством для хирургов. Наконец, эта монография исторически правильно освещала развитие местного обезболивания, отдавая должное русским учёным в этом вопросе (Анрепу В.К., Вредену Р.Р. и др.).

Несмотря на то, что русским хирургам на стыке XIX и XX веков принадлежит целый ряд бесспорных заслуг в развитии совершенных методов местного обезболивания, как отмечает А.А. Зыков (1954), всё же в первые годы ХХ столетия в России значительное распространение получила методика иностранных хирургов, хотя отечественные врачи не раз выступали с критикой их методов. Причины этого кроются в том, что периодическая печать отводила почётное место иностранным работам в ущерб публикациям русских авторов. В российских журналах всячески пропагандировали методы Реклю, Шлейха и Оберста. Благодаря этому создалось ложное впечатление, что развитию местного обезболивания отечественные хирурги обязаны исключительно иностранцам. Ранние русские работы, не потерявшие в то время своей актуальности, как, например, исследования В.К. Ан- 
репа, А.И. Лукашевича, А.В. Орлова, Н.Д. Монастырского, были совершенно забыты. Даже последние работы Р.Р. Вредена не находили должного отражения в русской печати. Если об опыте Шлейха мы встречаем указания почти в каждом номере хирургического журнала, то о замечательном опыте П.А. Герцена и А.П. Крымова мы находим лишь по одному сообщению. Естественно, что провинциальные хирурги прибегали чаще к таким методам, которые были наиболее широко рекламированы печатью.

Предпочтение, которое оказывалось работам иностранных авторов, объясняется тем, что в этот период в России экономическое и политическое вмешательство иностранного капитала достигло высокого уровня. Вместе с импортом капитала в России беспошлинно импортировалась и иностранная наука. Отсюда становится понятным, почему русской науке отводилось второстепенное, подчинённое значение. 


\section{МЕСТНОЕ ОБЕЗБОЛИВАНИЕ В ПЕРИОД ПРИМЕНЕНИЯ НОВОКАИНА}

Поиск первого местного анестетика химической структуры - «классического» прокаина - начался с кокаина. Наиболее успешная синтетическая субстанция, заменяющая кокаин, впервые была открыта в 1904 г. Эрнестом Фурно (Ernest Fourneau, 1872-1949) и называлась стоваин (stovaine).

С 1892 г. немецкий химик Альфред Айнхорн (Alfred Einhorn - рис. 110) упорно вёл поиск нового местного анестетика. 28 февраля 1900 г. профессор Айнхорн представил первую часть научной работы для публикации в «Анналах химии Либиха» (Einhorn А., 1900). Эта статья под названием «О новом лекарстве» была большим шагом к открытию прокаина. Цель исследования, которое стало в дальнейшем направлением в науке о местных анестетиках, Айнхорн выразил в следующих предложениях: «С этой статьи я начинаю публикацию результатов ряда исследований, которые мы предприняли вместе с более молодыми химиками в течение последних нескольких лет и собираемся продолжать. Их прямая цель не только в том, чтобы к нашим фармакопеям добавить новые соединения, пригодные для терапевтического использования и освобожденные от давно известных фармакологам нежелательных побочных эффектов, преобразовывая эти препараты в более подходящие производные. Кроме того, я хочу найти правильные связи между строением их органических составов и их физиологическим эффектом».
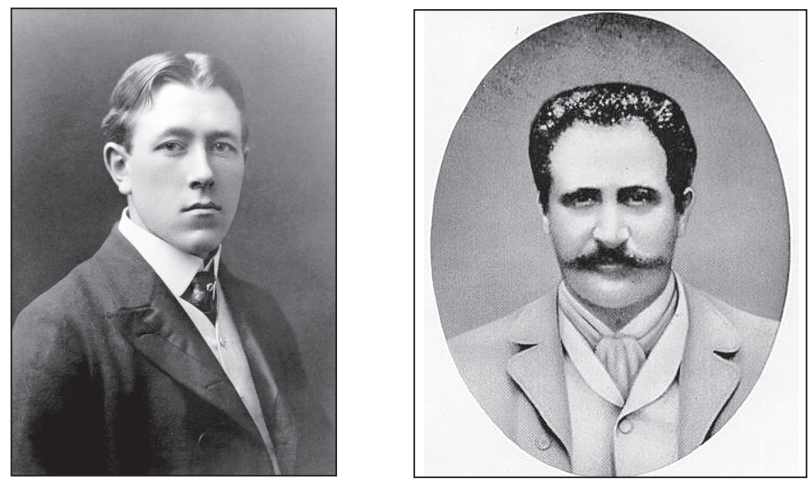

Рис. 110. Альфред Айнхорн (1856-1917), немецкий химик.

Синтезировал прокаин (новокаин). Основные работы посвящены исследованию связи между строением и физиологическим действием органических веществ, вызывающих анестезию, а также химии алкалоидов (кокаин, экгонин, тропидин и др.) 


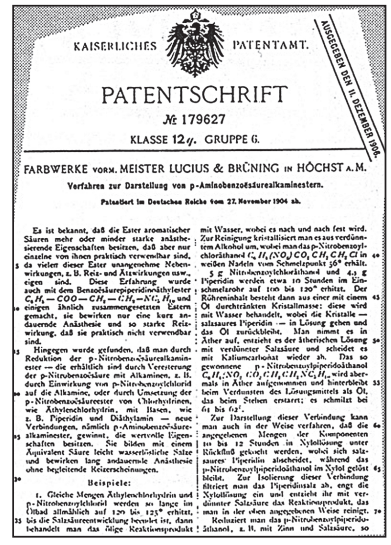

Рис. 111. Патент Айнхорна

на прокаин (Goerig M., 1995)

Много лет Айнхорн и его команда неустанно работали. На пути к открытию прокаина они нашли анестезирующие средства типа ортоформ, нео-ортоформ и нирванин, которые были полезны как поверхностные местные анестетики, но не отвечали всем четырём основным требованиям. Трудно оценить, по какому пути пошло бы развитие местной анестезии, если бы синтезированный А. Айнгорном и М. Оппенхаймером (M. Oppenheimer) в Хёхст в 1900 г. нирванин (nirvanin) - местный анестетик амидного типа - был бы безболезненным при инъекции. Нирванин же вызывал сильную боль во время введения, поэтому был невостребован.

Было обнаружено, что некоторые сложные эфиры аминобензойной кислоты, соли которых водорастворимы, не могли заменить кокаин из-за выраженной токсичности. Поэтому Айнхорн предложил другой подход, состоящий из введения основных групп в формулу. Это был решающий шаг, который обеспечил хирургию и стоматологию долгожданным местным анестетиком, был «одним из наиболее важных орудий в их борьбе против операционной боли». (Hadda S.E., 1962).

Трудно указать точную дату открытия Айнхорном новокаина. Вероятно, ему удалось синтезировать прокаин в 1904 г., не публикуя при этом никакого сообщения. 27 ноября 1904 г. завод химических красителей «Хёхст» на Майне выдал Айнхорну патент (DRP № 179627) на способ изображения p-Aminobenzoaesaeurealkaminesthern » (рис. 111). Один из этих химических составов (гидрохлорид пара-амино-бензоил-диэтиламиноэтанола) получил название прокаин.

Ниже приводим перевод первой страницы этого патента.

Заводы красителей в Хёхсте на Майне, руководимые Майстером, Луциусом и Брюнингом.

\section{Способы получения эфиров алкамина} пара-аминобензойной кислоть

Патент Немецкого государства от 27 ноября 1904 г. Выдан 11 декабря 1906 г.

Известно, что сложные эфиры ароматических кислот обладают более или менее сильными обезболивающими свойствами, однако только отдель- 
ные из них применимы в практике, так как многие обладают нежелательным побочным действием, например, раздражающим, прижигающим и т.д. Этот опыт проводился также с этиловым эфиром бензокислого пиперидина $\mathrm{C}_{6} \mathrm{H}_{3}-\mathrm{COO}-\mathrm{CH}_{2}-\mathrm{CH}_{2}-\mathrm{NC}_{2}-\mathrm{H}_{10}$ и несколькими другими сложными эфирами. Они вызывали только кратковременную анестезию и сильное раздражающее действие, из-за чего их практически не применяли.

Напротив, нашли, что получаются новые соединения эфиров алкамина пара-аминобензойной кислоты путём восстановления пара-нитробензоилхлорида на алкамины, или при превращении пара-нитробензокислого эфира из хлоргидрина, к примеру, пиперидин и диэтиламин, которые обладают ценными свойствами. Они образуют с эквивалентом кислоты хорошо растворимую в воде соль и вызывают длительную анестезию без сопровождающих симптомов раздражения.

\section{Примерь.}

Равные количества этиленхлоргидрина и пара-нитробензоил-хлорида медленно на масляной бане разогревают до $120-125^{\circ} \mathrm{C}$ до окончания образования хлористоводородной (соляной) кислоты, затем этот масляный продукт реакции взаимодействует с водой, изменяется и твердеет. Для очищения его кристаллизуют из разбавленного спирта, причём паранитробензоилхлорэтанол $\mathrm{C}_{5} \mathrm{H}_{3}\left(\mathrm{NO}_{2}\right) \mathrm{CO}_{2} \mathrm{CH}_{2}-\mathrm{CH}_{2} \mathrm{Cl}$ получают именно при температуре плавления $56^{\circ} \mathrm{C}$.

5 г нитробензоилхлорэтанола и 4,3 г пиперидина превращаются приблизительно в течение 10 часов в расплавленное состояние при нагревании до 100$120^{\circ} \mathrm{C}$. Сырой продукт состоит из кристаллической массы, причём кристаллы пропитаны маслом. При реакции с водой кристаллы солянокислого пиперидина переходят в раствор, и масло отделяется. Эфирный раствор с разбавленной хлористоводородной кислотой снова обрабатывается карбонатом калия. Так полученный пара-нитробензоилпиперидоэтанол $\mathrm{C}_{8} \mathrm{H}_{4}\left(\mathrm{NO}_{2} \mathrm{CO}_{2} \mathrm{CH}_{2} \mathrm{CH}_{2} \mathrm{NC}_{3} \mathrm{H}_{18}\right.$ вторично превращается в эфир и становится при испарении раствора в виде масла, как бы застывая, плавится около $61-62^{\circ} \mathrm{C}$.

К изображению этой связи можно приступать также таким образом, что указанные количества компонентов в течение 10-12 часов варятся в растворе ксилола с обратным холодильником, при этом отделяется солянокислый пиперидин, в то время как пара-нитробензоилпиперидоэтанол остаётся в растворе ксилола. Для выделения этого соединения деэтерифицируют соль пиперидина, плотно связанную в растворе ксилола, путём очистки выше описанным способом.

Восстанавливают пара-нитробензоилпиперидоэтанол, например, цинком в присутствии хлористоводородной кислоты так...» 


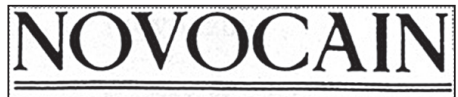

ein neues, vollkommen reizlos wirkendes Lokalanästhetikum.

NOVOCAIN ist bei gleich starkem anisthesierendem wie Koksin und $23 \mathrm{mal}$ weniger giftig wie dessen Erstzpedparate.

NOVOCAIN becinflusst. in nomulen die Zirkulation noch dic Respiration: die Herztatigkeit bleibt intakt. NOVOCAIN aul die Pupillenweite oder die peripheren Gelisse uns. NOVOCAIN

is !eicht wasser!óslich. Scine Lossungen reagieren noutral. werden rut resorbiert und sind durch Kochen sterilisierbar.

Рис. 112. Первый рекламный проспект о новокаине. (Из коллекции M. Goerig, предоставлена H. Wilms.)

Второй патент (DRP № 180291) Айнхорн получил в соавторстве с Эмилем Ульфельдером (Столяренко П.Ю., 2003).

Таким образом, после 20 лет безуспешных исследований учёных мира по созданию эффективного, не обладающего раздражающим действием заменителя кокаина, и 13 лет своей работы по синтезу различных химических соединений, Альфред Айнхорн и его коллеги (Эмиль Ульфельдер и др.) нашли решение проблемы и создали прокаина гидрохлорид (с января 1906 г. он стал выпускаться фирмой «Хёхст» на мировой фармацевтический рынок под торговым наименованием «новокаин»: с латинского - новый кокаин; несмотря на такое название новокаин не имеет
никакой связи с кокаином - рис. 112). Айнхорн писал: «Эрнст Фурно обнаружил в 1904 2. успешную замену кокаину, называемую стоваин. Но я улучшил это и получил в 1905 г. новый заменитель кокаина. Я хотел дать моему открьтию торговое название «новокаин», то есть новый кокаин.»

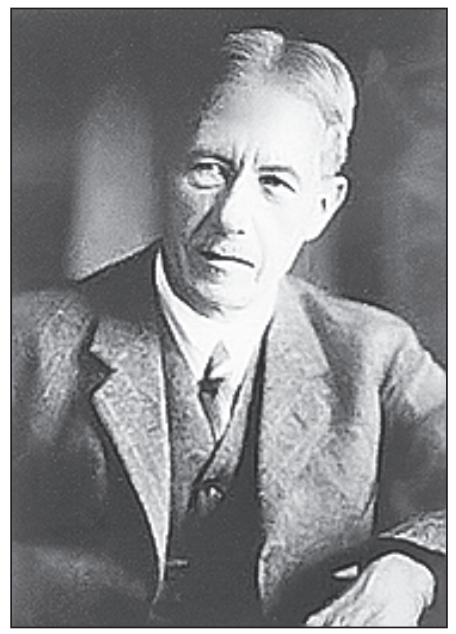

Рис. 113. Генрих Браун (1862-1934). Выдающийся немецкий хирург.

Первым в клинических условиях применил сочетание адреналина с местным анестетиком, разработал технику проводниковой анестезии в хирургии и стоматологии, ввёл в клиническую практику новокаин 

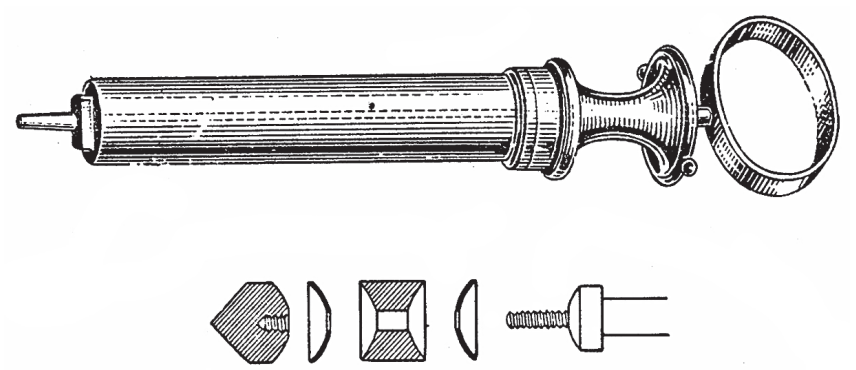

Рис. 114. Металлический шприц Брауна. (Ил. по С.С. Гирголав, 1936.)

С января 1906 г. новокаин стал производиться фармацевтической фирмой «Хёхст» (Германия).

Большое значение имело предложение хирурга из Лейпцига Генриха Брауна (Heinrich Braun - рис. 113, 114) использовать адреналин при местной анестезии: добавлять его в раствор кокаина. Браун случайно прочитал в 1901 г. в американском журнале сообщения Дж. Такамине и Т.Б. Олдрича об успешном извлечении этого гормона из надпочечников животных ${ }^{2}$. Благодаря описанию его свойств Браун сразу понял значение этого вещества для инфильтрационной анестезии. Вместе с Э. Майером (Е. Mayer) в 1901 г. он предложил сочетать адреналин с местным анестетиком, сравнивая его с «химическим турникетом» (жгутом), уменьшающим скорость всасывания кокаина и пролонгирующим анестезию. В 1902 г. Генрих Браун ввёл в клиническую практику при местном проводниковом обезболивании добавление адреналина к растворам кокаина. Он показал, что это средство наделяет анестезирующие растворы исключительными и ценными свойствами. Во-первых, адреналин значительно усиливает анестезирующее действие кокаина. Во-вторых, он увеличивает продолжительность обезболивания. В-третьих, при его добавлении значительно понижается опасность общей интоксикации кокаином, поскольку замедленное всасывание раствора страхует от слишком большого поступления алкалоида в кровь. Наконец, сосудосуживающее действие адреналина создаёт анемию в области операционного поля, что уменьшает кровотечение при операции и улучшает условия осмотра операционного поля. Все эти свойства адреналина оказались настолько ценными, что и по настоящее время непременным требованием для всякого нового местного анестетика ставится условие возможности его сочетания в растворе с адреналином.

${ }^{2}$ Более подробно история открытия и исследования адреналина освещена в работе П.Ю. Столяренко «История адреналина» (Самара, 2003). 
Первое в России сообщение о применении кокаина с адреналином в общей хирургии принадлежит Н.Н. Соханскому (1903), а в зубоврачебной хирургии П.И. Таубкину (1903).

Для местной анестезии в хирургии стали использовать таблетки кокаина с адреналином в большинстве случаев английского производства. Между тем профессор Генрих Браун в 1904 г. стал сотрудничать с «Заводами красителей Хёхст».

Как раз в это время химикам «Хёхст» докторам Фридриху Штольцу (Friedrich Stolz, рис. 115) и Францу Флэхеру (Franz Flaecher - рис. 116) после нескольких лет работы в научно-исследовательских лабораториях этого предприятия удалось завершить синтез адреналина, получаемого до того времени из надпочечников животных. Это был первый синтетически созданный гормон вообще (Stolz F., 1904). Дериват бренцкатехина со структурной формулой

$$
\mathrm{C}_{9} \mathrm{H}_{13} \mathrm{NO}_{3} \text {, }
$$

\section{O-Dioxyphenyl-Aethanol-Methylamin.}

После того как Г. Браун показал огромное значение добавления препаратов надпочечника в растворы, применяемые для местной инъекционной анестезии, A. Doenitz (1903) провёл опыты на животных, испытывая их действие при введении в подпаутинное пространство. Экспериментальные данные свидетельствовали о том, что добавление адреналина к раствору кокаина уменьшает токсичность последнего в три раза; если же адреналин ввести предварительно, то токсичность кокаина становится в пять раз меньше. Клинические испытания в клинике Августа Бира в 1904 г. у 109 пациентов дали такие хорошие результаты, что Бир сразу изменил своё весьма осторожное мнение о спинальной анестезии.

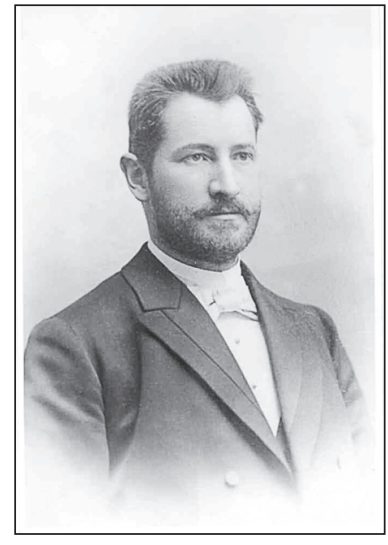

Рис. 115. Фридрих Штольц (1860-1936)

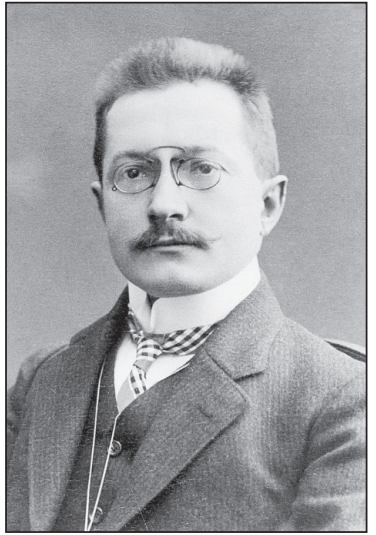

Рис. 116. Франц Флэхер (1876-1938) 
В 1905 г. хирург Генрих Браун, по результатам использования новокаина с 1904 г., опубликовав в Немецком Медицинском Еженедельнике статью «О некоторых новых местных анестетиках (стоваин, алипин, новокаин)», ввёл новокаин в медицину. После 20 -летнего применения кокаина открытие новокаина стало первым существенным успехом, обеспечившим широкое использование местной анестезии при многих медицинских, хирургических и стоматологических вмешательствах.

Увеличение продолжительности анестезии с добавлением к анестетику адреналина подтвердил и Август Гильдебрандт из клиники Бира (Hildebrandt A., 1905). А. Бир в 1909 г. на основании своих клинических наблюдений сохранил свою преданность адреналину, считая его «противоядием тропакокаина» (Юдин С.С., 1960).

После открытия А. Айнгорном новокаина и предложения Г. Брауна применять его в хирургической практике (1905), добавляя к анестетику небольшие дозы адреналина, началась новая эра в развитии местного обезболивания. Новокаин был во много раз менее токсичен, не вызывал лекарственной зависимости. Хирурги с полным успехом, без всяких побочных действий стали применять до 300-400 мл 1-2\% раствора новокаина с добавлением 5 капель адреналина (Sol. Adrenalini 1:1000) на 100 мл анестезирующего раствора. С введением в клиническую практику новокаина стали быстро развиваться различные способы местного обезболивания: инфильтрационная, проводниковая, спинномозговая и другие анестезии. В странах Европы новокаин быстро стал вытеснять кокаин. В США популяризировал его Гвидо Фишер (Guido Fischer), но замена кокаина на новокаин серьёзно началась лишь в 1927 г. благодаря фирме Cook White, которая добровольно обучала зубных врачей проводниковым анестезиям.

В России новокаин быстро получил широкое распространение и уже в 1907-1908 гг. в значительной степени вытеснил кокаин и другие анестезирующие препараты. В 1907 г. новокаин был глубоко изучен А.Е. Поповым. Но дальнейшее распространение местного обезболивания встречало решительное противодействие части хирургов - приверженцев наркоза и метода спинномозговой анестезии. Основным возражением против местного обезболивания по-прежнему оставался упрёк в психической травме больного. Особенно остро эта борьба развернулась на VII съезде российских хирургов (1907 г.), где программный доклад был о спинномозговой анестезии.

Крупным событием в развитии местного обезболивания в России за весь период применения новокаина нужно считать доклад И.К. Спижарного о местной анестезии на VIII съезде российских хирургов в Москве (1922 декабря 1908 г.). Он сообщил о весьма благоприятных результатах опе- 
раций под местным обезболиванием 0,5\% раствором новокаина у 383 больных. В прениях А.В. Воскресенский (Одесса) рассказал о 800 операциях под местным обезболиванием стоваином, Л.А. Дивавин (Москва), основываясь на опыте 200 операций под новокаин-адреналиновой анестезией, рекомендовал её. О широком применении местного обезболивания в своей практике сообщили Р.Р. Вреден, В.М. Минх, К.П. Сапожков и Н.М. Волкович.

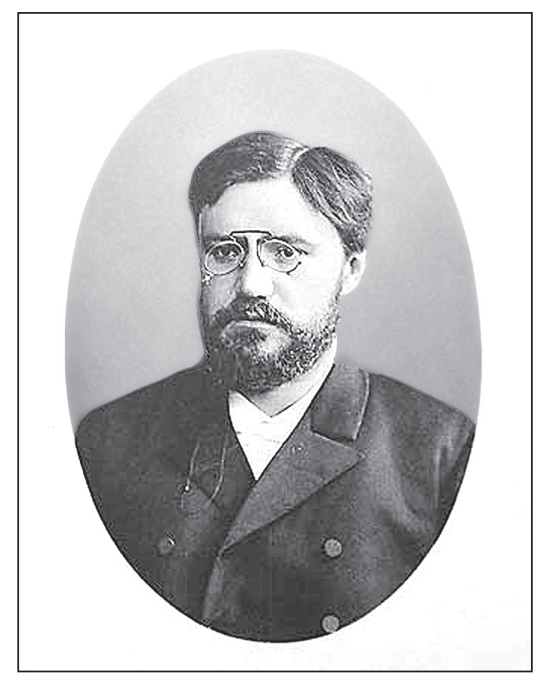

Рис. 117. Иван Константинович Спижарный (1857-1924).

Один из основоположников местного обезболивания в хирургии брюшной полости. Выдающийся отечественный хирург. В 1884 г. окончил медицинский факультет Московского университета и был оставлен сначала ординатором, а затем ассистентом при факультетской хирургической клинике. В 1890 г. защитил докторскую диссертацию «К учению о хирургии головного мозга и о процессе заживления ран этого органа». С 1891 г. - приват-доцент, с 1893 г. - экстра-ординарный, а с 1899 по 1906 гг. - ординарный профессор кафедры хирургической патологии. В 1906 г. возглавил факультетскую хирургическую клинику Московского университета. Им написано более 60 научный работ, в том числе, монографии о повреждениях и хирургических заболеваниях почек, о заболевании суставов при сирингомиелии, о злокачественных лимфомах, хирургии нервных стволов. Автор работ: «Повреждения и хирургические заболевания почек» (1905 г.), «Лечение хирургического туберкулеза» (1923 г.)

Впервые на съезде хирургов ставился программный вопрос о местном обезболивании, что, естественно, должно было привлечь внимание врачей к этой проблеме. Доклад И.К. Спижарного отразил успехи местного обезболи- 
вания, достигнутые не только в его клинике, но и в других лечебных учреждениях России. Касаясь работы самого И.К. Спижарного (рис. 117), следует указать, что он был последовательным приверженцем идеи местного обезболивания и являлся одним из основоположников его в хирургии брюшной полости. Продолжая учение Р.Р. Вредена о местной анестезии при полостных операциях, он развил его и превзошёл опыт самых известных немецких хирургов, применявших подобную методику. В начале 1909 г. И.К. Спижарный опубликовал свою работу «О местном обезболивании». Она явилась дополнением к докладу на VIII съезде российских хирургов. Так же, как и Р.P. Вреден, он считал очень важным предварительное введение перед операцией морфина и отвергал необходимость добавления адреналина к растворам новокаина. И.К. Спижарный далеко опережал Г. Брауна в отношении количества и объёма операций, производимых под местным обезболиванием. По статистике, опубликованной Ф. Гессе, наибольший процент проведения операций под местным обезболиванием в самых передовых в этом отношении немецких клиниках в 1908 г. не превышал 27. Согласно же материалам И.К. Спижарного, сообщённым на VIII съезде российских хирургов, под местным обезболиванием выполнено около 50\% операций. Цифры свидетельствуют, что даже в производстве больших операций И.К. Спижарный почти в 2 раза больше применял местное обезболивание, чем немецкие хирурги.

В 1912 г. вышло краткое руководство А.Ф. Бердяева под заглавием «Местная анестезия», которое имело большое практическое значение для хирургов, так как содержало ценные указания по применению этого метода. В эпиграфе к своей книге он пишет: «Где достижимо местное обезболивание, там недопустимо обезболивание общее». Но работа не лишена была и серьёзных недостатков. Автор игнорировал достижения русских учёных, работавших по местному обезболиванию, и показал это учение как полностью заимствованное за границей. Трудно себе представить, чтобы А.Ф. Бердяев, будучи современником Р.Р. Вредена и И.К. Спижарного, не был знаком с их работами. Но такова уж была эпоха - «истинная наука» находилась за пределами России. Неудивительно поэтому, что краткое руководство А.Ф. Бердяева представляло собой в значительной степени сжатый конспект книги немецкого хирурга Г. Брауна «Местная анестезия, её научное обоснование и практическое применение», вышедшей на русском языке в 1909 г. Все иллюстрации позаимствованы из той же книги. В предисловии А.Ф. Бердяев делает необоснованный вывод о быстром вытеснении общего обезболивания местным. Он пишет: «Кто знает, может быть, общее обезболивание станет в недалеком будущем только ненужным пережитком «доброго старого времени». 


\section{PETIOHAPHAG}

АНЭСТЕЗІЯ.

ДОКтоРА МЕДицины

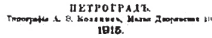

Рис. 118. Титульный лист монографии В.Ф. ВойноЯсенецкого
B.. . Rsenesuxla. ВoAнO.

Наряду с местной инфильтрационной анестезией совершенствовались способы проводникового обезболивания. В 1915 году В.Ф. Войно-Ясенецкий издал в Петрограде книгу «Регионарная анестезия» с собственными иллюстрациями. В 1916 году защитил её как диссертацию и получил степень доктора медицины. Эта работа сыграла большую роль в разработке и пропаганде регионарной анестезии. В ней автор обобщил многолетний опыт по применению этого вида местного обезболивания (рис. 118). Он с увлечением писал в своей книге: «Я не ошибусь, если назову регионарную анестезию наиболее совершенным методом местной анестезии». В своей работе он отразил не только возможности регионарного обезболивания и его перспективы для хирургов того времени, но и особо подчеркнул важность этой проблемы для хирургов на периферии. «Вероятно, каждому земскому хирургу, как и мне, - писал В.Ф. Войно-Ясенецкий, - неоднократно приходилось оставлять работу в брюшной полости, чтобы раздвинуть челюсти больному или вытянуть запавший язык. Такой наркоз заменить безопасной регионарной анестезией в высшей степени возможно, ибо он часто несравненно опаснее самой операции». Автор считал уместным сочетание местного обезболивания с инъекциями морфина или, в крайнем случае, лёгким эфирным опьянением, что в значительной степени понижает психическую травму больного во время операции.

Проверяя эффективность различных способов регионарного обезболивания, Войно-Ясенецкий критиковал метод внутриглазничного обезболивания тройничного нерва Брауна, а также его метод обезболивания решётчатых нервов. Подобной критике он подверг способ Гертеля для обезболивания верхнечелюстного нерва. В отличие от Брауна, рекомендовавшего проводить иглу к месту прохождения нерва без анестезии мягких тканей, Войно-Ясенецкий производил последовательную анестезию всех мягких тканей, вплоть до места прохождения нерва (рис. 119).

Во всех работах В.Ф. Войно-Ясенецкого подкупает математическая точность его исследований, наглядность доказательства благодаря хорошим анатомическим иллюстрациям, простота и ясность выражения мысли. Являясь активным сторонником регионарного обезболивания, автор вместе с тем ни в коей мере не скрывал его недостатков. Основным недостатком он считал не всегда наступающую анестезию. 

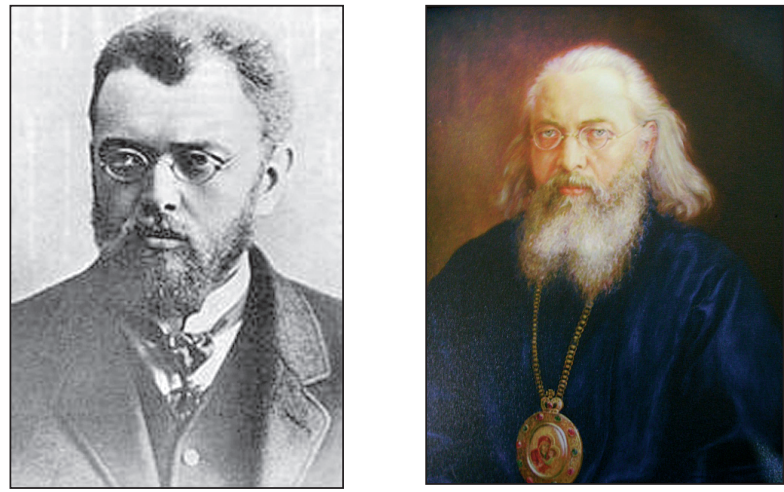

Рис. 119. Валентин Феликсович Войно-Ясенецкий

(Архиепископ Крымский и Симферопольский Лука, 1877-1961).

В мирской жизни - профессор, доктор медицинских наук. Разносторонний хирург.

Подробно разработал вопросы регионарной анестезии. За книгу «Регионарная анестезия» (1915) Варшавский университет присудил ему премию им. А.Ф. Хайнацкого, признав, таким образом, его основателем нового направления в науке. В 1916 г. получил степень доктора медицины. Автор монографии «Очерки гнойной хирургии», которая вышла в 1937 году и переиздавалась черыте раза. В его судьбе отразились все бури прошедшего столетия - революция, гражданская война, мировые войны, тоталитарный режим, Гулаг. В 1995 г. был причислен к лику святых.

Святой архиепископ Лука - заступник униженных и обездоленных, помощник всех хирургов в их праведном деле

Значение книги В.Ф. Войно-Ясенецкого для русской хирургии велико. Этот фундаментальный труд не только знакомил с существом регионарного обезболивания, но и давал правильную критическую оценку существовавших методов. Для практического хирурга книга являлась руководством к действию и давала подробный разбор регионарных методов обезболивания, в том числе и в челюстно-лицевой области, со всеми их положительными и отрицательными сторонами.

Начавшаяся первая мировая война (1914-1918) значительно сократила возможности местного обезболивания по многим причинам. Основная масса хирургов мирного времени ушла на фронт или была призвана лечить раненых в тыловых госпиталях. На фронтовых хирургических пунктах местное обезболивание почти не применялось, да и в тыловых госпиталях оно было не в ходу. Это было связано не только с условиями хирургической деятельности и изменившимся профилем хирургических больных в военное время, когда приходилось иметь дело, как правило, 
с инфицированными ранами, но и с тем, что новокаин и другие местные анестетики стали сразу же дефицитными. До войны в основном эти препараты в Россию привозились из Германии, а своя химическая промышленность их не производила.

Встал вопрос о замене остродефицитного и дорогого новокаина более доступными анестетиками. Ещё до начала войны, в феврале 1914 г., появились статьи русских хирургов, в которых предлагалось использовать новое химическое вещество в качестве местно-анестезирующего. Этим веществом была солянокислая соль хинина и мочевины. До войны его предлагали как заменитель новокаина вследствие большой длительности обезболивающего действия. Во время войны оно оказалось почти единственным доступным анестезирующим препаратом. Обезболиванию мочекислой солью хинина посвящено много работ военного времени (Гарнак Г.А., 1914; Власов Я.П., 1914; Иванов В.М., 1915; Потеенко В.В., 1916 и др.).

Г.А. Гарнак первый в России опубликовал свою работу об обезболивающем действии этого вещества при хирургических операциях. Одно из преимуществ этого раствора - отсутствие послеоперационных болей. На этом основании автор допускал возможность введения раствора в область операционной раны, произведённой под наркозом, для уменьшения послеоперационных болей. Ещё одно обстоятельство привлекало внимание хирургов. Благодаря бактерицидности хинина можно было рассчитывать, что этот раствор будет благотворно влиять на лечение гнойных ран.

Но уже в 1916 г. мочекислый хинин был осуждён как препарат, обладающий местно-токсическим действием, способным вызвать некроз кожи. На заседании общества русских хирургов в Москве Н.М. Крон сообщил о случае омертвения кожи на месте впрыскивания этого препарата. Испытав его на себе, Н.М. Крон получил на 3-й день после инъекции некроз кожи

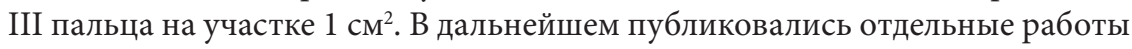
о применении мочекислого хинина в хирургической практике, но общего признания и распространения этот препарат не получил, и интерес к нему постепенно пропал.

Накопившийся опыт после открытий кокаина, адреналина и новокаина стал анализироваться в первые десятилетия XX века. Среди теоретиков обезболивания в стоматологии следует отметить французского исследователя D. Nogué и немецкого G. Fischer. Nogué обосновал и классифицировал различные виды инфильтрационной анестезии зубов: внутрислизистую, подслизистую параапикальную, поднадкостничную параапикальную, диплоэтическую и дистальную. Главное внимание он уделял кокаину, диплоэтической (спонгиозной) анестезии и недооценивал проводниковые инъек- 
ции. Fischer рассматривал дентальное обезболивание в отличие от Nogué с позиций другого местного анестетика - новокаина и поэтому энергично пропагандировал блокаду нижнелуночкового нерва, почти современный её вариант (рис. 120, 121). В начале века он выступал с лекциями в Москве, Петербурге и в городах США. Публикации Г. Фишера по научным основам, методам местной анестезии в полости рта и её осложнениям помещены в материалах I и II Одонтологических съездов $(1924,1926)$. Его основной труд «Die Lokale Anaesthesie in der Zahnheilkunde» с 1909 по 1955 г. переиздавался 10 раз на разных языках и остаётся классическим руководством для стоматологов всего мира.

В 20-30-х годах отчётливо проявилось различие в подходе к анестезиологическому обеспечению операций отечественных и многих зарубежных хирургов. В то время как у нас местное инфильтрационное обезболивание стало преобладающим методом, хирурги Западной Европы и США при операции среднего и большого объёма отдавали предпочтение общей анестезии, для проведения которой привлекался специально подготовленный медицинский персонал. Эти особенности в подходе к выбору анестезии сохранялись и во время второй мировой войны (Трещинский А.И. и соавт., 1973; Уваров Б.С., 1997).

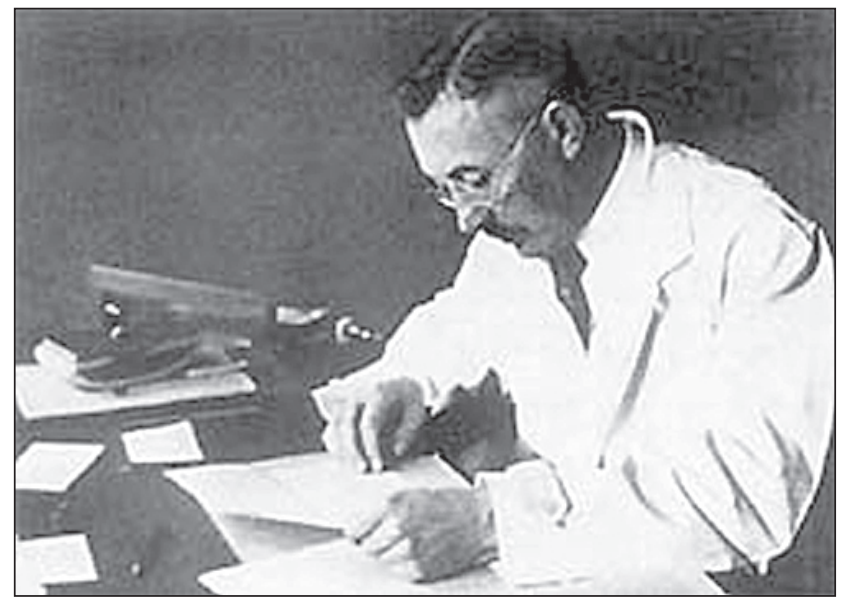

Pис. 120. Guido Fischer, 1877-1959. Директор дентального университета, профессор кафедры. Автор учебника «Местная анестезия в зубоврачевании» (1909). Внедрил применение новокаина

в зубоврачебную практику, сконструировал специальный дентальный шприц (1910), предложил способ мандибулярной анестезии (1911), снял первый в истории зубоврачевания учебный фильм о местной анестезии и хирургии полости рта (1914) 


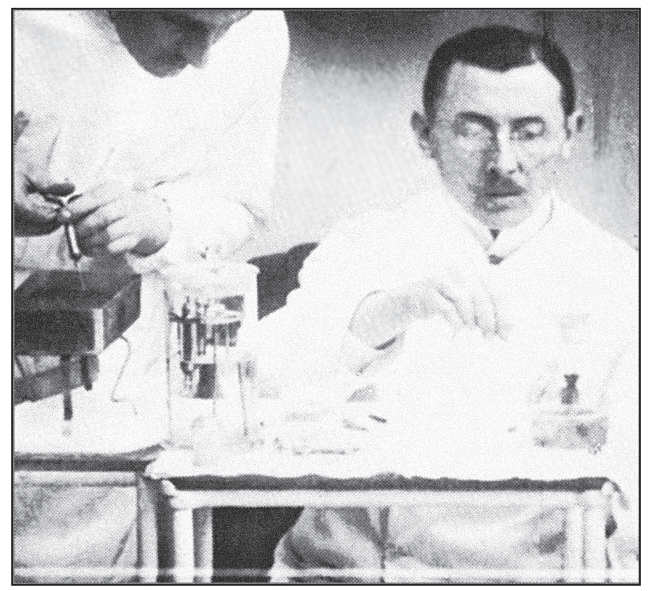

Рис. 121. Фишер при демонстрации своего метода - кадр из фильма.

(Ил. по W. Hoffmann-Axthelm, 1985.)

Чтобы избежать опасностей и осложнений, связанных с наркозом, А.В. Вишневский (рис. 122) приступил в 1922 г. к разработке нового метода местного обезболивания с «твёрдым намерением», как он писал, «найти способ, во что бы то ни стало избавиться от необходимости пользоваться общим наркозом», дававшим тяжёлые, смертельные осложнения. Критически оценивая существующие в то время методы местного обезболивания, выявляя в своей повседневной хирургической деятельности их недостатки, А.В. Вишневский поставил перед собой грандиозную задачу - разработать на основе инфильтрационной анестезии такой метод местного обезболивания, который позволил бы хирургу безболезненно оперировать на любых тканях и в любых полостях человеческого тела. При обычной принятой в то время методике инфильтрационной анестезии обезболивающий эффект наступал лишь после диффузии введённого раствора анестетика, что требовало от хирурга выжидания перед нанесением разреза. Кроме того, для лучшего обезболивающего эффекта хирурги применяли обычно концентрированные растворы, нередко токсичные. Однако и выжидание, и использование высококонцентрированных растворов анестетика не избавляли от болевых ощущений из-за травмирования перфорирующих ветвей глубже лежащих нервных стволов.

Все эти недостатки местной инфильтрационной анестезии препятствовали её применению в большой хирургии. Для преодоления перечисленных недостатков А.В. Вишневский разработал метод инфильтрационной анесте- 
зии, обеспечивающий прямой контакт анестезирующего вещества с нервом, - метод тугой инфильтрации тканей.

Таким образом, А.В. Вишневский создал свой метод местного обезболивания, основанный на оригинальном принципе продвижения нагнетаемого под давлением анестезирующего раствора по анатомическим футлярам и фасциальным щелям человеческого организма, открытом ещё Н.И. Пироговым. Этот метод был назван А.В. Вишневским по предложению его сына А.А. Вишневского методом ползучего инфильтрата (Кузин М.И., Харнас С.Ш., 1993). Для преодоления опасности интоксикации при введении больших доз анестезирующего раствора он предложил введение слабого 0,25\% раствора новокаина, не вызывающего токсических явлений. Пять изданий книги А.В. Вишневского по местному обезболиванию $(1932,1938,1942,1951,1956)$ стали библиографической редкостью (рис. 123).

Основные достоинства метода А.В. Вишневского: во-первых, быстрое начало действия на

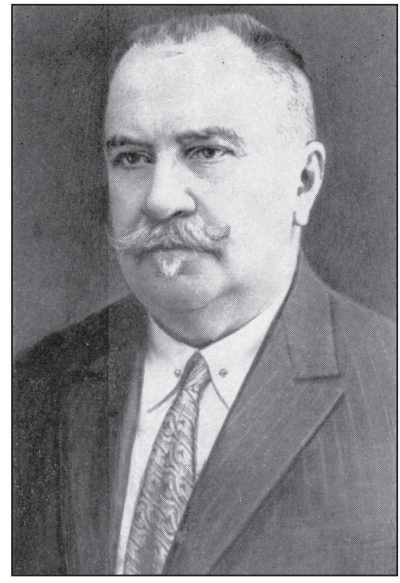

Рис. 122. Александр Васильевич Вишневский (1874-1948). Первый директор Института хирургии АМН СССР. Основоположник местной анестезии по методу тугого ползучего инфильтрата нервные окончания и стволы, что позволяет проводить рассечение тканей немедленно, без выжидания; во-вторых, послойная анестезия проводится на глаз «из малейшего участка обнажённой поверхности его», и, наконец, тугой ползучий инфильтрат, выполняя функцию гидравлической препаровки, значительно облегчает разъединение тканей и органов (Жоров И.С., 1951), имеющийся при инфильтрации элемент проводниковой анестезии используется как самостоятельный метод в виде широко известных новокаиновых блокад (Уваров Б.С., 1997). Но необоснованное расширение показаний многими хирургами, недостаточно бережное отношение к психике больного и нередко пренебрежение его страданиями при плохо проведённом местном обезболивании вызвали законные протесты со стороны немногих старых и опытных хирургов, сторонников наркоза.

Первый голос, прозвучавший в защиту адекватного обезболивания при операциях, принадлежал Я.О. Гальперну (1933), который в статье, напечатанной в журнале «Врачебное дело», выступил с критикой недостатков местного обезболивания (рис. 124). Его статья так и называлась - «В защиту обезболивания». Именно обезболивания, а не наркоза. Указывая на бесспорные заслуги местной анестезии, автор считал, что часто в клиниках этот метод проводится недоста- 


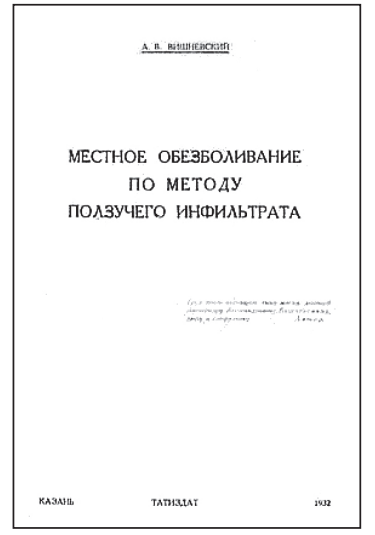

Рис. 123. Титульный лист первого издания монографии

А.В. Вишневского. Казань, 1932

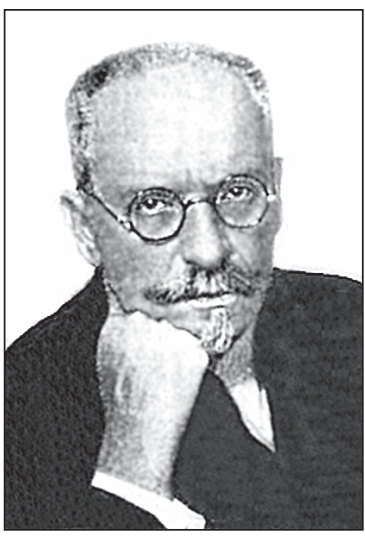

Рис. 124. Яков Осипович

Гальперн (1876-1941), известный хирург из клиники С.И. Спасокукоцкого точно, и полного обезболивания при нём нет. «В отчётах хирургических учреждений,- пишет Я.О. Гальперн, - где местная анестезия является методом выбора, никогда не указывается, сколько операций прошло совершенно безболезненно и сколько доведено до благополучного конца путём уговоров, ласковых «потерпите» или менее ласковых, с применением энергичных, но не парламентских выражений. В любой клинике можно убедиться, что стонущий во время операции больной - обычное явление». Далее Я.О. Гальперн резко критикует местную анестезию, проводимую за границей: «За границей приходилось наблюдать, как специально приставленный ассистент не только словесно, но и соответственными телодвижениями работает над больным, дабы обеспечить полное спокойствие оперирующему под местной анестезией шефу клиники».

Стремление автора не опорочить местное обезболивание как метод, но только ограничить его применение, звучит в следующей фразе: «...Было бы неправильно видеть в этих замечаниях попытку дискредитировать местную анестезию. В моей клинике не менее $50 \%$ операций проводятся под местной анестезией. Моя цель значительно скромнее - поднять голос в защиту полной безболезненности операций и, следовательно, необходимости ввести местную анестезию в известные границы, ввиду тенденции сделать её универсальным методом». Я.О. Гальперн высказывает сомнение в возможности производства под местной анестезией 98\% всех операций, которые проводит А.В. Вишневский в своей клинике. Гальперн считает, что следует различать операции под местной анестезией и местной гипестезией. Он резко критикует стремление заменить новокаин различными растворами, что совершенно не удовлетворяет элементарным требованиям обезболивания, и считает, что хирурги в своей нетребовательности к достаточному обезболиванию скатываются к прошлому столетию, к эпохе Вельпо, когда операция без боли считалась химерой. Одновременно с этим Гальперн критикует врачей, приносящих страдания больным и во время перевязок. 
В заключение автор как бы примиряет противоположные взгляды на обезболивание. «В настоящее время имеет право на существование, - пишет он, - и местная анестезия, и общий наркоз по выбору или в комбинации, но при неуклонном стремлении к полной безболезненности. От твёрдо поставленной цели - операция без боли - отступления не должно быть».

Подобная критика недостатков местного обезболивания была справедлива в полной мере и, конечно, нацеливала врачей на более вдумчивый и серьёзный подход к этому благодатному методу. Правильно осуждался «дух изобретательства» в области средств местного обезболивания, а также излишняя «твёрдость» хирургов при страданиях больных из-за неадекватного обезболивания. Но вместе с тем, как отмечает А.А. Зыков, эта критика скорее показывала завоевание идей местного обезболивания, чем его слабости, так как все эти недостатки были рождены поистине громадными масштабами местной анестезии в практической жизни хирургов. Действительно, некоторые из хирургов, неправильно восприняв методику, вульгаризировали местное обезболивание, но зато большая часть хирургов, правильно применявших местную анестезию, получила широкие возможности для своей оперативной деятельности. Да и сам факт исканий новых средств был отражением временных трудностей. После ликвидации нехватки новокаина все искания заменителей тотчас же отпали сами собой.

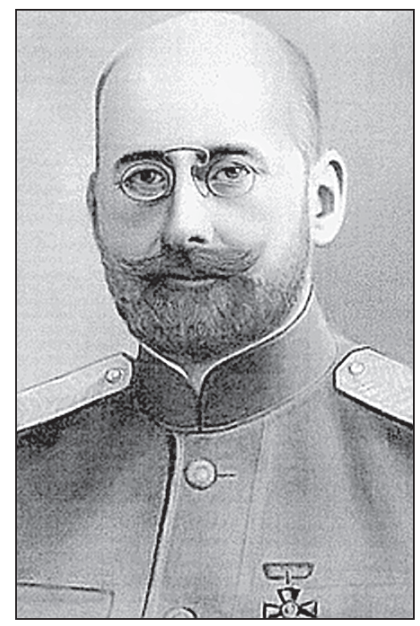

Рис. 125. Сергей Петрович Федоров (1869-1936). Выдающийся русский хирург.

Работал в хирургических клиниках Московского университета и Петербургской ВМА.

Под его руководством впервые был применён в клинике внутривенный гедоналовый наркоз и произведено первое в СССР переливание крови с учётом изоагглютинационных свойств крови донора и больного 


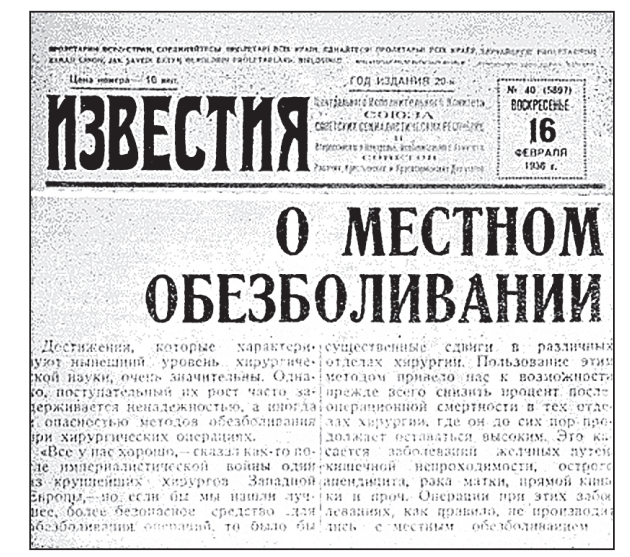

Рис. 126. Статья А.В. Вишневского, «Известия», 1936, № 40

В 1934 г. против местного обезболивания выступил С.П. Федоров (рис. 125). Его статья стала предметом широкого обсуждения в хирургических кругах. Сам заголовок - «Несколько мыслей о наркозе и местной анестезии» - отражал и содержание этой статьи. Действительно, это не была сравнительная статистика или доводы, подкреплённые каким-нибудь цифровым материалом. Статья отражала взгляд одного из крупнейших клиницистов нашей страны на обезболивание при операциях, а так как С.П. Федоров был сторонником наркоза, то, естественно, весь удар критики обрушивался на местную анестезию. «Каждый больной, которому приходится подвергаться операции, имеет право требовать от современного хирурга, чтобы он дал возможность, во-первых, не знать ни дня, ни часа производства операции, во-вторых, не видеть ни операции, ни приготовления к ней, в-третьих, обеспечения полного отсутствия боли при операции и вообе ощущений с ней связанных, а после операции полного забвения о ней».

И всё же подтверждением всеобщего признания местной анестезии у хирургов нашей страны в то время является статья А.В. Вишневского в газете «Известия», 1936 г., № 40 (рис. 126), в которой автор в популярной форме знакомит широкие круги читателей с основами своего учения.

В стоматологии впервые в Советском Союзе всесторонне и углубленно разрабатывал рациональные методы местного обезболивания С.Н. Вайсблат (рис. 127). Этому вопросу он посвятил 30 капитальных работ, которые отличались новизной и оригинальностью. Из них наиболее известна монография «Проводниковая анестезия в хирургии зубов и полости рта» (1925), которая выдержала 7 изданий. Эта книга остаётся настольным руко- 
водством и для настоящего поколения стоматологов, и челюстно-лицевых хирургов. Предложенные им методы местной проводниковой анестезии в челюстно-лицевой хирургии и пограничных областях широко известны не только в нашей стране, но и за рубежом.

В 1926 г. С.Н. Вайсблат выявил «важнейшее достоинство проводниковой анестезии, заключающееся в том, что сопутствующее ей «проводниковое обескровливание» уменьшает кровотечение из экстракционной и операционной раны, обеспечивая более благоприятное оперирование и скорейшее заживление. Уменьшение кровотечения даёт возможность лучше осмотреть операционное поле и лучше ориентироваться в ране». И далее: «...рана после удаления зуба, проведённого под проводниковой анестезией, заживает лучше, чем рана после удаления зуба без анестезии» (Вайсблат С.Н., 1962).

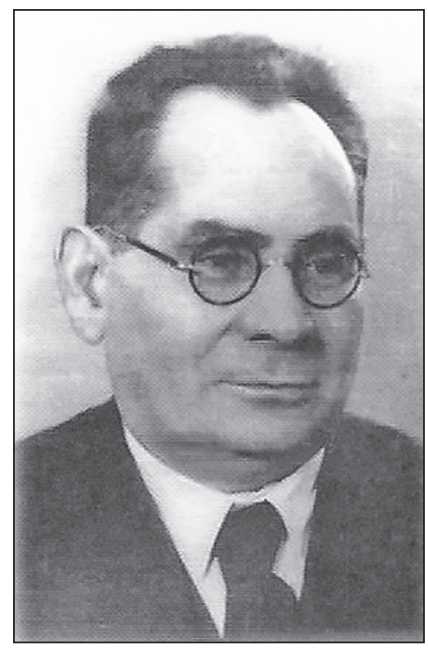

Рис. 127. Соломон Наумович Вайсблат (1887-1965).

Заслуженный деятель науки УССР, доктор медицинских наук, профессор, заведовал кафедрой хирургической стоматологии Киевского медицинского стоматологического института. Усовершенствовал технику проводниковой анестезии 


\section{ПЕРИОД ЛИДОКАИНА И АНЕСТЕТИКОВ IV ПОКОЛЕНИЯ}

В 1943 г. шведскому химику Нильсу Лофгрену (рис. 128) удалось ввести новый класс местно-анестезирующих веществ, синтезировав ксилокаин (лидокаин). Он заменил в промежуточной цепочке эфирное соединение на амидное. Препарат стал «анестетиком выбора» и заменил новокаин в качестве «золотого стандарта». На рынок препарат поступил в 1948 г. под коммерческим названием «ксилокаин». Основываясь на этом первом, и впоследствии распространённом по всему миру анестетике амидного типа, были разработаны многие другие местные анестетики.

История создания лидокаина началась в на-

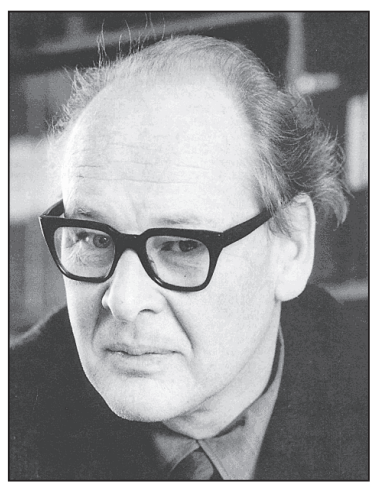

Pис. 128. Nils Magnus Löfgren (1913-1967) чале 30 -х годов XX века и связана с именем профессора Ганса ван Улера (Hans von Euler) и его институтом аналитической химии Стокгольмского университета. ${ }^{3}$ Во время исследования различных сортов ячменя, содержащих меньше обычного количество хлорофилла, он выделил токсический алкалоид, получивший название грамин. Позже к опытному химику Ольгеру Эрдману (Holger Erdtman) обратились с просьбой синтезировать грамин, однако он выбрал для синтеза сходное вещество изограмин. Исследуя полученное соединение, Эрдман обнаружил способность его вызывать онемение языка и губ. Было невозможно изготовить местный анестетик из изограмина из-за его высокой токсичности. Однако Эрдман вновь вернулся к исходному веществу и, когда попробовал его, то ощутил анестезирующий эффект. Это натолкнуло его на идею о возможности обнаружения вещества с анестезирующими свойствами среди сходных химических соединений. Нильс Лофгрен, молодой химик, предложил свою помощь Эрдману. Совместными усилиями они синтезировали и исследовали 16 соединений, 10 из которых были перспективными. С помощью фирмы

${ }^{3}$ Более подробно история открытия и исследования лидокаина освещена в научно-биографическом издании П.Ю. Столяренко «История создания лидокаина» (Самара; СамГМУ, 2001) 
«Astra» (Швеция) физиолог Ульф ван Улер (сын Ганса) исследовал соединения. Однако ни одно из них не могло конкурировать с доминировавшим в то время на рынке местным анестетиком прокаином. Эксперименты были прекращены, а результаты опубликованы в 1937 году. В начале 1940 г. Н. Лофгрен возобновил свою работу по местным анестетикам в попытке изменить конфигурацию молекул. В 1942 г. ему удалось синтезировать перспективную субстанцию, которую исследовал на себе студент Бенгт Лундквист (Bengt Josef Lundqvist, 1922-1952). Он провёл себе спинальную инъекцию, используя зеркало. Данное вещество было названо LL-30 в честь Люндквиста и Лофгрена, а цифра 30 связана с порядковым номером среди уже синтезированных опытных образцов (рис. 129). 22 ноября 1943 г. фирма «Astra» получила права на производство и распространение ксилокаина (лидокаина) во всём мире (рис. 130-133).

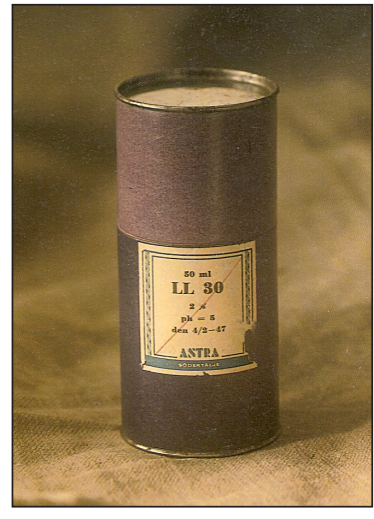

Pис. 129. LL 30 - образец местного анестетика ксилокаина.

(Ил. по K. Lindqvist, S. Sundling, 1993.)

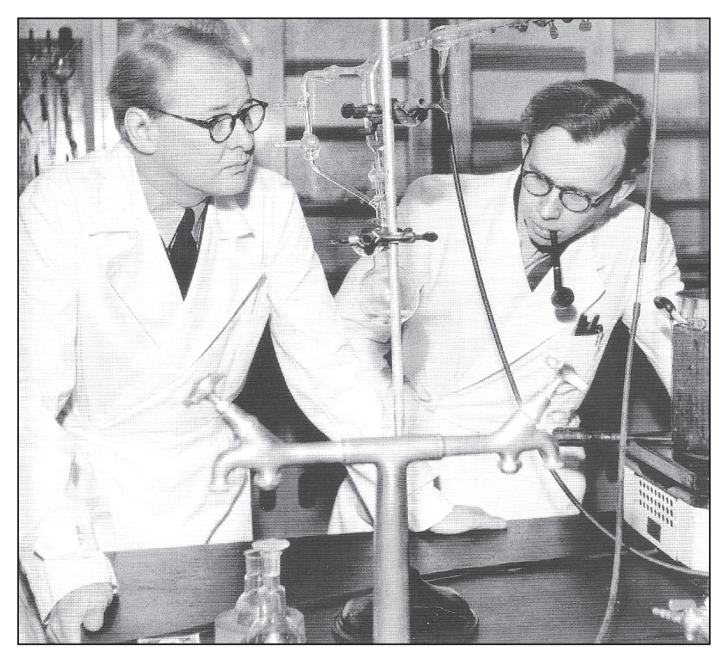

Рис. 130. Нильс Лофгрен (слева) и Бенгт Лундквист В лаборатории аналитической химии рядом с прибором, используемым для синтеза 


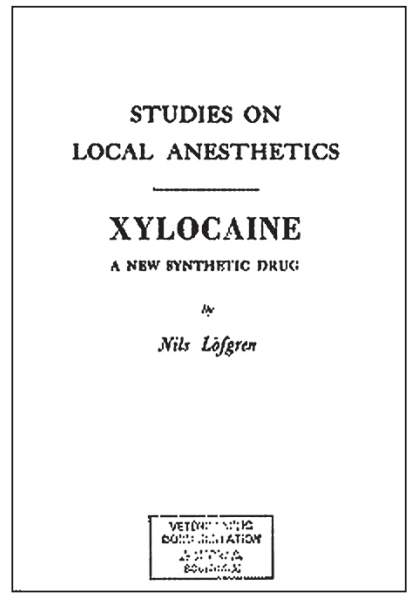

Рис. 131. Титульный лист докторской диссертации Нильса Лофгрена, в которой подведён итог исследований ксилокаина

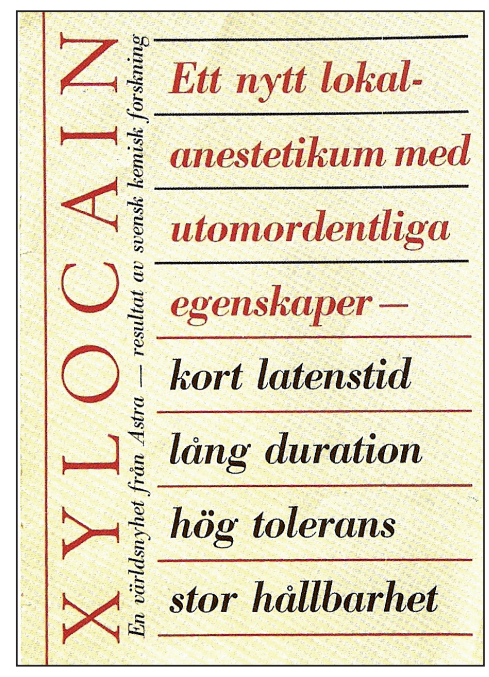

Рис. 132. Первая рекламная брошюра о ксилокаине

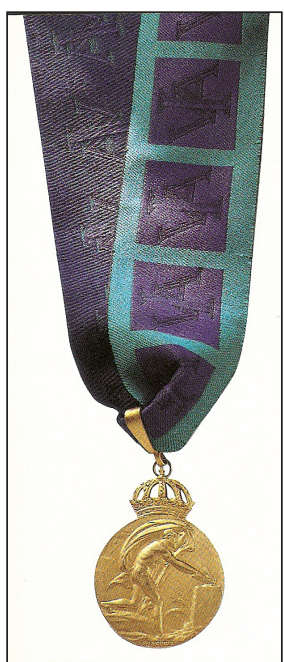

Рис. 133. Большая Золотая медаль Шведской Королевской академии естественных наук, которой Лофгрен награждён в 1956 году 


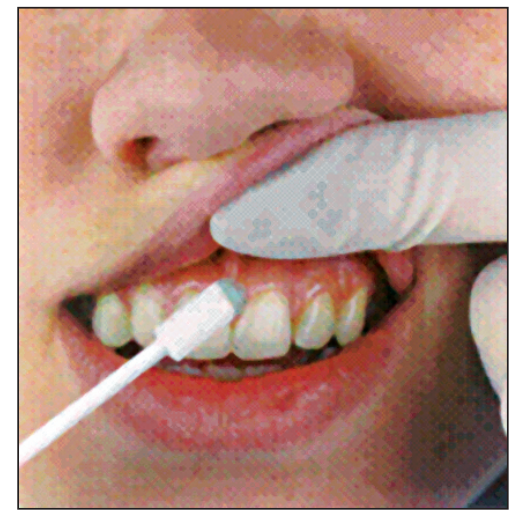

Рис. 134. Поверхностная анестезия уздечки верхней губы аппликацией геля на основе лидокаина

На сегодняшний день лидокаин является основным препаратом для поверхностной анестезии (рис. 134).

В 1946 г. N. Löfgren и B. Lundqvist синтезировали препарат LL-31, который впоследствии был назван тримекаином (мезокаином).

В 1953 г. Нильс Лофгрен (Nils Löfgren) и Клэйс Тегнер (Claes Tegner) впервые получили следующий местно-анестезирующий препарат - прилокаин (ксилонест, цитанест) - амидное производное толуидина с быстрым началом эффекта и средней продолжительностью действия. В литературе сообщения о нём появились в 1960 г. (рис. 135).

В 1956 г. в США Б.А.Ф. Экенштам (B.A.F. Ekenstam), Б. Эгнер (B. Egner) и Г. Петтерсон (G. Petterson) синтезировали мепивакаин амидное производное ксилидина. Основное преимущество этого препарата в том, что он значительно меньше лидокаина расширяет сосуды. 3\% раствор мепивакаина даёт удовлетворительную глубину и длительность анестезии без вазоконстриктора, не стимулирует сердечнососудистую систему. Разрешён к клиническому применению в 1960 г. Указанные преимущества позволяют использовать мепивакаин у пациентов с выраженной сердечно-сосудистой и эндокринной патологией. В настоящее время применяется при кратковременных, неосложнённых вмешательствах в стоматологии.

В 1956 г. в Институте фармакологии и химиотерапии АМН СССР синтезирован и изучен в лаборатории профессора Г.П. Пономарева первый отечественный амидный анестетик мезокаин (тримекаин) - производное ксилидина. 


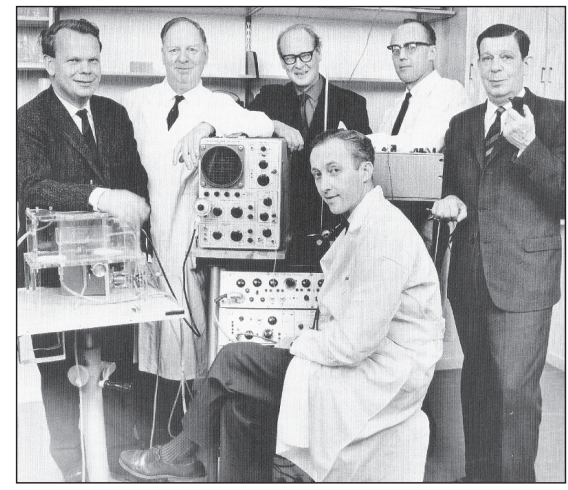

Рис. 135. Счастливый Лофгрен среди коллег в Astra в начале 60-х.

Он стал теперь профессором, и был получен цитанест. Слева направо: Стиг Вэлквист (Stig Wahlqvist), клинические тесты, Стин Вайдлинг (Sten Wiedling), начальные фармакологические тесты, Нильс Лофгрен и Клэйс Тегнер (Claes Tegner), с кем вместе синтезировал цитанест, Бертил Шегрен (Bertil Sjoegren), руководитель исследования, и (сидит) профессор Эрн Астрём

(Arne Astroem), который был ответственен за фармакологические исследования.

(Ил. по K. Lindqvist, S. Sundling, 1993. - p. 169.)

Этот анестетик был подробно исследован Н.Т. Прянишниковой (1956, $1957,1959)$ в эксперименте, а также Н.А. Шаровым $(1962,1964)$ в клинике.

Впервые в стоматологической практике этот препарат применён доцентом Ю.И. Бернадским в декабре 1957 г. в стоматологической клинике и поликлинике Кубанского медицинского института (г. Краснодар). В 1960 г. в журнале «Стоматология», № 2 Ю.И. Бернадский обобщил опыт 128 оперативных вмешательств под мезокаиновым обезболиванием (рис. 136).

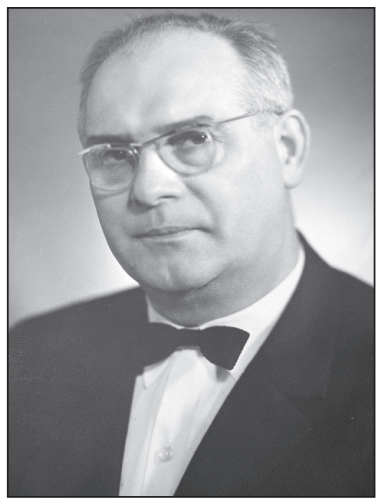

В 1957 г. американцем Б.А.Ф. Экенштамом (B.A.F. Ekenstam) синтезирован бупивакаин, разработанный на основе мепивакаина. Является самым длительно действующим на сегодняшний день местным анестетиком.

Рис. 136. Юрий Иосифович Бернадский (1915-2006).

Патриарх отечественной стоматологии.

Автор 450 научных работ. На основании изучения реакции организма на операционную травму внедрил в практику челюстно-лицевой хирургии премедикацию и потенцирование местной анестезии. Впервые в СССР при стоматологических вмешательствах применил анестезию тримекаином 


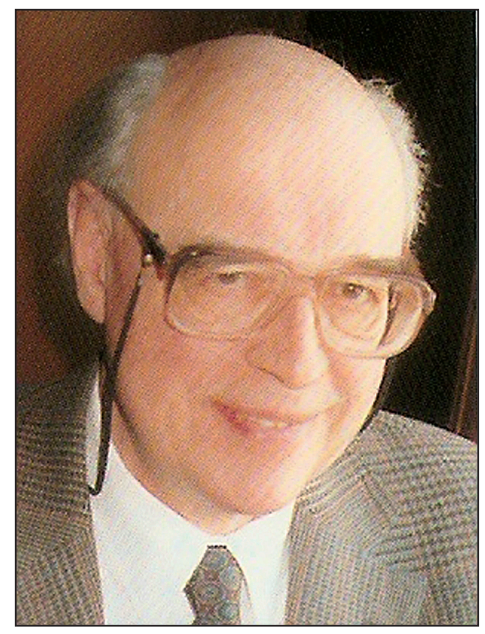

Puc. 137. Bertil H. Takman.

Был близким другом Лофгрена. Позже он работал химиком фирмы Аstra в США, синтезировал местный анестетик длительного действия дуранест.

(Ил. по K. Lindqvist, S. Sundling, 1993. - р. 49.)

В 1971 г. Б.Х. Такман (В.Н. Takman - рис. 137) синтезировал второй длительно действующий амидный анестетик - этидокаин (дуранест).

Артикаин - первый местный анестетик группы амидов, имеющий вместо бензольного кольца тиофеновое и дополнительную эфирную промежуточную цепь. Отличается от других препаратов рядом преимуществ, которые позволили ему занять первое место по соотношению эффективность/ безопасность. На сегодняшний день артикаин является одним из наиболее распространённых местных анестетиков, применяемых в стоматологической практике.

Артикаин является химическим соединением для местной анестезии. Открыт, разработан и внедрён компанией Hoechst AG (вошедшей в последующем в концерн Sanofi-Aventis).

Синтез артикаина и оформление патента произведены в 1969 году в Германии профессором химии, почётным доктором Генрихом Рушигом (Heinrich Ruschig, 1906 - 1991), Робертом Риппелем (Robert Rippel) в лаборатории компании Hoechst AG. В этом же 1969 г. были первые публикации об артикаине в Нидерландах. Выявление анестезирующих свойств и изучение в качестве лекарства произведены врачом и фармакологом профессором Романом Мушавеком (Roman Muschaweck) - рис. 138. 

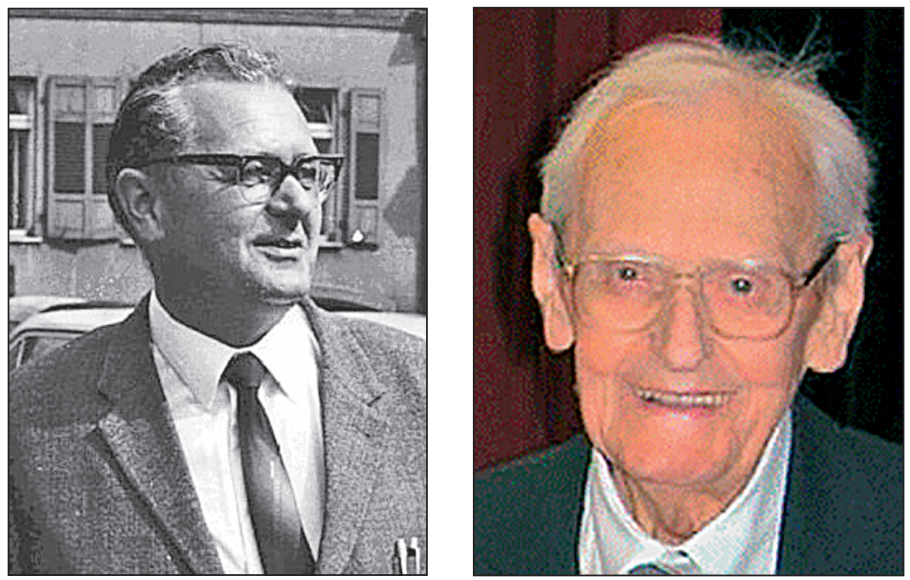

Pис. 138. Dr. Roman Muschaweck (1919-2007).

Немецкий фармаколог и токсиколог, получивший мировое признание.

Синтезировал мочегонные средства (Arelix ${ }^{\circledR}$, Lasix), кровозаменители (Haemaccel $^{\circledR}$ )

и местный анестетик артикаин $\left(\right.$ Ultracain $\left.^{\circledast}\right)$

В 1973 г. он исследовал обезболивающую активность препарата при поверхностной и инфильтрационной анестезии. Затем исследовано анестезирующее действие при проводниковом обезболивании.

Следующим этапом были общефармакологические исследования влияния на изолированные органы (сердце - Langendorff, кишка - Magnus, yхо - Pissemskt и др.). Далее проведено изучение влияния на кровяное давление, исследована токсичность. После этих успешных экспериментальных исследований на животных была открыта дорога для клинических испытаний на людях. В 1972 г. на конференции в г. Ландау были доложены первые результаты применения артикаина, и благодаря высокой активности, низкой токсичности и хорошей переносимости препарат быстро вошёл в повседневную практику. В 1974 году группа исследователей получила патент № 3855243 от фирмы Hoechst AG. Название «3-Aminoacylamino Thiophenes». Авторы: Роман Мушавек (Roman Muschaweck, Frankfurt am Main), Роберт Риппель (Robert Rippel, Hofheim, Taunus), Генрих Рушиг (Heinrich Ruschig, Bad Soden, Taunus), Манфред Шорр (Manfred Schorr, Frankfurt am Main). Заявка подана 1 октября 1973 г. Опубликован 17 декабря 1974 г.

Шульц-Гусман М. (Schulze-Husmann M.) в 1974 г. защитил в Бонне диссертацию по теме «Экспериментальное испытание нового местного анесте- 
тика ультракаина в стоматологической практике». С 1974 г. клинические испытания артикаина проводились в университетской клинике г. Франкфурта в отделении доктора медицины, профессора Г. Френкеля (G. Frenkel) и других медицинских учреждениях Германии. В 1975 г. артикаин был одобрен для применения в качестве местного анестетика. Внедрение на рынок зарегистрированного лекарства «Ultracain» началось с января 1976 г. До 1984 года международное незапатентованное название препарата было «картикаин/HOE 40 045», позднее препарат стал называться «артикаин». Компания-разработчик продаёт его под фабричной маркой Ультракаин Д-С, Ультракаин ${ }^{\circledast}$ Д-С Форте и Ультракаин ${ }^{\circledast}$ Д.

В клиническую практику артикаин был введён в 1974 г. Р. Мушавеком и Р. Риппелем после публикации статьи «Новый местный анестетик (Картикаин) из тиофенового кольца» в журнале «Практическая анестезиология». Препарат обладает надёжным анестезирующим действием - при консервативном лечении доля случаев успешной анестезии составляет 99\%, при хирургических вмешательствах - 98,5\% (по данным Woerner H, Mayer R., 1976).

C 1976 г. артикаин широко используется в Германии (фирма «Hoechst AG») и Швеции, с 1978 - в Нидерландах, с 1980 г. - в Австрии и Испании, с 1982 г. - в Канаде (Zorcaine ${ }^{\oplus}$, Astracaine Forte, Ultracain D-S Forte, Septanest SP), с 1984 г. - в Венгрии, с 1998 г. - в Великобритании. В США первоначально к артикаину отнеслись осторожно, были скептицизм и критика среди исследователей и клиницистов. Рассмотрение возможности для лечебного применения этого препарата продолжалось более 5 лет, и только после этого Управление по санитарному надзору за качеством пищевых продуктов и медикаментов (FDA) одобрило это лекарство для терапевтического использования в США, и только в концентрации адреналина 1:100 000 (Septocaine ${ }^{\varpi}$, Septodont Inc, апрель 2000 г.). Это, несмотря на то, что концентрация адреналина 1:200 000 в Европе и Канаде была доступна соответственно с 1976 и 1982 г. Одобрение для состава артикаина с адреналином 1:200 000 было получено в июне 2006 г. - Articadent ${ }^{\circledast}$.

В России ультракаин разрешён к применению с 1990 г., в стоматологии - с 1994 г. Первая апробация проводилась профессором И.А. Шугайловым с сотрудниками в Московском медицинском стоматологическом институте (сейчас ГОУ ВПО «Московский государственный медикостоматологический университет»). В Москве компанией «Мединфодент» организовано два международных симпозиума «Новые технологии местного обезболивания в стоматологии» (совместно с компаниями Hoechst в 1994 г. и Septodont в 1995 г.), на которых были обсуждены основные фарма- 
кологические свойства артикаина и поделились опытом применения препарата зарубежные и отечественные стоматологи. По данным R. Rahn (1996), H.G. Grigoleit (1996), S.F. Malamed (1997), а также Российских стоматологов, артикаин превосходит по активности новокаин в 4-5 раз, лидокаин в 1,5 раза. У взрослых пациентов эффективность анестезии при его использовании достигает 95-100\%. Важной особенностью артикаина является его высокая диффузионная способность, местно-анестезирующая активность и степень безопасности (Шугайлов И.А., 1996; Столяренко П.Ю., 1997; Рабинович С.А., 2000 и др.). Артикаин сегодня - обычно используемый местный анестетик в практике стоматолога в Германии, Швейцарии, Австрии, Франции, Польше, Чешской республике и др. странах (Rahn R., Ball B., 2001).

В настоящее время препараты на основе артикаина производятся многими зарубежными фирмами. В России разрешены к применению в стоматологии ультракаин (Д-С, Д-С форте и Д) ${ }^{4}$ и дженерики: септанест, альфакаин, убистезин, примакаин, цитокартин, артикаин ИНИБСА и выпускается артикаин в настоящее время двумя отечественными фармацевтическими фирмами: Брилокаин ${ }^{\circ}$-адреналин $(1: 200.000)$ и Брилокаин ${ }^{-}$ адреналин форте (1:100.000) ЗАО «Брынцалов-А» в карпулах по 1,8 мл; Артифрин-Здоровье (1:200.000) и Артифрин-Здоровье форте (1:100.000) ООО «Здоровье» в карпулах по 1,7 мл.

В Германии артикаин является наиболее используемым в стоматологии местным анестетиком, и его доля на рынке, по данным R. Rahn (1996, 2001), W. Jakobs (2009), составляет 90\%. В то время как во всём мире лидокаин является самым распространённым местным анестетиком, в Центральной Европе артикаин занимает наибольшую долю рынка (Daublaender M., 2005). С июня 2005 г. в Германии фирмой $3 \mathrm{M}$ ESPE выпускается убистезин с содержанием адреналина 1:400 000, применяемый в стоматологии для инфильтрационной и проводниковой анестезии при обычных (рутинных) вмешательствах продолжительностью до 30 мин (несложное удаление зуба, препарирование кариозной полости).

Внедрению артикаина в стоматологическую практику способствовали многие стоматологи, среди которых следует выделить Герхарда Френкеля, Райнера Ранна, Монику Даублэндер, Вольфганга Якобса, Стенли Меламеда, Жана-Фредерика Андре, И.А. Шугайлова, А.Ж. Петрикаса, С.А. Рабиновича.

${ }^{4}$ Обозначение «Д» свидетельствует, что анестетик для стоматологической практики (Dental), «С» - содержит адреналин (Suprarenin) 
В 90-е годы учёными фирмы «Astra» разработан новый анестетик длительного действия - наропин (ропивакаин). По химической структуре он аналогичен бупивакаину (бутиловая группа, присоединённая к амиду, заменена пропиловой). При применении наропина меньше вероятность сердечного коллапса и аритмии, а в случае возникновения кардиотоксического эффекта более вероятно успешное восстановление сердечной деятельности, чем при использовании бупивакаина. Применяется в основном для эпидуральной анестезии, блока периферических нервов и послеоперационного обезболивания. С 1999 г. проходит клинические испытания в стоматологии. В отличие от большинства других местных анестетиков, присутствие вазоконстриктора адреналина существенно не влияет на время наступления, продолжительность действия анестезии и ограничение системных реакций. Это позволяет в некоторых случаях, когда необходима длительная проводниковая блокада в челюстно-лицевой области (травматичные вмешательства, подавление боли при невралгии тройничного нерва), считать наропин анестетиком выбора у пациентов пожилого возраста (Столяренко П.Ю., Кравченко В.В., 2000). 


\section{ИСТОРИЯ МЕСТНОЙ АНЕСТЕЗИИ КОЖНЫХ ПОКРОВОВ}

Анестезия интактных кожных покровов многие годы была невозможна без предварительной болезненной инъекции раствора местного анестетика или сдавления, охлаждения тканей.

В 1957 г. S. Monash, а в 1971 г. J. Adriani, H. Dalili в поисках идеального препарата для местной анестезии кожных покровов показали, что некоторые местные анестетики обладали анестезирующим действием на кожные покровы, но ни один из предложенных препаратов не давал достаточной клинической эффективности. Спустя 10 лет Brechner предложил использовать 5 или 10\% аметокаин (тетракаин), растворённый в диметилсульфоксиде (DMSO - dimethyl-sulphoxide), который обеспечивает проникновение местного анестетика через интактные кожные покровы. Однако препарат не нашёл широкого распространения в клинической практике, так как DMSO вызывал различные патологические кожные реакции, связанные с выбросом гистамина. В 60 -е годы для местной анестезии кожных покровов использовался $30 \%$ лидокаин, однако применение такой высокой концентрации местного анестетика приводило к осложнениям токсического генеза. В конце 70 -х годов (B. Ponten и L. Ohlsen) был разработан кетокаин (местный анестетик с высокой липофильностью), который был эффективен для анестезии кожных покровов, но в дальнейшем его клиническое использование было прекращено из-за развития тяжёлых местных кожных реакций с образованием волдырей (Обзор «Topical anaesthesia of the skin», Paediatric Anaesthesia, 1993, № 3, p. 129-138).
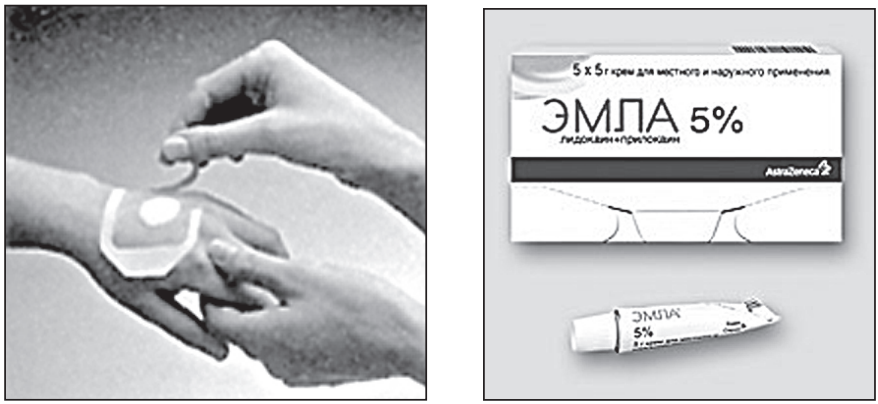

Рис. 139. Крем ЭМЛА 
На протяжении всей истории поиска препарата, способного обезболить поверхность кожных покровов, стало ясно, что для проникновения через поверхность интактной кожи и обеспечения местной анестезии анестетик должен удовлетворять двум основным требованиям: во-первых, иметь высокую концентрацию, которая могла бы обеспечить проникновение через липофильные кератиновые структуры кожи (поверхностный эпидермис), и, во-вторых, содержать достаточное количество воды, позволяющее увлажнить кожные покровы и улучшить процесс абсорбции препарата.

В начале 70-х годов исследователи фирмы «Astra» Ганс Эверс (Hans Evers) и Фредрик Броберг (Fredrik Broberg) создали специфическую смесь, состоящую из лидокаина и прилокаина, - ЭМЛА (EMLA) - крем, который удовлетворяет всем перечисленным требованиям и является первым анестетиком для проведения аппликационной анестезии интактных кожных покровов (рис. 139). EMLA - Eutectic Mixture of Local Anesthetics - эутектическая, то есть легкоплавкая, смесь местных анестетиков (5\% лидокаина и $5 \%$ прилокаина в соотношении 1:1). Точка плавления лидокаина и прилокаина значительно выше комнатной температуры $\left(67\right.$ и $37^{\circ} \mathrm{C}$ соответственно). Однако указанная смесь имеет точку плавления всего $18^{\circ} \mathrm{C}$, что примерно соответствует комнатной температуре. При нанесении на кожу оба анестетика переходят в жидкое состояние, несмотря на то, что изначально имеют кристаллическую структуру. Это облегчает процессы абсорбции через интактные кожные покровы. Крем ЭМЛА представляет собой эмульсию «масло в воде». Благодаря высокому содержанию воды в составе крема абсорбция эутектической смеси происходит и через неповреждённую поверхность кожи. Обязательным условием успешного применения этого крема является наличие специальной окклюзионной повязки Tegaderm, которая предупреждает испарение воды, входящей в состав крема.

Введение в клиническую практику (на европейский медицинский рынок крем ЭМЛА поступил в начале 80-х годов) нового препарата для анестезии интактных кожных покровов фирмой «Astra-Zeneca» стало новым значительным шагом в преодолении ятрогенной боли. Большая клиническая значимость внедрения в клиническую практику состоит в следующем:

1. Болезненные процедуры (пункция и катетеризация сосудов при анестезиологическом обеспечении, инфузионной терапии, взятии крови на исследование, дополнительное обезболивание перед инфильтрационной, внеротовой регионарной анестезией, продлённой проводниковой блокадой второй и третьей ветвей тройничного нерва) перешли в разряд безболезненных и не вызывающих негативных реакций (особенно у детей и пожилых пациентов). 
2. Анестезия кремом ЭМЛА стала самостоятельным методом обезболивания при поверхностных хирургических вмешательствах на коже лица (биопсия, дермабразия, пересадка кожных лоскутов, удаление кондилом, кожного рога, невуса, металлических спиц после остеосинтеза, лазерная, косметическая хирургия и др.).

\section{Шприцы}

Местное инъекционное обезболивание в стоматологии существует около 120 лет. Появилось оно благодаря ранее изобретённым шприцам, с помощью которых вводятся растворы местно-анестезирующих веществ. За это время шприцы подверглись значительным изменениям, и нашли широкое применение при лечении стоматологических заболеваний.

А как всё начиналось?.. Ещё в 1656 году в Лондоне на кафедре биологии Сэр Кристофер Рэн (рис. 140) проводил эксперименты на животных. Делая разрез кожи лезвием и вставляя в него ствол птичьего пера, он производил инъекции растворов веществ. После него, через восемь лет, в 1664 году, Elsholtz сделал попытку внутривенной инъекции и переливание крови от человека к человеку с помощью инъекционного приспособления, подобного стволу птичьего пера (HoffmannAxthelm W., 1981).

Примерно в 1656 г. К. Рэн начал проводить эксперименты по внутривенным введениям настойки опия, пива, вина, эля, молока и т.д. В качестве иньекционной иглы К. Рэн использовал птичье перо, а вместо шприца пузыри рыб и животных, ведь до изобретения полой иньекционной иглы и шприца оставалось ещё целых два века. Результаты этих исследований были опубликованы в 1665 г. в «Философских Трудах Лондонского Королевского общества». Таким образом, знаменитого английского архитектора Кристофера Рэна можно причислить к основоположникам современной инфузионной терапии и внутривенного наркоза.

Возникновению инъекционного обезболивания предшествовала разработка технических средств для введения лекарств. В 1844 г. ирландский врач Фрэнсис Ринд (Francis Rynd, 1801-1861) изобрёл полую иглу (рис. 141) и опубликовал концепцию местного применения лекарственных препаратов, вводимых в область периферических нервов с целью купирования боли (Pfender C.A., 1911; Hassouna H., 2003). 


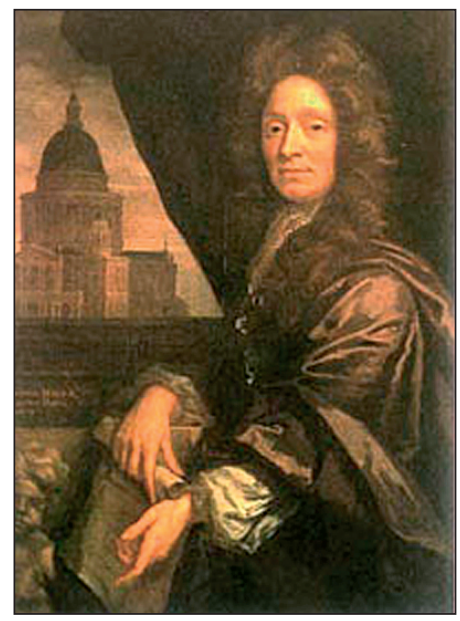

Рис. 140. Кристофер Рэн (Christopher Wren, 1632-1723) - крупнейший английский архитектор, математик и астроном. Он является автором проектов 53 лондонских церквей, а венцом его творчества и таланта стал собор Св. Павла в Лондоне. Кристофер Рэн был одним из основателей Лондонского Королевского общества, а в период с 1680 г. по 1682 г. был его президентом. Ещё до создания Лондонского Королевского общества, будучи в Оксфорде, Кристофер Рэн стал активным участником исследовательской группы Роберта Бойля (Robert Boyle, 1627-1691), в которую также входили Томас Уиллис (Thomas Willis, 1621-1675); Уильям Петти (William Petty, 1623-1687);

Ричард Ловер (R.Lower, 1631-1691); Джон Локк (John Locke, 1632-1704); Джон Мейоу (John Mayow, 1643-1679); Роберт Гук (Robert Hooke, 1635-1703), и другие

Изобретением шприца мир обязан великому французскому учёному Блезу Паскалю и его интересу к гидродинамике, гидростатике и атмосферному давлению. В 1647 г. Паскаль сделал сразу два важнейших изобретения - гидравлический пресс и шприц. Но в то время широкого применения последний не нашёл. Произошло это только в 1853 г., в Великобритании. В первой половине XIX столетия прообразами современныХ шприцев были «Стилет» Нойнера и шприц Фергюсона (рис. 142). Иллюстрация этой конструкции была найдена в журнале «Journal der Chirurgie by the Chief Physician of Darmstadt» в 1827 году (Рабинович С.А. и соавт., 2001). Конструкция была металлической и состояла из цилиндра и не прилегающего к его стенкам поршня со штоком, выходным отверстием служила суженная трубка. Сквозь всю эту конструкцию проходит простая игла с захватом, с помощью которого она вынимается из инъектора после прокалывания кожи (Hoffmann-Axthelm W., 1981). 


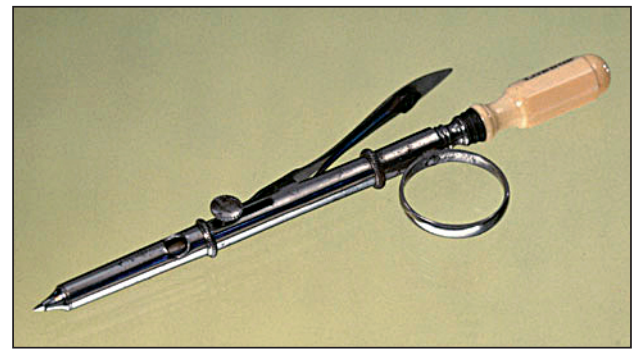

Рис. 141. Игла Ринда. Этот инструмент использовался для глубоких инъекций.

Он сделан из стали с ручкой из слоновой кости, и был изготовлен Weiss (Ил. Музея Науки, Лондон)

Шотландский врач из Эдинбурга Александр Вуд (Alexander F. Wood, 1817-1884), изучавший возможности расширения применения морфина для анестезии, впервые использовал шприц для введения морфина внутрь человеческого организма. Он приспособил к подкожной инъекции шприц, разработанный лондонскими производителями инструментов братьями Даниелом и Джоном Фергюсонами. Сегодня этот шприц можно увидеть в музее Британского Королевского хирургического общества (рис. 143). Практически одновременно с ним ветеринарный хирург из Лиона ШарльГабриэль Правац (Charle-Gabrial Pravaz, 1791-1853) выдвинул предположение о возможности введения лекарственных средств в организм при помощи сжатого воздуха. Продолжая исследования, Вуд и Правац в 1853 г. изобрели шприц и иглу для внутривенных и внутримышечных инъекций. Правац добавил полую иглу вместо трубки (рис. 144). В 1855 г. Вуд первым ввёл раствор морфина в область нервных стволов при приступе невралгических болей и получил положительный результат.

a

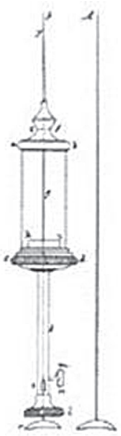

6

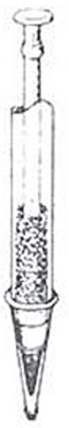

Рис. 142. Предшественники современных шприцев:

a - «Стилет Neuner`a (1827 г.); 6 - шприц Ferguson`s (1850) 

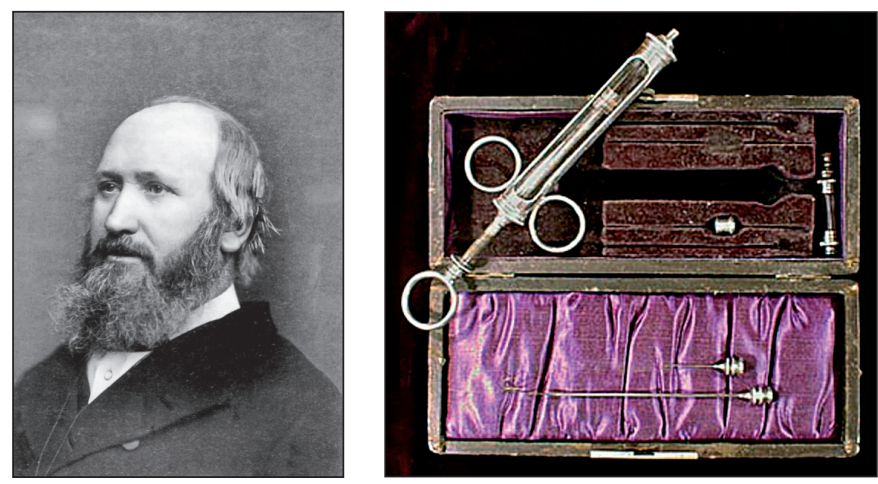

Рис. 143. Александр Вуд и его шприц (Ил. The Medical profession in all countries containing photographic portraits from life v. 1, no. 8. London: J. \& A. Churchill, 1873.

Downloaded from http://ihm.nlm.nih.gov/images/A19829

Универсальный шприц Праваца, близкий к современному шприцу, применялся в медицинской практике почти до середины XX века. Шприц Праваца состоял из стеклянного цилиндра ёмкостью 1 мл с оправой из твёрдого каучука и металлического стержня с кожаным поршнем (рис. 145).

Изобретение полой иглы и шприца позволило американцу В.В. Грину (Greene W.W.) в 1868 г. предложить инъекции морфина перед наркозом. Этим было положено начало фармакологической подготовке больных, известной в настоящее время под названием премедикация. Вскоре после этого Potain в 1869 г. наблюдал развитие местной анестезии после подкожного введения воды (Halsted W.S., 1885).

В зубоврачевании конца XIX века шприцы использовались для промывания и высушивания полостей зубов перед пломбированием (рис. 146). Из приведённых иллюстраций видно, что некоторые из шприцев стали прототипами современных стоматологических инъекторов, обеспечивая упор и обратное движение штока.

Важнейшим достижением начального периода применения местной анестезии явилась разработка функционального дентального шприца Блейхштайнером и Фишером (Bleichsteiner A., Fischer G., 1906). Главными их признаками были навинчивающаяся канюля и упоры для пальцев и ладони (рис. 147).

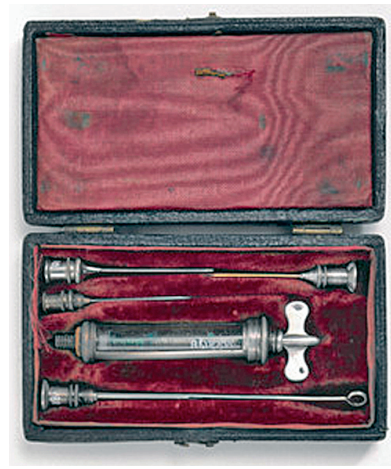

Рис. 144. Набор Праваца (Ил. Музея Науки, Лондон) 


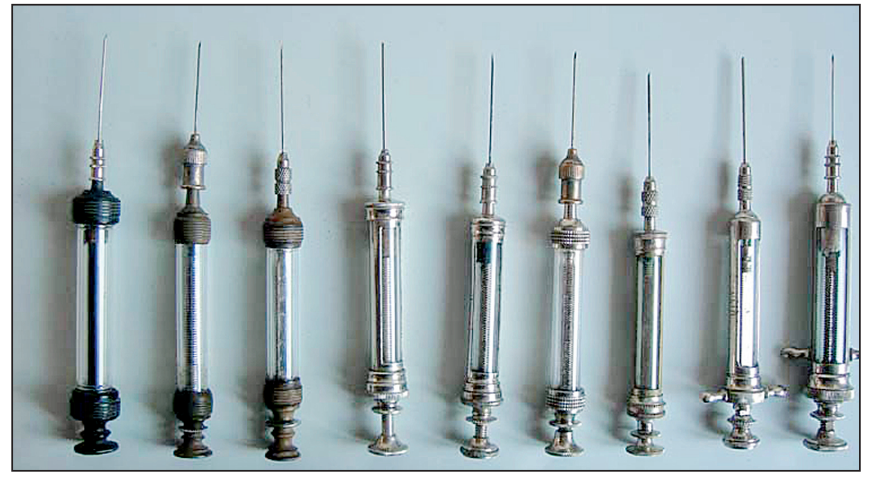

Рис. 145. Шприцы Праваца
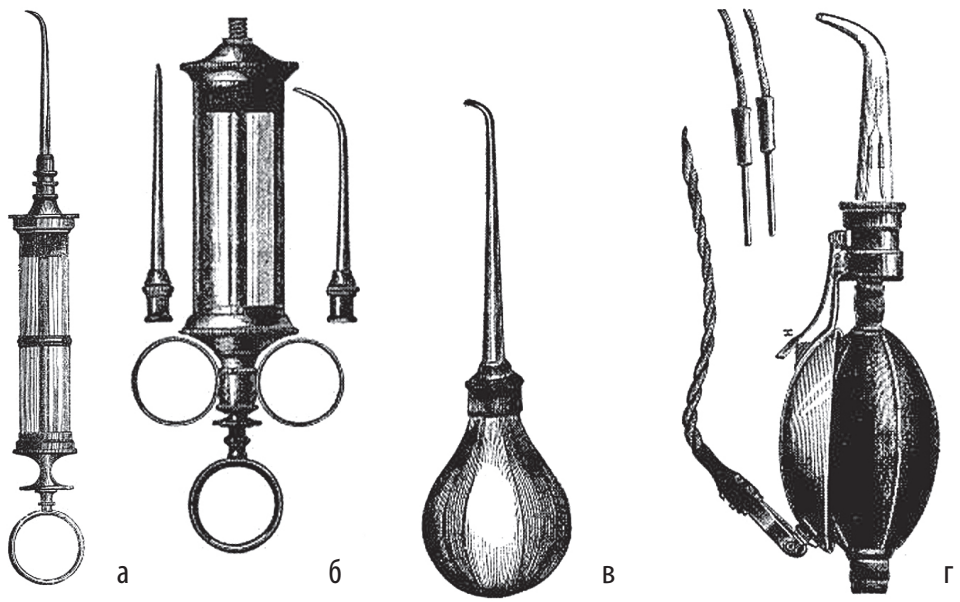

Рис. 146. Шприцы, применявшиеся в зубоврачевании перед пломбированием:

а) для промывания (Ил. по Ю. Шеффу, 1882); б) водяной шприц (Ил. по В.Д. Миллеру, 1898);

в) воздушный шприц для удаления частичек зубной ткани (Ил. по В.Д. Миллеру, 1898);

г) тепловоздушный шприц Telschow'a (Ил. по В.Д. Миллеру, 1898)

В 1906 году в России внедрён в производство многоразовый разборный шприц «Рекорд-Брюно» со стеклянным цилиндром, металлическим поршнем, герметично притёртым к стенкам цилиндра, и металлическими иглами. На боковой стенке цилиндра нанесены деления, что позволяет оценить количество раствора в шприце. Конструкция получилась удачной и простой в использовании, и поэтому её применяли в медицинской практике чаще других. 

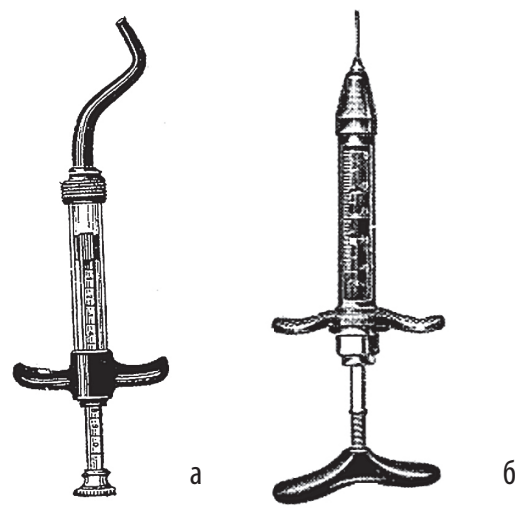

Рис. 147. Зубоврачебные шприцы для местной анестезии:

а) шприц Блейхштайнера; б) шприц Фишера (Ил. по: R. Neumann, 1929.)

Наибольшее распространение в общей медицине имели шприцы типа «Рекорд» - цилиндр из термостойкого стекла, а остальные детали металлические (рис. 148, а). Иглы на шприц не навинчиваются, а удерживаются за счёт фрикционности и конусности соединения, что увеличивает риск соскальзывания их во время введения раствора или промывания.
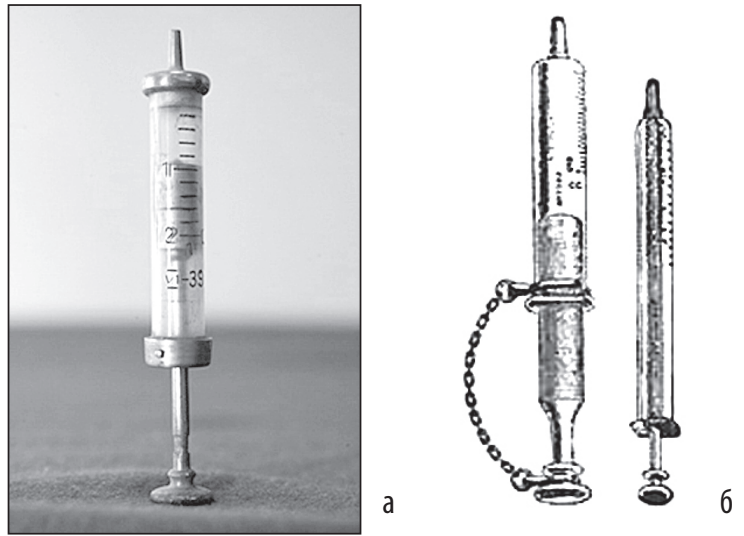

Рис. 148. Медицинские шприцы: $а$ - «Рекорд».

(Ил. К.А. Пашков, <www.historymed.ru>. 8.01.2010 г.); б - «Луер»

В 1870 г. производитель медицинских инструментов немецкого происхождения Герман Вулфинг Луер (? - 1883) в Париже представил первый 
стеклянный шприц с новым типом крепления иглы - Луер (рис. 148, б). Он также ликвидировал винтовой ход поршня и добавил градуировку на корпусе. Именно это соединение между шприцем и иглой используется в наши дни. Шприц Луера производится с 1898 г. Becton, Dickinson \& Co (BD). В 1925 г. полковник Fairleigh S. Dickinson разработал более крепкую фиксацию типа Luer-Lock ${ }^{\mathrm{m}}$, при которой игла навинчивается на конус цилиндра. Шприцы типов «Рекорд» и «Луер» отличаются формой канюли - подыгольного конуса. Следствием этого является то, что игла для шприца «Рекорд» не подходит к шприцу типа «Луер» и наоборот. Шприцы, изготовленные из стекла и металла, предназначены для многократного использования; они подвергаются стерилизации.

Главным недостатком шприцев из стекла является то, что они быстро бьются. В 1956 г. новозеландский фармацевт и ветеринар Ко́лин Мёрдок (19292008) изобрёл и запатентовал одноразовый пластмассовый шприц. С 1961 г. компания Becton Dickinson (Франция) стала выпускать первые доступные из небьющейся термостойкой пластмассы одноразовые шприцы BD Plastipak.

Зубоврачебная картриджная система для инъекций начала вводиться в Америке и Западной Европе в 20-е годы. Она включает в себя специальный шприц, картридж и иглу с двумя острыми концами (рис. 149).

Впервые карпулы (картриджи) были созданы ещё в 1917 г. во время I мировой войны американским военным хирургом Харвеем Куком (Harvey S. Cook), который изобрёл цилиндрические ампулы - прообраз современных карпул. Карпула представляла собой стеклянную цилиндрическую трубку, закрывающуюся с одной стороны резиновым поршнем (пробкой), а с другой - резиновой мембраной, прокалываемой иглой во время инъекции (рис. 150). Шприц «заряжался» карпулой, как оружие снарядом, - через затвор. В 1921 г. в лаборатории Кука был разработан первый аспирационный карпульный шприц.

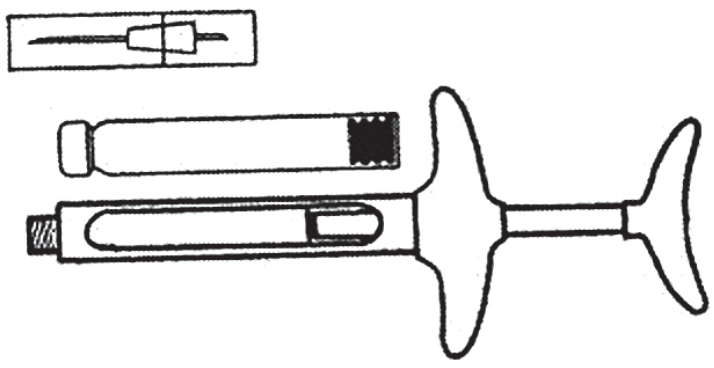

Рис. 149. Зубоврачебная картриджная инъекционная система: игла в контейнере, картридж, шприц с упорами для пальцев и ладони 


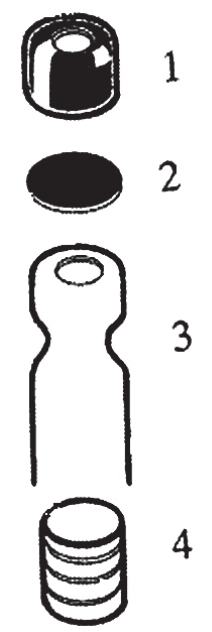

Рис. 150. Составные элементы карпулы (Ил. по Н. Evers, 1993):

1 - алюминиевый колпачок, 2 - эластичная мембрана, 3 - стеклянная ампула, 4 - эластичный поршень-пробка

Только с появлением лидокаина, обеспечивавшего надёжное обезболивание двумя миллилитрами раствора, эта инъекционная система вошла в широкую стоматологическую практику. Объём карпулы в 1,8 мл в 1947 г. произвольно выбрала фирма «Вауег», и он стал стандартом. В Великобритании, Австралии и некоторых странах Азии производятся карпулы объёмом 2,2 мл. Главным достоинством стоматологической картриджной системы является быстрая (менее минуты) подготовка к инъекции и гарантированная производителем стерилизация тех элементов (иглы и картриджи), которые контактируют с субэпителиальными тканями (Петрикас А.Ж., 1997).

Одним из недостатков классической картриджной системы была невозможность аспирации - обратного оттягивания поршня, чтобы исключить случайное попадание иглы в просвет сосуда. Для совмещения поршня-пробки картриджа со штоком (толкателем) шприца были предложены винтовое соединение (Novcol Company, 1947) и гарпунное (Cook-Weite Laboratories, 1957), требовавшие конструктивных изменений как самого картриджа, так и шприца. Последняя фирма в 1959 г. разработала к этому шприцу разовые стерильные иглы (Jastak J.T., Yagiela J.A., 1981). 

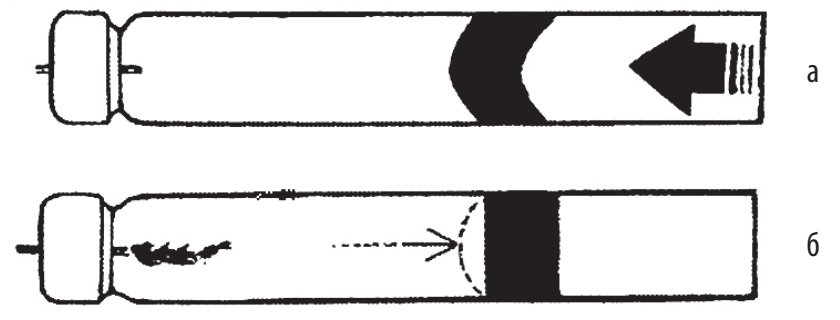

Рис. 151. Принцип самоаспирации в карпульной инъекционной системе. А - во время давления на пробку происходит её деформация.

B - форма пробки восстанавливается и в полости карпулы возникает отрицательное давление, куда может устремиться кровь из места инъекции. (Ил. по А.Ж. Петрикасу, 1997)

Обычные медицинские шприцы также не имеют конструктивных приспособлений для контрольного всасывания, поэтому при их использовании приходится одной рукой держать шприц, а другой - оттягивать назад поршень. Помимо неудобства в работе такая техника создаёт дополнительную опасность возникновения осложнений за счёт травмы тканей кончиком иглы вследствие его смещения. У зубоврачебных шприцев стали делать упор для большого пальца на конце штока в виде кольца, а для удержания самого шприца указательным и средним пальцами - захваты различной конструкции на его корпусе. Благодаря этому как надавливание на шток, так и оттягивание его стало возможно делать одной рукой, используя движения большого пальца. Чтобы обратное движение (оттягивание) передавалось на поршень-пробку карпулы, другой конец штока стали делать в виде крючка, конуса или зазубрины. При резком движении они вводятся в пробку и удерживаются там за счёт острых краёв и плотности резины. При обратном движении штока на 1-2 мм с ним смещается и пробка, создавая разрежение.

Помимо приспособлений для обеспечения обратного движения пробки-поршня были разработаны конструкции, которые обеспечивают автоматическое развитие аспирационного разрежения. Принцип работы этих конструкций заключается в том, что ввиду эластичности мембраны и резиновой пробки карпулы после прекращения давления на них во время инъекции может происходить пассивная аспирация за счёт возникающего разрежения (рис. 151).

A. Ritsky (Ритский А.) предложил устройство для пассивной аспирации за счёт деформации мембраны (рис. 152) - Evers H., 1993. 


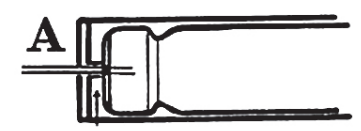

1
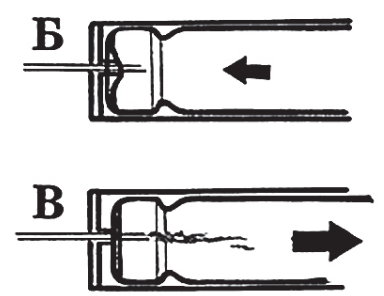

Рис. 152. Пассивная аспирационная система А. Ритского (Ил. по H. Evers, 1993):

1 - трубчатый штифт на внутренней поверхности фронтальной части шприца (А).

Во время инъекции карпула упирается в трубчатый штифт, изгибая мембрану внутрь (Б). После прекращения давления на поршень мембрана возвращается в исходное состояние,

вызывая пассивную аспирацию (B)

Конструкция фирмы «Аstra», предложенная более двух десятков лет назад в самоаспирационном шприце, осуществляет аналогичный принцип при деформации другой эластичной части карпулы - резиновой пробки (рис. 153). В этом шприце шток, упирающийся в пробку, заканчивается не круглым стержнем большого диаметра, соответствующего диаметру пробки, а зауженным стержнем без крючка. В результате этого надавливание штоком происходит не на заднюю часть пробки по всему его диаметру, а на центр передней части, до которой сквозь весь поршень проходит канал. При таком надавливании передняя часть пробки деформируется, выступая внутрь карпулы, а после прекращения давления оттягивается назад, восстанавливая свою форму. При этом в карпуле создаётся отрицательное давление, которое увлекает кровь из места инъекции, если игла попала в просвет сосуда.

Таким образом, при проведении аспирационного теста стало достаточно задержать иглу в месте инъекции на 1-2 сек., сняв при этом давление с поршня шприца.

В России с 1918 до 90-х годов в зубоврачевании (стоматологии) использовалась общемеди-

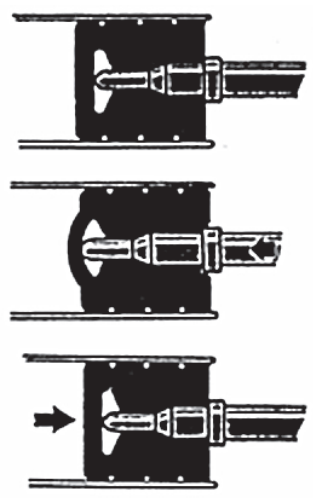

Рис. 153. Пассивная аспирационная система фирмы «Astra» (Ил. по Evers, Littorin) 

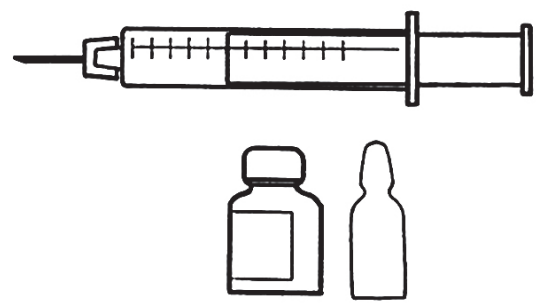

Рис. 154. 0бщемедицинская инъекционная система: шприц, игла, флакон, ампула цинская система инъекций (рис. 154). В ней задействованы стеклометаллический (комбинированный) шприц ёмкостью 5 мл и иглы для подкожных и внутримышечных инъекций. Вот как С.Н. Вайсблат (1962) обосновывает применение этой системы: «Мы давно отказались от применения специальных, так называемых зубоврачебных шприцев со специальными боковыми выступами для фиксации

пальцев и с навинчивающимися иглами, а с 1918 г. для инъекционной анестезии, в частности проводниковой, мы пользуемся шприцем «Рекорд», обычно пятимиллилитровым, и считаем его самым удобным: во-первых, он легко разбирается и так же легко составляется, во-вторых, хорошо стерилизуется, так как состоит только из металла и стекла, в-третьих, игла легко снимается и надевается на шприц. Это обстоятельство, как увидим ниже, весьма важно при некоторых проводниковых и инфильтрационных анестезиях...». По-видимому, закрытость и экономические проблемы России после 1917 г., а затем СССР, невозможность фабричного производства в нашей стране стоматологических шприцев, игл и применение в основном анестетика новокаина послужили причиной традиции использования в стоматологии общемедицинской инъекционной системы, которая была доступнее и дешевле. А.Ж. Петрикас и соавт. (1999) к достоинствам медицинской одноразовой системы относят то, что она занимает меньше места в полости рта и более компактна, меньше пугает россиян, возможно дозирование ещё при подготовке к инъекции, более герметична, для активной аспирации не требует специальных устройств, производится в России.

За рубежом в общемедицинской практике получили широкое распространение шприцы одноразового использования из полимерных материалов. В основном использовались две группы конструкций. К первой относились шприцы с эластичным уплотнением, выполненным из силиконовой резины (фирмы «Becton Dickinson», Франция, «Sherwood», США и др.). Технология производства включала дополнительные операции изготовления силиконовых резиновых уплотнений, что повышало надёжность конструкции в работе. Ко второй группе относились шприцы с эластичными цилиндрами и жёсткими штоками (фирма «Braun», ФРГ). Эти шприцы были менее надёжны в работе из-за частичного перетекания жидкости между поршнем и цилиндром. В нашей стране в 60-е годы предпринимались попытки раз- 
работать шприцы из полимерных материалов, но по разным причинам они были неудачными. Несмотря на это, работы над шприцами одноразового использования из полимерного материала продолжались, потому что преимущества этих шприцев были очевидны и заключались не только в технологии их изготовления, но и в значительном снижении проблемы «шприцевого» пути передачи вирусного гепатита В и других инфекций.

Во ВНИИ медицинских полимеров была разработана конструкция шприца одноразового использования ёмкостью 5 мл - прозрачный, гладкий цилиндр с чёткой шкалой, головка стандартного конуса шприца «Рекорд», в комплекте 2 иглы с пластмассовыми канюлями. Шприц поступал к потребителю стерильным, упакованным в индивидуальный полиэтиленовый пакет, предназначался для внутримышечных и подкожных инъекций. В 1971 г. на Ленинградском заводе медицинских полимеров была выпущена опытнопромышленная партия шприцев в количестве 100000 штук и передана для клинических испытаний в Москве и Ленинграде. В 1974 г. завод приступил к серийному выпуску этих шприцев (Перцов Р.И. и соавт.). Производство одноразовых шприцев несложно, высокопроизводительно, поддаётся механизации и автоматизации. Отмечалась экономия времени за счёт ликвидации операций по подготовке, обработке и стерилизации шприцев, лёгкий вес, прочность, малогабаритность и стерильность. Эти несомненные преимущества привели к постепенной смене стеклометаллических шприцев одноразовыми пластмассовыми, стерилизованными на производстве, не только в общемедицинской, но и стоматологической практике СССР.

\section{Безыгольные инъекторы}

Инъекционное введение анестетиков имеет ряд недостатков: болезненность в момент проведения анестезии, возможность травмы сосудов, поломки иглы, передачи через нее инфекции. Эти недостатки отсутствуют при безыгольном способе введения веществ в ткани организма (рис. 155).

Идея безыгольного способа введения лекарственных препаратов в организм возникла в 1866 г., когда француз А. Beclard описал аппарат, который позволял вводить вещество в ткани организма под высоким давлением (до 300 атм) в виде тончайшей струи. Однако только с 1947 г. благодаря исследованиям R.A. Hingson указанный способ приобрёл практическое значение.

Первое сообщение о применении струйных инъекций в стоматологии относится к 1958 г. (Margetis P. et al.). Авторы использовали инъектор «Нуроsprey» для местной анестезии у 66 стоматологических больных. 


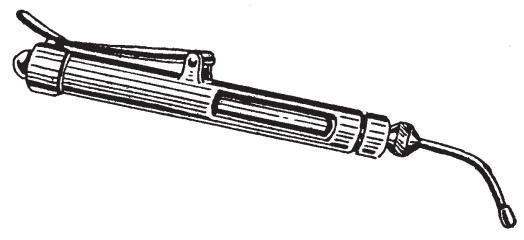

Рис. 155. Безыгольный инъектор БИ-1 с наконечником для стоматологической практики

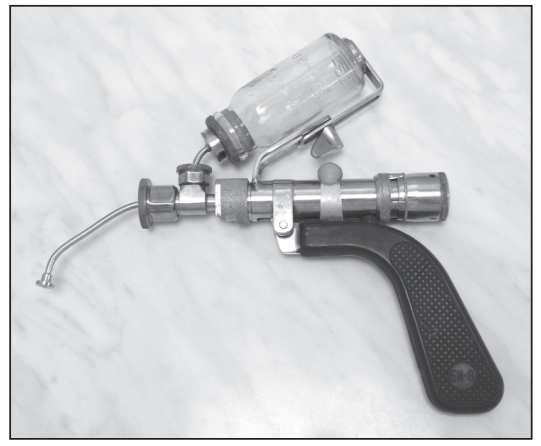

Рис. 156. Безыгольный инъектор БИ-8
Несмотря на то, что безыгольный инъектор был введён в клиническую практику более 40 лет назад, его широкое применение началось гораздо позже. В 60-70-е годы за рубежом этот способ получил широкое распространение. Создано множество разновидностей таких шприцев. Экспериментальные разработки по безыгольным инъекторам в нашей стране впервые проведены M.M. Трусовым в 1960 г. Первое клинико-экспериментальное исследование особенностей струйного способа проведения местной анестезии в стоматологии относится к 1972 г. (Гигаури В.С. и соавт.). Положительные результаты, полученные авторами, позволили применить отечественные безыгольные инъекторы для проведения местной анестезии в клинической стоматологической практике (Гигаури В.С. и соавт., 1973; Азрельян Б.А. и соавт., 1973). В среднем при операции удаления зуба, лечении по поводу пульпита, периодонтита требовалось 5-6 инъекций в разовой дозе 0,2 мл.

Этот метод в нашей стране стал шире применяться в стоматологической практике после того, как в 1977 г. отечественная промышленность начала выпускать специальный безыгольный инъектор, предназначенный для применения в полости рта (БИ-8 - рис. 156). Особенно активно он рекомендовался для применения в детской стоматологической практике (Васманова Е.В., Азрельян Б.А., 1979).

Если эти «шприцы без иглы» были полезны при проведении с соблюдением асептики массовых прививок безыгольным инъектором под названием «Пчёлка» (Воробьев А.А и соавт., 1972), то в стоматологии, несмотря на первые оптимистические отзывы (Мухин Н.А. и Гордиенко Т.П., 1972; Азрельян Б.А. и соавт., 1973; Berman C.L., 1967), инъекторы обнаружили недостатки, препятствующие их универсальному применению: многоинъекционность (Howe G.L., 
Whitehead F.J.H., 1972; Aling C.C., Christopher A., 1974; Bennett C.R., 1974), несовершенство конструкции (Рыбаков А.И. и соавт., 1979; Петрикас А.Ж., 1987) и осложнения в виде кровотечений, образования гематом и повреждений слизистой оболочки (Бернадский Ю.И., 1998).

Таким образом, отсутствие иглы не исключало попадание в кровеносное русло. Расчёт на пациентов, боящихся уко-

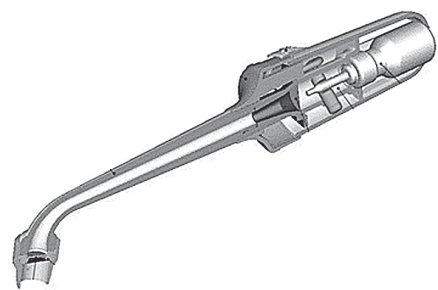

Pис. 157. Biojector 2000 лов, также не оправдал себя. Исследования А.Ж. Петрикаса показали, что эффективность анестезии безыгольным инъектором ниже по сравнению с обычной инъекционной техникой. При проводниковых анестезиях роль безыгольных инъекторов сводилась к обезболиванию места вкола иглы. Зарубежная модель «Сириджет Biojector 2000 (Bioject, Inc.) - рис. 157; Марк 2» (Syrijet Mark II, Mizzy, Inc.N.Y.) основана на картриджной системе и очень эргономична, позволяет решать анестетические проблемы пульпита, а не только обезболивания места вкола при инъекционной анестезии. Отечественный БИ-8 «капризен», имеет большую ёмкость для местного анестетика, рассчитанную на новокаин, и выполнен не из нержавеющей стали (более стойкой к воздействию кислых растворов анестетиков).

Несмотря на внедрение в клиническую практику и экономическую эффективность, безыгольные инъекторы разработанных конструкций не решали проблемы «шприцевого» гепатита и не соответствовали современным эпидемиологическим требованиям. В 1989 г. применение безыгольных инъекторов в нашей стране повсеместно прекращено «в целях обеспечения безопасности от кровяных инфекций» на основании Письма Минздрава СССР № 06-14/28-14 от 24 июля 1989 г. «О применении инактивированных гриппозных вакцин». Произошёл возврат к шприцевой вакцинации и анестезии.

За рубежом, особенно в США, Германии продолжалось совершенствование технологии безыгольной инъекции, и стали выпускать аппараты, соответствующие международному стандарту (ISO) и требованиям инфекционного контроля:

Madajet (MADA Medical Products, Inc.) - рис. 158 a;

Dermojet (Societe AKRA Dermojet) - рис. 159;

Vitajet (Vitajet Corp.);

Powderject (Powderject Pharmaceuticals Plc) и многие другие.

Американцы считают отцом современной безыгольной инъекционной системы Роберта Эндрю Хингсона (Robert Andrew Hingson, 1913-1996). 


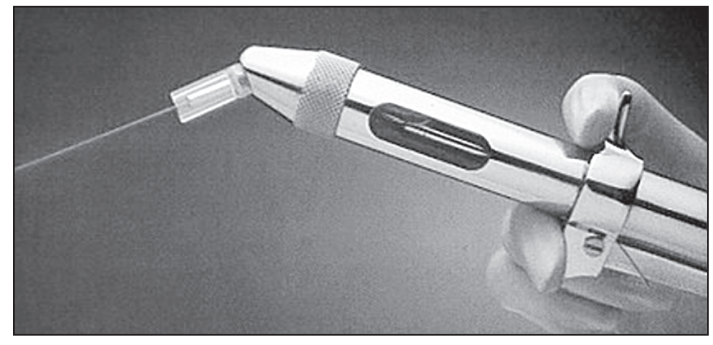

a

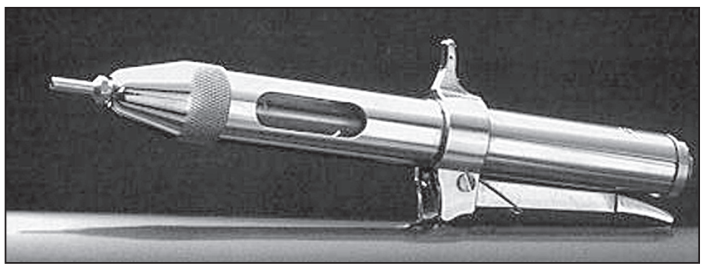

6

Рис. 158. Безыгольные инъекторы: а - Madajet; 6 - Madajet XL Dental

Biojector 2000 - безыгольная высокоскоростная система для введения лекарственных средств (анестетиков) с помощью одноразового стерильного наконечника. Пластмассовый наконечник - единственная часть системы, которая входит в контакт с кожей или слизистой оболочкой пациента. Благодаря этому устраняется риск гематогенного инфицирования пациента и медицинского персонала. После каждого введения наконечник отвертывается и вставляется новый для следующего пациента. Таким образом, исключается очистка, стери-

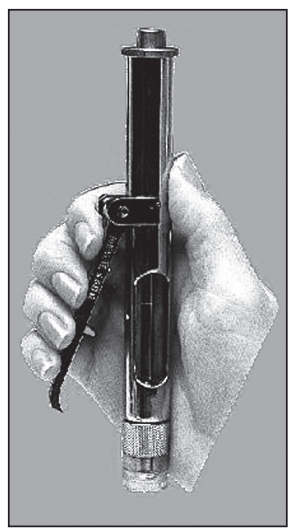

Рис. 159. Dermojet лизация и ежедневный контроль. Источник энергии сжатый углекислый газ - позволяет изгнать лекарственное средство через тончайшие отверстия за доли секунды. Каждый патрон с $\mathrm{CO}_{2}$ рассчитан на 10-15 инъекций. Одноразовый шприц запакован с иглой, которая используется только для забора лекарственного вещества в шприц. После заполнения шприца игла отсоединяется, а шприц вставляется в инъектор. Стерильный защитный колпачок обеспечивает предотвращение загрязнения контактной поверхности. Наконечник инъектора под углом $90^{\circ}$ плотно прижимается к месту инъекции. При нажатии на активатор производится инъекция. При анестезии у маленьких детей, боящихся уколов, к инъектору могут подсоединяться «Уши слона» - специальная насадка, напоминающая игрушку. 


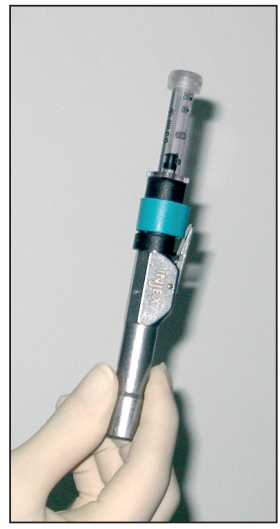

Рис. 160. Современный безыгольный инъектор Injex ${ }^{\text {TM }}$ (Rösch, Германия)

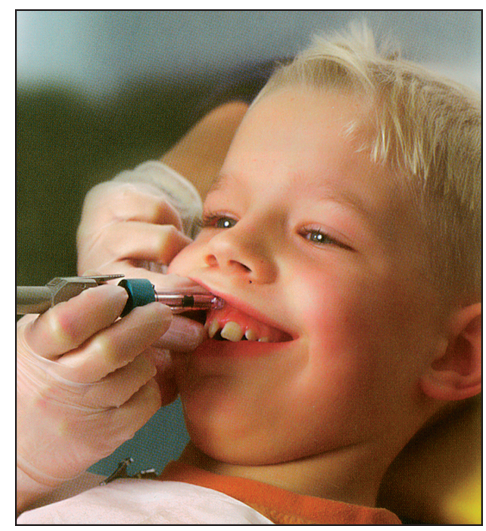

Рис. 161. Безыгольная инъекция в области фронтальных зубов у ребёнка

Madajet XL Dental (рис. 158 б) предназначен для местной анестезии нёба, регионарного блока в стоматологии и челюстно-лицевой хирургии.

Dermojet применяется для местной анестезии, иммунизации, лечения кожных заболеваний.

В последние годы в стоматологии используются различные безыголь-

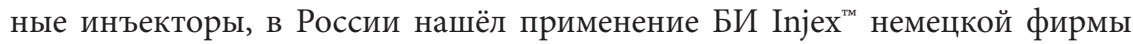
Rösch (рис. 160, 161). Особенно востребованы такие инъекторы в детской стоматологической практике из-за анатомо-топографических особенностей тканей и необычной конструкции шприцев.

Ампула объёмом 0,3 мл для анестезии 1-2 зубов. Количество вводимого анестетика (4\% артикаин) 0,1- 0,3 мл.

Показания к применению БИ «Injex» у взрослых пациентов (по данным Кузьменко Д.Ю., 2009): лечение резцов, клыков и премоляров по поводу кариеса, эндодонтическое лечение зубов, хирургическая санация полости рта.

Противопоказания: заболевания слизистой оболочки полости рта, периостит, острый периодонтит или обострение хронического периодонтита, экзостозы в области инъекции, лечение моляров.

\section{Автоматизированный компьютерный шприц}

В 1997 г. в США компанией «Milestone Scientific» изобретён новый шприц для местной анестезии в стоматологии с принципиально изме- 
нённой конструкцией. Это автоматизированный компьютерный шприц «WAND» (рис. 162). Прибор компактен. Состоит из рабочего блока с микропроцессором и индикаторами управления, ножной педали, с помощью которой производится подача анестетика, сетевого шнура и предлагаемого к ним набора одноразовых систем. В комплект также входят картридж для стандартной карпулы анестетика, капиллярный удлинитель и палочка с одноразовой иглой, которую изобретатели назвали «волшебной». Какие же он даёт преимущества?

1. В руках врача вместо традиционного шприца - наконечник в виде обычной шариковой авторучки с одноразовой иглой на конце. Визуальное изменение шприца не вызывает у пациента, особенно ребёнка, ассоциаций, связанных с болью. Наконечник (палочка) стерилен, им можно наносить гель аппликационного анестетика в место будущей инъекции.

2. Встроенная функция аспирации, выполняемая автоматически, позволяет уменьшить риск в образовании гематом, внутрисосудистых инъекций и осложнений, связанных с ними.

3. Конструкция прибора позволяет избежать инфицирования врача иглой после окончания процедуры анестезии, так как колпачок от иглы стоит в приёмном отверстии на приборе, и врач, промахнувшись, не уколет себя.

4. Упрощается техника анестезии: уменьшение проводниковых, увеличение возможностей нёбных инфильтраций и интралигаментарной анестезии.

5. Вращательная техника повышает точность проводниковой анестезии.

6. Точная дозировка и скорость введения анестетика независимо от плотности тканей (техника «SloFlow» при компьютерном управлении).
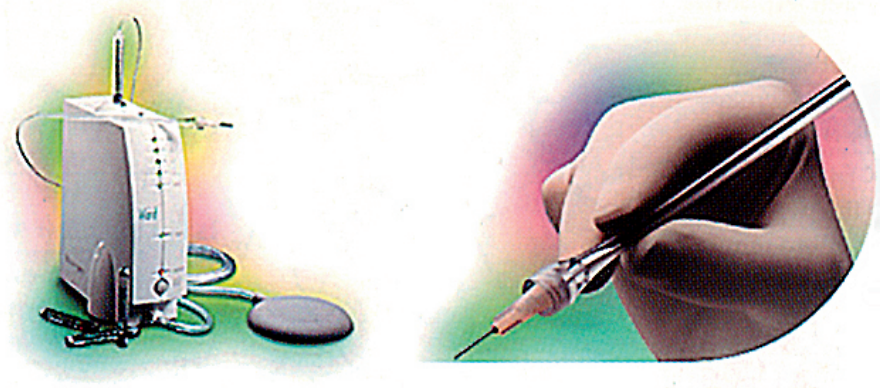

Рис. 162. Автоматизированный компьютерный шприц WAND для местной анестезии в стоматологии 


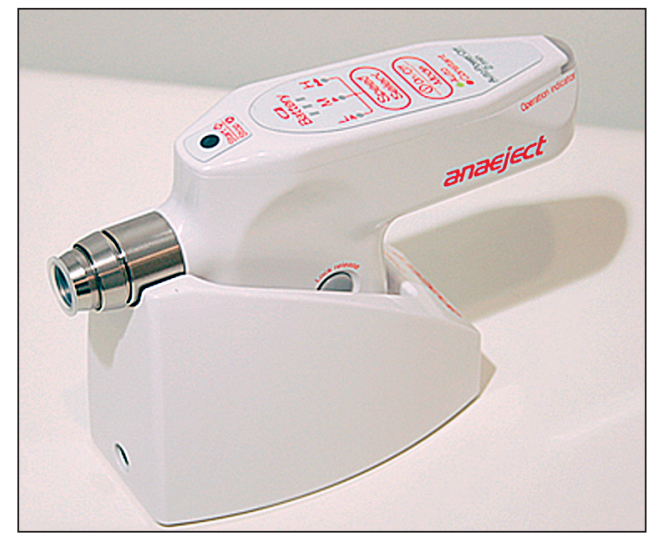

Рис. 163. Компьютерный шприц Аnaејесt (Япония)

На российском стоматологическом рынке эта система с 1998 г. представлена фирмой «СУАН».

Японская фирма «Нисака» несколько лет назад на стоматологический рынок стала производить первый в мире беспроводной электрический шприц Энэджект (Anaeject) со встроенной компьютерной программой управления. В шприце запрограммированы три скорости подачи местного анестетика. Безболезненна сама анестезия. Шприц эргономичен, вес его 240 г. Для устранения страха и стресса в процессе инъекции воспроизводится музыка (рис. 163). 


\section{ИСТОРИЯ РАЗВИТИЯ ТЕХНИКИ МЕСТНОЙ АНЕСТЕЗИИ В СТОМАТОЛОГИИ}

\section{Клетчаточные пространства}

Отечественные учёные внесли большой вклад в изучение топографической анатомии человека. Классические исследования в этой области, не утратившие своей научной ценности до наших дней, принадлежат гениальному русскому ученому-хирургу Н.И. Пирогову. Проведённое им (1852) изучение большой серии распилов замороженных трупов является и в наше время образцом точных анатомических исследований. Большое внимание Н.И. Пирогов уделил изучению топографии клетчаточных пространств, подробно описал расположение клетчатки в заднебоковом отделе лица, где выделил височно-крыловидно-челюстную ямку. Она ограничена сверху височной костью, снизу - углом нижней челюсти, с внутренней стороны крыловидным отростком основной кости, с наружной - нижней челюстью и скуловой дугой. Эта обширная область делится мышцами на несколько пространств: височно-крыловидное, расположенное между наружной поверхностью латеральной крыловидной мышцы и внутренней поверхностью височной мышцы; межкрыловидное, ограниченное латеральной и медиальной крыловидными мышцами, и крыловидно-челюстное (современное название: крыловидно-нижнечелюстное). Для врача-стоматолога знание особенностей строения крыловидно-нижнечелюстного пространства имеет большое практическое значение, так как в нём располагаются ветви нижнечелюстного нерва (Евдокимов А.И., 1930).

Топографической анатомии в связи с местным обезболиванием посвящены работы Я.А. Ицкина (1929), И.М. Айзенштейна (1940), С.Н. Вайсблата (1962), П.М. Егорова (1978, 1981).

\section{Инфильтрационная анестезия}

Большинство хирургов и анестезиологов считают, что приоритет открытия инфильтрационной анестезии принадлежит П. Реклю (1889) и K. Шлейху (1891). C.L. Schleich в 1891 году опубликовал результаты послойной кокаинизации тканей при 224 операциях, в том числе при лапарото- 
миях и устранении грыж. Меньшая часть, в основном отечественные специалисты, считают, что пионером инфильтрационной анестезии является русский врач А.И. Лукашевич. Он в 1886 году установил, что «инъекции кокаина вызывают обезболивание не только в месте введения, но и в области разветвления нервов, подвергшихся кокаинизации при инфильтрации (выделено нами) окружающих их тканей» (Вишневский А.В., 1954; Кузин М.И., Харнас С.Ш., 1993).

Один из основоположников местной анестезии A. Bleichsteiner считает, что начиная с 1885 года в немецкой литературе появилось такое обилие сообщений по инфильтрационному обезболиванию, что невозможно выделить среди них ведущее (Шефф И., Грубе В.Ф., 1896). Инфильтрационная анестезия зубов впервые проводилась в 1885 году A. Woltler, H. Landerer, A. Witzel (Петрикас А.Ж., 1997). Поэтому можно констатировать с большой степенью риска, что приоритет использования инфильтрационной анестезии принадлежит А. Вольтлеру, Г. Ландереру и А. Витцелю (Германия).

Первый этап развития местной инфильтрационной анестезии был завершён работами Реклю (P. Reclus) в 1890 г. и Шлейха (Schleich C.L.) в 1891 г. Шлейх, используя 0,01-0,2\% кокаин в гипотонических растворах различных солей, считал, что набухание тканей увеличивает анестезирующий эффект кокаина. Позднее растворы Реклю и Шлейха заменили 0,5\% раствором новокаина.

При обширных операциях ткани инфильтрировали по окружности операционного поля. Местная анестезия по Шлейху-Реклю была широко распространена, хотя давала лишь хорошую анестезию кожи и отчасти подкожной клетчатки. Принципиальным недостатком метода Шлейха-Реклю было то, что контакт анестезирующего раствора с нервными окончаниями и стволами обеспечивался диффузией. Этот метод не мог обеспечить надёжную анестезию при операциях в челюстно-лицевой области, на органах грудной и брюшной полостей. При манипуляциях на глубоких тканях приходилось выжидать 3-5 мин, прежде чем удавалось продолжить операцию. Все эти недостатки привели к тому, что к 20-м годам метод инфильтрационной анестезии по Шлейху-Реклю, по словам А.В. Вишневского, «был совершенно дискредитирован как метод широких возможностей».

Второй этап развития местной инфильтрационной анестезии связан с именем отечественного хирурга профессора А.В. Вишневского. Значение, преимущества и недостатки этого метода изложены выше.

Третий этап - возрождение инфильтрационной анестезии, особенно в стоматологии, - связан с разработкой более эффективных анестетиков и совершенствованием техники (интралигаментарная анестезия и др.). 


\section{Проводниковая (мандибулярная) анестезия}

Проводниковую анестезию нижнего альвеолярного и язычного нервов, так называемую мандибулярную анестезию, чаще всего используют при оперативных вмешательствах на нижней челюсти и окружающих её мягких тканях. В.Ф. Войно-Ясенецкий (1915) указывает, что мандибулярную анестезию впервые выполнили Halsted и Raymond в 1885 году. Raymond ввёл в область язычка нижней челюсти 13 капель 4\% раствора кокаина. Наступившее через 7 мин почти полное обезболивание правой половины нижней челюсти и языка продолжалось 28 мин.

В монографии А.Ж. Петрикаса (1997) приводится следующая историческая справка: «В ноябре 1884 г. С.A. Nash после инъекции раствора кокаина вблизи подглазничного отверстия известному хирургу P.С. Hall безболезненно препарировал и пломбировал центральный резец. Оба исследователя опубликовали это наблюдение. Затем в декабре 1884 г. Р.С. Нall описал клинику и технику проводниковой внутриротовой анестезии на нижней челюсти, которую ему произвёл коллега W.S. Halsted. Но только последний считается пионером мандибулярной анестезии». Итак, американский хирург Уильям Стюарт Холстед (William Steward Halsted) стал первым клиницистом, применившим кокаин для проводниковой блокады нижнего альвеолярного нерва при удалении зуба (рис. 164).

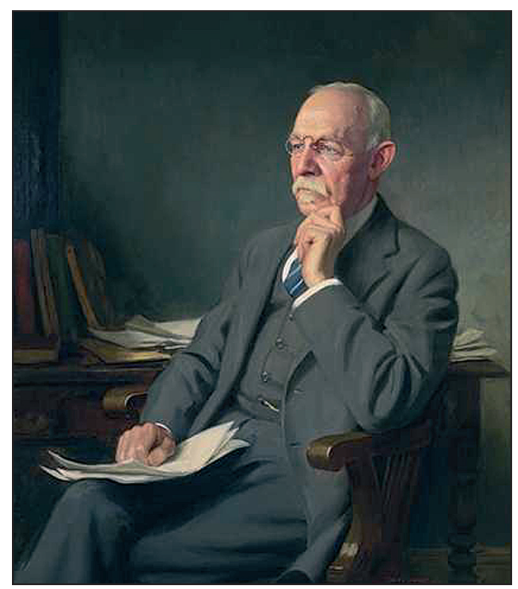

Рис. 164. Уильям Холстед (1852-1922). Американский хирург, ввёл в хирургическую практику проводниковую анестезию (1884), впервые применил резиновые стерилизуемые перчатки (1890), для ушивания поверхностных ран предложил однорядный внутрикожный непрерывный шов, а глубоких - двухрядный по Холстеду-Золтану 
К сожалению, Halsted, проводя свои эксперименты, стал наркоманом и потратил 2 года на борьбу с лекарственной зависимостью. В 1887 г. Дж. Крайл (Crile G.W.) сообщает об эндоневральной анестезии.

Подлинный же приоритет открытия проводниковой анестезии, как указывает А.М. Середницкий (1952), правда, в эксперименте и путём воздействия на нерв парами эфира, принадлежит русскому хирургу Н.В. Маклакову, который в своей монографии «Об употреблении в оперативной медицине паров серного эфира» (1847) писал: «...Обнажите у здорового животного нерв и приведите его в соприкосновение с эфиром, - животное в

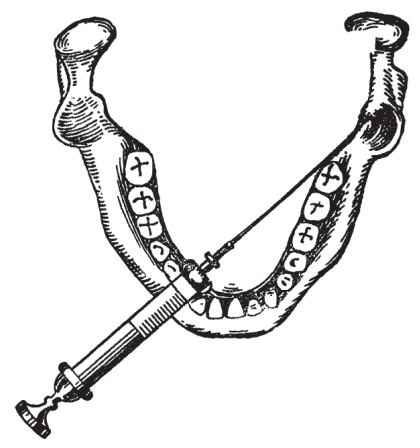

Рис. 165. Мандибулярная анестезия по Брауну (Ил. по В.Ф. ВойноЯсенецкому, 1946.) течение $1 / 2$ минуты будет обнаруживать от этого боль и производить органом усиленные движения. Через 1,5-2 минуты, пробуя раздражать нерв в точках соприкосновения с эфиром, вы уже заметите в нём значительный упадок чувствительности. По прошествии ещё 4-5 минут от начала опыта - как самый нерв, так и все те части, которым он посылает ветви, представляются совершенно парализованными, и после того уже ни чувствительность, ни способность производить движения к ним не возвращаются. Если вы посредством острой и тонкой иглы осторожно приподнимите и разорвёте наружную неврилематическую покрышку нерва и потом уже приведёте его в соприкосновение с эфиром, тогда парализация подлежащих частей произойдет несравненно быстрее». В дальнейшем успешные попытки обезболивания нижнего альвеолярного нерва предпринимали многие известные хирурги, стоматологи и зубные врачи. C.L. Schleich (1898), руководствуясь топографическими исследованиями на трупах, при проведении блокады нижнего луночкового нерва у нижнечелюстного отверстия рекомендовал найти пальцем передний край ветви нижней челюсти и вколоть иглу по середине расстояния между верхними и нижними молярами у внутренней поверхности переднего края ветви нижней челюсти. Затем продвинуть иглу несколько кверху и кзади вдоль кости по направлению к нижнему луночковому нерву на глубину 2-3 см. По мере продвижения иглы выпускают 2-2,5 мл раствора анестетика, который инфильтрирует периневральные ткани у язычка и блокирует нерв.

H. Braun (1905) учёл особенности расположения ветвей нижнечелюстного нерва у отверстия нижней челюсти и предложил другой способ их обез- 
боливания. При проведении анестезии он советовал указательным пальцем определить передний край ветви нижней челюсти, медиальнее которого находится ретромолярный треугольник, впервые детально описанный им. Автор рекомендовал расположить цилиндр шприца на противоположной стороне в области клыка и при широко открытом рте вколоть иглу в центр ретромолярного треугольника на 1 см выше жевательной поверхности нижней челюсти (рис. 165). На всём пути следования иглы, начиная от слизистой оболочки, под которой располагается язычный нерв, он советовал вводить 2-6 мл 1\% или 2\% раствора новокаина. Н. Braun подчёркивал, что описанную им методику модифицировать невозможно, так как она является «сама собой разумеющейся». Действительно, эта методика до настоящего времени не претерпела существенных изменений. Однако в отечественной и зарубежной литературе при описании этого метода мандибулярной анестезии многие авторы указывают иные ориентиры для вкола иглы в вертикальной и горизонтальной плоскостях, рекомендуют погружать иглу глубже или, наоборот, более поверхностно и т. д. (Гофунг М.Е., 1913; Гепштейн И.Я., 1929; Ицкин Я.А., 1929; Верлоцкий А.Е., 1938, 1960; Вейсбрем М.М., 1940; Коцубей Л.А., 1940; Энтин Д.А., 1940; Скопец Е.В., 1949; Кадочников Б.Ф., 1956; Сарманаев Р.Б., 1956; Войно-Ясенецкий В.Ф., 1956; Итина А.И. и соавт., 1958; Старобинский И.М., 1960; Александров Н.М. и соавт., 1976; Егоров П.М., 1981-1985; Петрикас A.Ж., 1997; Levit B., 1924, 1929; Sicher H., 1925; Kepper, 1926; Ginestet G., 1927; Berg H., 1940; Laguardia, 1940; Seldin H., 1948; Russanow J., 1956; Archer W.H., 1958; Kantorowisz A., 1959; Kriesell G., 1959; Jorgensen N.B., 1967; Dscherov D., Russanow J., 1971, Rood J.F., 1972; Goy-Gates G.A.E., 1973 и др.).

Другой распространённый способ мандибулярной анестезии был предложен G. Fischer (1911). С правой стороны его проводят следующим образом. Голову больного укладывают так, чтобы нижнечелюстная окклюзионная плоскость располагалась параллельно горизонтальной плоскости. Ощупывают передний край ветви нижней челюсти и помещают указательный палец левой руки в ретромолярную ямку. Цилиндр шприца располагают на премолярах левой стороны и при широко открытом рте вкалывают иглу на уровне середины ногтевой фаланги указательного пальца. После этого иглу продвигают на глубину около 6 мм, до контакта с костью, стараясь при этом не травмировать надкостницу. Далее, чтобы обойти височный гребень, осторожно перемещают шприц вправо до тех пор, пока он не будет располагаться параллельно молярам. Затем иглу продвигают ещё на 6 мм и медленно выпускают 0,5 мл раствора анестетика для выключения язычного нерва. После этого шприц осторожно переводят обратно примерно в первоначальное положение (в зависимости от отклонения ветви нижней челю- 
сти) и дополнительно перемещают иглу параллельно горизонтальной плоскости на глубину 10-15 мм, до контакта с костью в области заднего края бороздки шейки нижней челюсти, где вводят ещё 1,5 мл раствора анестетика. В зависимости от ширины ветви нижней челюсти общая глубина погружения иглы колеблется от 22 до 27 мм. При проведении обезболивания с левой стороны проводят те же манипуляции, ощупывание переднего края ветви нижней челюсти и ретромолярной ямки выполняют также левой рукой (рис. 166, 167).

Большую роль в усовершенствовании внутриротовых методов мандибулярной анестезии сыграли работы отечественных учёных. А.Е. Верлоцкий (1938) усовершенствовал беспальцевый, или так называемый аподактильный, способ внутриротовой мандибулярной анестезии. Автор рекомендовал помещать цилиндр шприца между нижним клыком

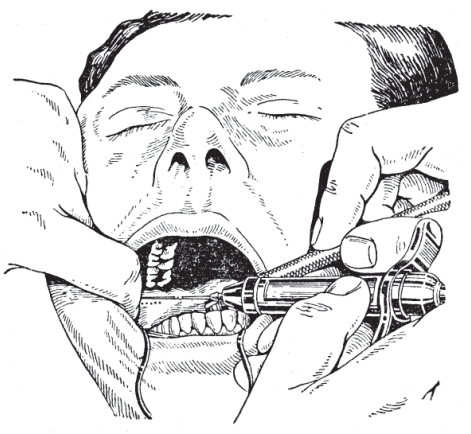

Рис. 166. Мандибулярная анестезия по Фишеру (Ил. по М.Д. Дубову, 1969.)

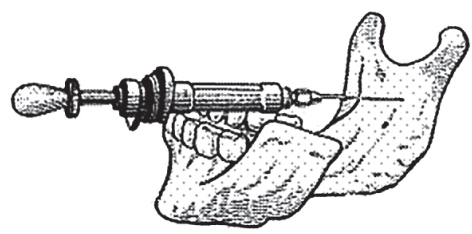

Рис. 167. Положение иглы при инъекции у нижнечелюстного отверстия (по Фишеру) и вторым моляром с противоположной стороны. Место укола - латеральный край крыловидно-нижнечелюстной складки и биссектриса угла, образованного плоскостями, проходящими через жевательные поверхности верхних и нижних зубов. По методике автора иглу продвигают вглубь мягких тканей на 1,5-2 см, до контакта с костью (рис. 168). Больным с широкой крыловидно-нижнечелюстной складкой А.Е. Верлоцкий рекомендовал делать инъекцию в середину крыловиднонижнечелюстной складки, а при узкой - в её медиальный край. Для выполнения анестезии этим способом необходимо широко открыть рот. При ограниченной подвижности нижней челюсти этот способ применять нельзя (Вайсблат С.Н., 1962).

Д.А. Энтин (1940) подчёркивает, что при выполнении мандибулярной анестезии по Брауну иногда происходит перелом иглы, и конец её оказывается в мышечном слое. Чтобы предупредить это осложнение и упростить технику мандибулярной анестезии, Д.А. Энтин рекомендует при максимально открытом рте направлять иглу почти перпендикулярно к внутренней по- 


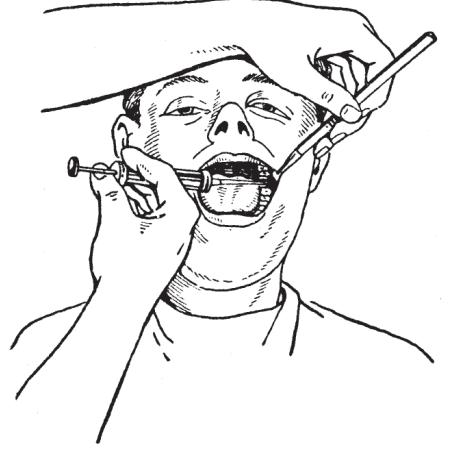

Рис. 168. Аподактильный способ внутриротовой мандибулярной анестезии по А.Е. Верлоцкому верхности ветви нижней челюсти. По его модификации делать инъекцию необходимо на 1 см кзади и выше нижнего третьего моляра и, продвинув иглу до кости, ввести 1 мл анестезирующего раствора, после чего, не прекращая введения анестетика, медленно вывести иглу. Через 2-15 мин наступает анестезия нижнего луночкового и язычного нервов. Для выключения щёчного нерва он рекомендует вводить дополнительно в зоне расположения нерва под слизистую оболочку 0,5 мл обезболивающего раствора. На основании результатов более чем 15 тыс. анестезий, выполненных по этой методике, Д.А. Энтин считает, что она наиболее эффективна.

По мнению B. Levit (1924), переломов иглы, которые часто встречаются при мандибулярной анестезии, можно избежать. Для этого надо исключить повороты и отклонения иглы от прямой линии при её продвижении к отверстию нижней челюсти. Он не советует также скользить концевым отделом иглы по неровной внутренней поверхности ветви нижней челюсти. B. Levit рекомендует вводить иглу при широко открытом рте в латеральный край крыловидно-нижнечелюстной складки на 1 см выше и параллельно окклюзионной плоскости нижних моляров. При этом продвигают иглу, не касаясь ею кости. На глубине 2,5 см выпускают 1,5 мл раствора анестетика для блокирования нижнего альвеолярного нерва. Затем, сохраняя то же направление, выводят иглу на половину глубины и вводят оставшиеся 0,5 мл раствора для блокирования язычного нерва. В 1929 г. B. Levit пришёл к очень важному и правильному выводу, что при любом способе мандибулярной анестезии, основанном на стандартной высоте вкола иглы, могут отмечаться случайности. Для устранения недостатков B. Levit внёс некоторые коррективы в свою методику мандибулярной анестезии. Он советует вводить иглу при максимально открытом рте в латеральный край крыловиднонижнечелюстной складки не на 1 см выше уровня поверхности смыкания нижних моляров, а в точку, расположенную на середине расстояния между верхней и нижней окклюзионными плоскостями. По мнению автора, такой подход к определению высоты вкола иглы позволяет учитывать индивидуальные особенности расположения бороздки шейки нижней челюсти. Способ определения высоты вкола иглы, по мнению П.М. Егорова (1985), Ле- 
вит заимствовал у Шлейха (1898) и по сути дела использовал также стандартное расстояние - половину высоты крыловиднонижнечелюстной складки.

Способ М.М. Вейсбрема - обезболивание на нижнечелюстном возвышении - предложен в 1940 г., а опубликован в журнале «Стоматология» в 1941 г. М.M. Вейсбрем, преподаватель зубоврачебной школы в Пятигорске, назвал нижнечелюстным возвышением (torus mandibulae) плоский костный выступ, расположенный впереди и выше язычка нижней челюсти. Этот выступ образован скрещением плоских гребешков, идущих книзу от мышелкового и венечного отростков, проецируется на слизистую оболочку полости рта в бороздке, которая образуется при широко открытом рте между краем крыловиднонижнечелюстной складки и слизистой оболочкой, покрывающей височный гребень (внутренний край ретромолярной ямки). В рыхлой клетчатке крыловиднонижнечелюстного пространства на уровне нижнечелюстного возвышения проходят нижний луночковый, язычный и щёчный нервы (рис. 169, 170). Таким образом, обезболивающий раствор, введённый в область нижнечелюстного возвышения, прерывает одновременно проводимость всех трёх нервов. По простоте, доступности выполнения и эффективности способ М.М. Вейсбрема заслуживает распространения (Дубов М.Д., 1969). На сегодняшний день он является методом выбора.

На рис. 171, 172 представлены схематическое изображение и клинический пример анестезии у нижнечелюстного отверстия, которые применяются в современных условиях.

Лагарди (Laguardia, 1940) предложил оригинальную внутриротовую методику мандибулярной анестезии, которую можно применять также и при контрактуре нижней челюсти. По его мнению, точность определения отвер-

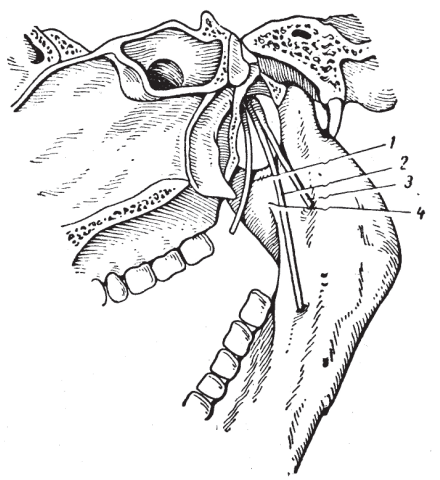

Рис. 169. Схема проекции нервов на нижнечелюстном возвышении (Вейсбрем M.M.)

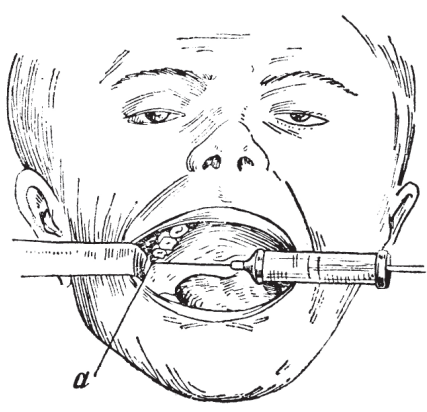

Рис. 170. Обезболивание по М.М. Вейсбрему 
стия нижней челюсти не имеет решающего значения при введении анестетика для блокады ветвей нижнечелюстного нерва. Значительно большую роль при этом играет всё пространство, расположенное над этим отверстием и над бороздкой шейки нижней челюсти, в котором проходят стволы нервов. Это пространство имеет ширину и высоту около 1 см. С латеральной стороны оно ограничено ветвью нижней челюсти, а сзади свободно и не имеет границ. Исходным пунктом для определения места вкола иглы является передний край ветви нижней челюсти. Концевой фалангой II пальца левой руки пальпируют место слияния наружной и внутренней косых линий над ретромолярным треугольником. Затем как можно выше ощупывают передний край ветви нижней челюсти и на уровне шеек зубов верхней челюсти делают инъекцию почти под прямым углом к верхнему зубному ряду. Иглу продвигают по внутренней поверхности ветви нижней челюсти на глубину 2 см.

Если ветвь нижней челюсти широкая, то иглу погружают глубже. По пути продвижения иглы выпускают небольшое количество обезболивающего раствора.

Далее иглу направляют вниз и латерально и тем ниже, чем выше место вкола иглы, и вводят оставшуюся часть анестетика. Обычно анестезия наступает через 2-3 мин и длится около 2 часов.

По мнению G. Fischer, предложенный Laguardia способ является лучшим из всех внутриротовых методов. Подлежащие блокированию у верхнего края борозды шейки нижней челюсти нижний альвеолярный и язычный нервы располагаются ближе друг к другу, поэтому их легче обезболить. Кроме того, одновременно блокируется щёчный нерв.

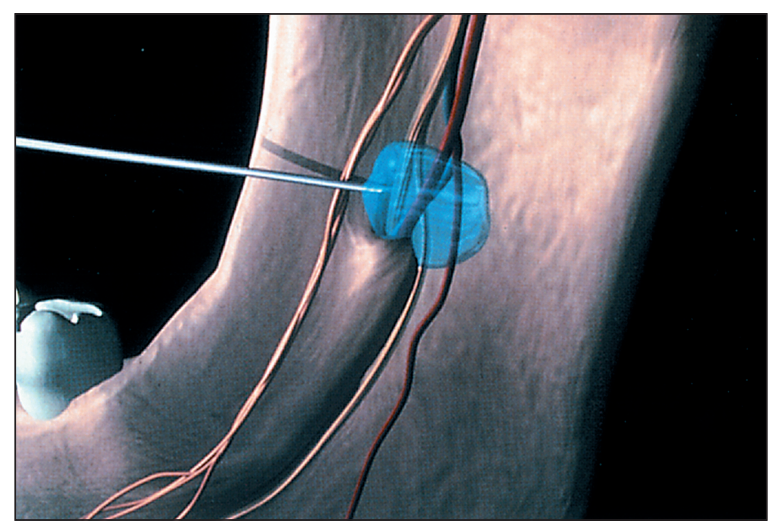

Рис. 171. Схематичное изображение проведённой правильно анестезии у нижнечелюстного отверстия. (Ил. М. Lipp, 1992.) 
В последнее десятилетие в отечественной литературе начато обсуждение методик блокады нижнелуночкового нерва по Гоу-Гейтсу (1973) и Вазирани (1960)-Акинози (1977) - рис. 173.

Так, в статье С.М. Шувалова «Блокады нижнелуночкового нерва по Гоу-Гейтсу и Б.Ф. Кадочникову (Вазирани-Акинози): особенности проведения обезболивания и преподавания студентам сто-

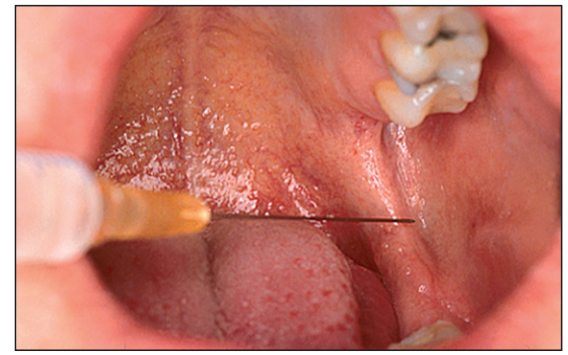

Рис. 172. Современная проводниковая анестезия у нижнечелюстного отверстия матологических факультетов», опубликованной в Материалах I съезда челюстно-лицевых хирургов Украины (2009), проведён анализ эффективности, техники проведения анестезии с учётом топографических особенностей расположения нижнечелюстного нерва по изготовленным им анатомическим препаратам. Представленный в статье материал содержит ряд критических замечаний о возможности широкого распространения данной методики обезболивания и совершенно справедливо указывается на приоритет Б.Ф. Кадочникова (1956) в разработке вестибулярного пути обезболивания нижнечелюстного нерва. В связи с чем приводим фрагмент этой статьи.

«Данные способы обезболивания считаются наиболее эффективными и безопасными и в тоже время наименее изученными и редко применяемыми. В одной из своих статей С.Т. Сохов и С.А. Рабинович (2009) назвали их альтернативными.

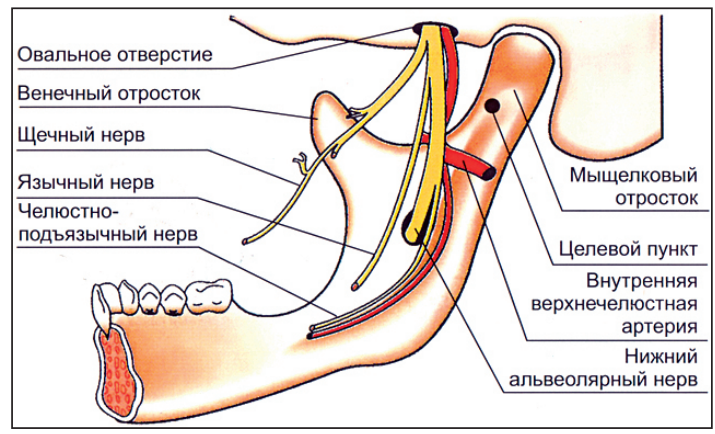

Рис. 173. Анестезия по Гоу-Гейтсу. Ориентиры и целевой пункт по методу Джорджа Гоу-Гейтса 


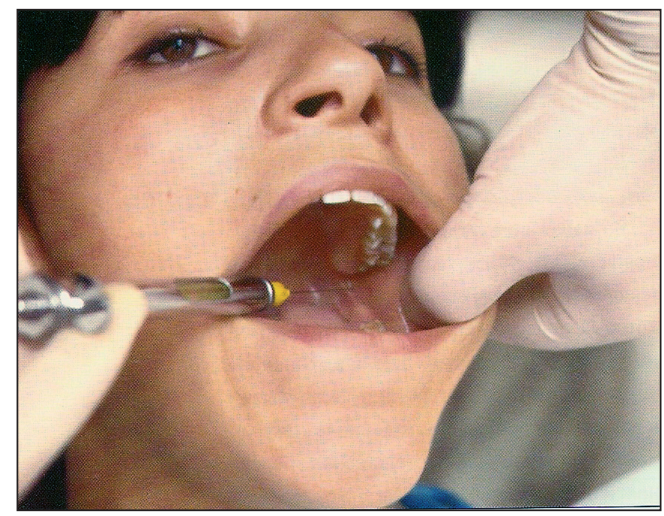

Рис. 174. Техника по Гоу-Гейтсу на нижней челюсти в модификации положения пальцев левой руки (Рабинович С.А., Московец О.Н., 1999; ил. по А.И. Бизяеву и соавт., 2000.)

Проведение данных блокад в настоящее время не получило широкого распространения, тем не менее, уже включено в учебную программу по хирургической стоматологии. Одним из недостатков блокады по Гоу-Гейтсу является сложность её проведения, несмотря на предложенную С.А. Рабиновичем и О.Н. Московцом (1999) высокоэффективную модификацию методики, включающую новые топографо-анатомические ориентиры и мануальный приём (рис. 174).

Известно также, что при данной блокаде анестезия наступает позднее, чем это происходит при широко распространённых методах (торусальной и мандибулярной). Этот факт косвенно свидетельствует о том, что кончик иглы при проведении его к целевому пункту находится на большом расстоянии от ствола n. mandibularis и лишь высокая диффузионная способность современных анестетиков позволяет достигать обезболивания. Нами были изготовлены несколько анатомических препаратов нижнечелюстного нерва от места его выхода из овального отверстия на основании черепа до входа в канал нерва в нижней челюсти. По выходе из овального отверстия нерв опускается почти вертикально вниз, а на уровне нижнечелюстного отверстия делает изгиб, располагаясь практически под прямым углом к ветви нижней челюсти. Данное расстояние (запас длины) обеспечивает безопасность нерва при широкой амплитуде движений нижней челюсти (рис. 175).

Природа предусмотрительно отвела этот достаточно мощный нервный ствол (от 3,5 до 7,5 мм в диаметре по данным Т.В. Золотаревой, Г.Н. Топорова, 1968) от подвижной капсулы височно-нижнечелюстного сустава и мыщелкового отростка, основание которого и является целевым пунктом проведения 
иглы, но нерв при этом оказывается значительно медиальнее. На этот факт совершенно определённо указывал В.Ф. Войно-Ясенецкий («Очерки гнойной хирургии». - Л.: Медгиз, 1956. - С. 607): «...игла должна быть вколота на 5-10 мм выше жевательной поверхности коренных зубов. Выше вкалывать иглу не следует, так как уже немного выше foramen mandibulare n.alveolaris inferior отходит кнутри от восходящей ветви челюсти».

Сравнивая внутриротовые способы проведения блокад нижнелуночкового нерва, ряд авторов (Ибрагимов 3.И. и соавт., 2009) методику ГоуГейтса назвали образно «высокой». Расположив способы проведения блокад по внутренней поверхности ветви нижней челюсти можно выделить три уровня: «мандибулярная», торусальная, у шейки мыщелкового отростка. А с учётом методики обезболивания нижнечелюстного нерва, у овального отверстия можно выделить и четвёртый уровень. Данное деление нам представляется методологически верным и удобным вариантом преподавания вопросов проводникового обезболивания.

Проведение блокад у шейки мыщелкового отростка и у овального отверстия требует выработки клинически обоснованных показаний, дальнейшего глубокого изучения, после чего возможно более широкое внедрение в практику. Данные методики обезболивания в настоящее время применяются лишь опытными врачами.

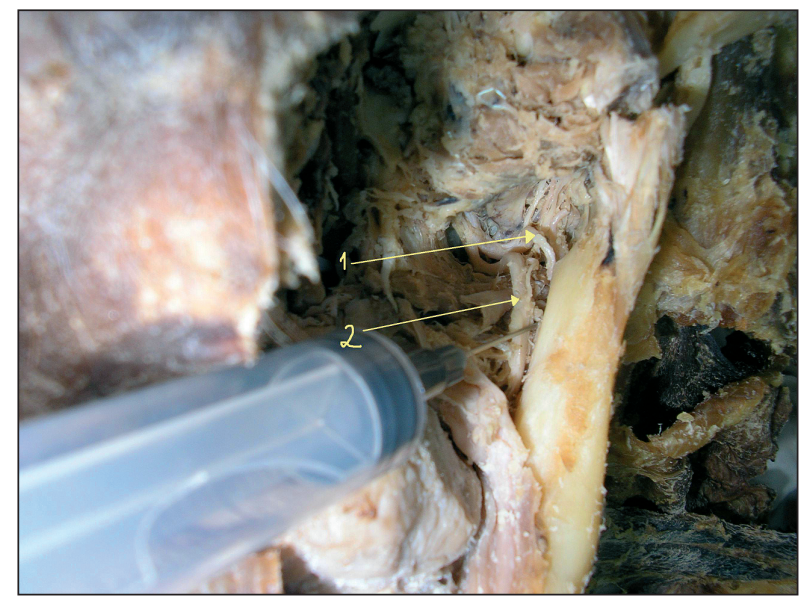

Рис. 175. Один из анатомических препаратов, любезно представленных профессором С.М. Шуваловым. 1 - нижнелуночковый нерв; 2 - язычный нерв, петля которого расположена наиболее близко к игле, в связи с чем анестезия, прежде всего, наступает в области языка. Препарат приготовлен С.М. Шуваловым и А.А. Малаховской. Публикуется с разрешения 
Другим видом обезболивания нижнелуночкового нерва, предложенным как новым, является блокада по Вазирани (1960)-Акинози (1977). Этот метод стал широко известен после опубликования его С. Маламедом (1990) в его «Руководстве по местному обезболиванию». Метод рекомендован при воспалительно-рефлекторной контрактуре нижней челюсти (рис. 176).

Суть его заключается в следующем: (цит. по С.А. Рабиновичу, 2000): «Шприи с иглой ориентируют параллельно окклюзионной плоскости и по касательной тинии к заднему отделу альвеолярного отростка верхней челюсти. Затем иглу вводят в слизистую возле третьего моляра верхней челюсти и продвигают вдоль медиальной поверхности ветви нижней челюсти. Рекомендуемая глубина погружения в ткани ... составляет 25 мм. После погружения кончик иглы должен расположиться у середины ветви нижней челюсти возле нижнечелюстного отверстия, где и вводят местноанестезирующий раствор».

Данный вид блокады был описан впервые в 1956 году Б.Ф. Кадочниковым в «Сборнике научных работ 209 стоматологической поликлиники Таврического военного округа»- Симферополь, 1956. - С. 63-66. Этот сборник научных трудов по стоматологии явился первым изданием в Советской Армии, а хирургический его раздел был представлен работами В.И. Кулаженко, Б.Ф. Кадочникова, В.Ф. Рудько, А.И. Рыбакова, в то время кандидатами медицинских наук. По описанию Б.Ф. Кадочникова: «Анестезия проводится по типу торусальной, но не со стороны собственно полости рта, а из преддверия рта на стороне анестезии, т.е. игла направляется не перпендикулярно к поверхности торуса, а проводится к нему по касательной линии.
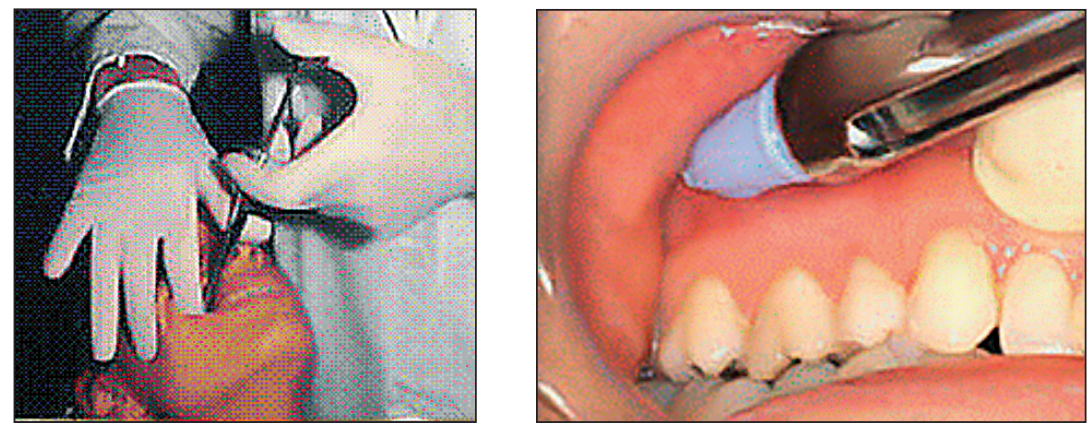

Рис. 176. Анестезия по Вазирани-Акинози. Справа крупный план.

(Ил. по N. Robb, 2005.) 

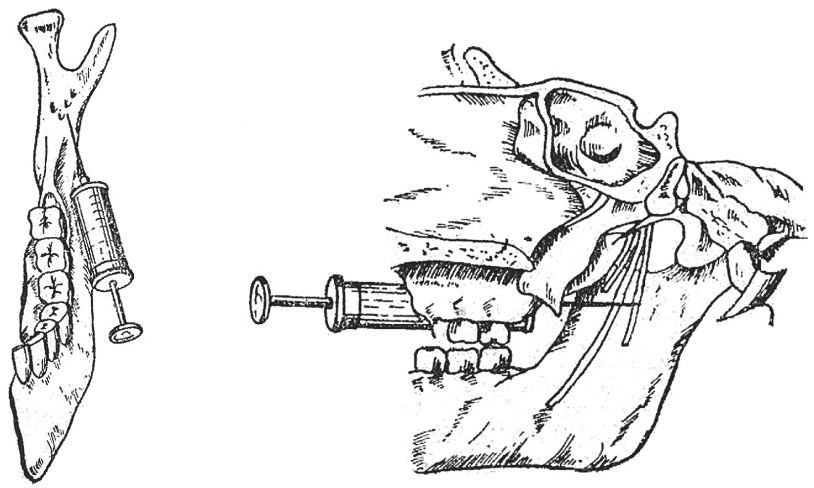

Рис. 177. Место введения иглы и большой позадимолярный треугольник.

(Ил. по Б.Ф. Кадочникову, 1956.)

Техника анестезии сводится к следующему. Игла средней толщинь, при неполностью открытом рте, прокалывает слизистую над верииной большого позадимолярного треугольника, образуемого наружной и внутренней косыми линиями нижней челюсти (рис. 177).

Срез игль следует направлять в сторону кости. Коснувшись в этом участке переднего края восходящей ветви челюсти, под небольшим углом кверху (20-30 ) и параллельно сагиттальной плоскости головы, игла проводится по внутренней поверхности восходящей ветви челюсти над торусом на глубину 3-31/2 см, где выпускается 2- 21/2 мл 2\%-ного раствора новокаина с адреналином, причём в ширище оставляется 1-11/2 мл анестезирующего раствора, который выпускается при выдвигании иглы наружу для обезболивания язычного и щёчного нервов. Таким образом, игла и шприи всё время находятся в преддверии рта.

При полностью открытом рте высота места укола иглы соответствует уровню жевательной поверхности верхнего зуба мудрости, при неполностью открытом рте - уровню шейки этого зуба, а при полностью сомкнутых челюстях - уровню свода переходной складки на стороне анестезии. Щека в этом случае отводится в сторону шпателем, которым одновременно определяют место укола игль, натягивая им слизистую над передним краем восходящей ветви челюсти.

1. При нашем способе, как правило, блокируется нижнелуночковый, язычный и щёчный нервы, а также и двигательный жевательный нерв, что играет роль в снятии явлений тризма челюсти. Анестезия на нижней челюсти наступает через 6-12 минут...» 


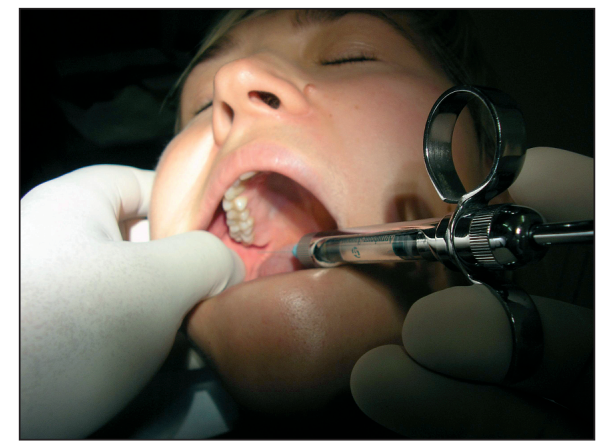

Рис. 178. Техника блокады двигательных ветвей нижнечелюстного нерва при дисфункции височно-нижнечелюстного сустава (Шувалов С.М., 2009)

Блокада по Б.Ф. Кадочникову (1956) приведена также в монографиях С.Н. Вайсблата (1962), П.Ю. Столяренко (2001), А.А. Тимофеева (2004).

Таким образом, приоритет описания вестибулярного пути анестезии ветвей нижнечелюстного нерва принадлежит Б.Ф. Кадочникову (1956), имя которого и должно занять своё достойное место в отечественной стоматологической литературе и учебной программе по хирургической стоматологии...»

В ранних стадиях рефлекторная контрактура легко устраняется выключением рецепторов, проводящих болевой импульс. Для прерывания патологической импульсации Д. Сабо (2005) предлагает при закрытом рте пациента вводить 2 мл анестетика в передний край собственно-жевательной мышцы (m. masseter). Этим выключаются болевые рецепторы собственножевательной и щёчной мышц. После увеличения объёма движений челюсти проводится проводниковая анестезия.

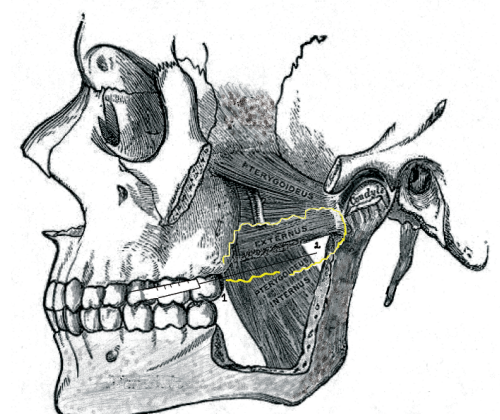

Рис. 179. Схема блокады двигательных ветвей нижнечелюстного нерва при дисфункции височно-нижнечелюстного сустава (Шувалов С.М., 2009) 
При болевых синдромах, вызванных дисфункцией височно-нижнечелюстного сустава, С.М. Шувалов $(2008,2009)$ предлагает внутриротовой способ блокады двигательных ветвей нижнечелюстного нерва. Способ осуществляется следующим образом (рис. 178), схема анестезии (рис. 179).

Точка вкола определяется при максимальном открытом рте на слизистой оболочке на расстоянии 1см кнаружи от места прикрепления верхнего края крыловидно-нижнечелюстной складки, что соответствует проекции соединения бугра верхней челюсти и пластин крыловидного отростка основной кости, к которым прикрепляются латеральная и медиальная крыловидные мышцы. Шприц устанавливают в противоположный угол рта. После прокола слизистой оболочки, постоянно выпуская анестетик, инфильтрируют клетчатку по ходу латеральной крыловидной мышцы на всём её протяжении до основания головки мыщелкового отростка, т.е. до капсулы сустава. Для более точного проведения иглы можно охватить ветвь нижней челюсти левой рукой, расположив большой палец на переднем крае ветви в полости рта, а четыре других на коже (экстраорально) по заднему краю ветви. Для проведения блокады достаточно 1,7 мл 4\% раствора ультракаина Д-С. Полное обезболивание тканей в области височно-нижнечелюстного сустава и восстановление движений нижней челюсти отмечается через 5-7 минут.

\section{Внеротовые способы обезболивания у нижнечелюстного отверстия}

В зависимости от места вкола иглы по отношению к ветви нижней челюсти разработаны следующие основные внеротовые способы обезболивания ветвей нижнечелюстного нерва:

1) через вырезку нижней челюсти - подскуловой путь (Mayer и Weyler, 1916; Maser, 1921; Bercher, 1922; Wiedhoph, 1925; Уваров В.M., 1928; Дубов М.Д., 1947; Korkhaus G., 1955; Бердюк И.В., 1958; Ходос А.Б., 1964; Егоров П.М., 1967 и др.);

2) со стороны нижнего края нижней челюсти - подчелюстной путь (Pehr Gadd, 1913; Klein B., Sicher H., 1915; Cieszynsky A., 1915; Kantorowisz A., 1915; Вайсблат С.Н., 1927; Berg, 1940);

3) со стороны переднего края ветви нижней челюсти (Фетисов Н.В., 1958; Егоров П.М., Лапис И.П., 1963);

4) со стороны заднего края ветви нижней челюсти (Pekkert и Wustrow, 1937; Wagner, цит. по С.Н. Вайсблату, 1962). 


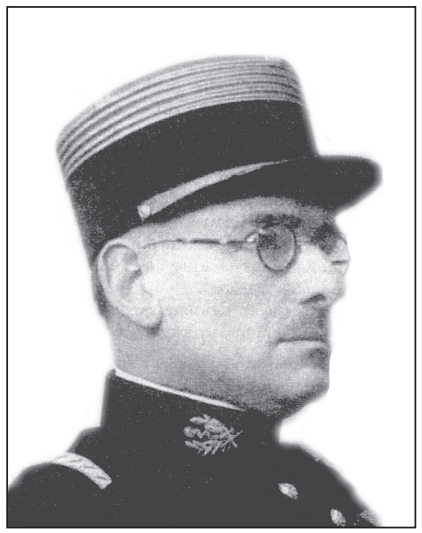

Pис. 180. Jean-Henri Bercher (1883-1963) - Бригадный генерал медицинской службы, «0фицер Почётного Легиона», автор метода блокады двигательных ветвей нижнечелюстного нерва. Ил. по Р. Friez (1963)

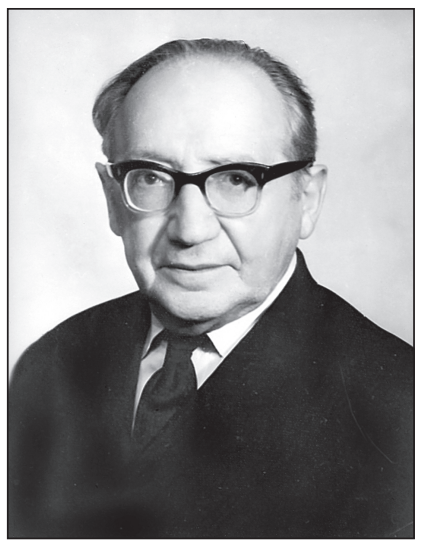

Рис. 181. Михаил Давыдович Дубов (1891-1988)
Впервые подскуловой доступ использовали для введения растворов анестетика в толщу жевательной мышцы с целью устранения её контрактуры Mayer и Weyler (1916), Wiedhoph (1925) и др. [Дубов М.Д., 1935].

В 1922 г. французский стоматолог ЖанАнри Берше (рис. 180) предложил для снятия рефлекторной контрактуры жевательных мышц вводить обезболивающий раствор через вырезку нижней челюсти на внутреннюю поверхность ветви, считая, что при этом прерывается проводимость двигательных нервов жевательных мышц. М.Д. Дубов (рис. 181), применяя этот метод, убедился, что наряду с понижением тонуса мышц наступает обезболивание, главным образом, нижнего луночкового нерва, как при обезболивании у нижнечелюстного отверстия, в области же, иннервируемой язычным нервом, болевая чувствительность сохраняется. При впрыскивании раствора метиленовой сини через вырезку нижней челюсти на трупе жидкость распространялась в сторону нижнечелюстного отверстия и окрашивала ткани вокруг него. Таким образом, было подтверждено воздействие только на нижний луночковый нерв. В 1941 г. при более глубоком введении на трупе жидкого агара он скапливался между брюшками латеральной крыловидной мышцы, где нижний луночковый и язычный нервы расположены рядом. Не исключалась возможность диффузии раствора и кпереди, по направлению к щёчному нерву. В 1947 г. М.Д. Дубов предложил продвигать иглу под скуловую дугу на глубину 3-3,5 см (рис. 182). Способ Дубова получил широкое распространение в нашей стране, особенно при сочетании с методом Берше.

B.М. Уваров (1928) при исследовании 50 черепов установил, что в области суставного бугорка на расстоянии в среднем 4,5 см от 
скуловой дуги находится овальное отверстие. Исходя из этих данных, он предложил метод блокады третьей ветви тройничного нерва у овального отверстия (рис. 183).

Pehr Gadd (1913) рекомендовал блокировать нижний альвеолярный нерв со стороны подчелюстного треугольника. Он назвал свой метод «наружная мандибулярная анестезия». Для обезболивания этим способом II пальцем левой руки определяют место пересечения лицевой артерией нижнего края нижней челюсти у переднего края жевательной мышцы. Вкол иглы производят на середине расстояния между задним краем угла нижней челюсти и пальпируемой лицевой арте-

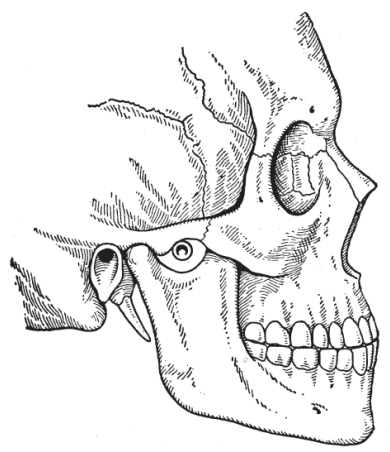

Рис. 182. Место укола при анестезии по Берше-Дубову рией у переднего края жевательной мышцы. Иглу проводят в контакте с внутренней поверхностью ветви нижней челюсти кзади и вверх на глубину 30 мм. Вводят 1-1,5 мл раствора анестетика для блокирования нижнего альвеолярного нерва. При необходимости обезболивания язычного нерва автор советует немного вывести иглу, затем продвинуть её несколько внутрь, кпереди и выше первоначального уровня. Здесь вводят 0,5-1 мл анестезирующего раствора для блокирования язычного нерва. (Цит. по П.М. Егорову, 1985).

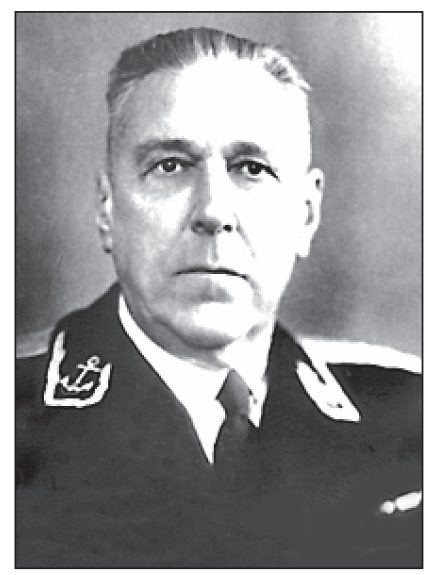

Рис. 183. Владимир Михайлович Уваров (1893-1982).

Крупный учёный стоматолог, доктор медицинских наук, профессор, один из основоположников советской и военной стоматологии. Предложил способ анестезии 3-й ветви тройничного нерва у овального отверстия (1928) 


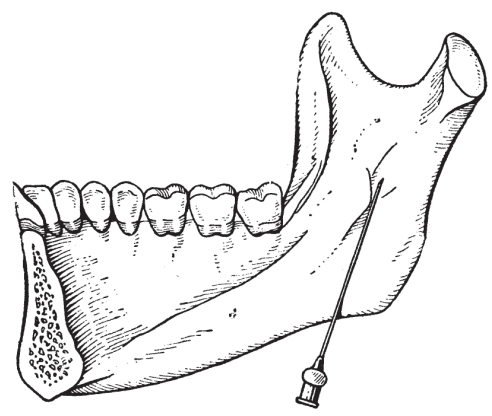

Рис. 184. Положение иглы на внутренней поверхности ветви нижней челюсти при подчелюстном доступе обезболивания у нижнечелюстного отверстия. (Ил. по H. Sicher, 1915)

В. Klein и Н. Sicher (1915), A. Cieszynsky (1915), A. Kantorowisz (1915), учитывая принципиально правильные установки П. Геда, стремились по возможности упростить его методику и наметить более доступные ориентиры (рис. 184). Авторы предлагают после вкола на внутренней поверхности тела челюсти у её края на расстоянии ширины ногтевой фаланги пальца от заднего края провести иглу параллельно кости на глубину до 40 мм, учитывая толщину слоя мягких тканей под нижним краем челюсти. Остриё иглы при этом дойдёт до нижнечелюстного отверстия. При этом нет необходимости вводить обезболивающий раствор выше отверстия, так как костный язычок не препятствует доступу к нему снизу (рис. 185 a, 6). A. Cieszynsky (1915) советовал нанести на лицо больного графическое изображение основных ориентиров для вкола и продвижения иглы.
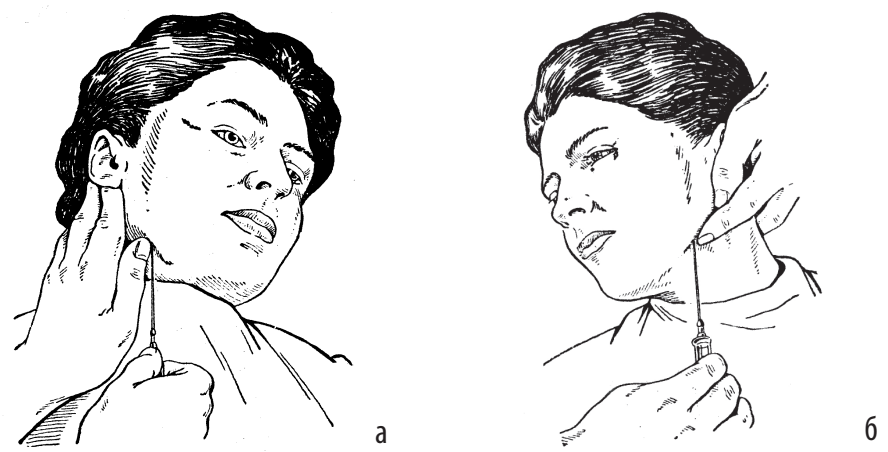

Рис. 185. Внеротовое обезболивание у нижнечелюстного отверстия: a - по B. Klein, H. Sicher (1915); 6 - по A. Kantorowisz, 1915) 
Позадичелюстной путь внеротовой мандибулярной проводниковой анестезии предложен Пеккертом (Pekkert) и Вустровом (Wustrow) в 1937 г., по способу которых укол делается на 1 см ниже сосцевидного отростка у заднего края ветви нижней челюсти. Игла продвигается сзади наперёд до крыловиднонижнечелюстного пространства. Вагнер (Wagner) и другие предлагают производить внеротовую проводниковую анестезию позадичелюстным путём с продвижением иглы не го-

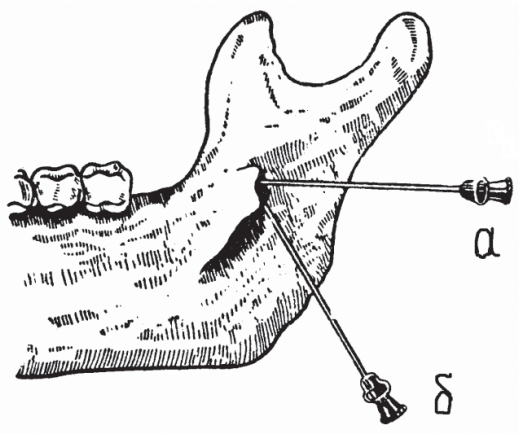

Рис. 186. Позадичелюстные пути мандибулярной анестезии: а - по Пеккерту и Вустрову; 6 - по Вагнеру ризонтально, а косо, снизу и сзади вверх и вперёд (рис. 186). Однако предложенная модификация, кроме недостатков доступа по Пеккерту, чревата тем, что конец иглы, продвигаясь по внутренней шероховатости угла нижней челюсти, может загнуться и вызвать рваную рану мягких тканей с повреждением нервов и сосудов.

\section{Центральные (стволовые) анестезии в челюстно-лицевой хирургии}

Бугорный (туберальный) способ крылонёбной анестезии. Путь, идущий вдоль бугра задней поверхности верхней челюсти и через крылонёбную ямку к круглому отверстию, был впервые предложен американским хирургом Матасом (Matas R.) в 1900 г. Его сообщение, напечатанное в малоизвестном журнале, прошло незамеченным. В практику этот способ ввёл Браун (1909), давший простое и ясное описание. Методика Матас-Брауна, при которой игла подводится к круглому отверстию, чревата серьёзными осложнениями, в первую очередь, возможностью попадания конца иглы в верхнюю глазничную щель и повреждения кавернозного синуса или попадания близко к зрительному отверстию и повреждения зрительного нерва. В 1929 г. С.Н. Вайсблат усовершенствовал бугорный путь крылонёбной анестезии, подводя конец иглы не к круглому отверстию, а только в крылонёбную ямку.

Глазничный путь. Доступ через глазницу предложил в 1909 г. В.Ф. Войно-Ясенецкий, его применяли и другие авторы (Härtel, Payr, Chevrier). 
В отличие от указанных авторов В.Ф. Войно-Ясенецкий предложил вводить иглу не по нижней стенке орбиты, а по наружной, считая этот путь менее опасным и более доступным для попадания концом иглы в круглое отверстие. С.Н. Вайсблат (1930) усовершенствовал глазничный путь, предлагая вводить иглу через нижний край глазницы на несколько миллиметров медиальнее от его середины. При проведении иглы по дну глазницы анестетик через нижнюю глазничную щель проникает в крылонёбную ямку, что достаточно для обезболивания верхнечелюстного нерва. В 1956 г. С.Н. Вайсблат предложил использовать путь через глазницу также и для обезболивания нижнечелюстного нерва у овального отверстия. Для этого иглу по нижнему краю глазницы вблизи её нижненаружного угла проводят через нижнеглазничную щель в подвисочную ямку и далее «в контакте с наружной пластинкой крыловидного отростка» - к овальному отверстию.

На возможность доступа к проксимальному отделу верхнечелюстного нерва через крылонёбный канал первым указал В.Ф. Войно-Ясенецкий в 1915 г. Однако он не испытал этого пути на больном, считая его неприемлемым ввиду невозможности при нём проникнуть концом иглы в круглое отверстие. Путь через большое нёбное отверстие и крылонёбный канал был предложен и применён на больном в 1921 г. Карреа (Carrea), а в 1924 г. разработан и внедрён С.Н. Вайсблатом. Он, в частности, предложил погружать иглу в канал не на 4-5 см, а на 2,5-3 см. Не продвигая иглу до круглого отверстия, а вводя обезболивающий раствор только в крылонёбную ямку, автору удавалось обезболивать всю верхнюю челюсть с меньшим риском серьёзных осложнений (поломка иглы, попадание в орбиту и ранение глазного яблока или зрительного нерва). К 1954 г. С.Н. Вайсблат располагал опытом 1397 случаев успешного проведения крылонёбной анестезии нёбным путём (рис. 187).
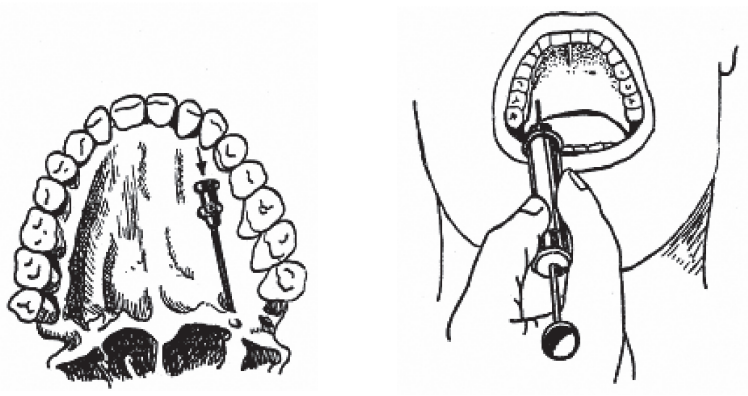

Рис. 187. Нёбный путь крылонёбной анестезии (начало инъекции). Конец иглы попадает в большое нёбное отверстие (слева). Нёбный путь крылонёбной анестезий (конец инъекции). Конец иглы в крылонёбном канале (справа) 

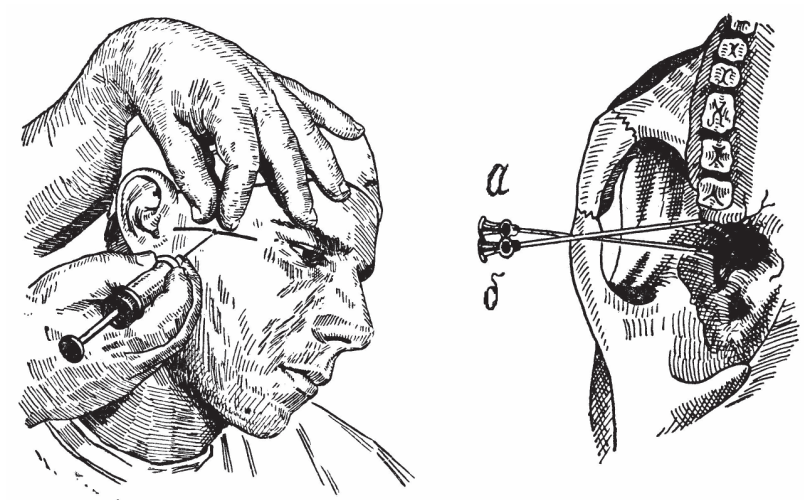

Рис. 188. Подскулокрыловидный путь крылонёбной анестезии (слева).

Положение иглы при крылонёбной анестезии подскулокрыловидным путём:

а - конец иглы упирается в наружную пластинку крыловидного отростка;

6 - конец иглы находится в крылонёбной ямке (справа). Ил. по С.Н. Вайсблату (1962)

Одним из наименее сложных доступов к проксимальным отделам верхне- и нижнечелюстного нервов является поперечный или подскуловой (подскулокрыловидный, по С.Н. Вайсблату), когда после вкола непосредственно под нижним краем скуловой дуги игла направляется перпендикулярно к поверхности щеки через вырезку нижней челюсти по направлению к основанию наружной пластинки крыловидного отростка. Позади этой пластинки, у её основания, находится овальное отверстие и, следовательно, выходящий из него нижнечелюстной нерв, впереди, в той же плоскости - вход в крылонёбную ямку. На этом основании путь, который раньше использовали для обезболивания только нижнечелюстного нерва (Braun, 1907; Offerhaus, Sicher), C.Н. Вайсблат в 1941 г. предложил и для обезболивания верхнечелюстного нерва (рис. 188). При разработке поперечного доступа в крылонёбную ямку необходимо было уточнить место вкола иглы и глубину её продвижения. По исследованиям С.Н. Вайсблата (1934) проекция середины ширины наружной пластинки крыловидного отростка на кожу под нижним краем скуловой дуги (ориентир Брауна) соответствует середине расстояния от основания козелка ушной раковины до нижненаружного угла глазницы (траго-орбитальная линия).

А.В. Вишневский (1932) описал следующий метод обезболивания по способу ползучего инфильтрата при операциях на головном мозге и резекции челюстей: «Под скуловой дугой, приблизительно по середине, делают вкол длинной иглой, которую направляют слегка кверху и кпереди. При постепен- 


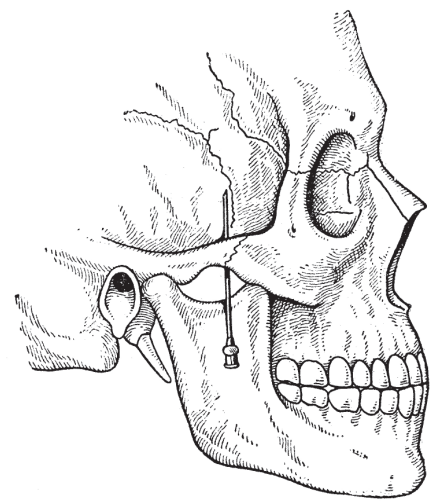

Рис. 189. Место укола и направление иглы при обезболивании по способу А.В. Вишневского - М.Д. Дубова

ном продвигании иглы в глубину сюда вводят 40-50 мл раствора». Способ рассчитан на пропитывание обезболивающим раствором тканей в подвисочной ямке, откуда он должен диффундировать в крылонёбную ямку и воздействовать на проксимальный отдел верхнечелюстного нерва и крылонёбный узел. Одновременно раствор распространяется к овальному отверстию и вызывает выключение нижнечелюстного и ушного нервов.

М.Д. Дубов (1959) после изучения на препарате черепа предложил видоизменить способ А.В. Вишневского, делая вкол не по середине скуловой дуги, а под основанием височного отростка скуловой кости (рис. 189). Если после этого продвинуть иглу медиальнее, кверху и несколько кпереди, то на глубине 3,5-4 см кончик иглы достигнет наружной поверхности большого крыла клиновидной кости под подвисочным гребнем, который отделяет височную поверхность большого крыла от подвисочной. Тем самым, по мнению М.Д. Дубова, был упрощён и сделан более доступным способ А.В. Вишневского.

Lindemann в 1926 г. предложил надскуловой путь для обезболивания верхне- и нижнечелюстного нервов в случае недоступности подскулового пути и через нижний край нижней челюсти. Прокалывая кожу у верхнего края скуловой дуги, он достигает подвисочного гребешка на глубине приблизительно 2 см. Отклоняя иглу назад и обходя гребешок, он скользит ею по кости, проходит ещё 3-3,25 см, пока не почувствует сопротивления наружной пластинки крыловидного отростка или угловой ости большого крыла основной кости, spina angularis, и тут находит нижнечелюстной нерв. С.Н. Вайсблат в 1955 г. усовершенствовал надскуловой путь крылонёбной анестезии по Пайру (1920) и у овального отверстия по Линдеману. Место вкола: по середине трагоорбитальной линии по верхнему краю скуловой дуги. Иглу проводят также во фронтальной плоскости, но с небольшим наклоном книзу, до упора в поверхность наружной пластинки крыловидного отростка. Дальнейшая техника как при подскуловом доступе (рис. 190). Основными достоинствами такой анестезии являются удалённость места вкола иглы от патологического очага в челюсти, уменьшение возможности образования гематомы, при необходимости одновременного обезболивания обоих нервов (например, у пострадавших, раненных в лицо) можно успешно провести обе центральные анестезии. 


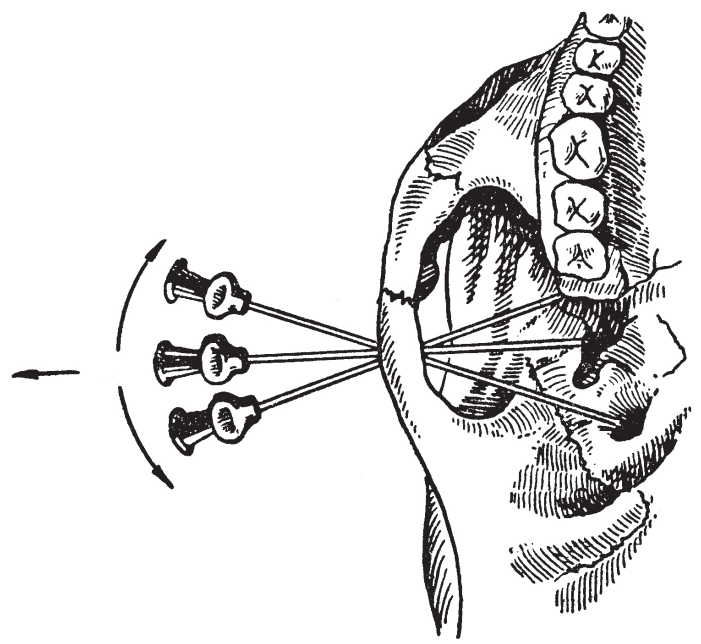

Рис. 190. Положение и направление иглы при крылонёбной анестезии (по Пайру - Вайсблату) и анестезии у овального отверстия (по Линдеману-Вайсблату) надскуловым путем:

а - конец иглы упирается в наружную пластинку крыловидного отростка;

6 - конец иглы находится у овального отверстия;

В - конец иглы находится в крылонёбной ямке
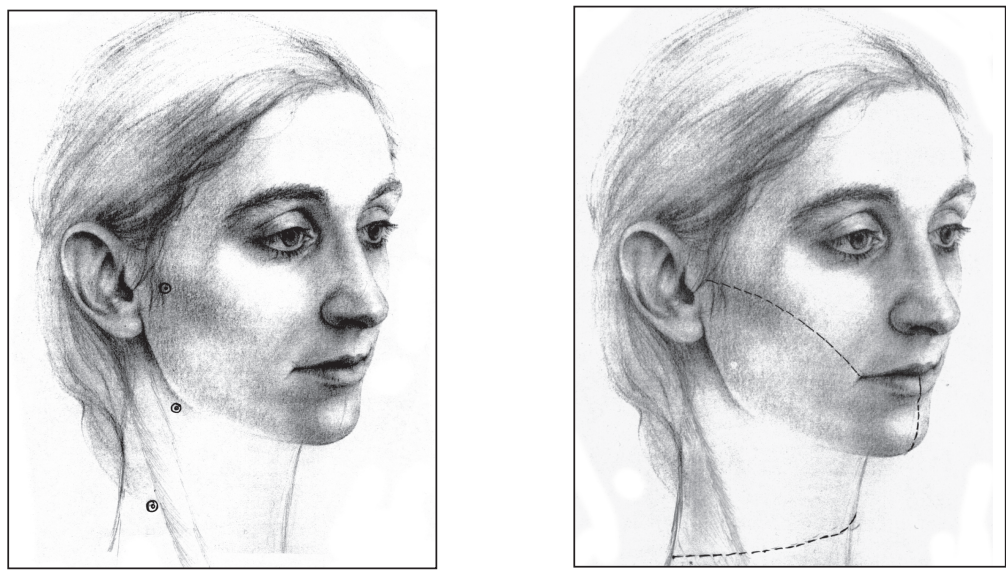

Рис. 191. Точки вкола для проводникового обезболивания нижней трети лица по методу С.М. Шувалова, А.А. Малаховской (слева); зона обезболивания (справа) 


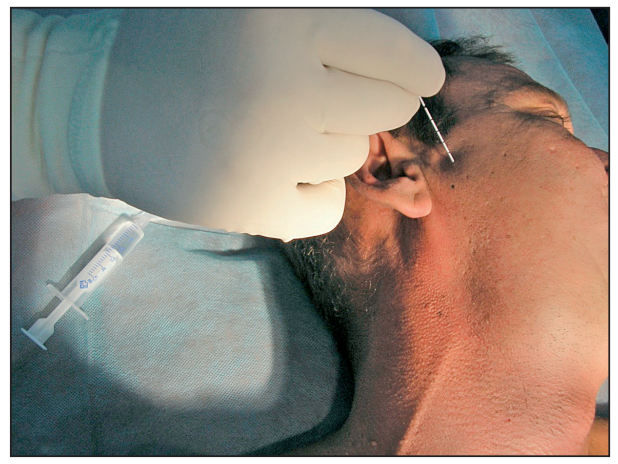

Рис. 192. Центральная проводниковая анестезия $\mathrm{n}$. mandibularis с помощью нервстимулятора Stimulplex DIG RC

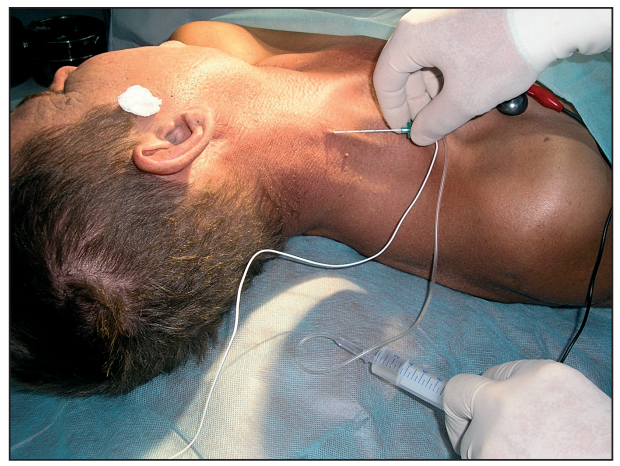

Рис. 193. Обезболивание шейного поверхностного сплетения

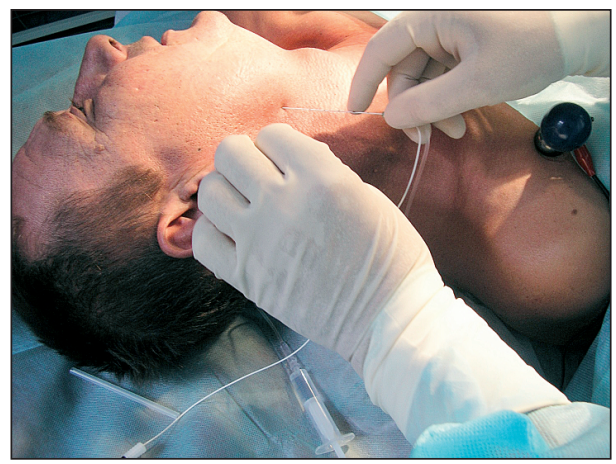

Рис. 194. Ангулярный метод обезболивания языкоглоточного нерва 
Шувалов В.М. и Малаховская А.А. (2009) предложили метод обезболивания в нижней трети лица (рис. 191-194), включающий в себя три проводниковые анестезии: центральную анестезию 3-й ветви тройничного нерва у овального отверстия, обезболивание поверхностного шейного сплетения и ангулярный метод обезболивания языкоглоточного нерва с помощью нервстимулятора Stimulplex DIG RC (фирмы B. Braun).

\section{Интралигаментарная анестезия}

Способу интралигаментарной анестезии более века. Впервые её описали французские дантисты Granjean в 1903 г. и D. Nogué в 1907 г. (Столяренко П.Ю., 2001; Dirnbacher Т., 2003). Одной из первых была диссертация C.-L. Bourdain в 1925 г., посвящённая удалению зубов под этой анестезией. Своим вторым рождением в конце 70-х годов этот метод обязан разработке специальных шприцев, развивающих высокое давление при небольшом усилии, и тонких игл (Walton R.E., Abbot B.J., 1981; Evers H., 1981; Frenkel G., 1989; Lipp M.; 1992; Malamed S.F., 1997; Dirnbacher T., 2003; Федосеева Т.Д., 1992; Столяренко П.Ю., Кравченко В.В., Киселёва Т.А., Беланов Г.Н., 1998 и др.). За рубежом интралигаментарная анестезия получила широкое распространение в 80 -е, в России - в 90-е годы ХХ века (рис. 195-198).

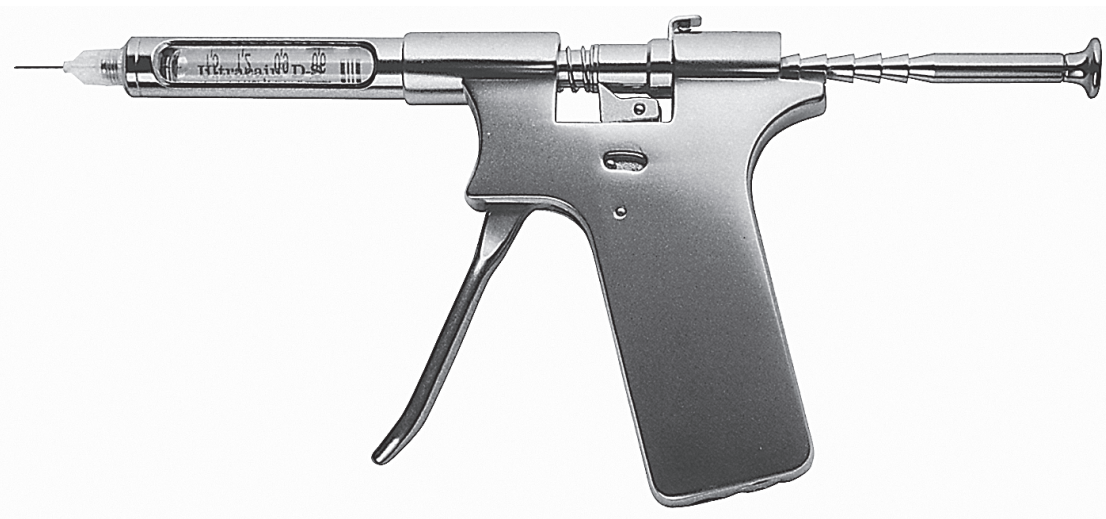

Рис. 195. Современный инъектор для интралигаментарной анестезии (ИЛА) 


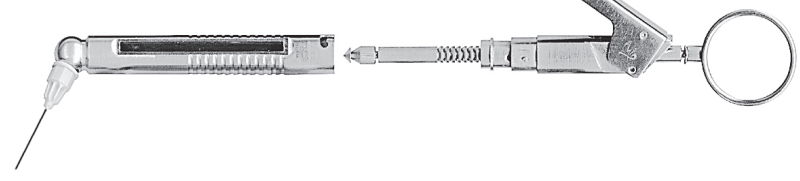

Рис. 196. Универсальный инъектор МИД ИС-03 (Россия).

Кроме ИЛА возможно проведение проводниковая и инфильтрационная анестезии

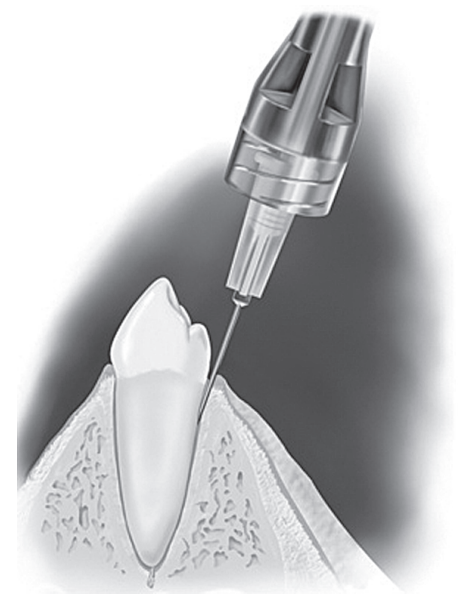

Рис. 197. Схема интралигаментарной анестезии

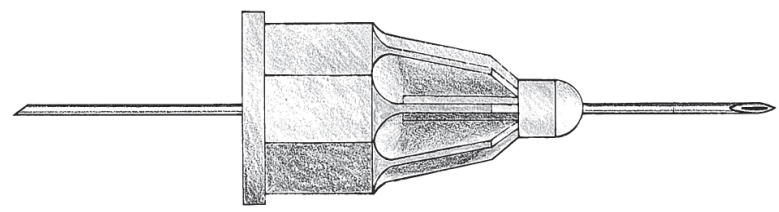

Рис. 198. Дентальная игла для интралигаментарной анестезии 0,3 x 10 мм

Интралигаментарная анестезия противопоказана пациентам пожилого возраста и с сопутствующими заболеваниями сердечно-сосудистой системы. При интралигаментарной инъекции Петрикасу А.Ж. и соавт. (2009) регулярно удавалось получать тонкую струйку крови в корпусе шприца (рис. 199). 


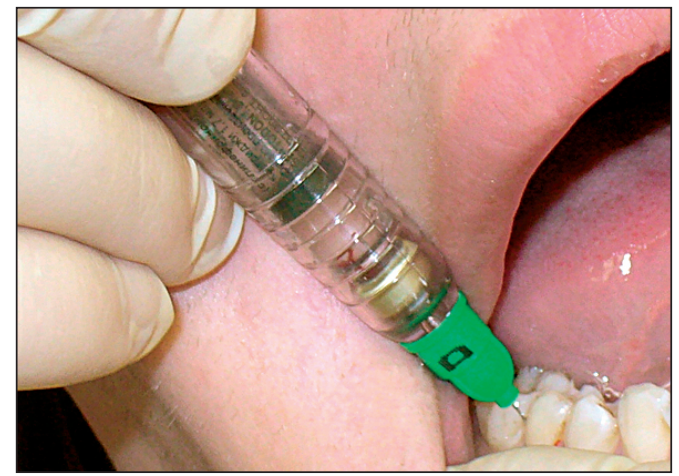

Рис. 199. Положительная аспирационная проба при интралигаментарной анестезии с помощью компьютерного инъектора Sleeper0ne. (Ил. Петрикаса А.Ж. и соавт., 2009.)

Итралигаментарная анестезия - метод обезболивания, расширяющий возможности местной анестезии. При соблюдении техники и показаний она представляет собой интересную, действенную альтернативу при кратковременном обезболивании во время лечения зубов, особенно по поводу пульпита. Техникой этой анестезии должен владеть каждый стоматолог. Данный вариант обезболивания может быть рекомендован как первичный метод местной анестезии, так и вторичный (дополнительный) - в тех случаях, когда неэффективна проводниковая и традиционная инфильтрационная анестезии. Освоение и применение интралигаментарного метода обезболивания в стоматологической практике позволит повысить эффективность анестезии при проведении стоматологических вмешательств, что создаст возможность увеличить объём стоматологической помощи, проводимой в одно посещение.

Значительному расширению возможностей внутрисвязочной анестезии должна способствовать компьютерная система WAND, обеспечивающая введение анестетика малым потоком, независимо от плотности тканей.

\section{Внутрикостная анестезия}

В стоматологии внутрикостное введение анестезирующих веществ для удаления зубов и других операций известно с конца XIX века. Впервые внутрикостная (спонгиозная) анестезия была применена в 1891 г. норвежцем Otte. Он вводил местный анестетик в кость через отверстие в кортикальной пластинке, сделанное бором. 
Английские и американские исследователи отдают первенство своим соотечественникам А.C. Parrot (1910) и G.N. Hein (1906). Было предложено несколько методов перфорации кортикальной пластинки челюсти с целью введения анестетика в губчатую ткань кости: бормашиной и шаровидным бором (Otte, 1891; Дитерихс M.M., 1907), бормашиной и дрильбором (Ing, 1907; Lilienthal В., 1975), инъекционной иглой (Поллак Н.А., 1936; Вайсблат С.Н., 1962), шиловидным гранёным инструментом (Петрикас А.Ж., 1974), инъекционной иглой и бормашиной (Бережной В.П., 1977; Конобевцев О.Ф., Макиенко М.А., Бережной В.П., 1979). Так, Н.А. Поллак успешно провёл 81 тыс. операций удаления зубов, вводя внутрикостно $2 \%$ раствор новокаина с адреналином в количестве 1,0-1,5 мл возле удаляемого зуба. Он дал высокую оценку данному методу обезболивания при удалении зубов, указывая на простоту выполнения и немедленное наступление анестезии. Однако этот метод обезболивания не получил распространения.

С 1973 г. Б.Н. Ланкин произвёл удаление 870 зубов и корней у 630 больных в возрасте от 14 до 75 лет. Уколы $2 \%$ раствором новокаина без адреналина автор производил шприцем «Рекорд» с обычной инъекционной иглой в сосочки десны с медиальной и дистальной сторон удаляемого зуба. У 18 больных анестезия была неполной из-за значительного сопротивления кости продвижению иглы.

Детальное изучение механизма дентальной внутрикостной анестезии было проведено А.Ж. Петрикасом $(1974,1983,1997,2009)$, который на основании результатов клинических, гистологических и рентгенологических исследований сформулировал представление о механизме действия внутрикостной анестезии, что нашло подтверждение в результатах последующих работ других авторов. Один из путей состоит в диффузии раствора в костной ткани, окружающей лунку зуба: по костномозговым пространствам межзубной перегородки и периапикальной области. Второй путь состоит в проникновении раствора в сосудистое русло.

В последующие годы вновь, но не очень активно вернулись к внутрикостной анестезии с помощью специально разработанных сверл-игл для внутрикостных вливаний В.П. Бережной (1978), а в дальнейшем R. Landrean (1984), A. Villette (1984), предложившие коммерческие их варианты.

Недавно внутрикостная анестезия вновь обрела популярность среди стоматологов США благодаря внедрению системы для местной анестезии Stabident (Fairfax, Miami, Fla). Она состоит из перфоратора, твёрдой иглы, которая перфорирует кортикальную пластинку кости с помощью обычного низкоскоростного углового наконечника, и иглы 27 размера длиной 8 мм, 
которая вводится в предварительно сделанное отверстие для инъекции анестетика (Маламед С., 1998).

Первым сосудистым методом местного обезболивания была «венозная региональная анестезия», предложенная Биром (A. Bier) в 1908 году для верхних и нижних конечностей. Внутрикостная анестезия конечностей, разработанная в годы Отечественной войны Фрайманом (1947); Атясовым (1970), Крупко (1969) и активно применяемая, рассматривалась как разновидность региональной венозной анестезии (Крупко И.П., Воронцов А.В., Ткаченко С.С. Внутрикостная анестезия. - Л.:

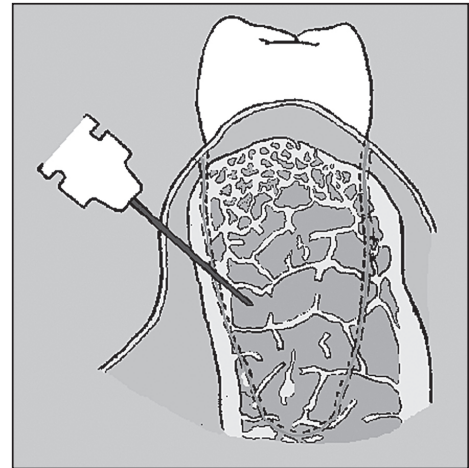

Рис. 200. Схема внутрикостной анестезии. (Ил. А.Ж. Петрикаса, 2009.) Медицина, 1969. - 168 с.).

Дентальная внутрикостная анестезия без каких-либо бандажей была предложена как вариант инфильтрационной кокаиновой анестезии зубов ещё в 1891 году норвежским дантистом Otte. При этом не учитывался и продолжает не учитываться сосудистый механизм внутрикостной анестезии (рис. 200). Некоторые особенности внутрикостной анестезии, например, высокая частота пульса, сразу после инъекции или высокий уровень анестетика в крови, схожий с внутривенным введением (Lilienthal,1975), не укладываются в «инфильтрационную» концепцию (Петрикас А.Ж. и соавт., 2009).

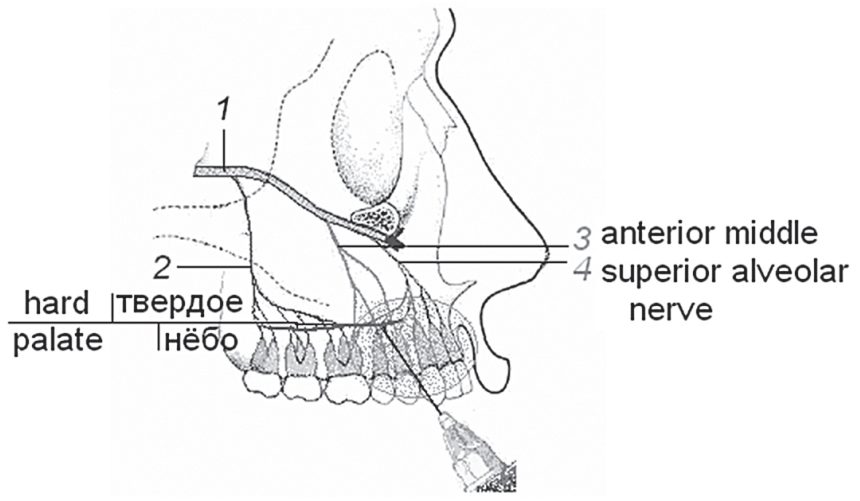

Pис. 201. Схема Anterior Middle Superior Alveolar nerve block - AMSA (Friedman, Hochman,1998). Ил. Петрикаса А.Ж. и соавт., 2009.) 
С появлением новых инъекционных систем, например, Wand-инъектор возникли и новые техники обезболивания с неясным механизмом действия, трактуемые как блок-анестезии.

На рис. 201 представлена схема AMSA блок - проводниковой анестезии, где блокируются альвеолярные нервы, расположенные внутрикостно и защищённые от инфильтрации толстой кортикальной пластинкой.

Интерес к новым анестезиям и возродившимся старым, таким как интралигаментарная, внутрикостная, интрасептальная, которые А.Ж. Петрикас объединяет термином «спонгиозные», а С.А. Рабинович - «пародонтальные», обусловлен активностью эндодонтии и в связи с этим более высокими требованиями к эффективности обезболивания зубной пульпы.

По мнению А.Ж. Петрикаса ${ }^{5}$, происходит смена экзодонтического обезболивания на эндодонтическое. Получает распространение инъекция в плотные нерастягивающиеся ткани: прикреплённая десна, периодонтальная связка, твёрдое нёбо. Технически это замена пальцевого давления во время инъекции на машинное: пресс-инъкторы, электронный инъекторы. При инъекции в плотные ткани высокое инъекционное давление в инкапсулированных тканях (костные ячейки, зубная пульпа, ткани твёрдого нёба) ведёт к разрывам мягких структур в области инъекции. Это стенки тонких вен и венозных синусов. Давление создаёт прорыв анестезирующей жидкости в венозную циркуляцию и свободное распределение её по сосудистой системе, как по току крови, так и против него. При инъекции в плотные ткани диффузное (инфильтрационное) распределение инъецируемой жидкости сменяется сосудистым.
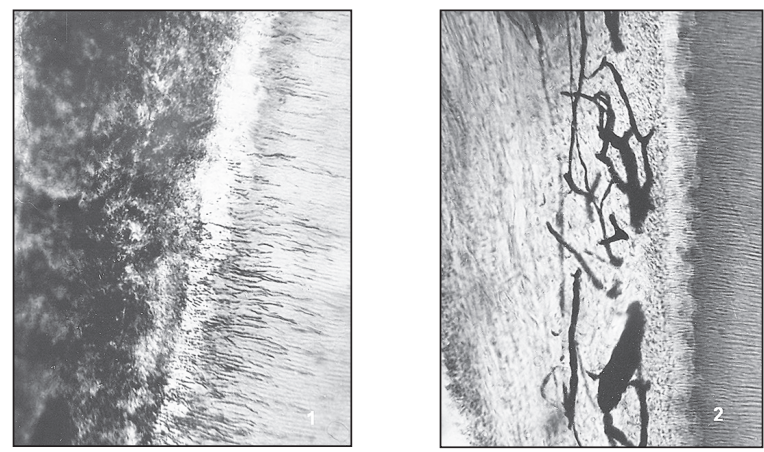

Рис. 202. 1 - диффузное распределение туши в коронковой пульпе (около иглы) сменяется в корневой пульпе (2) на сосудистое. (Ил. А.Ж. Петрикаса, 2009.)

${ }^{5}$ Использованы материалы доклада А.Ж. Петрикаса «Сосудистые методы анестезии» на конференции Дентал Ревю, Москва, 11 февраля 2009 г. 


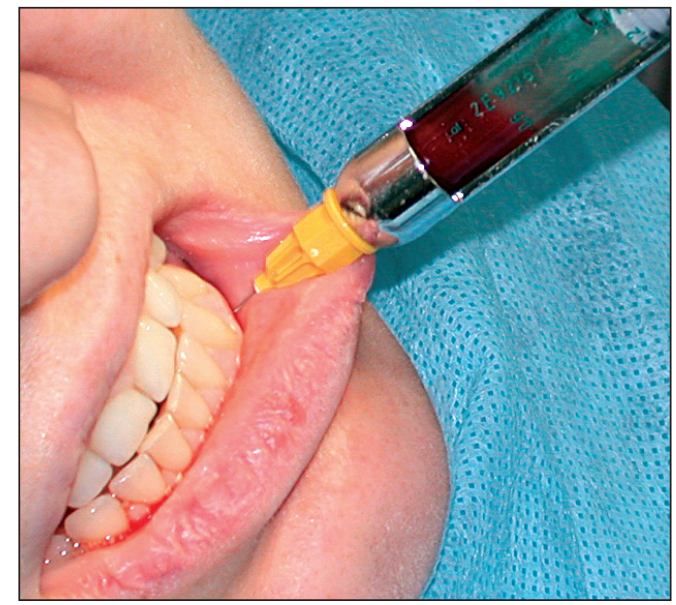

Рис. 203. Положительная аспирационная проба при внутрикостной анестезии (наблюдение Петрикаса А.Ж. и соавт., 2009.)

Инъекция в плотные ткани, например, внутрипульпарное введение туши демонстрирует, как диффузное распределение туши в коронковой пульпе (около иглы) сменяется в корневой пульпе на сосудистое (рис. 202).

При сосудистой инъекции развивается другой механизм местной анестезии и другая предсказуемая возможность резорбтивного действия анестетика и катехоламина на отдалённые от места введения мозговые и сердечные центры. Попадание иглы в сосуд при всех классических инъекциях в дентальной учебной анестезиологической литературе рассматривается как казус, медицинская ошибка.

Внутрикостная анестезия (успешная) всегда сопровождается положительной обильной аспирацией. Одно это уже позволяет признать её сосудистой (рис. 203).

Доказательства сосудистого механизма спонгиозных (внутрикостных) анестезий:

1. В общей медицине внутрикостный способ введения лекарств со времён второй мировой войны в Советском Союзе широко использовался не только для местного обезболивания, но и для оказания неотложной помощи, например, переливания крови.

2. Для внутрикостного введения характерно мгновенное (под иглой) наступление анестезии (40 сек). Клиницисты отмечают глубину анесте- 
зии. Если проводится электротестирование, то оно даёт максимальные величины.

3. Особенностью внутрикостной и интрасептальной анестезии является почти полное отсутствии парестезии мягких тканей. При интралигаментарной пациенты часто описывают ощущение «одеревенения зубов» в зоне инъекции.

4. Рентгеновское распределение контрастного вещества после внутрикостного и интрасептального введения демонстрирует его наличие как в сосудах, окружающих зуб, так и в самой пульпе (рис. 204).

5. Гистологическое исследование внутрикостной инъекции туши более чётко обнаруживает её в сосудах пульпы зубов в зоне инъекции.
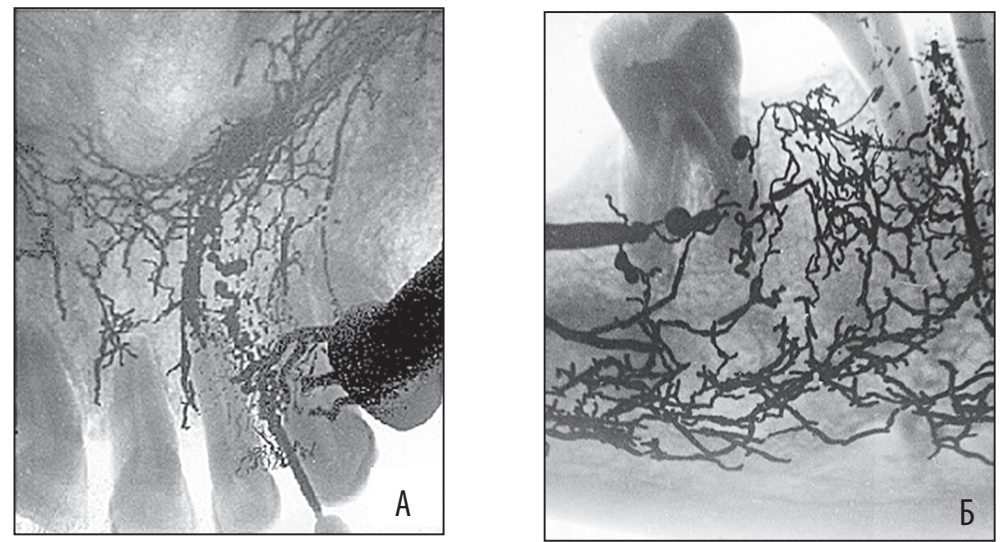

Рис. 204. Контрастные рентгенограммы после внутрикостной анестезии. Наличие анестетика в пульпе объясняет максимальную глубину обезболивания. (Ил. Петрикаса А.Ж. и соавт., 2009.)

При внутрикостных инъекциях эффективная доза анестетического раствора уменьшается более чем в 2 раза.

Механизм сосудистого (спонгиозного, внутрикостного) обезболивания обусловлен тем, что сосуды доводят раствор непосредственно до пульпы зуба, сближая место инъекции с объектом обезболивания.

Задержку анестетика в капиллярах и венах для временного контакта с нервными проводниками вблизи места инъекции обеспечивает ретроградное продвижение вводимой жидкости в артериальное русло и вазоконстрикция артериол за счёт блокады $\alpha$-адренорецепторов. 
Сосудистый эффект инъекции делает спонгиозную анестезию эндодентальной.

Спонгиозные методы увеличивают зону анестезии. Коэффициент полезного действия анестетика при региональном сосудистом введении в 2 раза выше, чем при классических диффузных дентальных инъекциях. Клиницистов смущает ярко выраженная реакция сердечнососудистой системы после спонгиозных инъекций анестетических растворов, содержащих вазоконстриктор-катехоламин (Boakes et al., 1972; Lilienthal B., 1975; Replogle K. et al., 1999).

При исследовании здоровых добровольцев во время внутрикостной анестезии имело место резкое учащение пульса через 1-2 мин после инъекции, которое возвращалось к исходному к 5 мин. Тоже наблюдалось и с систолическим артериальным давлением.
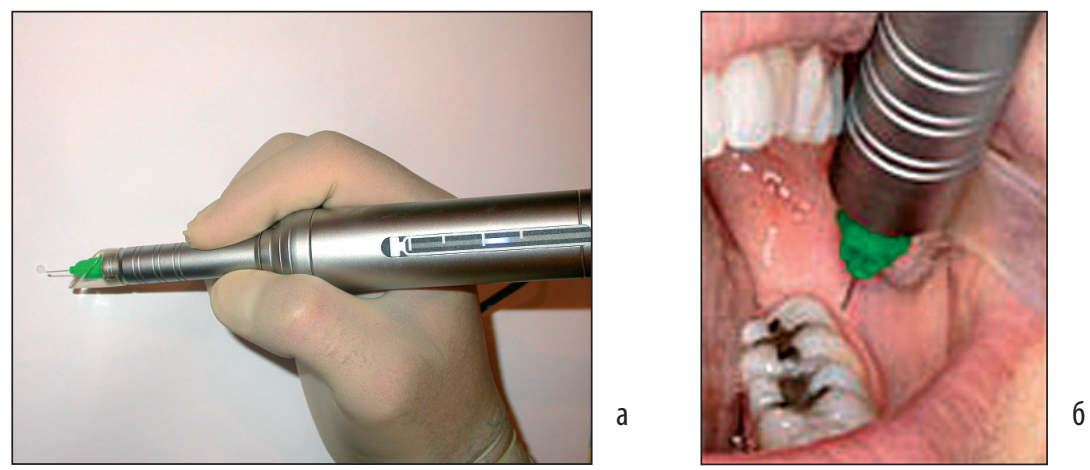

Рис. 205. A - система QuickSleeper («Dental Hi Teе», Франция);

Б - эксклюзивная система «PAR» (Permanent Analysis of Resistance - постоянный анализ сопротивления) обеспечивает равномерное введение анестетика, независимо от плотности тканей, и устраняет риск поломки карпулы

Исторически конец XX века характеризуется совершенствованием пульпарной анальгезии путём инъекции анестетика амидного типа в плотные ткани за счёт сосудистого механизма его распределения в анестезируемой области.

Сосудистый механизм распределения анестетического раствора обещает не только более сильное обезболивающее действие, но и нежелательный системный эффект.

Относительно безопасное проведение внутрикостных анестезий, исходя из опыта Петрикаса А.Ж. и соавт. (2009), обусловлено ограничением этого 

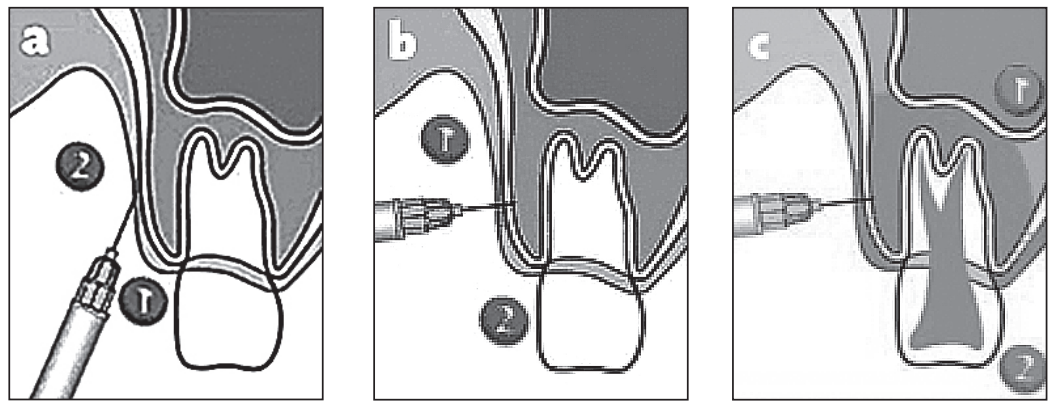

Рис. 206. Этапы транскортикальной анестезии.

Обезболивание десны (а). Перфорация кортикальной пластинки (b). Транскортикальная инъекция (c)

обезболивания у лиц, отягощённых серьёзной общей патологией и обязательным мониторингом показателей артериального давления и частоты пульса.

Электронная система QuickSleeper («Dental Hi Tec», Франция) обеспечивает простоту в осуществлении внутрикостной анестезии, тем самым значительно облегчая повседневную работу (рис. 205). Благодаря внутрикостной анестезии самый сложный клинический случай становится предельно простым. Состав системы: базовый блок, ножная педаль для подачи анестетика и аспирационной пробы, инъектора в виде ручки с картриджем для стандартной карпулы анестетика с одноразовой иглой. Проникновение в кортикальную пластинку, одноэтапная процедура анестезии. Электронный контроль параметров перфорации и инъекции предотвращает болезненную инъекцию. Инъектор выполнен в форме ручки, так что нет необходимости в усилии или давлении во время введения анестетика. В отличие от других приборов, нет необходимости в специальных расходных материалах, в замене различных частей, удорожающих работу с аппаратурой. С появлением этой технологии внутрикостная анестезия изменила название на транскортикальную. Методика транскортикальной анестезии основана на проникновении через кортикальную пластинку и введении анестетика в непосредственной близости с зубом, нуждающимся в лечении. Процедура проста и не отнимает времени, поскольку лечение можно начинать сразу после выполнения инъекции. Она состоит из трёх этапов (рис. 206).

Другой разновидностью внутрикостной анестезии в стоматологии является остеоцентральная анестезия, при которой анестетик вводится в центральную часть губчатой кости (как можно ближе к верхушке корня). Это обеспечивает намного более высокую эффективность и успешность, чем любая другая методика. Прокол выполняется длинной иглой 30G (16 мм) через вершину межзубной перегородки, где кортикальная кость наиболее тонкая и её легко проколоть. Для выполнения остеоцентральной анестезии 
используется система КвикСлипер (рис. 207). Количество анестетика зависит от числа зубов, которые нужно обезболить (от 2 до 8), требуемой продолжительности и интенсивности обезболивания. Перечисленные характеристики делают остеоцентральную анестезию одной из наиболее эффективных, особенно если учесть простоту её выполнения.
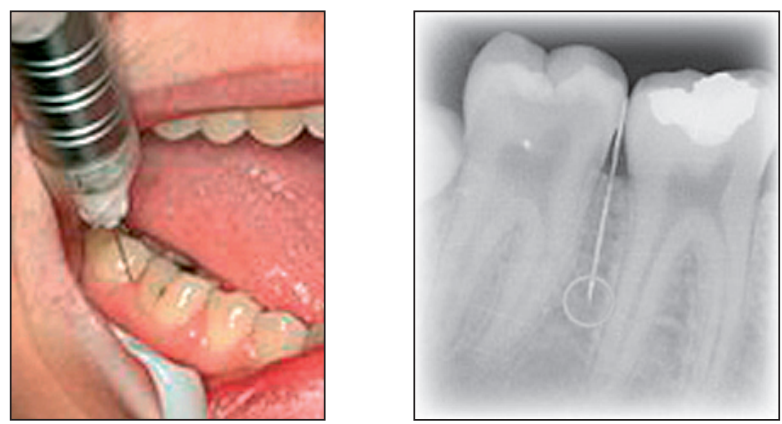

Рис. 207. Остеоцентральная анестезия (клинический пример и рентгенограмма).

Ил. Dental Hi Tec

Остеоцентральная анестезия обладает теми же преимуществами, что и транскортикальная, ведь она даёт возможность доставить анестетик непосредственно к тканям зуба. Это позволяет использовать концентрированные вазоконстрикторы (1:100 000 и более) с минимальным риском развития некроза. Остеоцентральная анестезия - метод выбора при обезболивании нижних моляров, даже при пульпите. 


\section{КРАТКАЯ ИСТОРИЯ РАЗВИТИЯ АНЕСТЕЗИОЛОГИИ (ПЕРИОД С НАЧАЛА ХХ ВЕКА)}

Первой была разработана методика ингаляционного наркоза, затем появилась местная анестезия, позже других стал развиваться внутривенный наркоз. В этом разделе остановимся на основных вехах развития анестезиологии после открытия первых ингаляционных анестетиков.

Ингаляционная анестезия. Несмотря на внедрение в практику других ингаляционных анестетиков (этилхлорид, этилен, дивиниловый эфир, циклопропан, трихлорэтилен, флуроксен и др.), эфир оставался наиболее распространённым ингаляционным анестетиком до начала 1960 г. Циклопропан, синтезированный в 1934 году, был единственным ингаляционным анестетиком, конкурировавшим с эфиром по безопасности и популярности. К сожалению, оба эти анестетика легко воспламеняются и поэтому постепенно были вытеснены невоспламеняющимися сильнодействующими фторсодержащими углеводородами: галотаном, (синтезировал Suckling в 1951 г., применение начато M. Johnston в 1956 г.); метоксифлураном (синтезирован в 1951 г., применение начато Artusio и соавт. в 1960 г.); энфлюраном (синтезировал Terrell в 1963 г., применение начато в 1972 г.); изофлюраном (синтезировал Terrell в 1965 г., применение начато в 1984 г.); десфлюраном (синтезирован 1966 г.) и др.

Неингаляционная анестезия. История развития неингаляционного наркоза начинается с 1847 г. Н.И. Пирогов в работе «Практические и физиологические наблюдения над действием паров эфира на животный организм» посвятил две главы неингаляционному наркозу: одну прямокишечному, другую внутривенному и внутриартериальному.

Внутривенный наркоз эфиром не получил распространения из-за многих осложнений. Однако попытки достигнуть наркоза внутривенным введением наркотических веществ неоднократно повторялись. В 1872 г. ПьерСиприен Орэ (Pierre-Cyprien Oré) вводил животным в вену хлоралгидрат и получил состояние наркоза. Через два года этот метод он применил у человека при лечении столбняка. В 1909 г. Буркхард (Burkhardt) вводил слабые растворы эфира и хлороформа. Им проведено 250 операций под таким обезболиванием без особых осложнений. Таким образом, идея Н.И. Пирогова о возможности достижения наркоза путём введения наркотических веществ непосредственно в кровь получила в дальнейшем всеобщее признание.

Новая эра в развитии внутривенного наркоза наступила тогда, когда для наркоза были предложены жидкие наркотические вещества с высокой 
точкой кипения, которые вследствие этого не переходили в сосудах в парообразное состояние.

Начало современному внутривенному наркозу положил крупнейший русский фармаколог Н.П. Кравков (рис. 208), доказавший принципиальную возможность и целесообразность применения неингаляционного наркоза в чистом виде и в комбинации его с ингаляционным. В 1902 г. он предложил пользоваться для внутривенного наркоза гедоналом. Опыты по применению гедоналового внутривенного наркоза были выполнены в 1902 г. на собаках П.П. Лампсаковым и 7 декабря 1909 г. впервые в клинике С.П. Федоровым. В зарубежной литературе гедоналовый наркоз называется русским методом внутривенного наркоза (Жоров И. С., 1959).

Барбитураты были синтезированы в 1903 г. Фишером (Fischer) и фон Мерингом (von Mering).

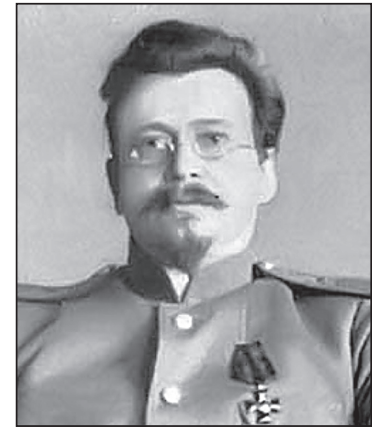

Рис. 208. Николай Павлович

Кравков (1865-1924), крупнейший отечественный фармаколог. Предложил для внутривенного наркоза гедонал Первым барбитуратом, применённым для вводного наркоза, оказался барбитал, но только после появления в 1927 г. гексобарбитала индукция анестезии барбитуратами получила широкое распространение. В 1932 г. синтезированы тиопентал-натрий Вольвилером (Volwiler) и Таберном (Tabern) и гексенал Веeзе (Weese). Впервые в клинике наркоз тиопенталом был применён Джоном Ланди (John Lundy - рис. 209) и Ральфом Уотерсом (Ralph Waters) в 1934 г. и до сих пор остаётся наиболее часто используемым препаратом для вводного наркоза. В нашей стране в изучение и внедрение в практику барбитурового наркоза большой вклад внёс Исаак Соломонович Жоров (рис. 210).

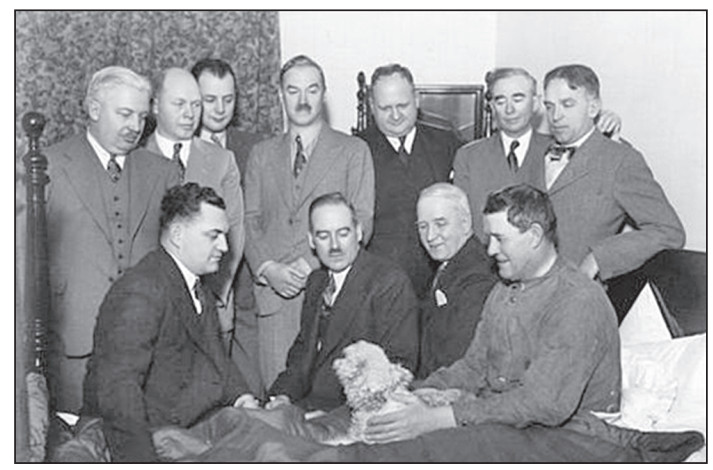

Рис. 209. Джон Ланди (сидит, первый слева) с коллегами 


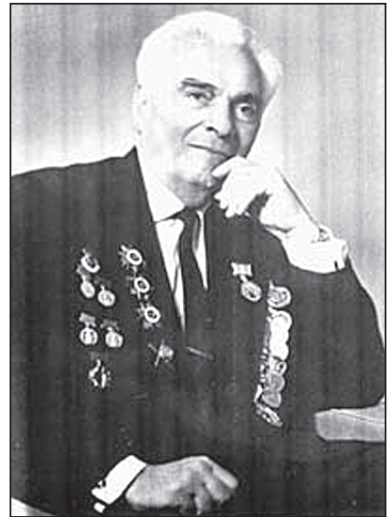

Рис. 210. Исаак Соломонович

Жоров (1898-1976). Корифей советской анестезиологии. Автор руководства по общему обезболиванию в хирургии, по которому училось не одно поколение анестезиологов

Метогекситал впервые был применён в клинике В.К. Стелтингом (Stoelting V.K.) в 1957 г. и является ещё одним барбитуратом, по сей день используемым для вводного наркоза. После того как в 1957 г. был синтезирован хлордиазепоксид, бензодиазепины - диазепам (1959 г.), лоразепам (1971 г.) и мидазолам (1976 г.) - стали широко использоваться для премедикации, индукции и потенцирования анестезии, а также для внутривенной седации. Кетамин был синтезирован в 1962 г. Стивенсом (Stevens), впервые применён в клинике в 1965 г. Корссеном (Corssen) и Домино (Domino), разрешён к широкому использованию в 1970 г. Кетамин стал первым неингаляционным анестетиком, введение которого сопровождалось лишь минимальным подавлением кровообращения и дыхания. В 1964 г. был синтезирован этомидат и разрешён к применению в 1972 г.

В 1976 г. синтезирован пропофол, в 1989 г. был разрешён к применению. Появление этого препарата имело огромное значение для амбулаторной анестезиологии в связи с кратковременностью его действия.

\section{Миорелаксанты}

Первые сведения о кураре проникли в Европу более 400 лет назад после возвращения экспедиции Колумба из Америки, где южноамериканские индейцы использовали его для смазывания наконечников стрел при стрельбе из лука или бамбуковых трубок (рис. 211).

Как гласит предание, смертоносный яд готовили старейшие женщины племени. На костре в большом котле варились корни ядовитых растений вместе со смолянистыми соками, змеиным ядом, головами муравьев, хвостами скорпионов и др. Яд признавали годным для применения только тогда, когда одна из варивших этот состав старух теряла сознание и погибала (рис. 212). Такого рода пагубное действие, по мнению ряда 

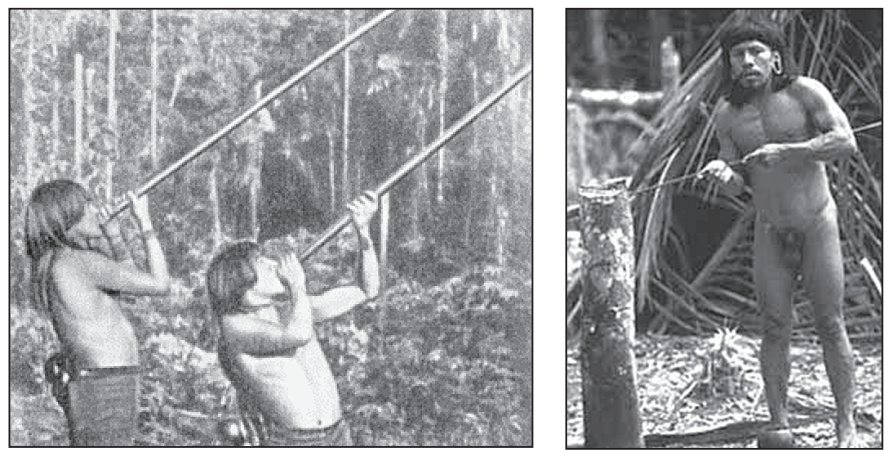

Рис. 211. Индейцы на охоте на птиц выдувают отравленные кураре стрелы из бамбуковых трубок

исследователей, вряд ли можно отнести за счёт кураре. По всей вероятности, усиленное вдыхание угара от примешанных к кураре неизвестных веществ оказывалось смертельным. К таким примесям, возможно, относились растения, подобные сумах - ядовитому дереву (Григорьев М.С., Аничков М.Н., 1957).

В 1857 г. Джон Сноу (John Snow) наблюдал, как во время наркоза хлороформом дыхание «... иногда выполнялось только диафрагмой, в то время как межрёберные мышцы были парализованы». (Цит. по Д. Ворнеру, 1998.)

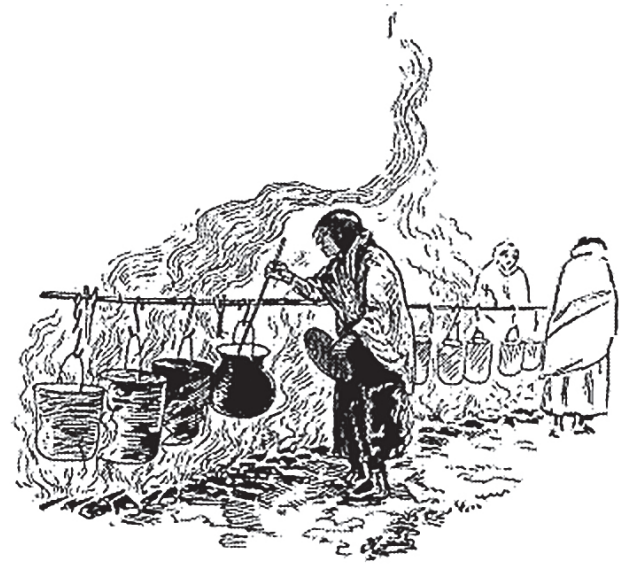

Рис. 212. Приготовление «стрельного яда», в состав которого включалось кураре 


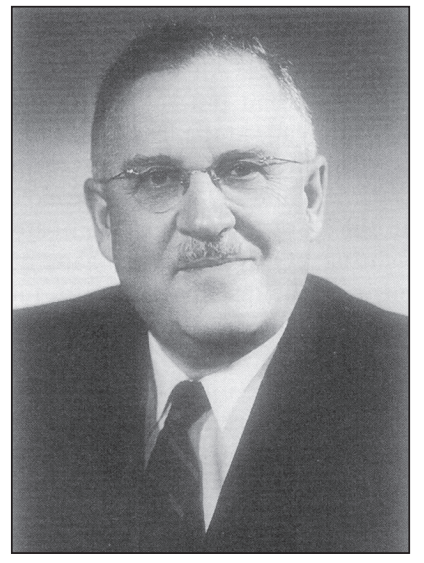

Рис. 213. Гарольд Гриффит (1894-1985). Президент канадской ассоциации анестезиологов (с 1943).

Ввёл в анестезиологическую практику мышечные релаксанты (кураре)
Кураре и искусственная вентиляция впервые были применены при лечении животных и в эксперименте сэром Benjamin Brodie в Англии в 1811 году.

К 1935 г. Кинг (King) выделил из кураре его основной естественный алкалоид - тубокурарин. Впервые мышечный релаксант тубокурарин (интокострин) был использован в клинике 23 января 1942 г. в Монреальском Гомеопатическом госпитале доктором Гарольдом Гриффитом (Harold Griffith) (рис. 213) и его помощницей Энид Джонсон (Enid Johnson - рис. 214) при операции аппендэктомия под циклопропановым наркозом 20летнему водопроводчику. Это стало вехой в развитии анестезиологии. Использование мышечных релаксантов значительно облегчало интубацию трахеи и позволяло проводить наркоз на поверхностном и более безопасном уровне.

Сукцинилхолин (дитилин) был синтезирован Бове (Bovet) в 1949 г. и разрешён к применению в клинике с 1951 г. Он стал препаратом выбора для обеспечения интубации и поддержания наркоза в челюстно-лицевой хирургии.

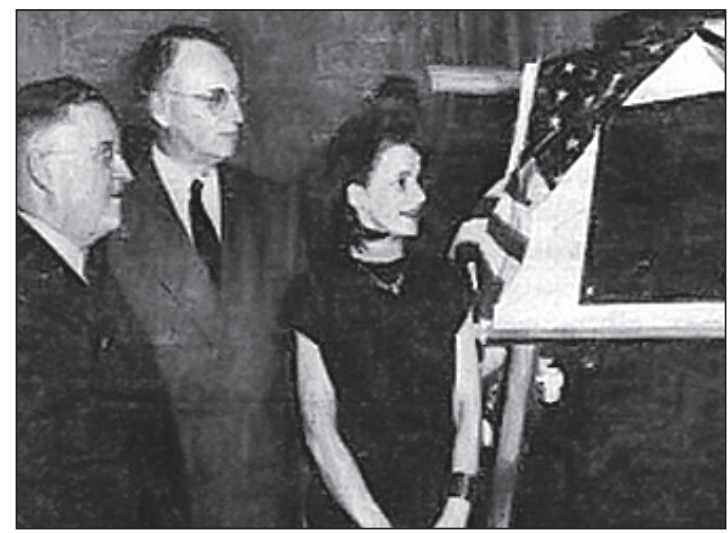

Pис. 214. В центре Enid Johnson MacLeod (род. в 1909 г.), слева Harold Griffith Ил. из лекции К.М. Лебединского (СПб МАПО) 
В нашей стране современный эндотрахеальный наркоз начали применять с 1946 г. В 1948 г. вышла первая отечественная монография, посвящённая этому методу, - «Интратрахеальный наркоз в грудной хирургии» (Григорьев М.С., Аничков М.Н.). Пионерами применения миорелаксантов на фоне эндотрахеального наркоза в нашей стране были М.С. Григорьев и М.Н. Аничков. Ими написана первая отечественная монография о миорелаксантах «Кураре и курареподобные препараты в хирургии», изданная в 1957 г.

В 1961 г. Американское общество анестезиологов (ASA) приняло классификацию объективного статуса больного, используемую при предоперационном обследовании.

\section{Ларингеальная маска (ЛМ) и другие воздуховоды}

В настоящее время во многих странах широкое распространение получил новый метод оптимизации проходимости дыхательных путей во время общей анестезии с помощью ларингеальной маски (рис. 215). Впервые тубус с блокирующей ротоглотку манжетой предложил в 1937 г. канадский анестезиолог Беверли Чарльз Лич (Beverly Charles Leech, 18981960 - рис. 216 - 218). Доктор Лич начал исследование размера и формы глотки в феврале 1935 года, в основном используя восковые отпечатки трупов. Его цель состояла в том, чтобы разработать плотно прилегающий глоточный воздуховод и расширить использование циклопропана, который в то время превосходил другие доступные анестетики, но требовал использования замкнутой системы. Он также желал избежать интубации, которую описал как «медленную и трудную, сопровождаемую риском ларингоспазма». Лишь в начале 80 -х годов прошлого века группа английских анестезиологов во главе с Арчибальдом Брэйном (A. Brain) разработала современную концепцию применения ларингеальной маски (рис. 219, 220).

История создания и применения ларингеальной маски включает в себя три периода:

1. Создание образцов-предшественников типа маски Гольдмана.

2. Создание прототипов ЛМ (1981-1988 гг.):

- силиконовые;

- латексные;

- смешанные модели.

3. Повсеместное распространение ЛМ (с 1988 г.). 

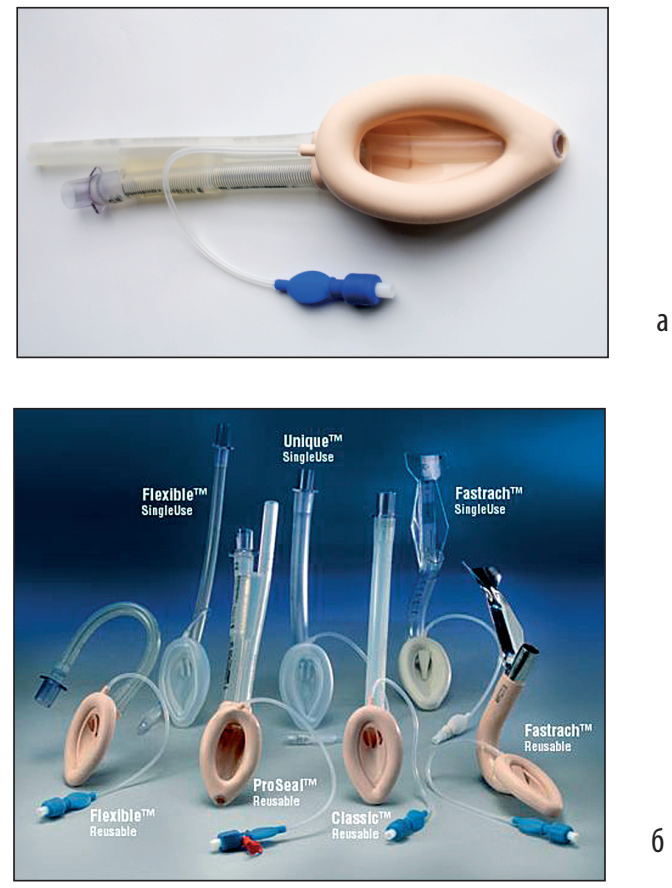

Рис. 215. Ларингеальная маска: A - ЛМ с каналом для желудочного зонда (Pro Seal). Б - различные варианты современных ЛМ

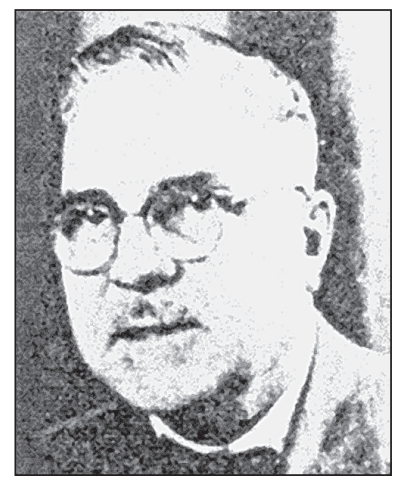

Рис. 216. Беверли Чарльз Лич (1898-1960). Ил. D.A.E.Shephard: Can. J. Anaesth. 1990, 37, 6, p. 689

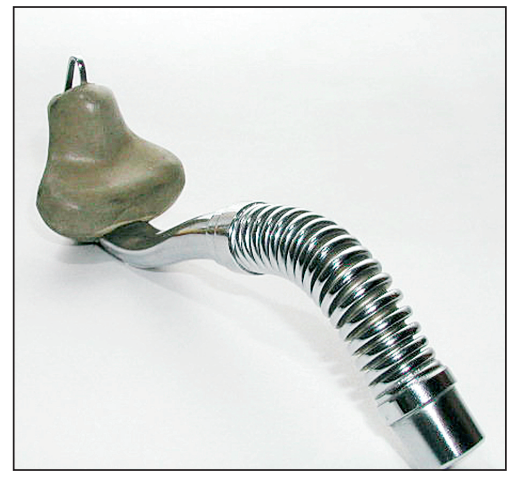

Рис. 217. Глоточный воздуховод Лича (1937). [Ил. E. Zadrobilek из коллекции Института истории медицины в Вене (Австрия)] 
Nop. 16, 1937.

B. C. LEECH

$2,099,127$

PEAATNOEAL BUEB OASWAY

Filod Doc, 30, 1956
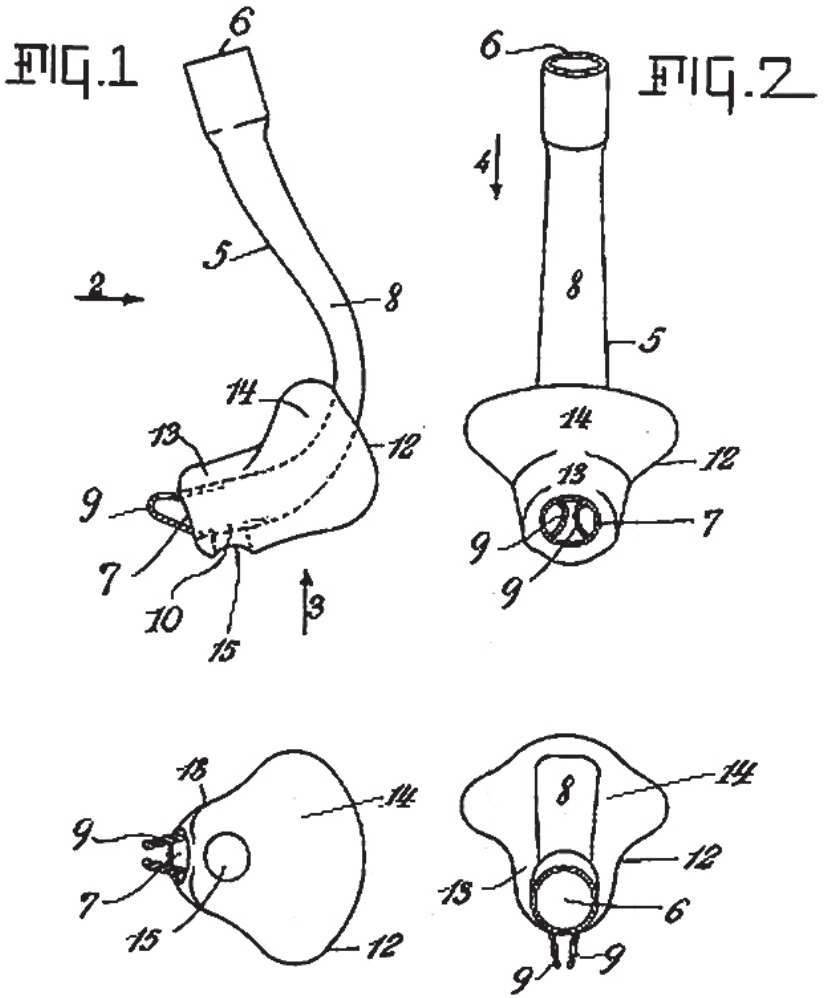

쿄딕.
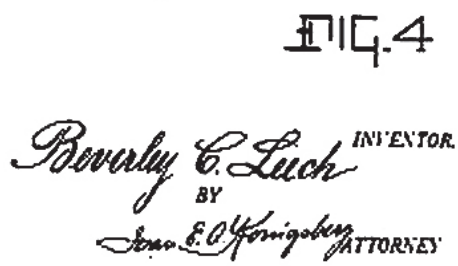

Рис. 218. Рисунки из патента на глоточный воздуховод Лича 


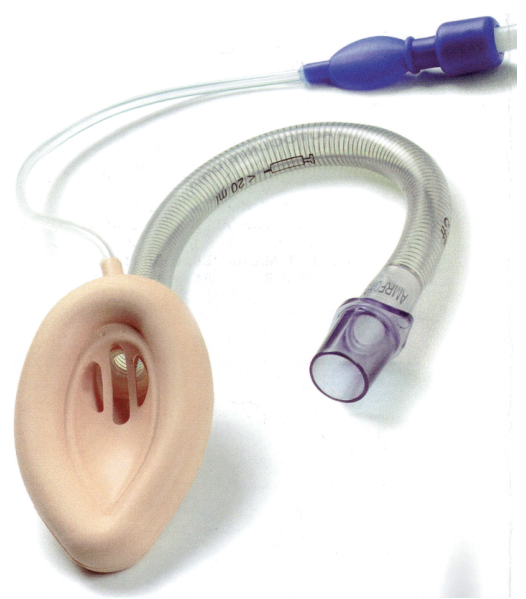

Рис. 219. Ларингеальная маска LMA Flexible ${ }^{\mathrm{TM}}$
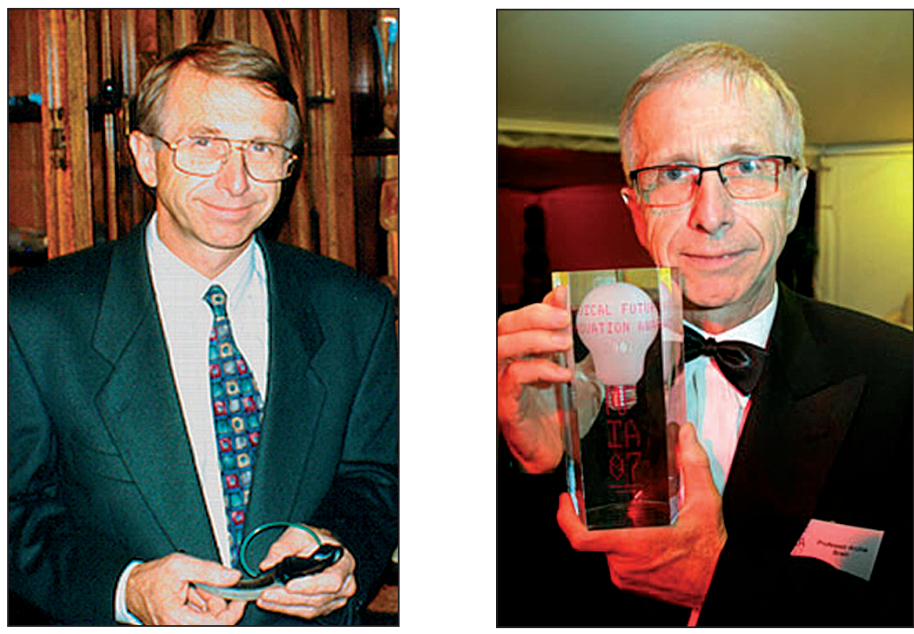

Рис. 220. Арчибальд Брэйн (род. 1942 г.).

В 1983 г. создал и внедрил ларингеальную маску для поддержания

проходимости дыхательных путей

Работая в 1981 г. в London Hospital Anaesthetics Unit доктор Брэйн под руководством профессора Раупе, изучая проблемы проходимости воздухоносных путей, сделал слепок ротоглотки трупа (рис. 221). 


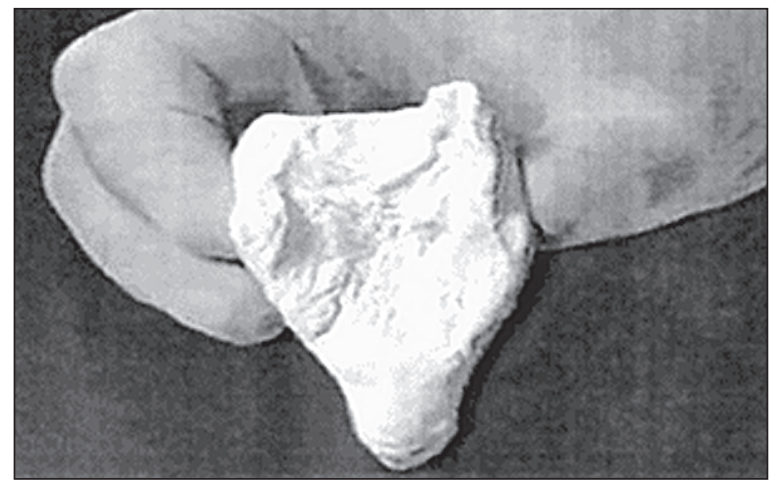

Рис. 221. Слепок ротоглотки, полученнный А. Брэйном

На слепке было обнаружено пространство, находящееся вокруг и позади глотки, куда могли попадать инородные тела и давить на гортань. В этот период доктор Брэйн работал в клинике хирургической стоматологии и для обеспечения проходимости дыхательных путей во время наркоза использовал воздуховод Мэйджила с присоединённой к нему стоматологической маской Гольдмана (Victor Goldman, рис. 222). Это была носовая маска одного размера с отсоединяющимся круговым надувным баллончиком. Баллончик, сформированный в форме эллипса, имел край для подсоединения ригидного компонента маски. Брэйн обратил внимание на сходство величины и формы баллончика маски Гольдмана и полученного слепка ротоглотки. Это привело его к экспериментам в нерабочие часы и открытию, что если края баллончика свести вместе по средней линии, формируя длинную ось эллипca, то получится совершенно новая форма, похожая на надувную лодку с краями, формирующими дно. В то же время искривления, вызванные сведением краёв маски Гольдмана, создавали большое сходство с фарингеальным слепком. При адаптации полученного образца и гортани трупа выявилось, что он очень хорошо сливается с грушевидной ямкой, в то время как лодкообразный нижний край баллончика плотно прилегает к треугольному контуру нижнего отдела глотки. Заключительным шагом этого рабочего этапа явилось подсоединение баллончика к трубке диаметром 10 мм и широкому краю маски с помощью акрилового клея. Баллончик опытного образца хорошо располагался в ротоглотке, и его можно было легко сдувать и раздувать, как манжетку интубационной трубки. Этот образец легко стерилизовался в хлоргексидине и использовался у больных мужчин при операции грыжесечения в William Harvey Hospital, Ashfort, Kent в 1981 г. 


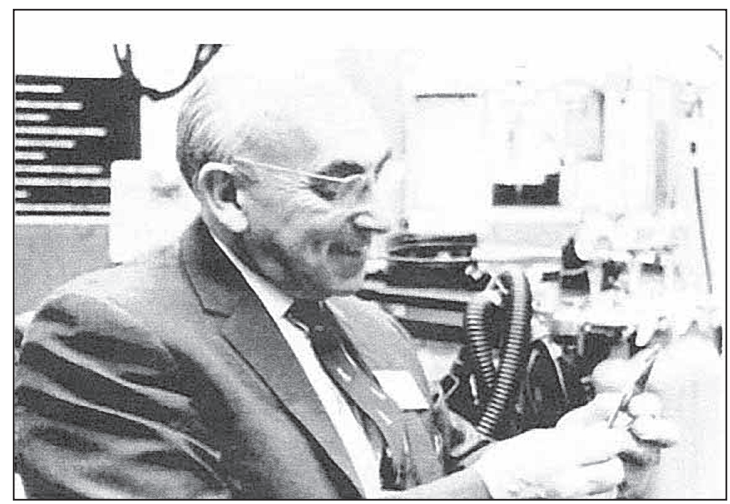

Рис. 222. Victor Goldman (1903-1993). Эта фотография использовалась Ассоциацией анестезиологов Великобритании и Ирландии на заседании в 2006 г., посвящённом Гольдману. Испаритель Гольдмана длительное время применяли в подразделении Виктора Гольдмана

в Eastman (томатологического института Лондона, крупнейшего стоматологического академического центра в Европе. (Ил. Bull. Hist. Anesth., 2003, vol. 21, № 4, p. 12.)

В феврале 1983 г. ЛМ была впервые использована в случае неудачной интубации у больного массой тела 114 кг для проведения неотложной лапаротомии. Вентиляция проводилась в течение трех часов с пиком давления в воздухоносных путях 6 кРа. Осложнений не было. Это побудило Брэйна провести в течение последующей недели 4 опыта на самом себе. ЛМ устанавливалась без медикаментозной подготовки и местной анестезии. Сохранялась хорошая проходимость дыхательных путей, болезненных ощущений не отмечалось. Так было установлено, что ЛМ может быть использована в трудных случаях и при правильной технике - атравматично.

В мае 1983 г. была проведена интубация трахеи «вслепую» через ЛМ, при этом трубка ЛМ составляла в диаметре 14 мм, а просвет интубационной трубки был 9 мм.

В связи с ростом коммерческого интереса в конце 1985 г. Dunlop по чертежам доктора Брайна сделала серию новых силиконовых масок в виде эллипса с перегородками в центральном отверстии. Этим самым предотвращалась обструкция гортани надгортанником. ЛМ стала лучше скользить, чем улучшилась её установка. Появилась возможность выпускать воздух из баллончика до получения тонких его краёв. Этим резко уменьшилась вероятность сталкивания баллончика ЛМ с надгортанником. Перестал использоваться металлический проводник, и изменилась техника введения ЛМ. Она стала устанавливаться напрямую, без поворота на $180^{\circ}$ и использования ларингоскопа. 
В апреле 1987 г. был зарегистрирован 21 случай использования ЛМ у больных с трудной интубацией. В мае 1987 г. силиконовый прототип ЛМ был успешно применён постовой медицинской сестрой отделения интенсивной терапии в госпитале святого Андрея в лондонском районе Боу для реанимации больного с остановкой сердца и дыхания. До этого сестра никогда не использовала ЛМ, но методику ей объяснили на словах.

В октябре 1987 г. Брэйном сконструирована назальная ЛМ и опробована у больного при удалении кисты языка. Идеей было сделать трубку разборной так, чтобы она могла бы быть удалена после установки.

ЛМ была введена в клиническую практику в 1988 г. и быстро получила распространение во всём мире, от госпиталей развитых стран до госпиталей Ганы, Камеруна и горного Непала. В США ЛМ применяется с 1992 г. и считается рутинной процедурой. J. Brimacombe, C. Verghese (1995) на ежегодном научном собрании австралийского анестезиологического колледжа в Тоунсвилле отразили опыт успешного использования ЛМ у 11910 пациентов. В Германии первые предварительные исследования на 15 пациентах проведены в 1991 г. и были сдержанно оценены немецкими анестезиологами. Однако уже через 2 года ЛМ заняла прочное место во многих немецких клиниках.

В России внедрение ЛМ начато в 1995 г. (г. Новосибирск). Первый обзор по применению ЛМ опубликован в 1994 г. М.В. Лукьяновым, а краткое руководство В.П. Шевченко «Физиологические основы и проблемы использования ларингеальной маски» - в 1997 г. Авторами первых отечественных работ по применению ЛМ в челюстно-лицевой хирургии и стоматологии являются П.Ю. Столяренко (1999) и С.А. Рабинович с соавт. (1999).

Относительно недавно компанией «Intersurgical» (Великобритания) был представлен созданный на основе инновационных технологий надгортанный воздуховод принципиально новой конструкции I-gel (рис. 223).

I-gel представляет собой изделие однократного применения, изготовленное из медицинского термопластического эластомера и представленное шестью размерами (три из них детские), применение которых обусловлено антропометрическими параметрами пациентов. Созданию I-gel предшествовали многочисленные исследования и интенсивный анализ литературы, посвящённой различным воздуховодным устройствам, - этот поиск охватил период, начиная с XVIII столетия и до наших дней (Мустафаева М.Н. и соавт., 2008). 

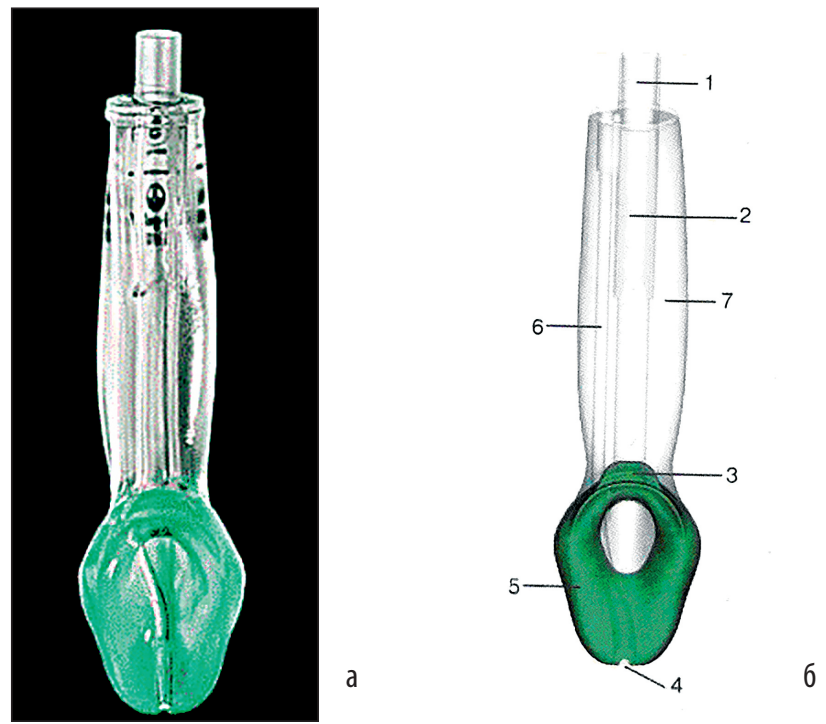

Рис. 223. а - общий вид надгортанного воздуховода i-gel;

6 - описание: 1 - коннектор диаметром 15 мм, 2 - защитное усиление, 3 - блокатор надгортанника, 4 - дистальное отверстие желудочного канала, 5 - нераздувная манжета, 6 - желудочный канал, 7 - ротовой стабилизатор

Надгортанный воздуховод идеологически близок ко всем существующим на данный момент аналогам, но в максимальной степени приближён к известному воздуховоду LMA ProSeal, поскольку имеет кроме основного - воздуховодного канала большого диаметра, второй - так называемый желудочный канал. Благодаря форме наружной поверхности нераздувной манжеты, соответствующей анатомическому строению гортаноглотки, а также свойствам мягкого и упругого, термопластического материала I-gel обеспечивает нетравматичный и герметичный контакт со структурами гортаноглотки и в то же время поддерживает необходимую жёсткость, обеспечивающую введение и установку воздуховода (рис. 224).

Как указывалось, I-gel не имеет раздувной манжеты и обладает за счёт этого рядом преимуществ: простотой введения, стабильностью положения после установки (не происходит смещения, свойственного ЛМ после раздувания манжеты, вследствие чего сводится к минимуму риск сдавливания тканей гортаноглотки). Гелеобразная нераздувная манжета точно соответствует анатомическим структурам гортаноглотки, зеркально отражая форму надгортанника, черпалонадгортанных 
складок, грушевидных карманов, соответствующих фрагмонтов щитовидного и перстневидного хряща, а также задней группы хрящей гортани. Каждой из этих структур соответствует определённой формы углубление на манжете, что помогает обеспечить герметичность, при этом верхушка, на которой открывается дистальное отверстие желудочного канала, попадает во вход в пищевод, изолируя его от входа в гортань и обеспечивая точное введение зонда. Трубка воздуховода изготовлена из более плотного материала, чем чаша. Её естественная кривизна, соответствующая форме ротоглотки, позволяет легко вводить воздуховод, удерживая только его проксимальный конец. Относительная «жёсткость» конструкции не предполагает использования пальца (или специального интродьюсера) для придания направления манжете в полости рта, как это необходимо для установки ЛМ.

Вся поверхность воздуховода мягкая и не имеет затрудняющих введение неровностей, что позволяет I-gel легко скользить (после предварительного смазывания) по твёрдому нёбу, вдоль задней стенки глотки и гортаноглотки. Ротовой стабилизатор представляет собой эллептическое (в разрезе), симметричное и уплощённое по бокам расшитение трубки воздуховода, обеспечивающее хорошую вертикальную устойчивость при установке. Он содержит в себе воздуховодный канал и отдельный желудочный канал, предназначенный для эвакуации желудочного содержимого посредством установки сквозь него гастрального зонда и предупреждения последствий возможной регургитации. В центре проксимального

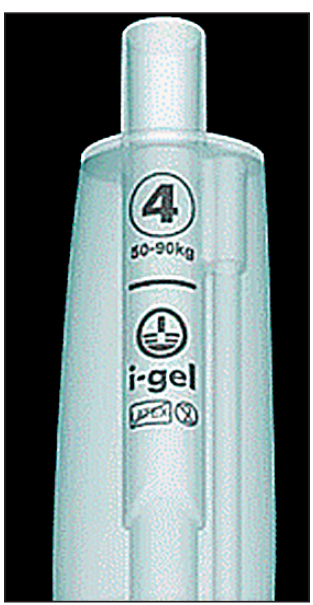

Рис. 225. Ориентир правильного положения воздуховода - чёрная горизонтальная линия (www.i-gel.com) участка ротового стабилизатора, дистальнее фланцев коннектора, встроено защитное усиление, предупреждающее повреждение зубами и перекрытие каналов. Имеется и ориентир для правильной 
установки: воздуховод введён правильно, если чёрная горизонтальная линия располагается на уровне зубов (рис. 225). I-gel не содержит латекса и предназначен для одноразового употребления. Выбор размера воздуховода зависит от массы тела больного.

Так же как ЛМ и другие надгортанные воздуховоды, I-gel может быть использован в качестве проводника для эндотрахеальной трубки при трудной или неудавшейся интубации трахеи. 


\section{ИСТОРИЯ ТРАХЕОСТОМИИ И ИНТУБАЦИИ ТРАХЕИ}

Попытаемся представить яркую и неоднозначную историю трахеостомии и интубации трахеи за 40 столетий с момента первого описания процедур - примерно 2000 лет до нашей эры - до середины до XX века - столетия, которое, считается началом современной эпохи анестезиологии. Ирландский драматург и философ Джордж Бернард Шоу стал известен в XX веке благодаря «язвительным комментариям» по проблемам медицины. В 1906 году он высмеял частоту, с которой в медицинской истории «теряются и открываются новые идеи» (Shaw G.B., 2008). Нет более изящной иллюстрации этого феномена, чем история трахеостомии и интубации трахеи. Хотя невозможно определить изобретателя отдельно взятого метода обеспечения проходимости дыхательных путей или устройства, методы и инструментарий сами по себе периодически возвращались в течение почти 4000 лет. Одним из наиболее ранних описаний проведения хирургической трахеостомии можно считать описание исцеления от разреза глотки в бронзовом веке в Rig Veda, древней индийской книге медицины, чьё появление датируется примерно 2000 г. до нашей эры (Colice G.L., 1994)). Через пять столетий в Египте согласно работам Имхотепа (вероятно отца современной медицины, который также был архитектором, поэтом, жрецом, судьёй, премьер-министром), был впервые документирован в письменной форме метод, подобный трахеостомии. На самом деле египетские врачи были «пионерами», описавшими ряд процедур - например: катетеризацию, чтобы предотвратить сильное кровотечение во время операции, дренирование для лечения гнойных образований и трахеостомию для лечения обструкции верхних дыхательных путей (Musso C.G., 2005).

Позднее в Греции Гиппократ (460-380 г.г. до нашей эры - рис. 226) описал интубацию трахеи у человека для проведения вентиляции лёгких.

Известно, что Александр Македонский (356-323 г.г. до нашей эры) использовал меч для разреза трахеи у солдата с удушьем вследствие аспирации костью (Colice G.L., 1994). Талмуд, сборник иудейских законов, этики, традиций и истории, накопленный в период между 200 г. до нашей эры и 400 г. нашей эры, содержит описания введения тростника через трахею для осуществления искусственного дыхания у новорожденного ребёнка [Babylonian Talmud, Shabbat 128b. http://www.sacred-texts.com/jud/t01/index.htm ].

Греческие врачи Эскулап и Аретей, а также Римский анатом Галленус документально подтвердили подобные операции. Примерно 100 лет до нашей эры трахеостомия могла быть рутинной (Frost E.A., 1976). 


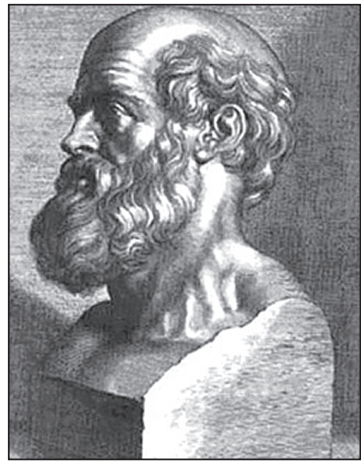

Рис. 226. Гиппократ

(460-380 г.г. до нашей эры) (гравюра Петер-Пауль Рубенса, 1638; Национальная Библиотека Медицины)

Движение воздуха и способы, с помощью которых это достигалось, часто кажутся «странными» и таким образом соответствуют положению мистера Шоу «открытые» в разное время на протяжении всей истории. В известных экспериментах Гален (129-199 гг. нашей эры) раздувал лёгкие мертвых животных через трахею с помощью воздуходувных мехов и сделал вывод, что движение воздуха вызывает «поднятие» грудной клетки. Однако важность этих данных не была оценена, и научные исследования по вентиляции лёгких не продвинулись вперёд в течение ряда столетий. Большой вклад в эксперименты в области дыхательных путей внёс мусульманский философ и врач Авиценна (980-1037 г.г. нашей эры), который описал интубацию трахеи с помощью «канюли из золота или серебра».

В последующих столетиях в Средние века исторических указаний по исследованиям в области дыхательных путей практически нет. В редких упоминаниях в тринадцатом веке трахеостомия называлась «полу-убийство и скандал хирургии» (Watkinson J.J., Gaz M.N., Wilson J.A., 2000). Это описание объясняет отказ от её применения в те века. Только в период рассвета в эпоху Возрождения трахеостомия появилась вновь как важная медицинская процедура, когда параллельно с искусством и другими науками, был отмечен рассвет медицины. Попытки обеспечить проходимость дыхательных путей у человека вновь обрели значимость, и можно найти многочисленные описания трахеостомии. В 1543 году, например, в одно и то же время Коперник оспаривал доктрину церкви, объявив, что земля вращается вокруг солнца, а фламандский анатом Андреас Везалий (рис. 227) в Падуе опубликовал De Humani Corporis Fabrica (Mamepuя человеческого тела), произведя революцию в анатомии человека. В тот же год Везалий ввёл тростник в трахею умирающего животного и поддерживал вентиляцию лёгких путём вдувания время от времени воздуха через тростник (Gillespie N.A., 1948). Эти действия, как он писал, заставляли лёгкие растягиваться и сердце восстанавливало нормальный ритм: «... жизнь можно так сказать возвращается к животному, следует попытаться сделать отверстие в стволе трахеи, в которое надо поместить трубку или тростник: затем вы дуете в него так, чтобы лёгкие могли вновь подниматься и животное получало воздух». 


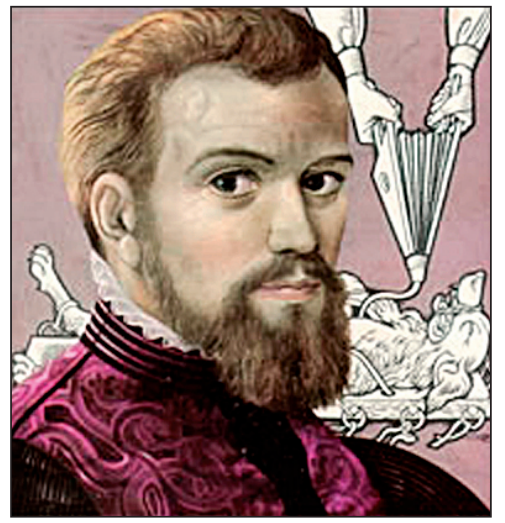

Рис. 227. Андреас Везалий (Andreas Vesalius, 1514-1564) - знаменитый врач (редневековья, один из основоположников анатомии вошёл в историю медицины критических состояний как автор одного из первых письменных описаний операции трахеостомии, выполненной им в эксперименте на животном с целью проведения искусственной вентиляции лёгких (1543 г.)

Вскоре после этого в 1546 году итальянский врач Антонио Брасавола (рис. 228) вновь провёл трахеостомию у человека, выполнив первую документированную попытку успешной трахеостомии (рис. 229) у пациента с тонзиллярной обструкцией (Colice G.L., 1994).

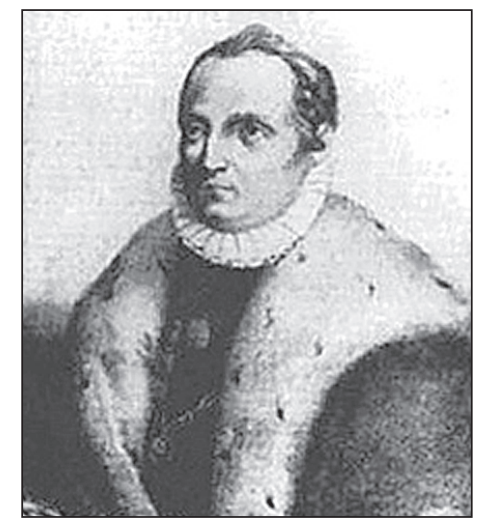

Рис. 228. Антонио Муса Брасавола (1490-1554), итальянский врач, выполнивший первую документированную попытку успешной трахеостомии. Он опубликовал свой отчёт в 1546 году. Пациент с абсцессом гортани выздоровел после проведения хирургической процедуры (Национальная Библиотека Медицины) 


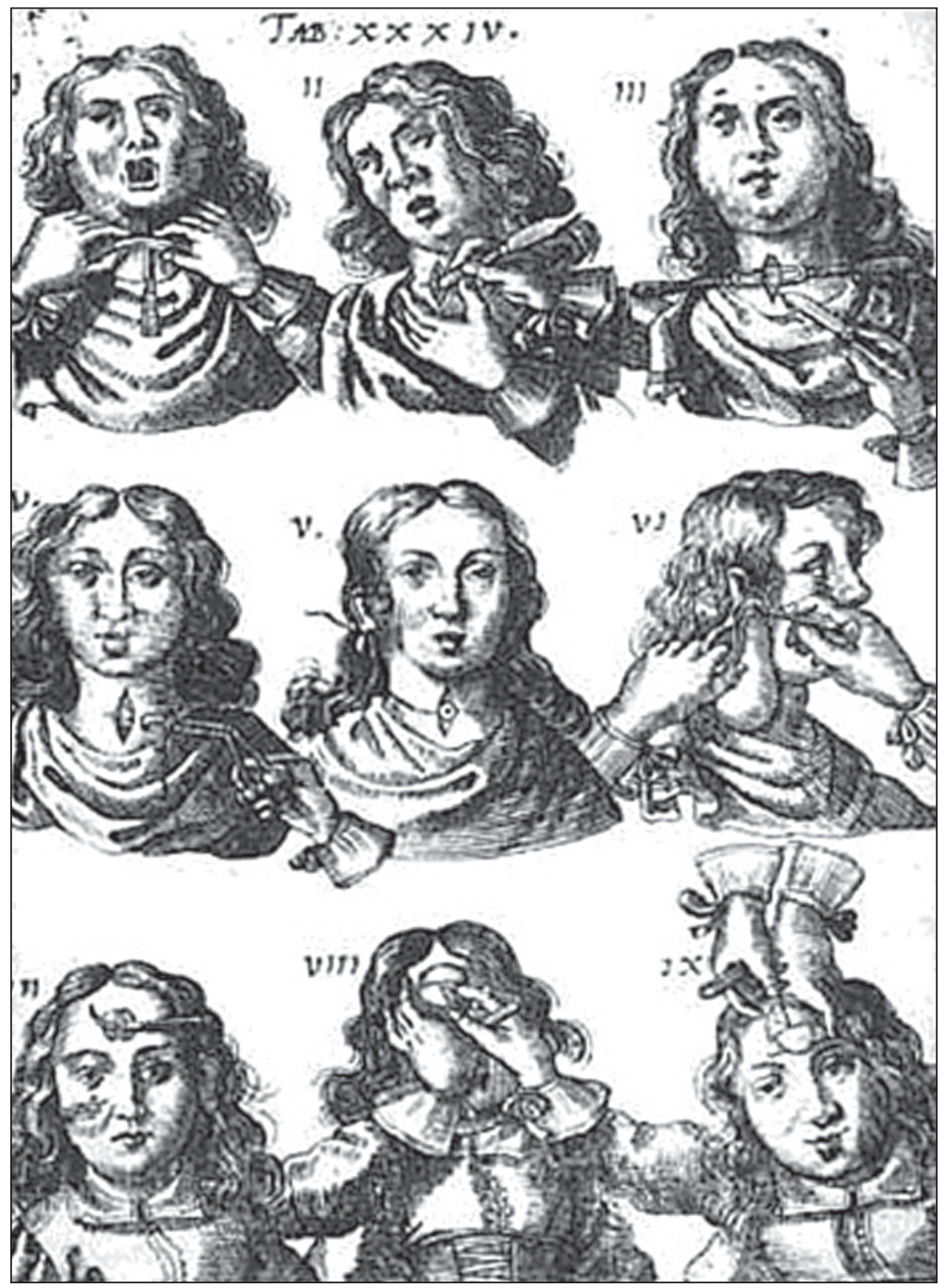

Рис. 229. Гравюра. Armamentarium chirurgicum bipartium , 1666.

(Национальная Библиотека Медицины). Первые пять изображений

на гравюре посвящены процедуре трахеостомии. В период между 1500 и 1833 г.г.

есть сообщения только 028 успешных трахеостомиях (Szmuk P. et al., 2008.) 
Эти примеры не единственные. Ряд медиков Эпохи Возрождения сделали акцент на важности «открывания дыхательных путей» для спасения жизни (Bradby M., 1966; Eavey R.D., 1998). Фабриций аб Аквапенденте (15371619), итальянский анатом, написал это историческое утверждение: «Из всех хирургических операций, которые выполняются у человека ... самой главной [является] операция, с помощью которой человек отзывается из быстрой смерти к внезапному восстановлению жизни ... операция - это открытие дыхательной артерии, с помощью которой пациенты из состояния практически удушья внезапно восстанавливают сознание и получают жизненный эфир, воздух, так необходимый для жизни, и вновь возобновляют существование, которое уже было почти уничтожено».

В 1620 году парижанин Николя Абико опубликовал книгу по трахеостомии. В ней Абико изложил подробно случай у 14-летней пациентки, которая проглотила кошель с золотыми монетами, чтобы спасти их от кражи. Кошель вызвал обструкцию верхних дыхательных путей, для устранения которой была проведена срочная трахеостомия. Другим героическим описанием в книге Абико - было описание мальчика, которой умирал от ранения в области шеи. После срочной трахеостомии и удаления сгустков крови из трахеи, мальчика успешно «реанимировали». Более драматичная история - это история осуждённого к повешению вора. Вор нанял хирурга для выполнения трахеостомии и введения длинной трубку для дыхания перед виселицей. Осуждённый мужчина тайно от тюремщиков провёл «эту искусную подготовку», но бесполезно. Несмотря на возможности трахеостомии защитить человека от удушения, она не смогла спасти преступника от перелома шейного отдела позвоночника.

В октябре 1667 года трахеостомия «была открыта» вновь: на собрании Королевского общества Роберт Гук (Robert Hooke, 1635-1703) выполнил трахеостомию у собаки и осуществлял вентиляцию с помощью воздуходувных мехов. Гук даже удалил грудную клетку и показал, что постоянный поток «свежего воздуха, изменяющий кровь», а не движение лёгких, как предполагалось, является главным для жизни (Атанасов А., Абаджиев П., 1963; Watkinson J.J., Gaz M.N., Wilson J.A., 2000). Однако следует отметить, что ещё в 1530 году Парацельс (1493-1541) использовал для искусственной вентиляции каминные меха и специальный ротовой воздуховод.

Несмотря на то, что Бенджамин Паф, английский акушер, описал вентиляционную трубку для реанимации новорожденного в 1754 году, первые эндотрахеальные интубации были использованы для реанимации «утопленников» и для реанимации пострадавших от дифтерии гортани (Szmuk P. et al., 2008). Большой прогресс в реанимации был сделан обще- 
ствами, созданными в Амстердаме, Париже, Лондоне, Венеции и Филадельфии для спасения «тонувших жертв из воды». В 1760 году Buchan описал первое применение открытия «дыхательного горла» у пациента во время реанимации (Colice G.L., 1994). Cullen предложил применение интубации трахеи и вентиляции воздуходувными мехами для «оживления предположительно мёртвых». Впоследствии Curry разработал интраларингеальную канюлю для реанимации (Colice G.L., 1994).

В 1788 году Чарльз Кайт впервые использовал эндотрахеальные трубки при реанимации тонувших людей и описал их применение оральным и назальным путём. Кайт писал: «Если какая-либо трудность возникает при раздувании лёгких... мы в большинстве случаев проводим выдвигание языка вперёд, который связан с надгортанником неэластичными связками, и который конечно должен быть приподнят. Если какие-либо другие препятствия возникают, изогнутую трубку, изгиб как на мужском катетере... следует ввести в голосовую щель через рот или через одну ноздрю; конец её следует соединить с дыхательной трубкой...» (Szmuk P. et al., 2008). 18 апреля 1774 года Cogan и Hawes основали лондонское общество спасения с громоздким названием «Институт для осуществления немедленного лечения у людей кажущихся мёртвыми при утоплении», которое позднее было переименовано в Королевское общество спасения. T. Cogan и W. Hawes указали, что интубация трахеи была более эффективной для выживания, чем дыхание рот в рот (Watkinson J.J., Gaz M.N., Wilson J.A., 2000).

В конце 1700-х годов Шосье (1746-1828) - гинеколог, работающий в родильном доме в Париже, выполнял трансларингеальные интубации самодельными трубками у новорожденных с обструкцией верхних дыхательных путей и был первым, кто назначил кислород новорожденным (Szmuk P. et al., 2008).

Несмотря на «открытия» и прогресс в обеспечении дыхательных путей за столетия, работа практиков была непредсказуемой. Решение выполнять или не выполнять процедуру - трахеостомию или интубацию трахеи - часто было настолько же решающим, как техническая возможность выполнить её успешно. В Вирджинии в декабре 1799 года, например, первый президент США через 3 года после отставки «лежал, борясь за жизнь»: «Это был холодный полдень, декабрь 1799 года, в Вирджинии... в тот день три врача собрались у постели умирающего мужчины. Мужчина менял положение, дышал с трудом. Врачи дали больному настой шалфея с уксусом для полоскания, но это вызвало у пациента удушье. Было ясно, что дыхательные пути поражены болезнью, но припарки помогали лишь незначительно». Один из присутствующих врачей знал о трахеостомии, но не выполнил её у такой важной персо- 
ны, так как посчитал процедуру бесполезной. В результате, Джордж Вашингтон умер от вполне предотвратимого удушья вследствие обструкции верхних дыхательных путей, вызванной бактериальным эпиглоттитом.

В подтверждение «колеблющихся» практиков эпохи - обеспечение дыхательных путей и методы вентиляции были предметом критики. Например, несмотря на то, что вентиляция положительным давлением с помощью воздуходувных мехов была впервые использована у жертв утопления в 1700-х годах, вскоре возникла проблема - такая терапия могла в действительности быть вредной для лёгких. В 1827 году Leroy показал, что сильная вентиляция воздуходувными мехами тонувшей собаки могла вызывать эмфизему и фатальный пневмоторакс. Французская Академия быстро отказалась от метода вентиляции воздуходувными мехами, а

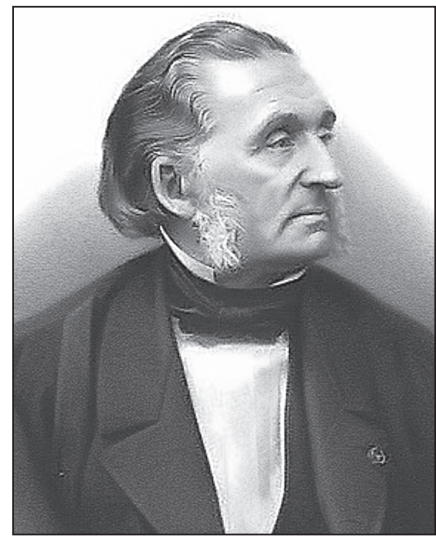

Рис. 230. Арман Труссо́ (Armand Trousseau, 1801-1867) французский терапевт, один из основоположников учения об инфекционных болезнях, член Национальной академии медицины вскоре от метода отказалось и Королевское общество спасения. Вентиляция положительным давлением была, таким образом, запрещена для общего применения, и не появлялась как «конкурент» другим методам более сотни лет. Несмотря на это значительное движение назад, трахеостомия и интубация трахеи продолжали выполняться и методики их проведения улучшались в течение последующих десятилетий, особенно при срочном обеспечении проходимости дыхательных путей (Szmuk P., 2008).

В 1833 году (по другим данным в 1837 году) француз Арман Труссо́ (рис. 230) рутинно выполнил при необходимости трахеостомию и таким образом спас жизни около 200 человек, страдающих дифтерией (Frost E.A., 1976). Труссо́ дал классическое описание дифтерии, разработал показания к трахеотомии и технику этой операции, изучил её осложнения. Он вторым после Бретонно с успехом произвёл трахеотомию при крупе, первым ввёл эту операцию в практику детских больниц и доказал, что трахеотомия с интубацией изогнутой двойной трубкой из твёрдого каучука (трубкой Труссо́) является эффективным и сравнительно безопасным методом неотложной терапии дифтерийного крупа. В конце XIX в. А. Труссо анатомический термин «дифтерит» заменил на термин «дифтерия». В то же время трахеостомия 


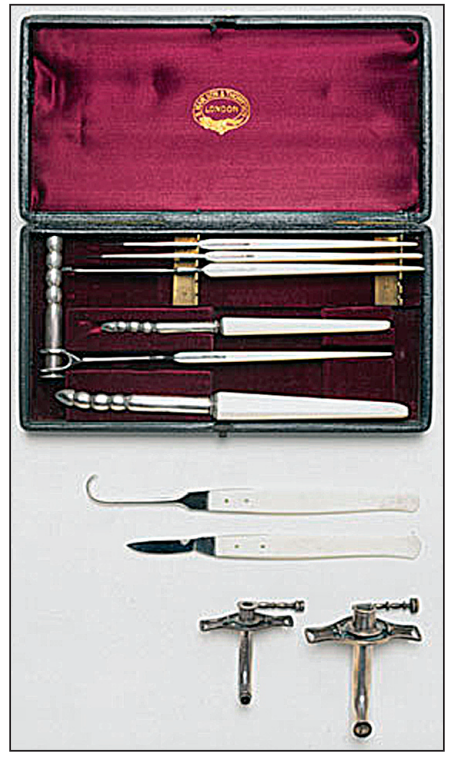

Рис. 231. Трахеостомический набор, применяемый в XIX веке продолжала выполняться только в срочных ситуациях ${ }^{6}$. На рис. 231 представлен трахеостомический набор XIX века, хранящийся в Британском музее медицины.

Принимая во внимание достижения Труссо 175 лет тому назад, следует отметить, что пациенты сегодня всё ещё умирают изза недостатков при обеспечении проходимости дыхательных путей с обструкцией; в челюстно-лицевой области, в частности, больные с флегмонами дна полости рта (Столяренко П.Ю., Кравченко В.В., 2000).

Впервые наркоз парами эфира и хлороформа через вставленную в трахею резиновую трубку при спонтанном дыхании выполнил в эксперименте на собаке в 1847 г. Н.И. Пирогов. В 1852 г. Джон Сноу трахеотомировал кролика, поддерживая хлороформом очень продолжительный наркоз, а затем применил этот метод в клинике на 4-летнем ребёнке при удалении инородного тела (пуговицы) из трахеи. С.С. Кликович (рис. 232) в 1881 г. в своей монографии, посвящённой закиси азота, опи-

сал эксперименты с введением закиси азота в трахею для достижения наркоза. Таким образом, они выполнили такой же эксперимент, описанный Везалием (1543) и Гуком (1667), за исключением дополнения анестетика.

Пионером применения ИВЛ во время анестезии стал американский хирург Рудольф Матас (рис. 233).

В мае 1898 г. в своём широко известном докладе Медицинскому Обществу штата Луизиана, позднее опубликованном в «Анналах Хирургии», Матас произвёл обзор проблем торакальной хирургии, наиболее подробно остановившись на проблеме пневмоторакса. В частности он отметил: «До тех пор, пока риск серьёзных нарушений функиии дыхания, обусловленньи острым коллапсом лёгкого, не будет устранён, или сведён к безопасному минимуму, для хирурга никогда не будет возможным провести аналогию между плеврой и брюшиной» (Matas R., 1899).

${ }^{6}$ М.А. Булгаков (1891-1940) в рассказе «Стальное горло» (1925) описал собственноручно проведённую трахеотомию при дифтерии в начале своей профессиональной деятельности.

Среди известных людей жертвой дифтерии стали французский композитор Ж. Визе и национальный герой Америки Дж. Вашингтон. 


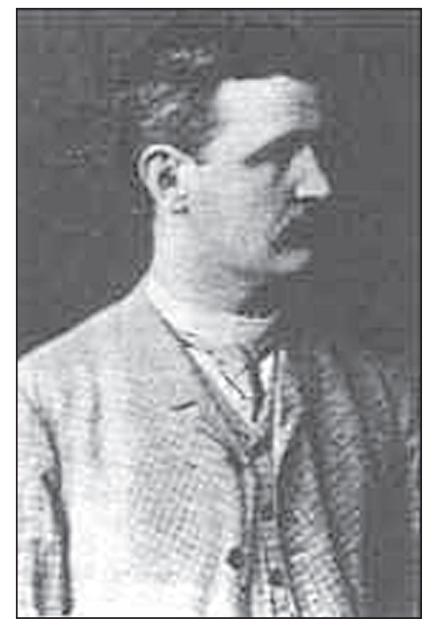

Рис. 232. Станислав Сигизмунд Кликович (1853-1910).

Русский военный врач. В историю российской анестезиологии он вошёл, благодаря своему фундаментальному исследованию свойств закиси азота (1880-1881).

Именно Кликович первым применил закись азота для обезболивания родов.

Он же первым применил этот анестетик эндотрахеально

В своём докладе Матас привел обзор литературы, на основании которого сделал вывод: «Проиедурами, которые гарантируют наибольший эфффект в предупреждении спадения тёгкого во время операций на грудной клетке являются искусственное раздувание лёгкого и ритмичное проведение искусственного дыхания с помощью трубки в голосовой щели, напрямую соединённой с воздуходувными мехами» (Matas R., 1899).

Кроме этого, Рудольф Матас был первым хирургом в США, последовавшим примеру немецкого хирурга Августа Бира и применившим спинномозговую анестезию во время хирургического вмешательства, говорит о многом (Bier A., 1899). По всей видимости, он был и первым в мире хирургом, применившим субарахноидальное введение опиатов при спинномозговой анестезии. Он добавлял к раствору кокаина морфин с целью потенцирования и пролонгирования действия анестезии, а также для создания седативного эффекта (Matas R., 1900).

Применяя метод трахеостомии, разработанный Н.И. Пироговым и Джоном Сноу на животных, в Германии в 1869 году Фридрих Тренделенбург (1844-1924 - рис. 234) сконструировал первую трахеостомическую трубку с манжетой и провёл первый эндотрахеальный наркоз через трахеостому 


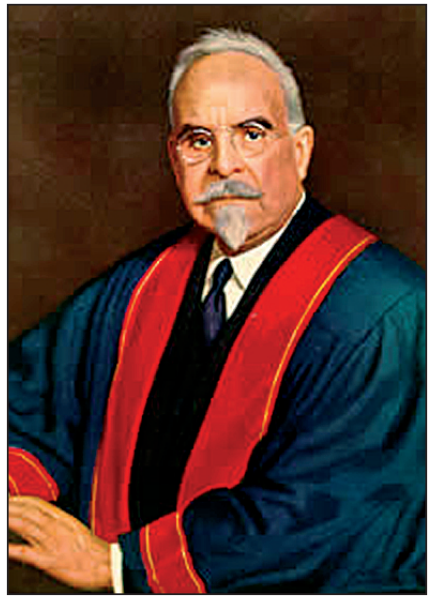

Puc. 233. Rudolph Matas (1860-1957). Ил. cwww.critical.ru

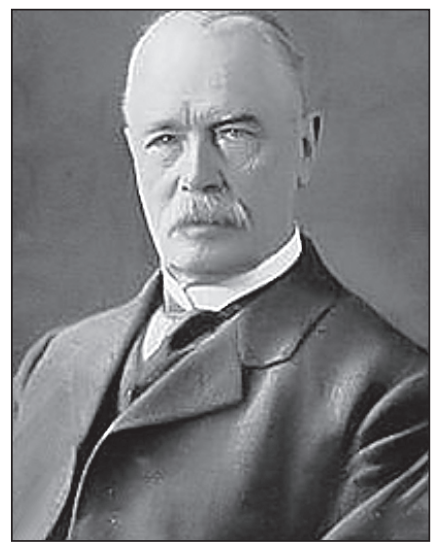

Pис. 234. Friedrich Trendelenburg (1844-1924). Выдающийся немецкий хирург, внёсший вклад в развитие анестезиологии у мужчины в начале 1871 года при операции в области носоглотки, предотвратив аспирацию стекающей крови (Атанасов А., Абаджиев П., 1963). В 1901 году эта первая трахеостомическая трубка с манжетой была названа «тампон Тренделенбурга».

Интубация трахеи помогала работе шотландского хирурга Уильяма Мак-Эвена (William MacEwen) и американца Джозефа О'Двайера (Joseph O'Dwyer, 1841-1898) во второй половине 19-го века. Вместе со многими достижениями в области хирургии, Мак-Эвен известен за первое плановое применение интубации трахеи для анестезии. В 1878 году готовясь к проведению удаления злокачественной опухоли корня языка, Уильям Мак-Эвен (William Macewan) выполнил «пальцевую слепую интубацию» трахеи через рот металлической трубкой у бодрствующего пациента под хлороформным наркозом, затампонировал глотку и далее продолжил анестезию уже через эту трубку (Howland W., Lewis J., 1956; Musso C.G., 2005). Основными его целями были - обеспечение непрерывного ровного снабжения анестетиком и профилактика аспирации крови в дыхательные пути. Мак-Эвен был также первым, кто провёл тампонаду глотки для предотвращения попадания в дыхательные пути крови, секрета и отделяемого из хирургической раны.

В 1885 году после получения доказательств о многочисленных эффектах быстрой трахеостомии, Джозеф О'Двайер (рис. 235), американский педиатр и акушер, разработал ряд металлических трахеальных трубок, которые он вводил через рот между голосовыми связками у пациентов с дифтерией, нуждающихся в операциях (рис. 236).

Трубки также использовались при стенозе гортани, вызванном различными другими заболеваниями, например, при сифилисе, и при стриктурах 
гортани вследствие ожогов. Сообщение о методе интубации, названном «метод О'Двайера », было впервые опубликовано в New York Medical Journal под названием «Интубация гортани» в 1888 году. В тот же год О'Двайер успешно интубировал и провёл искусственную вентиляцию у больных, которым проводились операции на грудной клетке.

Широкое распространение получил инструментарий для интубации системы Фруэна (Froin), представленный в 1892 году. Он состоял из роторасширителя, интубатора (интродуктора) и интубационных трубок шести размеров (рис. 237).

В конце 19-го века немецкий хирург Франц Кун (Franz Kuhn) внёс существенный вклад в

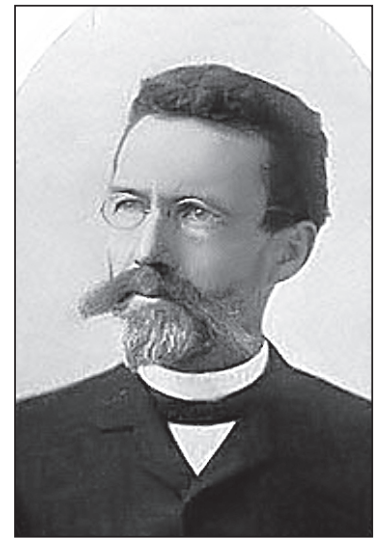

Puc. 235. Dr. Joseph 0’ Dwyer (1841-1898) повышение качества и безопасности общей анестезии. Он сконструировал металлические гибкие трубки, которые вводил через рот, используя пальцевой слепой метод (рис. 238). Работая в Касселе, Кун опубликовал более 90 работ, одна треть из которых была посвящена оротрахеальной интубации и технике вентиляции под положительным дав-
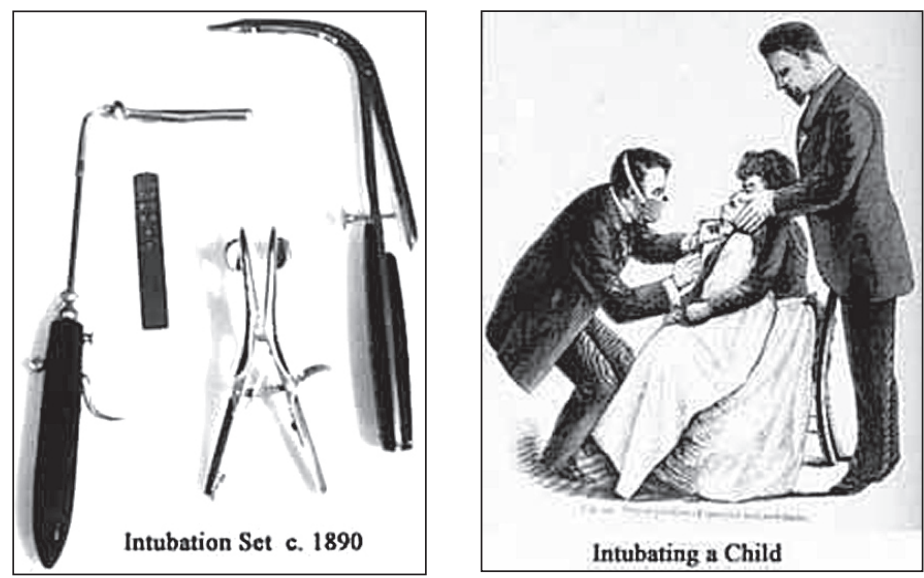

Pис. 236. Craig Gelfand, Интубационный набор доктора 0'Двайера (слева). Caduceus 1987; 3.2:1-35. 0'Двайер выполняет интубацию ребёнку, больному дифтерией 


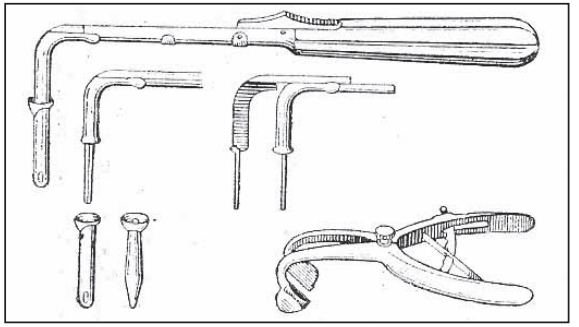

Рис. 237. Интубационный набор Фруэна лением. В 1900 г. у него умер пациент от внезапного кровотечения из глотки. По-видимому, этот печальный случай мотивировал Куна к развитию техники обеспечения проходимости дыхательных путей. В 1900 г. он предложил металлическую эндотрахеальную трубку. Первое детальное описание техники оротрахеальной интубации было в 1901 г. Он начал статью с цели работы: «Я описываю тубаж трахеи, чтобы гарантировать непосредственную безопасность проходимости дыхательных путей без трахеостомии». Кун писал, что интубация через рот поддерживает свободную проходимость дыхательных путей даже без выдвижения языка и нижней челюсти. Другое замечательное утверждение заключалось в том, что «даже прямая вентиляция воздуха в трахею резиновым мешком будет осуществима, как самая существенная мера в случае асфиксии». Он очень рано заметил важность поддержания проходимости дыхательных путей во время анестезии и операции. «Если во время анестезии дыхание становится неэффективным или прекращается, и есть потребность в искусственной вентиляции лёгких. Какая должна быть первая мера? Очистите и обеспечьте проходимость дыхательных путей. Как эта цель могла быть достигнута более быстро и более безопасно, чем при выполнении перорального тубажа?».
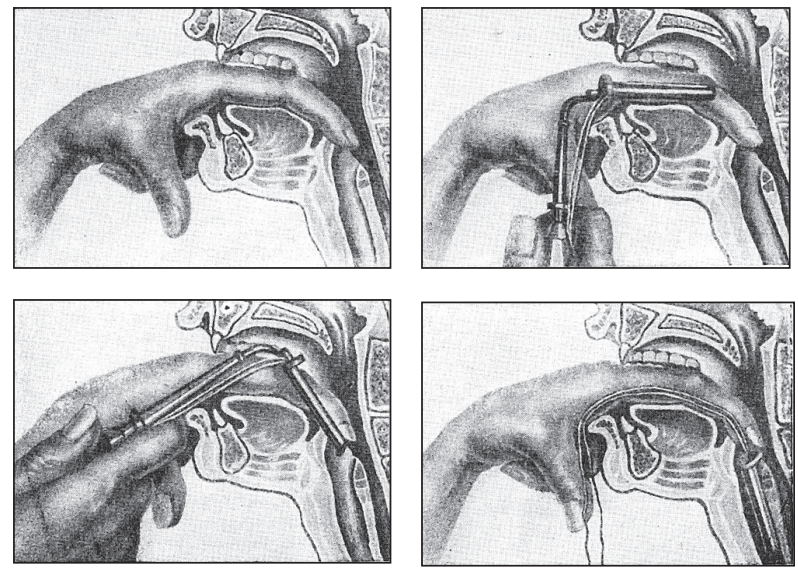

Рис. 238. Пальцевой слепой метод интубации 

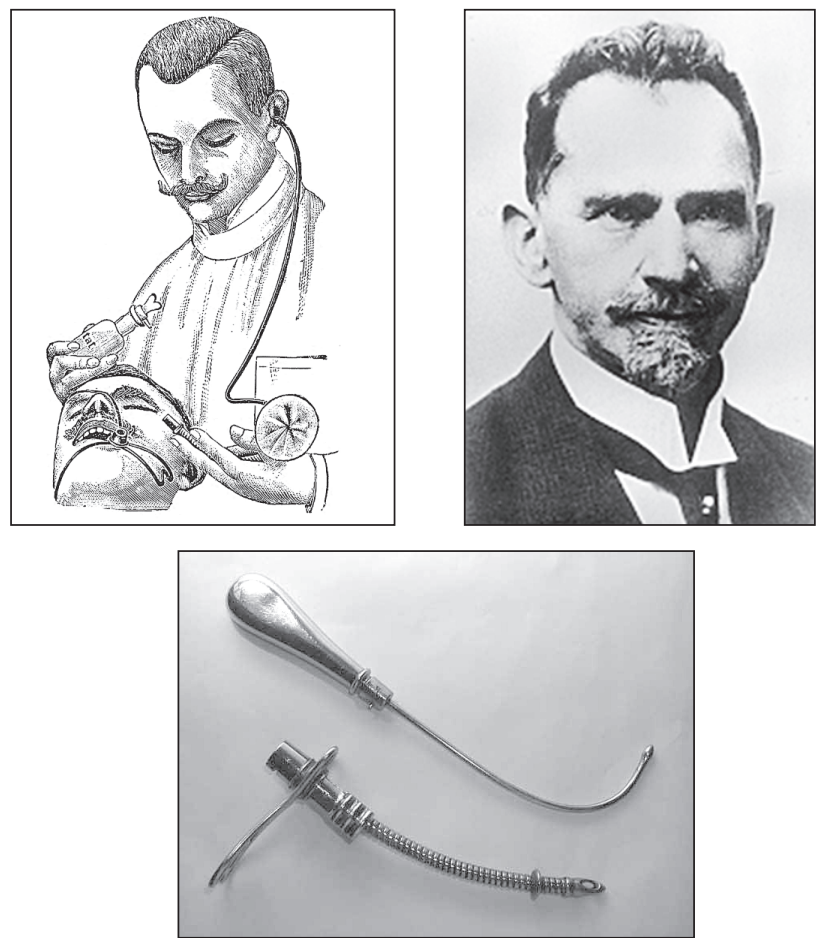

Рис. 239. Franz Kuhn (1866-1929) и его интубатор.

Из коллекции Carl Reiner (Вена, Австрия) http://www.adair.at

Интубатор Куна представлял собой трубку из металлических колец, соединённых при помощи резины так, чтобы трубка могла сгибаться, не закрывая при этом просвета. Составными частями интубатора являлись: рукоятка, крылья для фиксации трубки, сама трубка и клюв (рис. 239). Хотя Кун упоминал о возможности использования аутоскопа Kirstein, предшественника ларингоскопа, он обычно вводил трубку с помощью пальцевого ощупывания надгортанника и черпаловидных хрящей.

Интубатор вводился в трахею через рот при помощи изогнутого проводника (мандрена). После введения интубатора в трахею проводник удалялся, и наружный конец интубатора присоединялся к воронке Тренделенбурга, в которой находилась уложенная слоями марля. На эту марлю наливали каплями наркотическое вещество (эфир или хлороформ). Стетоскоп, приложенный к воронке Тренделенбурга, служил для контро- 
ля дыхания больного. Для премедикации использовал смесь атропина и морфина, которую вводил подкожно. При интубации Кун рекомендовал применять трубки различных размеров в зависимости от возраста и пола больных. Первые трубки Куна имели размер 12 и 15 см в длину с ограничителем, предотвращающим слишком глубокое продвижение трубки в трахею. В проксимальном конце трубки была установлена защитка для устранения возможности повреждения трубки зубами. Он рекомендовал использовать трубки с диаметром 6-7 мм для детей, 9 мм - для женщин и до 10 мм - для мужчин. Перед введением интубатора он предлагал либо анестезировать слизистую гортани раствором кокаина (иногда с добавлением адреналина), либо вводить пациента в наркоз при помощи маски. При этом Кун указывал, что наркоз должен быть достаточно глубоким. Кун чаще проводил интубацию трахеи при сохранённом сознании пациента. Он предпочитал в целях предотвращения аспирации использовать тампонаду гипофаринкса марлевым бинтом вместо трубок с манжетами. Кун успешно применил эндотрахеальный наркоз при 48 операциях в полости рта и носа. Он был первым, кто регулярно использовал интубацию трахеи во время анестезии с 1900 года. Кун описал применение изогнутого проводника. Кун также опубликовал первую статью по назальной интубации в 1902 году. Он считал, что назальные трубки «лежат лучше» и удаляются без затруднений при операции. Кун был первым, кто открыл, что нетупые хирургические раздражители легко могут приводить к спазму гортани. Он первым использовал позитивное давление для предупреждения коллапса лёгкого при открытой плевре.

Кун рекомендовал интубацию трахеи при асфиксии, реанимации, а самое важное - во время наркоза с использованием хлороформа. В широком диапазоне показаний, он описал использование этой техники у пациентов, оперированных на желчном пузыре, при резекции языка и опухолей нижней челюсти, нейрохирургических операциях и др.

В 1911 году Кун написал монографию «Интубация через рот» (рис. $240)$, в которой обобщил полученные данные по введению трубки в трахею (Kuhn F., 1911), совместно с Генрихом Дрэгером (Heinrich Draeger, 1847-1917) разработал наркозный аппарат (рис. 241). Он считал, что «кокаинизация» гортани является полезным дополнением при интубации и часто использовал её. Этот метод был в дальнейшем разработан Magill в Англии. Попытки Куна, возможно, были первыми историческими шагами к интубации трахеи у бодрствующего пациента под поверхностной анестезией - метод, часто используемый сегодня у пациентов с «трудными дыхательными путями». 
В начале XX столетия возникло научное противостояние Куна с Фердинандом Зауэрбрухом (Ferdinand Sauerbruch). Прежде чем Фердинанд Зауэрбрух изобрёл в 1904 г революционное понятие операционной палаты отрицательного давления для грудной хирургии, хирургические вмешательства на грудных органах были чрезвычайно затруднительны и редки. Пациент дышал спонтанно, в то время как его грудная клетка была помещена в большую барокамеру с отрицательным давлением, где хирурги могли работать на грудной клетке, избегая пневмоторакса из-за пониженного давления. Франц Кун, против общепринятого мнения, предложил использовать свою эндотрахеальную трубку после тампонады гипофарингса - чтобы выполнить положительное давление непосредственно к лёгким и избежать пневмоторакса во время торакотомии. Он также сделал эксперименты с резиновым покрытием его металлических трубок, чтобы проверить их воздухонепроницаемость. Резиновые воздушные шары, подобные раздувной манжете трубки, были помещены в зев, гортань или трахею, чтобы герметизировать воздухоносные пути и позволить вентиляцию под положительным давлением.

Вместе с Дрэгером (Dräger), изготовителем наркозных аппаратов, он разработал аппарат для анестезии Kuhn-Dräger для вентиляции под положительным давлением. Из-за спора с пользующимся авторитетом в те годы Зауэрбрухом о методах предотвращения пневмоторакса во время торакотомии и развития местных и региональных методов анестезии, ценность работ Франца Куна не была оценена ещё около 40 лет (Thierbach А., 2001).

В Касселе Франц Кун изучал также проблему трахеальной секреции. Наряду с пре-

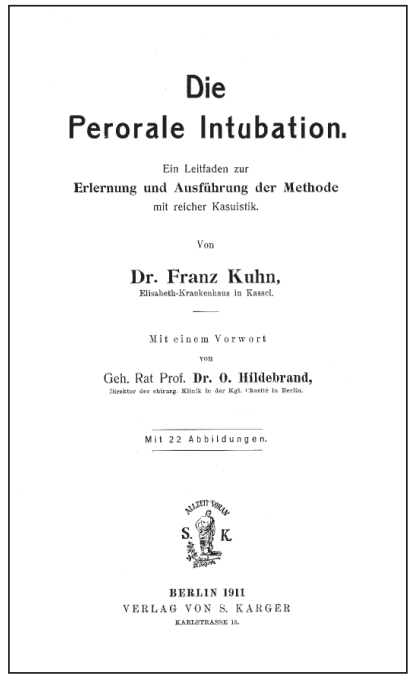

Рис. 240. Первый учебник по интубации трахеи (ил. любезно предоставлена Dr. Horst Luckey, Германия)

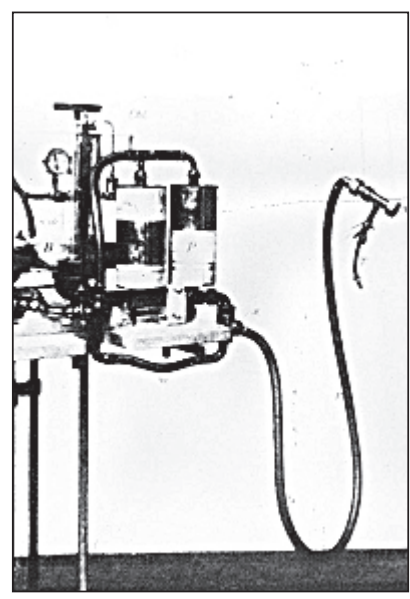

Рис. 241. Наркозный аппарат Куна-Дрэгера для вентиляции под положительным давлением 


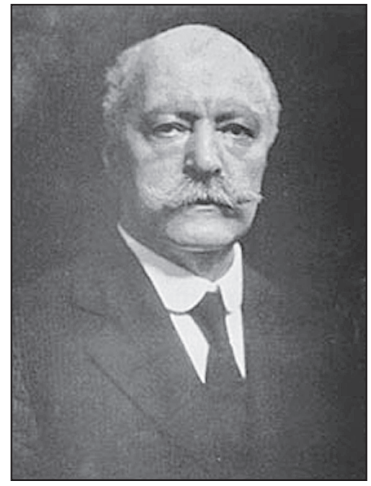

Puc. 242. Samuel James Meltzer (1851-1951)

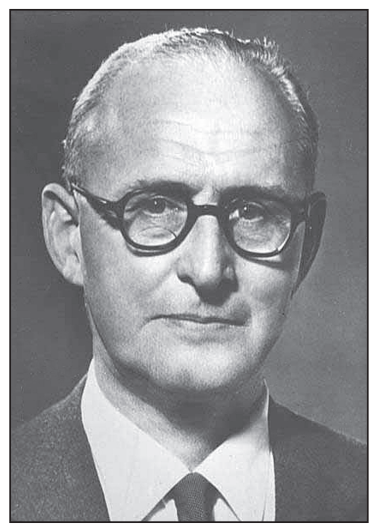

Pис. 243. Sir Ivan Whiteside Magill (1888-1986)

медикацией атропином, он использовал ручной всасывающий насос (аспиратор) и гибкие катетеры для удаления секрета и крови через его трубки. В хирургическую практику Кун ввёл стерильный кетгут (Kuhn F., 1906).

В 1974 г. Zinganell обнародовал мемориальную доску в больнице Элизабет в Касселе, где Кун выполнил свои главные работы:

Здесь работал с 1899 до 1913 год Доктор Франи Кун.

Его интубаиия трахеи через рот была работой, Которая проложила дорогу для анестезии в наши дни. Немеиякое Общество Анестезии и Возвращения кжизни Общество немеиких Анестезиологов.

Из других нововведений того времени следует отметить изобретения американцев Guedel и Waters, которые первыми прикрепили раздуваемую манжету к трахеальной трубке. В 1909 году Мельтцер (рис. 242) и Ауэр (John Auer, 1875-1948) в Германии описали инсуффляционный наркоз у животных, а в Англии Kelly применил метод у человека в 1912 году.

Сэр Айвэн Мэгилл (рис. 243), упомянутый выше, показал, что реконструктивные операции, выполненные у обезображенных солдат, были более успешными под общей анестезией с обеспечением проходимости дыхательных путей эндотрахеальными трубками.

Как результат - в течение первой мировой войны Magill и Rowbotham выполнили несколько эндотрахеальных интубаций и провели эндотрахеальный наркоз у больных с тяжёлыми повреждениями лица. Мэйджил также разработали щипцы, используемые для назальной интубации («щипцы Magill» - рис. 244), и в 1928 году ввели термин «интубация вслепую», выполнив назальную интубацию резиновыми трубками после кокаинизации дыхательных путей.

Следующим важным шагом для успешной эндотрахеальной интубации стала разработка ларингоскопии и постоянное улучшение ларингоскопов. Их «прототипы» существовали в примитивной форме и ранее. Первые инструмен- 
ты, использованные для визуализации ротовой полости, были основаны на эффекте отражения в металлической лопаточке (Leveret в 1743 году) или с помощью наружного светового источника, например, солнечного света или свечи. Непрямая ларингоскопия была впервые описана в 1855 году M. Garcia, учителем пения в Англии (Watkinson J.J., Gaz M.N., Wilson J.A., 2000). С помощью солнечного света и двух зеркал Garcia смог увидеть свои собственные двигающиеся голосовые связки. Прямая ларингоскопия была впервые выполнена в 1895 году Альфредом Кирстейном. Его «аутоскоп» имел наружный источник света. В 1913 году Chevalier Jackson из Филадельфии разработал ларингоскоп, который был позднее модифицирован Magill, Miller и Macintosh. Jackson был первым, кто описал интубацию трахеи под прямой ларингоскопией (рис. 245), и это был самый важный прогресс в интубации.

Ларинголог Чивлейер Джексон поставил ларингоскопию и интубацию трахеи на твёрдую научную основу. Джексон издал своё первое полное руководство по эндоскопии дыхательных путей в 1907 году, в котором он описал прямой ларингоскоп U-типа. Этот инструмент, всё ещё используемый хирургами ENT, облегчил осмотр гортани, не

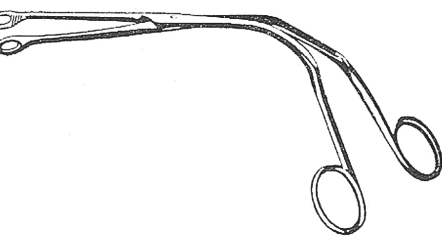

Рис. 244. Щипцы Мэйджила

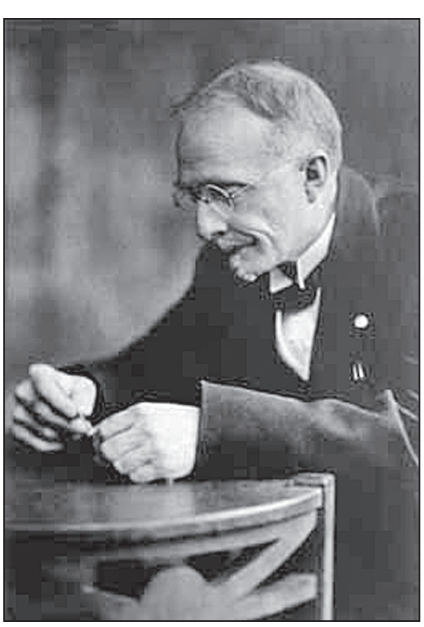

Puc. 245. Chevalier Jackson

(Ил. из Bull. Hist. Anesth., 2003, vol. 21, № 4, p. 4.) применяя прямое давление на верхние зубы. В 1909 году он описал технику интубации трахеи, которая является в основном неизменной сегодня (Jackson C., 1909).

Интерес Джексона был, прежде всего, к болезням верхних дыхательных путей и к удалению инородных тел. Преподавая свою технику практикам ENT, он также защищал использование своего ларингоскопа в статье, написанной анестезиологам в 1913 году (Jackson C., 1913). В течение периода с 1910 до 1925 год, Джексон синтезировал работу предыдущего столетия в систематический подход к устранению обструкции дыхательных путей с помощью прямой ларингоскопии (рис. 246). 


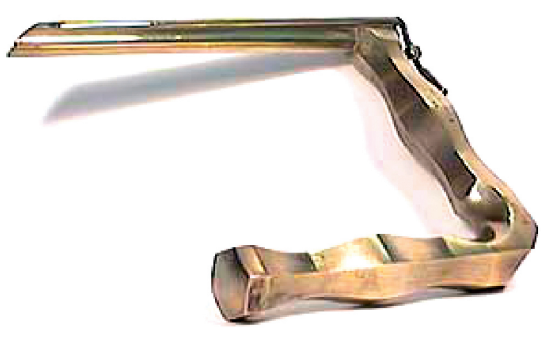

Рис. 246. Ларингоскоп Джексона
Джексон в 1922 году писал: «Эндотрахеальная анестезия - безусловно, самый безопасный путь для наркоза эфиром ... Операции на носу, придаточных пазухах и зеве, сопровождающиеся значительным кровотечением, становятся безопасными от пневмонии при эндотрахеальной анестезии. Это - самая безопасная анестезия при операциях по поводу зоба....

Она показана при операциях на голове, шее или грудной клетке, при которых есть опасность обструкции дыхательных путей ... при операциях, в которых есть возможность чрезмерного кровотечения...; и при операциях, где это желательно, чтобы держать отдельно анестезиолога от области операции.»

Однако интубация трахеи для обычных процедур редко делалась, и когда выполнялась - требовалась помощь отоларинголога.

Следующая фаза развития методов интубации была во время и сразу после первой мировой войны. Два британских анестезиолога Айвэн Мэгилл и Стэнли Роубасам, столкнувшись с потребностью обеспечения анестезии при операциях на лице и груди без инфицирования области операции. Используя гибкие резиновые трубки, они сначала проводили анестезию через инсуффляцию (вдувание). Поскольку метод был слишком дорогим и трудоёмким, чтобы быть реальным в течение военного времени, они решили поддерживать анестезию менее дорогим и более физиологичным методом ингаляции. Первоначально использовались две трубки; узкая передавала газы более низкому концу трахеи, в то время как другая более широкая, проходила через нос только в глотку и гарантировала свободный выход для газов. Они заметили, что иногда более широкая трубка скользила спонтанно в гортань. Это явление позже было описано Мэйджилом как «слепая интубация» (Rosenberg H., Axelrod J.K., 2003).

В 1923 году Роубасам изменил метод двух трубок на использование одной широкой трубки, вводимой в трахею. Пациент дышал через неё в оба направления. Он использовал метод после практики, которая была недавно популяризирована в Соединенных Штатах J.T. Gwathmey (Гвезмей) и McKesson (Мак Кессон) и в Англии R. Boyle ( Р. Бойль).

Уотерс с соавторами в статье по истории эндотрахеальной анестезии в 1933 году писали: «Эндотрахеальная интубация, с её свободой от дав- 
ления и опасности эмфиземы, вместе с её сохранением высокой температуры тела, влажности и кислотно-щелочного равновесия, полностью вытеснила инсуффляцию).» (Waters R.M., Rovenstine E.A., Guedel A.E., 1933). Первые общества практиков, преданных анестезиологии, были основаны в 1920-х и 30-х, а первый журнал, посвящённый анестезиологии, появился в 1922 году.

Уотерс расширил показания к использованию эндотрахеальной интубации, когда он популяризировал использование циклопропановой анестезии. С этим газом углеводорода индукция была значительно быстрее, чем с эфиром. Поскольку этот агент был очень взрывоопасным, для сокращения его утечки было особенно желательно использование закрытой системы с эндотрахеальной трубкой.

Таким образом, появлению прямой ларингоскопии первоначально способствовали ларингологи и хирурги. Среди анестезиологов, прямая ларингоскопия стала популярной благодаря Henry Harrington Janeway в НьюЙорке в 1913 году. Он разработал ларингоскоп с питанием от батареи, исключительно для интубации трахеи. Сэр Robert Macintosh - рис. 247) внедрил носящий его имя изогнутый клинок ларингоскопа, который используется до сих пор.

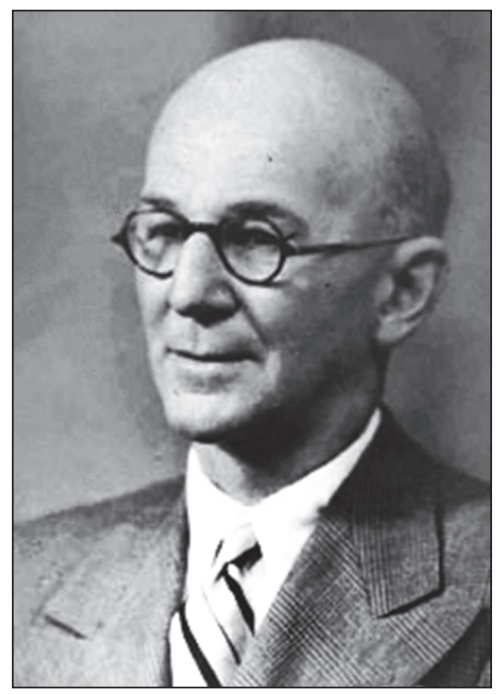

Рис. 247. Sir Robert Macintosh (1897-1989) - анестезиолог,

профессор Оксфордского университета, почти одновременно с Robert Miller (1941) из Техаса ввёл в употребление ларингоскопа с изогнутым клинком 
Эндотрахеальная интубация получила рутинное применение после внедрения мышечных релаксантов в анестезиологическую практику. Канадский анестезиолог Harold Griffith впервые использовал кураре при анестезии у человека в 1942 году. Griffith интубировал трахею у 25 пациентов, обеспечив релаксацию брюшной стенки для проведения операции.

Окончательным шагом, определившим «новую эру» анестезиологии, стало внедрение гибкой эндоскопической бронхоскопии в медицинскую практику в 1968 году Kensuke Ikeda из Японии. Бронхоскопия с волоконной оптикой заняла своё место как стандартный анестезиологический арсенал при обеспечении трудных эндотрахеальных интубаций.

Как мы видим, корни обеспечения дыхательных путей измеряются почти 4000 лет истории человечества. В течение этого времени разработка эффективных устройств для обеспечения проходимости дыхательных путей наряду с улучшением понимания патофизиологии верхних дыхательных путей, сформировала основу современной практики. Сегодняшнее понимание значения трахеостомии и интубации трахеи основано на волнообразном росте и падении их популярности в течение двух тысячелетий. Прогресс, сделанный с древних времён до середины XX века, позволил снизить анестезиологическую смертность вследствие нарушения проходимости дыхательных путей; а также сформировал основу для современного обеспечения нормальных и трудных дыхательных путей. 


\section{ИСТОРИЯ ПРИМЕНЕНИЯ ЭНДОТРАХЕАЛЬНОГО НАРКОЗА В ЧЕЛЮСТНО-ЛИЦЕВОЙ ХИРУРГИИ}

Уже первые попытки использовать ингаляционный наркоз при оперативных вмешательствах на лице и в полости рта встретили значительные трудности. Ещё в 1847 г. Н.И. Пирогов писал, что при операциях, производимых во рту, трудно приладить надлежащим образом эфирный аппарат и очищать рот от крови и слюны. Наличие маски на лице, мешающей работе хирурга, опасности аспирации крови, слюны и рвотных масс побуждали хирургов изыскивать новые пути для введения наркотических веществ в трахею через трахеостому. Первое сообщение об этом принадлежит Н.И. Пирогову. Изучая на животных действие эфира на организм, он вводил эфир в трахею собак через трахеостому и получал достаточно глубокий наркоз. Результаты экспериментов были опубликованы Н.И. Пироговым в 1847 г. на русском и французском языках в работах: «Практические и физиологические наблюдения над действием паров эфира на животный организм», «Наблюдения над действием эфирных паров как болеутолительного средства в хирургических операциях» и «Recherches pratigues et physioloques sur l'etherisation».

В 1850 г. А. Бекетов, а в 1858 г. J. Snow повторили опыт Н.И. Пирогова. Они вводили животным через трахеостому пары хлороформа. При этом А. Бекетов рекомендовал такой способ ингаляции для применения у людей в тех случаях, когда операции подвергалась «местность ... прямо или последовательно затрудняющая применение хлороформа, как-то: некоторые операции на лице и глазах».

Однако в клинике эндотрахеальный метод наркоза впервые был применён в 1869 г. немецким хирургом Фридрихом Тренделенбургом (Trendelenburg) при резекции верхней челюсти. Наркоз проводился через трахеостому с помощью специальной трубки с надувной муфтой (рис. 248). Надувная муфта предназначалась для закрытия пространства между введённой в трахею трубкой и стенками трахеи. К наружной части трубки присоединялась воронка, в которой находилась фланель, смоченная наркотическим веществом.

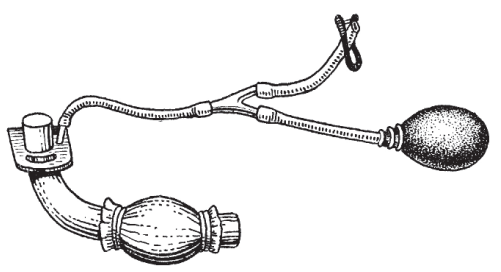

Рис. 248. Трубка Тренделенбурга 


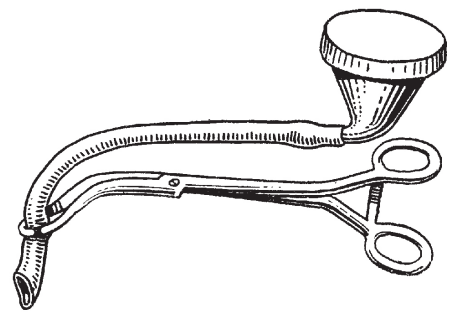

Рис. 249. Трубка 0'Двайера

Как указывает Я.Л. Ясный (1962), в России впервые наркоз через трахеостому применил Р.В. Бутц в 1887 г. тоже при резекции верхней челюсти. Позднее этим методом пользовались А.П. Прокунин (1897), Н.Н. Теребинский, В.М. Минц (1907) и др.

Дальнейшее развитие методики эндотрахеального введения наркотических веществ, как уже указывалось ранее, связано с именами хирургов: сэра Уильяма МакЭвена (William MacEwen) в Шотландии, Джозефа О'Двайера (Joseph O'Dwyer) в США и Франца Куна (Franz Kuhn) в Германии. По данным Howland и Lewis (1956), MacEwen в 1880 г. для удаления у больного злокачественной опухоли корня языка под хлороформным наркозом произвёл интубацию трахеи через рот на ощупь металлической трубкой, затампонировал глотку и далее продолжил наркоз уже через эту трубку.

J. O'Dwyer в 1897 г. предложил при операциях в полости рта, носа и носоглотки производить интубацию трахеи специальной трубкой, через которую наркотическое вещество можно было вводить непосредственно в трахею. Интубационная трубка О'Двайера представляла алюминиевую канюлю, которая вставлялась в гортань и посредством гуттаперчевой трубки соединялась с воронкой Тренделенбурга (рис. 249). Однако, как отметил Д. Баталин (1913), эта система имела тот недостаток, что при операциях в полости рта гуттаперчевая трубка легко сдавливалась и доступ воздуха через неё затруднялся. Более совершенным устройством для эндотрахеального наркоза был аппарат F. Kuhn, предложенный в 1900-1901 гг. [F. Kuhn, Der Metallschlauch in der Tubage und als Trachealkancile. Wien. klin. Rdsch. 28 (1900), p. 554. F. Kuhn, Die perorale Intubation. Zentralbl. Chir. 28 (1901), pp. 1281-1285]. Продолжая совершенствовать методы интубации при эндотрахеальном наркозе, Kuhn в 1902 г. описал технику интубации через рот (F. Kuhn, Technik der peroralen Tubage. Dtsch. med. Wochenschr. 28 (1902), pp. 539-541).

Работы F. Kuhn положили начало более широкому применению эндотрахеального наркоза при операциях на лице и в полости рта. Д. Баталин (1913) сообщил, что за рубежом эндотрахеальный наркоз при операциях на лице и в полости рта в период с 1901 по 1913 г. применяли Dirck, Köhler, Sagebiel, Lotsch и др. Анализируя результаты применения эндотрахеального наркоза при операциях в полости рта, Kölle (1911) высоко оценивал метод как наиболее безопасный и удобный (цит. по И.Н. Муковозову, 1965). 


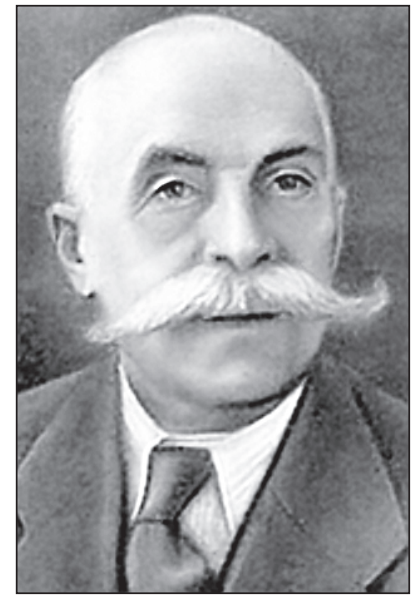

Рис. 250. Владимир Михайлович Мыш (1873-1950).

Профессор факультетской хирургической клиники Томского университета,

а затем Новосибирского медицинского института. Под его руководством впервые в России

проведён эндотрахеальный наркоз с интубацией трахеи через рот

Первая работа в России, посвящённая применению эндотрахеального наркоза через интубационную трубку при вмешательствах на лице и в полости рта, принадлежит Д. Баталину. Она опубликована в 1913 г. в «Хирургическом архиве Вельяминова» под названием «К вопросу о пероральном тубаже гортани по способу Кuhn». В этой статье Д. Баталин привёл собственные наблюдения по применению эндотрахеального наркоза в 1912 г. в клинике профессора В.М. Мыша (Томский университет) двум больным при резекции верхней челюсти и одному больному при операции по поводу рака миндалин (рис. 250). В заключение Д. Баталин отмечал, что «впечатления, полученные от пероральной интубации по способу Kuhn, очень хорошие и в этом способе хирурги найдут одно из наиболее действенных средств к устранению опасностей, связанных с затеканием крови, слюны и рвотных масс в дыхательные пути». В этом же 1912 г. С.И. Спасокукоцкий (рис. 251) в своей клинике в Саратове применял эндотрахеальный наркоз с помощью аппарата Kuhn при операциях на лице и в полости рта в тех случаях, когда возникала опасность затекания крови в верхние дыхательные пути.

Способ эндотрахеального введения наркотических веществ, который был разработан в основном для обеспечения операций в челюстно-лицевой области, с 1909 г. начинает внедряться и в грудную хирургию.

Однако при применении этого метода наркоза возникали значительные трудности, связанные с интубацией трахеи, которая осуществлялась в то вре- 


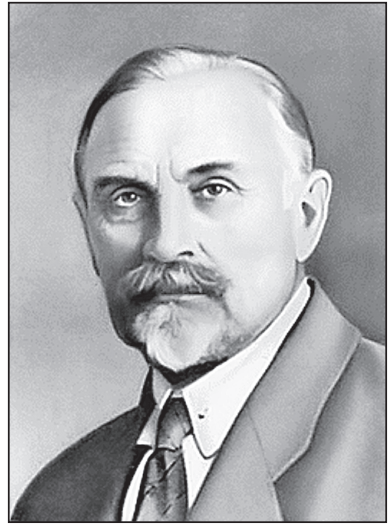

Рис. 251. Сергей Иванович Спасокукоцкий (1870-1943). Академик, один из крупнейших советских хирургов

мя через рот на ощупь или через нос «вслепую». Положение изменилось после внедрения в практику ларингоскопа (Liliental, 1910; Jakson, 1913), при помощи которого интубацию стали производить под контролем зрения.

Интубацию трахеи через нос под контролем прямой ларингоскопии разработал Гиллеспи (Gillespie) в 1941 г. Этот вариант интубации нашёл широкое использование в челюстнолицевой хирургии и отделениях интенсивной терапии (рис. 252).

Несмотря на облегчение техники интубации и некоторое усовершенствование наркозных аппаратов, этот способ наркоза долгое время в нашей стране оставался недоступным для широкого применения при операциях в челюстно-лицевой области. И.Н. Муковозов (1965) объясняет это следующими причинами. Во-первых, техника эндотрахеального наркоза всё ещё оставалась несовершенной, а надёжных наркозных аппаратов и принадлежностей к ним было мало. Во-вторых, особенности иннервации челюстно-лицевой области давали возможность широко применять местную (проводниковую и инфильтрационную) анестезию при многих операциях в этой области. Всё это привело к тому, что местное обезболивание в челюстнолицевой хирургии и стоматологии стало господствующим.

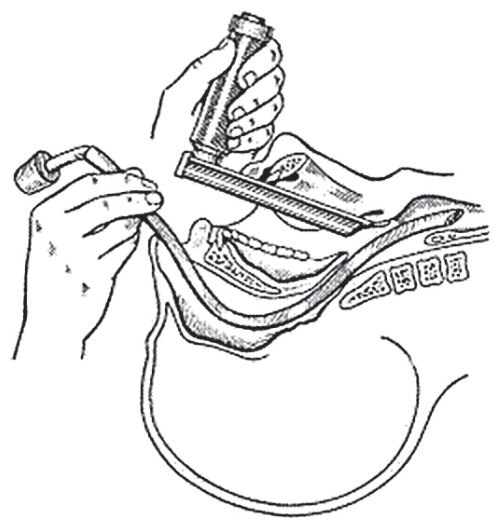

Рис. 252. Схема интубации трахеи через нос под контролем прямой ларингоскопии 


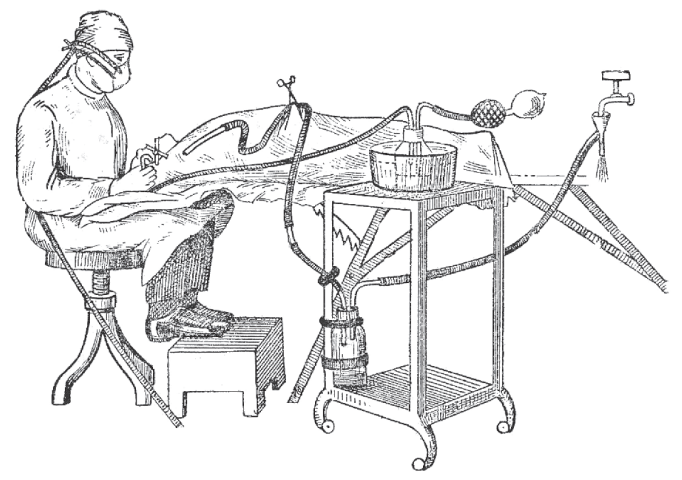

Рис. 253. 0бщая техника при операциях по поводу расщелин нёба и губы, проводимых под эфирным наркозом (Ил. по А.А. Лимберг, 1933.)

Так, в 30-е годы А.А. Лимберг и другие челюстно-лицевые хирурги радикальную уранопластику при расщелинах нёба детям после 7-8 лет проводили под местной проводниковой и инфильтрационной анестезией $2 \%$ раствором новокаина (10,0-15,0 мл) с добавлением адреналина (не более 10 капель раствора 1:1000). Детям меньшего возраста применяли ингаляционный наркоз эфиром. Вот как описывает А.А. Лимберг методику наркоза в 3-м томе «Руководства пластической хирургии» в 1933 году: «Усыпление производится под маской; после начала операции эфир подаётся в газообразном виде по стерильной резиновой трубке, с небольшим загнутым металлическим наконечником, зацепляемым за угол рта больного. Аппарат типа аппарата Боброва легко конструируется (рис. 253).

Способ подачи эфира достаточно прост (почти ничем не отличается от обычного ингаляционного наркоза) и допускает возможность хорошего контроля. Полное устранение маски является необходимым условием для правильного и быстрого выполнения всех отдельных моментов операции. При этом условии операция может быть выполнена в 40-60 минут. Единственным минусом этого способа является большая утечка эфира в окружающий воздух, главным образом в момент выдыхания, что особенно сильно ощущается оперирующим. Для защиты оперирующего на его лицо надевается небольшая маска из целлулоида, в которую посредством воздуходувки через резиновую трубку подаётся струя свежего воздуха. Эфирно-масляный и гедоналовый наркозы не показаны при операциях в полости рта, так как не дают быстрого послеоперационного пробуждения и поэтому опасны в отношении аспирационной пневмонии. 
Операция под наркозом производится при свешенной вниз голове: при наступлении наркоза больного, уже покрытого стерильным бельём, вместе с матрацем сдвигают за край переднего конца стола. Матрац с головой больного оперирующий укладывает себе на колени. Для уменьшения кровотечения при операциях под общим наркозом выгодно сделать инфильтрационную инъекцию $2 \mathrm{~cm}^{3}$ физиологического раствора или $1 \frac{1}{4} \%$ раствора новокаина с адреналином в области твёрдого и мягкого нёба. Большое техническое обеспечение при производстве операции и наркоза приносит применение аппарата, отсасывающего слизь и кровь из области операционного поля и области носоглотки.»

Однако методы эндотрахеального введения наркотических веществ не были забыты. Они совершенствовались и при определённых, правда, весьма ограниченных показаниях, использовались в челюстно-лицевой области. Более широко применялся эндотрахеальный наркоз за рубежом - в Англии и Америке, особенно после создания Waters в 1923 г. новых наркозных аппаратов, работающих по закрытому способу с рециркуляцией газов и поглощением углекислоты. Этому также способствовали разработка более совершенной техники интубации и усовершенствование трубок для этой цели.

В 1925 г. на Международном конгрессе по пластической хирургии Айвэн Мэгилл (Ivan Magill) из клиники Gillis доложил о довольно широком применении эндотрахеального наркоза при пластических операциях в челюстно-лицевой области. Он несколько усовершенствовал технику интубации трахеи через нос «вслепую» и предложил изогнутые, более совершенные трубки. Paluel J. Flagg (1951), впервые применивший этот метод наркоза в 1927 г. в клинике, отмечает, что при операциях на лице и шее в течение последних 25 лет он стал почти обязательным. Это же сообщают и другие авторы. По данным J. Lundy (1941), эндотрахеальный наркоз в клинике Мауо с 1928 по 1940 г. был применён 12751 раз. Lundy указывает на особую ценность этого метода при операциях на голове и шее.

Эндотрахеальный наркоз применялся и во время второй мировой войны в лечебных учреждениях английских и американских армий при хирургической обработке ран челюстно-лицевой области. Так, Mowlem (1943) писал, что предварительная хирургическая обработка раненых в челюстнолицевую область на главном перевязочном пункте должна в большинстве случаев проводиться под эндотрахеальным наркозом с тампонадой глотки. Эндотрахеальный наркоз при хирургической обработке у раненых с переломами нижней челюсти применяли Тhoma (1944) и Henny (1951).

В нашей стране современный эндотрахеальный наркоз при операциях в челюстно-лицевой области впервые был применён в клинике челюстно- 
лицевой хирургии и стоматологии Военно-медицинской академии им. С.М. Кирова 31 августа 1949 г. (Чуприна Ю.В., Александров Н.М.). До 1955 г. его применение носило эпизодический характер, так как наркоз проводился анестезиологами общехирургических клиник. С апреля 1955 г. проведением эндотрахеального наркоза стал специально заниматься сотрудник клиники Н.М. Александров, и наркоз стали применять более широко (Муковозов И.Н., 1965).

В последние годы в связи с расширением объёма хирургических вмешательств в черепно-челюстно-лицевой области при комплексных черепнолицевых травмах и в онкологии основания черепа обеспечение проходимости дыхательных путей затруднено, возникают ситуации, когда назо-, оротрахеальная интубация и наркоз через трахеостому нежелательны (Елизарьева Н.Л. и соавт., 2008). В 1998 году J.Martinez-Lage и соаввт. предложили альтернативу назотрахеальной интубации и трахеостомии в оперативном лечении больных с черепно-лицевой травмой. При этой технике, названной ретромолярной интубацией, полулунная остеотомия выполнялась в ретромолярном пространстве. Ретромолярная интубация не перекрывает операционное поле во рту, обеспечивает проходимость дыхательных путей и возможность выполнения межчелюстной фиксации во время операции. Тем не менее, при данной методике нарушается костная анатомия для создания пространства для трубки, на выполнение процедуры требуется в среднем 25 мин. Оценка восстановления прикуса зубных рядов может быть неточной вследствие наличия трубки в преддверии полости рта.
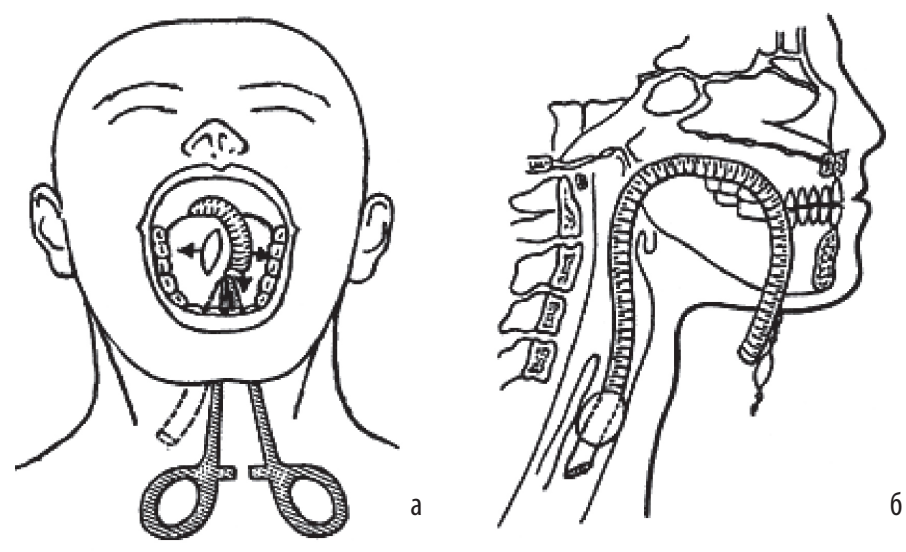

Рис. 254. Схема субментальной интубации (по Н.Л. Елизарьевой с соавт., 2008):

вид спереди (а) и сбоку (б) 

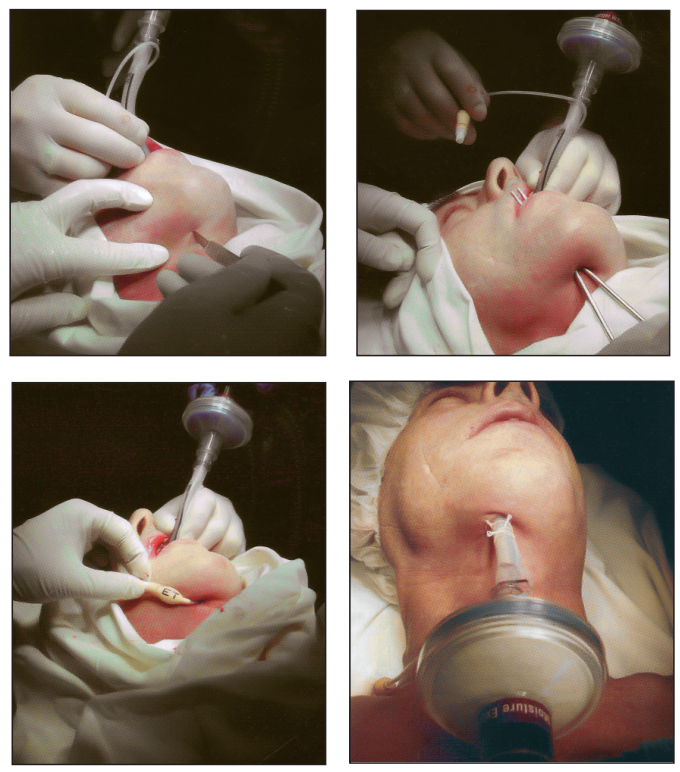

Рис. 255. Этапы субментальной интубации. Клинический пример.

(Ил. по Н.Л. Елизарьевой с соавт., 2008.)

Альтернативным методом, обеспечивающим проходимость дыхательных путей у пациентов с челюстно-лицевой травмой, которым не требуется вентиляционная поддержка в течение длительного времени, является субментальная интубация. Эта оригинальная техника описана впервые F. Altemir в 1986 г. Она заключается в следующем: после традиционной оротрахеальной интубации, выполненной армированной трубкой диаметром 7,5 или 8,5 мм, делают разрез кожи 2 см в субментальной области в парамедиальном регионе приблизительно в 1 см от края нижней челюсти и параллельно ей.

Используя кровоостанавливающий зажим, тупо и остро проходят ткани, раздвинув бранши зажима, создают тоннель. Манжета трубки сначала вводится в рот (рис. 254, 255) и проводится через тоннель. Затем эндотрахеальная трубка отсоединяется от аппарата, и проксимальный конец её выводится в субментальную зону. Трубка через коннектор соединяется с аппаратом и начинается ИВЛ. Обязателен контроль позиции трубки с помощью ларингоскопии, аускультации и капнографии для подтверждения надёжной проходимости дыхательных путей. Общая продолжительность процедуры составляет менее 5 мин. В конце операции применяются два метода экстубации: субментальная интубация переводится в оротрахеальную (экстубация проводится традиционным способом) или трубка удаляется через кожу с финальным наложением шва (Елизарьева Н.Л. и соавт., 2008). 


\section{РАЗВИТИЕ ОБЕЗБОЛИВАНИЯ В СТОМАТОЛОГИИ С 1946 ГОДА ДО НАЧАЛА ХХІ ВЕКА}

Несомненно, успехам челюстно-лицевой хирургии в значительной мере способствовало внедрение в хирургию новых методов обезболивания и элементов лечебно-охранительного и лечебно-стимулирующего режима; в частности, в литературе нашли отражение исследования, направленные на совершенствование местного обезболивания (Вайсблат С.Н., 1947-1962; Вейсбрем М.М., 1948; Даценко М.Ф. и Фетисов Н.В., 1959 и др.), местного потенцированного (Карленко С.Н., 1950; Кругляков И.О., 1951; Бернадский Ю.И., 1955-1969; Бажанов Н.Н., 1956-1962), эндотрахеального и масочного (Бердюк И.В., 1954; Александров Н.М., 1957; Митрофанов Г.Г., 1956; Муковозов И.Н., 1959-1965; Бизяев А.Ф., 1961-1967 и др.), а также гексеналового наркоза (Скопец Е.В., 1956). Особенно перспективным для использования в условиях челюстно-лицевых стационаров оказался метод потенцированного местного обезболивания с применением новых нейролептических препаратов, а в условиях поликлиники - местная анестезия, газовый наркоз закисью азота с кислородом, внутривенный наркоз.

В марте 1965 г. состоялся I Всероссийский съезд стоматологов в г. Калинине. Программным вопросом было «Обезболивание в стоматологии».

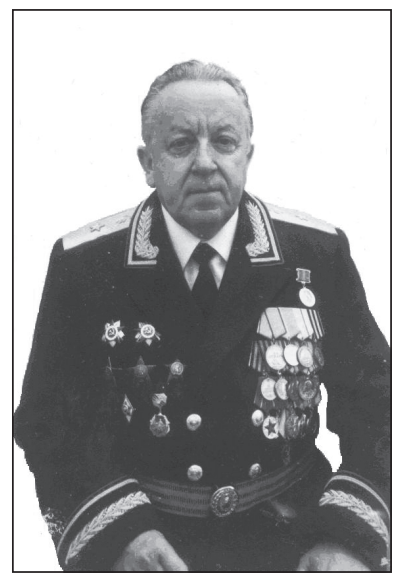

Рис. 256. Никита Михайлович Александров (1923-1992).

Первым в нашей стране применил эндотрахеальный наркоз в челюстно-лицевой хирургии. Генерал-майор медицинской службы. Главный стоматолог МО СССР, начальник кафедры челюстно-лицевой хирургии и стоматологии ВМедА им. С.М. Кирова (до 1983 г.) 

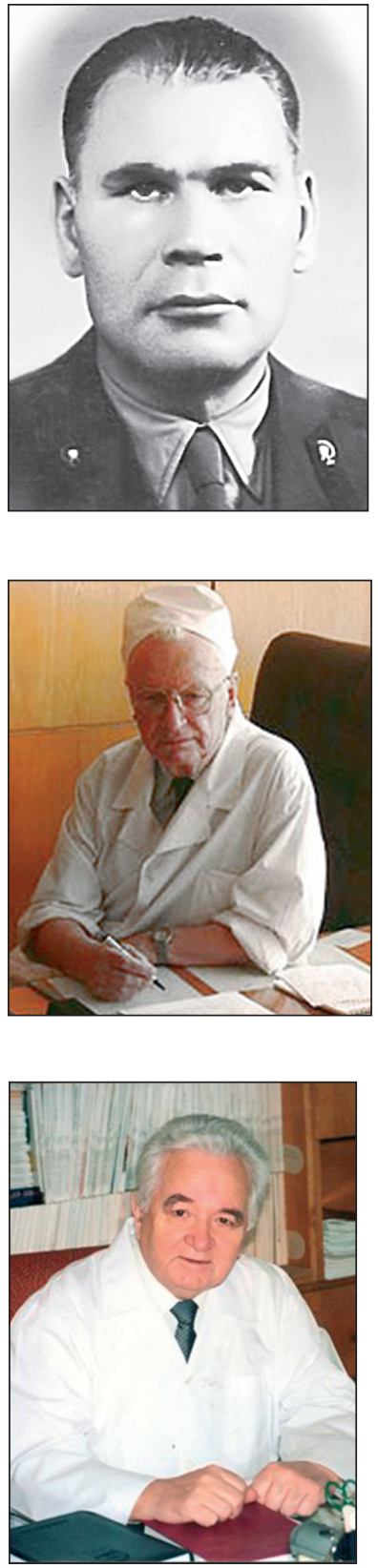

Рис. 257. Иван Николаевич Муковозов (1920-1992). Кандидат медицинских наук, подполковник медицинской службы. Работал в клинике челюстно-лицевой хирургии и стоматологии ВМедА им. С.М. Кирова. Автор двух монографий по наркозу в стоматологии и челюстно-лицевой хирургии $(1965,1972)$, по которым училось не одно поколение анестезиологов и стоматологов

Рис. 258. Николай Николаевич Бажанов. Родился в 1923 г. Академик РАМН, лауреат Государственных премий СССР и РФ, кавалер ордена СТАР «За большие заслуги перед стоматологией» I степени. Внёс существенный вклад в решение проблемы обезболивания в амбулаторной стоматологической практике у больных, перенёсших инфаркт миокарда, страдающих гипертонической болезнью, лекарственной непереносимостью, нервно-психическими заболеваниями

Рис. 259. Владимир Федорович Рудько. (1919-2008). Доктор медицинских наук, профессор кафедры хирургической стоматологии и челюстно-лицевой хирургии, академик хирургических наук Армении и международной академии им. Пьера Фошара (США). Единственный из россиян входит в состав 25 почётных стоматологов Мира. Награждён орденами Трудового Красного Знамени и «За большие заслуги перед стоматологией» I степени и 9 медалями. Под его руководством разработана и осуществлена программа целевых исследований «Борьба с болью в стоматологии». Результатом явилось внедрение в стоматологическую практику новых методик обезболивания при стоматологических операциях 
Рис. 260. Всеволод Николаевич Александров (1933-1996). Доктор медицинских наук, профессор. Организатор и заведующий кафедрой анестезиологии и реаниматологии ММСИ им. Н.А. Семашко (1973-1995). Был инициатором и организатором широкого спектра исследований по обезболиванию при амбулаторных стоматологических вмешательствах. Разработал ряд методов общей анестезии. Автор более 200 научных публикаций и 18 изобретений

Рис. 261. Алексей Федорович Бизяев. Доктор медицинских наук, профессор МГМСУ. Активный участник разработки и реализации программы обезболивания в стоматологии. Один из первых стоматологов-анестезиологов, внедривший современный эндотрахеальный наркоз при операциях в области головы и шеи. Научное направление его исследований посвящено разработке метода комбинированного местного обезболивания, основанного на концепции биоэнергетической коррекции степени выраженности психоэмоционального стресса при стоматологических вмешательствах в условиях поликлиники. Автор нескольких монографий и разделов по обезболиванию в учебниках и справочнике по стоматологии

Рис. 262. Игорь Александрович Шугайлов. Родился в 1948 г. Доктор медицинских наук, профессор, автор технологии объективной оценки болевой чувствительности человека и эффективности обезболивания в стоматологии. Основатель и заведующий кафедрой (1986-1997) анестезиологии и реаниматологии факультета усовершенствования стоматологов ММСИ, заведующий кафедрой стоматологии РМАПО МЗ РФ с 1997 г. и по настоящее время. Разработал серию карпульных инъекторов, которые прошли проверку у нас в стране, в Западной Европе, США, Новой Зеландии и получили высокую оценку специалистов
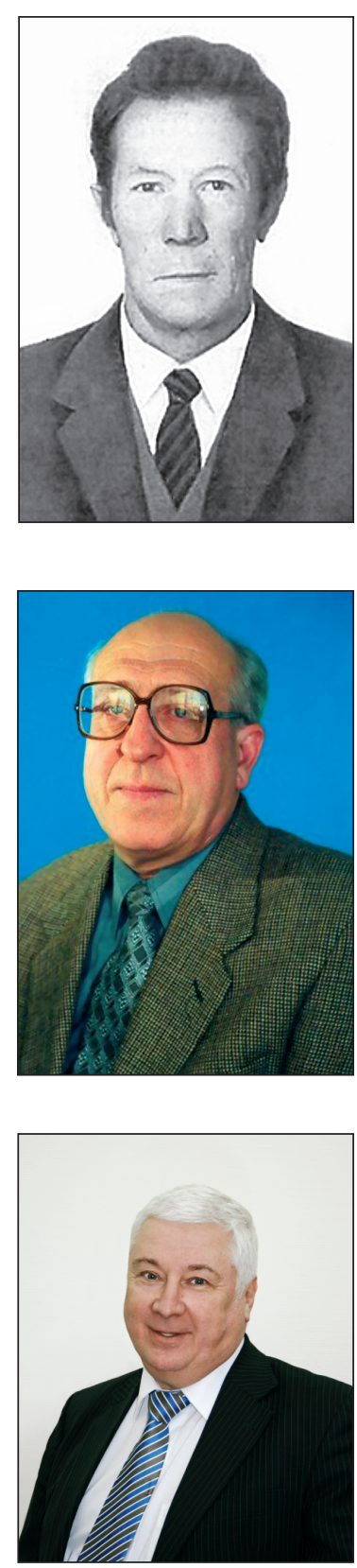

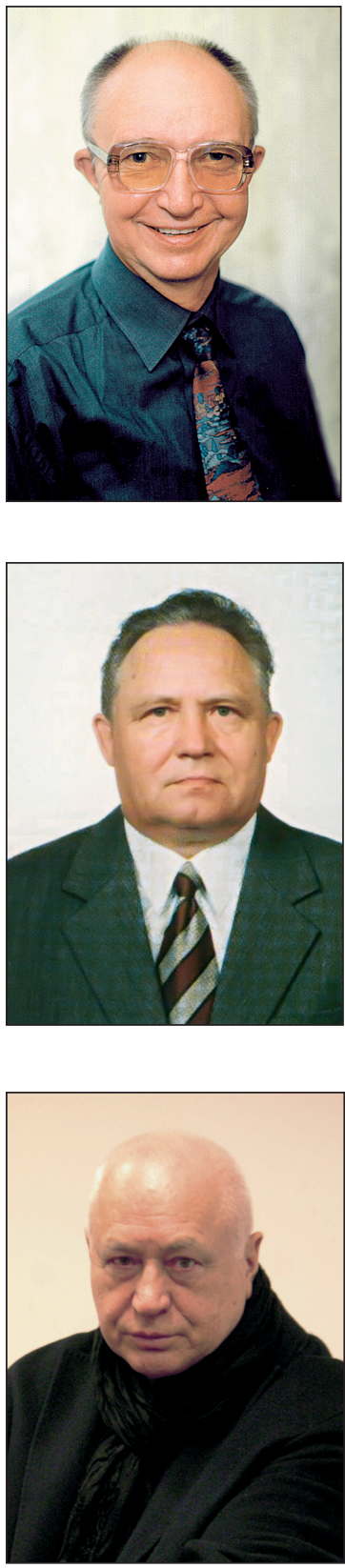

Рис. 263. Арнольд Жанович Петрикас. Родился в 1936 г. Заведующий кафедрой терапевтической стоматологии Тверской государственной медицинской академии, доктор медицинских наук, профессор, «Заслуженный врач РФ» (1997). Ведёт изучение местных анестетиков в клинике и эксперименте с акцентом на побочные реакции со стороны сердечно-сосудистой системы. Автор семи монографий, в т.ч. «0безболивание зубов» (1997), и многих статей, касающихся различных аспектов анестезии при лечении зубов

Рис. 264. Виталий Павлович Бережной. Родился в 1938 году. Доктор медицинских наук, профессор кафедры терапевтической стоматологии Самарского ГМУ (заведовал кафедрой с 1981 по 2007 гг.). Изучал особенности масочного наркоза смесью фторотана, закиси азота и кислорода при удалении зубов, хронометраж времени, внутрикостную и другие методы местной анестезии для обезболивания пульпы

Рис. 265. Станислав Фёдорович Грицук - доктор медицинских наук, профессор. Ведущий научный сотрудник ГУ НИИ Общей реаниматологии РАМН. До 2007 г. руководил отделом анестезиологии-реанимации ЦНИИС и ЧлХ Росмедтехнологий. Автор монографий «Анестезия в стоматологии» (1998) и «Клиническая анестезиология и неотложная терапия» (2004) 
Рис. 266. Сергей Талустанович Сохов, профессор кафедры стоматологии общей практики и анестезиологии ФПДО МГМСУ, Заслуженный врач РФ. Президент Российской секции Европейской ассоциации по обезболиванию в стоматологии (EFAAD)

Рис. 267. Соломон Абрамович Рабинович. Проректор по работе с иностранными учащимися и международным связям, заведующий кафедрой стоматологии общей практики и анестезиологии ФПДО МГМСУ. Заслуженный врач РФ, академик Академии медико-технических наук РФ, член национальной академии эстетической стоматологии, член Международной стоматологической академии (Academy of Dentistry International) доктор медицинских наук, профессор. Автор и соавтор 400 научных работ (в том числе 20 патентов и авторских свидетельств РФ, 15 монографий). Член координационного Совета Минсоцздрава по стоматологической помощи детскому населению в РФ. Руководитель Российской секции Всемирной ассоциации по обезболиванию в стоматологии (IFDAS). Избранный президент EFAAD

Рис. 268. Стенли Ф. Меламед (Stanley F. Malamed), доктор хирургической стоматологии, профессор анестезиологии и медицины. Стоматологический факультет Южнокалифорнийского университета. Лос-Анджелес, США. Автор капитального руководства по местной анестезии, выдержавшего 4 издания
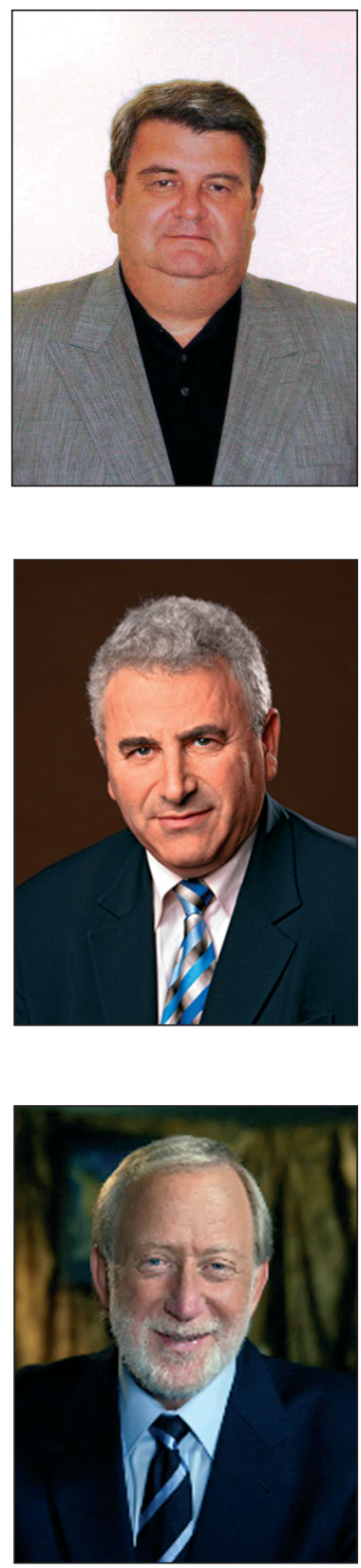

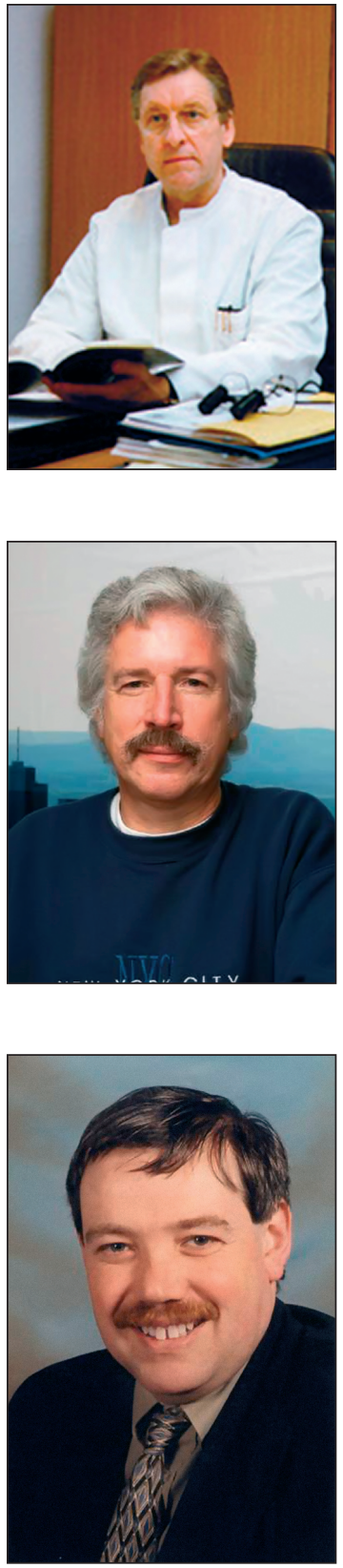

Рис. 269. Дитер Шуман (Diter Schumann), профессор, доктор медицины и стоматологии. Родился в 1939 г. Челюстно-лицевой хирург. Основные работы по премедикации, регионарной и местной анестезии в челюстно-лицевой хирургии, Германия

Рис. 270. Райнер Ранн (Rainer Rahn). Родился в 1952 г. в Карлсруэ. Приват-доцент, доктор медицины и стоматологии. Основные работы по обезболиванию посвящены выбору местных анестетиков у пациентов с общесоматическими заболеваниями и факторами риска. Франкфурт-на-Майне, Германия. Президент EFAAD 2003-2004

Рис. 271. Найджел Д. Робб (Nigel D. Robb) - профессор Стоматологического университета Глазго (Великобритания). Экспрезидент Совета EFAAD. Автор книг «Управление болью и волнением у стоматологического пациента в сознании» (1998) и «Неотложная медицинская помощь в стоматологии» (2006) 
Рис. 272. Моника Даублэндер (Monika Daublaender). Приват-доцент, доктор медицины и стоматологии. Главный врач поликлиники зубоврачебной хирургии университета Иоганна Гуттенберга в г. Майнц (Германия). Основные работы посвящены местной анестезии и вазоконстрикторам в стоматологии, организации лечения пациентов с факторами риска, хронической боли в челюстно-лицевой области. Президент EFAAD 2005-2006

Рис. 273. Вольфганг Якобс (Dr. Dr. Wolfgang Jakobs) - частный институт дентальной имплантологии и эстетической стоматологии, казначей IFDAS ( Шпайхер, Германия). Основные работы посвящены различным аспектам местной анестезии в стоматологии
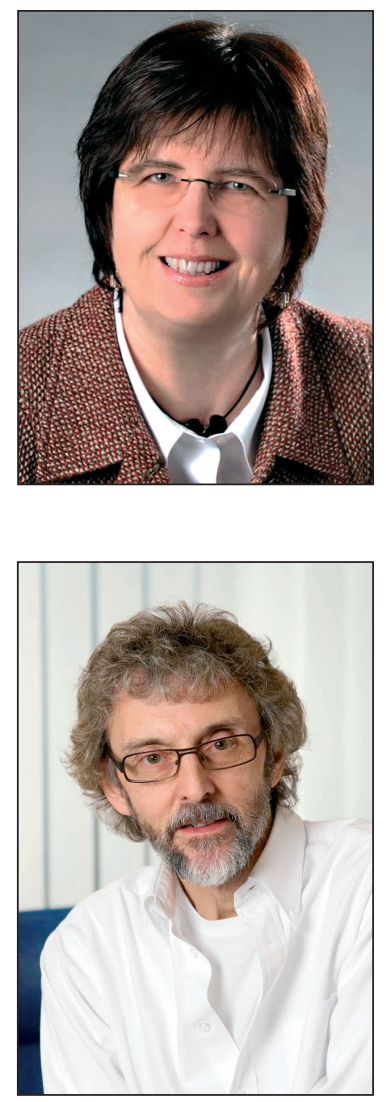

Рис. 274. Делегации Великобритании и России (в центре проф. С.А. Рабинович и доктор биологических наук, ведущий научный сотрудник лаборатории изучения боли и методов обезболивания О.Н. Московец)

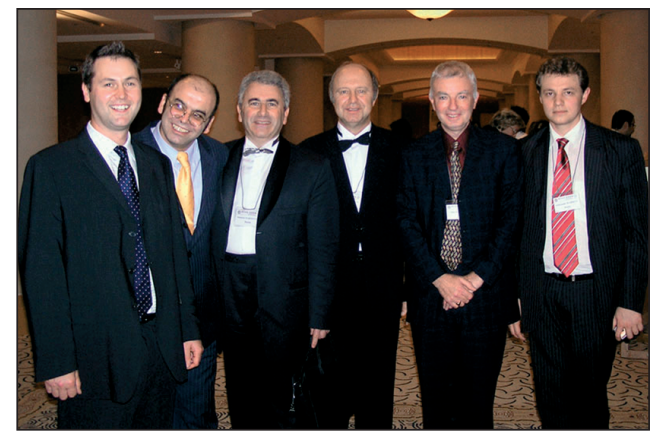




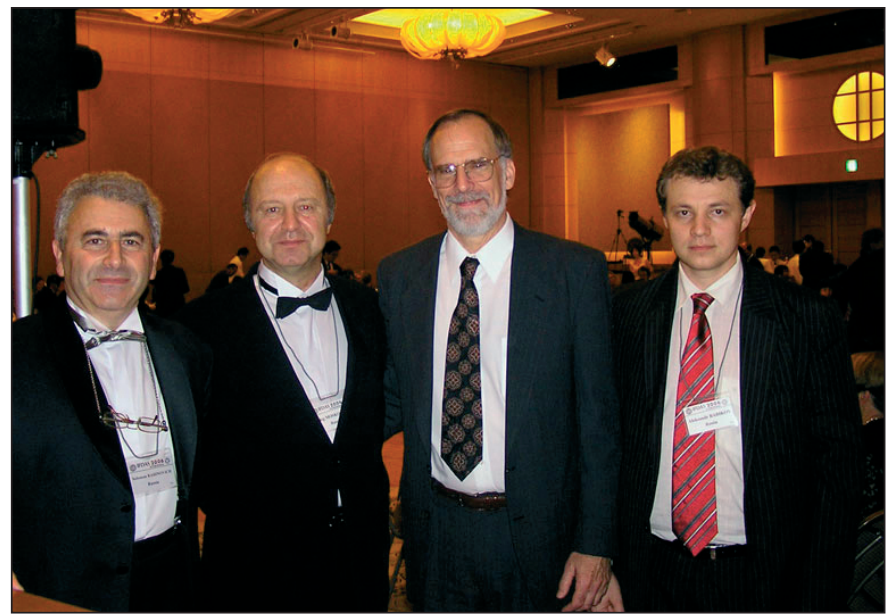

Рис. 275. Профессор John A. Yagiella (США) с участниками Российской делегации: профессором С.А. Рабиновичем, доктором биологических наук 0.Н. Московцом и кандидатом медицинских наук А.С. Бабиковым во время XI конгресса IFDAS в Иокогаме (Япония) в 2006 году

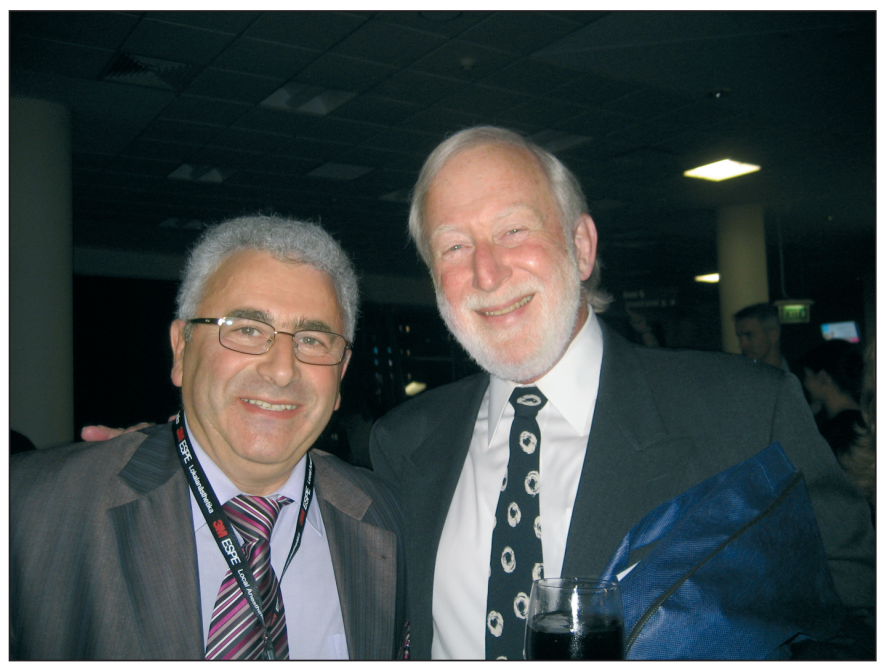

Рис. 276. Профессор С.А. Рабинович (Россия), профессор S. Malamed (США) встреча коллег во время работы XII конгресса IFDAS в Мельбурне (октябрь 2009 г.) 


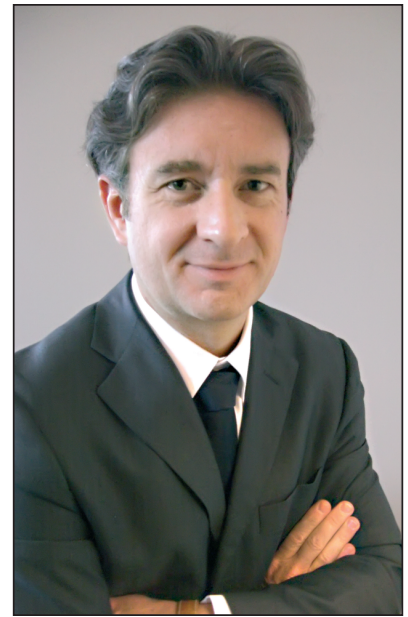

Рис. 277. Профессор Жан-Фредерик Андре

(Jean-Frederic Andre, Франция). Президент Европейской ассоциации по обезболиванию в стоматологии (EFAAD), руководитель стоматологической клиники (Эвиан, Франция)

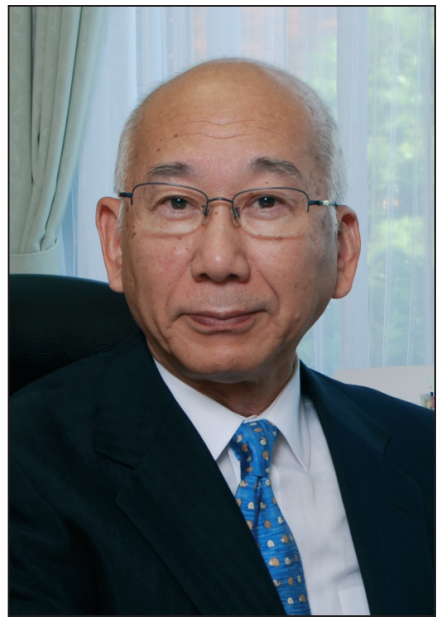

Рис. 278. Профессор Юзуро Канеко (Yuzuru Kaneko, Япония). Президент Всемирной Федерации анестезиологических обществ в стоматологии (IFDAS), ректор Токийского стоматологического колледжа, заведуюший кафедрой стоматологической анестезиологии

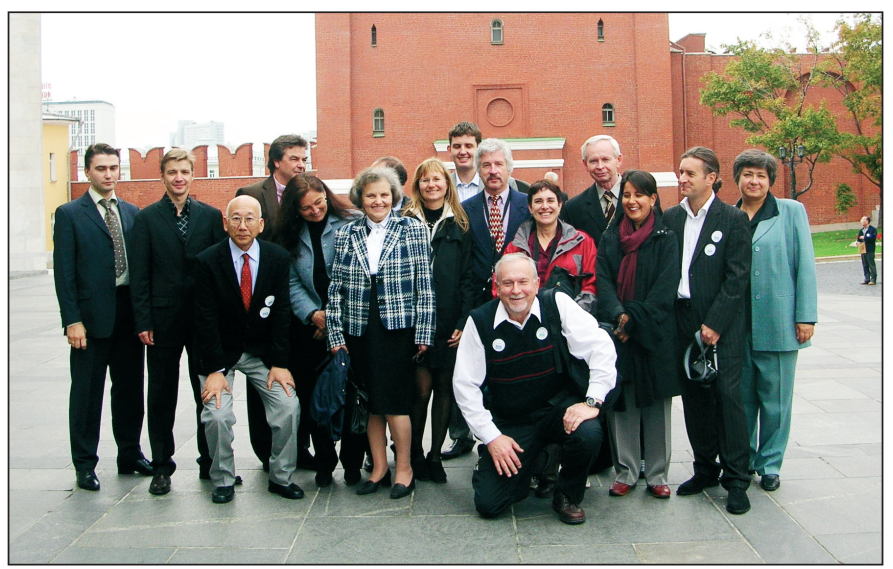

Рис. 279. Участники юбилейного конгресса EFAAD во время посещения Кремля (сентябрь 2005 г.). На переднем плане проф. Eliezer Kaufman (Израиль), второй ряд слева - проф. Yuzuru Kaneko, справа - проф. Jean Andre 
На V Всесоюзном съезде стоматологов (1968) Н.Н. Бажанов и В.Н. Александров (рис. 256) в докладе «Задачи организации анестезиологической службы в стоматологии» отметили специфичность проведения общего обезболивания в стоматологической поликлинической практике, и проблемы, связанные с подготовкой анестезиологов для этой области медицины.

\section{$* * *$}

Во второй половине XX в. (60-90-е годы) вопросами обезболивания в стоматологии занимались Г. Адкина, Л.И. Алексеев, А.И. Маркин, Ю.И. Бернадский, Н.М. Александров, В.С. Стародубцев, Ю.С. Привалов, И.Н. Муковозов, П.М. Егоров, Н.Н. Бажанов, С.С. Ганина, А.Ф. Бизяев, Н.Г. Беляева, Е.В. Васманова, О.Ф. Конобевцев, С.Ф. Грицук, В.Ф. Рудько, В.Я. Рябцев, В.Н. Александров, Б.А. Азрельян, В.К. Филатов, П.Ю. Столяренко, М.Г. Панин, А.С. Добронравов, Ю.В. Вовк, А.А. Несмеянов, Г.М. Иващенко, Н.И. Ивенский, В.П. Бережной, Н.К. Вячкилева, К.П. Шведов, А.В. Лепилин, И.А. Шугайлов, Е.Г. Шульгин, И.И. Левен, М.В. Лукьянов, В.И. Стош, С.Т. Сохов, Е.Н. Анисимова, А.Ж. Петрикас, С.А. Рабинович, Ю.В. Мишунин, E. Lanz, M.D. Lipp, R.E. Walton, S.F. Malamed, H. Evers, E. Glockmann, D. Schumann, R. Rahn, C.S. Reily, J.P. Rood, N.D. Robb, E. Kaufmann, Yu. Kaneko, W. Jakobs, J.-F. Andre, J.A. Yagiella, G.R. Seward, M. Simmons, J.T. Jastak, и многие другие (рис. 257-279).

Решению проблемы обезболивания в значительной мере способствовали результаты научно-практической деятельности, нашедшие своё отражение в монографиях, учебных пособиях, видеофильмах, которые опубликованы в последние годы в России (С.Ф. Грицук, 1998, 2004; П.Ю. Столяренко, 1998-2006; А.Ж. Петрикас, 1998; П.Ю. Столяренко, В.В. Кравченко, 2000; А.Ф. Бизяев с соавт., 2002; С.А. Рабинович с соавт., 2005, 2007 и др.).

На кафедре стоматологии общей практики и анестезиологии ФПКС МГМСУ в 2002 г. открыт музей истории обезболивания в стоматологии, в котором представлены мировые и отечественные достижения в этой области.

Стоматологическая ассоциация России уделяет большое внимание эффективности и безопасности обезболивания в стоматологических лечебных заведениях страны. В рамках программы «Борьба с болью в стоматологии» создана и утверждена съездом стоматологов России и Советом СтАР (2004) секция «Обезболивание и оказание неотложной помощи в стоматологии» под председательством профессора С.А. Рабиновича. В различных регионах учреждены филиалы под руководством опытных учёных: 


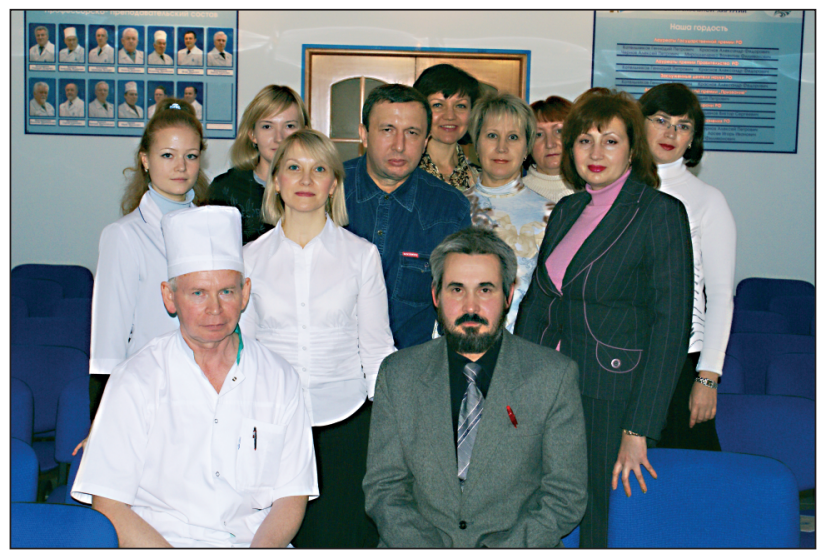

Рис. 280. Участники Мастер-класса в Самаре.

На переднем плане доцент Чемеков Р.Д. (кафедра стоматологии общей практики и анестезиологии ФПДО МГМСУ) и доцент Столяренко П.Ю. (кафедра челюстно-лицевой хирургии и стоматологии (амГМУ)

1. Поволжский - канд. медицинских наук, доцент П.Ю. Столяренко.

2. Северо-Западный - канд. медицинских наук, доцент А.А. Абрамов.

3. Южный - профессор А.В. Лепилин.

4. Центральный - профессор М.А. Губин.

5. Уральский (д-р П.И. Спицын).

В ноябре 2007 г. в Самаре проходила II Всероссийская конференция «Обезболивание в стоматологии» и Мастер-класс «Современные методы местной анестезии в стоматологии. Ошибки и осложнения. Пути профилактики. Тренинг по оказанию медицинской помощи при неотложных состояниях» (рис. 280).

Традиционными стали проводимые СтАР и МГМСУ профессиональные конкурсы - Чемпионаты стоматологического мастерства в номинации «Обезболивание и оказание неотложной помощи в стоматологии (рис. 281), в которых приняли участие десятки врачей-стоматологов из многих регионов России. В 2008 г. проведён 8-й Всероссийский Чемпионат стоматологического мастерства (рис. 282).

Главная идея конкурсов - внедрение новых технологий обезболивания в свмых отдалённых уголках России. Чемпионат стоматологического мастерства в номинации «Обезболивание и оказание неотложной помощи в стоматологии» стал хорошей школой для врачей-стоматологов всех специальностей. В 2010 г. состоялся юбилейный, 10-й конкурс. 


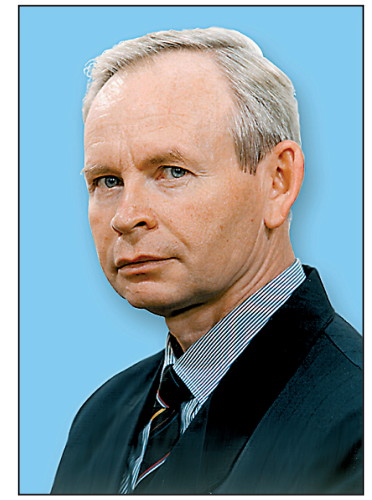

Рис. 281. Победитель первого Всероссийского Чемпионата в номиниции «0безболивание и оказание неотложной помощи в стоматологии (2001 г.), канд. медицинских наук, доцент Самарского государственного медицинского университета П.Ю. Столяренко

Значительно расширилась международная деятельность стоматологов, решающих проблемы обезболивания. Актом международного признания явилось принятие в 2003 г. Российской секции по развитию обезболивания в стоматологии в Европейскую и Всемирную ассоциации анестезиологических стоматологических обществ (EFAAD) и (IFDAS).

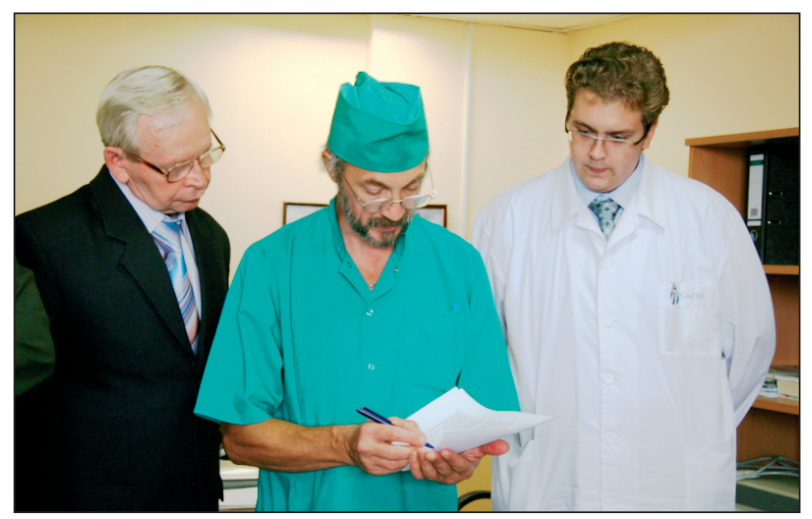

Рис. 282. 0бсуждение результата практического экзамена по реанимации на 8-м Чемпионате.

Слева направо: доцент П.Ю. Столяренко, доцент И.А. Зиновьев, участник конкурса из Самары Е.В. Васюк (8 сентября 2008 г.) 


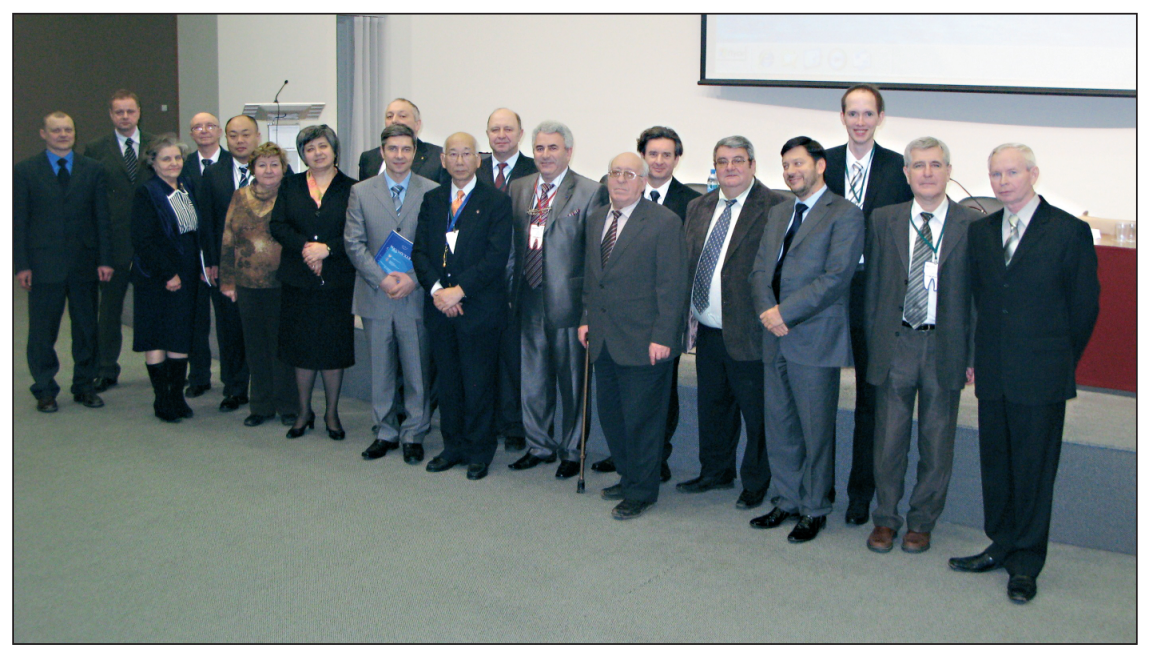

Рис. 283. Участники пленарного заседания конференции «Дентал Ревю - 2009». Москва, 10 февраля 2009 г. (Ил. любезно представлена обозревателем газеты «(томатология сегодня» Г.И. Масис.)

В 2005 г. в Москве состоялся Европейский конгресс EFAAD, посвящённый проблеме обезболивания в стоматологии и приуроченный к 100-летию синтеза и начала клинического применения новокаина (прокаина).

В 2006 г. в Иокогаме проходил XI конгресс IFDAS.

В 2009 г. в Москве состоялся VI Всероссийский научно-практический форум с участием зарубежных коллег «Дентал Ревю - 2009» «Образование, наука и практика в стоматологии» по объединённой тематике «Обезболивание в стоматологии» (рис. 283).

В 2010 г. во Франции конгресс EFAAD по проблеме седации в хирургической стоматологии. 


\section{ПОСЛЕОПЕРАЦИОННОЕ ОБЕЗБОЛИВАНИЕ}

В 1806 г. 20-летний аптекарь из Патерборна Фридрих Вильгельм Адам Сертюрнер (Sertürner F.) выделил активный компонент опия (рис. 284, 285). Болеутоляющие свойства опиумного мака были известны многие столетия. Сертюрнер первым назвал новый алкалоид «princinium somniferum», но в последующем изменил его на «морфин» в честь Морфея, греческого бога сна (Macht D.J., 1915).

Изобретение шприца и игл позволило врачам готовить и вводить точно дозированные количества морфина, а в последующем местных анестетиков. Эти достижения и открытие мощных местно-анестезирующих свойств кокаина открыли дорогу всё более обширным хирургическим вмешательствам (Madigan S.R., Raj P.P., 1992).

Ceorg Crile (Джордж Крайль) в самом начале 1890-х годов предположил, что преодоление послеоперационной боли окажет благоприятное влияние на результаты операции (рис. 286).

Хороший обзор по вопросам возможных последствий неконтролируемой боли представлен Brovn (1989).

На протяжении всей истории развития местной анестезии исследователи пытались найти способы пролонгации местно-анестезирующего эффекта (Sunada K., Furuya Н., 1993). (Цит. по С.Т. Сохову и соавт., 2000.) В целом было предложено более 60 способов удлинения и углубления анестезии, однако многие из них не нашли широкого применения.

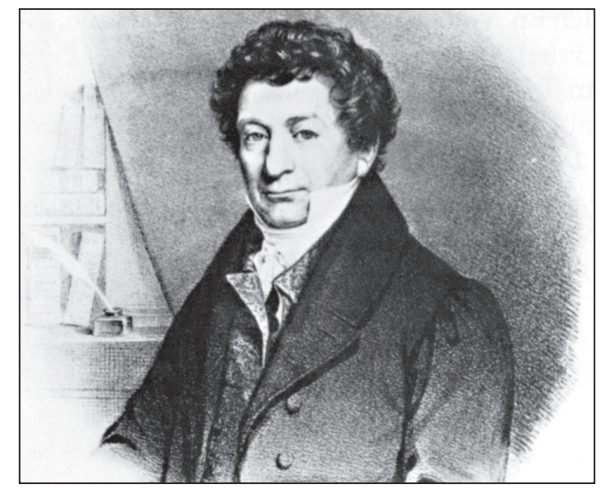

Рис. 284. Фридрих Вильгельм Адам Сертюрнер (1763-1841), немецкий химик и фармацевт.

Образование получил самостоятельно, работал аптекарем в Гамелне. Основное направление фармацевтическая химия. Впервые выделил активное вещество из опийного мака 
Новокаин был первым из синтетических местных анестетиков, введённых в клиническую практику. Он обладает сравнительно слабым обезболивающим действием, которое проявляется медленно и длится недолго. Относительно малая активность и быстрый гидролиз в крови объясняют слабую токсичность новокаина. Однако парааминобензойная кислота, образующаяся при гидролизе, вызывает аллергические реакции, особенно при повторном введении.

Лидокаин был первым из препаратов группы амидов, широко применяемых в клинике. Бупивакаин был первым из местных анестетиков, сочетающих в себе способность вызывать быстрое и длительное обезболивание при чётком разграничении сенсорной и двигательной

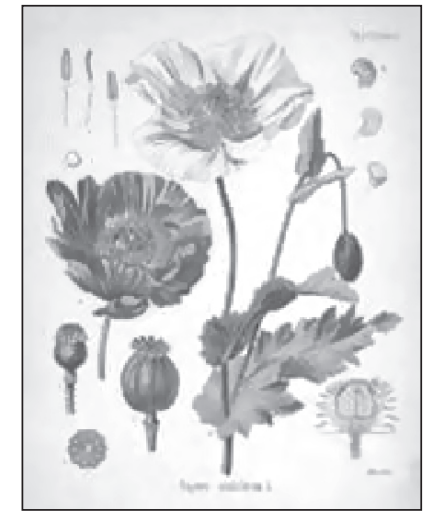

Рис. 285. Восточный мак. Опиум представляет собой сухой порошок, полученный из сока незрелых коробочек мака блокады. Обезболивающее действие этидокаина развивается быстрее, чем у бупивакаина. Наиболее совершенным из местных анестетиков длительного действия является ропивакаин (наропин).

Чрескожная электронейростимуляция (ЧЭНС). Электростимуляцию для обезболивания и лечения различных заболеваний, как указывалось ранее, использовали ещё в древности. Электричество применяли для лечения болей уже в античные времена. В 46 г. н.э. римский врач Скрибоний Ларгин использовал электрических угрей для лечения подагры, головных болей и других болезней (Kellaway P., 1946; Кane K., Taub A., 1975). Больной орган пациента помещали в ванну с водой, где плавала эта рыба. В некоторых случаях пациенты теряли сознание, но боли проходили или ослабевали.

B XVII и XVIII веках возрос интерес к электричеству и его связи с биологией. Благодаря исследованиям Жильборта, фон Гуерика, Грея, Гальвани, Вольта было установлено, что электричество можно производить, хранить и передавать (Becker R.O., Marino A.A., 1982). Многие врачи и шарлатаны начали использовать электричество для лечения различных болезней. Книга под названием «Электрическая медицина» была опубликована Иоганом Шнеффером в 1752 г.

С середины XIX века в США начали производить ручные стимуляторы. Они приобрели наибольшую популярность в 1910-1940 годах и продавались в большинстве магазинов. Однако пределы технических возможностей и прогресс фармакотерапии снизили интерес к электростимуляции (Katz N., 1998). 


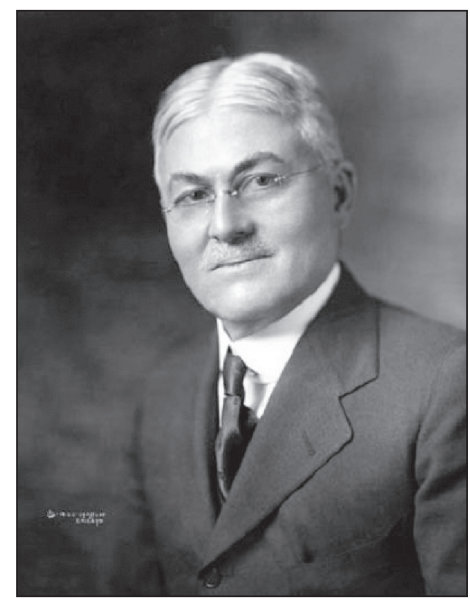

Рис. 286. Джордж Крайл (1864-1943). Американский хирург, профессор (1900).

Ему принадлежат десятки новаторских предложений в различных областях хирургии, в т.ч. оперативное лечение метастазов рака некоторых органов полости рта (операция Крайла). По проблеме обезболивания: предложил восстановление сердечной деятельности с помощью адреналина (1904), сочетание наркоза с местной анестезией (1914). Фото Moffett, Чикаго, 1920 г.

B 1965 г. R. Melzack и P. Wall предложили свою теорию «ворот боли». Они выдвинули гипотезу, что афферентная активность больших миелинизированных волокон (А) блокирует центральную трансмиссию ноцицептивных импульсов по малым миелинизированным волокнам (А) и немиелинизированным волокнам (С-волокна), закрывая таким способом «ворота» трансмиссии болевых импульсов. Эта теория дала новый толчок для изучения нервной стимуляции и её роли при анальгезии.

B 1967 г. P. Wall и W. Sweet при воздействии электростимулятором на подглазничный нерв у здоровых лиц отметили снижение болевой чувствительности в его области.

A. Hymes и сотр. в 1973 г. первыми сообщили о применении ЧЭНС при острых послеоперационных болях. После работ этих авторов ЧЭНС стали применять во многих лечебных учреждениях всего мира в борьбе с хронической и послеоперационной болью.

ЧЭНС - это один из неинвазивных и безопасных методов анальгезии. Несмотря на обезболивающий эффект, подтверждённый клиническими и лабораторными наблюдениями, до сих пор не получено данных, подтверждающих прямую причинную связь между анальгезией и проводимой стимуляцией. Тем не менее, ЧЭНС может стать ценным методом в определённых клинических ситуациях (Katz N., 1998). 


\section{Вклад Джона Джозера Боники в дело борьбы с болью}

Джон Джозеф Боника (рис. 287) родился 16 февраля 1917 года на Филикуди, одном из островов Эолийского архипелага, расположенном у северовосточного побережья Сицилии. В 1928 году семья эмигрировала в США (г. Нью-Йорк). В молодости Джон имел большие достижения в вольной борьбе, в 1941 году стал чемпионом мира среди тяжеловесов (рис. 288). Титулом чемпиона мира Джон Боника владел всего шесть месяцев, так как очень скоро ему пришлось выбирать между медициной и профессиональным спортом. В результате этого выбора выиграла мировая анестезиология, а наука о борьбе с болью получила своего нового непревзойдённого чемпиона. Но нет никаких сомнений в том, что Джон Боника ещё долго мог бы выступать в борьбе на высоком профессиональном уровне.

За эти годы упорный Джон Боника выиграл не только титул чемпиона мира. После шести лет непрерывной осады такой неприступной крепости как Эмма Луиза Болдетти (Emma Louise Baldetti) ему удалось выиграть и её руку и сердце. Они поженились в 1942 году, после того как Джон закончил обучение в школе медицины университета Маркетта. В связи с начавшейся второй мировой войной срок прохождения Джоном интернатуры в госпитале Св. Винсента (Нью-Йорк) был сокращён до шести месяцев. В этом же лечебном учреждении он прошёл 18-месячную резидентуру по анестезиологии, после чего сразу же был призван на военную службу и назначен заведующим отделением анестезии в 7700-коечном Мадиганском армейском госпитале (Форт Льюис, штат Вашингтон). Надо заметить, что такой ответственный пост он занял в 27-летнем возрасте. Он самостоятельно обучился методам регионарных блокад, как для обезболивания хирургических операций, так и для облегчения боли своих пациентов в послеоперационном периоде, и применил их более чем в 10000 случаях хирургического лечения раненых американских солдат и офицеров, доставленных в Мадиганский госпиталь из театра военных действий с Японией. Страдания этих раненных послужили Джону Боника главным определяющим импульсом в приоритетном выборе своих дальнейших профессиональных и научных интересов. Всю

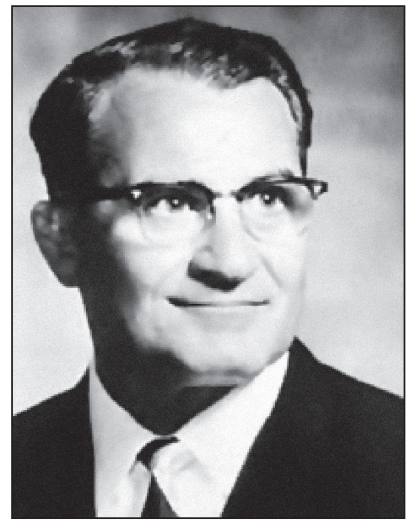

Pис. 287. John Joseph Bonica (1917-1994) -американский анестезиолог 


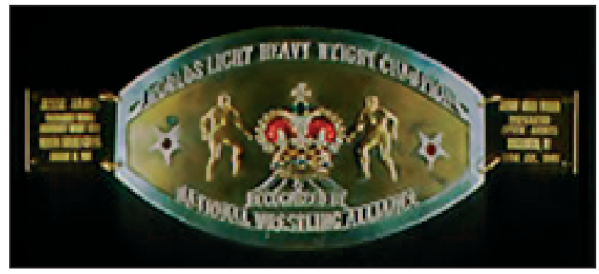

Рис. 288. Один из чемпионских поясов Джона Боника свою дальнейшую жизнь Джон Боника посвятил борьбе с болью. Уже тогда он понимал, как много значит в этом деле грамотная организация процесса обучения врачей и медсестёр методам обезболивания. Поэтому за два с половиной года службы в Мадиганском армейском госпитале он регулярно проводил 3-месячные образовательные циклы для вра-

чей (обучено более 60 курсантов), и 6-месячные курсы для медицинских сестёр. Именно в это же время он определился со своим вторым приоритетным выбором - борьба с родовой болью. Главным поводом для этого послужили обстоятельства, сопутствовавшие появлению на свет его первой дочери. Его жена Эмма во время этих родов едва не погибла от осложнённого примитивного капельно-масочного эфирного наркоза. В эти дни Джон Боника пришёл к выводу о важности внедрения в акушерскую анестезиологию регионарных методов обезболивания. Рождение второй дочери Джона Боники уже не было ничем омрачено, а сама Эмма Боника стала самой первой роженицей на Тихоокеанском побережье США, получившей обезболивание методом продлённой эпидуральной анальгезии.

В 1947 году Джон Боника возглавил отделение анестезиологии в клинике Такома (Вашингтон), где он разработал и внедрил первую во всём штате программу резидентуры по анестезиологии. В 1952 году его отделение стало одним из немногих частных американских госпиталей, обеспечивающих круглосуточную дежурную анестезиологическую службу в акушерском стационаре. Кроме того, в отличие от других американских клиник структура анестезиологических пособий в этом отделении имела резко выраженный акцент в пользу регионарных блокад (длительная каудальная или эпидуральная анальгезия).

В 1953 году Джон Боника представил вниманию медицинской общественности главную книгу своей жизни «Лечение боли» (The Management of Pain), ставшую классическим руководством для врачей всего мира. Эта книга объёмом в 1500 страниц заработала впоследствии репутацию «Библии» по диагностике и лечению боли. Автор описал острую, хроническую боль, проблемы лечения боли в онкологии, представил обширнейший литературный обзор по боли, и вооружил своих читателей ключевыми алгоритмами в деле лечения различных видов боли. Второе издание этой книги состоялось в 1990 
году. Третье издание увидело свет в 2001 году, уже после смерти Боника, и в дань всемирного уважения к автору книга вышла под названием «Bonica's Management of Pain» (рис. 289).

В 1960 году Джон Боника основал отделение анестезиологии в медицинской школе Университета Вашингтона в Сиэтле, и проработал в этой школе профессором и руководителем кафедры анестезиологии в течение 18 лет. В 1961 году он вместе с медицинской сестрой Дороти Кроулей и нейрохирургом Лоуэллом Уайтом открыли первую в мире мультидисциплинарную клинику борьбы с болью. Чуть позже к этой команде присоединились специалисты в области таких медицинских дисциплин как ортопедия, хирургия, семейная медицина, психиатрия, реабилитология, физиология. Созданная таким образом мо-

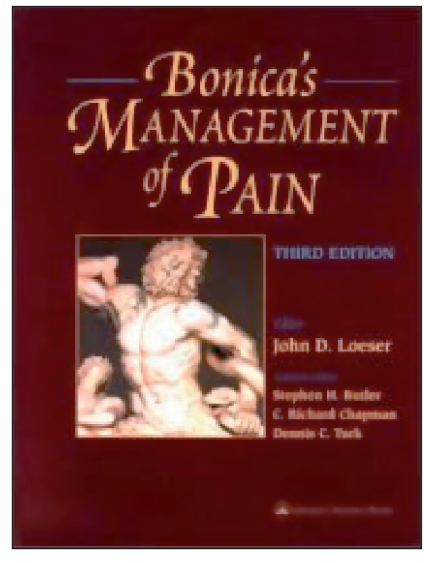

Рис. 289. Книга «Bonica's

Management of Pain» дель мультидисциплинарной противоболевой клиники в настоящее время очень широко распространена во всём мире.

В 1978 году Джон Боника ушёл с поста руководителя отделения анестезиологии и полностью посвятил себя изучению патофизиологии синдромов острой и хронической боли. Времени на всё остальное уже не хватало. Ещё в 1973 году Боника организовал и провёл I Международный симпозиум по боли, что в свою очередь привело к созданию Международной Ассоциации по изучению боли (IASP - International Association for the Study of Pain). Длительное время Джон Боника входил в руководство этой организацией и был её Почётным президентом. В настоящее время в IASP состоит около 6000 членов, представляющих 83 страны мира.

Кроме того, Джон Боника с 1952 года был активным членом Американского Общества Анестезиологов (ASA), а в 1966 году он был избран президентом ASA. Он помог ASA присоединиться к Всемирной федерации Обществ Анестезиологов (WFSA) в 1960 году, и сразу же был избран членом исполнительного комитета WFSA. Также он возглавил один из научных консультативных комитетов WFSA, основной задачей которого являлось распространение анестезиологических знаний в развивающихся странах. Боника предложил создать Латиноамериканский анестезиологический учебный центр в Каракасе (Венесуэла), который открылся в 1966 году. В течение 1972-1976 годов Боника был Генеральным секретарем WFSA, а с 1980 по 1984 год занимал пост Президента WFSA. 


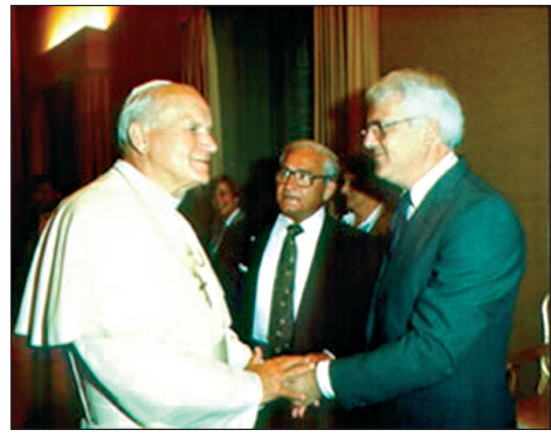

Рис. 290. Вручение награды

Научное литературное наследие Джона Боника включает 41 книгу. Из их 18 книг были полностью написаны им лично, 23 вышли под его редакцией. Кроме того, он является соавтором 60 книг, и опубликовал 274 научные статьи, большинство из которых имели отношение к исследованию патофизиологии боли и её терапии, включая даже такие методы, как акупунктура.

Такая энергичная деятельность и научная продуктивность

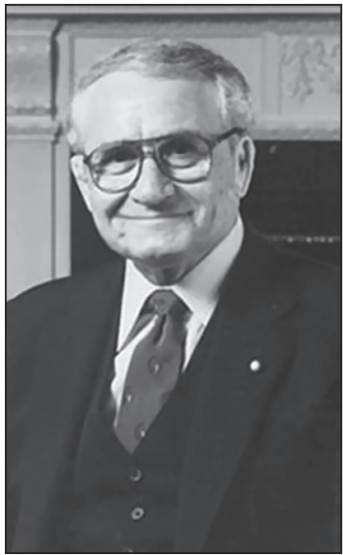

Рис. 291. Джон Боника «Чемпион по борьбе с болью» очень часто бывают не под силу даже здоровым людям. Мало кто знает, что прославленный «чемпион по борьбе с болью» сам мучительно страдал от серьезного хронического болевого синдрома, обусловленного спортивным прошлым Боники и мышечными травмами, полученными на борцовском ковре. В дни обострений болевого синдрома он практически не спал, иногда боль настигала его во время научных заседаний, лекций, занятий со студентами. Но он никогда не откладывал намеченных дел, и не позволял себе отклоняться от намеченного плана работы. Коллеги Боники говорили, что он многим в своих успехах обязан своей жене Эмме, всегда энергично поддерживающей его во всех делах. И, наверное, это действительно так.

За свою жизнь Джон Боника получил огромное количество наград и почётных званий, включая и награду за выдающуюся деятельность в ASA, полученную им в 1973 году. Сам Боника очень гордился наградой за вклад в социальное обеспечение людей всего мира, полученную им в 1990 году от Папы Римского Иоанна Павла II (рис. 290).

Имя Джона Боники никогда не будет забыто благодарным человечеством (рис. 291). Начиная с 1984 года, с периодичностью раз в три года, на Всемирных Конгрессах по проблемам боли читаются лекции им. Джона Боники. И каждый раз их читает учёный, который, по всеобщему мнению, внёс за этот трехлетний период времени самый значительный вклад в дело борьбы с болью. 


\section{Криоанальгезия}

Заключается в воздействии низких температур на нервы с целью обезболивания. Самый обычный криозонд вызывает замораживание при выпускании под повышенным давлением закиси азота через узкое отверстие на верхушке зонда (рис. 292). Замораживание происходит в результате расходования тепла на испарение закиси азота или углекислого газа. M. Maiwand и сотр. (1986) показали, что оптимальная блокада обеспечивается при охлаждении каждого нерва в течение не менее 30 с. Однократный цикл замораживания вместо двух 30-секундных циклов создаёт анальгезию

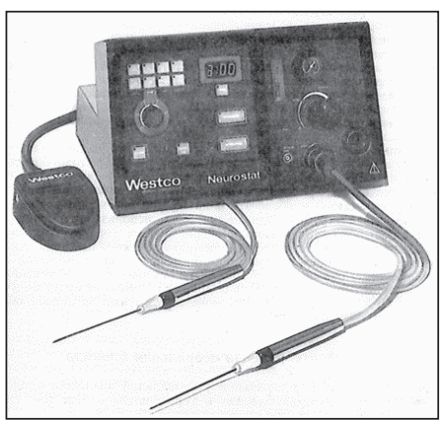

Рис. 292. Аппарат для криоанальгезии с криозондами. (Ил. по Ф. Ферранте, Т.Р. ВейдБонкору, 1998.) сроком на 1 месяц и снижает частоту расстройств чувствительности. Однако даже при однократном цикле замораживания всё же возможно повреждение нерва, хотя сохранение эндотелия обеспечивает со временем прорастание нейронов.

\section{Акупунктура}

Уже 4000 лет назад в Китае было известно, что введение игл в определённые точки тела вызывает анальгезию. Согласно китайской философии Чи, жизненная сила циркулирует в теле по путям, называемым меридианами. Повреждение и заболевание могут блокировать эту циркуляцию, вызывая боль и расстройства. Полагают, что акупунктура снимает такие блоки и восстанавливает баланс энергии человека. Традиционно акупунктурные точки стимулируются путём введения тонких игл, которые затем вращаются вручную или стимулируются с помощью тепла (моксинагревание) или электричества. Чтобы акупунктурная анальгезия была эффективной, пациент должен испытывать чувство тяжёлого онемения (называемого те-чи), распространяющегося от акупунктурной точки.

Можно считать, что акупунктура продуцирует высокоинтенсивную низкочастотную стимуляцию. Полагают, что она вызывает выброс энкефа- 
линов и эндорфинов, которые ответственны за наблюдаемые анальгетический и седативный эффекты.

В стоматологии чаще используют блок тройничного нерва и его ветвей при лечении больных невралгией тройничного нерва.

В 1883 г. К. Тирш (К. Thiersch) предложил неврэкзерез, а в 1901 г. P. Шлёсcер (R. Schlösser) - алкоголизацию нервов.

В 1931 г. удалось добиться продления действия местной анестезии получением тетракаина (введением заместителя в ароматическое кольцо прокаина). Но вещество оказалось в 10 раз токсичнее, чем прокаин, и поэтому в сегодняшней стоматологии применяется только для поверхностной анестезии.

\section{Продлённая проводниковая блокада второй и третьей ветвей тройничного нерва}

Одним из путей повышения эффективности местной проводниковой анестезии в челюстно-лицевой хирургии является продлённая проводниковая блокада (ППБ) ветвей тройничного нерва. Метод предложен П.Ю. Столяренко в 1987 г. Сущность его заключается в подведении к второй или третьей ветви тройничного нерва местного анестетика внеротовым доступом через тонкий пластиковый катетер (рис. 293, 294). Это позволило усовершенствовать методики комбинированного обезболивания во время операций, а также исключить в послеоперационном периоде

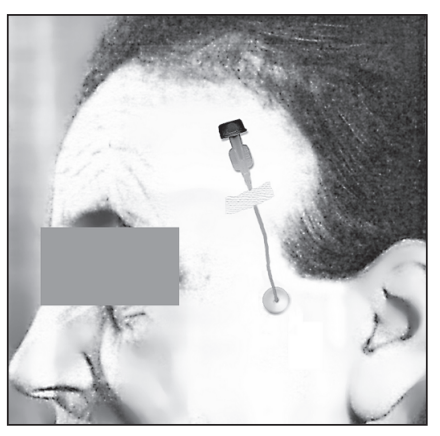

Рис. 293. Вид больной с катетером для продлённой проводниковой блокады третьей ветви тройничного нерва (собственное наблюдение) назначение опиатов, угнетающих дыхание и кашлевой рефлекс, усиливающих посленаркозную депрессию и возможность возникновения ятрогенной наркозависимости. Применение катетера, обеспечивающего повторное введение болюсных доз или постоянную инфузию местного анестетика, G. Smith (1998) считает наиболее эффективным способом пролонгации обезболивания.

В 80-е годы уходящего века появился метод создания лекарственных веществ направленного действия за счёт сочетания известных препаратов с особыми магнитными носителями, способными обеспечивать их адресную доставку к органам. 


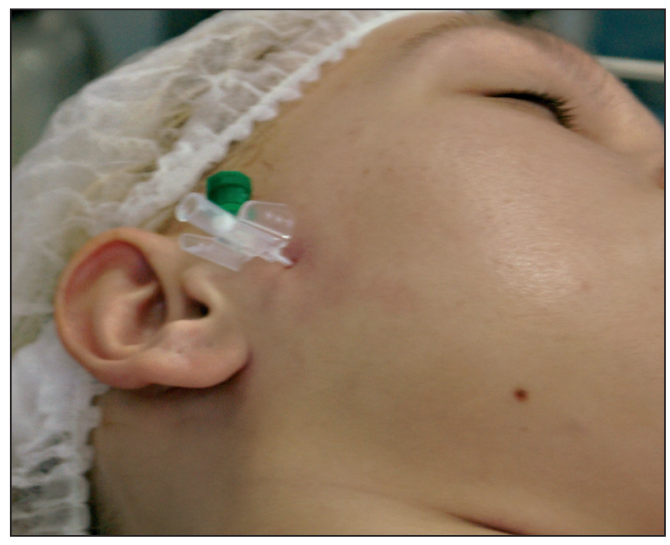

Рис. 294. Для продлённой проводниковой блокады использован периферический венозный катетер G 18 (собственное наблюдение)

Экспериментально-клиническая разработка магнитоуправляемого местного анестетика феррокаина позволила кумулировать анестетики в биологически активных тканях под действием внешнего магнитного поля, и начать клиническое применение в амбулаторной стоматологии (Сохов С.Т., 1997). 


\section{ИСТОРИЯ АНЕСТЕЗИОЛОГИИ В САМАРЕ}

Известен вклад дантистов в развитие обезболивания в хирургии (Юдин С.С., 1960; Столяренко П.Ю., Федяев И.М., 2006 и др.). В России наркоз закисью азота стали применять с 1869 года. Началась эта эра с зубоврачебной практики. В «Московских ведомостях» появилось объявление, в котором американский зубной врач Л. Бернардо-Беркмеер предлагал удаление зубов «без чувства боли, используя закись азота».

В Самарской губернии впервые использовал наркоз в 1874 году дантист Берг Исаевич Гаухман, применяя «лечение, пломбирование и вставление искусственных зубов под веселящим газом» (рис. 295) [Адрескалендарь и памятная книжка Самарской губернии за 1874 год]. В 18801881 годах русский военный врач Станислав Сигизмунд Кликович провёл фундаментальное исследование свойств закиси азота. Под влиянием его исследований наркоз закисью азота стал постепенно распространяться в России. С 1888 года этот газ применяли в Петербурге для наркоза дантисты, в 1896 году А. Рахманов и в 1898 году С.И. Халафов - для обезболивания родов. В 1902 году в Петербургском обществе зубных врачей был заслушан доклад Ф.А. Звержховского об успешном опыте использования закиси азота с кислородом при удалении зубов. Тем не менее, этот вид обезболивания не мог в тот период получить широкого и должного распространения, так как закись азота для наркоза было сложно получать. Использование этого газа было дорого, Россия не обладала аппаратурой для газового наркоза.

В 20-е годы прошлого столетия зубные врачи в основном применяли местную анестезию раствором новокаина. При изучении рекламных объявлений обращает на себя внимание, без боли гарантировалось только удаление зубов (рис. 296).

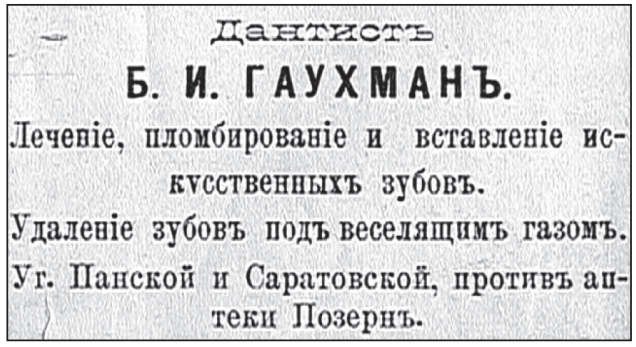

Рис. 295. Реклама дантиста Б.И. Гаухмана
В Самаре на трёх хирургических кафедрах (госпитальной, факультетской и пропедевтической) медицинского университета (ранее назывался Куйбышевский медицинский институт) до середины $50-x$ годов прошлого века наиболее широко использовался масочный нар- 
коз, ректальный и спинномозговая анестезия. Основными анестетиками были эфир и новокаин.

Эндотрахеальный наркоз впервые начали применять на кафедре факультетской хирургии. Связано это было с разработкой операций на лёгких (зав. проф. Г.Л. Ратнер - рис. 297, и его предшественник проф. С.Л. Либов). На кафедре госпитальной хирургии (зав. проф. А.М. Аминев - рис. 298) челюстно-лицевых больных стали оперировать под эндотрахеальным наркозом с середины 60-х годов прошлого века (резекция нижней, верхней челюстей, экстирпация языка, уранопластика и хейлопластика у детей с врождёнными пороками лица.

Путь развития эндотрахеального наркоза в челюстно-лицевой области был сопряжён не только с его сложным техническим обеспечением, но и с подбором ингаляцион-

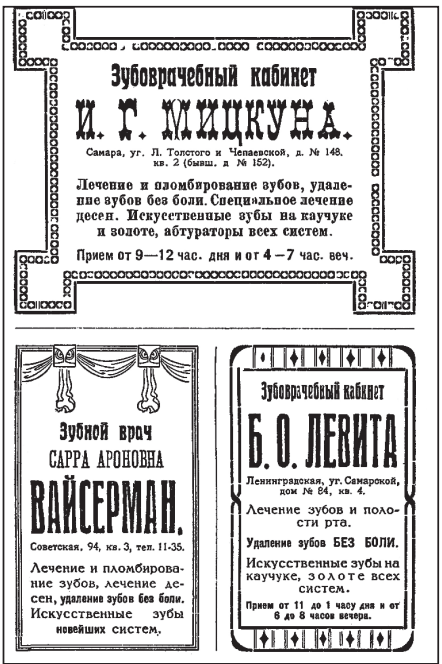

Рис. 296. Рекламные объявления Самарских зубных врачей из книги «Вся Самара и Губерния на 1926 год» ных и неингаляционных анестетиков. Отрабатывались методы премедикации, вводного наркоза. Частым грозным осложнением, приводившим к летальным исходам у больных с челюстно-лицевой патологией, была дезинтубация из-за не надёжной фиксации стандартного тройника на груди больного.

Интубационная трубка, введённая через рот, мешала при проведении хирургических вмешательств в полости рта. Для устранения этих недостатков И.М. Федяевым (рис. 299) и А.М. Барановым в 1965 году были предложены тройник и коннектор, которые крепились на лбу больного. Это позволило надёжно фиксировать эндотрахеальную трубку и во время хирургического вмешательства избегать случайной экстубации, особенно у детей во время уранопластики. Тройник и метод его фиксации на лбу больного до настоящего времени используется на кафедре челюстно-лицевой хирургии и стоматологии.

Первыми профессиональными анестезиологами на кафедре госпитальной хирургии были Б.Н. Зимнев, Юрий Павлович Балуев (рис. 300) и Марат Николавич Елисеев (рис. 301). Медсёстрами-анестезистками работали Д.А. Зимукова и М.П. Бурлакова, позже - С.В. Кравченко, затем Ж.Б. Лернер, а медбратом был В.В. Кравченко (в настоящее время он является директором ООО «Клиника доктора Кравченко», доктор медицинских наук, доцент СамГМУ). 


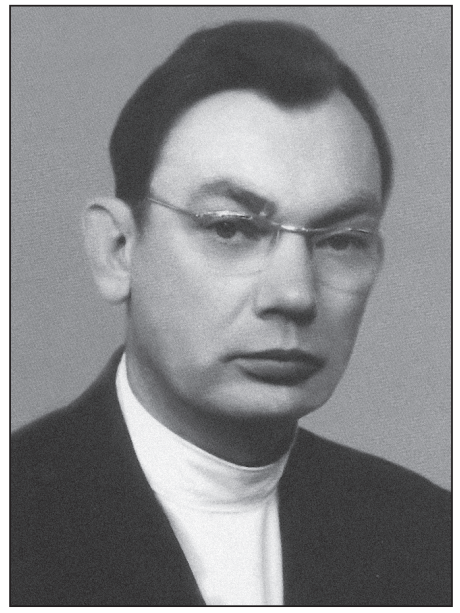

Рис. 297. Георгий Львович Ратнер (1926-2001)

Заслуженный деятель науки РФ, доктор медицинских наук, профессор, заведующий кафедрой и клиникой факультетской хирургии с 1962 по 2001 г. Основатель научно-педагогической школы сердечнососудистых хирургов. Приоритетные направления научно-практической деятельности: хирургия сердца, сосудов, торакальная хирургия. Г.Л.Ратнером написаны 11 монографий, получено 40 авторских свидетельств на изобретения. Им подготовлено 32 доктора и 92 кандидата медицинских наук. Среди его учеников академик РАМН, первый проректор ММА им. И.М. Сеченова профессор И.Н.Денисов; член-корреспондент РАМН, руководитель отдела аорты в РНЦ хирургии, профессор Ю.В. Белов; заслуженный врач РФ, заведующий кафедрой кардиохирургии ИПО СамГМУ, руководитель областного кардиохирургического центра профессор В.П.Поляков; заслуженный врач РФ, заведующий кафедрой хирургии ИПО, профессор В.Н.Чернышев. Профессора В.П.Поляков и В.Н. Чернышев, а также преемник по кафедре - профессор А.Н.Вачев успешно развивают научные направления школы.

С открытием стоматологического факультета в Куйбышевском медицинском институте в 1966 году и организацией кафедры стоматологии 25 сентября 1968 года, а затем и кафедры хирургической стоматологии (зав. - профессор М.А. Макиенко) вопросам анестезиологического обеспечения стали уделять большое внимание. У профессора М.А. Макиенко (рис. 302) за плечами был опыт лечения раненых в челюстно-лицевую область в годы Великой Отечественной войны и реабилитация их в послевоенные годы. Она как никто другой представляла себе важность устранения психоэмоционального напряжения и полноценного обезболивания при операциях в челюстно-лицевой области. М.А. Макиенко раньше других стоматологов поняла необходимость иметь на кафедре и в клинике специалистов, подготовленных для анестезиологического обеспечения, оказания неотложной помощи и реанимации больных стоматологического профиля. 


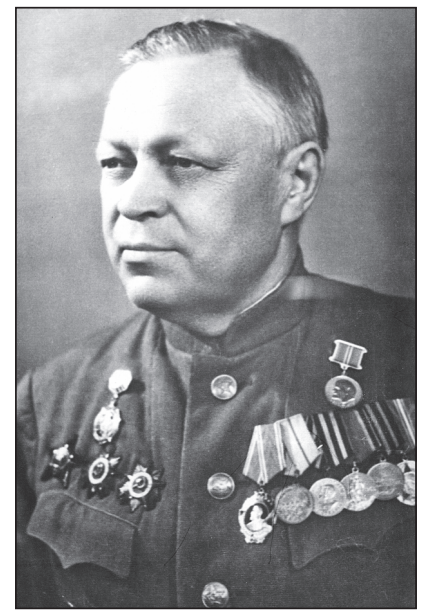

Рис. 298. Александр Михайлович Аминев (1904-1984)

Заслуженный деятель науки РСФСР, лауреат премии им. Н.И. Пирогова, доктор медицинских наук, профессор, заведующий кафедрой и клиникой госпитальной хирургии с 1945 по 1984 г. Всемирно известный проктолог и хирург. Окончил медицинский факультет Пермского университета. Работал заведующим кафедрой общей хирургии стоматологического института (1939), ректор Астраханского медицинского института (1941), главный хирург 5-й армии П.А. Ротмистрова (1942). Автор около 500 научных работ
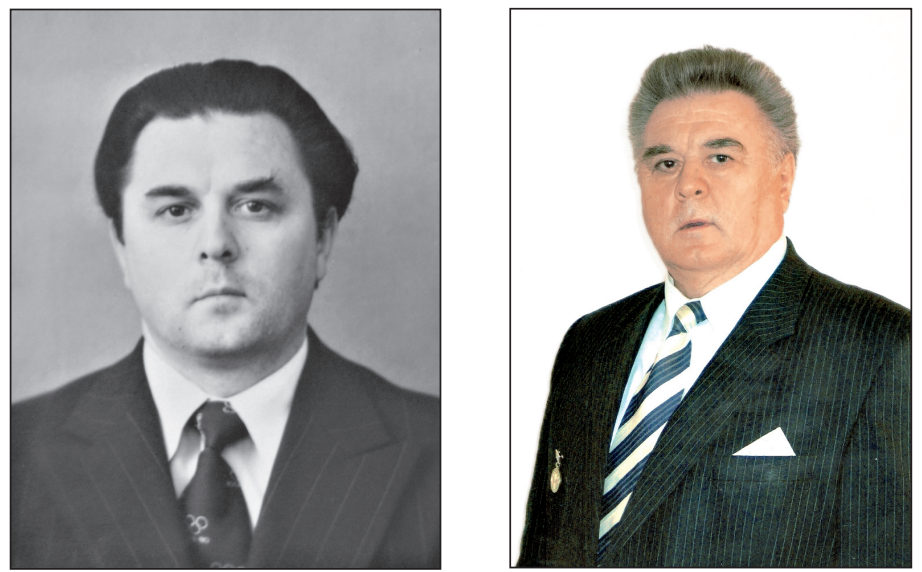

Рис. 299. Игорь Михайлович Федяев

Заведующий кафедрой и клиникой хирургической стоматологии с 1979 по 2007 г., в настоящее время Заслуженный врач РФ, почётный профессор Самарского государственного медицинского университета, президент Стоматологического института СамГМУ 


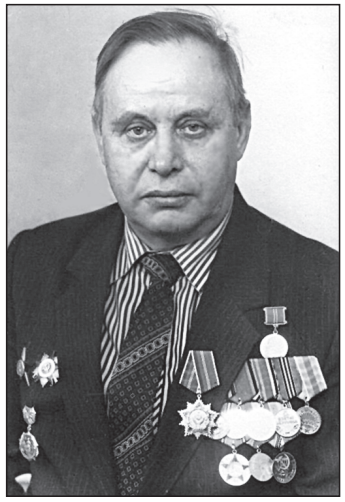

Рис. 300. Юрий Павлович Балуев (1923-1998)

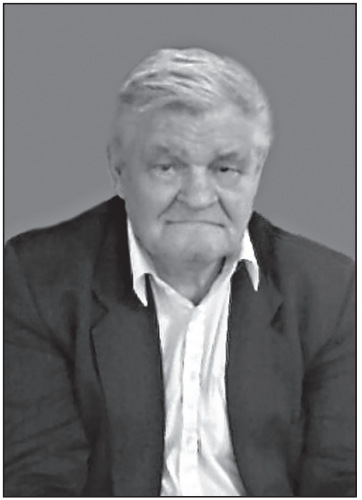

Рис. 301. Марат Николаевич Елисеев

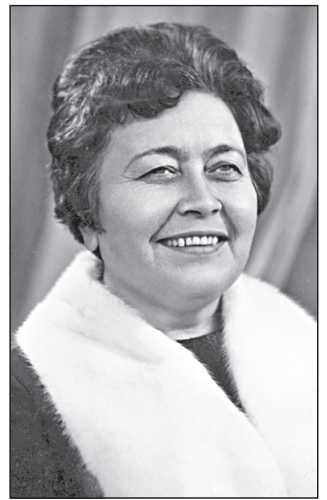

Рис. 302. Профессор

М.А. Макиенко (1918-1979). Основоположник стоматологического факультета и школы Самарских стоматологов

После переезда клиники хирургической стоматологии на ул. Пензенскую, 226 первым анестезиологом был Алексей Иванович Скитер (с 1971 по 1972 год). Анестезисткой с ним работала Нина Калякаева. Короткий период проводил наркозы Владимир Кузьмич Поленичкин (в настоящее время он заведует кафедрой хирургической стоматологии и челюстнолицевой хирургии Новокузнецкого государственного института усовершенствования врачей, д.м.н., профессор, академик АТН, академик МАИСФ). По экстренной помощи в этот период наркозы проводили анестезиологи из клиники травматологии и ортопедии Николай Сергеевич Пичеев (зав. отделением с 1970 по 1981 г. - рис. 303), Александр Михайлович Старухин (рис. 304), Владимир Иванович Тихомиров, Владимир Иванович Скотников, Михаил Юрьевич Рухлядев. В последующие годы в содружестве со стоматологами работали Владимир Федорович Крайнюков (с 1974 по 2007 год), Иван Филиппович Гаврилов (зав. отделением в 1981-1984 гг.), Ольга Николаевна Бобровская (зав. отделением с 1984 по 2004 г.), Наталья Петровна Сергачёва, Евгения Викторовна Двойникова, Ольга Анатольевна Порывай, Людмила Александровна Иващенко, Владимир Петрович Болонкин (в настоящее время - главный врач ГСП № 2 и профессор кафедры челюстно-лицевой хирургии и стоматологии) рис. 311. 


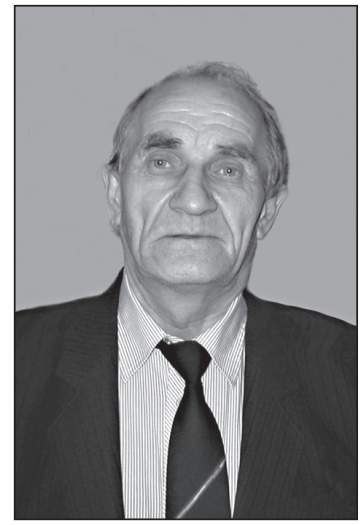

Рис. 303. Н.С. Пичеев

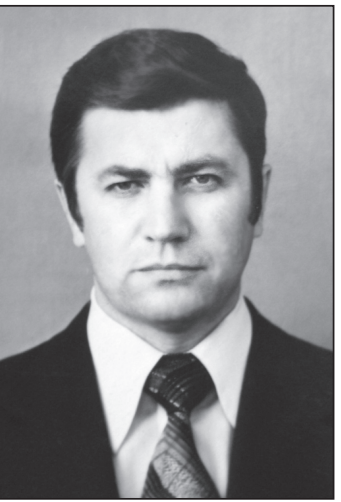

Рис. 306. В.К. Филатов

(1938-2002)

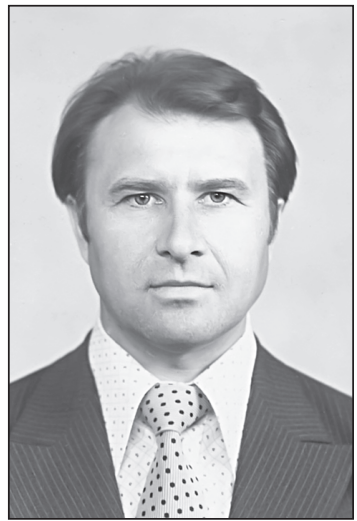

Рис. 304. Кандидат мед. наук

А.М. Старухин

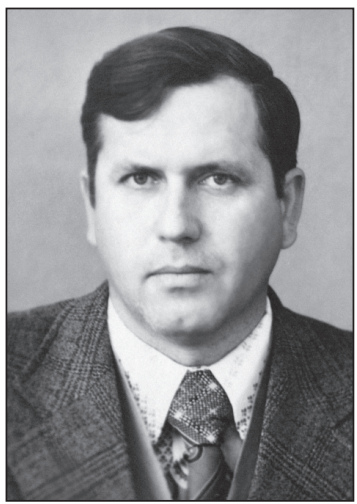

Рис. 307. В.В. Бережнов

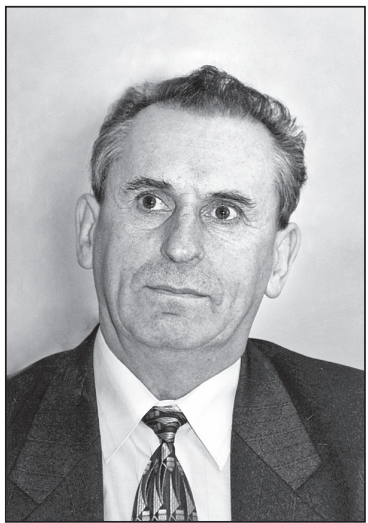

Рис. 305. В.М. Зотов

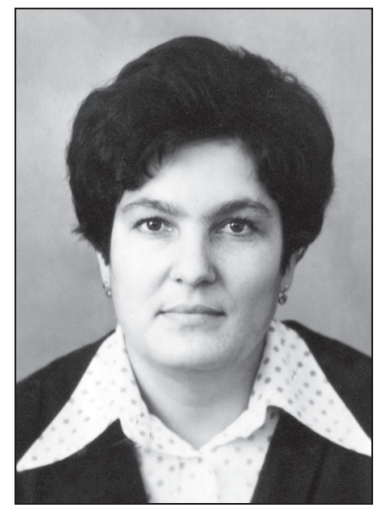

Рис. 308. М.П. Бурлакова

В стоматологическом отделении в начале 70 -х годов при плановых операциях наркозы в стационаре проводили ординатор клиники хирургической стоматологии Валентин Михайлович Зотов (в настоящее время - профессор кафедры ортопедической стоматологии, рис. 305), старший лаборант кафедры хирургической стоматологии Владимир Викторович Бережнов (кандидат медицинских наук, сейчас он работает в отделении детской стоматологии Областной клинической больницы им. М.И. Калинина - рис. 307), Зоя Александровна Винокурова (рис. 310) и 


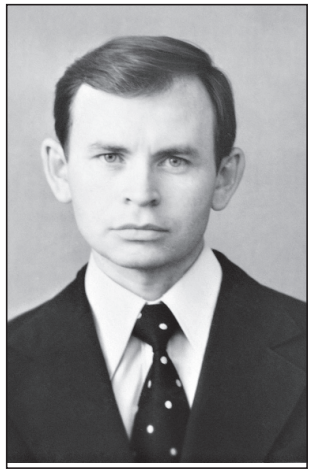

Рис. 309. П.Ю. Столяренко

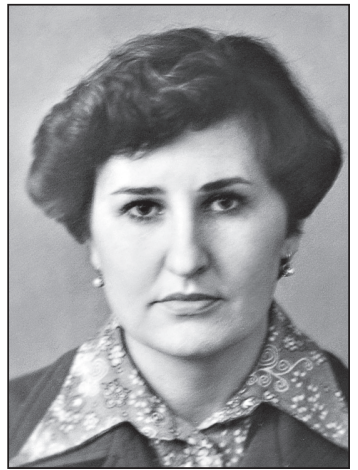

Рис. 310. 3.А. Винокурова

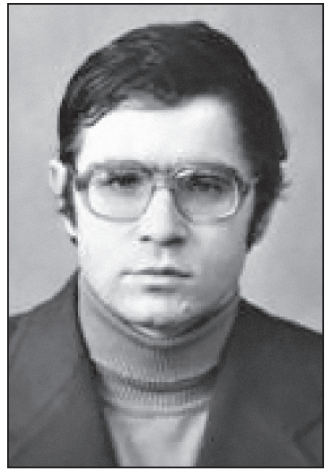

Рис. 311. В.П. Болонкин

старшая операционная сестра Мария Павловна Бурлакова (рис. 308). Она выполнила первый амбулаторный наркоз закисью азота с кислородом на аппарате АН-2 при удалении и лечении зубов. Было это в стоматологическом кабинете клиники хирургической стоматологии.

В 1971 г. профессор М.А. Макиенко пригласила на должность ассистента кафедры хирургической стоматологии анестезиолога из отделения травматологии и ортопедии Виктора Константиновича Филатова (рис. 306). Ему предстояло организовать не только практическую работу по анестезиологическому обеспечению в клинике, но и учебный процесс на стоматологическом факультете по разделу «обезболивание», амбулаторный наркоз (рис. 312) в базовых стоматологических поликлиниках (областная и Октябрьского района). Следует отметить высокие профессиональные качества В.К. Филатова. Выполняя большой объём лечебной работы, он сумел подготовить много стоматологов по анестезиологическому обеспечению и оказанию неотложной помощи в стоматологии, в том числе и автора этой книги. Его и профессора М.А. Макиенко статья в журнале «Стоматология» о преподавании частной анестезиологии студентам стоматологического факультета, хотя и была опубликована в порядке дискуссии, тем не менее, имела большой резонанс и в то время была очень полезна преподавателям этой дисциплины. Ассистент В.К. Филатов в 1984 году в ММСИ защитил кандидатскую диссертацию по теме «Комбинированный наркоз сомбревином и газонаркотической смесью фторотана, закиси азота и кислорода при амбулаторных стоматологических вмешательствах» (14.00.21 - стоматология, 14.00.37 - анестезиология и реаниматология). 


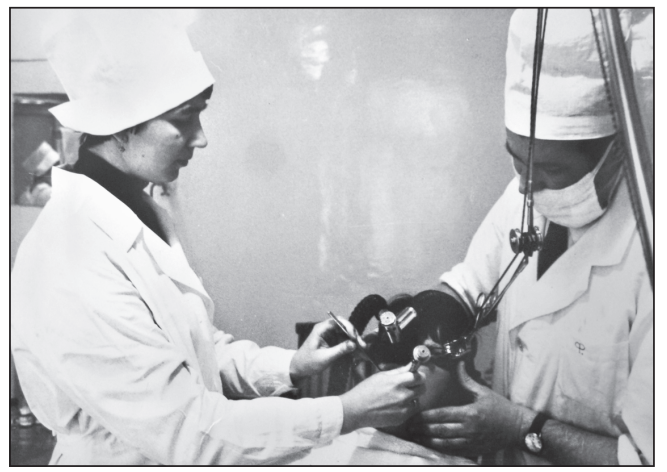

Рис. 312. Лечение зубов под масочным наркозом (стоматолог Н.М. Гриненко, анестезиолог В.К. Филатов)

В 1972 г. в клинику хирургической стоматологии проф. М.А. Макиенко пригласила на должность больничного ординатора выпускника стоматологического факультета Павла Юрьевича Столяренко (рис. 309) с условием совмещения работы в качестве хирурга-стоматолога и анестезиолога. В 1970-80-е годы в клинике хирургической стоматологии осуществлялась интенсивная лечебная и научная работа, в т.ч. и по анестезиологии. Проводилось много наркозов, как в стационаре, так и в поликлиниках. Разработаны новые методики - интубация трахеи по проводнику при ограничении открывания рта (модифицирован способ Waters и с использованием фибробронхоскопа). Авторы: Филатов В.К., Столяренко П.Ю., Бережнов В.В. Это позволило уменьшить показания к трахеостомии для проведения наркоза (рис. 313). Внедрены новые препараты - сомбревин (В.К. Филатов), калипсол (П.Ю. Столяренко). В настоящее время при сложной интубации трахеи применяем фибробронхоскопию (рис. 314).

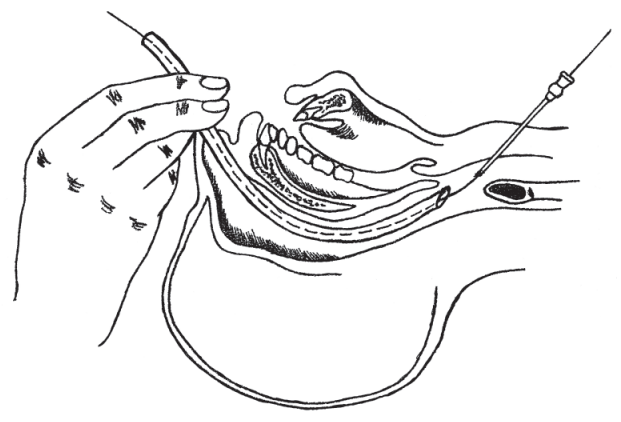

Рис. 313. Схема интубации трахеи по проводнику 


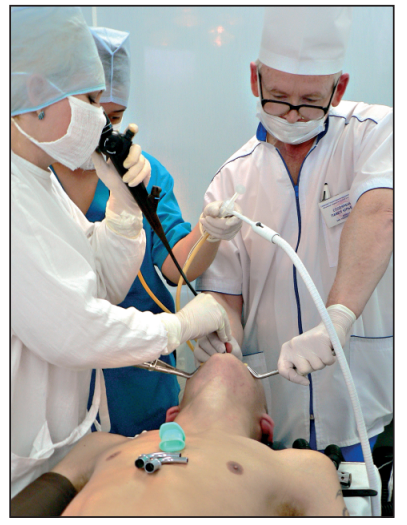

Рис. 314. Интубация трахеи с помощью фибробронхоскопа

В 1987 г. Столяренко П.Ю. предложил и внедрил в клиническую практику новый метод обезболивания - продлённую проводниковую блокаду 2-й и 3-й ветвей тройничного нерва с помощью катетера, который с успехом используется более 20 лет. Сочетанное применение анальгезии и регионарной анестезии позволяет уменьшить риск анестезиологических осложнений при операциях в челюстнолицевой области и обеспечить обезболивание в послеоперационном периоде без назначения наркотических анальгетиков и угнетения кашлевого рефлекса.

Разработаны новые методы диагностики и профилактики бронхолёгочных осложнений у больных с воспалительными процессами, травмой, деформациями и новообразованиями челюстно-лицевой области, что повысило эффективность и безопасность хирургического лечения, позволило снизить летальность в 2,5 раза. Автором впервые разработаны методы прижизненной диагностики аспирации содержимого полости рта во время эндотрахеального наркоза при операциях в челюстно-лицевой области. Для выявления скрытой дыхательной недостаточности предложен новый метод функциональной диагностики - назальная электромиография. С целью профилактики бронхолёгочных осложнений - метод волнового вибропневмомассажа с помощью аппарата «БИОМ-ПУЛМО». Внедрён мониторинг сердечно-сосудистой деятельности и газообмена в амбулаторной стоматологической практике, даны рекомендации по обезболиванию у пациентов пожилого возраста и с факторами риска. Впервые в отечественной литературе опубликован цикл работ по истории обезболивания в стоматологии, фрагменты которых включены в 1-й том интерактивной энциклопедии «История мировой анестезиологии». Раскрыты многие малоизвестные факты из истории анестезии, биографии учёных, иллюстрации и документы. Кандидатская диссертация П.Ю. Столяренко на тему «Профилактика и лечение нарушений внешнего дыхания у больных с флегмонами челюстнолицевой области и шеи» (14.00.21 - стоматология, 14.00.37 - анестезиология и реаниматология) защищена в 1980 г. в ММСИ им. Н.А. Семашко.

Бережнов В.В. в 1994 г. в Самаре защитил кандидатскую диссертацию по теме «Обоснование методов обезболивания у больных с переломами нижней челюсти при различных способах остеосинтеза» (14.00.21 - стома- 
тология). Автором проведена комплексная оценка различных видов обезболивания у больных с переломами нижней челюсти с позиции поликардиографических, реоэнцефалографических исследований, изменений КОС, объёма циркулирующей крови и её компонентов, электролитов плазмы, фазовый анализ сократительной функции миокарда на различных этапах обследования и оперативного вмешательства. Впервые изучены показатели температуры кожи в симметричных точках - проекциях выхода периферических ветвей тройничного нерва на этапах репозиции костных отломков, определены потоотделительные показатели. На основании этих исследований В.В. Бережнов разработал и внедрил в практику показания к использованию различных ви-

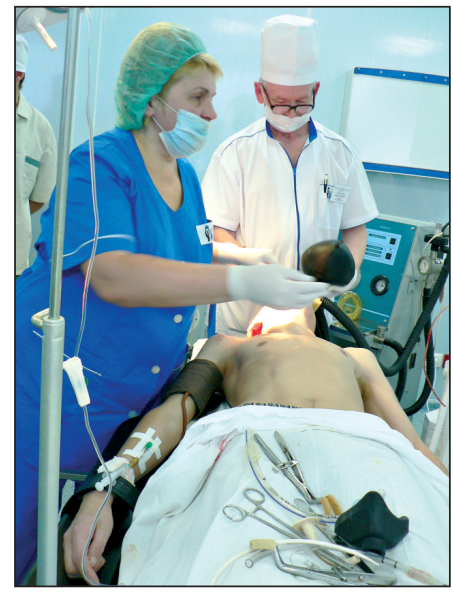

Рис. 315.Л.И. Губарева и П.Ю. Столяренко перед сложной интубацией трахеи у больного санкилозом ВНЧС дов обезболивания (местное, местное в сочетании с НЛА, эндотрахеальный наркоз).

Следует отметить медсестёр-анестезисток, которые в разные годы работали в отделении: Шеина-Сыроватко Лидия Ивановна, Шевалеева Алла, Хлюпнёва Татьяна, Галимова Галия, Абзипарова Вера, Ильина Елена, Головачёва Марина. Губарева Людмила Ивановна (работала с 1986 по 2006 год - рис. 315). Скромные, исполнительные труженицы анестезиологической службы.

\section{Основные публикации по вопросам обезболивания:}

1. Столяренко П.Ю. Продлённая проводниковая блокада в челюстнолицевой хирургии: Монография. - Самара; СамГМУ, 1996. - 72 с.

2. Современные технологии местного обезболивания в стоматологии: Метод. рекомендации. Сост. П.Ю.Столяренко. - Самара; СамГМУ, 1997. - 40 с.

3. Столяренко П.Ю., Кравченко В.В. Обезболивание в стоматологии у лиц пожилого возраста: Учебное пособие. - Самара; НИИ «Международный центр по проблемам пожилых», СамГМУ, 1998. - 72 с.

4. Столяренко П.Ю., Федяев И.М., Кравченко В.В. Местная анестезия в стоматологии. Выбор препаратов. Осложнения. Профилактика: Учебное пособие. - Самара, НВФ «СМС», СамГМУ, 1998. - 102 с. 
5. Интралигаментарная анестезия в терапевтической, хирургической и ортопедической стоматологии (возможности, особенности, противопоказания): Метод. рекомендации. Сост. П.Ю.Столяренко, В.В.Кравченко, Т.А.Киселева, Г.Н.Беланов. - Самара, СамГМУ. - 1998. - 15 с.

6. Столяренко П.Ю. Ларингеальная маска - перспективы и возможности применения в челюстно-лицевой хирургии и стоматологии: Краткое практическое руководство. - Самара: НВФ «СМС», СамГМУ, 1999. - 32 с.

7. Столяренко П.Ю., Кравченко В.В. Местная и общая анестезия в геронтостоматологии: Монография. - Самара; СамГМУ, Самарский научный центр РАН, НИИ «Международный центр по проблемам пожилых», 2000. $196 \mathrm{c}$.

8. Столяренко П.Ю. История обезболивания в стоматологии (от древности до современности): Монография. - Самара: НВФ ООО «Сенсоры. Модули, Системы»; СамГМУ, 2001. - 172 с., ил.122.

9. Столяренко П.Ю. История создания лидокаина: Научно-биографиеское издание. - Самара; СамГМУ, 2001. - 36 с., ил. 16.

10. Столяренко П.Ю. Фридрих Штольц (к 100-летию синтеза адреналина): монография. - Самара; ООО «Офорт»; ГОУВПО «СамГМУ», 2004. - 76 с.

11. Столяренко П.Ю. История адреналина: Научно-биографическое издание. - Самара; СамГМУ, 2003. - 48 с.

12. Столяренко П.Ю. Вклад стоматологов Жана Берше, В.М. Уварова и М.Д. Дубова в развитие местной анестезии в челюстно-лицевой области: Научно-биографическое издание. - Самара: «Офорт»; ГОУ ВПО «СамГМУ», 64 с.

13. Столяренко П.Ю. История создания новокаина (к 100-летию открытия Альфреда Айнхорна): Научно-биографическое издание. - Самара; ГП «Перспектива»; СамГМУ, 2003. - 70 с.

14. Столяренко П.Ю., Федяев И.М. Вклад дантистов в развитие хирургического обезболивания: Монография. - Самара: ООО «Офорт», ГОУ ВПО «СамГМУ», 2006. - 146 с.

15. Столяренко П.Ю., Федяев И.М., Кравченко В.В. Местная анестезия в стоматологии. Выбор препаратов. Осложнения. Профилактика: Учебное пособие. - 2-е изд., перераб. и доп. - Самара: ООО «Офорт»; СамГМУ, 2009. $235 \mathrm{c}$.

16. Неотложная помощь и реанимация в амбулаторной стоматологической практике у взрослых и детей: Учебное пособие / Составители: П.Ю. Столяренко, И.М. Федяев, И.М. Байриков, С.А. Пряников. - Самара: ООО «Офорт»; ГОУ ВПО «СамГМУ», 2009. - 138 с. 


\section{НЕГАТИВНЫЕ СТОРОНЫ ДОСТИЖЕНИЙ В БОЛЕУТОЛЕНИИ}

Наряду с явным прогрессом развитие обезболивания даёт и весьма ощутимые негативные последствия, создаёт новые проблемы.

Изобретение шприца для инъекций открыло следующий этап в новейшей истории наркотиков. Действие веществ, попадающих прямо в кровь, усиливалось в несколько раз. Сегодня употребление наркотиков в первую очередь связывают с инъекциями, хотя их и едят, и пьют, и курят, и нюхают.

Явление наркозависимости было отмечено в 70-е годы XIX века. Сначала речь шла о только что изобретённых лекарствах (кокаин, морфин), затем европейцы узнали, что в Перу, к примеру, листья коки жевали ещё во времена Великого Инки, а употребление опийного мака на территории Испании известно как минимум с 4200 года до н.э. Сегодня в перечне наркотических средств, психотропных веществ и их прекурсоров, то есть необходимых для приготовления добавок, более трехсот наименований. Главным свойством этих веществ является способность изменять сознание человека, а история их употребления уходит в глубокое прошлое. Античные авторы лишь зафиксировали наличие этой куда более древней традиции. Об этом свидетельствует известная, хотя и не совсем ясная история Геродота, за пять веков до нашей эры описавшего скифские племена, которые кочевали между Доном и Дунаем, к северу от Чёрного моря. Геродот подивился их обычаю использовать зерна конопли (Cannabis sativa). Скифы не то принимали паровые ванны, бросая на раскалённые камни эти зерна, не то жгли их в костре, усевшись вокруг, но так или иначе они пьянели, как греки от вина, и начинали петь и танцевать. Теперь коноплю называют марихуаной и выращивают в 120 странах, и это самый распространённый наркотик в мире.

Христианство в борьбе с язычеством и шаманизмом, неразрывно связанными с наркотическими веществами, подвергло их строжайшему запрету. Европейская цивилизация стала заново открывать для себя эти вещества в конце XVIII - начале XIX веков. А сто лет спустя - начался фармакологический бум. Выдающиеся врачи Европы надеялись, что синтез новых лекарств позволит совершить прорыв в терапии.

В 1845 г. в Париже психиатр Жак-Жозеф Моро присутствует на собраниях «Клуба любителей гашиша» - среди них Александр Дюма, Теофиль Готье, Шарль Бодлер, Эжен Делакруа. В 1803 г. немец Фридрих Сертюрнер из опиума выделил морфин, который впоследствии применялся как внутривенный анестетик; в 1898 г. его соотечественник Генрих Дрезер синтезировал героин, который действует в 100 раз сильнее опиума-сырца. В 1859 г. 
ещё один немец, Альберт Ниманн, выделил из листьев коки хлоралгидрат кокаина, а через 20 лет его предлагает своим пациентам доктор Зигмунд Фрейд. Увлечённые химическими экспериментами врачи и не подозревали, что собственными руками открывают дверь в коллективное бессознательное царство человечества.

В 1938 г. в Швейцарии Альберт Хоффман, искавший средство для облегчения мигрени и спазмов матки во время беременности, открыл галлюциноген ЛСД-25. Самым сильным наркотиком галлюциногенной группы на сегодняшний день считается диметилтриптамин (ДМТ).

Внутривенное потребление наркотиков привело к стремительному распространению ВИЧ-инфекции и вирусного гепатита. С начала 2000 года в России отмечен бурный рост заболеваемости. По Самарской области на 22 ноября 2000 г. выявлено 4180 ВИЧ-инфицированных. В 98\% случаев отмечено совместное употребление наркотиков (Гусарова Г.И., 2000; Столяров Е.А. и соавт., 2000). По данным клиницистов и эпидемиологов, заболеваемость разными видами наркомании в целом по России в период с 1991 по 2001 г. возросла более чем в 14 раз, среди подростков - в 17 раз, резко увеличилась доля женщин, студентов и даже пожилых людей (Т. Чернобровкина. МГ №71. 21.09.2007). 


\section{ХРОНОЛОГИЯ ОСНОВНЫХ ДАТ ИСТОРИИ ОБЕЗБОЛИВАНИЯ В СТОМАТОЛОГИИ}

\begin{tabular}{|c|c|c|}
\hline ГОДЫ & СОБЫТия & АВТОРЫ \\
\hline 25-22 вв. до н.э. & $\begin{array}{l}\text { При раскопках в Месопотамии найдены } \\
\text { тексты, в которых описывается лекарство } \\
\text { от зубной боли, приготовляемое из семян } \\
\text { белены и мастики из камеди }\end{array}$ & \\
\hline XV в. до н.э. & $\begin{array}{l}\text { В Древней Греции и Риме, в Древнем Китае } \\
\text { и Индии использовались настойка мандра- } \\
\text { горы, белладонны (атропина) и опия для } \\
\text { обезболивания и «одурманивания" }\end{array}$ & \\
\hline 1550 г. до н.э. & $\begin{array}{l}\text { Папирус Эберса - «Книга приготовления } \\
\text { лекарств для всех частей тела». Содержат- } \\
\text { ся первые сведения об обезболивании при } \\
\text { разрезах, ожогах и др. }\end{array}$ & $\begin{array}{c}\text { G.Ebers, } \\
\text { нем. египтолог } \\
\text { и писатель } \\
\text { (1837-1898) }\end{array}$ \\
\hline VI в. до н.э. & $\begin{array}{l}\text { Древнекитайский врач одним из первых } \\
\text { исследовал пульс, в совершенстве овладел } \\
\text { методом иглотерапии }\end{array}$ & Цинь-Юз-Жень \\
\hline III в. до н.э. & $\begin{array}{l}\text { В Китае составлен первый крупный меди- } \\
\text { цинский трактат «Ней-цзин», в котором } \\
\text { подробно описывается метод чжек-цзю- } \\
\text { терапии, т.е. иглоукалывания }\end{array}$ & \\
\hline Конец I в. & $\begin{array}{l}\text { Римский врач, грек по происхождению, } \\
\text { Диоскорид Педаний написал 6-томный } \\
\text { трактат «De Materica» (О лекарственных } \\
\text { средствах), в котором описал наркотико- } \\
\text { подобное действие мандрагоры и первым } \\
\text { применил термин анестезия }\end{array}$ & Dioscorides \\
\hline II в. & $\begin{array}{l}\text { Китайский врач первым при операциях } \\
\text { для обезболивания использовал индий- } \\
\text { скую коноплю }\end{array}$ & $\begin{array}{c}\text { Хya To } \\
(141-203)\end{array}$ \\
\hline $250-265$ & $\begin{array}{l}\text { Трактат «Цзя-и-цзин» (Основы медици- } \\
\text { ны) - классический труд по иглоукалы- } \\
\text { ванию, который считается настольной } \\
\text { книгой современных китайских врачей, } \\
\text { занимающихся иглоукалыванием }\end{array}$ & $\begin{array}{c}\text { Хуан Фу-ми } \\
(215-285)\end{array}$ \\
\hline
\end{tabular}


Продолжение таблицы

\begin{tabular}{|c|c|c|}
\hline Х в. & $\begin{array}{l}\text { Обезболивание с помощью охлаждения } \\
\text { конечностей }\end{array}$ & $\begin{array}{c}\text { Авиценна } \\
\text { (Ибн Сина Абу } \\
\text { Али, 980-1037) }\end{array}$ \\
\hline 1200 & Открытие этилового эфира & R. Lullius \\
\hline XI-XIII вв. & \begin{tabular}{|l|} 
На территории Перу инки, создатели \\
одной из древнейших цивилизаций, \\
пользовались соком листьев коки для \\
местного обезболивания ран и улучшения \\
самочувствия
\end{tabular} & \\
\hline 1516 & $\begin{array}{l}\text { Испанский историк П. д’Анхиера описал } \\
\text { действие кураре (стрельного яда) }\end{array}$ & $\begin{array}{l}\text { P. d'Andhiera } \\
(1457-1526)\end{array}$ \\
\hline 1647 & Изобретение шприца & $\begin{array}{c}\text { B. Pascal } \\
(1623-1662) \\
\text { Франция } \\
\end{array}$ \\
\hline 1661 & $\begin{array}{l}\text { Использование холода для местной ане- } \\
\text { стезии }\end{array}$ & T.Bartholinus \\
\hline 1728 & $\begin{array}{l}\text { «Le chirurgien dentiste» - первый трактат } \\
\text { по стоматологии }\end{array}$ & P.Fauchard \\
\hline $1772-1774$ & Открытие кислорода & $\begin{array}{l}\text { C.W. Scheele, } \\
\text { J.Priestley }\end{array}$ \\
\hline 1772 & $\begin{array}{l}\text { «Experiments and observations on different } \\
\text { kinds of air» (Опыты и наблюдения над } \\
\text { различными видами воздуха) - открытие } \\
\text { закиси азота. Выделил и испытал на себе }\end{array}$ & $\begin{array}{c}\text { J.Priestley } \\
(1733-1804) \\
\text { Англия }\end{array}$ \\
\hline 1779 & $\begin{array}{l}\text { Австрийский врач Ф. Месмер продемон- } \\
\text { стрировал в Париже опыты с «животным } \\
\text { магнетизмом», посредством которого } \\
\text { якобы можно излечивать болезни и про- } \\
\text { водить обезболивание, но вместе с тем } \\
\text { это стало началом использования гипноза } \\
\text { с целью анестезии и суггестивного воз- } \\
\text { действия анестезиолога-психотерапевта }\end{array}$ & $\begin{array}{l}\text { F.A.Mesmer } \\
(1734-1815)\end{array}$ \\
\hline 1799 & $\begin{array}{l}\text { Английский химик Х. Дэви открыл опья- } \\
\text { няющее действие закиси азота в опытах } \\
\text { на себе (проходила зубная боль) и пред- } \\
\text { ложил применять её в хирургии для обез- } \\
\text { боливания }\end{array}$ & $\begin{array}{c}\text { H. Davy } \\
(1778-1829)\end{array}$ \\
\hline
\end{tabular}


Продолжение таблицы

\begin{tabular}{|c|c|c|}
\hline 1806 & $\begin{array}{l}\text { Немецкий учёный Ф. Сертюрнер выделил } \\
\text { в чистом виде и установил химические } \\
\text { свойства наиболее важного алкалоида } \\
\text { опия - морфина }\end{array}$ & $\begin{array}{l}\text { F.W. Sertürner } \\
(1783-1841)\end{array}$ \\
\hline $1807-1808$ & $\begin{array}{l}\text { Опубликовано первое оригинальное } \\
\text { отечественное «Руководство к преподава- } \\
\text { нию хирургии» в 3-х частях, выдержало } 5 \\
\text { изданий }\end{array}$ & $\begin{array}{l}\text { И.Ф. Буш } \\
(1771-1843)\end{array}$ \\
\hline $\begin{array}{c}1829, \\
12 \text { апреля }\end{array}$ & $\begin{array}{l}\text { Первая операция под гипнозом выполнена } \\
\text { во Франции Жилем Клоке, врачом и писа- } \\
\text { телем, другом Флобера }\end{array}$ & $\begin{array}{l}\text { J. Cloquet } \\
(1790-1883)\end{array}$ \\
\hline $\begin{array}{c}1842, \\
30 \text { марта }\end{array}$ & $\begin{array}{l}\text { Американский хирург К. Лонг первым } \\
\text { применил эфир при операции удаления } \\
\text { опухоли затылочной области }\end{array}$ & $\begin{array}{l}\text { C.W. Long } \\
(1815-1878)\end{array}$ \\
\hline 1844 & Эфирный наркоз при ампутации бедра & $\begin{array}{c}\text { Я.А.Чистович } \\
(1820-1885) \\
\end{array}$ \\
\hline $\begin{array}{l}1844, \\
11 \text { декабря }\end{array}$ & $\begin{array}{l}\text { Первый наркоз закисью азота. Американ- } \\
\text { ский дантист Хорас Уэллс подверг себя } \\
\text { наркозу «веселящим газом» при удалении } \\
\text { зуба мудрости } \\
\end{array}$ & $\begin{array}{l}\text { H.Wells } \\
(1815-1848)\end{array}$ \\
\hline 1844 & Изобретение полой иглы & $\begin{array}{c}\text { F. Rynd } \\
(1801-1861), \\
\text { Ирландия } \\
\end{array}$ \\
\hline $\begin{array}{c}1846, \\
16 \text { октября }\end{array}$ & $\begin{array}{l}\text { Первая публичная демонстрация эфирно- } \\
\text { го наркоза американским дантистом Мор- } \\
\text { тоном при удалении сосудистой опухоли } \\
\text { подчелюстной области. Эта дата вошла в } \\
\text { историю медицины как открытие эфирно- } \\
\text { го наркоза }\end{array}$ & $\begin{array}{l}\text { W.T.G.Morton } \\
(1819-1868)\end{array}$ \\
\hline $\begin{array}{l}1846, \\
18 \text { ноября }\end{array}$ & $\begin{array}{l}\text { Первая статья «Отсутствие чувствитель- } \\
\text { ности во время хирургической операции» } \\
\text { в Бостонском медицинском и хирургиче- } \\
\text { ском журнале }\end{array}$ & $\begin{array}{l}\text { H.J. Bigelow } \\
(1818-1871)\end{array}$ \\
\hline 1847 & $\begin{array}{l}\text { Первая в мире монография о наркозе. } \\
\text { Рождение внутривенного наркоза }\end{array}$ & $\begin{array}{c}\text { Н.И. Пирогов } \\
(1810-1881)\end{array}$ \\
\hline 1847 & Применение хлороформа для наркоза & $\begin{array}{l}\text { J.Y. Simpson } \\
(1811-1870)\end{array}$ \\
\hline
\end{tabular}


Продолжение таблицы

\begin{tabular}{|c|c|c|}
\hline 1847 & $\begin{array}{l}\text { Описание стадий наркоза эфиром, } \\
\text { применение лицевой маски }\end{array}$ & $\begin{array}{c}\text { J. Snow } \\
(1813-1858)\end{array}$ \\
\hline 1847 & $\begin{array}{l}\text { Эндотрахеальный, ректальный, внутри- } \\
\text { венный и внутриартериальный наркоз в } \\
\text { эксперименте и клинике }\end{array}$ & Н.И. Пирогов \\
\hline 1853 & $\begin{array}{l}\text { Изобретение прообраза современного } \\
\text { шприца и иглы для подкожных, внутри- } \\
\text { мышечных и внутривенных инъекций со } \\
\text { скошенным концом }\end{array}$ & $\begin{array}{l}\text { A.F. Wood (Шот- } \\
\text { ландия), Ch.-G. } \\
\text { Pravaz (Франция) }\end{array}$ \\
\hline 1855 & $\begin{array}{l}\text { Из листьев коки выделено действую- } \\
\text { щее начало, которому дано название } \\
\text { Erythroxylon }\end{array}$ & $\begin{array}{c}\text { F. Gaedke } \\
(1828-1890) \\
\text { Германия } \\
\end{array}$ \\
\hline 1859 & $\begin{array}{l}\text { Выделение алкалоида кокаина из листьев } \\
\text { коки }\end{array}$ & $\begin{array}{c}\text { A. Niemann } \\
(1834-1861), \\
\text { Германия } \\
\end{array}$ \\
\hline 1864 & Синтез барбитуровой кислоты & $\begin{array}{c}\text { A. von } \\
\text { Baeyer (Герма- } \\
\text { ния) }\end{array}$ \\
\hline 1863 & $\begin{array}{l}\text { Ассоциация дантистов в Лондоне под ру- } \\
\text { ководством Колтона широко применяла за- } \\
\text { кись азота, хлороформ, диэтиловый эфир } \\
\text { при зубоврачебных вмешательствах }\end{array}$ & \\
\hline 1866 & $\begin{array}{l}\text { Способ местной анестезии распылением } \\
\text { эфира }\end{array}$ & $\begin{array}{l}\text { B.Richardson } \\
\text { (Англия) }\end{array}$ \\
\hline 1868 & Морфин для премедикации перед наркозом & $\begin{array}{l}\text { W.W. Greene } \\
\text { (США) }\end{array}$ \\
\hline 1869 & $\begin{array}{l}\text { Эндотрахеальный наркоз через трахеосто- } \\
\text { му при резекции верхней челюсти }\end{array}$ & $\begin{array}{c}\text { F. Trendelen- } \\
\text { burg (Германия) }\end{array}$ \\
\hline 1869 & $\begin{array}{l}\text { В «Московских ведомостях» впервые по- } \\
\text { явилось объявление, в котором американ- } \\
\text { ский зубной врач Л. Бернардо-Беркмеер } \\
\text { предлагал удаление зубов «без чувства } \\
\text { боли» с помощью закиси азота }\end{array}$ & \\
\hline 1872 & $\begin{array}{l}\text { Внутривенное введение хлоралгидрата } \\
\text { животному вызвало состояние наркоза. Че- } \\
\text { рез два года эта методика была применена } \\
\text { у человека при лечении столбняка }\end{array}$ & $\begin{array}{l}\text { P.-C. Oré } \\
\text { (Франция) }\end{array}$ \\
\hline
\end{tabular}


Продолжение таблицы

\begin{tabular}{|c|c|c|}
\hline 1879 & $\begin{array}{l}\text { Открытие местно-обезболивающих } \\
\text { свойств кокаина }\end{array}$ & $\begin{array}{c}\text { В.К. Анреп } \\
(1852-1927) \\
\text { Россия } \\
\end{array}$ \\
\hline 1883 & $\begin{array}{l}\text { Синтез антипирина - положивший начало } \\
\text { эры синтетических анальгетиков }\end{array}$ & $\begin{array}{c}\text { L. Knorr «Hoechst» } \\
\text { (Германия) }\end{array}$ \\
\hline 1884 & $\begin{array}{l}\text { Применение кокаина для обезболивания } \\
\text { в офтальмологической практике }\end{array}$ & $\begin{array}{c}\text { И.Н. Кацауров, } \\
\text { К. Кoller, } \\
1857-1944 \\
\text { (Австрия) }\end{array}$ \\
\hline 1884 & $\begin{array}{l}\text { Проводниковая анестезия кокаином ниж- } \\
\text { него альвеолярного нерва при удалении } \\
\text { зуба }\end{array}$ & $\begin{array}{l}\text { W. Halsted, } \\
\text { R.J. Hall (CШA) }\end{array}$ \\
\hline 1885 & $\begin{array}{l}\text { Первая инфильтрационная анестезия } \\
\text { кокаином в зубоврачебной практике }\end{array}$ & $\begin{array}{l}\text { A.Woltler, } \\
\text { G. Landerer, } \\
\text { A.Witzel } \\
\text { (Германия) }\end{array}$ \\
\hline 1885 & $\begin{array}{l}\text { Первая внутрипульпарная анестезия ко- } \\
\text { каином }\end{array}$ & Bock (Германия) \\
\hline 1885 & Получение синтетического кокаина & E. Merck \\
\hline $1885-1886$ & $\begin{array}{l}\text { Первое применение регионарной анесте- } \\
\text { зии (для обезболивания пальцев) }\end{array}$ & А.И. Лукашевич \\
\hline 1887 & $\begin{array}{l}\text { Установление преимущества низких кон- } \\
\text { центраций кокаина }\end{array}$ & А.В. Орлов \\
\hline 1887 & $\begin{array}{l}\text { Первый эндотрахеальный наркоз в России } \\
\text { (при резекции верхней челюсти) }\end{array}$ & Р.В. Бутц \\
\hline $1890-1891$ & $\begin{array}{l}\text { Введение инфильтрационной анестезии } \\
\text { в хирургию }\end{array}$ & $\begin{array}{c}\text { P. Reclus (Франция), } \\
\begin{array}{c}\text { C.L. Schleich } \\
\text { (Германия) }\end{array} \\
\end{array}$ \\
\hline 1891 & $\begin{array}{l}\text { Первое применение внутрикостной } \\
\text { (спонгиозной) анестезии }\end{array}$ & $\begin{array}{c}\text { Otte } \\
\text { (Норвегия) }\end{array}$ \\
\hline 1891 & $\begin{array}{l}\text { Применён хлорэтил как местный ане- } \\
\text { стетик }\end{array}$ & \\
\hline 1897 & $\begin{array}{l}\text { Американский фармаколог Дж. Абель вы- } \\
\text { делил из надпочечника эпинефрин (адре- } \\
\text { налин) }\end{array}$ & $\begin{array}{c}\text { J. Abel } \\
(1857-1938)\end{array}$ \\
\hline
\end{tabular}


Продолжение таблицы

\begin{tabular}{|c|c|c|}
\hline 1900 & Бугорный способ крылонёбной анестезии & R. Matas (США) \\
\hline 1901 & $\begin{array}{l}\text { Разработка технологии получения гормона } \\
\text { адреналина в чистом виде }\end{array}$ & $\begin{array}{l}\text { J. Takamine, } \\
\text { T.B Aldrich } \\
\text { (CШA) }\end{array}$ \\
\hline 1901 & Интубация трахеи через рот & $\begin{array}{c}\text { F. Кuhn } \\
\text { (Германия) }\end{array}$ \\
\hline 1901 & Алкоголизация нерва & $\begin{array}{l}\text { R.Schlösser } \\
\text { (Германия) }\end{array}$ \\
\hline 1902 & Изучение анафилаксии & $\begin{array}{l}\text { M.M. Portier } \\
\text { C. R. Richet } \\
\text { (Франция) }\end{array}$ \\
\hline 1902 & $\begin{array}{l}\text { Неингаляционный внутривенный наркоз } \\
\text { гедоналом }\end{array}$ & $\begin{array}{c}\text { Н.П. Кравков } \\
(1865-1924)\end{array}$ \\
\hline 1903 & $\begin{array}{l}\text { Введение адреналина в клиническую } \\
\text { (зубоврачебную) практику в сочетании с } \\
\text { местным анестетиком кокаином }\end{array}$ & $\begin{array}{c}\text { Н. Вгаun } \\
(1862-1934)\end{array}$ \\
\hline 1903 & $\begin{array}{l}\text { Первое в России сообщение о применении } \\
\text { кокаина с адреналином в зубоврачебной } \\
\text { хирургии }\end{array}$ & П.И. Таубкин \\
\hline 1903 & Синтез барбитуратов & $\begin{array}{l}\text { E. Fischer, } \\
\text { von Mering } \\
\text { (Германия) } \\
\end{array}$ \\
\hline 1904-1905 & Синтез прокаина (новокаина) & $\begin{array}{l}\text { A. Einhorn, } \\
\text { 1856-1917, } \\
\text { (Германия) }\end{array}$ \\
\hline $1903-1907$ & $\begin{array}{l}\text { Разработка интралигаментарной ане- } \\
\text { стезии }\end{array}$ & $\begin{array}{l}\text { Granjean, } \\
\text { D. Nogué, } \\
\text { (Франция) }\end{array}$ \\
\hline 1905 & $\begin{array}{l}\text { Первое клиническое применение новокаи- } \\
\text { на с адреналином }\end{array}$ & $\begin{array}{l}\text { H. Braun } \\
\text { (Германия) }\end{array}$ \\
\hline $\begin{array}{c}\text { 1906, } \\
\text { январь }\end{array}$ & $\begin{array}{l}\text { Новокаин стал производиться фармацев- } \\
\text { тической фирмой «Хёхст" }\end{array}$ & $\begin{array}{l}\text { «Ноесhst» } \\
\text { (Германия) }\end{array}$ \\
\hline 1906 & $\begin{array}{l}\text { Разработка функционального зубоврачеб- } \\
\text { ного шприца }\end{array}$ & $\begin{array}{l}\text { A. Bleichsteiner, } \\
\text { G.Fischer } \\
\text { (Германия) } \\
\end{array}$ \\
\hline 1909 & $\begin{array}{l}\text { Глазничный доступ блокады 2-й ветви } \\
\text { тройничного нерва }\end{array}$ & $\begin{array}{l}\text { В.Ф. Войно- } \\
\text { Ясенецкий }\end{array}$ \\
\hline
\end{tabular}


Продолжение таблицы

\begin{tabular}{|c|c|c|}
\hline 1909 & Комбинированный наркоз & $\begin{array}{l}\text { Н.П. Кравков и } \\
\text { С.П. Федоров }\end{array}$ \\
\hline 1910 & Интубация трахеи через нос & $\begin{array}{c}\text { F. Кuhn } \\
\text { (Германия) }\end{array}$ \\
\hline 1911 & $\begin{array}{l}\text { Интубация трахеи с помощью ларинго- } \\
\text { скопа }\end{array}$ & Liliental \\
\hline 1914 & $\begin{array}{l}\text { Способ внутриротовой мандибулярной } \\
\text { анестезии }\end{array}$ & $\begin{array}{l}\text { G. Fischer } \\
\text { (Германия) }\end{array}$ \\
\hline 1914 & $\begin{array}{l}\text { Подскуловой доступ обезболивания } \\
\text { нижнечелюстного нерва }\end{array}$ & $\begin{array}{l}\text { Н. Braun } \\
\text { (Германия) }\end{array}$ \\
\hline 1914 & $\begin{array}{l}\text { Сочетание наркоза с местным обезболи- } \\
\text { ванием }\end{array}$ & $\begin{array}{c}\text { G. Crile } \\
\text { (1864-1943), } \\
\text { США }\end{array}$ \\
\hline 1915 & Монография «Регионарная анестезия» & $\begin{array}{l}\text { В.Ф. Войно- } \\
\text { Ясенецкий }\end{array}$ \\
\hline 1917 & $\begin{array}{l}\text { Изобретение цилиндрической ампулы, } \\
\text { прообраза современной карпулы для мест- } \\
\text { ной анестезии }\end{array}$ & H.S. Cook (США) \\
\hline 1920 & $\begin{array}{l}\text { Первый маркетинг дентального карпуль- } \\
\text { ного шприца }\end{array}$ & $\begin{array}{l}\text { Cook Co, } \\
\text { (СШA) }\end{array}$ \\
\hline 1920 & Описаны стадии анестезии & $\begin{array}{l}\text { A. E. Guedel } \\
(1883-1956), \\
\text { США }\end{array}$ \\
\hline 1921 & $\begin{array}{l}\text { Нёбный доступ для проводниковой блока- } \\
\text { ды верхнечелюстного нерва }\end{array}$ & Carrea \\
\hline 1922 & $\begin{array}{l}\text { Способ блокады двигательных нервов же- } \\
\text { вательных мышц }\end{array}$ & $\begin{array}{l}\text { J.-H. Bercher } \\
\text { (Франция) }\end{array}$ \\
\hline 1924 & $\begin{array}{l}\text { Аподактильный способ мандибулярной } \\
\text { анестезии }\end{array}$ & B. Levit \\
\hline 1925 & $\begin{array}{l}\text { Монография «Проводниковая анестезия в } \\
\text { хирургии зубов и полости рта» выдержала } \\
7 \text { изданий } \\
\end{array}$ & С.Н.Вайсблат \\
\hline 1926 & $\begin{array}{l}\text { Надскуловой доступ для обезболивания } \\
\text { верхне- и нижнечелюстного нервов }\end{array}$ & Lindemann \\
\hline 1928 & $\begin{array}{l}\text { Способ блокады 3-й ветви тройничного } \\
\text { нерва у овального отверстия }\end{array}$ & В.М. Уваров \\
\hline
\end{tabular}


Продолжение таблицы

\begin{tabular}{|c|c|c|}
\hline 1930 & $\begin{array}{l}\text { Предложение метода местного обезбо- } \\
\text { ливания по типу тугого ползучего ново- } \\
\text { каинового инфильтрата (разработан в } \\
\text { 1923-1928 гг.) }\end{array}$ & $\begin{array}{c}\text { А.В.Вишневский } \\
(1874-1948)\end{array}$ \\
\hline 1932 & Синтез гексенала (эвипана натрия) & $\begin{array}{l}\text { H. Weese, } \\
\text { W. Scharoff } \\
\text { (Германия) }\end{array}$ \\
\hline 1932 & Синтез тиопентала натрия (пентотала) & $\begin{array}{l}\text { E.H. Volwiler, } \\
\text { D.L. Tabern }\end{array}$ \\
\hline 1929 & $\begin{array}{l}\text { Открыты анестетические свойства цикло- } \\
\text { пропана }\end{array}$ & $\begin{array}{c}\text { G.Lucas и } \\
\text { V.E. Henderson }\end{array}$ \\
\hline 1933-1934 & $\begin{array}{l}\text { Введение пентотала (тиопентала) в клини- } \\
\text { ческую практику }\end{array}$ & $\begin{array}{l}\text { J. Landy } \\
\text { (США) }\end{array}$ \\
\hline 1937 & $\begin{array}{l}\text { Предложение позадичелюстного доступа } \\
\text { внеротовой мандибулярной анестезии }\end{array}$ & Pekkert, Wustrow \\
\hline 1938 & $\begin{array}{l}\text { Усовершенствование аподактильного } \\
\text { способа внутриротовой мандибулярной } \\
\text { анестезии }\end{array}$ & А.Е.Верлоцкий \\
\hline 1940 & Способ торусальной анестезии & М.М. Вейсбрем \\
\hline 1940 & $\begin{array}{l}\text { Способ мандибулярной анестезии } \\
\text { при контрактуре нижней челюсти }\end{array}$ & Laguardia \\
\hline 1941 & $\begin{array}{l}\text { Крылонёбный доступ для обезболивания } \\
\text { верхнечелюстного нерва. (Модификация } \\
\text { способа Г.Брауна) }\end{array}$ & С.Н.Вайсблат \\
\hline 1942 & $\begin{array}{l}\text { Применение кураре при комбинирован- } \\
\text { ном наркозе }\end{array}$ & $\begin{array}{l}\text { H. Griffith, } \\
\text { E. Jonson } \\
\text { (Канада) }\end{array}$ \\
\hline 1943 & Синтез лидокаина & $\begin{array}{l}\text { N. Löfgren } \\
\text { (Швеция) }\end{array}$ \\
\hline 1946 & Синтез тримекаина & $\begin{array}{l}\text { N. Löfgren и } \\
\text { B. Lundquvist }\end{array}$ \\
\hline 1947 & $\begin{array}{l}\text { Модификация метода Берше с целью блокады } \\
\text { нижнего альвеолярного и язычного нервов }\end{array}$ & М.Д. Дубов \\
\hline 1947 & $\begin{array}{l}\text { Электростимуляция зубов для оценки эф- } \\
\text { фективности обезболивания }\end{array}$ & $\begin{array}{l}\text { G. Bjorn } \\
\text { (Швеция) }\end{array}$ \\
\hline
\end{tabular}


Продолжение таблицы

\begin{tabular}{|c|c|c|}
\hline 1948 & $\begin{array}{l}\text { Начало широкого производства ксилокаи- } \\
\text { на (лидокаина) }\end{array}$ & $\begin{array}{l}\text { Фирма «Astra» } \\
\text { (Швеция) }\end{array}$ \\
\hline 1949 & Синтез дитилина (сукцинилхолина) & D. Bovet \\
\hline $\begin{array}{c}1949, \\
31 \text { августа }\end{array}$ & $\begin{array}{l}\text { Первый современный эндотрахеальный } \\
\text { наркоз в нашей стране при операции в } \\
\text { челюстно-лицевой области }\end{array}$ & Н.М. Александров \\
\hline 1951 & $\begin{array}{l}\text { Синтез галотана. Применение в } 1956 \text { г. } \\
\text { М. Джонстоном }\end{array}$ & C.W. Suckling \\
\hline 1953 & Синтез прилокаина & $\begin{array}{l}\text { N. Löfgren, } \\
\text { C. Tegner } \\
\text { (Швеция) }\end{array}$ \\
\hline 1955 & $\begin{array}{l}\text { Начало производства на мировой меди- } \\
\text { цинский рынок баралгина }\end{array}$ & $\begin{array}{c}\text { Фирма «Hoechst» } \\
\text { (Германия) }\end{array}$ \\
\hline 1956 & Синтез мепивакаина & $\begin{array}{c}\text { B.A.F.Ekenstam, } \\
\text { B.Egner, G. Petterson } \\
\text { (CША) } \\
\end{array}$ \\
\hline 1956 & $\begin{array}{l}\text { Вестибулярный метод блокады нижнече- } \\
\text { люстного нерва }\end{array}$ & Б.Ф.Кадочников \\
\hline 1956 & $\begin{array}{l}\text { Изобретён и запатентован одноразовый } \\
\text { пластмассовый шприц }\end{array}$ & $\begin{array}{c}\text { C. Murdoch } \\
\text { (Новая Зеландия) }\end{array}$ \\
\hline 1957 & $\begin{array}{l}\text { Первое клиническое применение триме- } \\
\text { каина в отечественной стоматологии }\end{array}$ & Ю.И. Бернадский \\
\hline 1957 & Синтез бупивакаина & $\begin{array}{l}\text { B.A.F. Ekenstam } \\
\text { (СШA) }\end{array}$ \\
\hline 1957 & $\begin{array}{l}\text { Создан аспирационный шприц (гарпунно- } \\
\text { го типа) }\end{array}$ & $\begin{array}{l}\text { Cook White Co } \\
\text { (США) }\end{array}$ \\
\hline 1958 & $\begin{array}{l}\text { Атаралгезия. Первое сообщение о методе } \\
\text { на обществе анестезиологов и реанимато- } \\
\text { логов Франции }\end{array}$ & $\begin{array}{l}\text { J.Du Cailar c соавт. } \\
\text { (Франция) }\end{array}$ \\
\hline 1958 & $\begin{array}{l}\text { Начало применения безыгольных инъекто- } \\
\text { ров в стоматологии }\end{array}$ & $\begin{array}{c}\text { B. Lindberg, } \\
\text { P.Margetis (США) }\end{array}$ \\
\hline $1958-1961$ & $\begin{array}{l}\text { Синтезированы и запатентованы сильно- } \\
\text { действующий морфиноподобный анальге- } \\
\text { тик - фентанил и нейролептик - дегидро- } \\
\text { бензперидол (дроперидол) }\end{array}$ & $\begin{array}{c}\text { Фирма «Janssen } \\
\text { Pharmaceutica» в г. } \\
\text { Берсе (Бельгия) }\end{array}$ \\
\hline
\end{tabular}


Продолжение таблицы

\begin{tabular}{|c|c|c|}
\hline 1959 & $\begin{array}{l}\text { Нейролептанальгезия. Первое сообщение } \\
\text { о методе } 12 \text { июля } 1959 \text { г. на Х съезде ане- } \\
\text { стезиологов Франции в г. Лионе }\end{array}$ & $\begin{array}{l}\text { J. De Castro, } \\
\text { P. Mundeleer } \\
\text { (Бельгия) }\end{array}$ \\
\hline 1959 & Синтез диазепама (седуксена) & Sternbach, Reeder \\
\hline 1960 & Синтез оксибутирата натрия & $\begin{array}{l}\text { H. Laborit и соавт. } \\
\text { (Франция) }\end{array}$ \\
\hline 1961 & $\begin{array}{l}\text { Принятие классификации Американской } \\
\text { ассоциации анестезиологов (ASA) оценки } \\
\text { физического состояния пациентов }\end{array}$ & \\
\hline 1962 & Синтез кетамина & C. Stevens \\
\hline 1963 & Синтез энфлюрана & $\begin{array}{l}\text { R. Terrell et al. } \\
\text { (СШA) }\end{array}$ \\
\hline 1964 & $\begin{array}{l}\text { Клинически изучен и испытан ультрако- } \\
\text { роткий анестетик для внутривенного вве- } \\
\text { дения пропанидид (эпонтол, сомбревин) }\end{array}$ & \\
\hline 1964 & $\begin{array}{l}\text { Синтезирован этомидат (гипномидат), } \\
\text { пополнив арсенал средств для кратковре- } \\
\text { менной и безопасной анестезии. В ане- } \\
\text { стезиологии начал применяться с } 1973 \text { г. } \\
\text { A. Doenicke }\end{array}$ & $\begin{array}{c}\text { Janssen } \\
\text { Pharmaceutica }\end{array}$ \\
\hline 1965 & Синтез изофлюрана & R. Terrell et al. \\
\hline 1965 & $\begin{array}{l}\text { Теория «ворот боли», давшая новый тол- } \\
\text { чок для изучения нервной стимуляции и } \\
\text { её роли при анальгезии }\end{array}$ & R. Melzack, P.Wall \\
\hline 1966 & Синтез десфлюрана & R. Terrell et al. \\
\hline 1966 & $\begin{array}{l}\text { Начало клинического применения кетами- } \\
\text { на для неингаляционной анестезии }\end{array}$ & $\begin{array}{l}\text { G. Corssen } \\
\text { и E.F. Domino }\end{array}$ \\
\hline 1969 & Синтез артикаина (картикаина) & $\begin{array}{l}\text { H. Ruschig, } \\
\text { R. Rippel } \\
\text { (Германия) }\end{array}$ \\
\hline 1970 & Синтез севофлюрана, энфлюрана & $\begin{array}{l}\text { R. Wallin et al. } \\
\text { (Англия) }\end{array}$ \\
\hline 1971 & Синтез лоразепама & Lab. Roche \\
\hline 1971 & Синтез этидокаина & $\begin{array}{l}\text { B.H. Takman } \\
\text { (СШA) }\end{array}$ \\
\hline
\end{tabular}


Продолжение таблицы

\begin{tabular}{|c|c|c|}
\hline 1973 & $\begin{array}{l}\text { Образование международной Ассоциации } \\
\text { Исследования Боли (IASP) }\end{array}$ & J.J. Bonica (США) \\
\hline 1973 & $\begin{array}{l}\text { Крем EMLA - первый анестетик для обез- } \\
\text { боливания кожи }\end{array}$ & $\begin{array}{l}\text { H. Evers, } \\
\text { F. Broberg } \\
\text { (Швеция) }\end{array}$ \\
\hline 1973 & $\begin{array}{l}\text { Разработка нового способа мандибуляр- } \\
\text { ной анестезии с использованием внерото- } \\
\text { вых ориентиров }\end{array}$ & $\begin{array}{l}\text { G.A.E.Gow-Gates } \\
\text { (Австралия) }\end{array}$ \\
\hline 1973 & $\begin{array}{l}\text { Выявление анестезирующих свойств ар- } \\
\text { тикаина } \\
\text { Первое в СССР применение безыгольного } \\
\text { инъектора для обезболивания в стоматологии }\end{array}$ & $\begin{array}{l}\text { R. Muschaweck } \\
\text { (Германия) } \\
\text { Б.А. Азрельян }\end{array}$ \\
\hline 1974 & $\begin{array}{l}\text { Получение патента, клинические испы- } \\
\text { тания, введение в клиническую практику } \\
\text { артикаина (картикаина) }\end{array}$ & $\begin{array}{l}\text { R. Muschaweck, } \\
\text { R. Rippel, } \\
\text { H. Ruschig, } \\
\text { M. Schorr } \\
\text { (Германия) } \\
\end{array}$ \\
\hline $1974-2000$ & $\begin{array}{l}\text { Изучение механизма внутрикостной } \\
\text { анестезии, оценка эффективности различ- } \\
\text { ных анестетиков при обезболивании зубов }\end{array}$ & А.Ж. Петрикас \\
\hline 1975 & $\begin{array}{l}\text { Шприц с мультипликатором для инъекции } \\
\text { в плотные такни, кость, периодонт }\end{array}$ & $\begin{array}{l}\text { A. Colombo } \\
\text { (Италия) }\end{array}$ \\
\hline 1976 & $\begin{array}{l}\text { Синтез мидазолама (дормикума) } \\
\text { Синтез пропофола (дипривана) } \\
\text { Внедрение на рынок местного анестетика } \\
\text { «Ультракаин» }\end{array}$ & \begin{tabular}{|c} 
Ф.Хоффманн-Ля \\
Рош (Швейцария) \\
\\
Лаборатория хи- \\
мического концер- \\
на «ICI» (Англия) \\
Ноесhst \\
(Германия) \\
\end{tabular} \\
\hline 1981 & $\begin{array}{l}\text { Разработка современной ларингеальной } \\
\text { маски }\end{array}$ & $\begin{array}{l}\text { A.I.J. Brain } \\
\text { (Англия) }\end{array}$ \\
\hline 1983 & $\begin{array}{l}\text { Создана концепция тотальной внутривен- } \\
\text { ной анестезии (TIVA) }\end{array}$ & M. Morgan \\
\hline 1985 & $\begin{array}{l}\text { Монография «Местное обезболивание в } \\
\text { стоматологии», в которой приведены ана- } \\
\text { томические данные, необходимые для пра- } \\
\text { вильного проведения анестезии, изложены } \\
\text { новые, в т.ч. и разработанные автором, } \\
\text { способы местного обезболивания } \\
\end{array}$ & $\begin{array}{l}\text { П.М. Егоров } \\
(1922-1992)\end{array}$ \\
\hline
\end{tabular}


Продолжение таблицы

\begin{tabular}{|c|c|c|}
\hline 1986 & $\begin{array}{l}\text { Синтез нестероидного противовоспали- } \\
\text { тельного препарата лорноксикама (ксефо- } \\
\text { кама) }\end{array}$ & $\begin{array}{c}\text { D.A. Binder, фирма } \\
\text { «Никомед» } \\
\text { (Австрия) }\end{array}$ \\
\hline 1987 & $\begin{array}{l}\text { Разработка метода продлённой проводни- } \\
\text { ковой блокады 2-й и 3-й ветвей тройнич- } \\
\text { ного нерва с помощью катетера }\end{array}$ & П.Ю. Столяренко \\
\hline 1987 & $\begin{array}{l}\text { Создание антагониста бензодиазепинов } \\
\text { фирмой «Рош» - анексат (флюмазенил) }\end{array}$ & $\begin{array}{c}\text { Фирма «Хоффман } \\
\text { Ля Рош», } \\
\text { Швейцария }\end{array}$ \\
\hline 1989 & $\begin{array}{l}\text { Внедрение в клиническую практику ди- } \\
\text { привана }\end{array}$ & $\begin{array}{l}\text { Фирма «Zeneca» } \\
\text { (Англия) }\end{array}$ \\
\hline 1990 & Научная разработка анестезии ксеноном. & $\begin{array}{l}\text { Н.Е. Буров и др. } \\
\text { (Россия) }\end{array}$ \\
\hline 1992 & Синтез десфлурана & \\
\hline 1994 & $\begin{array}{l}\text { Внедрение в России в стоматологическую } \\
\text { практику первого анестетика артикаино- } \\
\text { вого ряда - ультракаина }\end{array}$ & И.А. Шугайлов \\
\hline 1996 & $\begin{array}{l}\text { Клиническая апробация местного анесте- } \\
\text { тика длительного действия ропивакаина } \\
\text { (наропина) }\end{array}$ & $\begin{array}{c}\text { Фирма «Astra } \\
\text { - Zeneca» Швеция, } \\
\text { Великобритания) } \\
\end{array}$ \\
\hline 1997 & $\begin{array}{l}\text { Разработка компьютерного шприца } \\
\text { WAND для местной анестезии в стомато- } \\
\text { логии }\end{array}$ & $\begin{array}{c}\text { Компания } \\
\text { «Milestone } \\
\text { Scientific» (США) }\end{array}$ \\
\hline 1997 & $\begin{array}{l}\text { Экспериментально-клиническая разработ- } \\
\text { ка магнитоуправляемого местного анесте- } \\
\text { тика феррокаина }\end{array}$ & С.Т. Сохов \\
\hline 1999 & $\begin{array}{l}\text { Первое сообщение о применении в России } \\
\text { ларингеальной маски в практике челюстно- } \\
\text { лицевой хирургии и стоматологии }\end{array}$ & $\begin{array}{l}\text { П.Ю.Столяренко, } \\
\text { С.А. Рабинович, } \\
\text { М.В. Лукьянов }\end{array}$ \\
\hline 1999 & $\begin{array}{l}\text { В России впервые в мире ксенон разрешён } \\
\text { к применению для ингаляционного наркоза }\end{array}$ & $\begin{array}{c}\text { Приказ МЗ РФ } \\
\quad \text { № } 363\end{array}$ \\
\hline 2000 & $\begin{array}{l}\text { «Местная и общая анестезия в геронтосто- } \\
\text { матологии»- первая отечественная моно- } \\
\text { графия по обезболиванию в стоматологии } \\
\text { у пожилых пациентов }\end{array}$ & $\begin{array}{l}\text { П.Ю.Столяренко, } \\
\text { В.В. Кравченко }\end{array}$ \\
\hline
\end{tabular}


Продолжение таблицы

\begin{tabular}{|c|c|c|}
\hline 2000 & \begin{tabular}{|l} 
Монография «Современные технологии \\
местного обезболивания в стоматологии»
\end{tabular} & С.А. Рабинович \\
\hline 2001 & $\begin{array}{l}\text { «История обезболивания в стоматологии } \\
\text { (от древности до современности)» - пер- } \\
\text { вая отечественная монография по истории } \\
\text { обезболивания в стоматологии }\end{array}$ & П.Ю.Столяренко \\
\hline $\begin{array}{c}2000 \\
3 \text { февраля }\end{array}$ & $\begin{array}{l}\text { В России зарегистрирован местный ане- } \\
\text { стетик наропин }\end{array}$ & $\begin{array}{c}\text { Фирма } \\
\text { «AstraZeneca» }\end{array}$ \\
\hline 2001 & $\begin{array}{l}\text { Первый Всероссийский чемпионат } \\
\text { Стоматологического мастерства «Обезбо- } \\
\text { ливание и оказание неотложной помощи в } \\
\text { стоматологии» }\end{array}$ & $\begin{array}{c}\text { СтАР, кафедра } \\
\text { стоматологии } \\
\text { общей практики } \\
\text { и анестезиологии } \\
\text { ФПКС МГМСУ }\end{array}$ \\
\hline 2001 & $\begin{array}{l}\text { Вступление Российской секции по развитию } \\
\text { обезболивания в стоматологии в EFAAD }\end{array}$ & С.А.Рабинович \\
\hline 2002 & $\begin{array}{l}\text { Открыт музей истории обезболивания в } \\
\text { стоматологии }\end{array}$ & $\begin{array}{c}\text { Кафедра стомато- } \\
\text { логии общей прак- } \\
\text { тики и анесте- } \\
\text { зиологии ФПКС } \\
\text { МГМСУ }\end{array}$ \\
\hline 2003 & $\begin{array}{l}\text { Вступление Российской секции по развитию } \\
\text { обезболивания в стоматологии в IFDAS }\end{array}$ & С.А.Рабинович \\
\hline 2004 & $\begin{array}{l}\text { В рамках программы «Борьба с болью в } \\
\text { стоматологии» создана и утверждена съез- } \\
\text { дом стоматологов России и Советом СтАР } \\
\text { секция «Обезболивание и оказание неот- } \\
\text { ложной помощи в стоматологии» }\end{array}$ & $\begin{array}{c}\text { СтАР, } \\
\text { С.А. Рабинович }\end{array}$ \\
\hline 2005 & 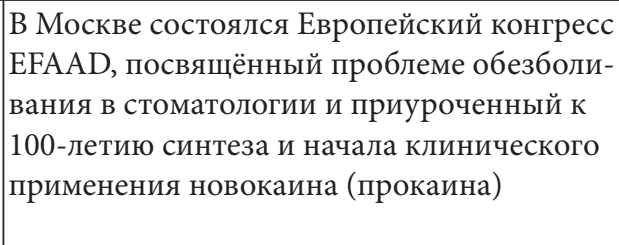 & $\begin{array}{c}\text { СтАР } \\
\text { Кафедра стомато- } \\
\text { логии общей прак- } \\
\text { тики и анесте- } \\
\text { зиологии ФПКС } \\
\text { МГМСУ }\end{array}$ \\
\hline
\end{tabular}


Окончание таблицы

\begin{tabular}{|c|c|c|}
\hline $\begin{array}{c}2006 \\
\text { октябрь }\end{array}$ & В Иокогаме проходил 11-й конгресс IFDAS & $\begin{array}{l}\text { IFDAS, } \\
\text { Y. Kaneko }\end{array}$ \\
\hline 2007, ноябрь & $\begin{array}{l}\text { В Самаре проходила II Всероссийская } \\
\text { конференция «Обезболивание в стомато- } \\
\text { логии» и Мастер-класс «Современные ме- } \\
\text { тоды местной анестезии в стоматологии» }\end{array}$ & $\begin{array}{c}\text { СтАР, СамГМУ, } \\
\text { кафедра ЧЛХ и } \\
\text { стоматологии }\end{array}$ \\
\hline 2009, февраль & $\begin{array}{l}\text { В Москве состоялся VI Всероссийский } \\
\text { научно-практический форум с участием } \\
\text { зарубежных коллег «Дентал Ревю - 2009» } \\
\text { «Образование, наука и практика в сто- } \\
\text { матологии» по объединённой тематике } \\
\text { «Обезболивание в стоматологии» }\end{array}$ & $\begin{array}{c}\text { МГМСУ, } \\
\text { EFAAD, IFDAS }\end{array}$ \\
\hline $\begin{array}{c}2009, \\
14-17 \text { октября }\end{array}$ & $\begin{array}{l}\text { В Мельбурне проходил XII конгресс } \\
\text { IFDAS (International Federation of Dental } \\
\text { Anesthesiology Societies) }\end{array}$ & $\begin{array}{l}\text { IFDAS, } \\
\text { Y. Kaneko }\end{array}$ \\
\hline $\begin{array}{c}2010, \\
14-15 \text { октября }\end{array}$ & $\begin{array}{l}\text { Европейский конгресс «Седация в хирур- } \\
\text { гической стоматологии» г. Evian-les-Bains } \\
\text { (Франция) }\end{array}$ & $\begin{array}{l}\text { EFAAD } \\
\text { J.-F. Andre }\end{array}$ \\
\hline
\end{tabular}




\section{БИБЛИОГРАФИЧЕСКИЙ СПИСОК}

Азрельян, Б.А. Новые аспекты проблемы местной анестезии в стоматологии / Б.А. Азрельян, В.С. Гигаури, Б.В. Смоляров // Стоматология. - 1973. - № 6. C. 49-51.

Айзенштейн И.М. О распространении нагноений по внутренней поверхности восходящей ветви нижней челюсти (крылочелюстное пространство) // Хирургия. 1940. - № 10. - С. 27-35.

Анреп В.К. Кокаин как средство местно-анестезирующее // Врач. - 1884. - Т. 5. - № 46. - С.773-774.

Александров Н.М. Интратрахеальный эфирно-кислородный наркоз при операциях на лице и челюстях // Труды ВМА. - Т. 66. - Л., 1957. - С. 197-203.

Александров Н.М., Клементьев А.В., Малышев В.А. Неотложная стоматологическая помощь. - Л.: Медицина, 1976. - 127 с.

Атанасов А., Абаджиев П. Анестезиология. - 3-е изд. / Пер. с болгарск. - София: Медицина и физкультура, 1963. - 460 с.

Барский Ф.Я. О подкожных впрыскиваниях солянокислого кокаина в хирургической практике с целью местной анестезии // Врач. - 1886. - Т. 7. - № 50.

Баталин Д. К вопросу о пероральном тубаже гортани по способу Кuhn // Хирургический архив Вельяминова. - 1913. - Т. 29. - Кн. 6. - С. 1001.

Бекетов А.О. (1850). (Цит. по И.Н. Муковозову, 1965.)

Беляевский А.Д., Монченко Г.Д. Очерки по истории анестезиологии (фрагмент монографии) // Вестн. интенсивной терапии. - 1999. - № 2. - С. 82-83.

Бердюк И.В. Закись азота в амбулаторной практике хирургической стоматологии // Стоматология. - 1955. - № 4. - С. 26-28.

Бердюк И.В. К вопросу о новокаиновой блокаде при воспалительном тризме // Новокаиновая блокада: Сб. науч. работ Запорож. ин-та усов. врачей. - 1958. - С. 12-16.

Бердяев А.Ф. Местная анестезия (краткое руководство). - СПб.: Издание Главного военно-санитарного управления, 1912. - 92 с.

Бережной В.П. Пролонгированная внутрикостная анестезия зубов у детей // Организация стоматологической помощи детям: Сб. науч. работ / Под ред. М.А. Макиенко. - Куйбышев, 1977. - С. 31-33.

Березовский С.Е. Хлористый метил как местно-анестезирующее средство // Летопись хирургического общества в Москве. - 1890.

Бернадский Ю.И. Советская стоматологическая литература (библиографический указатель). - Т. I (1917-1945). - М.: Медгиз, 1951. - 692 с.

Бернадский Ю.И. Материалы к проблеме обезболивания в хирургической стоматологии / Дис. ... докт. мед. наук. - Краснодар, 1957. Автореф. дис. - докт. мед. наук. - М., 1958. - 35 с. 
Бернадский Ю.И. Применение местного непотенцированного и потенцированного мезокаинового обезболивания в хирургической стоматологии // Стоматология. - 1960. - № 2. - С. 48-50.

Бернадский Ю.И., Пинский И.Х. Советская стоматологическая литература (библиографический указатель). - Т. 2. (1946-1955). - М.: Медицина, 1965. - 696 с.

Бернадский Ю.И. Основы челюстно-лицевой хирургии и хирургической стоматологии. - 3-е изд., перераб. и доп. - Витебск: Белмедкнига, 1998. - 416 с.

Бобров А.А. Курс оперативной хирургии и хирургической анатомии. - М., 1887.

Браун Г. Местная анестезия, ее научное обоснование и практическое применение / Пер с нем. - СПб., 1909. - 290 с.

Буш И.Ф. Руководство к преподаванию в хирургии. - СПб., 1807-1808. (Цит. по Г.Н.Троянскому и соавт., 2000.)

Вайсблат С.Н. Проводниковая анестезия в хирургии зубов и полости рта.Киев: Госмедиздат УССР, 1925. - 96 с.

Вайсблат С.Н. К вопросу об экстраоральных проводниковых уколах // Тр. III Всесоюзн. одонтологич. съезда. - Л., 1929. - С. 410-416.

Вайсблат С.Н. Проводниковое обескровливание как важное достоинство проводниковой анестезии зубоврачебной хирургии // Стоматология. - 1937. - № 5. - С. 92-94.

Вайсблат С.Н. Орбитальный путь крылонебной анестезии // Стоматология. 1944. - № 3. - С. 47-50.

Вайсблат С.Н. Анестезия верхнечелюстного нерва и ее значение в хирургической стоматологии // Стоматология. - 1948. - № 3. - С. 3-10.

Вайсблат С.Н. Проводниковое обезболивание в хирургии зубов и челюстей. 6-е перераб. и доп. изд. - Киев: Госмедиздат УССР, 1954. - 290 с.

Вайсблат С.Н. О надскуловых, так называемых височных, путях проводникового обезболивания верхне- и нижнечелюстного нервов // Стоматология. - 1955. № 5. - С. 28-31.

Вайсблат С.Н. Глазничный путь нижнеглазничной анестезии // Стоматология. - 1956. - № 3. - С. 17-18.

Вайсблат С.Н. Местное обезболивание при операциях на лице, челюстях и зубах. - 7-е изд. - Киев: Госмедиздат УССР, 1962. - 470 с.

Васманова Е.В., Азрельян Б.А. Применение отечественного безыгольного инъектора БИ-8 для местной анестезии в детской стоматологии // Стоматология. 1979. - № 6. - С. 29-33.

Вейсбрем М.М. Новая модификация аподактильного метода анестезии у мандибулярного отверстия // Стоматология. - 1941. - № 2. - С. 80-82.

Верлоцкий А.Е. Аподактильный внутриротовой способ мандибулярной анестезии // Стоматология. - 1938. - № 6. - С. 77-80.

Верлоцкий А.Е. Обезболивание на челюстях, в полости рта и околоротовой области // Хирургическая стоматология: Учебник. - М.: Медгиз, 1960. - С. 27. 
Ворнер Д. Влияние анестезии на дыхательную мускулатуру / Освежающий курс лекций; Пер. с англ. под ред. Э.В. Недашковского. - Архангельск-Тромсё, 1998. Вып. 5. - С. 40-44.

Виноградов К.Н. Описание смертельного отравления кокаином в клинике С.П. Коломнина // Врач. - 1889. - № 26. - С. 321.

Вихеркевич // Врач. - 1885. - № 42. - С. 704. (Цит. по А.А. Зыкову, 1954.)

Вишневский А.А. Анестезия местная // БМЭ. - 2-е изд. - Т. 2. - М.: Гос. изд-во мед. литературы, 1957. - С. 130-131.

Вишневский А.В. Местное обезболивание по методу ползучего инфильтрата. Казань: Татиздат, 1932. - 186 с.

Вишневский А.В. О местном обезболивании // Известия ЦИК СССР. - № 40. 16 февраля 1936 г.

Вишневский А.В. Местное обезболивание по методу ползучего инфильтрата. Изд. 5-е, перераб. и доп. А.А. Вишневским. - М.: Медгиз, 1956. - 352 с.

Войно-Ясенецкий В.Ф. Регионарная анестезия при операциях на шее, языке и верхней челюсти / Труды Московского хирургического общества. -1909.

Войно-Ясенецкий В.Ф. Регионарная анестезия: Монография. - Петроград: Типография А.Э. Коллинс, 1915.

Войно-Ясенецкий В.Ф. Очерки гнойной хирургии / Способы анестезии (приложение). - М.: Медгиз, 1946. - С. 511-539.

Воробьев А.А., Некрасов И.Л., Бондаков Л.Ф. Безыгольный способ введения биологических препаратов в организм. - М.: Медицина. - 1972. - 102 с.

Вреден Р.Р. Кокаин в современной хирургии // Летопись русской хирургии. 1898. - № 5-6.

Вреден Р.Р. О местной анестезии в брюшной хирургии: Протоколы 185-го заседания русского хирургического общества Пирогова. - 20.09. 1900 г. // Летопись русской хирургии. - 1901. - № 4.

Вреден Р.Р. К технике вылущения гортани под местной анестезией // Русский врач. - 1904. - № 10. - С. 356-357.

Гальперн Я.С. В защиту обезболивания // Врачебное дело. - 1933. - № 6-7; Новый хирургич. архив. - 1933. - Кн. 111-112. - Т. 28. - С. 508-513.

Гарнак Г.А. Местное обезболивание солянокислой солью хинина и мочевины // Хирургия. - 1914. - № 2. - С. 51-52.

Гейнац В.Н. Опыты и наблюдения над обезболиванием пропитыванием тканей по способу Шлейха: Протоколы 176-го заседания русского хирургического общества Пирогова от 3.11.1899 г. // Летопись русской хирургии. - 1900. - № 4.

Гейнац В.Н. Наблюдения над адреналино-кокаиновой анестезией // Русский врач. - 1904. - № 5. - С. 182.

Гепштейн И.Я. К вопросу о мандибулярной анестезии / Тр. III Всесоюзн. Одонтол. съезда. - Л., 1929. - С. 430-433. 
Гессе Ф. Маленькая книжка о наркозе / Пер. с 7-го нем., вновь переработ. изд. В.Л. Ваневского. - М.: Медгиз, 1958. - 88 с.

Гигаури В.С., Короткова А.В., Азрельян Б.А. Преимущества безыгольного способа проведения местной анестезии в стоматологии // Стоматология. - 1973. - № 1. C. 28-29.

Гигаури В.С., Попова Е.Б. Особенности безыгольных инъекций и перспективы применения инъекторов // Хирургия. - 1972. - № 12. - С. 22-26.

Глязер Г. Драматическая медицина. Опыты врачей на себе / Пер. с нем. - М.: Молодая гвардия, 1962. - 208 с.

Гофунг Е.М. Современное состояние местной анестезии в зубоврачевании // Одонтологическое обозрение. - 1913. - № 5.

Готтлиб М. Местная анестезия по Шлейху // Хирургия. - 1897. - Т. 2. - № 11. C. 368 .

Григорьев М.С., Аничков М.Н. Интратрахеальный наркоз в грудной хирургии. - 3-е изд. - М.: Медгиз, 1957.

Григорьев М.С., Аничков М.Н. Кураре и курареподобные препараты в хирургии / Под ред. П.А. Куприянова. - Л.: Медгиз, 1957. - 86 с.

Гусарова Г.И. Проблема СПИДа напрямую связана с проблемой наркомании // Комсомольская правда (в Самаре). - 2000, 26 ноября. - С. 16.

Данович Ф.М. История развития наркоза закисью азота // Вестн. хирургии. 1946. - Т. 66. - № 5-6. - С. 13-16.

Делицин С.Н. Местное и общее обезболивание: Русская хирургия. - Отд. I. СПб., 1904.

Джонс Э. Жизнь и творения Зигмунда Фрейда: Пер. с англ. Старовойтова В.В. М.: «Гуманитарий» АГИ, 1996. - 448 с.

Дубов М.Д. К столетию обезболивания // Стоматология. - 1947. - № 2. - С. 3-8.

Дубов М.Д. Местное обезболивание в стоматологической практике. - Л.: Медицина, 1969. - 136 с.

Дьяконов П.И. По поводу русской статистики наркозов // Летопись хирургического общества в Москве. - 1896. - Т. 15. - № 4. - С. 176.

Дьяконов П.И. Заключительное слово председателя VII съезда российских хирургов. - СПб., 1907. / Съезд росс. хир. VII. - М., 1908. -С. 105-107.

Дитерихс М.М. К вопросу об обезболивании зубов и челюстей // Зубоврачебн. вестн. - 1907. - № 12. - С. 910-912. (Цит. по О.Ф. Конобевцеву, М.А. Макиенко, В.П. Бережному, 1979.)

Дитерихс М.М. О хлороформном наркозе // Русский хирургич. архив. - 1908. T. 24. - С. 429-447.

Елизарьева Н.Л., Сысолятин П.Г., Левин О.Б., Колосов А.Н. Субментальная интубация трахеи для обеспечения проходимости дыхательных путей в челюстно- 
лицевой хирургии (Обзор) // Российский стоматологический журнал. - 2008. № 1. - C. $45-48$.

Ефремовский И. Об употреблении распыленного серного эфира и охлаждающих смесей как местно-анестезирующих средств при некоторых кровавых операциях: Дис. - СПб., 1896.

Жоров И.С. Развитие хирургического обезболивания в России и СССР. - М.: Изд-во АМН СССР, 1951. - 173 с.

Жоров И.С. Общее обезболивание в хирургии. - М.: Медгиз, 1959. - 486 с.

Загорский А.К. Обзор работ по хирургии // Хирургия. - 1897. - № 8.

Залога А. Евкаин в зубной практике // Хирургия. - 1898. - № 2.

Захарьевский А. К вопросу о местном влиянии кокаина на глаз // Врач. - 1884. № 49.

Звержховский Ф.А. Анестезия кокаином при удалении зубов // Зубоврачебн. вестн. - 1899. - № 6. - С. 36-38.

Зильбер А.П. 150 лет эры анестезиологии (1846 - 16 октября 1996): Календарь к юбилейному семинару «Актуальные проблемы медицины критических состояний и анестезиологии». - Петрозаводск, 1996. - 27 с.

Змеев Л.Ф. Былое врачебной России (очерк о жизни и деятельности). - СПб., 1890. (Цит. по В.И. Селиванову, 1977.)

Зыков А.А. История местного обезболивания в отечественной хирургии: Автореф. дис. ... канд. мед. наук. - М., 1949. - 18 с.

Зыков А.А. Очерки развития местного обезболивания в СССР. - М.: Медгиз, Ленингр. отд., 1954. - 120 с.

Иванов В.М. Солянокислая соль хинина и мочевины как местное обезболивающее средство в хирургии // Медицинское обозрение. - 1915. - № 13. - С. 24.

Ицкин Я.А. Интраоральная мандибулярная анестезия и сопровождающие ее осложнения // Одонтол. и стоматология. - 1929. - № 10. - С. 16-25.

Итина А.И., Итин 3.Е., Гутнер Я.И., Архангельская Н.В. Проводниковое обезболивание нижней челюсти в ретромолярной ямке (ретромолярная анестезия) // Стоматология. - 1958. - № 2. - С. 32-35.

Кадочников Б.Ф. Вестибулярная проводниковая анестезия ветвей нижнечелюстного нерва / Сборн. науч. работ 209-й стоматологической поликлиники Таврического военного округа. - Симферополь, 1956. - С. 63-66.

Календарь Critical http://critical.ru/calendar/0602Esdaile.htm (03.02.2009).

Каменская М. О местном обезболивании // Зубоврачебн. вестн. - 1900. - № 8. - С. 9.

Каппелер О. Анестезирующие средства / Руководство к общей и частной хирургии. - Отд. 30; Пер. с нем.; Под ред. Бильрота и Люкке. - СПб.: Типография Б.Г. Ямпольского, 1881. - 290 с. 
Кацауров И.Н. О местном влиянии кокаина на глаз // Врач. - 1884. - № 43. C. 733 .

Кацауров И.Н. Еще несколько слов о кокаине в офтальмологии // Врач. - 1884. № 45. - С. 767.

Коцубей Л.А. Опознавательные точки вкола при интраоральной мандибулярной анестезии // Проблемы стоматологии. - 1940. - № 2. - С. 98-105.

Конобевцев О.Ф., Макиенко М.А. Бережной В.П. Методика внутрикостной анестезии в стоматологии // Стоматология. - 1979. - № 4. - С. 17-19.

Корячкин В.А., Страшнов В.И. Эпидуральная и спинномозговая анестезия: Пособие для врачей. - М.: Симс Портекс, 1998. - 80 с.

Крон Н.М. Случай омертвения после применения местной анестезии солянокислой солью хинина и мочевины по методу впрыскивания / Труды общества русских хирургов. - М., 1915-1916.

Крымов А.П. Несколько слов по поводу местного обезболивания кокаином // Русский врач. - 1903. - № 33. - С. 1157.

Кузин М.И., Харнас С.Ш. Местное обезболивание. - 2-е изд., перераб. и доп. М.: Медицина, 1993. - 224 с.

Лавкина А.А. Медицинская книга России до 1917 г. - Самара, 1994. - 122 с.

Леви Д. Руководство к зубоврачебной науке. - СПб.: Изд. К. Риккера, 1882. - 137 с.

Левицкий А.П. Материалы к истории зубоврачевания в России // Одонтологическое обозрение. - 1899. - № 1, 3, 8, 9. - 1900. - № 1, 2, 3.

Левшин Л.Л. Неотложная хирургия: Руководство к производству важнейших для практического врача хирургических операций. - СПб.: Практическая медицина, 1909. - 626 c.

Лимберг А.А. Повреждения и заболевания скелета лица (челюстей) и болезни зубов / Руководство пластической хирургии. - Т. 3. - Л: Леногиз, 1933. - 580 с.

Лукьянов М.В. Ларингеальная маска - новая концепция в поддержании проходимости дыхательных путей // Анестезиология и реаниматология. - 1994. - № 5. С. 58-66.

Лукашевич А.И. О подкожных впрыскиваниях кокаина // Медицинское обозрение. - 1886. - Т. 25. - № 10. - С. 950.

Маклаков Н.В. Об употреблении в оперативной медицине паров серного эфиpa. - M., 1847.

Маслов Г.А. Курс экстракции зубов. Обезболивание местное. Наркоз. - М., 1904.

Менджерицкий М.С. Анестезия и воспалительные заболевания полости рта // Советск. врачебн. журнал. - 1937. - № 14. - С. 1083-1090.

Мизиков В.М. Новый местный анестетик длительного действия ропивакаина гидрохлорид (наропин) // Анестез. и реаним. - 2000. - № 4. - С. 72-77.

Миллер В.Д. Руководство консервативного зубоврачевания / Пер. с нем. - СПб.: Изд. журнала Практическая медицина, 1898. - 368 с. 
Мироненко Г.С. Стоматология в Санкт-Петербурге // Клинич. имплантология и стоматология. - 1997. - № 1. - С. 10-12.

Михайлова Л.В. Выдающийся русский хирург С.П. Коломнин // Вестник хирургии им. И.И.Грекова. - 1962. - № 4. - С. 119-124.

Морган Дж.Э.-мл., Михаил М.С. Клиническая анестезиология. - Кн. 1-я / Пер. с англ. - М., СПб.: Изд-во «Бином», «Невский диалект», 1998. - 431 с.

Муковозов И.Н. Общая анестезия в челюстно-лицевой хирургии и стоматологии: Монография. - Л.: Медицина, 1965. - 167 с.

Муковозов И.Н. Наркоз и реанимация в челюстно-лицевой хирургии: Монография. - Л.: Медицина, 1972. - 239 с.

Мухин Н.А., Гордиенко Т.П. / Сборн. работ Волгоградского мед. ин-та. - Волгоград, 1972. - Вып. 25. - С. 549-551.

Мыш В.М. К столетию общего наркоза в хирургической клинике // Хирургия. 1947. - № 8. - С. 3-30.

Николаев М.П. Учебник фармакологии. - Изд. 2-е, перераб. и доп. - М.: Медгиз, 1948. - 560 с.

Овечкин А.М., Гнездилов А.В. Наропин (ропивакаин) в лечении боли: идеальный выбор? (обзор литературы) // Вестн. интенсивн. тер. - 2000. - № 3. - Анестезиология. - С. 13-18.

Орлов А.В. Несколько слов о местной анестезии солянокислым кокаином // Врач. - 1887. - Т. 8. - № 4. - С. 536.

Островский В.Ю. Борьба с болью, или человек на операционном столе. - М.: Знание, 1983. - 144 с.

Панкратьев Б.Е. История обезболивания // Многотомное руководство по хирургии. - Т. 1. - М.: Медицина, 1962. - С. 251-294.

Паррейдт Н. Краткое руководство по зубным болезням; Пер. с нем. - СПб.: Издание журн."Практическая Медицина», 1890. - 172 с.

Перцов Р. И., Зеленецкий В.Е., Триханова Г.А. Пластмассовый шприц одноразового использования // Мед. техника. - 1974.- № 4. - С. 50-52.

Петрикас А.Ж. Местная анестезия пульпы и твердых тканей зубов: Дис. ... докт. мед. наук. - Калинин, 1987. - 413 с.

Петрикас А.Ж. Обезболивание зубов. - Тверь, 1997. - 112 с.

Петрикас А.Ж., Липунова М.В., Мишина Н.Н. Картриджный шприц - опыт применения // Новое в стоматологии. - 1999. - № 6. - С. 10-14.

Петрикас А.Ж. Пульпэктомия. - Тверь, 2000. - 268 с.

Петрикас, А.Ж. Сосудистые методы обезболивания зубов / А.Ж. Петрикас, Л.А. Якупова, Д.В. Медведев и др.: сб. трудов VI Всерос. научно-практ. конфер. «Образование, наука и практика в стоматологии» по объединённой тематике «Обезболивание в стоматологии»; под ред. О.О. Янушевича, И.Ю. Лебеденко, С.А. Рабиновича. - М., 2009, 10-13 февраля. - С. 68-70. 
Пирогов Н.И. Наблюдения над действием эфирных паров как болеутолительного средства в хирургических операциях. Записки по части врачебных наук Петербургской медико-хирургической академии. - СПб., 1847. - Кн. 2. - Ч. 1. - С. 1-74.

Поллак Н.А. Спонгиозная анестезия // Советская стоматология. - 1936. - № 1. C. 70-71.

Попов А.Е. О действии новокаина на глаз: Диссертация. - СПб., 1907. (Цит. по С.Н. Вайсблату, 1962.)

Потеенко В.В. К местной анестезии при помощи раствора солянокислой соли хинина и мочевины // Хирургический архив Вельяминова. - 1916. - № 3-4.

Прыгова Н.М. Зубоврачевание у народов доколумбовой Америки // Стоматология. - 1978. - № 5. - С. 86-87.

Прянишникова П.Т., Шаров Н.А. Тримекаин. Фармакология и клиническое применение. - Л.: Медицина, 1967. - 240 с.

Рабинович С.А. Загадка эффективности местной анестезии нижнечелюстного нерва по Гоу-Гейтсу / С.А. Рабинович, О.Н. Московец // Клинич. стоматология. 1999. - № 3. - С. 43-47.

Рабинович С.А., Лукьянов М.В., Заводиленко Л.А. и др. Обезболивание в амбулаторной стоматологии // Тр. VI съезда СтАР. - М., 1999. - С. 115-116.

Рабинович С.А. Современные технологии местного обезболивания в стоматологии. - М.: ВУНМЦ МЗ РФ, 2000. - 144 с.

Рабинович, С.А. Современные технологии местного обезболивания в стоматологии / С.А. Рабинович. - М.: ВУНМЦ МЗ РФ, 2000. - 144 с.

Рабинович С.А., Бабиков А.С., Московец О.Н., Анисимова Е.Н. От птичьего пера до компьютерного шприца (часть 1). - Клинич. стоматология. - 2001. № 2. - С. 42-45.

Рабинович С.А., Зорян Е.В., Сохов С.Т. и др. От новокаина к артикаину (к 100летию синтеза новокаина. - М.: ООО Медицинское информационное агентство, 2005. - 248 c.

Рудько В.Ф., Бизяев А.Ф., Шугайлов И.А. Борьба с болью в хирургической стоматологии // Тр. VII Всесоюзн. съезда стоматол. - М., 1981. - С. 100-104.

Руководство общей и частной хирургии с включением топографической анатомии и учения об операциях и повязках / Под ред. д-ра Питы и д-ра Бильрота; Пер. с нем. - Т. І. - Ч. 1: Историческое развитие хирургии и сословия хирургов. - СПб.: Типография Якова Трея, 1867. - 907 с.

Руководство практической хирургии: в 4-х томах.- Т. I: Хирургия головы; Пер. с нем. / Под ред. Е. Бергмана и П. Брунса. - М.: Изд. А.А. Карцева, 1901. - 1147 с.

Рыбаков А.И., Конобевцев О.Ф., Мошков К.В. и др. Определение эффективности безыгольных инъекторов // Стоматология. - 1979. - № 1. - С. 65-67.

Сабо, Д. Хирургия полости рта и челюстно-лицевой области / Д. Сабо; Пер. с венг. - Киев: Книга плюс, 2005. - 302 с.

Сарманаев Р.Б. Модификация проводниковой анестезии нижнеальвеолярного нерва // Стоматология. - 1957. - № 3. - С. 57. 
Селиванов В.И. Я.А. Чистович. - М.: Медицина, 1977. - 56 с.

Середницкий А.М. О приоритете в открытии проводниковой анестезии // Мед. работник. - 1952. - № 46. (Цит. по С.Н. Вайсблату, 1962.)

Скопец Е.В. О некоторых осложнениях при мандибулярной анестезии // Тр. Пермск. гос. стоматол. ин-та. - Пермь, 1949. - Вып. 8. - С. 195-200.

Смирнов Н. Медицинские успехи Петра I «Царь Петр рвал ... зубы очень искусно и платил за то по шиллингу» // Мед. газета. - 1998. - № 53, 3 июля. - С. 16.

Соханский Н.Н. К вопросу об адренал-кокаиновом обезболивании. Протоколы заседания русского хирургического об-ва Пирогова от 15 октября // Врач. - 1903. № 48. - С. 1724.

Сохов С.Т. Клинико-экспериментальное обоснование повышения эффективности местного обезболивания при проведении амбулаторных стоматологических вмешательств (14.00.21): Автореф. дис. ... докт. мед. наук. - М., 1997. - 41 с.

Сохов С.Т., Сохова И.А., Шкловская Н.И. и др. Экспериментальная оценка селективного депонирования местного магниточувствительного анестетика феррокаина в биологических тканях животного // Тр. VI съезда СтАР. - М., 1999. - С. 120-122.

Сохов, С.Т. Эффективность альтернативных способов проводникового обезболивания на нижней челюсти / С.Т. Сохов, С.А. Рабинович: Сб. трудов VI Всерос. научно-практ. конфер. «Образование, наука и практика в стоматологии» по объединённой тематике «Обезболивание в стоматологии»; Под ред. О.О. Янушевича, И.Ю. Лебеденко, С.А. Рабиновича. - М., 2009, 10-13 февраля. - С. 97-98.

Спижарный И.К. О местной анестезии // Врачебная газета. - 1909. -№ 1. - С. 18.

Спижарный И.К. О местной анестезии // Тр. VIII съезда российск. хир. - М., 1909.

Спримон В.Ф. К вопросу о действии кокаина // Мед. обозрение. - 1884, октябрь.

Старобинский И.М. Местное обезболивание // Стоматология. - Изд. 3-е, перераб. и доп. - М.: Медгиз, 1955. - 288 с.

Столяренко П.Ю. Современные технологии местного обезболивания в стоматологии: Метод. рекомендации. - Самара; СамГМУ, 1997. - 40 с.

Столяренко П.Ю. Ларингеальная маска - перспективы и возможности применения в челюстно-лицевой хирургии и стоматологии: Краткое практическое руководство. - Самара: НВФ «СМС», СамГМУ, 1999. - 32 с.

Столяренко П.Ю., Кравченко В.В. Местная и общая анестезия в геронтостоматологии: Монография. - Самара; СамГМУ, Самарский науч. центр РАН, «Международный центр по проблемам пожилых», 2000. - 196 с.

Столяренко П.Ю., Федяев И.М., Столяренко Т.И. Малоизвестные страницы из истории местной анестезии // Маэстро стоматологии. - 2003. - № 2 (11). - С. 99-106. 
Столяренко П.Ю. Зигмунд Фрейд и кокаин // Российский стоматологический журнал. - 2006. - № 5. - С. 44-47.

Столяренко П.Ю., Федяев И.М. Вклад дантистов в развитие хирургического обезболивания: Монография. - Самара: ООО «Офорт»; ГОУ ВПО «СамГМУ», 2006. - 146 c.

Столяров Е.А., Грачев Б.Д., Батаков Е.А. Асептика и антисептика: Учебное пособие по курсу общей хирургии. - Самара; СамГМУ, 2000. - 126 с.

Таубер А.С. О наркозе закисью азота // Врач. - 1880. - № 1. - С. 25.

Таубкин П.И. Адреналин как вспомогательное средство при местной анестезии кокаином и как гемостатическое // Одонтологич. обозр. - 1903. - № 10.

Тельчаров Д.И., Беляева Н.Г. Криообезболивание в практике ортопедической стоматологии // XXX научная сессия: Сб. тезисов КМИ. - Куйбышев, 1972. - С. 390-391.

Тимофеев, А.А. Руководство по челюстно-лицевой хирургии и хирургической стоматологии / А.А. Тимофеев. - 4-е изд, перераб. И доп. - Киев ООО «Червона Рута-турс», 2004. - 1018 с.

Трещинский А.И., Заманский Я.Л., Тверской М.Н. Из истории отечественной анестезиологии. - Киев: Здоров'я, 1973. - 164 с.

Троянский Г.Н. История советской стоматологии (очерки). - М.: Медицина, 1983. - 144 c.

Уваров Б.С. Краткий очерк истории анестезиологии // Руководство по анестезиологии / Под ред. А.А. Бунятяна. - 2-е изд., стереотипн. - М.: Медицина, 1997. - С. 7-16.

Уваров В.М. Регионарная анестезия при остеомиелитах челюстей // Tp. III Bceсоюзн. Одонтологич. съезда. - Л., 1929. - С. 294-298.

Ушомирская А. Памятник эфиру // Кругозор. - 2008. - № 6. Электрон-ная версия http://www.krugozormagazine.com/main/archive/2008/06/ether-monument.html

Федоров С.П. Несколько мыслей о наркозе и местной анестезии // Новый хир. архив. - 1934. - Т. 31. - № 1. - С. 98-100.

Фетисов Н.В. Новые принципы инъекционного метода обезболивания в челюстно-лицевой области: Тез.докл. Всесоюзн. конфер. челюстно-лицевых хирургов. - Л., 1958. - С. 53-54.

Фишер Г. О методах местной анестезии в полости рта // Тр. I Одонтологич. съезда. - М., 1924. - С. 270-272.

Фишер Г. Научные основы местной анестезии // Тр. II Одонтологич. съезда. M., 1926. - С. 252-256.

Фишер Г. Об осложнениях при местной анестезии. - Там же. - С. 256-258.

Харитонов И.Ф. Истоки, современное состояние и перспективы развития местной анестезии // Казанский мед. журн. - 1964. - № 5. - С. 68-71.

Чехов А.П. Общее образование. Последние выводы зубоврачебной науки // ПСС. Т. 3. (Рассказы 1885-1886). - М.: Гос. изд-во Художеств. литер., 1961. - С. 253-257.

Чистович Н.Я. Яков Алексеевич Чистович. Биографический очерк // Русский врач. - 1910. - № 42. - С. 1472. 
Шаров Н.А. Клинико-экспериментальная оценка тримекаина при некоторых экстренных и плановых хирургических операциях: Автореф. дис. ... канд. мед. наук. Смоленск, 1964. - 27 с.

Шевченко В.П. Физиологические основы и проблемы использования ларингеальной маски: Монография. - Новосибирск: НИИТО, 1997. - 231 с.

Шефф Ю. Учебник зубных болезней для практических врачей и студентов; Пер. с нем. - М.: Типогр. А.И. Мамонтова, 1882. - 332 с.

Шольц И. Фармакокинетика ингаляционных анестетиков // Освежающий курс лекций «Актуальн. пробл. анестезиол. и реаним.» - Вып. 6 / Матер. 10-го Европейского конгресса анестезиологов; Под ред. Э.В. Недашковского. - Архангельск, 2000. - С. 175-181.

Шувалов, С.М. Блокады нижнего луночкового нерва по Гоу-Гейтсу и Б.Ф. Кадочникову (Вазирани-Акинози): особенности проведения обезболивания и преподавания студентам стоматологических факультетов: Матер. I съезда черепночелюстно-лицевых хирургов Украины. - Киев, 2009. - С. 36-38.

Шугайлов И.А. Метод комплексной оценки болевой реакции // Анестезиол. и реаниматол. - 1985. - № 1. - С. 24-27.

Шугайлов И.А. Выбор препаратов для местной анестезии в стоматологии: Метод. рекомендации. - М.: ВУНМЦ, 1996. - 39 с.

Шугайлов И.А. Профилактика общесоматических осложнений и экстренная помощь при неотложных состояниях в стоматологической практике: Учебное пособие. - М.: Мединфодент, 1998. - 122 с.

Юдин С.С. Избранные произведения. Вопросы обезболивания в хирургии. М.: Медгиз, 1960. - 322 с.

Юдин С.С. Этюды желудочной хирургии. - 2-е изд. - М.: Медицина, 1965. - 270 с.

Ясный Я.Л. 75 лет интратрахеального наркоза в России // Советская медицина. - 1962. - № 11. - С. 152.

Adriani J., Dalili H. Penetration of local anaesthetic through epitelial barriers // Anesth. and Analg. - 1971. - Vol. 50. - № 5. - P. 834-841.

Akinosi J.O. A new approacb to the mandibular nerve block // Br. J. Oral Surg. 1977. - Vol. 15. - P. 83.

Aling C.C., Christopher A. // J. Amer. dent. Ass. - 1974. - Vol. 89. - P. 1171-1176.

Altemir F.H. // J. Maxillofac. Surg. - 1986. - Vol. 14. - P. 64-65.

Anrep V.K. Über die physiologische Wirkung des Cocain // Archiv fuer die gesammte Physiologie des Menschen und Thiere. - Bonn: Verlag von Emil Strauss, 1879. - Bd. 21. H. 1-2. - S. 38-77.

Archer W.H. A manual of dental anesthesie. - Philadelphia - London, 1958.

Arnott J. On the treatment of neadache by bending cold. - Brighton, 1849; Lancet, Juli et Sept. 1848. (Цит. по О. Каппелеру, 1881.)

Artusio J.F., Van Poznac A., Hunt R.E. et al. //Anesthesiology. - 1960. - Vol. 21. P. 512. 
Baker R. Dr. Morton: Pioneer in the Use of Ether. New York: Julian Messner, Inc., 1946. -224 p.

Bartholinus T. De nivis usu medico. - Hafn. - 1661. - Cap. XXII. - P. 132 (Med. Tim. Mai 4, 1867). (Цит. по О. Каппелеру, 1881.)

Bause G.S. Gwathmey's 1914 Anesthesia // Anaesthesiology. - 2010. - Vol. 112. № 6. - P. 1344.

Beddous. On factitions airs. - Bristol, 1795.

Becker D. Cultivori prussiaci curatio singularis. - Leyde, 1636.

Becker R., Marino A.A. Electromagnetism and Life // State University of New York Press, Albany, 1982.

Beclard F. // Bull. Acad. Imp. Med. - Paris. - 1866. - Vol. 32. - P.327.

Bennett C.R. Monheim's local Anesthesia and Pain Control in dental Practice. - Saint Louis, 1974.

Bennett M.R. One hundred years of adrenaline: the discovery of autoreceptors // J. Clin. Auton. Res. - 1999. - Vol. 9. - Issue 3. - P. 145.

Berman C.L. // Milit. Med. - 1967. - Vol. 137. - Р. 108-109. (Цит. по А.Ж. Петрикасу, 1978.)

Bier A. Experiments regarding the cocainization of the spinal cord. Reprinted in 'Classical File'. Surv. Anesthesiol. 6 (1962), pp. 52-59 (orginally from Dtsch. Z. Chir. 1899; 51: 361-369).

Bier A. Ueber einen neuen Weg Localanaesthesie an den Gliedmassen zu erzeugen // Archiv fuer klin. Chirurgie. - 1908. - Bd. 86. - S. 1007.

Biographisches Lexikon der hervoragenden Ärzte hrag. - Fischer. - Berlin - Wien, 1933. - Bd. 2. - S. 1580.

Biojector 2000: http // www. bioject. com.

Boakes A.J. et al. Adverse reactions to local anesthetic vasoconstrictor preparations: a stude of the cardiovascular responses to xylostesin and hostacain-with-noradrenaline // Brit. Dent. J. - 1972. - Vol. 133. - P. 137-140.

Bourdain C.-L. L'Anesthésie par l'injection intra-ligamentaire pour l'extraction des dents. These de Doctorat, Editions de la Semaine Dentaire, Paris, 1925.

Bradby M. History of tracheotomy // Nursing Times. - 1966. - Vol. 25. - P. 1548-1550.

Brain A.I.J. The laryngeal mask - a new concept in airway management // Br. J. Anaesth. - 1983. - Vol. 55. - P. 801-805.

Brain A.I.J. The laryngeal mask - A possible new solution to airway problems in the emergency situation // Arch. Emergency Med. - 1984. - № 1. - P. 254.

Braun H. Über den Einfluss der Vitalitaet der Gewebe auf die örtlichen und allgemeinen Giftwirkungen lokalen anästhesierender Mittel und über die Bedeutung des Adrenalins für die Lokalanästhesie // Arch. Klin. Chir. - 1903. - Bd. 69. - S. 541-591.

Braun H. Die Lokalanästhesie, ihre wissenschaftlichen Grundlagen und praktische Anwendung. - Leipzig, 1905. - 436 S. 
Braun H. Die Lokalanästhesie, ihre wissenschaftlichen Grundlagen und praktische Anwendung. - Leipzig, 1905; 1907; 1913 (рус. пер. СПб., 1909).

Bieter R.N. Applied pharmacology of local anesthetics // Amer. J. Surg. - 1936. - Vol. 34. - P. 500-510.

Brimacombe J.R., Verghese C. Survey of laryngeal mask airway in 11910 patients // Abstract a 84 from the annual scientific meeting. - Townsville, Australia, 1995, May.

Brodie B.C. // Journal de mid de Leroux. (Цит. по О.Каппелеру, 1881.)

Burkhardt L. Über Chloroform und Aether - Narkose durch intravenose Injection // Mnchener Med. Wschr. med. Wschr. - 1909. - № 2. - S. 2365-2369.

Butterwort J.F., Strichartz G.R. Molecular mechanisms of local anesthetics (EMLA) cream // Anesth. Analg. - 1994. - Vol. 78. - № 3. - P. 574-583.

Carrea. Stammanästhesie der Oberkiefer. Z. Ru. - 1922. // La Odontologia. - 1921. Н. 9. (Цит. по С.Н. Вайсблату, 1962.)

Cerwantes J. Common Bile Duct stons Revisited after the First Operation 110 Years Ago // World. J. Surg. - 2000. - Vol. 24. - № 10. - P. 1278-1281.

Christison. On poisons. - Edinbourgh, 1836.

Cieszynski A. Beitrage zur exakten Injektionstechnik in der Ramus des Ganglion Gasser // Vierteljahrschr. für Zahnheilk. - Österr. - Ungar. - 1918.

Clover J.T. Trans. Int. Congr. Med. - 1888; 2: 392; In Duncum B.M. The Development of Inhalational Anaesthesia, Ist ed. London: Oxford University Press, 1947: 604.

Colice G.L. Historical background. In: Tobin M.J. (ed). Principle and practice of mechanical ventilation. McGraw-Hill, New York, 1994. - P. 1-37.

Crile G.W., Lower W.E. Anoci-Association. WB. Saunders, Philadelphia, 1914.

Dawy H. Chemical and philosophical ressearches, chiefly concerning nitrous oxyde and its respiration. - London, 1799.

De Castro J., Mundeleer P. Anesthesie sans barbituriques - la neuroleptanalgesie // Anesth. Analg. Reanim. - 1959. - Vol. 16. - P. 1022-1056.

Desai S.P., Desai R.M., Battit G.E. A Tale of Two Paintings Depictions of the First Public Demonstration of Ether Anesthesia // Anesthesiology. - 2007. - Vol. 106. - P. 1046-1050.

de Jong R.H. Local Anesthetics. - Mosby Year Book, 1993.

Dirnbacher T. Reduzierung unerwünschter Effekte bei der zahnärztlichen Lokalanästhesie / Dis. Dr. med. Dent. - Jena, Friedrich-Schiller-Universität, 2003. - 88 S.

Dioscorides P. Opera ommia / Пер. с латинского и комментарий Matthielus Venet. - 1554. (Цит. по О. Каппелеру, 1881.)

Du Cailar J. Histoire de la Narro - ataralgisie // Ann. Anaesth. Franc. - 1966. - Vol. 7. - N special. 1. - P. 177-181.

Eavey R.D. (1998) The history of tracheotomy. In: Myers E.N., Johnson J., Murry T. (eds) Tracheotomy: airway management, communication, and swallowing. - San Diego: Singular, 1998. - P. 1-8.

Einhorn A. On the chemistry of local anesthetics. - 1899. - MMW 46. - P. 1218-1220. (Цит. по M. Lipp, 1992.) 
Evans P.J. Cryoanalgesia. The application of low temperatures to nerves to produce anaesthesia or analgesia // Anaesthesia. - 1981. - Vol. 36. - № 11. - P. 1003-1013.

Evers H., von Dardel O., Juhlin L. et al. Dermal effects of compositions based on the eutectic mixture of lignocaine and prilocaine // Br. J. Anaesth. - 1985. - Vol. 57. - P. 997-1005.

Evers H. The Dental Cartrige System // Astra Pain Control A.B. - 1993. - 51 p.

Faraday M. // Quarterly Journal of science. - 1818. (Цит. по О. Каппелеру, 1881.)

Fischer G. Die lokale Anaesthesie in der Zahnheilkunde. - 3. Auflage. - Berlin: Verlag Hermann Meusser, 1914.

Fischer G. Die ortliche Betaubung in der Zahnheilkunde. - 4. Auflage. - Berlin: Verlag Hermann Meusser, 1925. - 7. Auflage. - Leipzig, 1955.

Fischer E., von Mering J. Ueber eine neue Klasse von Schlafmitteln. Therap. Gegenw., 1903.

Flagg P.J. // Arch. Otolaryng. - 1951. - Vol. 5. - № 4.

Frost E.A.Tracing the tracheostomy // Ann. Otol. Rhinol. Laryngol. - 1976. - Vol. 85. - P. 618-624.

Gajraj N.M., Pennant J.H., Watcha M.F. Eutectic mixture of local anesthetics (EMLA) cream // Anesth. Analg. - 1994. - Vol. 78. - № 3. - P. 574-583.

Giacomini. Triate philosophique et experimental de Matere medicale et de Therapentique. (Цит. по О. Каппелеру, 1881.)

Gillespie N.A. The history of endotracheal anaesthesia. In: Gillespie N.A. (ed.) Endotracheal anaesthesia. - 2-nd edn. - New York, 1948: University of Wisconsin Press, Madison, p.p. 67-84.

Ginestet G. Anesthesie des nerfs masseterin, buccal, linqual et dentaire inf. en un seul temps par modification de l'anesthesie trunculaire a l'epine de spix // La revue de Stomatologie. - 1927. - № 10.

Glover J. Vasoconstrictors in dental anaesthetics contraindication - fact or fallacy? // Aust. Dent. J. - 1968. - Vol. 13. - № 1. - P. 65-69.

Gow-Gates G.A.E. Mandibular conduction anesthesia: a new technique using extraoral landmarks // Oral surg. - 1973. - Vol. 36. - № 3. - P. 321-328.

Griffith H.R., Johnson E. The use of curare in general anaesthesia // Anaesthesiology. 1942 (July). - № 3. - P. 418-420.

Grundy J.R. Intraligamentary anaesthesia. A survey of use by general practitioners and by staff and students in a dental school // Restorative Dent. - 1984. - Oct. 1 (2). Vol. 36, 38. - P. 41-42.

Guedel A.E. A nontraumatic pharyngeal airway // JAMA. - 1933. - Vol. 100. - P. 1862.

Halsted W.S. Practical comments on the use and abuse of cocain // New York Med. J. - 1885. - Vol. 42. - P. 294.

Hassouna H. History of local anesthesia in dentistry. - $2003<$ http://www.pua.edu.eg/ PUASite/uploads/file/Dentistry/.pdf> 21.06.2010.

Henny F.J. // Oral Surg. - 1951. - № 9. - P. 3. 
Hesse F., Lendle L., Schoen R. Allgemeinnarcose und örtliche Betäubung. - Leipzig, 1934.

Hesse F. Kleines Narkosebuch. - Siebente Neubearbeitete Auflage. - Leipzig, 1956. - 88 S.

Hewitt F.W. An artificial «airway» for use during anaesthetisation // Lancet. - 1908; Feb. 15. - P. 490-491.

Hickman H.H. A Letter on suspended animation, containg experiments shewing that it may be safely employed during operations on animals, with the view of ascertaining its probable utility in surgical operations on the human subject. Ironbridge, W. Smith, 1824.

Hingson R. // Anaesth. and Analg. - 1947. - Vol. 26. - P. 221.

Hoffmann C. De Thorace lib. XXV. c. 94. (Цит. по О. Каппелеру, 1881.)

Hoffmann-Axthelm W. History of dentistry. - Chicago: Quintessence Publishing Co, 1981. -343 p.

Hoffmann-Axthelm W. Ein Jahrhundert Lokalanaesthesie // Aktuelle Aspekte der zahnaerztlichen Lokalanaesthesie. - Frankfurt am Main: Hoechst, 1985. - S. 7-17.

Howard-Jones N. A critical study of the origins and early development of hypodermic medication // J. Hist. med. - 1947. - Vol. 2. - P. 201-249; Mogey, G.A. Centenary of hypodermic injection // Brit. Med. J. - 1953. - Vol. 2. - P. 1180-1185.

Howe G.L., Whitehead F.J. Local Anaesthesia in Dentistry. - Bristol, 1972. - P. 78.

Howland W., Lewis J. // Cancer. - 1956, 9, 6. (Цит. по И.Н. Муковозову, 1965).

Hymes A.C., Yonehiro E.G., Raab D.E. et al. Electrical surface stimulation for control of acute postoperative pain and prevention of ileus // Surg. Forum. - 1973. - Vol. 24. - P. 447.

Jackson C. Tracheotomy // Laryngosrope. - 1909. - Vol. 19. - P. 285-290. (Cit. Rosenberg H., Axelrod J.K., 2003.)

Jackson C. The technique of insertion of intratracheal insufflation tubes // Surg. Gyn. \& Obs. - 1913. (Cit. Rosenberg H., Axelrod J.K., 2003.)

Jastak J.T., Yagiela J.A. Regional Anesthesia of the oral cavity. - Saint-Louis etc., 1981. -212 p.

Kane K., Taub A. A history of local electrical analgesia // Pain. - 1975, Jun. 1:2. - P. 125-138.

Kantorowisz A. Die extraorale Leitungsanästhesie // Dtsch. Mschr. Zahnheilk. 1915.

Katz N. Чрескожная электростимуляция нерва // Послеоперационная боль: Руководство / Пер. с англ.; Под ред. Ф. Майкла Ферранте, Тимоти Р.Вейд-Бонкора. - М.: Медицина, 1998. - С. 439-458.

Kellaway P. The part played by electrical fish in the early history of bioelectricity and electrotherapy // Bukk. Hist. Med. - 1946. - Vol. 20. - pH2.

Killian H. Narkose zur Operatives Zwechen. - Berlin, 1934.

Klein B., Sicher H. Die perkutane Leitungsanästhesie des Nervus alveolaris inferior // Vierteljahrsch. für Zahnheilk. - Österr. - Ungar. - 1915.

Koller K. Vorläufige Mitteilung über lokale Anästhesierung am Auge // Berichte Dtsch. Ophthalm. Ges. - 1884. - S. 60-63. 
Koller-Becher H. Carl Koller and cocaine // The Psychoanalytic Quarterly. - 1963. Vol. XXXII. - № 3. - P. 309-373.

Köhler. Die Neuern Arbeiten über Anaesthetica // Schmidt's Jahrbűchern. - 18691871. - Bd. 142, 145, 151. (Цит. по О. Каппелеру, 1881).

Köhler. Lokale Anästhesierung durch Saponin. - Halle, 1873. - S. 102.

Kuhn F. Der Metallschlauch in der Tubage und als Trachealkancile // Wien. klin. Rdsch. - 1900. - Vol. 28. - P. 554.

Kuhn F. Die perorale Intubation // Zentralbl. Chir. - 1901. - Vol. 28. - P. 1281-1285.

Kuhn F. Technik der peroralen Tubage // Dtsch. med. Wochenschr. - 1902. - Vol. 28. - P. 539-541.

Kuhn F. Kein Pressen und Erbrechen bei Narkosen // Bin. klin. Wochenschr. - 1903. Vol. 17. - P. 402-403.

Kuhn F. Perorale Tubage mit und ohne Druck. I. Teil: Perorale Tubage und pulmonale Narkose // Dtsch. Z. Chir. - 1905. - Vol. 76. - P. 148-207.

Kuhn F. Katgut vom gesunden Schlachttier // Münch. Med. Wochenschr. - 1906. Bd. 41 - S. 2018-2020.

Kuhn F. Die perorale Intubation; ein Leitfaden zur Erlernung und Ausführung der Methode mit reicher Kasuistik [Oral Intubation; A Guide for Learning and Executing this Method Including a wide Selection of Casuistics]. - Berlin: Verlag von S. Karger, 1911.

Kulenkampff D. Heinrich Braun (Nekrolog) // Zbl. Chir. - 1934. - Bd. 61. - № 24. S. 1393.

Kurier, специальное обозрение. История шприца. Александр Дельфин. - № 15. 2000; http://www. kurierweb. com.

Leech B.C. The pharyngeal bulb gasway: a new aid in cyclopropane anesthesia // Anesth. Analg. - 1937. - Vol. 16. - P. 22-25.

Liliental, B. (1975). - Цит. по А.Ж. Петрикас и соавт. (2009.)

Lindemann. Ein neues Verfahren der Anaesthesierung des Ober- und Unterkieferreiches // Dtsch. Mschr. Zahnneilk. - 1926. - Bd. 44. - S. 387.

Lindqvist K., Sundling S. Xylocaine - a discovery - a drama - an industry. Stockholm: Astra, 1993. - 190 S.

Lipp M.D.W. Die Lokalanästhesie in der Zahn-, Mund- und Kieferheilkunde. - Berlin: Quintessenz. - 1992. - 174 S.

Löfgren N., Lundqvist B. Svensk kem. Tidskr. - 1946. - Vol. 58. - P. 206.

Löfgren N. Studies on local anesthetics. Xylocaine a new synthetic drug. - Stockholm, 1948.

Löfgren N., Tegner C., Takman B. // Acta chem. Scand. - 1957. - Vol. 11. - № 10. P. 17-24.

Lundy J.S. Intravenous anesthesia: Preliminary report of the use of the two new thiobarbiturates. Proceedings of the Staff Meetings of the Mayo Clinic, 1935. - Vol. 10.P. 536-543.

Lundy J.S. Clinical Anesthesia. - Philadelphia, 1945. 
Lundy J.S. et al. // Военная медицина за рубежом: Сб. рефератов. - M., 1992.

Macht D.J. The history of opium and some of its preparations and alkaloids. J.A.M.A., 1915. - Vol. 64. - S. 477.

Madigan S.R., Raj P.P. History and current ststus of pain management. - P. 3. // Practical Management of Pain / P.P. Raj (ed) - 2 nd Ed. - Mosby-Year Book, Malvern, PA, 1992.

Maiwand M.O., Makey A.R., Rees A. Cryoanalgesia after thoracotomy. Improvement of technique and review of 600 cases // J. Thorac. Cardiovasc. Surg. - 1986. - Vol. 92. № 2. - P. 291-295.

Malamed S.F. Handbook of local anesthesia. - 4th ed. - Saint Louis: Mosby, 1997. - 327 p.

Malamed S.F. Back to basics: emergency medicine in dentistry // J. Calif. Dent. Assoc. - 1997. - Vol. 25. - № 4. - P. 14-25.

Margetis P., Quarautillo E., Lindberg R. // U.S. Armed. Forces Med. J. - 1958. - Vol. 9. - P. 625-633.

Martinez Lage J.L., Eslava J.M., Cebrecos A.L., Marcos O. // J. Oral Maxillofac. Surg. 1998. - Vol. 56. - P. 302-306.

Marx G.F. Die historische Entwicklung der geburtshiflichen Anaesthesie // Anaesthesist. - 1987. - Bd. 10. - S. 537-540.

Matas R. On the management of acute traumatic pneumothorax // Ann. Surg. 1899. - Vol. 29. - P. 409-434.

Matas R. Local and regional anesthesia with cocaine and other analgesic drugs, including the subarachanoid method as applied in general surgical practice // Philadelphia Med. J. - 1900. - Vol. 6. - P. 820-843.

Matas R. Local anesthesia: a retrospect and prospect // Amer. J. Surg. - 1934. - Vol. 25. - P. 189-196.

Mayer R. Die Intraligamentare Anaesthesie in der Zahnheilkunde // Z. Stomatol. 1989. - Bd. 86. - № 6. Okt. - S. 323-339.

McGoldrich K.E. The laryngeal mask airway: an qverview//Survey of Anesthesiology. 1955. - Vol. 39. - P. 203-207.

McIntyre J.W.R. Oropharyngeal and nasopharyngeal airways: I (1880-1995) // Can. J. Anaesth. - 1996. - Vol. 43. - № 6. - P. 629-635.

Mega Book; http://www.megakm.ru/health/encyclop.

Melzack R., Wall P.D. Pain mechanisms: a new theory // Science. - 1965. - Vol. 150. P. 971.

Modlin I. Surgical Triumvirate of Theodor Kocher, Harvey Cushing, and William Halsted // World J. Surg. - 1998. - Vol. 22. - № 1. - P. 103-113.

Monash S. Topical anaesthesia of the unbroken skin // Arch. of Dermatology. 1957. - Vol. 76. - P. 752-756.

Moore J. A method of preventing or diminising pain in several operations of surgery. London, 1784. 
Moore P.A. Bupivacaine: A long anesthesia and Pain Control in dental practice. Saint Louis: Mosby, 1961. - 330 p.

Muschaweck R., Rippel R. Ein neues Lokalanaesthetikum (Carticain) aus der Thiophenreiche // Prakt. Anaesth. - 1974. - Bd. 9. - № 3. - S. 135-146.

Musso C.G. Imhotep: the dean among the ancient Egyptian physicians // Humane Medicine Health Care. - 2005. - № 5. - P. 169.

Nehme A.E., Warfield C.A. Cryoanalgesia: freezing of peripheral nerves // Hosp. Pract. - 1987. - Vol. 22. - № 1A. - P. 71-72, 77.

Neumann R. Fuehrer durch die operative zahnheilkunde. - Berlin: NW 87, 1929. $302 \mathrm{~S}$.

Niemann N. Ueber eine neue organische Base in den Cocablatten. Archiv Pharm. 1860; 153:129-55,291-308. (Cit. by D.A.E. Shephard, 2009.)

Nusstein J., Reader A., Nist R. et al. Anesthetic efficacy of the supplemental intraosseous injection of 2\% lidocaine with 1:100 000 epinephrine in irreversible pulpitis // J. Endod. 1998. - Vol. 24. - № 7. - P. 487-491.

Offerchaus. Die Technik der Injektion in die Trigeminustamme und das Ganglion Gasseri // Arch. f. Klin. Chir., 92. (Цит. по С.Н. Вайсблату, 1962.)

Oré P.-C. De l'anesthesia produite chez l'home par les injections de chloral dans les veines. Reprint from: Compte rendus des séances de l'Académie des Sciences, vol. 78, 1874 .

Orfila. Toxicologie generale. - Kuehn, Leipzig. - 1830. - Bd. 11. - P. 392.

Partsch C. Ueber Kiefercysten // Deutsche Monatsschrift fuer Zahnheilkunde.1892.

Pelikan. Bulletin der Kaiserl. Akadem. - Petersburg, 1867, XII, c. 253. - Berlin: Klin. Wochenschr., 36, 1867. (Цит. по О. Каппелеру, 1881.)

Pfender C.A. Historical synopsis of the development of hypodermic medication // Washington Med. Ann. - 1911. - № 10. - P. 346-359. 1847.

Pirogoff N. Recherches pratigues et physiologiques sur l'etherisation. - St. Petersburg,

Plinius secundus. Historia naturalis lib. XXV. - S. 94. (Цит. по О. Каппелеру, 1881.)

Portier P., Richet Ch. De l'action anaphylactique de certains venims // C R Soc. Biol. 1902. - Vol. 54. - P. 170-172.

Pravaz Ch. Sur un nouveau moyen d'opérer la coagulation du sang dans les artères, applicable à la guérison des aneurisms // Comp. Rend. Acad. Sci (Paris). - 1853. - Vol. 36. - P. 88-91.

Priestley J. Observations on different kinds of airs // Phil. Trans. Roy. Soc. - 1772; 62 : 210-222. (Cit. by D.A.E. Shephard, 2009.)

Rahn R., Lodz M., Mohr A. Local anesthetic efficasy of articaine with epinephrine in different concentration // Abstracts book of 8th Dental Congress on Modern Pain Control in Christchurch, New Zealand 1-4 April 1977; 85. 
Raj P.P. Practical Management of Pain. - 3 rd ed. - Texas: Mosby, 2000. - 1088 p.

Raper H. Man against Pain. - New York, 1945.

Reclus P. L'anesthesie par la cocaine. - Gaz. Hóp. - Paris, 1891. - 64. - P. 132-133.

Replogle K. et al. (1999). - Цит. по А.Ж. Петрикас (2009.)

Richardson B.W. On voltiac narcotism etc. // Med. Tim. and Gaz., Febr. 12 n. June 25, 1859, Febr. 3, 1866. (Цит. по О. Каппелеру, 1881.)

Richardson B.W. A new method of producing local anesthesia applicable to dental surgery // Trans. Odont. Soc. G.B. - 1866. - Vol. 5. - P. 45-68.

Robinson V. Victory over Pain. A. History of Anesthesia. - New York, 1946. - 338 p.

Rose W. Heinrich Braun (1862-1934) - a pioneer in anesthesiology in Germany // Anaesthesiologie, Intensivmedizin, Schmerztherapie. - 1993. - Bd. 28(7). - S. 459-466.

Rosenberg H., Axelrod J.K. The introduction and popularization of endotracheal intubation into anesthesia practice // Bulletin of anesthesia history. - 2003. - Vol. 21. № 4. - P. 1, 4-6.

Russian Server of Anaesthesiologists - Astra Zeneca World Leader in Local Anesthetics; http://www.rusanesth.com/Localanest/ksilok.htm.

Rutkow I.M. William Halsted and Germanic influence on education and training programs in surgery // Surg. Gynecol. Obstet. - 1978. - Vol. 147. - № 2. - P. 602.

Rynd F. Neuralgia: Introduction of fluid to the nerve // Dublin Med. Press. - 1845. Vol. 13. - P. 167-168.

Rynd F. Neuralgia: Introduction of fluid to the nerve // Dublin Med. Press. - 1845. Vol. 13. - P. 167-168.

Schleich C.L. Drei Laparotomien ohne Chloroformmaske unter Anwendung der localen combinierten Aether-Cocainanaesthesie // Berl. Klin. Wocheschr. - 1891. - Bd. 28. - S. 1202.

Schleich C.L. Die infiltrationsanaesthesie und ihr Verhaeltnis zur allgemeinen Narcose // Dtsch. Chir. Kongress. - Berlin, 1892.

Schleich C.L. Schmerzlose operationen.Oertliche betäubung indifferenten Flüssigkeiten. Psychophysik des natürlichen und künstlichen Schlafes. Fourth revised edition. - Berlin: Springer, 1899. - 303 S.

Shaw G.B. (2008) The doctor's dilemma, act I. http://www.1stWorldLibrary.org

Sheon R.P. Transcutaneous electrical nerve stimulation. From electric eels to electrodes // Postgrad Med. - 1984. - Vol. 75. - № 5. - P. 71-74.

Shephard D.A.E. History of Canadian Anaesthesia: Beverly Charles Leech (18981960) // Can. J. Anaesth. - 1990. - Vol. 37. - № 6. - P. 689.

Shephared D.A.E. Why Was there a Four-Decade Delay before Anesthesia was Introduced in 1846? // Bulletin of Anesthesia History. - Vol. 27. - № 2, July 2009. P. 33-38.

Shipway F. Airway for intranasal operations // Br. Med. J. - 1935; April 13. - P. 767. 
Sicher H. Anatomie und Technik der Leitungsanästhesie in Bereiche der Mundhöhle. Berlin-Wien: Verlag Julius Springer, 1920. - S. 55-57.

Simpson J.Y. Remarks on the superinduction of anaesthesia in natural and morbid parturition: with cases illustrative of the use and effects of chloroform in obstetric practice. Edinburg: Sutherland \& Knox, 1847:2. - 48 p. (Cit. Defalque R.J., Wright A.J., 2007.)

Smith W.D.A. Under the Influence: A History of Nitrous Oxide and Oxygen Anesthesia. - Macmillan: WLM, 1982.

Snow J. On the Inhalation of the vapour of ether in surgical operations: containing a description of the various stages of etherization and a statement of the result of nearly eighty operations in which ether has been employed in St. George's and University College Hospitals. - London: John Churchill, 1847. - 88 p.

Snow J. On chloroform and other anaesthetics: their action and administration. Edited, with a memoir of the author, by Benjamin W. Richardson, M.D. 1858. FACSIMILE. Reprinted by the American Society of Anesthesiolo- gists. - 443 p.

Stolz F. Ueber Adrenalin und Alkynaminoacetobrenzcatechin.- Berl. dtsch. chem. Ges. - 1904. - Bd. 37. - S. 41-49.

Шувалов С.М. Спосіб блокади рухових гілок нижньощелепного нерву при больовому синдромі, викликаному больовою дисфункцією скронево-нижньощелепного суглобу // Новини стоматології. - 2008. - № 2. - С. 104-105.

Szmuk P., Ezri T., Evron S., Roth Y., Katz J. A brief history of tracheostomy and tracheal intubation, from the Bronze Age to the Space Age // Intensive Care Med. - 2008. Vol. 34. - P. 222-228.

Tabern D.L., Volwiler E.H. Sulfur-contained barbiturate hypnotics // J. Am. Chem. Soc. - 1932. - Vol. 58. - P. 696.

Takamine J. Terapeutic Gazette. - 1901. - Vol. XXVII. - P. 221.

Takman B.H. The chemistry of local anaesthetic Agents: Classification of blocking Agents // Brit. J. Anaesth. - 1975. - Vol. 47. - P. 183-190.

Thierbach A. Franz Kuhn, his contribution to anaesthesia and emergency medicine // Resuscitation. - 2001. - Vol. 48. - Issue 3. - P. 193-197.

Thoma K.N. // Surg. Gynecol. Obstet. - 1944. - Vol. 78. - P. 4.

Travers B., ed., World of Scientific Discovery. - Gale, 1994. - 480 p.

Trendelenburg F. Beitrage zur den Operationen an Luftwegen // Arch. Klin. Chir. 1871. - Bd. 12. - S. 112.

Vandam L. D. Robert Hinckley's «The First Operation with Ether» // Anesthesiology. 1980. - Vol. 52. - P. 62-70.

Wall P.D., Sweet W.H. Temporary abolition of pain in man // Science. - 1967. - Vol. 155. - Jan. 6. - № 758. - P. 108-109.

Waters R.M., Rovenstine E.A., Guedel A.E. Endotracheal anesthesia and its historical development // Anesth. \& Analg. - 1933, Sept.-Oct. - Vol. 12. P. 196-203. 
Weese H., Scharpff W. Evipan. ein neuartiges Einslaffmittel // Deutsch. Med. Wochenschr. - 1932. - Bd. 58. - S. 1205-1207.

Wells H. History of applicanion of Nitrous oxyde gas, Ether and other vapours to Surgical operations. - Hartford U.S., 1847.

West R. Intravenous Curarine in the Treatment of Tetanus // Lancet. - 1936. - Vol. 1. - P. 12 .

West R. Intravenous Curarine in the Treatment of Tetanus // Lancet. - 1936. - Vol. 1. - P. 12 .

Whizar-Lugo V., Carrada-Perez S., Martinez-Andrade M. // Rev. Mex. Anesthesiol. 1998. - Vol. 21. - P. 151-158.

Winther J.E., Nathalang B. Effectivity of new local analgesic Hoe 40045 // Scand. J. Dent. Res. - 1972. - Vol. 80. - № 4. - P. 272-278.

Wilkinson D.J. And Sir Peter makes nine... but this is still not good enough // Anaesthesia News. - 2007 Aug. - № 21. - P. 28-30.

Wolfe R.J. Robert C. Hinckley and the Recreation of the First Operation under Ether. Boston, The Boston Medical Library in The Francis A. Countway Library of Medicine, 1993.

Wood A. New method of treating neuralgia by the direct application of opiates to the painful points // Edinb. Med. Surg. J. - 1855. - Vol. 82. - P. 265-281.

Wörner H., Mayer R. Klinische Erfahrungen mit Ultracain ${ }^{\oplus} / /$ Dtsch. Zahnarztl. Z. 1976. - Bd. 31. - № 8. - S. 657-660.

Wren Ch. An account of the rise and attempts, of a way to convey liquors immediately into the mass of blood. Reprint from: Philosophical Trans- actions of the Royal Society of London, vol. 1, p. 128-130, Dec. 4, 1665.

Wustrow. Retromandibuläre Mandibularanästhesie // Dtsch. Zahnheilk. Woche. 1937. - H. 3.

Zaric D., Nydahl P.A., Philipson L. et al. The effect of continuous lumbar epiducar infusion of ropivacaine $(0,1 \%, 0,2 \%$ and $0,3 \%)$ and $0,25 \%$ bupivacaine on sensory and motor block in volunteers: a double - blind study // Reg. Anesth. - 1996. - Vol. 21. - № 1. - P. 14-25.

Zinganell K. Franz Kuhn, pioneer of peroral intubation // Anaesthesist. - 1974. - Vol. 23 . - P. 308-311. 


\section{УКАЗАТЕЛЬ ИМЁН AUTOR INDEX}

\section{A}

Абель Дж. (Abel J.) 118, 293

Абзипарова В. 285

Абико Н. 229

Абрамов А.А. 263

Абу Али Ибн Сина (Авиценна) 11, 226

Адкина Г. 262

Адриани Дж. (Adriani J.) 154

Азрельян Б.А. 168, 262, 299

Айзенштейн И.М. 174

Айнхорн А. (Einhorn А.) 125, 126, 128,131 , 286, 294

Айри В. (52)

Акинози Дж.О. (Akinosi J.O.) 183, 186

Александров В.Н. 255, 262

Александров Н.M. 178, 251, 253, 262

Алексеев Л.И. 262

Altemir F. 252

Амбруаз Паре 7-11, 16

Аминев А.М. 277, 279

Англада (Anglada) 37

Андре Ж.-Ф. (Andre J.-F.) 152, 260, 262

Андхиера П. (d`Andhiera P.) 290

Андрюс Э. (Andrews E.) 46

Анисимова Е.Н. 262

Анреп В.К. 103-105, 107-110, 123, 124,293

Аран (Aran) 23

Аретей 225
Арнотт Дж. (Arnott J.) 18

Apxep B.Г. (Archer W.H.) 178

Астрём Э. (Astroem A.) 148

Ауэ Г.X. 120

Ауэр Дж. (Auer J.) 240

Афина (А q h n a) 13

\section{Б}

Бабиков А.С. 260

Бажанов Н.Н. 253, 254, 262

Байер А. фон (Baeyer A. von)

Байриков И.М. 286

Балуев Ю.П. 277, 280

Баранов А.М. 277

Барский Ф.Я. 110-112

Бартолин Т. (Bartholinus T.) 11, 18, 19, 290

Баталин Д. 246, 247

Беддо Т. (Beddoes Т.) 36

Бейли Н. (Baily N.) 5

Бекер Д. (Becker D.) 6,7

Бекетов А. 245

Беклар А. (Beclard А.) 167

Беланов Г.Н. 199

Белл Б. (Ball В.) 152

Белл Ч. (Bell Ch.) 62

Беляева Н.Г. 262

Беннет K.P. (Bennett C.R.) 169

Бер П. (Bert P.) 46-48 
Бердюк И.В. 253

Бердяев А.Ф. 133

Бережнов В.В. 281, 283, 284

Бережной В.П. 256, 262

Березовский С.Е. 21

Берг Х. (Berg H.) 178

Берман К.Л. (Berman C.L.) 168

Бернадский Ю.И. 148, 253, 262, 297

Бернардо-Беркмеер Л. 276

Берше Ж.-А. (Bercher J.-H.) 286, 295

Бёкл 115

Бёрнс P. (Burns R.) 13

Бигелоу Г. Дж. (Bigelow Н.J.) 57, 77, 78,81 , 83,88 , 89,95 , 291

Бизяев А.Ф. 184, 255, 262

Бильрот Т. (Bilroth Т.) 23

Биндер Д.А. (Binder D.A.) 300

Бир А. (Bier А.) 121, 130, 131, 233

Блейхштайнер A.

(Bleichsteiner A.) 159, 161, 294

Боард Э. (Board Е.) 87

Бобров А.А. 64, 115, 120, 249

Бобровская О.Н. 280

Бове Д. (Bovet D.) 297

Боден Ж. (Bodin J.) 6

Бодлер Ш. 287

Бойль P. (Boyle R.) 36, 157, 242

Бок (Bock) 293

Болдетти Э.Л. (Baldetti E.L.) 269, 270,
Болонкин В.П. 280, 282

Боника Дж.Д. (Bonica J.J.) 269-272, 299

Брасавола А.М. 227

Браун Г. (Braun H.) 105, 110, 118, 128, $129,130,131,133$, 134, 177, 178, 193, 294, 295

Брен (Bren) 67

Бреттауер Дж. (Brettauer J.) 105, 106, 109

Brechner V.L. 154

Броберг Ф. (Broberg F.) 155, 299

Бродий Б. Сэр (Brodie B. sir) 37

Brovn 266

Брунс фон П.-В. (Bruns P.-V. von) 25, 58

Бруншвиг (Брауншвейгский)

И. (Brunschwig H.) 10

Брэйн А. (Brain A.I.J.) 220, 221, 299

Брюнинг A. (Bruening A.) 126

Бук (Book) 25

Булгаков М.А. 232

Bunker J.P. 96

Бурден К.-Л. (Bourdain C.-L. 199)

Бурлакова М.П. 281

Бутц Р.В. 246, 293

Буш И.Ф. 25, 291

Buchan 230

Бъёрн Г. (Bjorn G.) 296

Бэйкер P. (Baker R.) 90, 92

Бэктон M.У. (Becton M.W.) 162, 166

Бэлль (Belle) 16

Бэрри Дж. (Barry J.) 81 
B

Вазирани С. (Vasirani S.J.) 183, 186

Вайдлинг С. (Wiedling S.) 148

Вайсблат С.Н. 142, 143, 166, 174, 179, 188, 194-197, 253, 295, 296

Вайтхэд Ф. (Whitehead F.J.H.) 169

Васманова Е.В. 168, 262

Васюк Е.В. 264

Вашингтон Дж. 231, 232

Веезе Г. (Weese Н.) 211, 296

Везалий 226, 227, 232

Вейдбонкорд Т.Р. 273

Вейсбрем М.М. 181, 253, 296

Велл П. (Wall P.) 298

Веллин P. (Wallin R.) 298

Веллингтон У.У. (Wellington W.W.) 81, 83, 84

Велтон P.Э. (Walton R.E.) 262

Вельпо А. (Velpeau A.) 38, 43, 58, 140

Венэйбл Дж. (Venable J.) 49

Верлоцкий M.M. 178-180, 296

Вёлер Ф. (Woehler F.) 102

Виго Ж. (Vigo J.) 10

Визе Ж. 232

Визе Х. (Weese Н.) 296

Вильмс Г. (Wilms H.) 128

Виноградов К.Н. 114, 115

Витцель А. (Witzel A.) 175, 293

Вихеркевич 113

Вишневский А.А. 110, 139
Вишневский А.В. 22, 104, 110, 138 $140,142,175,195$, 196, 296

Вовк Ю.В. 262

Войно-Ясенецкий В.Ф. 134, 135, 176, $178,185,193$, 194, 294, 295

Волкович Н.М. 132

Вольвилер Э.Х. (Volwiler Е.Н.) 211, 296

Вольта А. (Volta А.) 267

Вольтлер A. (Woltler A.) 175, 293

Ворд Дж.К.А. (Ward J.Q.A.) 94

Воробьев А.А. 168

Воскресенский А.В. 132

Воткинс Дж. (Watkins J.) 37

Вреден Р.P. 104, 105, 110, 119-124, 133

Вуд А. (Wood A.) 22, 101, 158, 159, 292

Вулкомб (Woolcombe) 37

Вустров (Wustrow) 296

Вэлквист С. (Wahlqvist S.) 148

Вэлл П. (Wall. P) 268

Вячкилева Н.К. 262

Гаврилов И.Ф. 280

Газо (Gaso) 102

Гайе К. (Gayet C.J.A.) 63

Гален К. 225, 226

Галимова Г. 285

Гальвани Л. (Galvani L.) 267

Гальперн Я.О. 139, 140 
Ганина С.С. 262

Гарнак Г.А. 136

Гарсия M. (Garcia M.) 241

Гатре C. (Guthrie S.) 61, 63

Гаухман Б.И. 276

Гведел А. (Guedel A.) 74, 75, 240, 295

Гвезмей Дж.Т. (Gwathmey J.T.) 242

Гед П. (Gadd Р.) 189, 192

Гедке Ф. (Gaedke F.) 101, 292

Гейнац В.Н. 120, 122

Гейфельдер И.Ф. (Heyfelder I.F.) 58

Гепштейн И.Я. 178

Герман (Hermann) 46

Герман Дж. (Herman J.) 77

Геродот (Gerodot) 287

Гертель Ф.Ф. (Haertel F.F.) 134, 193

Герцен П.А. 124

Гecce Ф. 133

Гёриг М. (Goerig М.) 128

Гибсон Ч. (68)

Гигаури В.С. 168

Гиллеспи Дж.Д. (Gillespie J.D.) 64

Гиллеспи H.A. (Gillespie N.A.) 248

Гиллис Дж.Т. (Gillis J.T.)) 250

Гильдебрандт А. (Hildebrandt A.) 131

Гиппократ (Hippokrates) 6, 10, 11, 225, 226

Гирголав С.С. 129

Глокман Э. (Glockmann E.) 262

Глязер Г. 62, 63

Головачёва М. 285

Голубев Ф.А. 122

Гольдман B. (Goldman V.) 220
Гордиенко Т.П. 168

Готтлиб М. 118

Гоу-Гейтс Дж. А.Э.

(Gow-Gates G.A.E.) 178, 183-185, 299

Гофман К. (Goffman C.) 6

Гофунг М.E. 178

Готье Т. 287

Гранджан (Granjean) 199

Грей 267

Григолайт Г.-Г. (Grigoleit H.-G.) 152

Грин B.B. (Greene W.W.) 159, 292

Гриффит Г. (Griffith Н.) 244, 296

Грубе В.Ф. 112, 175

Губарева Л.И. 285

Губин М.А. 263

Гуерик фон 267

Гук Р. (Hooke R.) 157, 229, 232

Гулд О.Э. (Gould А.А.) 77, 78, 79, 81, 95

Гусарова Г.И. 288

д

Дагер Л.Ж.М. (Daguerre L.J.M.) 90 Даублэндер М. (Daublaender M.) 152, 259

Даценко М.Ф. 253

O 'Двайер Дж. (O 'Dwyer J.) 75, 234, 235,246

Двойникова Е.В. 280

Дедюлин В.И. 105

Де Кастро Ж. (De Castro J.) 297 
Делакруа Э. 287

Делицин С.Н. 104, 122, 123

Дестрегюль (Destrégull) 47

Дехиров Д. (Deherov D.) 178

Дёнитц А. (Doenitz A.) 130

Джейнвэй Г.Г. (Janeway Н.Н.) 243

Джексон Ч. (Jackson Ch.) 241, 242, 248

Джексон Ч.T. (Jackson Ch.T.) 44, 50, 51, 56,57

Джиакомини К. (Giacomini C.) 37

Джонс Э. (Johns E.) 106

Джонсон Э. (Johnson E.) 214, 296

Джонстон M. (Johnston M.) 210, 297

Джоргенсен Н.B. (Jorgensen N.B.) 178

Дивавин Л.А. 132

Дидай Ф. (Diday F.) 63

Дизей С.П. (Desai S.P.) 77, 79, 80, 82

Дикинсон Ф.С. (Dickinson F.S.) - 162, 166

Диоскорид Педаний (Dioscorides

Pedanius) 5, 6, 289

Дирк (Dirck) 246

Дирнбахер Т. (Dirnbacher T.) 199

Диффенбах И.Ф. (Diffenbach J.F.) 58

Добронравов А.С. 262

Домино Э.Ф. (Domino E.F.) 298

Дреббель К. ван (Drebbel C. van) 35

Дрезер Г. 287

Дресcер Л. (Dresser L.) 93

Дрэгер Г. (Draeger H.) 238, 239

Дубов М.Д. 179, 181, 286, 296

Du Cailar J. 297

Дьяконов П.И. 64
Дэви Х. (Davy H.) 41, 42, 44, 46, 290

Дэйлил X. (Dalili H.) 154

Дэлтон Дж.К. (Dalton J.C.) 79, 81

Дюма А. (Dumas A.) 287

Дюма Ж.Б.А. (Dumas J.B.A.) 61

\section{E}

Егоров П.М. 174, 178, 180, 191, 262, 299

Елизарьева Н.Л. 251, 252

Елисеев М.Н. 277, 280

Ефремовский И. 20

\section{ж}

Жерард (Gerard) 18

Жерарден Э. (Gerarden E.) 42

Жильборт 267

Жинест Ж. (Ginestet G.) 178

Жоров И.С. 61, 107, 110, 139

Жюве (Juvet) 16

3

Загебил (Sagebill) 246

Залога А. 120

Занчевский 114

Зауэрбрух Ф. (Sauerbruch F.) 239

Захарьевский А. 107 
Звержховский Ф.А. 48, 276

Зильбер А.П. 36

Зимукова Д.А. 277

Зиновьев И.А. 264

Зихер Г. (Sicher H.) 178

Змеев Л.Ф. 76

Золтан Я. (Zoltan J.) 176

Зотов B.M. 281

Зыков А.А. 23, 104, 106, 107, 110, 112, $115-117,123,141$

\section{и}

Ибрагимов 3.И. 185

Иванов B.M. 136

Иващенко Г.М. 262

Ивенский Н.И. 262

Иеллинек Э. (Jellinek E.) 106, 108

Икеда К. (Ikeda K.) 244

Ильина Е. 285

Имхотеп 225

Иноземцев Ф.И. 59-61, 76

Итина А.И. 178

Ицкин Я.А. 174, 178

$\mathbf{K}$

Кавендиш Г. (Cavendish J.) 34

Кадочников Б.Ф. 178, 183, 186-188, 297

Кадьян А.А. 120

Кайт Ч. 230
Кальари П. (Caliari P.) 100

Калякаева Н. 280

Канеко Ю. (Kaneko Yu.) 260, 262, 301, 302

Канторович A. (Kantorowisz A.) 178

Каппелер O. (Kappeler O.) 61, 64, 65, 71

Карамзин Н.M. 5

Карл X (Charles X) 42

Карленко С.Н. 253

Каролюс-Дюран (Carolus-Duran) 77

Карлсон (Carlson) 22

Kappea (Carrea) 295

Кауфман Э. (Kaufmann E.) 260, 262

Кацауров И.Н. 107, 108, 293

Келли (Kelly) 240

Кеппер (Kepper) 178

Кёлер (Koehler) 246

Кёлле (Koelle) 246

Кёнигштайн Л. (Koenigstein L.) 106

Кирстейн А. (Kirstein A.) 237

Киселёва Т.А. 199

Кистлер Дж.Ф. (Kistler J.Ph.) 81, 84

Кларк У.Э. (Clarke W.E.) 48,49

Кликович С.C. 232, 233, 276

Кловер Дж. Т. (Clover J.Т.) 66, 68-73, 75

Клоке Ж. (Cloquet J.) 291

Кнорр Л. (Knorr L.) 293

Коган Т. (Cogan T.) 230

Коллер К. (Koller K.) 105-108, 293

Коломбо А. (Colombo A.) 299

Коломнин С.П. 113-116 
Колтон Г. (Colton G.) 44-46

Колумб Х. 12

Конвей M. (Conwey M.) 113

Конобевцев О.Ф. 262

Коперник Н. 226

Кордус В. (Cordus V.) 36

Корнинг Дж.Л. (Corning J.L.) 110, 121

Корссен Г. (Corssen G.) 298

Котельников Г.П. 4

Коцубей Л.А. 178

Кравков Н.П. 211, 294, 295

Кравченко В.В. 153, 199, 262, 277, 285, 286, 300

Кравченко С.В. 277

Крайл Дж. (Crile G.W.) 177, 266, 268, 295

Крайнюков В.Ф. 280

Красовский А.Я. 48

Кризл Г. (Kriesell G.) 178

Крисп Ч.Ф. (Crisp Ch.F.) 81

Крон Н.М. 136

Кроулей Д. 271

Кругляков И.О. 253

Крымов А.П. 122, 124

Кузин М.И. 175

Кузьменко Д.Ю. 171

Кук Х. (Cook H.S.) 131, 162, 163, 297

Кулаженко В.И. 186

Кун Ф. (Kuhn F.) 75, 235-239, 246, 247, 294, 295

Курри (Curry) 230

Кут X. (Coote Н.) 62, 63
Л

Лабори А. (Laborit H.) 298

Лавуазье A. (Lavoisier A.) 28, 29, 3236

Лагардиа (Laguardia) 178, 181, 182, 296

Ландерер Г. (Landerer H.) 175, 293

Ланди Дж. (Lundy J.) 75, 250, 296

Ланц Э. (Lanz E.) 262

Лаокоон (Laokown) 13

Ларгин С. 267

Ларрей Д.Ж. (Larrey D.J.) 42

Ларуайенна (Laroyenne С.-J.) 63

Левен И.И. 262

Леви Д.С. 23

Левит Б. (Levit B.) 178, 180, 295

Левшин Л.Л. 18, 22

Лепилин А.В. 262, 263

Лернер Ж.Б. 277

Либих Ю. фон (Liebig Ju. von) 61, 125

Либов С.Л. 277

Либрейх (Libreich) 23

Лигард (Ligard) 16

Лилиенталь (Liliental) 248, 295

Лиман Г.M. (Lyman H.M.) 49

Лимберг А.А. 249

Линдберг Б. (Lindberg B.) 297

Линдеман (Lindemann) 295

Линдквист К. (Lindqvist K.) 145, 148, 149

Липп М. (Lipp М.) 26, 101, 105, 106, $110,182,199,262$

Листон P. (Liston R.) 58 
Литторин (Littorin) 165

Ловер P. (Lower R.) 157

Локк Дж. (Locke J.) 157

Ломоносов M.B. 34

Лонг К.У. (Long C.W.) 36, 48, 49, 57, 97, 98,291

Лонгсдейл (Longsdale) 58

Лосневский Д.Я. 63

Лоссен В. (Lossen W.) 102

Лофгрен H.M. (Lofgren N.M.) 144-148, 296, 297

Лоч (Lotsch) 246

Луер Г.В. (Luer H.W.) 161, 162

Лукас Г.Х.У. (Lucas G.H.W.) 296

Лукашевич А.И. 110-112, 124, 175, 293

Луккей Х. (Luckey H.) 239

Лукьянов М.B. 221, 262, 300

Лундквист Б. (Lundqvist В.) 145, 147, 296

Луциус О. (Lucius Eu.N.) 126

Люкке В. (Lucke W.) 23

Люллиус P. (Lullius R.) 36, 290

\section{M}

Мадонна (Дева Мария) 95

Майер Э. (Mayer Е.) 118, 129

Major R.H. 92

Македонский А. 225

Макиенко М.А. 280, 282, 283

Макинтош P. (Macintosh R.) 241, 243

Мак Кессон (McKesson) 242
Маклаков Н.В. 59, 177

Мак-Эвен У. (Macewen W.) 75, 234, 246,

Малаховская А.А. 185, 197-199

Мальген Ж.Ф. (Malgaigne J.F.) 58

Мантегацца П. (Mantegazza P.) 101

Манэш С. (Monash S.) 154

Mao Xoa 35

Маргетис П. (Margetis Р.) 167, 297

Маркин А.И. 262

Мартинес-старший (Martinez-Lage) 251

Маршак С.Я. 13

Маслов Г.А. 122

Матас Л.C. (Matas L.S.) 99

Матас P. (Matas R.) 193, 232-234

Меерович И.Я. 121

Мейоу Дж. (Mayow J.) 157

Меламед С.Ф. (Malamed S.F.) 152, 199, 257, 260, 262

Мельзак P. (Melzack R.) 268, 298

Мельтцер С.Дж. (Meltzer S.J.) 240

Меринг И. фон (Mering J. von) 211, 294

Мерк Э. (Merck E.) 112, 293

Месмер Ф.А. (Mesmer F.A.) 38,40, 290

Мёнье Ж. (Meusnier J.) 34

Микеланджело Б. (Michelangelo В.) 15

Миллер В.Д. 27, 160

Миллер (Miller) 241

Минх В.М. 132

Минц В.М. 122, 246

Митрофанов Г.Г. 253 
Мишунин Ю.В. 262

Молем (Mowlem) 250

Монастырский Н.Д. 110, 112, 115, 116, 124

Морган M. (Morgan M.) 299

Моро Ж.-Ж. 287

Морозов 114

Мортон У.Т.Г. (Morton W.T.G.) 36, 44, 49$52,54-58$, 76-79, 81, $82,84-96$, 98,291

Московец О.Н. 184, 259, 260

Моффетт (Moffett) 268

Муковозов И.Н. 246, 247, 251, 253, 254, 262

Мунделеер П. (Mundeleer P.) 297

Мур Дж. (Moore J.) 16

Мухин Н.А. 168

Мушавек P. (Muschaweck R.) 149-151, 299

Мыш B.M. 247

Мэгилл А. сэр (sir Magill I.W.) 238, 240242,250

Мэйуанд M.O. (Maiwand M.O.) 273

H

Найтингейл Ф. (Nightingale F.) 69

Наполеон Ч.Л. (Наполеон III) 69

Несмеянов А.А. 262

Николаев М.П. 105, 110

Николай I 91
Ниманн А. (Niemann А.) 102, 105, 288, 292

Ногю Д. (Nogué D.) 136, 137, 294

Нойман P. (Neumann R.) 161

Нойнер фон (Von Neuner) 157, 158

Нэш C.A. (Nash K.A.) 176

Оберст M. (Oberst M.) 112, 123

Олдрич Т. (Aldrich Т.) 129, 294

Оливиер Дж. ( Olivier G.) 118

Омбредан Л. (Ombredanne L.) 73

Оппенхаймер М. (Oppenheimer M.) 126

Орлов А.В. 110, 111, 115-117, 124, 293

Орфилла П. (Orfilla P.) 37

Орэ П.-С. (Oré P.-С.) 210, 292

Островский В.Ю. 76

Отте (Otte) 293

Оулсен Л. (Ohlsen L.) 154

$\Pi$

Пайрсон А.Л. (Peirson A.L.) 83

Панин М.Г. 262

Парацельс Т. 36, 229

Паре А. (Pare A.) 7-11, 16

Паркман С. (Parkman S.) 83, 95

Паррейдт Ю. (Parreidt J.) 24, 26

Парч K. (Partsch K.) 25 
Паскаль Б. (Pascal B.) 157, 158, 290

Паф Б. 229

Пашков К.А. 161

Пеан Дж.Э. (Pean J.E.) 48

Пеккерт (Pekkert) 189, 296, 193

Перси С. (Persi S.) 102

Перцов Р.И. 167

Петерсон Г. (Petterson G.) 147, 297

Петрикас А.Ж. 25, 152, 163, 164, 166, $169,175,176,178,200$, 201-207, 256, 262, 299

Петрякин (63)

Петти У. (Petty W.) 157

Пётр I 14, 15

Пиль P. (Peel R.) 69

Пирогов Н.И. 59-61, 63, 76, 116, 120, $121,139,174,232,233$, 245, 291, 292

Пирсон А.Л (Peirson A.L.) 79, 84

Пита Ф.Ф. (Pitha F.F.) 23

Пичеев Н.С. 280, 281

Пла Ц. (Plá C.)

Плиний младший

(G.Plinius Caecilius Secundus) 6

Плиний старший (G.Plinius Secundus) 20

Поленичкин В.К. 280

Поль А.И. 63

Пономарев Г.П. 147

Понтен Б. (Ponten B.) 154

Попов А.Е. 131

Портье П. (Portier P.) 294

Порывай О.А. 280

Потен П.Ш.Э. (Potain P.Ch.Е.) 159

Поуп Э. (Рope Е.) 49
Правац Ч.-Г. (Pravaz Ch.-G.) 101, 158, 159, 160, 292

Привалов Ю.С. 262

Пристли Дж. (Priestley J.) 28-33, 41, 290

Проскурин А.П. 246

Проспери Л. (Prosperi L.) 77, 80-85

Проспери У. (Prosperi W.) 77, 80-86

Пряников С.А. 286

Прянишникова Н.Т. 148

P

Рабинович С.А. 152, 157, 183, 184, $186,221,257,259$, $260,262,301$

Радзевич 76

Раймонд Э. (Raymond E.) 176

Райнер K. (Reiner K.) 237

Ранн P. (Rahn R.) 152, 258, 262

Ратимов B.A. 119, 120

Ратнер Г.Л. 277, 278

Рахманов А. 276

Резерфорд Э. (Rutherford Е.) 41

Рейнолд Э.X. (Raynold E.H.) 25

Реклю П. (Reclus P.) 11, 112, 116, 123, $174,175,293$

Рембрандт X. 82

Риггс Дж. (Riggs J.) 44,45

Ридер Э. (Reeder E.) 298

Ринд Ф. (Rynd F.) 101, 156, 158, 291

Риппель P. (Rippel R.) 149-151, 298, 299 
Ритски А. (Ritsky А.) 164, 165

Ричардсон Б. (Richardson B.) 18-21, 24, 292

Рише Ш.P. (Richet Ch.R.) 294

Роб6 Н.Д. (Robb N.D.) 186, 258, 262

Роб6 X. (Robb H.) 186

Робертс (Roberts) 111

Робинсон В. (Robinson V.) 59

Робинсон Дж. (Robinson J.) 58

Pocc6ax M. (Rossbach M.) 110

Ротмистров П.А. 279

Ротмунд (Rotmund) 58

Роубосам C. (Rowbotham S.) 240, 242

Ру Ф.-И. (Roux Ph.-I) 58, 116

Рубенс П.-П. 226

Руд Дж.П. (Rood J.P.) 262

Руд Дж.Ф. (Rood J.F.) 178

Рудько В.Ф. 186, 254, 262

Руссанов Дж. (Russanow J.) 178

Рухлядев М.Ю. 280

Рушиг Г. (Ruschig H.) 149, 150, 298, 299

Рыбаков А.И. 169, 186

Рэйли K.C. (Reily C.S.) 262

Рэн К. сэр (Wren C. sir) 156, 157

Рябцев В.Я. 262

\section{C}

Сабо Д. (Szabo Gy.) 188

Саклинг К.У. (Suckling C.W.) 210, 297

Сапожков К.П. 132

Сарманаев Р.Б. 178
Свит У. (Sweet W.) 268

Северный М.A. 12

Седилло Ч.-Э. (Sedillo Ch.-E.) 62

Селден X. (Seldin H.) 178

Семашко Н.A. 255, 284

Серапиний Старший 20

Сергачёва Н.П. 280

Середницкий А.М. 177

Сертюрнер Ф.В.

(Sertürner F.W.) 266, 287, 291

Сивард (Seward) 262

Сикора П. (Sykora P.) 47

Сильвестр X.P. (Silvester H.R.) 67

Симмонс M. (Simmons M.) 262

Симпсон Дж.Я. (Simpson J. Yu.) 62, 63, 291

Скитер А.И. 280

Склифосовский Н.В. 120, 122

Скопец Е.В. 178, 253

Скотников В.И. 280

Смит Г. (Smith G.) 274

Сноу Дж. (Snow J.) 67-70, 73, 75, 232, $233,245,292$

Снэп (Snap) 24

Соберан Э. (Souberain E.) 61

Соханский Н.Н. 130

Сохов С.Т. 183, 257, 262, 266, 275, 300

Спасокукоцкий С.И. 247, 248

Спижарный И.К. 131-133

Спир (Spir) 50

Спицын П.И. 263

Спримон В.Ф. 111

Старобинский И.М. 178 
Стародубцев В.С. 262

Старухин А.М. 280, 281

Стерн Э. (Stern E.) 81

Стивенс К. (Stevens C.) 212, 298

Столяренко П.Ю. 128, 129, 144, 152, $153,188,199,221$, 262-264, 274, 276, 282-286, 300

Столяров Е.А. 288

Стош В.И. 262

Сундлинг С. (Sundling S.) 145, 148, 149

Сутуорт A.C. (Southworth A.S.) 94

$\mathbf{T}$

Таберн Д.Л. (Tabern D.L.) 211, 296

Такамине Дж. (Takamine J.) 118, 129, 294

Такман Б.Х. (Takman B.H.) 149, 298

Таубер A.С. 48

Таубкин П.И. 130, 294

Таусенд С.Д. (Townsend S.D.) 81

Тегнер К. (Tegner C.) 147, 148, 297

Теребинский Н.Н. 246

Террел Р.K. (Terrell R.C.) 210, 298

Тимофеев А.A. 188

Тирш К. (Thirsch К.) 274

Тихомиров В.И. 280

Тома К.Г. (Thoma K.H.) 250

Топорова Г.Н. 184

Тренделенбург Ф.

(Trendelenburg F.) 233, 234, 237, 245, 246, 292

Трещинский А.И. 110, 137
Троянов А.А. 120

Троянский А.В. 121

Трусов М.М. 168

Tpycco A. (Trousseau A.) 231, 232

Турнер M. (Turner M.) 36

y

Уайт Л. 271

Уваров Б.С. 137, 139

Уваров В.М. 286, 295

Уилсон Э. Сэр (Wilson E. Sir) 69

Улер Г. ван (Euler H. von) 144, 145

Улер У. ван (Euler U. von) 145

Ульфельдер Э. (Uhlfelder Е.) 128

Уолди Д. (Waldi D.) 62

Уоррен Дж.К. (Warren J.C.) 44, 51-56, $78,79,81$, $83,84,89$, $90,92,95$, 96

Уоррен Дж.М. (Warren J.M.) 37, 55, 79,83 , 84,95

Уотерс P.M. (Waters R.M.) 74, 75, 240, 243,250

Уэллс X. (Wells H.) 36, 43-46, 50, 55, $57,97,99,291$

\section{$\Phi$}

Фабрицкий А. 229

Фарадей М. (Faraday M.) 37, 44 
Федоров С.П. 141, 142, 295

Федяев И.М. 4, 276, 277, 279, 285, 286

Фергюсон Д. (Ferguson D.) 157, 158

Фергюсон Дж. (Ferguson J.) 158

Ферранте Ф. 273

Фетисов Н.В. 253

Филатов В.К. 262, 281-283

Фишер Г. (Fischer G.) 105, 110, 113, $119,131,136$, $137,138,159$, $161,178,179$, $181,182,294,295$

Фишер Ф. (Fisher F.) 58

Фишер Э. (Fischer Е.) 211, 294

Флуранс М.-Ж.-П. (Flourens M.-J.-Р.) 61

Флэг Р.Дж. (Flagg Р.J.) 250

Флэхер Ф. (Flaecher F.) 130

Фовель (Fovel) 102

Фошар П. (Fauchard P.) 290

Франко А. (Franko А.) 99

Фрейд 3. (Freud S.) 105, 106

Френкель Г. (Frenkel G.) 151, 152, 199

Фробениус O. (Frobenius O.) 36

Фрост Э. (Frost E.) 50, 77, 81, 86, 87

Фруэн (Froin) 235, 236

Фурнелль 63

Фурно Э. (Fourneau E.) 125, 128

\section{$\mathbf{X}$}

Хавес У. (Hawes W.) 230

Хайден (87)
Хайнацкий А.Ф. 135

Халафов С.И. 276

Ханаока С. (Hanaoka S.) 12

Хантер Дж. (Hunter J.) 16, 22

Харвес (Harwes) 230

Харнас С.Ш. 139, 175

Хау Г.Л. (Howe G.L.) 168

Хейвуд Ч.Ф. (Heywood Ch.F.) 81, 89, 95

Хейуорд Дж. (Hayward G.) 55, 83

Хелдрет Ч.О. (Hildreth Ch.H.) 79, 83

Хемскерк М. ван

(Heemskerck M. van) 14

Хендерсон В.Э. (Henderson V.E.) 211, 296

Хенни (Henny) 250

Хикмен Г.Х. (Hickmann Н.Н.) 36, 4244

Химес А. (Hymes А.) 268

Хинкли Р.K. (Hinckley R.C.) 77-79, 81-85

Хлюпнёва Т. 285

Хоес Дж.Дж. (Hawes J.J.) 93, 94

Холл Р.Дж. (Hall R.J.) 176, 293

Холмс О. (Holmes O.) 5, 57

Холстед У.C. (Halsted W.S.) 159, 176, 177,293

Хонтхорст Г. ван

(Honthorst G. van) 14

Хофман-Акстельм В.

(Hoffmann-Axthelm W.) 138, 156, 157

Хоффманн А. (Hoffmann А.) 288

Христофр А. (Christopher А.) 169

ХуаТо 289 
Хуан Фу-ми 289

Хьюитт Ф. (Hewitt F.) 73-75

4

Цейдлер Г.Ф. 122

Цинганелл (Zinganell) 240

Цинь-Юз-Жень 289

4

Чемеков Р.Д. 263

Чернобровкина Т. 288

Чехов А.П. 46

Чистович Н.Я. 76

Чистович Я.А. 76, 291

Чуприна Ю.В. 251

\section{Ш}

Шаров Н.А. 148

Шарплс Э.У. (Sharples E.W.) 30

Шарпф В. (Scharpff W.) 296

Шведов К.П. 262

Шевалеева А. 285

Шевченко В.П. 221

Шегрен Б. (Sjoegren B.) 148

Шееле К. (Scheele C.) 28-33

Шеина-Сыроватко Л.И. 285

Шерцер К. (Scherzer K.) 102
Шефф Ю. 24, 25, 160, 175

Шлейх К. (Schleich C.) 17, 117, 118, 120, 123, 124, 174, 175, 177, 181, 293

Шлёссер P. (Schloesser R.) 274, 294

Шнеффер И. (Schneffer I.) 267

Шорp M. (Schorr M.) 150, 299

Шосье 230

Шоу Дж.Б. 225, 226

Шрофф К.Д. (Schroff K.D.) 102, 103

Штернбах Л. (Sternbach L.) 298

Штокман (Stockmann) 41

Штольц Ф. (Stolz F.) 130, 286

Шу (Schu) 58

Шувалов С.M. 183, 185, 188, 189, 197 199

Шугайлов И.А. 151, 152, 255, 262, 300

Шульгин Е.Г. 262

Шульц-Гусман М.

(Schulze-Husmann M.) 150

Шуман Д. (Schumann D.) 258, 262

Шухман (Schuhman) 16

\section{Э}

Эббот Дж. (Abbott G.) 51, 53, 55, 78, 79,90

Эберс Г. (Ebers G.) 289

Эванс Т.У. (Evans T.W.) 72

Эверс Г. (Evers Н.) 155, 163-165, 199, 262, 299

Эгнер Б. (Egner B.) 147, 297

Эдуард VII (Edward VII) 75

Эйкинс Т. (Eakins T.) 82 
Эйлинг К.К. (Aling С.С.) 169

Экенштам Б.А.Ф.

(Ekenstam B.A.F.) 149, 297

Эллиотсон Дж. (Elliotson J.) 38-40

Энгельс Ф. 33

Энтин Д.А. 178-180

Эрдман О. (Erdtman H.) 144

Эсдейл Дж. (Esdaile J.) 38-40

Эскулап 225

Эсмарх Ф. (Esmarch F.) 16-18

\section{Ю}

Юдин С.С. 6, 7, 51, 55, 131, 276

Юнкер Ф.Э. (Junker F.E.) 74

\section{Я}

Ягиела Дж.А. (Yagiela J.A.) 163, 260

Якобс В. (Jakobs W.) 152, 259, 262

Ясный Я.Л. 246

Ястэк Дж.Т. (Jastak J.T.) 163, 262 


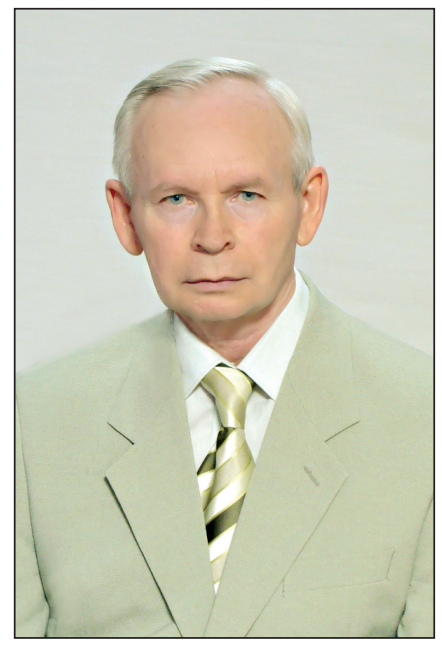

Столяренко Павел Юрьевич - кандидат медицинских наук, доцент кафедры челюстно-лицевой хирургии и стоматологии Самарского государственного медицинского университета. Лауреат международной премии им. Т.И. Ерошевского в области медицинской геронтологии (2000 г.). Награждён нагрудным знаком М3 и СР «Отличник здравоохранения» (2007 г.), медалью СтАР «Отличник стоматологии» I степени. Победитель первого Всероссийского профессионального конкурса «Обезболивание и неотложная помощь в стоматологии». Автор 202 научных работ (в том числе 11 монографий, 2 авторских свидетельств на изобретения и 1 руководства по вопросам обезболивания и неотложной помощи в челюстно-лицевой хирургии и стоматологии). Руководитель Поволжского регионального центра Российской секции Европейской (EFAAD) и Всемирной ассоциаций по обезболиванию в стоматологии (IFDAS). 


\section{Содержание}

Предисловие

4

ПРИМЕНЕНИЕ ОБЕЗБОЛИВАНИЯ

ОТ ГЛУБОКОЙ ДРЕВНОСТИ ДО ХVIII ВЕКА

5

ОБЕЗБОЛИВАНИЕ В ЗУБОВРАЧЕВАНИИ ХІХ ВЕКА

20

ОТ ОТКРЫТИЯ ЭФИРНОГО НАРКОЗА

ДО МЕСТНОГО ОБЕЗБОЛИВАНИЯ

(Лавина открытий - кто же первый?) ………………………………………...28

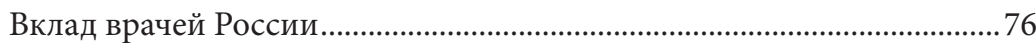

Отображение открытия анестезии

в изобразительном искусстве и литературе

МЕСТНОЕ ОБЕЗБОЛИВАНИЕ

В ПЕРИОД ПРИМЕНЕНИЯ РАСТВОРОВ КОКАИНА

(1884 - до 20-х годов XX века).

МЕСТНОЕ ОБЕЗБОЛИВАНИЕ

В ПЕРИОД ПРИМЕНЕНИЯ НОВОКАИНА

ПЕРИОД ЛИДОКАИНА И АНЕСТЕТИКОВ IV ПОКОЛЕНИЯ ..........144

ИСТОРИЯ МЕСТНОЙ АНЕСТЕЗИИ КОЖНЫХ ПОКРОВОВ ...........154

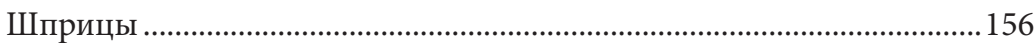

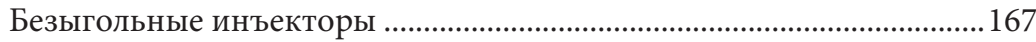

Автоматизированный компьютерный шприц.........................................171 
ИСТОРИЯ РАЗВИТИЯ ТЕХНИКИ МЕСТНОЙ АНЕСТЕЗИИ

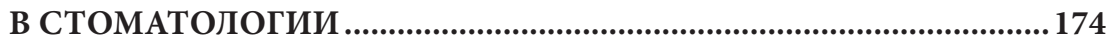

Клетчаточные пространства......................................................................174

Инфильтрационная анестезия ................................................................174

Проводниковая (мандибулярная) анестезия ........................................176

Внеротовые способы обезболивания

у нижнечелюстного отверстия....................................................................189

Центральные (стволовые) анестезии

в челюстно-лицевой хирургии ................................................................. 193

Интралигаментарная анестезия ………………………………………......199

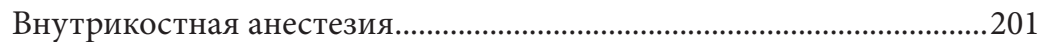

КРАТКАЯ ИСТОРИЯ РАЗВИТИЯ АНЕСТЕЗИОЛОГИИ

(период с начала XX века) ...........................................................................210

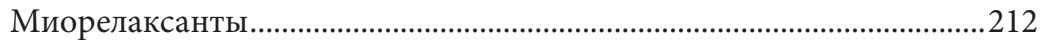

Ларингеальная маска (ЛМ) и другие воздуховоды..............................215

ИСТОРИЯ ТРАХЕОСТОМИИ И ИНТУБАЦИИ ТРАХЕИ ....................225

ИСТОРИЯ ПРИМЕНЕНИЯ ЭНДОТРАХЕАЛЬНОГО НАРКОЗА

В ЧЕЛЮСТНО-ЛИЦЕВОЙ ХИРУРГИИ .............................................245

РАЗВИТИЕ ОБЕЗБОЛИВАНИЯ В СТОМАТОЛОГИИ

С 1946 ГОДА ДО НАЧАЛА ХХІ ВЕКА …………………….......................25

ПОСЛЕОПЕРАЦИОННОЕ ОБЕЗБОЛИВАНИЕ ......................................266

Вклад Джона Джозера Боники в дело борьбы с болью.........................269

Криоанальгезия …………………………………………............................22

Акупунктура..................................................................................................273 
Продлённая проводниковая блокада

второй и третьей ветвей тройничного нерва

ИСТОРИЯ АНЕСТЕЗИОЛОГИИ В САМАРЕ ……………………….....276

Основные публикации по вопросам обезболивания.............................285

НЕГАТИВНЫЕ СТОРОНЫ ДОСТИЖЕНИЙ В БОЛЕУТОЛЕНИИ ...287

ХРОНОЛОГИЯ ОСНОВНЫХ ДАТ

ИСТОРИИ ОБЕЗБОЛИВАНИЯ В СТОМАТОЛОГИИ

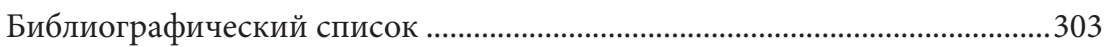

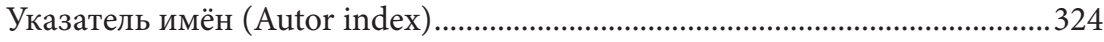


Научное издание

Столяренко Павел Юрьевич

E-mail: stoljarenko@bk.ru

\section{ИСТОРИЯ ОБЕЗБОЛИВАНИЯ В СТОМАТОЛОГИИ (ОТ ДРЕВНОСТИ ДО СОВРЕМЕННОСТИ)}

2-е издание, испр. и доп.

Монография

На обложке:

фрагмент картины Warren \& Lucia Prosperi «День Эфира, 1846 год», 2001 г. Массачусетская больница общей практики, Бостон. Благодарность за разрешение публикации Michelle Marcella и M.D. Sukumar P. Desai

ГОУ ВПО «Самарский государственный медицинский университет» 443099, г. Самара, ул. Чапаевская, 89. 
Подписано в печать 8.07.2010.

Формат 60x84/16. Бумага мелованная. Печать офсетная.

Объем 19,99 усл. печ. л. Тираж 300 экз. Заказ № 1327.

Издательство ООО «Офорт».

443080 , г. Самара, ул. Революционная, 70, литера П.

Тел.: 372-00-56, 372-00-57.

Отпечатано в типографии ООО «Офорт». 